\title{
La utopia pervinguda. El model d'autoria de Marcel Broodthaers
}

Tanya Angulo Alemán 


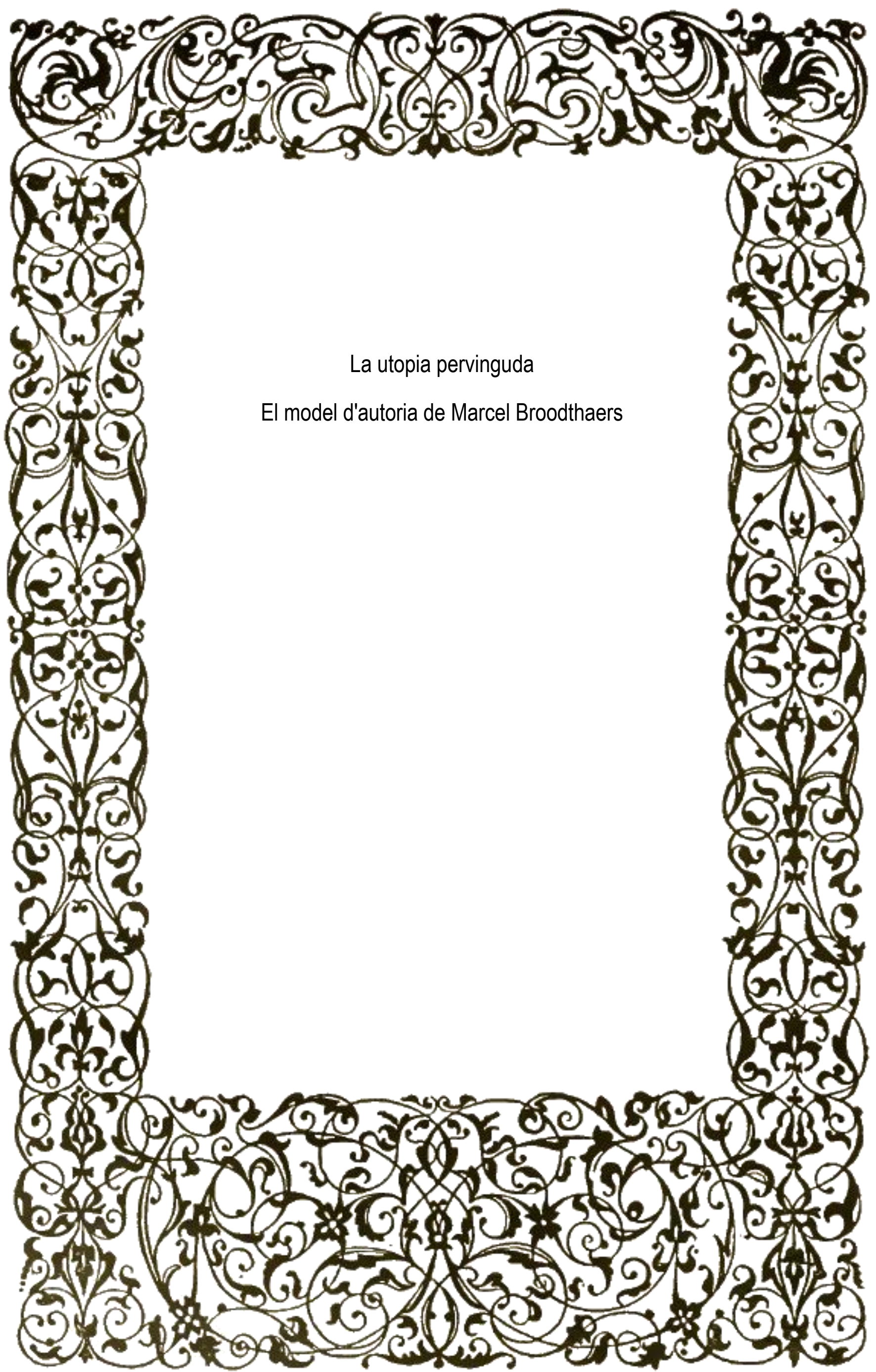


Universitat Politècnica de València

Facultat de Belles Arts

Departament d'Escultura

\section{La utopia pervinguda \\ El model d'autoria de Marcel Broodthaers}

TESI DOCTORAL que presenta la llicenciada Tanya Angulo Alemán

per optar al títol de doctora en Belles Arts

Dirigida per la Dra. Elena Edith Monleón Pradas

Professora Titular d'Escultura en la

Universitat Politècnica de València

València, juny del 2003 


\section{L'Editorial UPV és membre de I'UNE, cosa que en garanteix la difusió i la comercialització de les

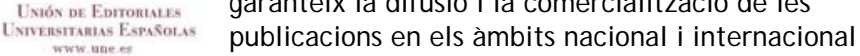

(c) Tanya Angulo Alemán, 2012

\section{(c) d'aquesta edició:}

Editorial Universitat Politècnica de València

Tel. 963877012

www.editorial. upv.es

ISBN: $978-84-8363-864-4$

Queda prohibida la reproducció, la distribució, la comercialització, la transformació i, en general, qualsevol altra forma d'explotació, per qualsevol procediment, de la totalitat o de part dels continguts d'aquesta obra sense l'autorització expressa i per escrit dels autors. 
A les persones que m'han inspirat $i$ sobretot, a les persones que $m$ 'han estimat.

Moltes gràcies

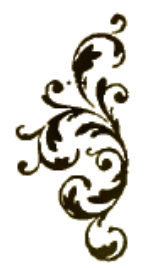


Deixem caure una pedra a l'aigua, apareixen cercles, els coagulem, d'això extraiem una teoria. Llancem una altra pedra més lluny, treballem voluntàriament en una obscuritat.

MARCEL BROODTHAERS

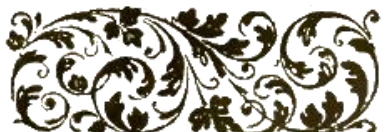


En el context de l'art contemporani, una investigació centrada en l'autoria de Marcel Broodthaers mai no és innocent. L'examen de la seua trajectòria artística amb un enfocament teòric i crític permet valorar el seu treball com una obra heterogènia $i$ coherent més que com una sèrie d'experiments que abasten la poesia, la fotografia, el cinema o l'escultura en el sentit estricte del gèneres .

Globalment, les seues propostes giren entorn de la qüestió del paper de l'art en la societat i del paper de l'artista. Broodthaers comença a realitzar els seus primers assemblages per finals del 1963 preguntant-se si no podria vendre alguna cosa. Després, el 1968, construeix a Brussel-les la ficció del Musée d'Art Moderne, Département des Aigles enmig de l'ambient de revolta social amb la intenció d'escenificar l'enfrontament entre la violència institucional i la violència poètica. L'empremta d'aquesta experiència justifica posteriorment la concepció d'exposicions retrospectives o antològiques com a altres formes de ficció i la idea de Decor esdevé la síntesi dels seus interrogants sobre la funció social de l'obra d'art. Tanmateix, la repercussió del treball de Broodthaers i la seua relació amb les institucions artístiques galeries, museus, feries d'art, macroexposicions, biennals, etc. - és d'allò més interessant.

L'autoria de Broodthaers constitueix un model d'utopia. Però, no es tracta d'una utopia romàntica pura sinó d'una utopia bastarda i mestissa que actualitza els llegats artístics de Mallarmé, de Baudelaire, de Duchamp, de Schwitters i de Manzoni. Aquest model d'autoria pervé ser una forma d'exercir la llibertat artística i de preservar la memòria: una estratègia de resistència i de supervivència espiritual, la qual cosa resulta avui dia prou estimulant. 


\section{RESUMEN}

En el contexto del arte contemporáneo, una investigación centrada en la autoría de Marcel Broodthaers nunca es inocente. El examen de su trayectoria artística con un enfoque teórico y crítico permite valorar su trabajo como una obra heterogénea y coherente más que como una serie de experimentos que abastan la poesía, la fotografía, el cine o la escultura en el sentido estricto de los géneros.

Globalmente, sus propuestas giran en torno a la cuestión del papel del arte en la sociedad y del papel del artista. Broodthaers comienza a realizar sus primeros assemblages a finales de 1963 preguntándose si no podría vender algo. Después, en 1968, construye en Bruselas la ficción del Musée d'Art Moderne, Département des Aigles en medio del ambiente de revuelta social con la intención de escenificar el enfrentamiento entre la violencia institucional y la violencia poética. La huella de esta experiencia justifica posteriormente la concepción de exposiciones retrospectivas o antológicas como otras formas de ficción y la idea de Décor deviene la síntesis de sus interrogantes sobre la función social de la obra de arte. Lógicamente, la repercusión del trabajo de Broodthaers y su relación con las instituciones artísticas - galerías, museos, ferias de arte, macroexposiciones, bienales, etc. - es de lo más interesante.

La autoría de Broodthaers constituye un modelo de utopía, pero no se trata de una utopía romántica pura sino de una utopía bastarda y mestiza que actualiza los legados artísticos de Mallarmé, de Baudelaire, de Duchamp, de Schwitters y de Manzoni. Este modelo de autoría consigue ser una forma de ejercer la libertad artística y de preservar la memoria: una estrategia de resistencia y de supervivencia espiritual, lo cual resulta hoy día muy estimulante. 


\section{ABSTRACT}

In the context of contemporary art, an investigation centred in Marcel Broodthaers' authorship is anything but casual. The examination of his artistic career focused both theoretically and critically allows us to value his work as heterogeneous and coherent rather than as a series of experiments which includes poetry, photography, cinema or sculpture in the strict sense of the genres.

Globally, his proposals turn around the question of both the role of art and also the role of the artist in society. Broodthaers began to make his first assemblages at the end of 1963 wondering whether he might sell anything. Later on, in 1968, he built in Brussels the fiction Musée d'Art Moderne, Départament des Aigles in the middle of a social atmosphere of revolt intending to put into stage the confrontation between institutional violence and poetic violence. The impression left by this experience justifies eventually the conception of retrospective or anthological exhibitions as other forms of fiction, and the idea of Decor becomes the synthesis of his queries about the social function of the work of art. However, the repercussion of Broodthaers' work and his relationship with the artistic institutions - galleries, museums, fairs of art, macroexhibitions, etc. - is most interesting.

Broodthaers' authorship constitutes a model of utopia. Yet it is not a pure romantic utopia but a bastard and hybrid utopia which updates the artistic legacy of Mallarmé, Baudelaire, Duchamp, Schwitters and Manzoni. This model of authorship becomes a way to exert artistic freedom and also to preserve the memory: a strategy of resistance and spiritual survival which nowadays proves to be rather exciting. 
ÍNDEX GENERAL 


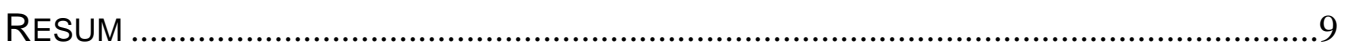

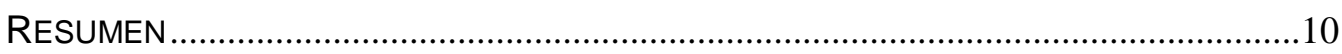

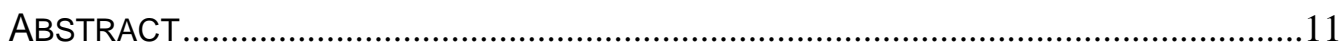

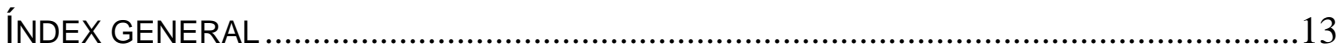

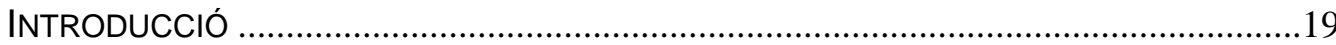

1. Marcel Broodthaers 1924 - 1976. Darrere l'empremta de l'experiència...................................35

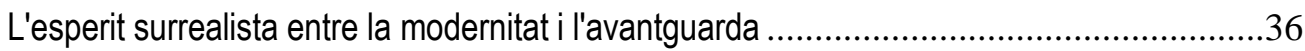

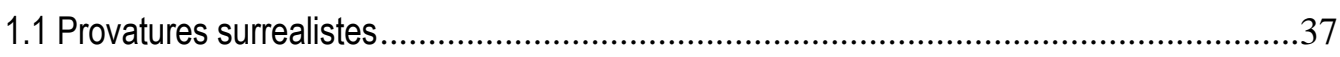

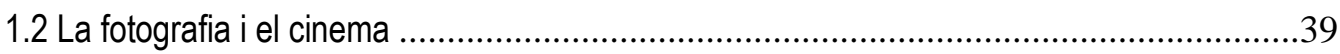

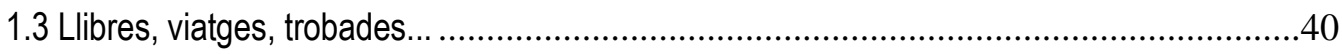

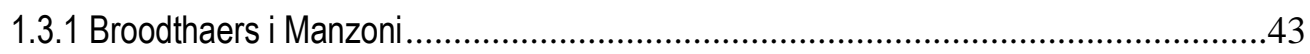

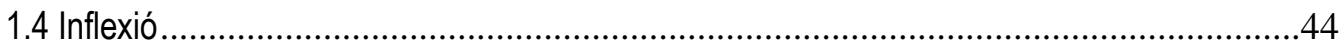

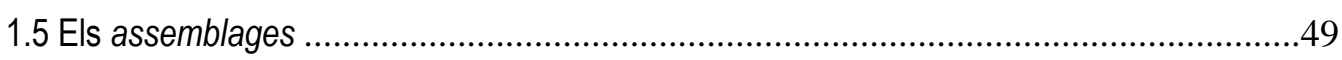

1.6 Les exposicions i el Musée d'Art Moderne Département des Aigles ...................................50

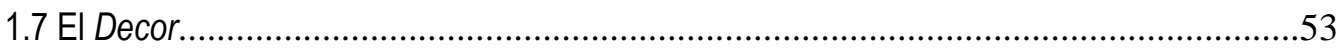

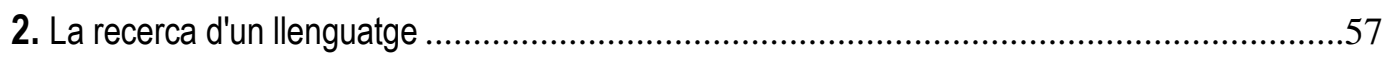

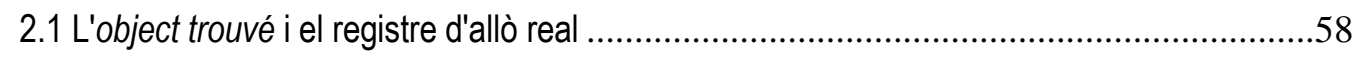

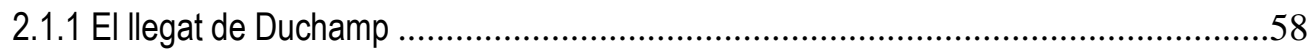

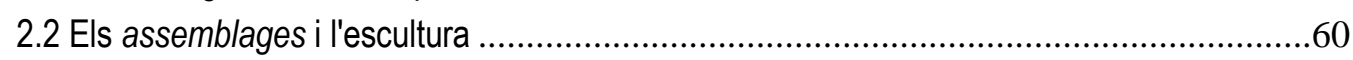

2.3 La pintura, la fotografia i la influència de René Magritte ...................................................64

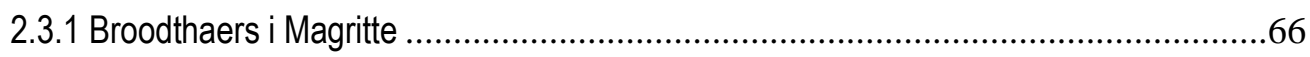

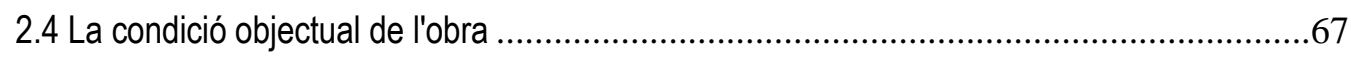

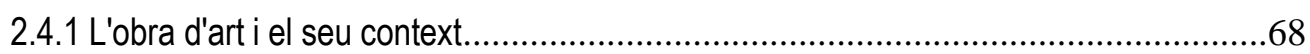

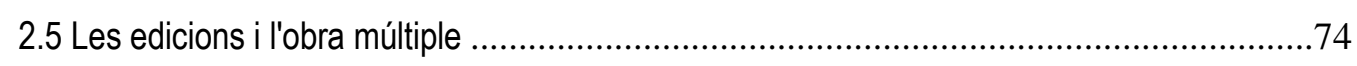

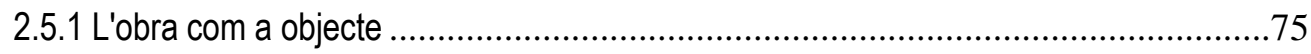

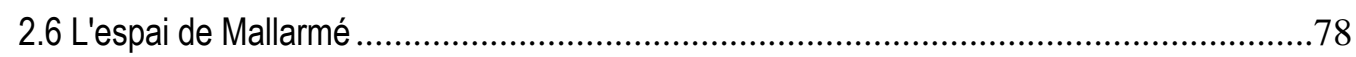

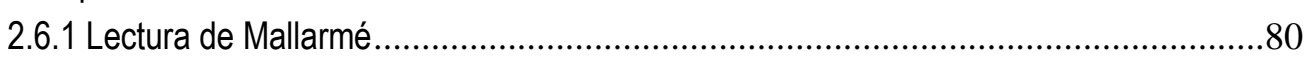

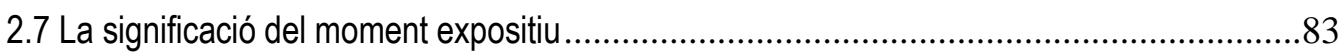

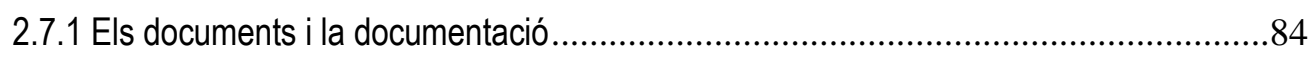




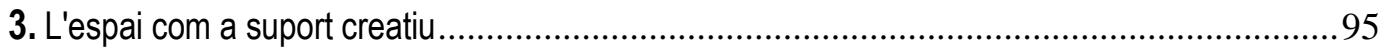

El Musée d'Art Moderne Département des Aigles: Obertura..............................................96

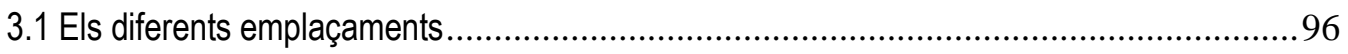

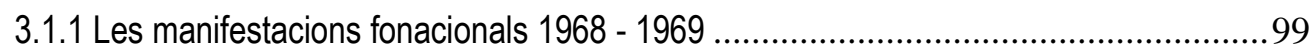

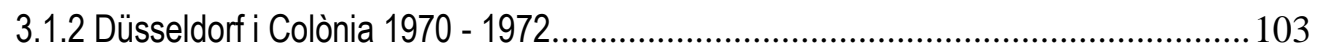

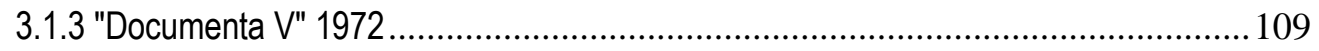

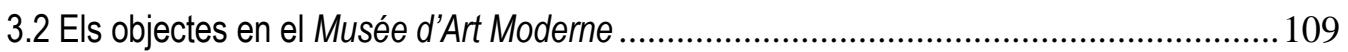

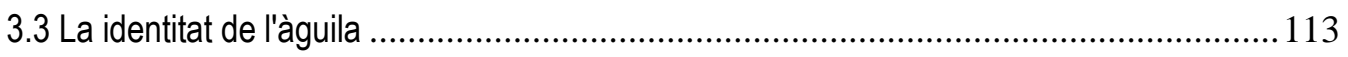

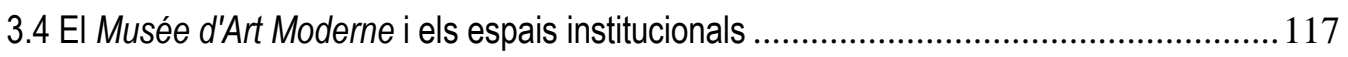

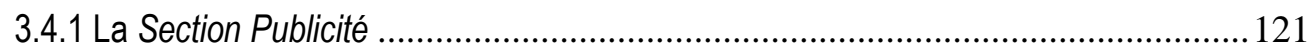

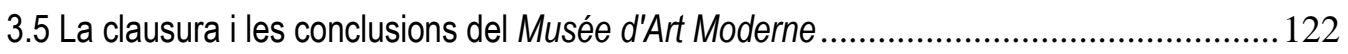

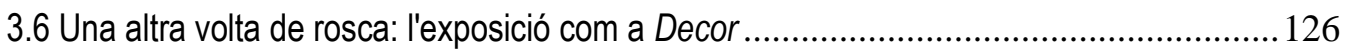

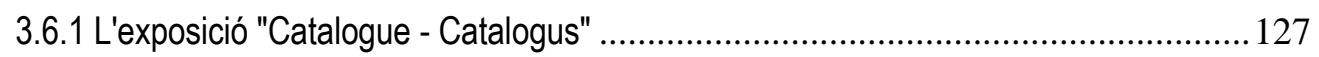

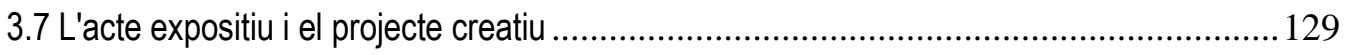

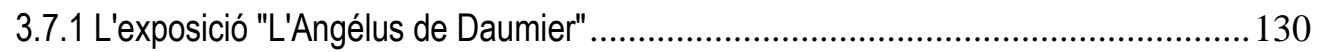

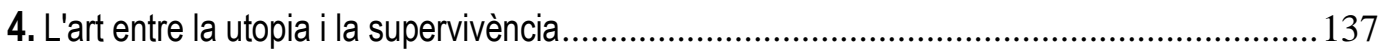

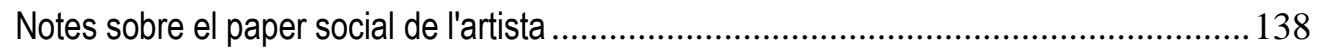

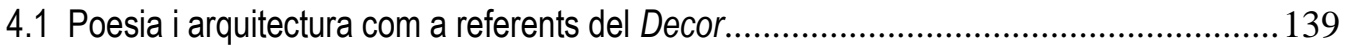

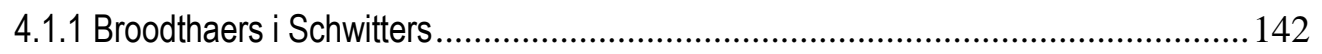

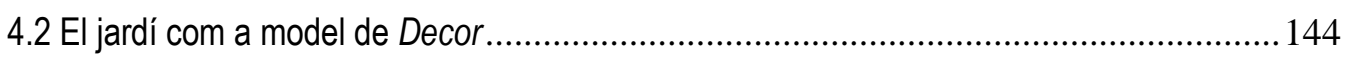

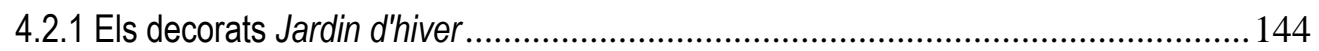

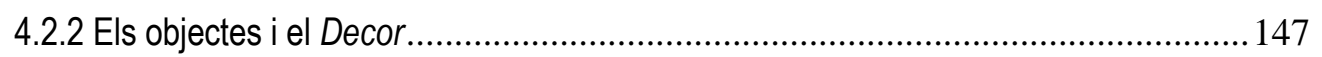

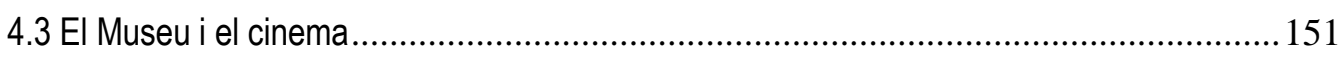

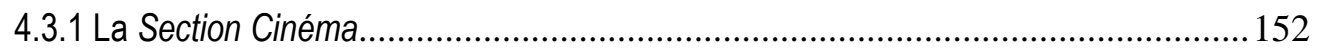

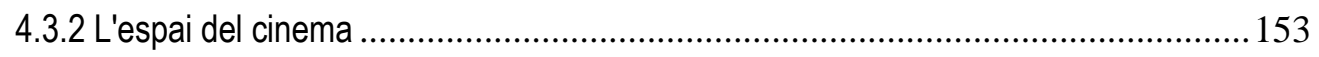

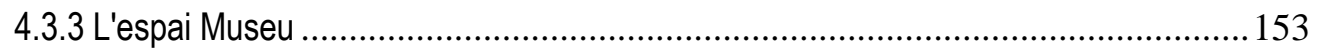

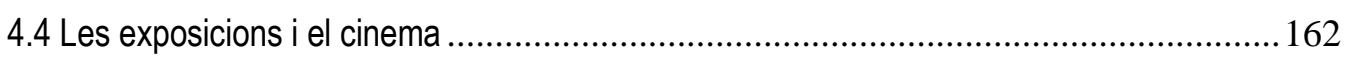

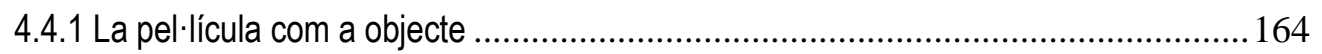

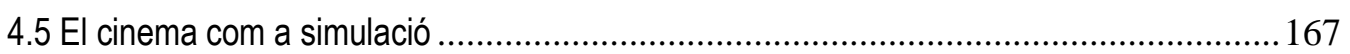

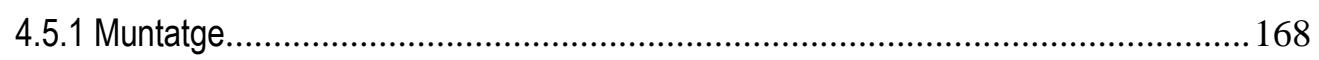

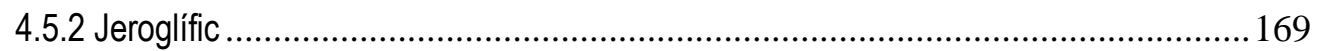

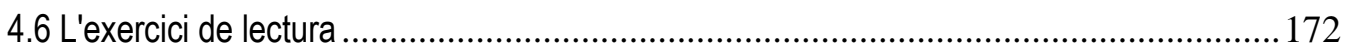

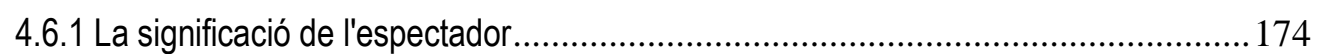

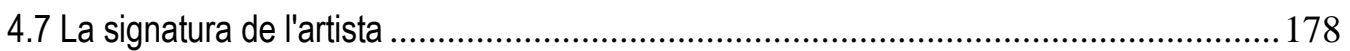

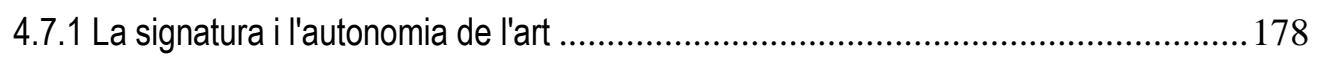

4.7.2 Legitimació i subversió de l'objecte mitjançant la signatura .................................... 182

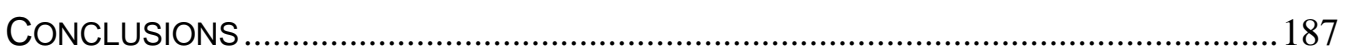




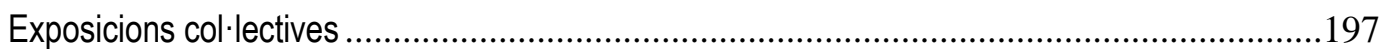

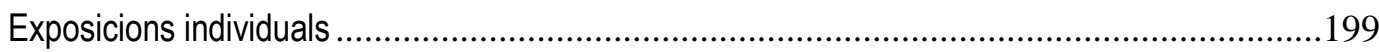

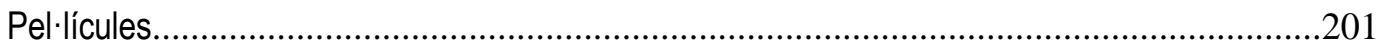

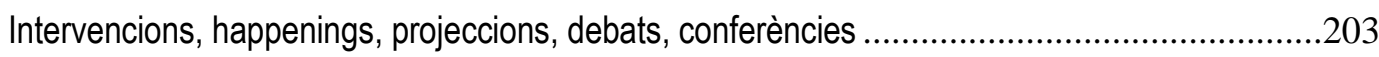

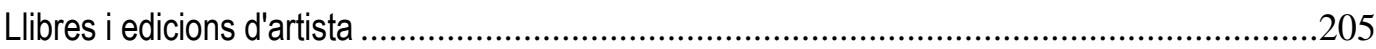

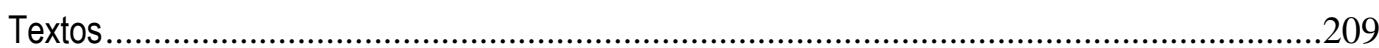

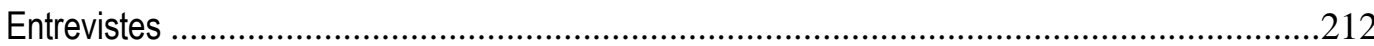

AnNeX 2. ReCulL de textos de MARCEL BroOdthaERS .....................................207

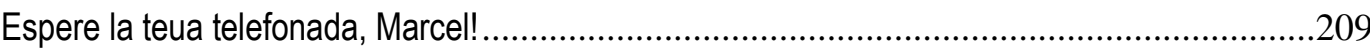

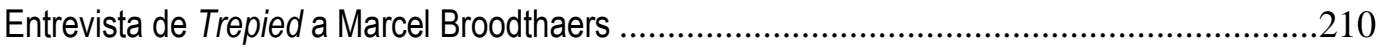

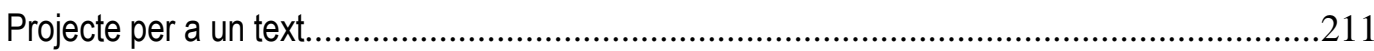

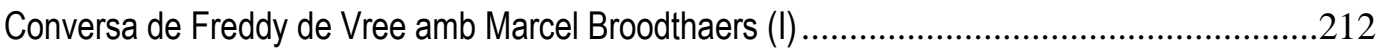

Conversa de Freddy de Vree amb Marcel Broodthaers (II) .....................................................214

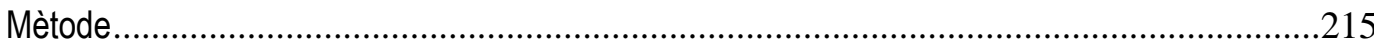

Conversa de Jürgen Harten i Katarina Schmidt amb Marcel Broodthaers ...............................216

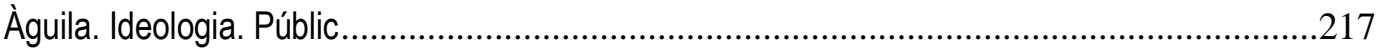

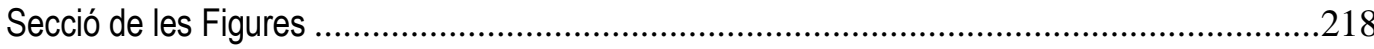

El Musée d'Art Moderne Département des Aigles és simplement una mentida ........................219

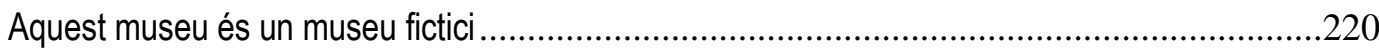

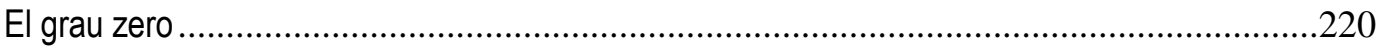

Conversa de Freddy de Vree amb Marcel Broodthaers (III) ................................................221

Deu mil francs de recompensa. Entrevista a Marcel Broodthaers .............................................223

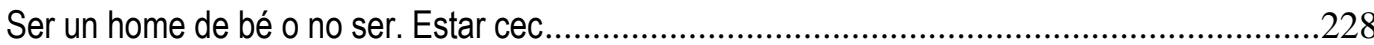

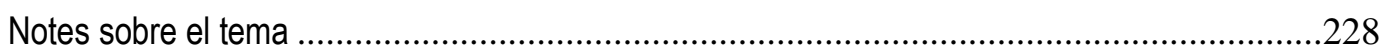

És l'Àngelus qui somnia. L'última entrevista a Marcel Broodthaers ..........................................229

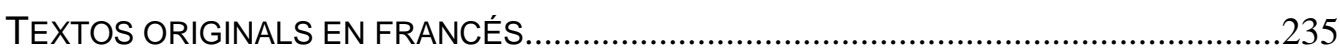

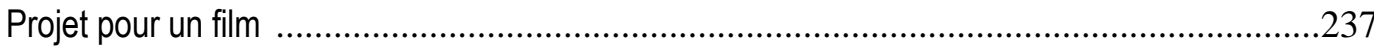

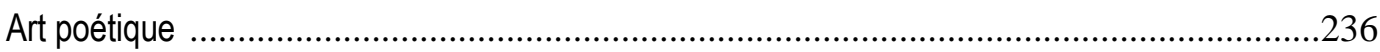

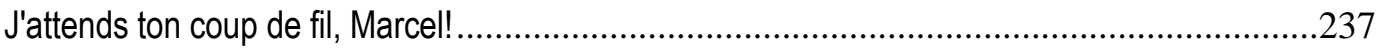

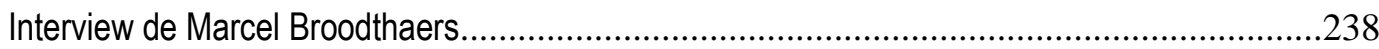

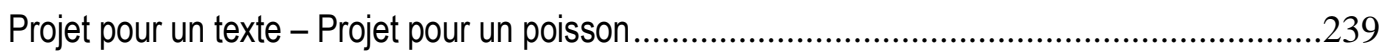

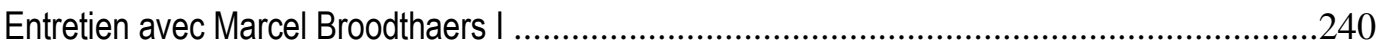

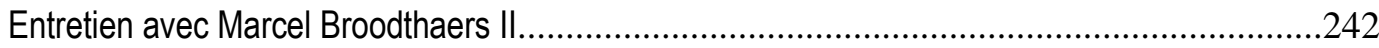

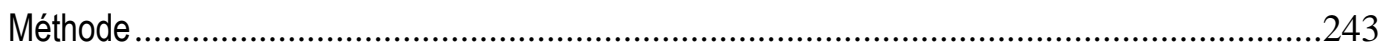

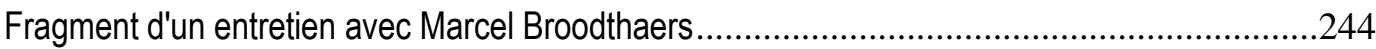

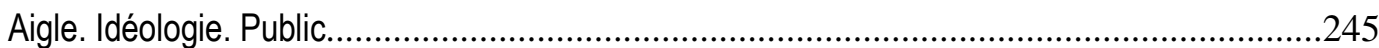

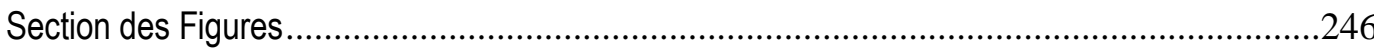


Le Musée d'Art Moderne Département des Aigles est tout simplement un mesonge.

Ce musée est un musée fictif 248

Le degré zéro 249

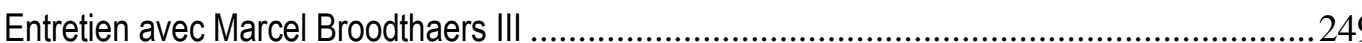

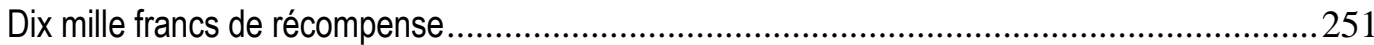

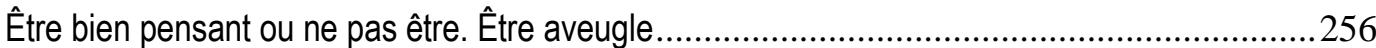

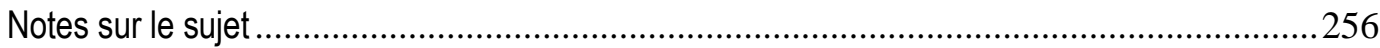

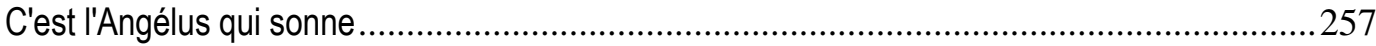

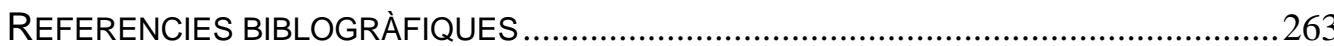

Textos de Marcel Broodthaers. Referències comentades.................................................265

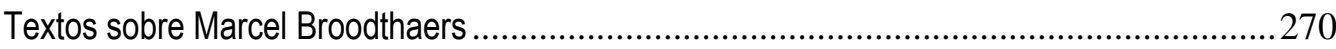

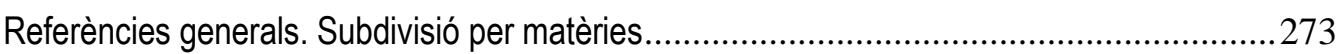

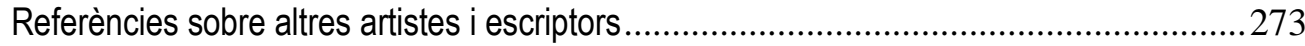

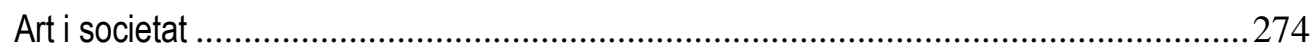

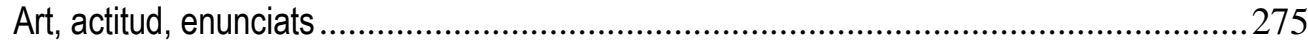

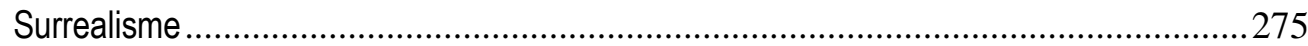

Pràctiques objectuals, pop art i nouveau réalisme ..........................................................276

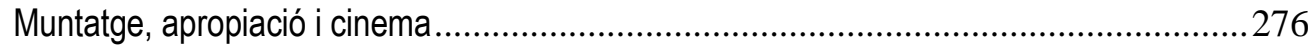

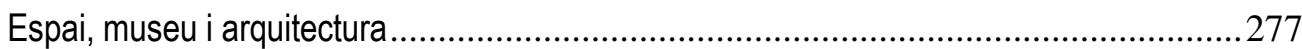

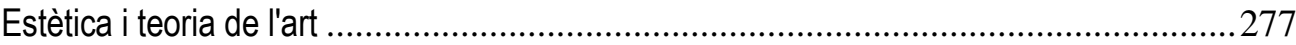

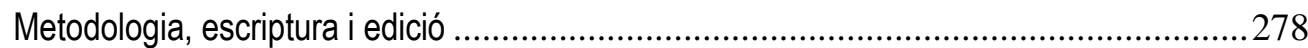

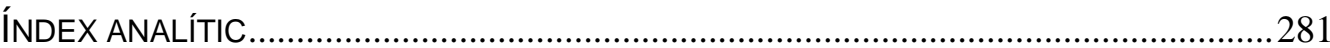


INTRODUCCIÓ 


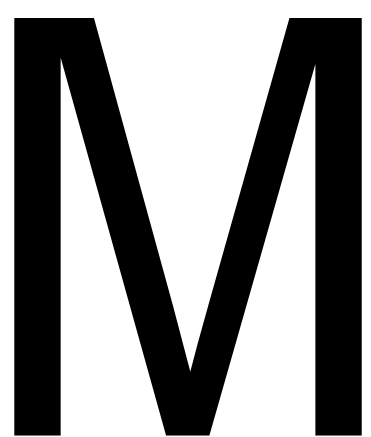

ARCEL Broodthaers està considerat una de les referències obligades de l'art contemporani. En els últims vint-i-set anys, el seu treball ha recorregut les principals galeries $\mathrm{i}$ museus d'Europa i d'EuA $i$ ha sigut objecte d'estudi dels més prestigiosos investigadors. Ara mateix, si introduïm el seu nom en la finestra de recerca del Google obtindrem centenars de referències. És lògic que siga així. Això no obstant, no deixa de cridar l'atenció la generalitat d'aquest consens afirmatiu i unànime sobre un autor que ha transcendit justament en qualitat d'artiste terrible per donar una visió molt crítica del funcionament de les institucions artístiques i, sobretot, del paper de l'art i de l'artista en la societat contemporània.

La relació entre la societat i la cultura es comporta com un trompe-l'oeil en molts aspectes. Això vol dir que, a grans traços, el discurs institucional versa sobre l'art com a discurs i, alhora, el discurs de l'art versa sobre el discurs institucional. Broodthaers mateix en va ser plenament conscient $i$, actualment, la situació no ha canviat massa: més prompte s'han perfeccionat les estratègies per ambdues parts. Per aquests motius, molts creadors ens preguntem, en aquestes condicions, si és possible seguir formulant preguntes i mantenir una postura individual; inclusivament ens preguntem si això mateix és necessari, per què i per a qui. En aquestes condicions, ens preguntem què significa ser artista.

El secret de l'èxit de Broodthaers radica en la validesa contrastada dels seus resultats - fins on hauria arribat? - ; això no obstant, el seu treball mai no té el mateix significat per a una institució, per dinàmica que siga, o per a un teòric que per a un artista.

La recerca, la investigació en el camp de les belles arts té grans dosis d'empirisme. Aquesta particularitat li aporta bona part de la seua empremta d'originalitat i d'efectivitat, però al mateix temps camufla la seua condició de praxi. Aquest és el nostre gran maldecap. Per això, una de les coses que, personalment, més em va cridar l'atenció de Broodthaers com a artista és l'absència de sorolls en aquest canal. És a dir, Broodthaers treballa des de la certesa d'estar desenvolupant una praxi. De fet, davant el desconcert que sovint generava el seu treball, ell es feia el despistat i eixia a parlar de la seua condició d'amateur, d'artista autodidacta.

Així doncs, aquesta investigació sobre Broodthaers s'ha centrat en l'anàlisi dels seus resultats no tant com una sèrie d'execucions heterogènies sinó com una praxi. Aquest enfocament del fenomen és el fet que ha dut a formular la hipòtesi de la utopia com a model de l'autoria singular de Broodthaers. Aquesta hipòtesi és una paradoxa. Utopia és un concepte amb una densitat filosòfica i històrica que mai no podem ignorar. En el cas de Broodthaers, però, no es pot parlar d'una utopia pura, d'una utopia romàntica, sinó d'una utopia bastarda i contingent. 
Si considerem que la utopia és una cosa irrealitzable, la hipòtesi seria insostenible, però es tracta de la utopia com a ideal, com a model. Però, quin tipus de model i en quin sentit? Un model de referència d'allò que pot ser la pràctica artística. Quant a Broodthaers, la utopia com a model consisteix a percebre $\mathrm{i}$ a comprendre la pràctica artística com un terreny de maniobres, com un marc per formular preguntes i per buscar solucions, com una postura personal respecte de l'art les conseqüències de la qual s'estenen a l'àmbit d'allò social i d'allò polític. En aquest sentit, sí és possible plantejar la utopia com un model de praxi artística i, en el cas de Broodthaers, es pot parlar, a més a més, d'una utopia pervinguda.

El terme autoria prové de l'àmbit del dret penal, encara que dins del camp de la teoria de l'art el venim llegint i escoltant des de fa temps. S'entén que quan parlem d'autoria en l'àmbit de les arts plàstiques ens referim al conjunt de causes i d'efectes promoguts per un autor o per un conjunt d'autors les consequiències dels quals conflueixen particularment en una obra $i$ en tot un discurs artístic. Tanmateix, es tracta d'un concepte comú i singular per a qualsevol artista que en cada cas, però, abasta un significat diferent. La valoració de l'autoria depén, en primera instància, de l'autor en qüestió i, després, de la particularitat dels enfocaments del concepte mateix, del punt de vista que fa sorgir una investigació i de la relació entre tots aquests factors, així com de les lectures fixades i possibles en el si d'una col·lectivitat.

Fins ara, el treball de Broodthaers ha sigut objecte de nombroses investigacions els resultats de les quals s'han vist materialitzats principalment com a exposicions monogràfiques, algunes a gran escala $i$ altres amb un perfil temàtic. Concretament en el context de l'Estat espanyol va tenir lloc una gran exposició monogràfica el 1992 a Madrid, a poc de temps d'una altra similar que va fer-se a París el 1991, i ambdues van estar sota la comissaria de Catherine David. Després, el 1997, va haver-hi a Barcelona una altra exposició monogràfica, però dedicada al cinema de Broodthaers. Un dels comissaris d'aquesta exposició, Manuel Borja-Villel (director actual del MACBA), és una de les persones que hi han investigat i promogut la seua obra assíduament. Així, Broodthaers ha estat present també en exposicions com Els límits del museu (1995), Mirades (sobre el museu) (1996), Antagonismes. Casos d'estudi (2001), i ara, inclusivament, és un dels pilars de la col·lecció d'art contemporani del MACBA.

Altrament, de treballs precedents, n'hi ha alguns que cal destacar. En primer lloc, hi ha diverses persones, responsables d'institucions i investigadors, com són Johannes Cladders, Freddy de Vree, Jürgen Harten i Yves Gevaert que a causa de haver tingut contacte estret amb Broodthaers han aportat detalls i punts de vista molt importants sobre el seu treball. Després, és menester esmentar Benjamin Buchloh (investigador, professor i editor fundador de la revista October), un dels primers que va recollir i va difondre estudis teòrics i crítics sobre Broodthaers en el context d'EUA, de l'Amèrica en general i de part d'Europa. Els temes més rellevants aleshores van ser el Museu fictici (per compte de: Johannes Cladders, Michael Compton i Benjamin Buchloh), la seua relació amb Mallarmé i amb Baudelaire (Benjamin Buchloh, Yves Gevaert i Dore Ashton, respectivament) i l'anàlisi filosòfica de la lectura de Jacques Lacan present en l'obra de Broodthaers (Birgit Pelzer).

Més recentment, al llarg de la dècada passada, els estudis sobre Broodthaers s'han centrat en aspectes molt concrets del seu treball: l'arquitectura com a referent de diversos projectes (Maurice Culot), la Section Publicité del Museé d'Art Moderne, Département des Aigles (Benjamin Buchloh, Maria Gilissen i la galerista Marian Goodman) l'obra gràfica i les edicions (Wilfried Dichoff i Michael Compton), el cinema dins del context de la seua producció poètica i plàstica (Jean-Cristophe Royoux i Bruce Jenkinns), els decors (Yves Gevaert i Philippe Cuenat), etc. 
Tanmateix, cal fer menció de la influència que va tenir Broodthaers sobre tota una generació d'artistes que des dels anys vuitanta van començar a enfocar el treball artístic com un instrument epistemològic. Avui dia, en el segle XXI, Broodthaers ocupa un lloc destacat en museus d'art contemporani i en l'àmbit universitari. A nivell d'actualitat artística, Broodthaers representa una figura consagrada que tothom admira i ningú desacredita. Sembla, però, que en general les institucions difonen una lectura massa teòrica de la seua obra, una lectura massa difícil d'aprehendre per part dels espectadors que, alhora, són artistes. Això no obstant, en el segle XXI vivim en una realitat sociològica que no és massa diferent de la que va tractar Broodthaers; això si, amb tres dècades més d'arrelament. Per això, en el segle XXI és menester llegir Broodthaers molt a prop. Allò més important, però, és que la seua experiència com a creador, com a individu, i la de molts espectadors i artistes contemporanis són molt pròximes. Només cal adonar-se'n. Broodthaers és com Lao Tse i està esperant ser llegit.

Broodthaers ha sigut definit com un artista difícil vist que el conjunt del seu treball es desmarca de qualsevol classificació. I tant. És difícil catalogar el treball d'un artista que sistemàticament ens denega aquesta possibilitat. Per això és perfectament constatable que la seua catalogació general és una comesa amb difícil justificació teòrica. Justament allò d'hermètic $i$ allò d'excèntric, allò d'utòpic $i$ allò d'escèptic que es manifesten en la seua actitud posen en relleu, per una part, el grau d'implantació que gaudeixen els models d'autoria tradicionals i, per l'altra, la forma en què l'autoritat de l'individu, particularment de l'artista, es troba políticament desautoritzada. Les investigacions i les exposicions temàtiques, en canvi, han aconseguit registrar i analitzar el treball de Broodthaers sense violentar els seus paràmetres. A causa d'això, s'ha vist la necessitat d'acotar ben prompte el tema sobre el qual s'ha formulat la hipòtesi d'aquesta investigació: el model d'autoria de Marcel Broodthaers.

La finalitat d'aquest treball ha sigut, en primer lloc, centrar un tema que siga capaç de despertar motivació $i$, després, realitzar una investigació d'acord amb els paràmetres científics $i$ acadèmics que s'exigeixen a una tesi doctoral. Les expectatives personals quant al treball han sigut avaluar críticament les conclusions i extraure experiències que puguen servir per a resoldre problemes en el camp de la creació artística i també per a promoure nous dubtes, noves preguntes. Quin tipus de solucions i de preguntes podrien sorgir? Això depén, òbviament, dels interessos que tinguem i de la lectura que en fem. Globalment, és a dir, fent confluir oportunament tots els interessos esmentats anteriorment, la finalitat que s'ha perseguit és formular un problema teòric d'interés en el camp de la teoria i de la pràctica artístiques, resoldre'l, obtenir resultats teòrics concrets i traure conclusions de profit tant per als investigadors com per als artistes.

Així doncs, tenint en compte tant la finalitat esmentada com el coneixement dels treballs precedents i el context temàtic acotat, s'han formulat tres objectius bàsics, d'on s'ha derivat tot el desenvolupament d'aquesta tesi doctoral, els quals s'exposen a continuació:

1. Examinar la trajectòria artística de Broodthaers no tant com una sèrie de successos $\mathrm{i}$ d'experiments heterogenis sinó com una praxi

2. Analitzar l'autoria de Broodthaers examinant la seua pràctica artística de forma sistemàtica i detallada i aprofundir en els seus aspectes productiu i discursiu.

3. Sintetitzar les principals idees derivades de l'anàlisi de l'autoria de Broodthaers i destacar els interrogants que planteja respecte al paper de l'artista i a la finalitat de l'art. 
Fins ací, en formular la hipòtesi (la utopia pervinguda), en definir del tema (el model d'autoria de Marcel Broodthaers) i havent parlat del motius i de la finalitat del treball, s'ha explicat el context de justificació d'aquesta TESI DOCTORAL.

A continuació, cal passar a la seua classificació. Pel que fa a la relació d'aquest treball de tesi amb el seu camp (les arts plàstiques o Belles Arts) es tracta d'una investigació bàsica perquè el seu objecte és el coneixement i la comprensió d'un fenomen concret (l'autoria de Marcel Broodthaers), encara que els seus resultats ben prompte poden donar lloc a qualsevol utilitat experimental posterior. D'altra banda, per la seua dimensió i pel seu abast temporal, es tracta d'un treball monogràfic i contemporani. Això respecte, hi és menester remarcar que els aspectes històrics, panoràmics i fenomenològics relacionats amb el tema i amb l'autor s'han tingut en compte com cal, tal i com es pot verificar en l'apartat REFERÈNCIES GENERALS. SUBDIVISIÓ PER MATÈRIES en el capítol de referències bibliogràfiques. L'exposició escrita, però, n'ha sigut selectiva i sintètica deliberadament per tal de no distraure de l'objecte de la investigació. Així, els aspectes esmentats no han conformat un únic capítol, sinó que han sigut exposats al llarg de tot l'escrit i desenvolupats en funció d'analitzar, de contrastar i d'unificar caràcters concrets de l'obra i de l'autoria de Broodthaers. De tot això es deriva que, quant a la naturalesa i al caràcter del treball, es tracta d'una investigació teòrica sobre causes i efectes, però que també contempla amplis estudis descriptius i puntuals interpretacions.

Altrament, cal definir el context teòric d'aquesta investigació. De primer, i en sentit general, s'ha tingut en compte el marc de la metodologia de la investigació científica. De segon, i quant a la necessitat d'adequació del marc general, s'ha fet servir la crítica d'art com una disciplina instrumental específica.

Dins del camp de la metodologia de la investigació científica s'han analitzat, s'han confrontat i s'han valorat diferents referències cercant i seleccionant els mètodes més adients amb el context teòric general on s'emmarca aquest treball en tant que Tesi Doctoral. Així doncs, les referències teòriques utilitzades són diverses. En primer lloc, i com a punt d'eixida, està el treball d'Umberto Eco [Cómo se hace una tesis. Técnicas y procedimientos de estudio, investigación y escritura (1977)]. Per últim, i complementàriament, per raó de resoldre dubtes i problemes concrets sorgits a peu d'obra, estan els treballs d'autors espanyols com són, principalment, Franch Alcina [Aprender a investigar. Métodos de trabajo para la redacción de tesis doctorales en humanidades y ciencias sociales (1994)], Olegario García [Metodología de la investigación científica. Cómo hacer una tesis en la era de la informática (1994)] y Restituto Sierra [Tesis doctorales y trabajos de investigación científica. Metodología general de su elaboración y documentación (1986)]. De tot això s'han pogut treure moltes respostes als dubtes de la inexperiència així com solucions concretes a les exigències pròpies de la investigació en el nostre context específic (regional, universitari i camp artístic-teòric).

Quant al camp de la crítica d'art s'han fet servir els treballs de Román de la Calle (concretament els textos "Crítica y creatividad: las funciones del texto crítico", "John Dewey: experiencia estética y crítica de arte" i, en general, el llibre En torno al hecho artístico) perquè els seus estudis sobre la crítica d'art com a disciplina instrumental de la estètica aporten un sòlid basament científic $i$, per tant, constitueixen excel-lents referents què es poden fer servir com un context teòric específic per a abordar la investigació científica en el camp de les arts. Això respecte, és menester hi aportar els principals basaments metodològics que s'han reciclat a partir dels treballs de Román de la Calle. 
Com a punt d'eixida, està el succés crític més enllà de la crítica i dins d'aquesta categoria es pot incloure, encara que no sempre, la tasca d'investigació en el camp de les arts. La condició és que hi haja una confluència entre el succés científic i el succés crític. D'altra banda, la qüestió de l'originalitat en referència a la contribució científica d'un treball pot confluir amb la qüestió de la creativitat de la crítica. En ambdós casos s'han de conjugar la intuïció en el moment d'aprehendre un fenomen, la capacitat intel-lectiva per a sistematitzar el treball dins del seu camp i l'habilitat per a formular les idees creativament. I, tanmateix, està la quiestió de la funció referencial del text crític, el comportament de la qual es pot fer servir com a model en un treball científic dins del camp de les arts. Tal i com planteja Román de la Calle, la funció referencial fonamenta l'estatut de la crítica, però, sobretot, consolida el seu estatut epistemològic, la qual cosa constitueix el vertader fonament d'un treball científic.

Per últim, i després d'exposar breument els principals basaments metodològics del treball, queda remarcar que totes les referències esmentades al llarg de l'explicació del context teòric d'aquest treball estan detallades en l'apartat corresponent de la bibliografia. Una vegada definits i analitzats el context de justificació i el context teòric, arriba el moment d'abordar el desenvolupament de la investigació així com els procediments i els materials implicats.

El desenvolupament de la TESI DOCTORAL és resultat d'una investigació íntegra que ha comprés dos processos bàsics: la documentació (des del març del 2001 fins a l'octubre del 2001, a temps complet, amb interrupcions) i l'elaboració (des del març del 2002 fins al juny del 2003, a temps parcial, sense interrupcions).

Al llarg del procés de documentació, la revisió bibliogràfica es va iniciar a partir del material de la biblioteca personal i es va completar amb títols de la biblioteca central de la Universitat Politècnica de València, de la biblioteca de la Facultat de Belles Arts i de la biblioteca del Departament d'Escultura. Com a punt d'eixida es va fer servir la bibliografia del Treball d'Iniciació a la Investigació (Estrategias discursivas y significación del espectador en la obra de Marcel Broodthaers). A continuació, per a la recerca bibliogràfica centrada ja en la hipòtesi del treball, s'ha hagut de recórrer a centres de documentació especialitzats com ara són la Fundació Tàpies i el MACBA (ambdós a Barcelona) perquè són els únics (a l'Estat espanyol) que contaven amb prou de materials específics (llibres i documents sobre Marcel Broodthaers) i amb el suport necessari.

El procés d'elaboració va començar en paral-lel al de documentació ja que aquesta tasca contempla des de les fitxes bibliogràfiques fins a l'escriptura del text. Per últim, s'ha realitzat la revisió i l'edició del escrit. En el cas de les fitxes - bibliogràfiques, de contingut, d'idees, etc. - es tracta de material produït o recuperat durant el procés d'investigació mateix (algunes havien sigut generades al llarg dels estudis de doctorat o durant el treball d'iniciació a la investigació). Altrament, les notes han sigut, més que un material, un suport de treball en tota regla perquè han permés arreplegar idees, ampliar-les, elaborar esquemes i registrar resultats.

La naturalesa teòrica d'aquesta investigació ha condicionat que els materials emprats siguen bàsicament materials d'estudi i d'escriptura: llibres, documents (principalment textos, fotografies i pel-lícules), fitxes (de bibliografia, de referències, d'idees, d'esquemes, etc.) i notes. En parlar de materials, també cal destacar la gran ajuda que ha representat treballar amb un ordinador personal equipat amb processador de textos i d'imatges. Com que ara mateix estan a l'abast de tothom, sembla un lloc comú que no cal esmentar. La realitat és, però, que de l'ús que habitualment se'n fa depenen molts detalls importants que influeixen 
necessàriament tant en el procés com en els resultats del treball. De tot això cal destacar principalment els recursos per a generar i per a treballar amb textos llargs així com les ferramentes de revisió i d'edició.

L'elaboració del text ha jugat un paper molt important en l'elaboració de la tesi perquè en un treball d'aquest tipus es necessita de la paraula per a fixar, per a mirar, per a valorar i per a acceptar les nostres percepcions i els nostres pensaments. Per això, crec que la recerca de les paraules, dels ritmes i dels intervals que millor expressen els nostres pensaments és també un treball d'investigació. Inclusivament, moltes vegades la paraula construeix els pensaments. Tanmateix, l'escrit de la TESI DOCTORAL, és a dir, allò que és l'objecte llegible i avaluable, constitueix la materialització d'un procés intel-lectual en el qual hi ha implicats molts procediments de treball i, en aquest sentit, l'escrit és la síntesi de la investigació.

En començar l'anàlisi del desenvolupament de la investigació és important assenyalar que al llarg dels processos de documentació i d'elaboració ha hagut un lligam estret entre els procediments implicats i les diferents parts estructurals del text de la tesi. Això vol dir que:

- La recerca d'idees ha orientat, inicialment, la revisió de la bibliografia i després la recerca d'altres fonts i documents. Per consegüent, el capítol de REFERÈNCIES BIBLIOGRÀFIQUES va funcionar des del principi com un suport del treball per a la revisió, per al registre i per a la selecció de referències.

- Les fitxes i les notes on s'han apuntat idees han servit per a aclarir els motius i la finalitat de la investigació, per a formular la hipòtesi i els objectius al llarg del treball i, després, per a exposar-los de forma adient a la introducció.

- Mitjançant l'elaboració de mapes d'idees i, posteriorment, d'un esquema ordenat s'ha obtingut l'íNDEX GENERAL, el qual s'ha fet servir com un esborrany de l'estructura del text i ha permés visualitzar i corregir la relació entre les parts i el conjunt, així com fer un seguiment del desenvolupament de la investigació.

L'escrit de la TESI DOCTORAL s'ha estructurat en quatre parts bàsiques o blocs de text argumentatiu i dos annexos, a més a més de les referències bibliogràfiques, la introducció, les conclusions i, d'altres parts funcionals com són ara el resum, la llista d'abreviacions, l'índex general i l'índex analític. Quant a les quatre parts o blocs de text argumentatiu i als annexos és menester remarcar que, tant els uns com els altres, responen al registre i al desenvolupament dels tres objectius bàsics de la investigació.

Com s'ha procedit fins a arribar a l'estructura esmentada i quina relació existeix entre els objectius i la composició del text? En síntesi, s'ha procedit de la manera següent:

- De l'examen de la trajectòria artística de Broodthaers com una praxis (objectiu 1) s'han derivat el bloc 1. MARCEL BROODTHAERS 1924 - 1976. DARRERE L'EMPREMTA DE L'EXPERIÈNCIA i l'annex 1. BIOGRAFIA RAONADA DE MARCEL BROODTHAERS.

- De l'anàlisi de l'autoria de Broodthaers a partir de l'examen sistemàtic i detallat de la seua pràctica artística (objectiu 2) s'han derivat dos blocs de text argumentatiu: el 2. LA RECERCA D'UN LLENGUATGE i el 3. L'ESPAI COM A SUPORT DISCURSIU.

- De la síntesi de les idees extretes de l'anàlisi de l'autoria de Broodthaers destacant les interrogants que planteja respecte al paper de l'artista i a la finalitat de l'art (objectiu 3) s'ha derivat el bloc 4. L'ART ENTRE LA SUPERVIVÈNCIA I LA UTOPIA, i l'annex 2. RECULL DE TEXTOS DE MARCEL BROODTHAERS. 
Ara és el moment d'exposar el procés de desenvolupament del treball. Com s'ha procedit i quina relació hi ha entre el procés i l'escrit? A partir d'aquest punt, el desenvolupament del treball ha estat lligat a la seqüenciació i a l'execució de diferents procediments d'investigació en funció dels objectius formulats. Els procediments s'han numerat per fer més fàcil l'exposició i la lectura d'un procés abstracte. A continuació s'exposen els detalls:

1. Revisió bibliogràfica i documental dels aspectes ja coneguts.

2. Compilació raonada del treball de Broodthaers consultant totes les fonts a l'abast i recerca de noves referències bibliogràfiques.

3. Confrontació de les fonts, anàlisi i verificació de les dades.

4. Recerca d'elements de judici relacionats amb la hipòtesi general de tesi.

5. Revisió crítica de les fonts i selecció dels elements.

6. Formulació d'una hipòtesi subordinada (la trajectòria artística de Broodthaers com una praxis) per organitzar les referències i les dades obtingudes.

7. Anàlisis de les dades com a contextualització específica del tema (l'autoria de Marcel Broodthaers. Reestructuració de les dades en unitats independents en funció d'enfocaments específics. Elaboració escrita de l'estructura, dels arguments i d'exemples.

8. Plantejament dels continguts de la primera part MARCEL BROODTHAERS 1924-1976. DARRERE L'EMPREMTA DE L'EXPERIÈNCIA i de l'annex BIOGRAFIA RAONADA DE MARCEL BROODTHAERS.

9. Síntesi dels resultats, verificació i formulació de conclusions específiques.

10. Examen detallat de diferents objectes que composen el treball de Broodthaers (escrits, exposicions, projectes, pel-lícules, etc.). Recerca d'elements unificadors en l'autoria i confrontació dels resultats amb la hipòtesi general d'aquesta investigació.

11. Formulació d'hipòtesis específiques per interpretar els resultats (la recerca i l'experimentació artística en funció de la recerca d'un llenguatge; la utilització de l'espai com un suport discursiu)

12. Examen sistemàtic dels objectes (escrits, exposicions, projectes, etc.) tenint en compte tant els resultats ja obtinguts com les hipòtesis.

13. Revisió bibliogràfica, anàlisis de les fonts directes i recerca de noves referències.

14. Verificació i argumentació dels resultats.

15. Elaboració de mapes d'idees i d'esquemes per analitzar, en cada cas, les relacions entre els distints objectes.

16. Organització sistemàtica i detallada de l'esquema per a sintetitzar idees.

17. Plantejament de les hipòtesis com a unitats de text independents (el bloc 2. LA RECERCA D'UN LLENGUATGE i el bloc 3. L'ESPAI COM A SUPORT DISCURSIU) amb continguts específics. Desenvolupament de cada contingut com un capítol o un apartat interrelacionats per cada hipòtesi. 
18. Examen crític de les fonts específiques (escrits, exposicions, projectes, etc.) per a desenvolupar d'exemples argumentatius amb recursos descriptius i comparatius.

19. Revisió bibliogràfica i documental; confrontació d'idees.

20. Confrontació i justificació de les hipòtesis que organitzen els dos blocs de text.

21. Síntesi dels resultats i formulació de conclusions específiques.

22. Recompte dels resultats obtinguts (la qual cosa requereix repassar el procés que compren la sèrie de procediments des del 9 fins al 15).

23. Recerca i formulació d'una hipòtesi-resum (l'art com a instrument, l'art entre la utopia i la supervivència) com una idea unificadora per a una última part (bloc 4. L'ART ENTRE LA SUPERVIVÈNCIA I LA UTOPIA).

24. Estructurar cadascun dels resultats verificats com un capítol o com un apartat diferenciat, però tots interrelacionats per la hipòtesi-resum.

25. Revisió crítica dels resultats, síntesi de les conclusions específiques.

26. Verificació de la hipòtesi general. Repàs de les fonts específiques i documentals.

27. Selecció crítica de fonts específiques i documentals (reproduccions i fotografies d'obres de Marcel Broodthaers: assemblages, quadres, projectes, fotografies, pel-lícules i esdeveniments; poemes, texts, entrevistes, etc.) per incloure-les com a suport il-lustratiu i com a context dels arguments, dels exemples i de les cites textuals presents en les quatre parts principals de l'escrit.

28. Elaboració d'una llista d'il·lustracions i d'un recull de textos (l'annex RECULL DE TEXTOS DE MARCEL BROODTHAERS)

29. Formulació de les conclusions de la investigació.

Fins ací, l'exposició dels procediments implicats en el desenvolupament de la TESI DOCTORAL. Ara resta comentar alguns aspectes relacionats amb l'escrit.

Quant a l'estructura textual de l'escrit, cada part o bloc de text argumentatiu té set capítols numerats. Alguns capítols, però no tots, contenen un o més d'un apartat per facilitar l'exposició i l'argumentació de les idees. Així doncs, el text està estructurat en tres nivells: als blocs els correspon el primer nivell; als capítols, el segon nivell i als apartats, el tercer nivell. Pel que fa als títols de cada part o bloc de text, cal remarcar que guarden relació amb la hipòtesi (específica) que els unifica, tal i com ha quedat explicat en l'exposició dels procediments. Per la seua part, els títols dels capítols i dels apartats es corresponen amb cadascun dels aspectes abordats. Un altra cosa a tenir en compte és que les conclusions específiques dels diferents aspectes abordats apareixen en el text quan el discurs argumentatiu ho requereix, normalment, com a recapitulació.

Així mateix convé explicar altres dues qüestions particulars de l'estructura de l'escrit, les quals necessiten d'esclariment perquè s'aparten una mica d'allò ordinari. Es tracta dels annexos, organitzats com a dues capítols independents i amb una extensió considerable en proporció al conjunt del treball, i del tractament dels aspectes contextuals (fenomenològics, històrics i panoràmics), què no estan remarcats com una unitat independent, sinó disposats al llarg del text. 
Quant als capítols d'annexos, la raó d'incloure'ls és la utilitat de la informació que presenten. Ambdós són resultat del procés de treball la qual cosa ha quedat explicada, en general, en l'exposició dels procediments i, en detall, en les pàgines 187 i 207 d'aquest treball. Això no obstant, ara és menester justificar-los adientment.

En particular, en l'annex BIOGRAFIA RAONADA DE MARCEL BROODTHAERS s'ofereixen una sèrie de dades objectives, contrastades en diverses fonts, sobre l'obra de Broodthaers: quines exposicions individuals va fer, en quines exposicions col-lectives va participar, els textos que va publicar, les pel-lícules que va fer, etc. El propòsit ha sigut, principalment, complementar l'anàlisi del treball de Broodthaers com una praxi. D'altra banda, s'ha estimat que aquestes dades havien d'aparèixer perquè, parlant de l'autoria de Marcel Broodthaers, hi acompleixen el paper de context específic de l'objecte d'estudi.

Pel que fa a l'annex RECULL DE TEXTOS DE MARCEL BROODTHAERS el propòsit ha sigut oferir una sèrie de fonts que il-lustren les opinions i els punts de vista que conformen l'autoria de Broodthaers, igual o potser millor que les reproduccions fotogràfiques dels assemblages, dels projectes o de les pel-lícules que acompanyen l'escrit. Això respecte, cal tenir en compte que Broodthaers és un autor singular amb una producció poètica i crítica prou significativa; inclusivament la seua producció plàstica mateixa és com un centaure: imatge i text alhora. No obstant això, en el moment d'abordar la tasca de recopilació hi ha sigut menester no privilegiar l'obra mateixa i, en canvi, fer servir uns criteris de selecció d'acord amb els objectius de la investigació de tesi. Així, de textos poètics, n'hi ha poca cosa, però prou d'eloqüent, la majoria dels quals es troben integrats en el text com a il-lustracions i com a annex només hi ha la versió en llengua original; de textos crítics, n'hi ha una mostra, la qual és fonamental perquè fa referència a projectes prou complexos quant a l'anàlisi de l'autoria: el Musée d'Art Modern, Département des Aigles i els Decors; i d'entrevistes, en canvi, n'hi ha més, ja que han constituït documents privilegiats per analitzar diferents aspectes de l'autoria al llarg de tota la trajectòria artística de Marcel Broodthaers i, sobretot, n'han esdevingut fonamentals per confrontar i per verificar idees al respecte de la hipòtesi d'aquest treball.

Quant al tractament dels aspectes relacionats amb el context (històric, panoràmic i fenomenològic), no hi ha cap dubte que són fonamentals en una investigació de tesi. La manera d'abordar-los, però, mai no és estàndard sinó que està en funció del tema i de la seua classificació. Tal i com assenyala Eco (1976: 31) una monografia tracta sobre un tema únicament i, com a tal, és oposada a una història de. Això respecte, ja s'hi ha fet un comentari específic en aquest sentit (cf. pàgina 24) en parlar de la classificació del tema. Això no obstant, cal explicar-hi què s'ha fet i justificar-ho.

La raó per la qual aquests aspectes no s'han desenvolupat amb autonomia com una primera part o bloc independent és que, durant el procés d'elaboració, es va veure que exposant-los a soles quedaven deslligats entre ells i respecte dels diversos fenòmens i objectes amb els quals havien d'estar relacionats. Això respecte, Eco (1976: 32) remarca que és millor que una tesi s'assemble a un assaig que no a una enciclopèdia o a una història. Aleshores, qual va ser la solució? La primera part MARCEL BROODTHAERS 1924 - 1976. DARRERE L'EMPREMTA DE L'EXPERIÈNCIA, què respon a l'objectiu 1 , ha permés desenvolupar una panoràmica de la trajectòria artística de Broodthaers on també han trobat lloc els aspectes històrics i fenomenològics de caràcter general. Després, a mesura que s'han analitzat qüestions específiques en la resta de l'escrit, s'han desenvolupat altres aspectes històrics i fenomenològics amb significat de context. 
Abans d'acabar l'explicació de l'estructura textual de l'escrit resta parlar d'altres parts reglamentàries de l'escrit: les REFERÈNCIES BIBLIOGRÀFIQUES, el RESUM, l'́NDEX ANALÍTIC i l'ÍNDEX GENERAL i, finalment, comentar algunes qüestions relacionades amb l'edició.

És menester explicar que el capítol de REFERÈNCIES BIBLIOGRÀFIQUES ha reunit tant les obres citades al llarg del text com les que han sigut consultades i utilitzades directament en la investigació. És important deixar clar, però, que no és una bibliografia total ni de l'autor ni del tema ja que això constitueix un altre objecte d'investigació. Aquestes referències han sigut redactades segon les normes UNE 50 - 104 - 94 - Referencias bibliográficas. Contenido, forma y estructura de l'AENOR i l'ISO 690 - 2 - Information and documentation - bibliographic references - Part 2: Electronic documents or parts thereof, les quals regulen la selecció dels camps i la seqüència de presentació per a documents impresos - llibres complets, parts o capítols d'un llibre, articles en publicacions periòdiques, etc. - $\mathrm{i}$ per a documents $\mathrm{i}$ fons electròniques, respectivament. Aquest capítol bibliogràfic està dividit en diversos apartats per fer distinció entre les referències de Marcel Broodthaers, les referències sobre Marcel Broodthaers i les referències generales de la investigació que, per la seua part, estan subdividides per matèries.

El RESUM, en tant que part fonamentalment utilitària d'una tesi doctoral, és un text breu (268 paraules) on s'han exposat de la manera més sintètica possible l'assumpte, el tema, l'objecte i els resultats. A més a més, s'ha intentat fet servir una sèrie de mots clau així com els noms d'altres autors esmentats en el treball per a possibilitar entrades diverses en les bases de dades $i$ en els abstracts de la nostra disciplina.

L'ÍNDEX GENERAL arreplega detalladament tots els continguts de la Tesi doctoral: blocs o parts de l'escrit, capítols, apartats, annexos, etc. així com l'estructura que presenten. L'índex general es troba al principi de l'escrit, després de les pàgines dedicatòries, mentre que l'índex analític i el resum s'han col-locat al final.

Altrament, en l'ÍNDEX ANALÍTIC s'han agrupat una sèrie d'estructures que també són utilitàries: l'íNDEX DE NOMS, que ha arreplegat els noms de totes les obres analitzades o esmentades en l'escrit així com també noms d'autors, d'institucions, de publicacions, etc. D'altra banda, l'ÍNDEX DE CONCEPTES s'ha confeccionat estimant i senyalant tots els conceptes, les idees i els continguts transversals que s'han tractat al llarg del treball; i l'íNDEX D'IL·LUSTRACIONS, presenta una relació ordenada alfabèticament de les illlustracions - quadres de text generats en el marc de la investigació, reproduccions i fotografies d'obres de Marcel Broodthaers: poemes, facsímils de texts, fotografies, assemblages, quadres, projectes, esdeveniments, pel-lícules, etc. - que s'han fet servir com a suport de l'escrit. Encara que l'índex analític no és una part obligatòria, s'ha decidit fer-ho i incloure'l estimant la seua utilitat posterior per a realitzar consultes ràpides en funció d'interessos diversos.

Respecte de l'edició, tothom sap que és un factor important en la presentació/ publicació d'un text i que, a més i a més, pot influir d'una manera important en la seua lectura i avaluació general. Quant a les tesis doctorals, hi ha una sèrie d'aspectes formals que cal respectar, però també n'hi ha altres que, en no constituir norma fins ara, s'han decidit particularment.

Pel que fa a aquesta TESI DOCTORAL, s'ha treballat en format DIN A-4 vertical i utilitzant, casi sempre, les dues cares de la pàgina. En general, s'ha tingut en compte fer ús racional del paper, la qual cosa implica, de primer, consumir en la mesura necessària - cosa prou recomanable avui dia - i, de segon, que l'ús racional del paper permet, posteriorment, l'ús racional dels espais d'emmagatzematge. 
En l'edició de les pàgines de text han regit els criteris de llegibilitat quant al tipus i a la composició de l'escrit, i s'han fet servir dos tipus de lletra i diferents cossos per atendre a totes les necessitats de variació. Així, per al text general dels quatre blocs principals, la introducció, les conclusions i l'annex 2 s'ha utilitzat lletra romana; mentre que per al text general de la resta d'escrits - l'annex 1, les referències bibliogràfiques, els índex, etc. - s'ha utilitzat un tipus paloseco. D'altra banda, els texts principals tenen un cos d'11 punts, mentre que els texts secundaris - notes, cites, epígrafs d'il-lustracions, etc. - tenen un o dos punts menys. En els texts indicatius s'ha utilitzat el tipus paloseco amb un cos igual o major respecte del text general, però amb diferents ulls de lletra i amb variacions ortotipogràfiques. Quant a l'edició de les pàgines de principis i les de cortesia, el text s'ha col-locat a partir de la línia àuria $i$, després, per remarcar el començament de la introducció, de les conclusions i dels quatre blocs de text argumentatiu, s'ha utilitzat una lletra inicial gràfica del mateix tipus que el text.

Quant a la composició del text, s'ha optat per l'interlineat senzill i els marges amples la qual cosa permet tant la lectura ràpida com la possibilitat d'afegir comentaris. Pel que fa a les il-lustracions, s'han disposat de forma paral-lela al text aprofitant la interrupció que es produeix amb el canvi de pàgina. Aquesta disposició té l'avantatge que no interfereix en la llegibilitat del text $\mathrm{i}$, a més a més, ha permés conjugar millor els diferents intervals de la seqüenciació de la imatge i del text. El epígrafs d'il-lustracions, però, s'han ubicat en la pàgina de text amb un tipus de lletra diferent.

A causa de les característiques de l'edició, l'escrit d'aquest treball no passa de les tres-centes pàgines en total, la qual cosa, tanmateix, podria ser preocupant o almenys cridar l'atenció. Per això s'ha considerat necessari oferir dades més exactes de l'escrit, com són el nombre de paraules. Per exemple, els quatre blocs de text argumentatiu sumen 137 pàgines i 35068 paraules. L'annex 1 té 17 pàgines i 8029 paraules i l'annex 2 té 27 pàgines i 14602 paraules, sense incloure els textos en francés. Així, l'escrit bàsic de la investigació suma 57699 paraules. Òbviament, som conscients que ni la quantitat de paraules ni la quantitat de pàgines són determinants de la qualitat d'una investigació.

Per a concloure, cal dir que en la realització d'aquest treball de TESI DOCTORAL s'ha comptat amb l'ajuda de moltes persones i d'institucions i és just hi expressar-los els merescuts agraïments. De primer, cal agrair el suport donat pels centres de documentació científica de la Universitat Politècnica de València, de la Fundació Tàpies i del Museu d'Art Contemporani de Barcelona i, en especial, a Ana María Checa, a Glòria Domènech i a Marta Vega, respectivament. Així mateix, ha sigut fonamental el suport ofert pel Servei de Normalització Lingüística i pel Centre d'Autoaprenentatge de Valencià de la Universitat Politècnica de València i en concret per Àlvar Gómez, qui ha revisat curosament els esborranys de l'escrit i per Antoni Martínez i Bernat, qui ha atés generosament tota mena de dubtes lingüístiques. També cal agrair especialment a Milagros Feria, traductora i intèrpret llicenciada en filologia francesa, per la seua important col-laboració en aquest treball. De manera personal s'agraeix a Miguel Molina, professor del Departament d'Escultura de la Universitat Politècnica de València, la seua direcció al llarg dels anys d'estudis de doctorat; a Emilio Martínez, professor del mateix departament, els suggeriments crítics que va aportar a l'esborrany de l'escrit; i principalment el suport rebut per part de la directora, la professora Mau Monleón. A més de la seua professionalitat, li agraeix sincerament la gran dosi d'exigència, de confiança i d'empatia que hi ha aportat, totes coses que han sigut vitals per a dur endavant aquesta tasca. Finalment resta agrair a la Comissió Científica-tècnica i d'Investigació del Departament d'Escultura els 
suggeriments crítics que va fer al treball, la qual cosa va motivar una profunda i necessària revisió autocrítica i va contribuir de manera important a millorar l'exposició i l'argumentació d'aquesta TESI DOCTORAL.

Finalment, espere que aquest treball aporte un punt de vista més a l'estudi de l'obra de Marcel Broodthaers i que puga ser útil per a futures investigacions tant en el camp de la teoria i de la crítica d'art com en el camp experimental de la pràctica artística. Ara com ara, l'autoria de Broodthaers és una referència modèlica. Els dubtes plantejats per Marcel Broodthaers així com el seu treball artístic han constituït una bona lliçó per a tothom: comissaris, institucions, crítics, espectadors i artistes. La seua remembrança em fa acudir la memòria d'un altre artista, el cineasta cubà Tomás Gutiérrez Alea (Titón). Sobre la seua pel-lícula Memorias del Subdesarrollo (1968), Titón va comentar que el seu propòsit va ser documentar i reflexionar sobre una sèrie de fenòmens de la realitat social que prompte serien superats. Ara com ara, però, aquesta pel-lícula - com l'obra de Broodthaers - és una reflexió atemporal sobre l'individu en la societat: un fet que l'artista va haver de reconéixer i d'assumir conseqüentment, vint anys després, malgrat ser una lectura a les antípodes de la seua intenció. 
1. MARCEL BROODTHAERS 1924 - 1976. DARRERE L'EMPREMTA DE L'EXPERIĖNCIA 
ovint, el primer interrogant sobre Broodthaers està relacionat amb la seua decisió de desertar de la poesia per convertir-se en artista plàstic i, encara més, tenint en compte la significació especular que ell mateix hi va fomentar. Llavors, hem d'enfocar alternativament els diferents aspectes que hi concorren. D'una banda, cal recórrer la seua trajectòria personal com una successió de situacions on conflueixen la vocació, l'entorn i la definició d'interessos; i de l'altra, és menester donar relleu al context que envolta i modela la seua experiència.

Marcel Broodthaers va nàixer a Brussel-les el 1924 i des de molt jove es va sentir atret per la poesia. El 1942 ingressa en la universitat i es matricula en Química, però al poc de temps abandona els estudis, decidit a dedicar-se a la literatura. En començar a freqüentar l'ambient intel-lectual de la seua ciutat, Broodthaers coneix el poeta Gabriel Piqueray i l'escriptor Théodore Koening - futur editor de la revista Phantomes -. Pel 1943 es vincula al partit comunista belga i, com tants altres intel-lectuals, es veu obligat a viure de forma més o menys clandestina durant l'ocupació alemanya a Bèlgica.

El 1945 Broodthaers publica el seu primer text: un poema simbolista titulat Le ciel bleu, en el setmanari L'Ille Sonnante, de tendència surrealista. També col-labora amb la revista comunista Le Salut Public (Heddomadaire de précision politique et littéraire). La majoria d'articles hi aparegueren sota el pseudònim Marcel Canal i eren textos que tractaven sobre l'actualitat política i literària: "Le problème allemand"; "Jules Barbey d'Aurevilly ou le pertedrapeau", etc. Únicament, hi publicà un text amb el seu nom, "Le Rêve d'un jeune homme malheureux ou l'anarchiste anodin", una mena de ficció autobiogràfica.

Els primers escrits de Broodthaers connectaven amb l'aspiració modèlica de molts artistes de contribuir al canvi social i posaven en relleu el seu desig d'assumir un compromís polític en l'art. Aleshores, la seua vocació poètica i la seua militància política discorrien paral-lelament. La primerenca vinculació que mantingué Broodthaers amb el partit comunista belga i amb el moviment surrealista belga és un fet que cal entendre'l i significar-lo en el seu àmbit sociohistòric.

És clar que les transformacions històriques, polítiques i socials que van tenir lloc al llarg de tot el segle XX tingueren un influx important sobre l'esdevenir de les experiències artístiques i estètiques i sobre la dialèctica de les relacions entre l'art i la societat. De tot això, cal que hi veiem, particularment, com l'obra plàstica va pervenir privilegiada enfront de l'obra literària i les conseqüències que va traure'n.

La influència del context sobre la vocació i els interessos de Broodthaers va propiciar, de primer, actituds i actuacions que podem considerar avantguardistes, sempre en un sentit més moral que purament estètic. Però, a poc a poc, a mesura que viu diferents experiències, les actituds i les actuacions de Broodthaers es tornen de contingència, de resistència, de desmitificació i de desestabilització del sistema artístic des de dins del sistema mateix. 


\section{L'esperit surrealista entre la modernitat i l'avantguarda}

Cal tenir en compte que ja des del començament del segle Xx, l'avantguarda i el moviment modern participaven de la reflexió i de la recerca de solucions als problemes de la societat europea, però en una línia que arreplegava i actualitzava bona part del llegat filosòfic alemany quant al paper transcendent que atribuïen a l'experiència estètica. ${ }^{1}$ Aleshores, molts artistes i intel-lectuals van tenir una actitud d'agitadors amb la finalitat de constituir una alternativa socialment renovadora i revolucionària. El moviment surrealista és un bon exemple en aquest sentit, tant pel que fa a la seua gènesi com al seu desenvolupament.

D'alta banda, és un fet que entre avantguarda i societat va haver-hi tensions perquè no en parlaven el mateix llenguatge i sovint els artistes quedaven relegats a la marginació. Però, si històricament tant les institucions com la societat en genera eren renitents d'acceptar les avantguardes, durant la segona postguerra, a partir dels anys cinquanta i seixanta, van convertir-se en la troballa d'un mercat artístic ja hegemònic però mancat de tradició i amb avidesa de glamour. Van passar de ser els marginals que proclamaven el prestigi de la revolta a ser els paradigmes de prestigi social i, a més i a més, d'enriquiment i d'especulacions.

Quant al moviment surrealista, actualment no hi ha cap dubte a considerar-lo com un moviment modern i d'avantguarda; encara que cal distingir entre ambdues definicions. Així doncs, allò modern és allò que pertany a l'època present. És una variable que afecta la història, els costums, les arts i el gust; per tant, és una categoria relativa als trets definitoris de cada època. En l'art, la modernitat és la confrontació d'allò transitori i contingent amb allò etern $\mathrm{i}$ immutable i va ser Charles Baudelaire qui va abordar-hi i definir-hi el concepte tal com l'hem entés en occident al llarg del segle XX. ${ }^{2}$ A banda d'això, hem de tenir en compte que el terme avantguarda, del francés avant-garde, prové del context militar i denomina un destacament avançat que inicia una acció. Les arts van adoptar-lo per designar tendències innovadores en oposició a les establertes. En els plantejaments de les avantguardes existeix un mòbil de caràcter històric i social: la idea de progrés com a herència de la Il-lustració i de la Revolució Industrial. Les arts del segle XX van heretar aquestes idees, les quals van haver de conviure amb la consciència crítica i pessimista propiciada per les guerres i per les transformacions socials. ${ }^{3}$

En concret, el moviment surrealista va originar-se en el terreny de la literatura amb l'escriptura automàtica i, de seguida va manifestar-se en altres àmbits culturals: pensament, pintura, teatre, cinema, fotografia, etc. En el període d'entreguerres i a partir del 1930, el moviment surrealista va participar de l'ideal il-lustrat: va defensar l'home universal per damunt dels valors nacionals, va optar per un compromís de l'artista amb la societat i amb l'època. Després, en l'època de la postguerra, va advocar per la revolució individual i social com a

\footnotetext{
1 "S'ha de començar creant ciutadans per a la constitució abans de donar una constitució als ciutadans". Per a Schiller, la confiança en les possibilitats d'una conducta i d'un intercanvi lliures, alliberats de les dependències i coaccions de la moral i de la política hauria de construir-se mitjançant l'educació estètica. F. Schiller citat per H. R. Jauss. Las trasformaciones de lo moderno. Estudio sobre las etapas de la modernidad histórica. Ma.: Visor, 1995: p. 106 i s. [F. Schiller "Carta al Duc d'Augustenburg", 13 de juliol, 1793. En Die französische Revolution im Spiegel der deutschen Literatur. Frankfurt: C. Träger, 1975: p. 264]

${ }^{2}$ Cf. C. Baudelaire "El pintor de la vida moderna", en Salones y otros escritos. Ma.: Visor, 1996; p. 347 - 392.

${ }^{3}$ Vegeu J. Brihuega. "Las vanguardias artísticas: teorías y estrategias". En V. Bozal (ed.). Historia de las ideas estéticas y de las teorías artísticas contemporáneas. Ma.: Visor, 1996: vol. II, p. 135.
} 
contribució al bé comú i al canvi social. Això no obstant, el moviment surrealista va acabar institucionalitzat. $^{4}$

Amb tot i això, no és gens senzill fer-ne ni una generalització, ni una catalogació definitiva, ni molt menys una crítica total. Més prompte, cal entendre'l com una actitud abans que com un estil i, sobretot, com una presa de posicions. ${ }^{5}$ També és fonamental distingir entre el moviment surrealista mateix i el potencial revolucionari i contestatari que va impulsar el seu missatge. Recordeu la crida la imaginació al poder del maig del 1968.

Però, encara que la vinculació de Broodthaers amb el moviment surrealista belga $\mathrm{i}$ amb el partit comunista belga va fer fallida, va ser sincera i reveladora perquè expressava la intenció d'ultrapassar la finalitat tradicional de les pràctiques artístiques per a inscriure-les en l'àmbit social com una opció moral fonamentalment.

\subsection{Provatures surrealistes}

En els anys següents al final de la Segona Guerra Mundial, Broodthaers estigué immers en la intensa activitat artística i política que es va viure a Brussel-les. Juntament amb uns altres intel-lectuals, participà en la primera reunió de postguerra de la Central Surrealista belga, la qual estigué presidida per l'escriptor Achille Chavée. Aquesta reunió va tenir el propòsit d'agrupar les forces surrealistes de Bèlgica mitjançant la seua eventual adhesió al partit comunista. ${ }^{6}$ En aquest cercle Broodthaers conegué i féu amistat amb els poetes Marcel Lecomte i Paul Nogué. Un dels projectes del col-lectiu surrealista belga fou la creació d'una revista pròpia, la qual duria el nom de La Centrale. La direcció estaria a càrrec del grup d'escriptors, entre els quals es trobava Broodthaers. Però, finalment no se n'arribà a publicar cap exemplar.

El 1947, per iniciativa d'un grup d'intel-lectuals entre els quals es trobaven Achille Chavée i el pintor Cristian Dotremond, es va constituir a Brussel-les el Despatx del Surrealisme Revolucionari. Les activitats del col·lectiu començaren amb la redacció d'un libel que qüestionava radicalment la concepció de surrealisme revolucionari representat per André Breton. El manifest, titulat "Pas de quartiers dans la revolution", fou publicat en la revista del partit comunista belga, Le Drapeau Rouge. Entre els signants es trobaven Broodthaers i Magritte, si ben bé cap d'ells dos se'n considerava ja incondicional.

Poc després, el moviment dissident es desplaçà a França i en acabant el 1947 hi organitzaren la Conferència Internacional del Surrealisme Revolucionari, presidida per Chavée. En aquest context, els surrealistes belgues i francesos redactaren conjuntament i publicaren un segon libel - "La Cause est entendre" - dirigit una altra volta contra Breton, fent-li responsable de conduir el moviment cap a unes vies incompatibles amb l'acció política. També en aquesta ocasió, Broodthaers figurava entre els signants. A París es publica, el 1948, el primer i únic número de la revista Surrealisme Révolutionnaire, l'edició de la qual va estar a

\footnotetext{
${ }^{4}$ Tal ha sigut també el destí d'altres moviments i actituds avantguardistes. Davant la qüestió és interessant apuntar un altre enfocament: la idea del prestigi de l'avantguarda pot seguir intacta quan, al llarg del segle xx, cap ideologia s'ha lliurat de la crítica?. Cf. J. Clair, La responsabilidad del artista. Ma. Visor, 1998; p. 15-21.

5 Un desenvolupament molt interessant d'aquestes idees l'ha fet F. Calvo Serraler. "La teoría artística del surrealismo". En A. Bonet (coord.). El surrealismo. Ma.: Cátedra, 1983: p. 27-56.

${ }^{6}$ Però, l'adhesió primitiva dels surrealistes al partit comunista va tenir lloc en el nucli parisenc cap a l'any 1925. Cf. A. Breton. El surrealismo: puntos de vista y manifestaciones. Bar.: Seix Barral, 1972: p. 121 i també M. Nadeau. Historia del surrealismo. Bar.: Ariel, 1975: p. 137.
} 
la cura de Dotremond, i entre els textos hi publicats hi havia un poema de Broodthaers: "Project pour un film".

A finals d'aquest mateix any, el moviment del Surrealisme Revolucionari va fragmentarse definitivament després d'un intent de reconstitució i, per iniciativa de Dotremond, alguns dels seus antics membres van reorganitzar-se formant el grup COBRA. Molt possiblement, la secessió de Broodthaers del moviment surrealista va tenir lloc quan va adonar-se que hi havien diferències irreconciliables. Anys després, les declaracions de Broodthaers quan li pregunten sobre la seua etapa surrealista són prou eloqüents:

M'ho sé de memòria: «Tot duu a creure que existeix un punt en l'esperit des del qual la vida i la mort, allò real $i$ allò imaginari, el passat $i$ el futur, allò comunicable $i$ allò incomunicable, allò alt $i$ allò baix cessen de ser apercebuts com a contradictoris». Espere no tenir gens d'això en l'esperit.7

1. "Projet pour un film" [Projecte per a una pel-lícula] (1948)

Una mosca va envair

l'immòbil paisatge

Les fulles tremolen al seu

pas, els ocells ressusciten $i$

de sobte el molí de l'alba va

posar-se en marxa.

L'escola està deixada anar

el professor vacil-lant es refugia

en un brossegar.

\section{TRES POEMES DE L'ILLA DESERTA}

Trobem Indians, son pare, sa mare: parlem dels continents desapareguts darrere l'horitzó per crear una vida en profunditat.

Una nit, en tornar a casa, quan pujava les escales, les formacions parasurrealistes es deixaven caure per l'altre costat de la barana i en l'últim replà estava assegut Johnny Joes que filosofava a soles.

Un geperut va emergir de l'estanc i es va apropar. Els seu nas en la meua porta. Una ràbia terrible va manar-me esclafar-li la gepa. Li vaig traure uns quants poals de clorofil-la amb la que vaig pintar el meu interior i el rostre de tots aquells que vaig trobar-me.

El nisorève porta els seus castells de popa en fusta de roure com els dels navilis antics. Em fan l'efecte d'una brandada sobre una imaginació desèrtica.

\footnotetext{
${ }^{7}$ I. Lebeer (1974). "Dix mille francs de récompensa". En Marcel Broodthaers. París: Galerie Nationale du Jeu de Paume, ca. 1991: p. 248 - 251. [Broodthaers parafraseja Breton. Cf. E. Westerdahl. "Panorama vital del surrealismo". En A. Bonet; op. cit.: p. 25.]
} 
Però, sens dubte l'orientació alliberadora, progressista i crítica del moviment surrealista i sobretot el seu eclecticisme estètic $\mathrm{i}$ ideològic van aportar a Broodthaers experiències importants. Potser en aquest sentit que va confessar:

Crec que les meues exposicions han depés, i encara depenen, dels records d'una l'època en què assumia la situació creativa d'una forma heroica i solitària.... ${ }^{8}$

\subsection{La fotografia i el cinema}

Després d'allunyar-se del moviment surrealista, Broodthaers desenvolupa activitats molt diverses, si ben bé allò més evident va ser el seu replegament de les posicions avantguardistes que fins al moment havia compatibilitzat amb la seua vocació de poeta i escriptor.

$\mathrm{Al}$ voltant del 1950 decideix desfer-se dels seus llibres rars, per la qual cosa organitzà una venda pública en la galeria Themis a Brussel-les. D'aquesta forma diu adéu a la seua empresa de llibrer i d'ara endavant es guanya la vida desenvolupant diversos oficis. Un d'aquests va ser l'organització de les visites guiades de la Societat d'Exposicions del Palau de Belles Arts de Brussel-les durant diversos anys.

Endut per la seua curiositat intel-lectual, Broodthaers comença a interessar-se per la fotografia i pel cinema. Coneix l'artista Serge Vandercam i el fotògraf Julien Coulommier, amb els quals organitza una exposició de fotografies el 1957, a petició del Palau de Belles Arts. Les obres seleccionades pertanyien a Kurt Dejmo, Laszlo Moholy-Nagy, Otto Steinert, Raoul Hausmann, Man Ray, Serge Vandercam i Minor White. Broodthaers va aprendre amb Coulommier els procediments elementals de la fotografia i tot seguit de la primera col-laboració sorgeix una idea per fer un llibre en comú, Statues de Bruxelles, que emportaria fotografies de Coulommier i textos de Broodthaers. Però, aquest llibre no va ser editat sinó pòstumament, trenta anys després.

$\mathrm{Al}$ voltant del 1957 Broodthaers comença a fer cinema. El seu primer curtmetratge, La clef de l'horloge (Poème cinématographique en l'honneur de Kurt Schwitters), fou rodat en el Palau de Belles Arts de Brussel-les durant una exposició de l'artista alemany per la tardor del 1956. El 1959 realitza un documental titulat Le chant de ma génération, del qual solament es conserva el guió, algunes notes i fotografies d'esdeveniments d'actualitat que va prendre Broodthaers. Molt possiblement va haver-hi més muntatges cinematogràfics d'aquest tipus els quals van formar part d'un projecte de titulat Poésie-Cinema ideat per Broodthaers i presentat en el Palau de Belles Arts de Brussel-les.

Paral-lelament, Broodthaers continua escrivint i publicant articles d'opinió sobre temes d'actualitat literària així com uns altres escrits de caràcter més personal i pròpiament poètics. Entre el 1954 i el 1956 va publicar diversos textos en la revista Phantomes, entre aquests un homenatge a l'escriptor Marcel Havrenne, un dels signants dels libels del Surrealisme Revolucionari. També hi publica de forma anònima un poema titulat "Adieu Police!", signat amb tres asteriscs juntament amb un topònim literari, Castell d'If. Igualment hi publica un altre poema, "Le Roi Midi", però signat *** Castell d'Af, un topònim fictici.

Entre el 1957 i el 1958 Broodthaers realitza diversos reportatges sobre les obres de l'Exposició Universal que va tenir Brussel-les com a escenari. D'aquests reportatges - "Les confessions du siècle", "Un autre monde", etc. - Broodthaers va fer els textos i també les fotografies i els va publicar en la revista Le patriote illustré; i un altre que tractava sobre un

\footnotetext{
${ }^{8}$ I. Lebeer (1974). Íd.
} 
viatge en globus, "Le ballon ce n'est pes fait pour se tuer", va publicar-lo en el setmanari Germinal.

El caràcter futurista d'alguns dels pavellons de l'Exposició Universal de Brussel-les i l'aura fantàstica del projecte li resultaven fascinants. Per poder moure's amb llibertat per l'ambient de les obres en construcció, Broodthaers va aconseguir que li contractaren per treballar com a manobre. Després, durant els mesos de l'exposició, va treballar com a guia de visitants.

2. "Un autre monde" (1958). Fotos de Marcel Broodthaers. Facsímil

3. "L'Atomium" (1958). Reportatge fotogràfic de l'Exposició Universal de Brussel.les. Fotos de Marcel Broodthaers. Facsímil (p. següent)

4. Fotografia per al documental Le Chant de ma géneration (ca. 1959) (p. següent)

\subsection{Llibres, viatges, trobades...}

La capacitat de Broodthaers per traure partit de totes les seues experiències es perfila com una de les característiques que, a poc a poc, van definint la seua vocació i els seus interessos com a artista. Això no obstant, paral-lelament a les seues primeres incursions en la fotografia $i$ el cinema, encara va continuar interessat per la literatura.

El seu primer llibre apareix a finals del 1957. Es tractava d'un conjunt de relats poètics reunits sota el títol de Mon livre d'ogre i acompanyats de gravats de l'artista Serge Vandercam. En aquest llibre apareix un breu poema, l'últim vers del qual - "O mélancolie aigre château des aigles" - es fa recurrent en el seu darrer treball artístic. El 1960 publica Minuit, també il-lustrat per Vandercam. El 1961 edita, pel seu compte, un altre llibre de poemes titulat La bête noire, il-lustrat amb gravats de l'artista Jan Sanders, el qual era una espècie de bestiari amb animals del zodíac i de la ficció literària.

En l'edició dels llibres de poesia, Broodthaers intervé personalitzant d'alguna manera els exemplars, cercant-ne una fórmula a mig camí entre l'objecte de factura industrial produït en sèrie i l'obra original manufacturada. Aleshores, el llibre encara era el principal vehicle de la seua proposta poètica.

En la primavera del 1961 Broodthaers coneix la fotògrafa Maria Gilissen, en qui troba la seua companya. Entre l'abril i el juny del 1961 va ser a Londres on visita les exposicions i els museus; també hi realitza fotografies de l'ambient de la ciutat i hi escriu les seues impressions. D'ací sorgeixen una sèrie d'articles que publica en el Journal des Beaux-Arts de Brussel-les sota el títol "Un poète en voyage... à Londres". ${ }^{9}$ A continuació, se'n va a París on sobreviu treballant com a ajudant de llauner i després com a guàrdia nocturn d'un hotel.

\footnotetext{
${ }^{9}$ Aquest títol sembla una paròdia del títol d'un llibre de memòries escrit pel músic Jacques Offenbach, Notes d'un musicien en voyage (1877), en el qual relatava el seu periple i les seues experiències a Amèrica.
} 


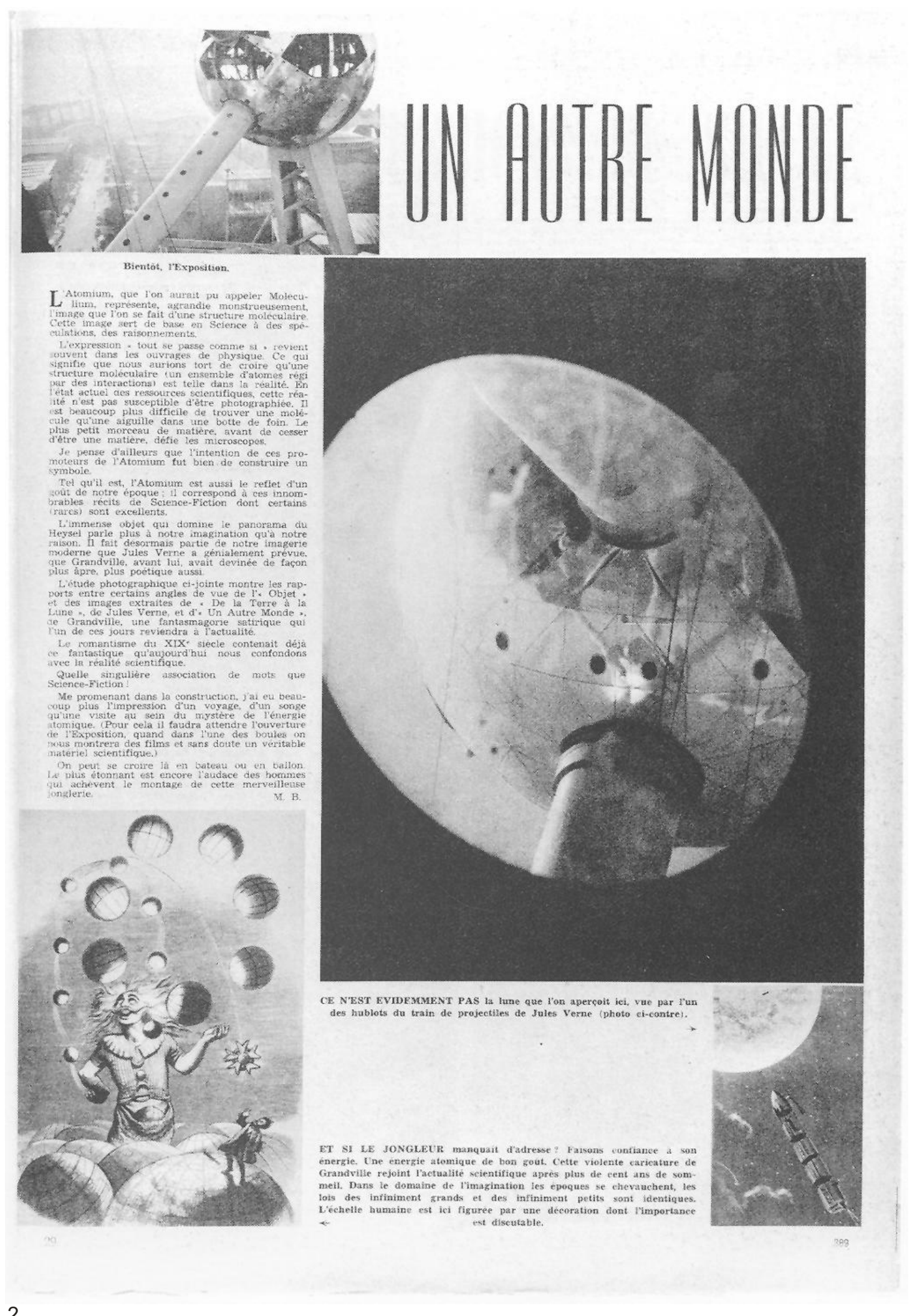




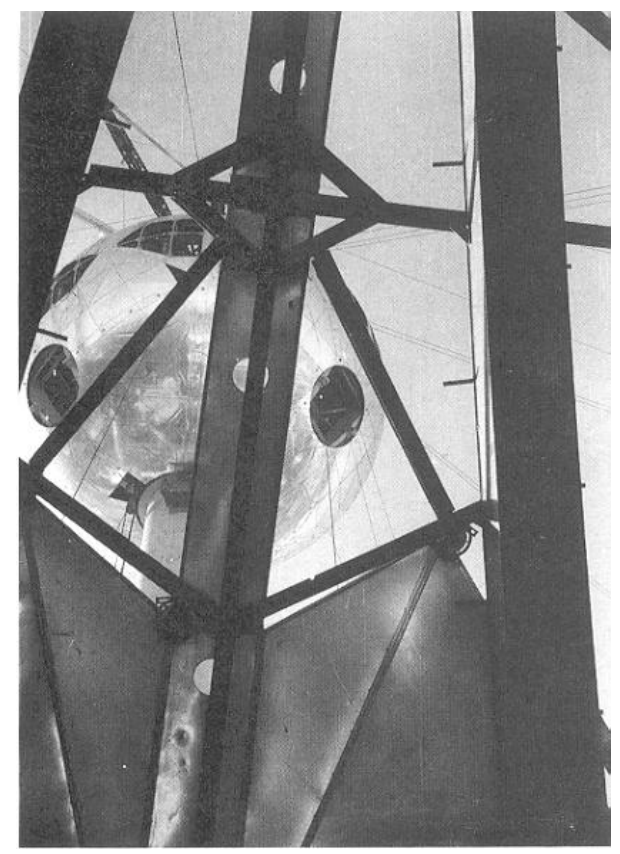

$3 a$
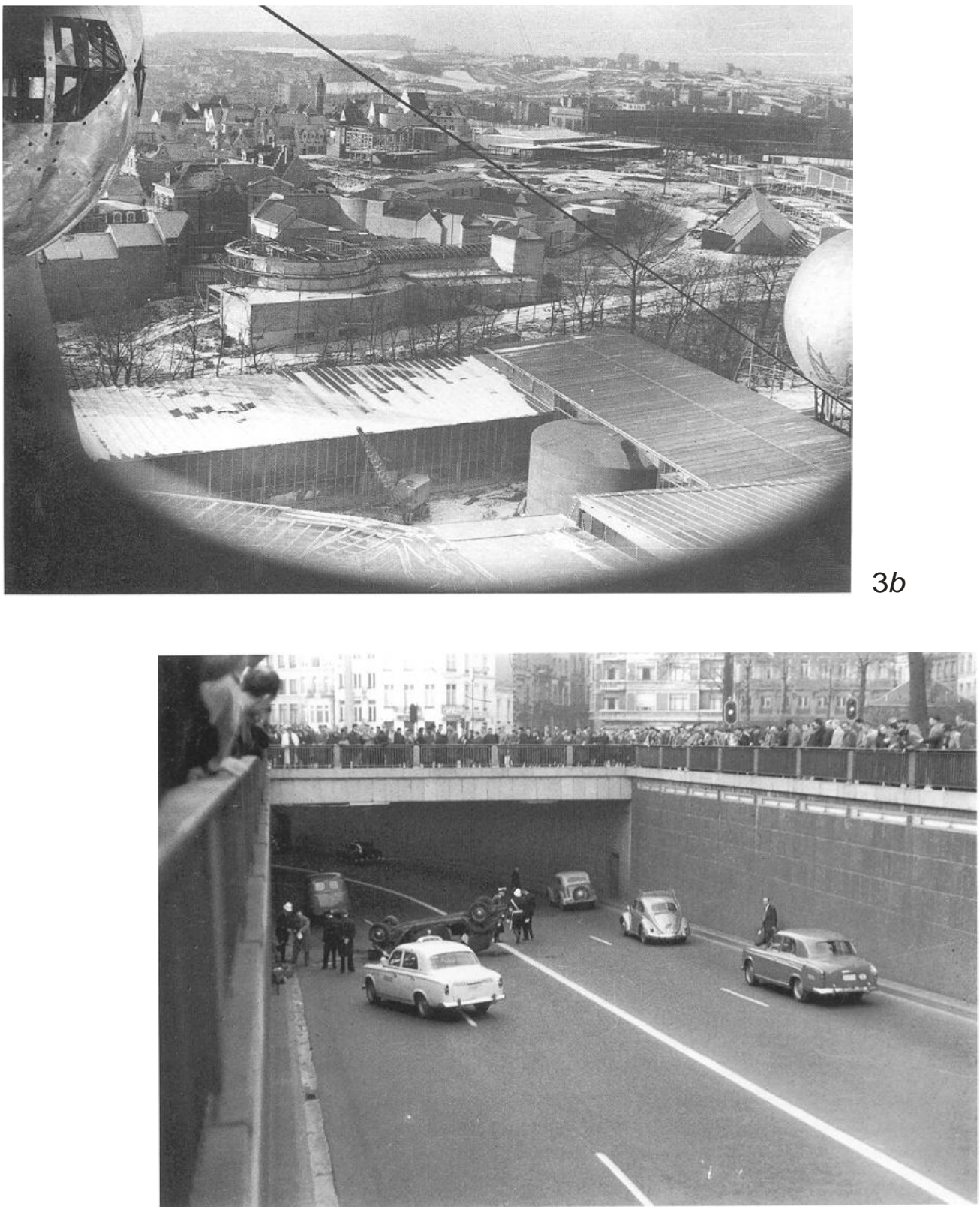
En retornar a Brussel-les, el 1962, Broodthaers torna a escriure i comença a publicar més regularment en el Journal des Beaux-Arts. Principalment, hi escriu articles sobre les exposicions d'alguns novells artistes belgues com Livinus i Fernand Lerin. També hi publica un text molt crític i vehement - "Deux peintres: Paul Delvaux et Èmile Salkin et un de leurs élèves: Charles Deroux" - sobre uns frescs pintats en el Palau de Congressos de Brussel-les. Paral-lelament, continua organitzant visites guiades i conferències en el Palau de Belles Arts.

Aleshores, Broodthaers coneix Piero Manzoni durant una exposició de l'artista italià en la galeria Aujourd'hui de Brussel-les.

\subsubsection{Broodthaers i Manzoni}

La trobada amb Piero Manzoni, pel febrer del 1962, i l'intercanvi d'idees que tingué lloc entre ambdós van ser molt significatius per a Broodthaers.

Manzoni proposa sense subterfugis l'equivalència entre obra d'art i mercaderia i l'homologació del valor d'ús i del valor de canvi. Això no obstant, el seu producte artístic subvertia tan el concepte tradicional d'obra d'art com la idea mateixa de mercaderia.

Llavors, Broodthaers pren consciència de l'operacionisme de l'obra plàstica i dels seus avantatges comparades amb l'obra literària en tant que vehicle crític i efectivitat comunicativa. L'actitud i l'experiència artística de Manzoni li permeten observar, d'una banda, el caràcter estratègic que podia admetre el suport objectual dins de la pràctica artística, així com la versatilitat del paper de l'artista. D'altra banda, en contrastar les limitacions del poema enfront d'una obra objectual, en pot advertir la subversió implícita en el reconeixement d'aquestes limitacions.

Les conclusions de Broodthaers resumeixen la importància i la repercussió que tingué el diàleg amb Manzoni:

Vam trobar-nos com si fórem comediants. Aquesta trobada amb Manzoni [...] va permetre'm apercebre la distància que separa el poema d'una obra material que qüestiona l'espai fine arts. Dit d'una altra manera, veure-hi el valor del missatge amb la noció de mercaderia solament identificada com a mercaderia. ${ }^{10}$

Per l'estiu del 1962 Broodthaers torna a París, on és un any aproximadament, i s'hi dedica a escriure articles sobre temes artístics i d'actualitat per a una agència encarregada d'editar $i$ distribuir setmanalment els fulls d'actualitats per a diversos diaris regionals. També visita els museus i les galeries d'art, i entre aquests veu una exposició de George Segal i coneix l'obra d'altres artistes dels denominats pop com són Jim Dine, Claes Oldeburg i Roy Lichtenstein.

Totes aquestes experiències van contribuir en gran mesura a la maduració de les idees i dels interessos de Broodthaers. Un any més tard, en un article titulat "Gare au defi! Le Pop Art, Jim Dine et l'influence de René Magritte" Broodthaers reflexiona sobre les connexions entre la pintura de René Magritte i el sentit transgressiu de les noves pràctiques objectuals. Darrerament, Broodthaers confessa que, a més de l'empremta deixada pel "seny irritable i malapte de Magritte", els buidatges de Segal li havien proporcionat "el punt de partida, la sacsejada" que li conduiria a produir obres. 11

\footnotetext{
${ }^{10}$ M. Broodthaers citat en "Marcel Broodthaers antes de 1964". En Marcel Broodthaers. Ma.: MNCARS, 1992: p. 47. [Piero Manzoni. Brussel-les, Galerie des Beaux-Arts, 1987]

${ }^{11}$ M. Broodthaers (1965a). "À la galerie Aujourd'hui. Marcel Broodthaers par Marcel Broodthaers". En Marcel Broodthaers. Ma., op. cit.: p. 70.
} 
5. "Gare au Defi! Le Pop Art, Jim Dine et l'influence de René Magritte". Facsímil (interior del plego)

\subsection{Inflexió}

Broodthaers comença a realitzar els seus primers assemblages per finals del 1963, potser en retornar de París. Paral-lelament, publica un altre llibre de poemes: Pense-Bête i, tot seguit, el fa servir en la seua experimentació plàstica. La transformació dels llibres en obra plàstica esdevé, per excel-lència, l'emblema de l'inici de la seua cursa com a artista plàstic $i$, alhora, de la seua deserció de la poesia, de la superació de les seues limitacions. No obstant això, els llibres inutilitzats hi representaven "l'objecte d'una prohibició." ${ }^{12}$

6. "Art poètica" (ca. 1963). Poema en prosa que formava part del llibre Pense-Bête.

Antany, el llibre va ser un dels principals transmissors d'informació i de coneixements, però també, el primer objecte de consum cultural que va entrar en la indústria. L'estructura lineal de l'escriptura i l'organització de la informació textual condicionava unes formes de percepció i de pensament també lineals. El text resultava enriquit per mitjà de la imatge, ja siga el gravat o després la reproducció fotogràfica. Encara que la imatge oferia un altre tipus d'informació i constituïa un vehicle de comunicació, el text gaudia d'una posició privilegiada. En l'època contemporània, però, la preeminència de la dimensió audiovisual de la informació i de la comunicació va donar lloc a la transformació de la visió lineal i del pensament generalitzador a favor d'una percepció del fragment, de l'anècdota. Amb la invenció de la fotografia y amb el desenvolupament de noves tècniques de la imatge, la cultura fundada en la impremta o galàxia Gutenberg va perdre terreny enfront de la creixença de la nova indústria cultural fundada inicialment sobre el cinema i després sobre la televisió.

Tot això tingué una gran incidència sobre la cultura, sobre la societat i sobre els creadors. Tanmateix, la producció artística va deixar de ser eminentment artesana i els llenguatges artístics tradicionals, en canvi, van veure disminuïda la seua capacitat de comunicar: la nova dinàmica els abocava a l'obsolència. Aquesta realitat tan prolífica va motivar els creadors a la recerca de recursos expressius més d'acord amb les noves tecnologies, la qual cosa va propiciar la vinculació dels artistes amb les entitats col-laboradores i proveïdores de mitjans, establint noves i avantatjoses relacions entre l'art, les institucions i la indústria. Però, tot això també va suposar conviure amb una altra realitat com és el mercat, la manipulació i la censura: totes coses que hi havien existit sempre i que ara apareixien revestides d'unes altres formes. ${ }^{13}$

\footnotetext{
${ }^{12}$ I. Lebeer (1974); op. cit.

${ }^{13}$ No obstant això, paral-lelament a l'eclosió d'artistes i tendències dels anys seixanta i setanta es van produir unes altres respostes artístiques i culturals anomenades moviments underground, potser més representatius en el cinema i en la música però igualment vàlids en les arts plàstiques. Les seues propostes es movien principalment en dos sentits. D'una banda, la creació de canals alternatius com a formes de promoció i distribució paral·leles a les institucions amb el fi d'evitar la manipulació dels seus missatges, i d'altra, la utilització dels canals institucionals mateixos per desafiar les seues convencions. Vegeu A. M. Guash "El arte de los objetos encontrados: el neodadá y el assemblage" i " La acción y el compromiso: el happening en Europa". En El arte del siglo XX en sus exposiciones. Ma.: Ediciones del Serbal, 1997; p. 55 - 56 i 70 - 73.
} 


\section{ART POĖTICA}

El gust pel secret i la pràctica de l'hermetisme, s'han acabat i són per a mi, un joc favorit. Però, vull desvelar les fonts de la meua inspiració, ara sí, abandone tot pudor.

Les obres jurídiques, sovint, van exitar la meua imaginació. El lloc que hi ocupa la paraula és privilegiat. L'ambigüitat del Dret es revela sens dubte en la interpretació del text, en l'esperit essencial i mai no en la lletra.

La paraula en els còdexs llueix com un solitari. Vegeu ací què va atrapar-me quan vaig aprendre a llegir. Perillosa presó, obsessiva passió el prim resultat de les quals, alguns poemes despullats de la seua naturalesa humana i d'objecte.

Ací teniu un extracte del meu llibre de capçalera. 


\section{GARE $A U$ DEFI! Le Pop Art, Jim Dine et l'influence de René Magritte}

D appelons d'abord cette exposiR tion des ensembles de George Segal que la galerie Sonnabend, Paris présenta le mois dernier. Elle était à la pointe de ce \& Nouveau Réalisme ^ ou «Pop Art » dont il est fort question en ce moment. Art figuratif, peut-être, mais de caractère si dépouillé qu'il semble tomber dans un vide spécial. Les personnages de Segal sont de vulgaires moulages d'êtres -humains surpris dans un mouvement de la vie quotidienne. Ici l'homme est penché sur la glace brillante d'un billard électrique. Là, il est assis sur une misérable banquette. Il tient une tasse de grossière faïence. Le billard, la tasse sont des objets réels. Ils ne sortent pas d'un atelier d'artiste mais d'une fabrique. Aux personnages de Segal, il n'y a rien à demander. D'où viennent-ils, menaçants? De quel monde étrangement lunaire? Je ne pourrais pas écrire qu'ils expriment la terreur sans exprimer la mienne. Ici, nous ne dépassons pas le plan de la trouvaille ou plutôt celui de l'invention. Invention si extraordinaire, qu'elle annule tous les pouvoirs de l'imagination, ou, au contraire, les libère. C'est selon la tendance du spectateur. Le résultat est identique. Il ne lui est pas possible d'observer d'autre point de comparaison que lui-même. C'est la victoire de Narcisse. C'est d'un humour si noir que nous voilà aveuglés. C'est, en effet, beaucoup de choses.

Segal vient de l'univers américain, comme Jim Dine que la Galerie Aujourd'hui présente à Bruxelles à partir du 16 novembre. Le parallèle est tentant entre notre ville et une ville moyenne américaine. Boston, par exemple. Ces tours qui s'élèvent dans le ciel... Nous ne les édifions pas pour les oiseaux. Je veux dire que cette exposition vient à son heure. Jim Dine est également un enfant du délire. In lui fallait cette galerie étroite, peut-être trop secrète.

Sans pour cela s'être fait une spécialité dans le genre, la Galerie Aujourd'hui a quelquefois exposé des artistes qui ont pour idéal essentiel l'humour noir et l'absurde. Ainsi,
l'Italien Piero Manzoni, avec ses tubes de parfum soigneusement disposés sous vitrines et ses tableaux composés de facile laine de verre Manzoni est mort, physiquement mort. Il était jeune. $\mathrm{Y}$ a-t-il un rapport entre cette mort précoce et l'attitude qu'il avait adoptée sur le plan artistique? Il est certain que l'humour dont il se réclamait n'est pas une position confortable. Et si cela est la cause, profonde sera notre interrogation devant les événements artistiques, devant tous les événements. Bien sûr, Manzoni sera dans le livre terrible du XX* siècle. Et le français Arman, qui Dieu merci se porte bien. De ce dernier, nous nous souvenons d'objets accumulés dans des boîtes vitrées; manomètres, têtes de poupées, destinées à l'on ne sait quel musée industriel. A partir du 26 novembre, ce sera Jim Dine avec des tableaux grands formats pourvus d'une tablette, quelque chose comme un dessus de cheminée. L'un d'eux représente un chapeau melon et, ô génie, sur la tablette un véritable melon, un chapeau. Pas tout à fait cependant, il est recouvert d'une couche de couleur (noire) et ca parait coller. Burlesque et détendue, voilà une physionomie américaine qui n'est pas sans rappeler le cinéma comique. Moyens plus que sobres, moyens élémentaires mais encore picturaux. Endeçà de la frontière... bien que la route infernale n'en connaisse point.

Une étiquette recouvre les artistes américains partisans du défi à l'harmonie et au bon goût. C'est - Pop Art . Pop est l'abréviation de popular. Nous sommes loin, cependant d'un art qui puiserait ses forces aux sources populaires. Le Pop, c'est aussi bien la bouteille de limonade agrandie que la boîte de conserve peinte avec une précision photographique. Le Pop relève du pamphlet ou de la provocation ou de la poésie. In lance la malediction et sur sa tête appelle l'injure et le mépris. Dans un numéro récent de 1'Express, Pierre Schneider remarque à propos du Pop, ceci : - L'auteur de ces tableaux qui vous font ricaner ou qui vous donne la nausée, cet homme qui n'a plus d'autre

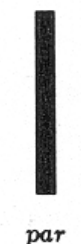

Marcel

BROODTHAERS

moyen pour exprimer sa singularité que le choix entre les biens de consommation qu'on lui propose c'est vous.

Ces artistes poursuivent la construction de la route infernale inaugurée par Dada, mouvement international. Eh bien, Vive Dada, Vive Dadapop, Vive Jim Dine.

Marcel Duchamp et Kurt Schwitters, particulièrement ce dernier, quelle que fut leur volonté destructrice, ont fait une œuvre qui se définit dans le cadre rigoureux des lois plastiques. Aussi, ce n'est pas chez eux, ni chez Max Ernst, que nous verrons la source originelle de cette tendance «néfaste . Mais chez l'un de nos plus grands artistes, René Magritte, un Belge qui sans bouger de notre territoire exigu, a certainement influencer et déterminer tout ce courant de l'art qui fleurit à New York. Magritte nie le caractère esthétique de la peinture. (Ce qui n'empêche qu'en dépit de lui-même, il a réussi quelques beaux tableaux.) - Ce n'est pas une pipe. Un tableau aussi énigmatique que le sourire de la Joconde porte ce titre. Il est célèbre à New York. Tous les tableaux de Magritte sont célèbres à New York. Magritte est célèbre. Fidèle à ses parti-pris initiaux, il continue à élaborer un langage poétique destiné à saper celui dont nous vivons. Le chapeau melon de Jim Dine grandeur nature est, j'imagine, destiné à le saluer. Faut-il une explication? Y en $a-t-i l$ une autre que le contexte des mondes voués à l'actualité publicitaire, à la surproduction et aux horoscopes. 


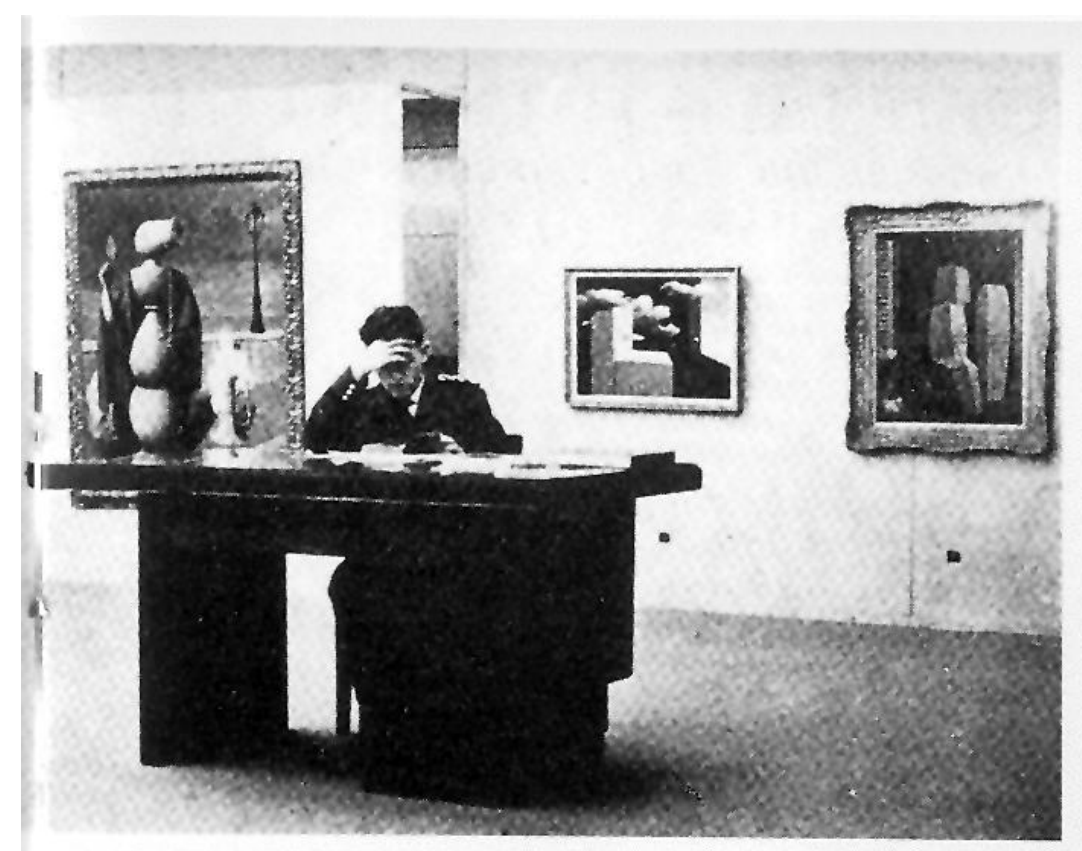

L'influence de René Magritte envers et contre tous les accidents d'une carrière apparait aujourd'hui particulièrement. La photo ci-dessus, véritable Magritte dans la réalité, a été prise lors d'une exposition du peintre en Belgique. (Photo Marcel Broodthaers.) 


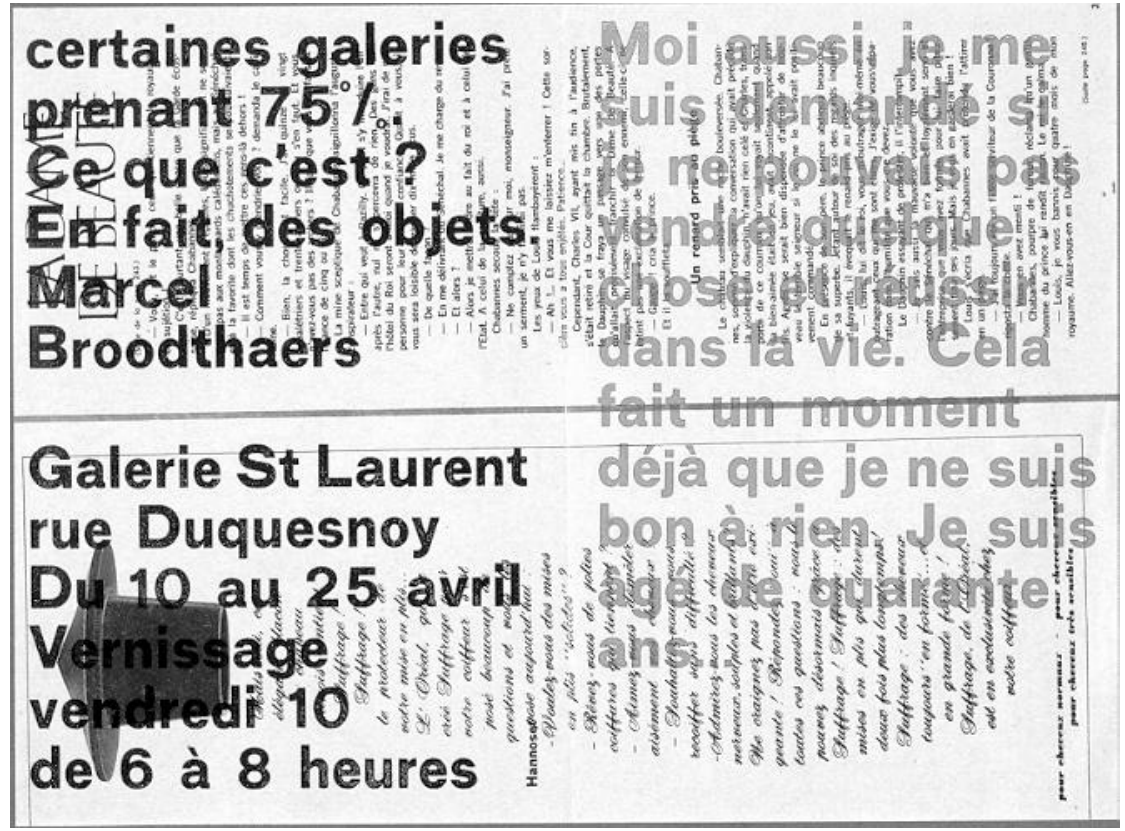

\begin{tabular}{|c|c|}
\hline 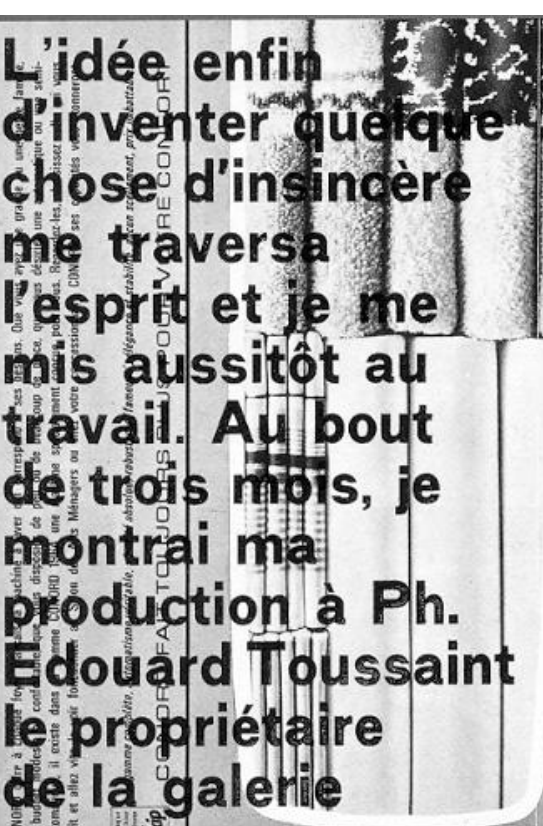 & 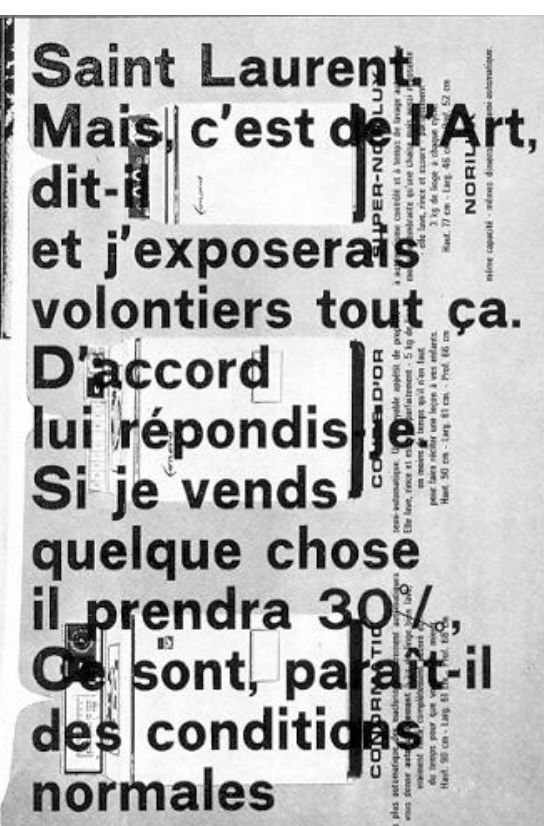 \\
\hline
\end{tabular}


Broodthaers va percebre que tota una noció de l'art que representava la poesia quedava reduïda a ser un relicte del passat. Possiblement, la intensitat de l'escena artística de Londres configurada per l'Independent Group i pel Institute of Contemporary Arts (ICA) va causar-li la trista impressió que el progrés com una noció lligada a la cultura de masses, la publicitat i el consum era un guany a costa de l'exili de la subjectivitat i de la llibertat individual. La crònica de la seua estada no amaga ni la malenconia ni la ironia:

En aquest país, més que en cap altre, els poetes mai no han volgut saber què són i, al mateix temps, la societat els utilitza com a rètol, com a nom fals per a les seues mercaderies. Espantat per aquest descobriment d'ordre moral, vaig dedicar-me a explorar les galeries. [...] Sembla que els pintors escapen del destí dels poetes. D'altra banda, estan molt millor representats en el món dels negocis. ${ }^{14}$

Posteriorment, Broodthaers escenifica el començament de la seua trajectòria com a artista plàstic com un segrest simbòlic de la seua producció poètica. La transformació del llibre Pense-Bête en un assamblage és la imatge d'una opció de consciència. En principi, l'Art representava l'opció alliberadora i un paradigma del treball no alienat; però semblava que la poesia ja no constituïa un model per excel-lència. No obstant això, endavant Broodthaers s'allibera del "destí dels poetes" en la mesura que aconsegueix no deixar d'escriure-hi, de pintar-hi, de filmar-hi, d'actuar-hi, de projectar-hi i de pensar-hi.

\subsection{Els assemblages}

Finalment la idea d'inventar algun simulacre va travessar-me l'esperit i vaig posar-me a treballar de seguida. [...] Jo també m'he preguntat si no podria vendre alguna cosa i triomfar-hi. Vaig pensar-ho tan sols un moment. Ja tinc quaranta anys... ${ }^{15}$

En la recerca de possibilitats creatives adients, l'assemblage resulta per a Broodthaers un procediment molt dúctil i avantatjós. Aleshores, el 1964, presenta la seua primera exposició personal - "Moi aussi, je me suis demandé si je ne pouvais pas vendre quelque chose..." - en la galeria Saint-Laurent de Brussel-les.

Les obres exposades estaven fetes a partir d'objectes i de materials trets del entorn quotidià combinats amb escaiola i pintura, i semblaven molt bé sintonitzades amb l'art més avantguardista del moment. Però, la programàtica confluència amb el Nouveau Réalisme i el pop art pretenia, en realitat, fer una crida d'atenció sobre l'exaltació complaguda dels nous fenòmens artístics i, alhora, sobre l'excessiu protagonisme del mercat en l'àmbit de la cultura.

En certa forma, la proposta novella de Broodthaers representa una mena de revenja de l'apropiació del collage i del ready-made per part del pop art i del Nouveau Réalisme. Altrament, també recalca el paper estratègic de la galeria d'art com a espai socialment designat per inscriure i legitimar la producció artística.

7. Targeta d'invitació de l'exposició "Moi aussi je me suis demandé si je ne pouvais pas vendre quelque chose...". (anvers i revers) Brussel-les, 1964

\footnotetext{
${ }^{14}$ M. Broodthaers citat per B. Pelzer "Los indicios del intercambio". En: Marcel Broodthaers. Ma., op. cit: p. 26. [M. Broodthaers "Un poéte en voyage... à Londres". Journal des Beaux-Arts, 3 abril, 1961, núm. 931: p. 12]

${ }^{15}$ M. Broodthaers (1964a). "Moi aussi, je me suis demandé si je ne pouvais pas vendre quelque chose...". En Marcel Broodthaers. Ma., op. cit.: p. 56.
} 
A banda de la seua tasca com a artista, Broodthaers continua escrivint i publicant textos de ficció i articles sobre exposicions, per exemple, entrevistes apòcrifes i una autoentrevista. En general, cal fer notar una actitud un poc histriònica per part de Broodthaers, com una falsa heteronomia, la qual cosa sembla una forma de distanciament per remarcar una intenció crítica i contestatària al temps que posa en qüestió la utilitat de la crítica. ${ }^{16}$

8. "A la Galerie Aujourd'hui Marcel Broodthaers per Marcel Broodthaers". Facsímil

N'és un bon exemple una fotografia de Maria Gilissen presa en l'exposició "Pop Art, Nouveau Réalisme, etc." i publicada, darrerament, en la revista Phantomes. En la fotografia apareix el crític Otto Hahn sostenint la mà dreta d'una escultura de Segal mentre que Broodthaers sosté la ma dreta del crític. La imatge de Broodthaers ha sigut enfosquida fins a encobrir-la. Solament hi és visible una silueta negra amb unes mans blanques que donen a la figura una aparença fantasmal.

El muntatge de la foto il-lustra allò que Broodthaers anomena "el mecanisme parasitari del pensament crític tradicional". ${ }^{17}$ El mim que fa el crític al costat de l'escultura i el que fa Broodthaers mateix posen en qüestió els tòpics de la llibertat d'expressió artística i del judici crític en un intent per desmitificar tant el naixement com el reconeixement de l'obra original.

9. Broodthaers i Otto Hahn posant amb una escultura de George Segal. Foto de Maria Gilissen

\subsection{Les exposicions i el Musée d'Art Moderne Département des Aigles}

A més d'assemblages, la tasca de Broodthaers comença a incloure pel-lícules i edicions d'obra gràfica, de llibres i d'objectes. El nexe comú de tota la seua producció és l'exploració de la naturalesa objectual de l'obra artística. D'altra banda, si ben bé Broodthaers comença per utilitzar l'exposició de les seues obres com a mise en scène; a poc a poc, l'exposició esdevé un projecte amb una intencionalitat múltiple on els elements s'organitzen en funció de la lectura de l'espectador. Així doncs, l'espai expositiu cessa de ser-hi apercebut únicament com un fòrum i esdevé un suport de treball.

Paral-lelament, el 1968, sorgeix el Musée d'Art Moderne, Département des Aigles: una institució contestatària inventada per Broodthaers que va funcionar durant quatre anys adoptant la forma de diferents seccions què s'inauguraven i es clausuraven en diferents emplaçaments de manera successiva. El propòsit inicial d'aquest Museu va ser exercir de contrapunt amb la resta d'institucions oficials i constituir un espai de discussió dins del context artístic i social del moment.

\footnotetext{
16 "Broodthaers ha assenyalat la inserció estructural del subjecte en el llenguatge i les seues paradoxes: si el subjecte hi arriba a través del llenguatge, s'hi perd per raó d'estar simplement representat, però, alhora disposa d'un marge, d'un retrocés enunciatiu respecte de la seua representació. Així doncs, si la seua retòrica se sustenta en la ficció constitutiva del llenguatge, ho fa amb la finalitat d'elucidar les diferents condicions de veritat. Efectivament, una de les possibles modalitats de relació del subjecte amb el llenguatge és el fingiment. Qui parla no sols pot fingir sinó que pot fingir que fingeix." Cf. B. Pelzer; op. cit.: p. 24.

${ }^{17}$ M. Broodthaers citat en "Marcel Broodthaers antes de 1964". En Marcel Broodthaers. Ma., op. cit.: p. 54. [M. Broodthaers "A propós d'une émission de Jean Antoine sur Giorgio de Chirico". Journal des Arts Plastiques, 1966, núm. 28]
} 


\section{MARCEL BROODTHAERS}

\section{pa r M a rce l B r o o d t h a e r s}

Distinction prix Jeune Sculpture 63. En 64 exposition personnelle Galerie St-Laurent et accrochages aux galeries Smith et les Contemporains. En 65, participation à des expositions de groupe à Paris; Comparaisons et le Ranelagh. Marcel Broodthaers se réclame du Pop' Art. Il définit ici, lui-même, sa position.

Des moules, des œufs, des objets, sans contenu autre que l'air et sans grâce. Seulement leurs coquilles exprimant le vide forcement. C'est le socle qu'il faut regarder. En fait, je vous livre de la réalite avec mes ceuvres.

Sans doute ai-je à présent un emploi et jauraí du mal à m'en défaire. Ce mornent du choix d'une profession, $\mathrm{j}$ 'ai bien cru, dans ma naivete, pouvoir le reculer jusqu'à Theure de ma mort. Dans quel piege suis-je tombe, mois, le veur, linconsolé, le ténébreux; ce prince d'Aquitaine ce loup populaire?

Le romantisme classique et son expression récente, le surrealisme, n'auront constitué qu'une barrière fragile. Je suis tombé dans le trou, beau encore et à peine menace côte du coeur. Oui, à présent, je fais partie intégrante de la société comme tous les artistes.
Il y a 18 mois que j'ai vu à Paris nne exposition de moulages, ceux do Segal; ce fut le point de depart, le choc qui m'entraina jusqu'a produite moi-meme des cuvres. Puis ce furent Liechtenstein, Jim Dine et Oldenburg qui acheverent la germination des graines qu'avaient semé lirritable, le maladroit, le grand René Magritte. Le PopArt s'est inspire de sa poesie et sest approprie ses humeurs et sa séverite. A mon tour, je ne pouvais quaccepter le monde dans la forme des rapports sociaux et humains que suppo l'Art.

Ferai-je tomber d'autres hommes dans le piège? Qui sait? Je l'espère. Devenu ami de la société, je rombreux, bêtes et méchants.

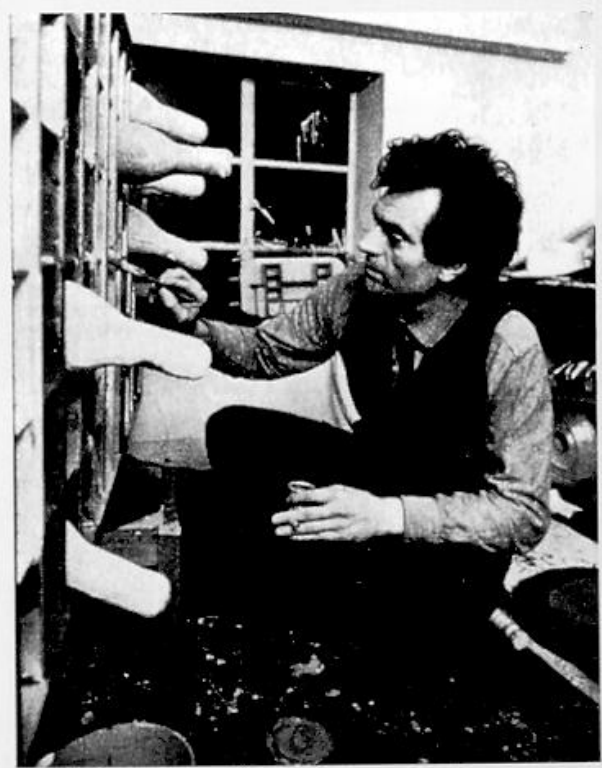
haers dan atelier. (Photo ean-Marie De Witte.

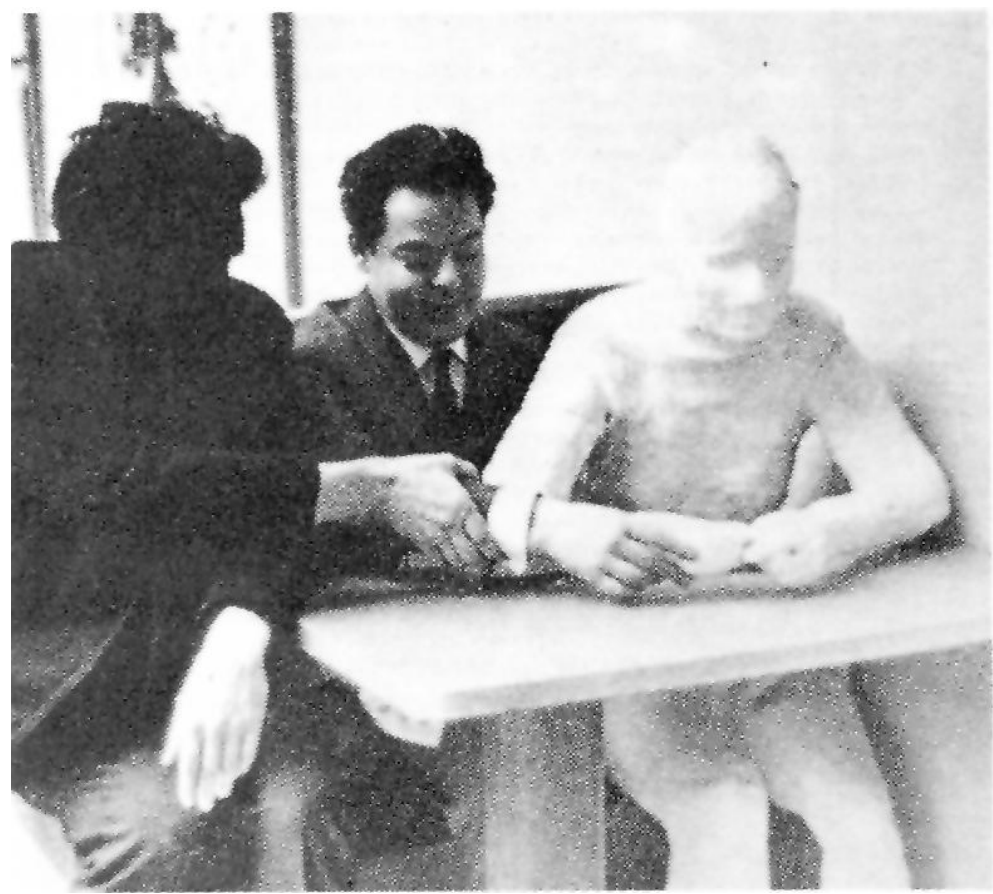



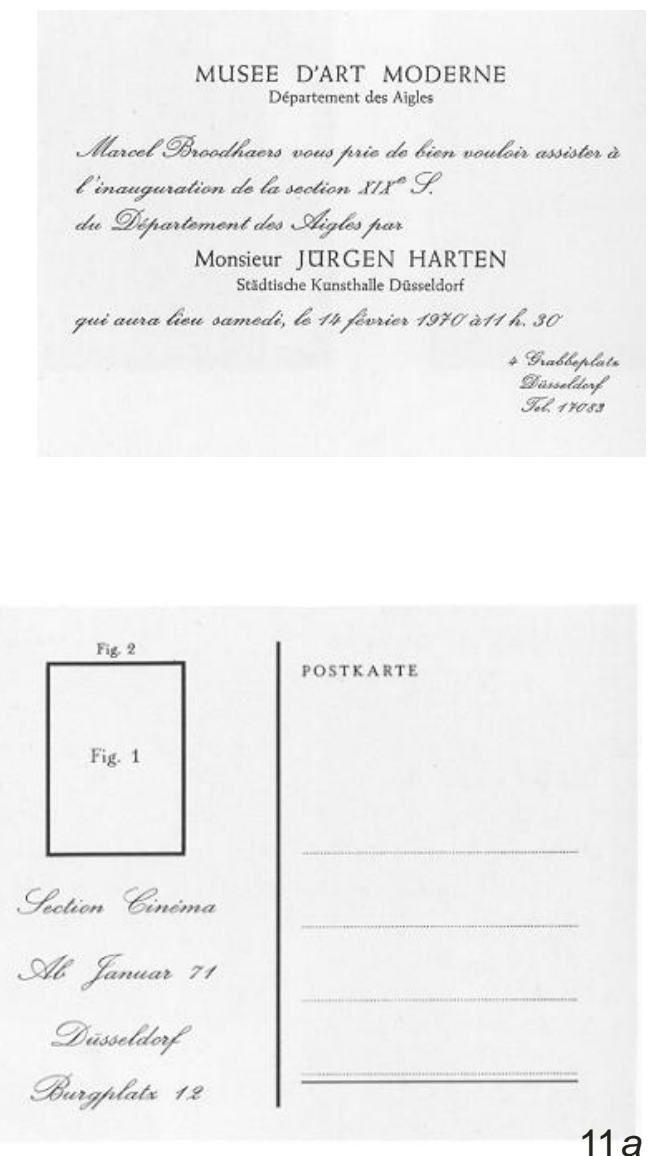

MUSEE D'ART MODERNE

DEPARTEMENT DES AIGLES

- 1968 . Bruxelles XIX' siècle

- 1969 . Antwerpen XVII' siècle

- 1970 . Düsseldorf XIX* siècle (bis)

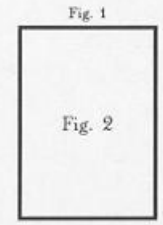

- SECTION CINEMA

Af partir de jamies if

Trom fanuary it

Surgplatis 18

4 Dusseldorf

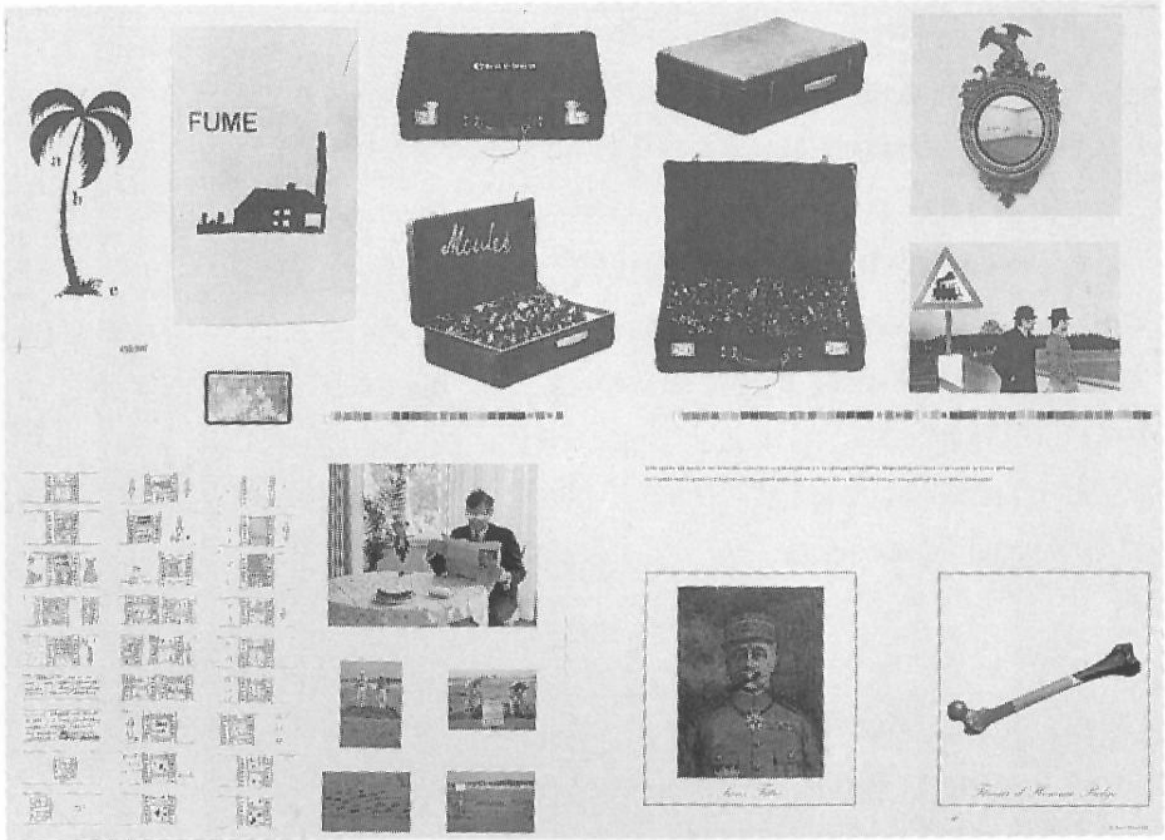


Des del seu paper com a director/ conservador del Musée d'Art Moderne..., Broodthaers promou nombrosos esdeveniments dins de la seua política contestatària. En canvi, no hi havia cap guió ni cap direcció traçada a priori, sinó que cada manifestació desenvolupava determinats pressupostos a partir del seu estament fictici. Així doncs, els resultats assolits donaven lloc a altres manifestacions. La clausura definitiva del Museu tingué lloc a Kassel durant "Documenta V".

Finalment, les conclusions derivades de l'experiència del Musée d'Art Moderne... juntament amb la significació que assoleix el moment expositiu i la reflexió sobre el caràcter objectual de l'obra d'art conflueixen en la noció décor: l'exposició com a Decor i com a finalitat del treball artístic. ${ }^{18}$

10. Targeta d'invitació de la Section xixe siècle (bis). Düsseldorf, 1970.

11. Targeta d'invitació de la Section Cinéma. Düsseldorf, 1971.

\subsection{El Decor}

Encara que la noció de Decor ja era part del barrejat d'algunes exposicions, va ser sobretot a partir del 1972, després d'esgotar l'experiència del Musée d'Art Moderne, quan Broodthaers comença a parlar-ne i a executar-hi les seues exposicions. Es tractava, essencialment, de combinar diferents elements - obres i objectes diversos, fragments d'altres exposicions, reedicions, projeccions de pel-lícules, etc. - cada vegada amb un propòsit particular. Sovint, aquesta etapa del seu treball ha sigut subvalorada o passada per alt, presumptivament des de l'opinió que no aportava cap novetat.

Molts d'aquests projectes pertanyen a la categoria d'exposicions retrospectives o antològiques, cosa que respon a la intenció de Broodthaers de proposar un sistema de lectura. No obstant això, aquesta finalitat didàctica està farcida de detalls irònics i de senyals de complicitat a l'espectador, al temps que hi fa servir un to paròdic per a burlar la complaença $\mathrm{i}$ el narcisisme inherent a aquests gèneres de muntatges.

Sens dubte, l'exposició com a Decor imprimeix una aparent frivolitat a la tasca de Broodthaers, cosa que, aleshores, resultà inesperada i prou enigmàtica; sobretot, tenint en compte l'abast i la repercussió que van assolir les seues propostes anteriors, en particular, les manifestacions del Musée d'Art Moderne Département des Aigles. No obstant això, sembla que van ser justament l'abast i la repercussió el que va dur Broodthaers a replantejar-se les condicions de continuïtat del seu treball. ${ }^{19}$

Potser aquesta qüestió no haja sigut compresa ben bé fins ara, encara ser prou clara $\mathrm{i}$ sintonitzar coherentment amb l'actitud de tota la seua carrera. La mort de Broodthaers, el 28 de gener del 1976 a Colònia, deixa en suspens la seua obra, una de les més completes i apassionants del nostre temps.

12. Cartell de l'exposició "Catalogue - Catalogus". Brussel-les, 1974.

\footnotetext{
${ }^{18}$ El terme decor té una doble una accepció tant en valencià com en francés (décor). És l'art de decorar els edificis amb tot allò que s'hi fa servir i també és la correcció de maneres i el capteniment social d'algú.

${ }^{19}$ La anàlisi de la noció Decor en les exposicions de Broodthaers, la significació en el seu treball, així com la relació entre Decor i Museu i entre Decor i cinema s'ha desenvolupat en el capítol 3.6 "Una altra voltade rosca: l'exposició com a Decor", en el capítol 3.7 "L'acte expositiu i el projecte creatiu" i al llarg del bloc 4. "L'art entre la supervivència i la utopia".
} 
2. LA RECERCA D'UN LLENGUATGE 


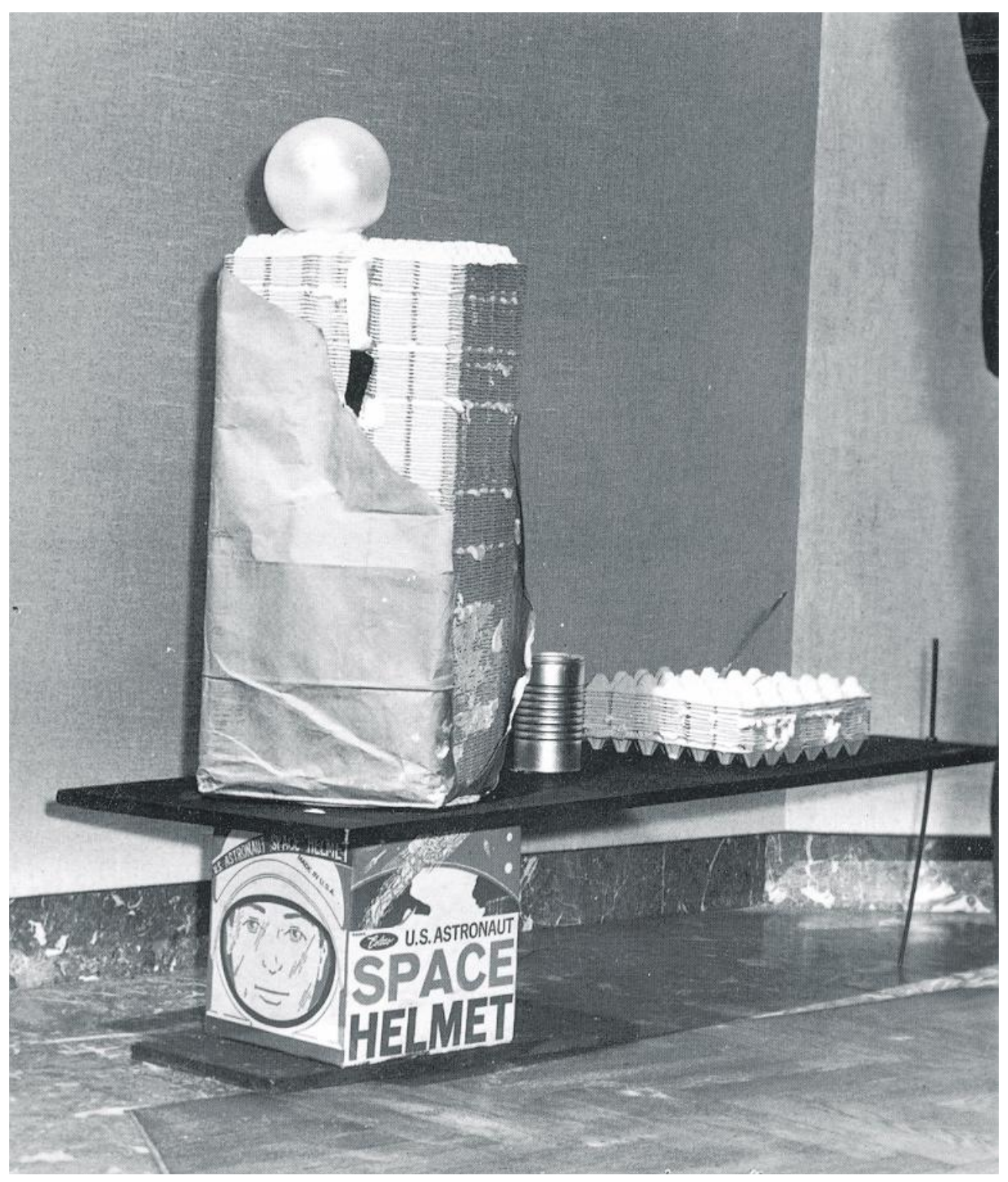




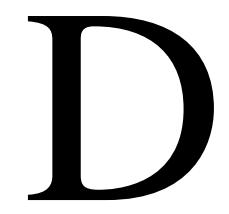

esprés d'un apropament general a la seua biografia artística, una interpretació més atenta de les propostes de Broodthaers ens indueix a assenyalar dues qüestions principals. D'una part, el seu treball artístic es defineix com a resultat d'una sèrie d'operacions retòriques i poètiques que tenen lloc a partir de l'apropiació i la resignificació de l'objecte com a referent d'allò real en el sentit més ampli. Altrament, la galeria d'art en tant espai públic constitueix per a Broodthaers un àmbit productiu i comunicatiu carregat de referències i prou significatiu en el qual l'obra també és un referent d'allò real, és a dir, l'exposició i l'obra representen el conjunt de circumstàncies que intervenen en l'esdeveniment artístic.

Des d'un punt de vista cronològic, la primera iniciativa de Broodthaers per a llançar-se públicament com a artista plàstic va ser la presentació de diverses obres per a la convocatòria d'un certamen d'escultura - "Premi Jove d'Escultura belga" - el 1964. Les obres que hi resultaren seleccionades van exposar-se en el Palau de Belles Arts de Brussel-les, entre les quals hi havia una de Broodthaers: Monument Public $N^{\circ} 4$. Aquest fet assenyala l'inici de la seua trajectòria.

13. Monument Public No4 (1963)

Es tractava d'un assemblage realitzat a partir de materials desertats: caixes buides, cartons d'ous i altres deixalles. Aquests materials no guardaven cap relació amb el seu entorn original sinó que hi apareixen units amb escaiola $i$ formant una espècie de torre amb un embolcall de paper mig desfet que permetia veure el que hi havia dins. El conjunt estava unit a un tauler de fusta que li servia com a base i que alhora descansava sobre una caixa i un peu de metall que acomplien la funció de pedestal de l'escultura.

Però allò més interessant és la manera en què Broodthaers aborda el concepte de monument. Encara que hi estaven presents els elements bàsics del llenguatge de l'escultura monumentària, com són la figura exempta, la base i el pedestal, Broodthaers havia desestimat els materials nobles i perdurables hi vinculats tradicionalment $i$, en canvi, hi havia utilitzat escaiola, caixes buides i resines sintètiques. La banalitat dels materials emprats i la precarietat del conjunt contradeien la significació transcendental del monument. Amb tot això Broodthaers ironitza sobre la idea de monument al temps que escenifica la precarietat real de la funció pública de l'art.

Altrament, cal assenyalar que l'ús de l'escaiola hi era més funcional que escultòric i l'esfera de poliuretà representava un volum pur al temps que incorporava al monument un material no tradicional, la qual cosa remetia a les pràctiques artístiques més novelles.

En sentit general, l'obra plàstica primerenca de Broodthaers enjudicia l'apologia de la novetat en l'art apropiant-se de forma pública de les estètiques del pop art i del nouveau réalisme. En la targeta d'invitació de la seua segona exposició, "Objets de Broodthaers / Voorwerpen van Broodthaers", Broodthaers declara: 
Ja faig Pop. [...] Com ho he aconseguit? Molt senzill. No he fet res més que seguir les empremtes, encara fresques, deixades per René Magritte i per Marcel Duchamp; i les de George Segal, les de Roy Lichtenstein i les de Claes Oldenburg en les sorres artístiques. ${ }^{20}$

Aquesta afirmació justificada per mitjà d'una genealogia que inclou artistes aleshores novells però de primera divisió, així com Duchamp i Magritte feia referència a una forma d'entendre l'art basada en la llibertat de l'artista per validar com a art qualsevol objecte o idea.

És clar que aquests plantejaments van significar un desafiament a les idees establertes, cosa que, en el seu moment, va remoure els ciments de la creació i la recepció artística. Però, per a Broodthaers la validació d'un objecte o d'una idea com a art, si ben bé trencava la idea de l'art com a manufactura i alliberava la funció estètica, instituïa l'artista com a creador d'una noció d'art altra, independitzada de d'uns codis d'excel-lència, però susceptible igualment d'instituir-se com a objecte de culte.

Per a Broodthaers l'exaltació d'aquesta noció d'art per si mateixa i la seua proliferació conduïen cap a un buit de sentit que neutralitzava l'impacte del desafiament original. Així doncs, l'afiliació que declara Broodthaers no és aquiescent, sinó provocativa i especulativa, la qual cosa trasllada el nucli de la reflexió cap al conjunt de circumstàncies alienes que envolten el fet artístic.

\subsection{L'object trouvé i el registre d'allò real}

La majoria dels assemblages de Broodthaers estan realitzats a partir de deixalles closques de musclos, cascares d'ous, cendres, óssos... - i d'estris del l'entorn domèstic com són olles, paelles, taules, cadires, armaris, maletes, caixes, etc., que sovint apareixen com a basament dins de l'obra mateixa.

Després d'objet trouvé, per a Broodthaers l'objecte representa, inevitablement, la qualitat física de l'obra i l'ocupació material de l'espai artístic, al temps que constitueix un suport de la seua producció plàstica. Sobre el tema declara:

Jo utilitze l'objecte com una paraula zero. ${ }^{21}$

Aquest pressupost il-lustra un procediment que consisteix a cancel-lar les referències originals de l'objecte per convertir-lo en signe, en element d'un llenguatge. D'altra banda, es tracta d'objectes alienats en el mateix sentit que Marcel Duchamp va entendre el ready-made.

\subsubsection{El llegat de Duchamp}

Si per a Broodthaers l'objecte representa una paraula-zero, cal contrastar-ho amb el fet que per a Duchamp l'objecte també era un instrument, era la referència més eficaç per a destruir la concepció artesana tradicional de la pràctica artística. ${ }^{22}$

\footnotetext{
${ }^{20}$ M. Broodthaers (1965b). ¿¿Pop Art? Preguntádselo a Jean Dypréau...". En Marcel Broodthaers. Ma., op. cit.: p. 69.

${ }^{21}$ I. Lebeer (1974); op. cit.

${ }^{22}$ Duchamp i Picabia van escometre una radical renovació del concepte d'obra artística i del llenguatge plàstic a partir de l'experimentació al voltant de l'objecte mecànic. Els ready-mades van ser paradigmes de la destrucció de la idea de l'art com a realització artesana i individual, on la destresa de l'artista va ser substituïda per l'objecte
} 
En el procés que duia al ready-made, l'objecte no sofria cap modificació des de la seua selecció fins a la seua presentació. El mòbil per a l'elecció era la indiferència i d'aquesta forma qualsevol implicació emotiva o intel-lectual per part de l'artista quedava exclosa. ${ }^{23}$ L'objecte era transformat en obra d'art únicament en virtut de la seua presentació en l'espai de la galeria o del museu. Llavors, es tractava de "...la proclamació de la «personalitat de selecció» per damunt de la «personalitat d'ofici»". ${ }^{24}$ Així doncs, la col·locació de l'objecte en el context consagrat a les arts el convertia en art, a més a més que hi constituïa una proposta antiart.

Darrerament, durant la dècada dels seixanta, la recuperació del procediment ready-made significà un profund canvi d'actitud en les esferes de la creació i la recepció artístiques. Segon Pierre Restany, un dels crítics més influents del moment, es tractava d'un realisme nou perquè l'art assumia els elements de la realitat en estat brut, i en diu textualment: "el nouveau réalisme registra la realitat sociològica sense cap transformació i sense cap intenció polèmica." ${ }^{25}$ Però, més que el registre de la realitat, sembla que es tractava de definir-hi la relació; i com a actitud artística, és més propera la idea d'apropiació.

En apropiar-se de la realitat aquests artistes formulen, de forma més o menys conscient, un problema davant la creació artística: la qüestió de l'originalitat; tota vegada que en renuncien a l'empremta de la individualitat. ${ }^{26}$ En reacció contra l'expressionisme, la implicació emocional amb el procés creatiu estava démodé. Però, si l'esperit estètic no hi és gens d'elaborat, el sentit de l'humor hi és més fi i més ambigu. Broodthaers va adonar-se que l'humor evitava una interpretació dramàtica de l'actualitat artística - "el canvi que havia esdevingut en el tema de l'Art..." - alhora que resultava molt més eficaç que la crítica a ultrança. ${ }^{27}$

Els artistes del nouveau réalisme i del pop art van rebutjar tota jerarquia de llenguatges tradicionals i van proclamar l'origen de l'art en l'entorn quotidià, trobant en la natura del segle $X X$ - la cultura urbana, el desplegament tecnològic, la publicitat o la televisió - els motius susceptibles de ser apropiats.

Però, per aconseguir-ho, van començar a actualitzar el procediment ready-made com una estètica de l'objecte, la qual cosa va cancel-lar el seu potencial revolucionari original. L'acolliment d'aquest fenomen desplaçà de l'escena artística els moviments figuratius tant a Europa com als Estats Units i consegüentment els llenguatges artístics interessats a enregistrar allò real mitjançant l'objecte acabaren per instituir-se en poc de temps.

industrial apropiat. Sobre aquest tema, vegeu V. Nieto. "Surrealismo y máquina: entre la metáfora y el objeto". En A. Bonet; op. cit.: p. 57-69.

${ }^{23}$ Cf. M. Duchamp (1961). "A propósito de los ready-mades". En M. Duchamp. Escritos. Duchamp du signe. Bar.: Gustavo Gili, 1978: p. 164.

${ }^{24}$ Segons una definició de L. Aragon citada per V. Nieto; op. cit.: p. 64. [L. Aragon "Collages dans le roman et dans le film", s. r.]

${ }^{25}$ Segons paraules de P. Restany citades per A. Pelegrini. "Nuevas tendencias de la pintura". En G. Mosquera. Del Pop al Post. Una antología sobre la plástica y la arquitectura occidentales de los últimos 25 años. La Habana: Arte y Literatura, 1993: p. 44. [s. ref.]

${ }^{26}$ Restany ho va descriure com "...l'apassionant aventura d'allò real apercebuda en sí mateixa i no mitjançant el prisma de la transcripció conceptual o imaginativa. [...] Estem fins al coll en el bany de l'expressivitat directa i a quaranta graus per damunt del zero dadà, sense complex d'agressivitat, sense voluntat polèmica caracteritzada, sense més picor de justificació que el nostre realisme". P. Restany. "Manifiesto de los nuevos realistas". En S. Marchán. Del arte obejtual al arte de concepto. Ma.: Akal, 1997: p. 347-348.

${ }^{27}$ Vegeu M. Broodthaers (1965d). "Como la mantequilla en un sandwich". En Marcel Broodthaers. Ma., op. cit.: p. 71-72. 
Altrament, alguns artistes van promoure actituds iròniques i desestabilitzadores per mostrar el revers d'aquesta mateixa realitat: les deixalles generades pel consum o l'avançament incontrolat de la tecnologia; i tot adoptant-ne una postura crítica amb la seua obra. Òbviament, l'actitud de Broodthaers és més propera a aquestes actituds ja que mitjançant l'assimilació de les pràctiques objectuals s'hi proposava il-lustrar com l'entrada de l'objecte en l'art estava sent idealitzada i sobreestimada amb la complicitat de crítics i de marxants fins al punt d'oblidar la seua original significació subversiva.

Amb tot, mitjançant la recreació dels aspectes banals de la realitat, Broodthaers excedeix l'univers de símbols que caracteritzava els seus poemes, en sintonia amb la seua recerca de noves possibilitats comunicatives per incidir sobre l'espai de l'art. D'aquesta forma, Broodthaers dirigeix l'atenció cap al sentit instrumental dels seus assemblages:

El desbordament dels musclos en l'olla mai no segueix les lleis de l'ebullició, sinó que segueix les regles de l'artifici per arribar a la construcció d'una abstracció. ${ }^{28}$

14. Pyramide de moules (1966) (p. oposada)

15. $S / T$ (Soroll secret) (1965 - 66) (p. oposada)

16. Trioumphe de Moules I (moules casserole) (1965) (p. oposada)

Les closques de musclos i les d'ous que fa servir Broodthaers en els seus assemblages són restes d'aliments, les acumulacions dels quals remeten a l'home i al consum. La insinuació d'un paral-lelisme entre consum alimentari i consum artístic vincula corrosivament ambdues esferes mitjançant una mateixa pulsió que evoca la mateixa intenció de transgredir els límits entre l'art i la realitat, entre allò privat i allò públic, entre allò banal i allò artístic.

\subsection{Els assemblages i l'escultura}

A més a més de la qüestió de l'objet trouvé hi ha, en l'obra de Broodthaers, la qüestió de l'organització i de la codificació dels materials.

A partir del 1964, Broodthaers realitza nombrosos assemblages. Aquest procediment li ofereix un ampli registre de possibilitats d'expressió que assumeix no únicament com la solució per a combinar diferents objectes i materials des del punt de vista formal, sinó, i sobretot, per a fer confluir diferents idees i per a articular els seus interessos respecte de la pràctica artística.

Gran part dels assemblages són obres tridimensionals on hi ha objectes que serveixen com a suports per a l'acumulació d'uns altres o bé s'hi fan servir superfícies planes amb formats regulars. Així doncs, aquestes composicions són apercebudes com a escultures o com

${ }^{28}$ I. Lebeer (1974); op. cit. 

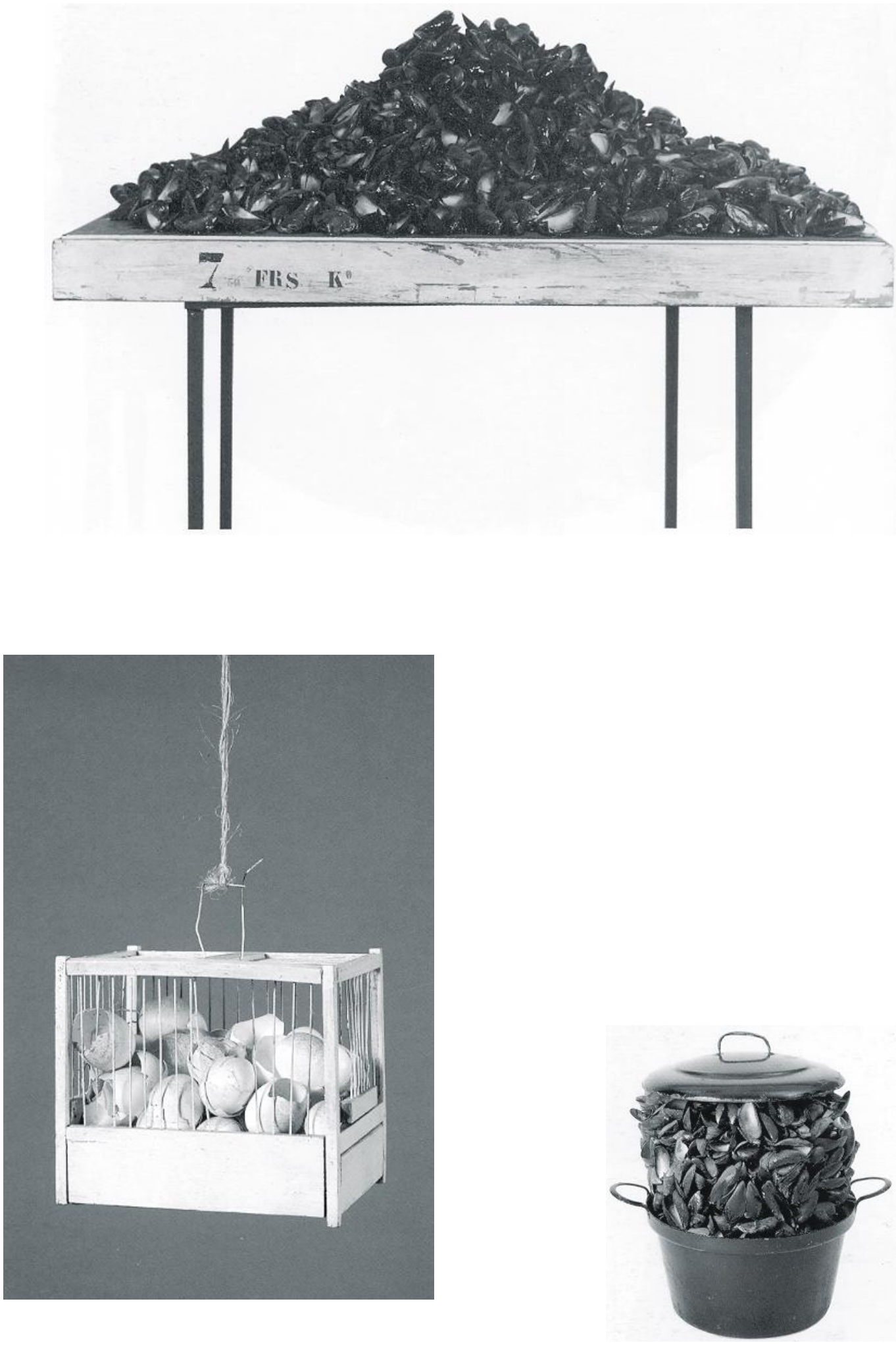

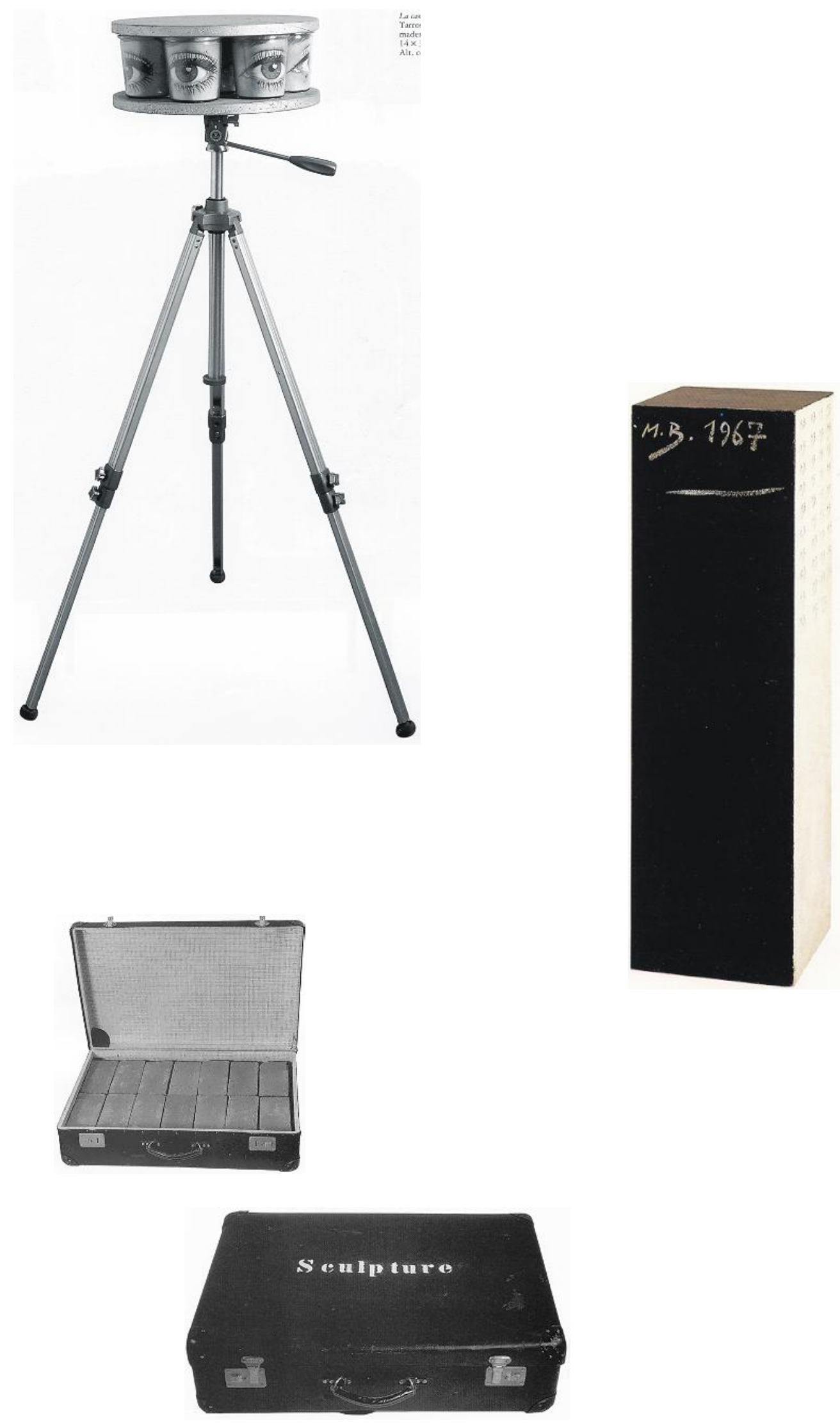
a quadres segon el caràcter dels materials hi emprats així com per l'organització i per la relació que es produeix entre aquests materials i el seu suport.

Altrament, alguns d'aquests assemblages recorden aquella imatge antològica de la trobada casual entre un paraigua i una màquina de cosir sobre una taula de disseccions. ${ }^{29}$ Però, l'elecció i la combinació d'aquests objets trouves de la realitat quotidiana no és ni accidental ni excèntrica, sinó que pretén demanar-hi l'atenció sobre les relacions entre aquests.

Però, en els assemblages de Broodthaers la trobada d'objectes i la seua combinació en una mateixa obra no crea cap atmosfera, ni tampoc és atzarosa, sinó que hi genera un sentit insòlit. ${ }^{30}$ És l'objecte mateix qui interroga sobre el seu sentit. En un altre nivell, la combinació d'objectes condueix a la combinació d'idees.

Broodthaers mateix ho explica d'aquesta manera:

Més que objectes i idees, allò que organitze és la trobada de funcions diferents que remeten al mateix món: la taula i l'ou, el musclo i l'olla a taula i en l'art, en el motlle i en la gallina. ${ }^{31}$

Una obra titulada La caméra qui regarde n'és un bon exemple. Es tracta d'una mena de poema-objecte on no es veu cap càmera sinó un trípode amb molts ulls. En el lloc de la càmera, damunt del trípode, hi ha una composició feta amb imatges d'ulls col-locats dins d'envasos de vidre disposats en cercle de manera que abasten la totalitat de l'angle visual. Però, el fet d'anomenar càmera l'assemblage si ben bé funciona com a trobada de funcions diferents, és a dir, com a referència comuna a l'acte d'enregistrar allò real però amb objectes diferents, produeix un trencament entre el concepte que representa la paraula i la significació de l'objecte representat.

Un altre exemple significatiu és una altra obra titulada Sculpture. És una maleta omplida de rajoles. Si d'una banda, la seua presència en la galeria d'art remet al procediment readymade, d'altra, el títol confronta el resultat amb el procediment i emporta l'obra al terreny de les proposicions lingüístiques. Així doncs, l'argument de la trobada de funcions diferents funciona com a justificació i com a distanciament entre el procediment i la seua finalitat.

17. La caméra qui regarde. Assemblage (1966) (p. següent)

18. Sculpture (1974) (p. següent)

19. Socle (1967) (p. següent)

Amb tot, les fronteres entre l'assemblage i l'escultura no són gens clares. De fet, l'assemblage com a procediment va molt més lluny de la idea de l'escultura, entesa com a gènere estancat, i transgredeix els seus límits.

\footnotetext{
${ }^{29}$ Aquesta frase del Comte de Lautremont [Isidore Ducasse. Cantos del Maldoror] va proveir als surrealistes d'una metàfora de l'atzar i d'allò insòlit protagonitzada per objectes desnaturalitzats. Però, l'interés per la màquina i per l'objecte mecànic no hi apareix com un tema nou sinó com una crítica dels temes tradicionals de l'art. Cf. V. Nieto; op. cit.: p. 58.

${ }^{30}$ Cosa que, en canvi, sí succeeix en els collages de Schwitters. Perquè cal recordar que els orígens del procediment de l'assamblage deriven bàsicament dels collages de Kurt Schwitters i dels ready-made de Marcel Duchamp. Altrament, en els anys seixanta els artistes que se servien de l'assamblage apel-laven a la relació de l'art amb el fet quotidià i van rebutjar qualsevol jerarquia de materials i de formes.

${ }^{31}$ I. Lebeer (1974); op. cit. És significatiu el joc de sentits que promou Broodthaers al voltant del terme moule que significa musclo però també motlle i model.
} 
Per la seua part, Broodthaers té cura de no plantejar-se l'assemblage com a oposició o com a superació dels gèneres tradicionals. La majoria de les seues composicions són ambigües, és a dir, no transgredeixen cap dels límits sinó que s'hi mouen. En consequiència, tota referència explícita a l'escultura o a la pinturaés més una qüestió lingüística que artística que remet indubtablement a la reflexió iniciada per Magritte.

Particularment, en una obra titulada Socle, Broodthaers presenta un pedestal amb la seua signatura i la data. Però, el pedestal no hi era un objecte indiferent, com l'urinari, sinó un objecte culpable. ${ }^{32}$ D'una banda, Broodthaers manté la identitat entre l'objecte real i la seua representació lingüística però, la seua signatura nega la definició i converteix l'objecte en obra d'art. D'altra banda, es tracta d'una figura estretament vinculada amb la tradició escultòrica. ${ }^{33}$ Això no obstant, per a Broodthaers l'esdevenir del pedestal era comparable, en cert sentit, a l'entrada de l'objecte en l'art i, així doncs, la seua signatura hi constituïa un gest extrem dirigit a desmitificar el paper de l'artista com a creador.

\subsection{La pintura, la fotografia i la influència de René Magritte}

D'igual manera que determinades combinacions d'objectes i de materials donaven lloc a composicions que podien ser escultòriques, Broodthaers també va conjugar elements netament pictòrics en els seus assemblages. Aquests elements són: la superfície plana, la taca de color, la pàtina i la pinzellada, a més a més de la utilització de tècniques de reproducció fotogràfica.

L'ús del color en els assemblages de Broodthaers, ja siguen quadres o escultures, sembla més una qüestió de presència o d'actitud que un interés pictòric o experimental en sí mateix. Mai no hi apareix en funció de dibuixar o ressaltar figures sinó com a matèria. Pel que fa a la pinzellada s'hi observa la mateixa cosa: més que un gest, és la representació del gest.

Un collage de closques d'ou i grans taques de color sobre una superfície rectangular penjat de la paret és, al mateix temps, un assemblage i un quadre. L'elaboració de composicions amb elements del llenguatge pictòric i objectes de la realitat, o també combinant objectes i reproduccions fotogràfiques, respon al mateix procediment que els assemblages escultòrics: es tracta d'elements aillats, trets del seu context original - la taca, el color, la tela, la imatge... - i combinats per crear la trobada de funcions diferents.

20. L'erreur (1966) (p. anterior)

21. Roule moule (1967) (p. anterior)

22. Bocal avec texte (1967) (p. anterior)

Pel que fa a la utilització d'imatges fotogràfiques dins dels quadres, Broodthaers va utilitzar-les com a registrament, com a mitjà d'apropiació de l'objecte mitjançant la imatge. En general, les tècniques de reproducció mecànica van ser emprades igualment pels artistes per aconseguir l'absència d'empremta personal. Inclusivament van irrompre com l'antítesi de

\footnotetext{
${ }^{32}$ Indiferent en el sentit que va donar Duchamp als ready-mades, inspirat en el vers de Baudelaire: "La bellesa de la indiferència", i culpable en el sentit que va declarar Broodthaers: "culpables [els objectes] dins de l'art com a llenguatge i innocents dins del llenguatge com a art". Cf. M. Duchamp (1961); op. cit. i també I. Lebeer (1974); op. cit.

${ }^{33}$ Els escultors d'avantguarda van prendre el pedestal, van modificar el seu paper d'accessori i van incorporar-lo a l'objecte escultòric, ja com a element compositiu o simplement com a material.
} 


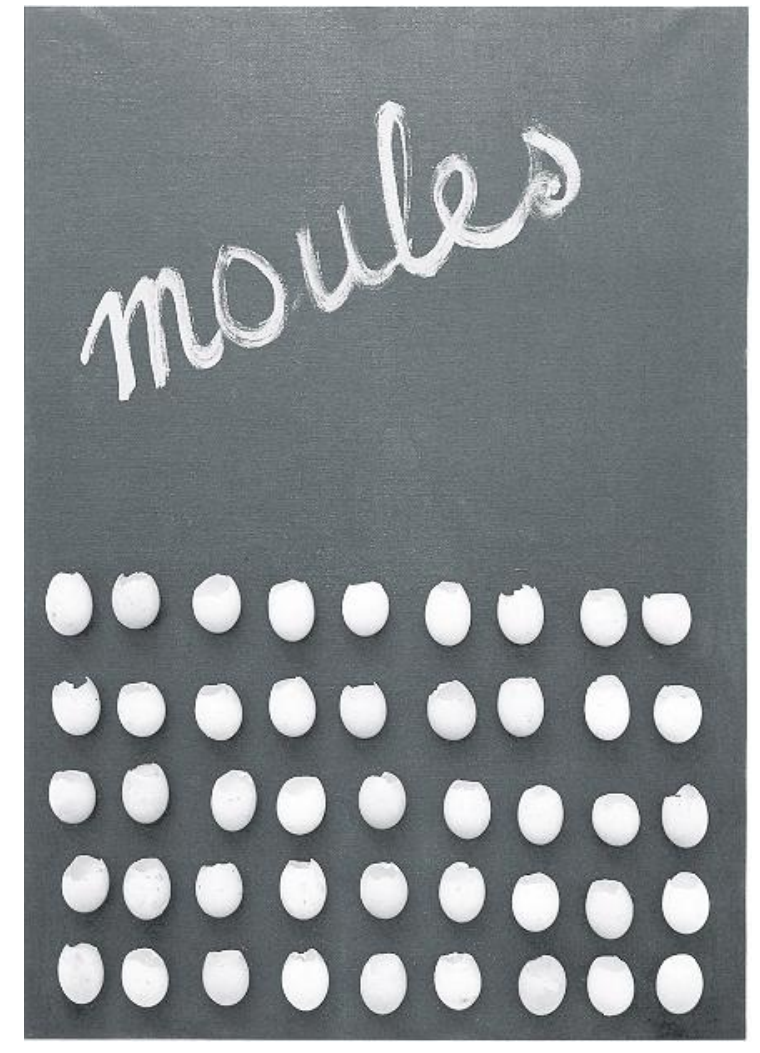

20
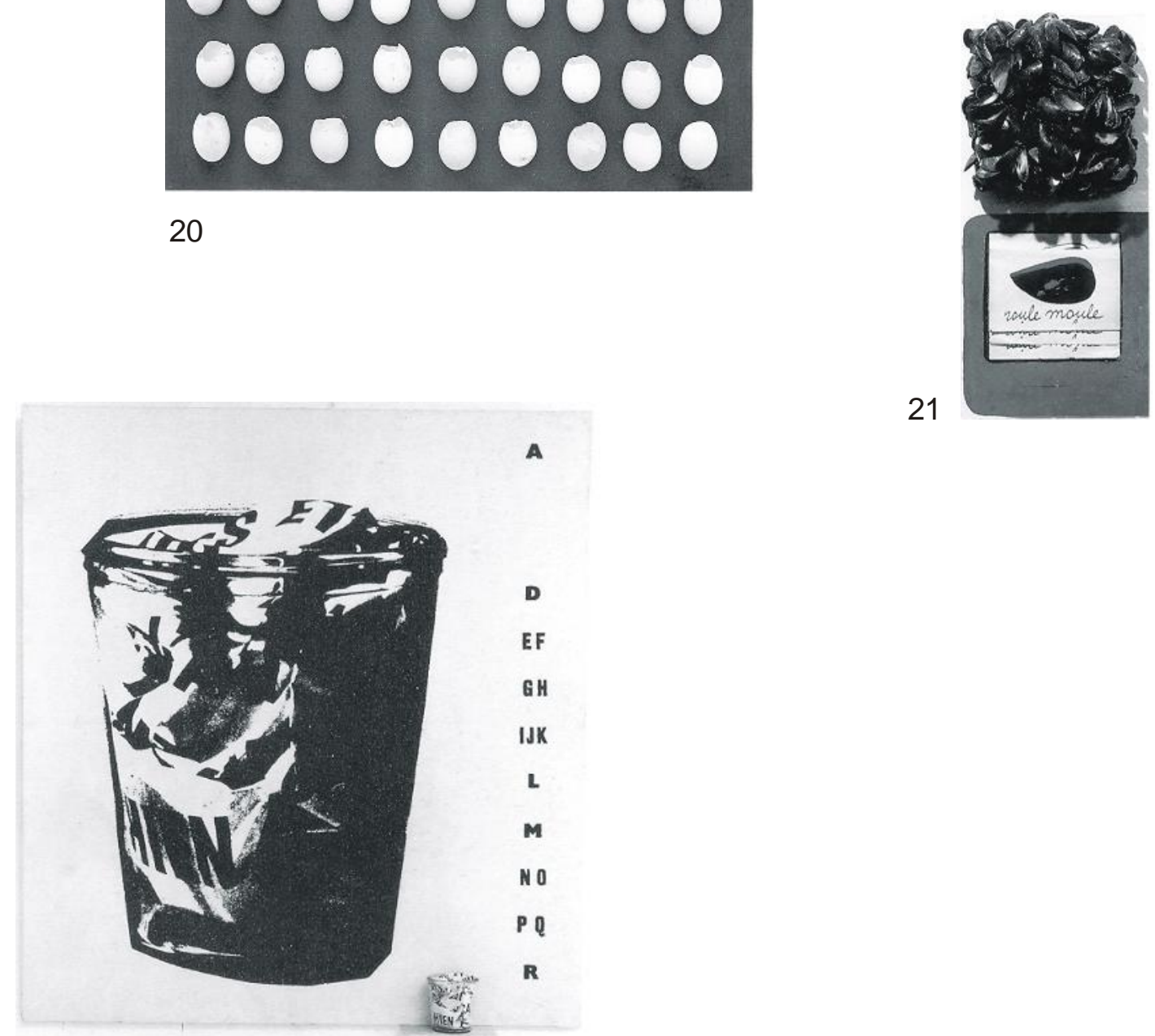
l'acction paintig, encara que igualment en van esdevenir una estètica. ${ }^{34}$ La fragmentació de l'objecte, l'alteració de proporcions o la confrontació de la imatge amb l'objecte real dins de l'obra mateixa són procediments que cancel-len el significant. Igualment, la relació entre els objectes, reals o reproduits, i la paraula o en els títols de les obres serveix a Broodthaers per a abordar la qüestió de la representació en l'art, però apel·lant a la confrontació de funcions.

Broodthaers va plantejar-se els problemes de la representació més seriosament que els seus contemporanis. Es pot dir que, aleshores, cap artista no es va adonar de la qüestió de la representació, la qual fou plantejada per Magritte i després per Broodthaers. Cal tenir en compte que en els anys seixanta i setanta, les noves pràctiques artístiques solament van fer ús de la fotografia com a representació directa d'allò real i com a substitució i descrèdit de la representació pictòrica tradicional. ${ }^{35}$ Les seues obres van tenir present els experiments lingüístics de Magritte com una referència fonamental per qüestionar la identitat entre l'objecte i els codis de la seua representació.

\subsubsection{Broodthaers i Magritte}

La figura de Magritte és fonamental per a Broodthaers com a punt de partida de les seues reflexions artístiques i sobretot com a model d'artista intel-lectual. La trobada entre Broodthaers i Magritte va tenir lloc el 1946. Broodthaers havia respost les preguntes d'una enquesta anònima sobre l'afecció a les coses publicada en la revista Le savoir vivre, la qual havia sigut preparada per Magritte. Per aquell temps Broodthaers tenia muntada en la zona antiga de Brussel-les una llibreria petita de segona mà on podien trobar-se exemplars antics $\mathrm{i}$ rars. Aleshores, quan es conegueren personalment, Magritte obsequià Broodthaers amb una edició antiga del poema de Mallarmé Un coup de dés jamais n'abolira le hasard.

En els quadres de Magritte hi ha una atmosfera d'irrealitat i d'improvisació que sintonitzava amb les línies surrealistes exposades per Breton. ${ }^{36}$ Però, a banda d'això, Magritte aborda per mitjà de la pintura el problema de la percepció lligada als diferents mitjans partint dels plantejaments de Saussure. La relació més important entre la imatge o l'objecte i el nom se sustenta en una convenció que és qüestionada per Magritte: "un objecte mai no produeix el mateix efecte que el seu nom o la seua reproducció" - escriu en "Les mots et les images". ${ }^{37}$ També hi planteja: "en un quadre, les imatges visuals i les paraules són apercebudes de manera diferent." ${ }^{138}$

Per a Broodthaers, Magritte "nega el caràcter estètic de la pintura", la qual cosa dirigeix el camp d'acció fins al caràcter instrumental de la pintura per desemmascarar l'artifici de la representació artística i del llenguatge com a representació de la idea. ${ }^{39}$

${ }^{34}$ Cf. A. Pelegrini; op. cit.: p. 19-69.

${ }^{35}$ En aquest sentit citem una eloqüent comparació de Breton entre la fotografia i l'escriptura automàtica: "l'invent de la fotografia ha assestat un cop mortal als antics modes d'expressió, tant en pintura com en poesia, on l'escriptura automàtica apareguda cap a finals del segle XIX és una autèntica fotografia del pensament". A. Breton citat per F. Calvo Serraler; op. cit.: p. 35.

${ }^{36}$ De jove, Magritte va estar vinculat amb el moviment surrealista de París, encara que després el va abandonar. Cf. U. M. Schneede. René Magritte. Bar.: Labor, 1978: p. 4-5.

${ }^{37}$ Article publicat originalment en l'últim número de la revista La Révolution Surréaliste. (París) 15 desembre 1929. Cf. U. M. Schneede; op. cit.: p. 42-43.

${ }^{38}$ R. Magritte. "Les mots et les images". En U. M. Schneede; op. cit.: p. 43.

${ }^{39}$ Cf. M. Broodthaers (1963c). "Gare au Défi! Le Pop Art, Jim Dine et l'influence de René Magritte". En Marcel Broodthaers. Ma., op. cit.: p. 52-53. 
En canvi, Broodthaers no té cap interés ni per la pintura ni per cap altre gènere, ni per cap procediment combinatori en si mateixos; el que li interessa és la condició objectual de l'obra, és a dir, la pintura com a codi, el quadre con a objecte i ambdós com a suports d'una reflexió sobre el significat de la creació artística i com a recerca d'un altre llenguatge.

\subsection{La condició objectual de l'obra}

La reflexió al voltant de la condició objectual de l'obra d'art és u dels eixos fonamentals del treball de Broodthaers. Això es manifesta gairebé com una constant al llarg de tots els seus projectes encara que n'adopta formes diverses.

De primer, Broodthaers intervé sobre el procés d'edició dels seus llibres de poemes. Posteriorment, aquesta faceta d'editor abasta els catàlegs de les exposicions i sobretot la realització d'obres com a múltiples, la qual cosa ja implica l'assumpció plena de la seua naturalesa objectual.

Altrament, l'ús d'objectes trets de la realitat - de primer, per a compondre els assemblages i, després, pels decorats - així com la utilització de l'obra d'art mateixa com un objecte emmarcat en l'espai expositiu també són part de la investigació de Broodthaers al voltant de la condició objectual de l'obra.

Broodthaers hi procedeix abstraient l'objecte de la seua condició original per a emprar-lo com a signe. Per a ell, els objectes són "culpables dins de l'art com a llenguatge i innocents dins del llenguatge com a art." 40

El llibre ocupa un lloc preeminent en el treball de Broodthaers ja que, a més de suport comunicatiu pel text i per la imatge, el llibre li permet explorar tant la dimensió espacial com la qualitat objectual de l'obra. Els seus primers volums de poemes, Mon livre d'ogre i Minuit, van tenir una edició limitada. El curós tractament que van rebre els exemplars mitjançant la diversificació de l'edició intentava emplaçar-los en el límit entre l'objecte produït en sèrie i l'obra original.

En l'edició de Mon livre d'ogre Broodthaers va fer diferents sèries segon el tipus de suport dels exemplars. N'hi havia tres impresos sobre paper de Xina i cinc sobre paper japonés, enumerats de la $A$ a la $E$; després uns altres vint-i-cinc exemplars impresos sobre paper auverge enumerats de l'1 al 25; i la resta d'exemplars impresos sobre vitel-la, enumerats del 26 al 176. Els trenta-tres exemplars d'eixida duien una litografia de Serge Vandercam signada per l'artista mateix. En l'edició de Minuit, un poema il-lustrat també per Vandercam, els exemplars d'eixida també portaven una aquarel-la original signada, estaven impresos sobre paper d'Holanda i enumerats amb xifres romanes. En total, la tirada era de poc més de doscents exemplars.

L'edició dels llibres de poesia La bête noire i Pense-Bête va assumir-la Broodthaers mateix. El llibre La bête noire estava il.lustrat amb gravats de Jan Sanders. Els vint exemplars d'eixida estaven impresos artesanament sobre paper d'arches i eren d'un format major, estaven enumerats amb xifres romanes i tres d'aquests duien dibuixos originals. Completaven l'edició uns altres set-cents exemplars, també enumerats.

\footnotetext{
${ }^{40}$ I. Lebeer (1974); op. cit.
} 
Pel que fa a Pense-Bête, Broodthaers canvia el procediment i ja no intervé sobre el procés d'edició, sinó que a posteriori va manipular, un per un, la majoria dels exemplars col-locantlos rectangles de paper de colors sobre les pàgines impreses de forma que obstaculitzava la lectura convencional del text. Era el punt d'inflexió d'un procés on la relació entre el poema i el llibre comença a invertir-se: la paraula cedeix el protagonisme a la imatge i el poema a l'objecte. Sembla que va arribar un moment en què per a Broodthaers escriure poemes era insuficient. La manipulació de l'edició va funcionar-hi com un ritual per donar ànima al llibre i convertir-lo, a poc a poc, en testimoni de la situació d'incomunicació i abandonament que llavors experimentava la poesia.

Poc després, Broodthaers acaba per utilitzar els últims cinquanta exemplars de PenseBête per a compondre una obra tridimensional. Va unir amb escaiola el paquet dels llibres i una esfera blanca de material plàstic amb un gran cub negre que els servia com a pedestal. Tant l'escaiola com el pedestal constitueixen elements genèrics del llenguatge escultòric que juntament amb els llibres, tractats com un material més de la composició, feien que el conjunt fora apercebut com una obra plàstica. El paper que envoltava els cinquanta exemplars així com la escaiola acomplien la funció d'immobilitzar els llibres de manera que era impossible disposar-ne novament per a llegir-los. La naturalesa del llibre en tant objecte múltiple i indiferenciat és cancel-lada per a donar pas a un únic original.

Aquest gest de Broodthaers així com la seua reflexió sobre el tema van esdevenir una espècie de manifest de la seua adopció de les belles arts:

...el llibre és l'objecte que em fascina perquè per a mi significa l'objecte d'una prohibició. [...] Vaig escaiolar a mitges un paquet de cinquanta exemplars d'una recopilació de poemes, Pense-Bête. [...] No es podia llegir el llibre sense destruir l'aspecte plàstic. Aquest gest concret remetia la prohibició a l'espectador, al menys això creia jo; però, per a la meua sorpresa, la reacció va ser molt distinta. Tots hi havien apercebut l'objecte com una expressió artística o com una curiositat. «Mireu, uns llibres escaiolats!». Ningú va tenir curiositat pel text, ignorant si es tractava del soterrament d'una prosa, d'una poesia, de tristesa o de plaer. Ningú es va emocionar per allò prohibit. Fins aquell moment jo vivia pràcticament aillat; des del punt de vista de la comunicació, el meu públic era fictici. De sobte, se'n va fer real en el nivell on és una qüestió d'espai i de conquista. ${ }^{41}$

23. Pense-Bête (1963 - 64). Llibres manipulats per Broodthaers ( $p$ oposada)

24. Pense-Bête (1963-64). Assemblage (p. següent)

Així doncs, la transformació dels llibres en una escultura significava la superació de les limitacions comunicatives del poema. Això no obstant, l'obra plàstica va conservar el títol del llibre de poemes, Pense-Bête, de manera que, amb tot i això, els llibres escaiolats feien referència a la poesia, al passat, a allò prohibit.

\subsubsection{L'obra d'art i el seu context}

En començar a interessar-se per les arts plàstiques, Broodthaers visità, el 1956, una exposició antològica de l'obra de Kurt Schwitters en el Palau de Belles Arts de Brussel-les. Es tractava d'una de les primeres exposicions que presentava el conjunt de l'obra d'aquest artista, quasi gens conegut fins aquell moment.

\footnotetext{
${ }^{41}$ I. Lebeer (1974); op. cit.
} 

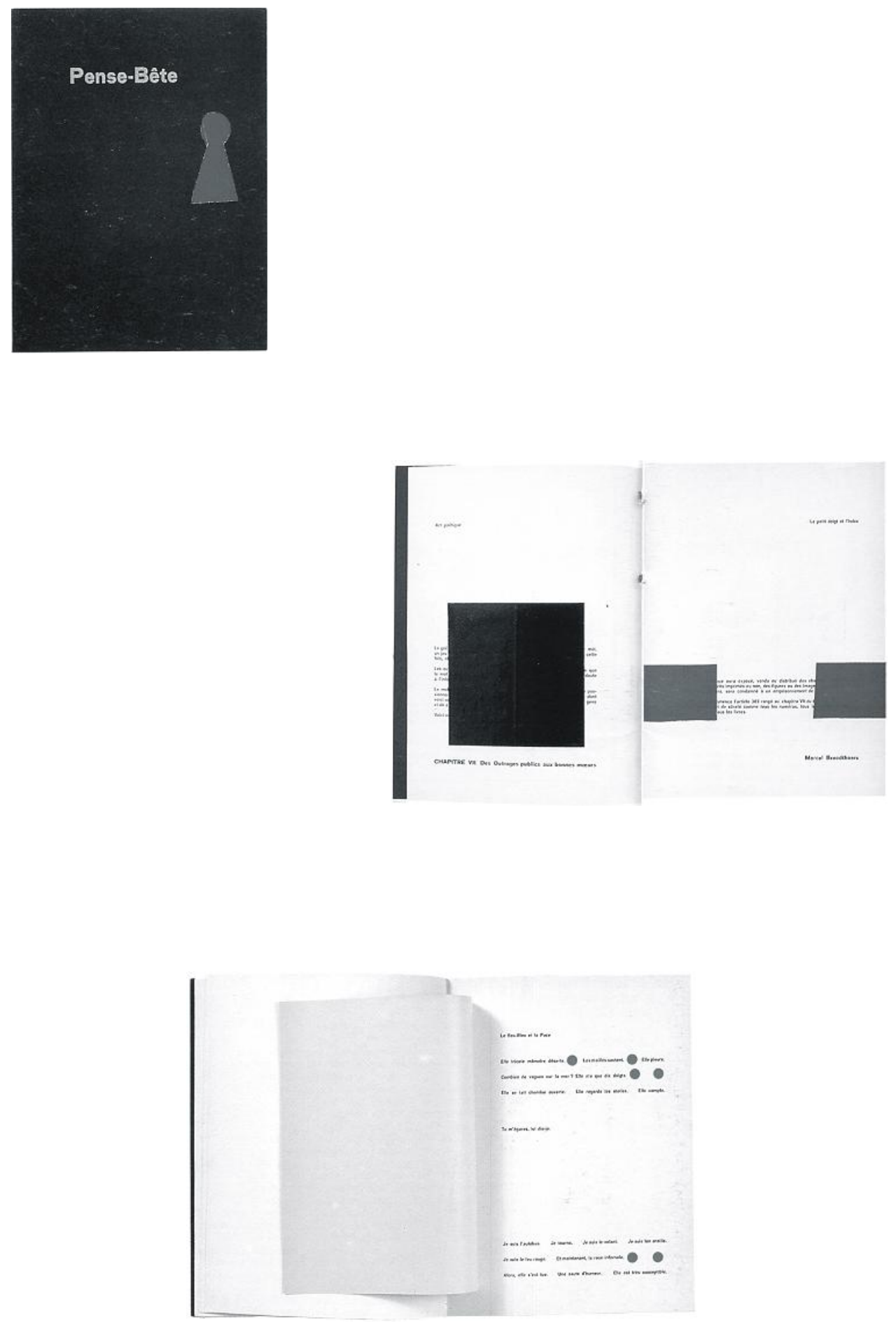


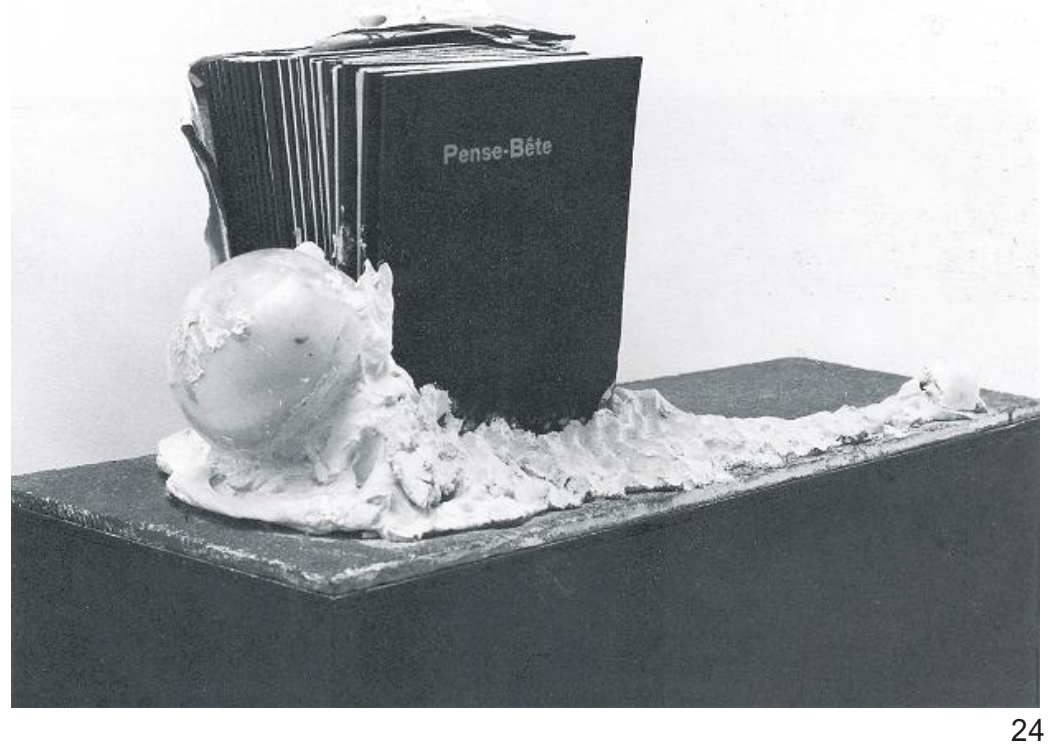


Broodthaers, qui admirava Schwitters, reflexiona sobre com l'entorn del museu despenjava les obres de la seua significació original i les transformava en objectes d'exposició. Aquest fet va motivar la consideració de Broodthaers i va servir com a punt de partida per a la pel-lícula, La clef de l'horloge (Poème cinématographique en l'honneur de Kurt Schwitters ), realitzada el 1957.

Mitjançant la càmera, Broodthaers explora l'obra de Schwitters i mostra primers plans de la paraula Merz, de rodes, de trossos de paper, de pinzellades i de lletres aïllades. Tot això destruïa la unitat dels quadres. El propòsit de Broodthaers era recompondre la primitiva naturalesa fragmentària de l'obra de Schwitters:

Per a mi, si l'objecte també perdia la seua naturalesa, era per convertir-se en signe d'un lirisme parlat. Així, fins i tot partint de composicions preservades per una estructura curosament traçada, jo no dubtava d'aïllar els objectes, resituar-los dins d'un context que evocara el misteri dels sostremorts... 42 .

25. Fotogrames de la pel-lícula La clef de l'horloge (Poème cinématographique en l'honneur de Kurt Schwitters) (1957) (p. següent)

26. "Des champs de blés coupés de coquilecots...". Poema de Broodthaers sobre Kurt Schwitters

27. Merzbild Einunddreibig (1920). Quadre de Kurt Schwitters.

28. "La clef de l'horloge". Poema de Broodthaers sobre Kurt Schwitters.

Amb aquesta espècie de censura al museu, Broodthaers també reprovava la institucionalització pòstuma de l'obra d'un artista a qui les institucions havien tractat amb indolència, negant-li el suport i el reconeixement mentre va viure.

D'ara endavant, Broodthaers aborda el tema de la condició objectual de l'obra ja no solament manipulant el seu suport material o reflexionant críticament sobre el seu destí, sinó també analitzant les circumstàncies en què l'espectador percep l'obra. Pel 1967, Broodthaers realitza una pel-lícula inspirada en una faula de La Fontaine, Le corbeau et le renard, en la qual ja no tracta de restituir el sentit original d'una obra determinada sinó d'adaptar la idea a un altre llenguatge artístic.

De primer, Broodthaers va rescriure lliurement la faula. A continuació, seguint-ne un procés molt similar al que emprava per a compondre els seus assemblages, va manipular i incorporar-hi fotografies familiars i objectes de l'entorn quotidià per a ambientar la pel-lícula.

Per al públic en general, les faules de La Fontaine mai no resultaven desconegudes puix estaven en la seua memòria des de l'època escolar. Per a Broodthaers era molt rellevant el fet que La Fontaine havia escrit les seues Faules al segle XVII a partir de les faules recaptades per Esop i per Fedre a la Grècia antiga. Per la seua part, en la pel-lícula Le corbeau et le renard Broodthaers fa el mateix treball que La Fontaine: aprofita el sentit didàctic i alliçonador de les Faules per a fer referència als problemes contemporanis.

\footnotetext{
${ }^{42}$ M. Broodthaers (1971d). "La Figure 0". En Marcel Broodthaers. Cinéma. Bar.: Fundació Antoni Tàpies, $1997:$ p. 25.
} 
72 La utopia pervinguda. El model d'autoria de Marcel Broodthaers
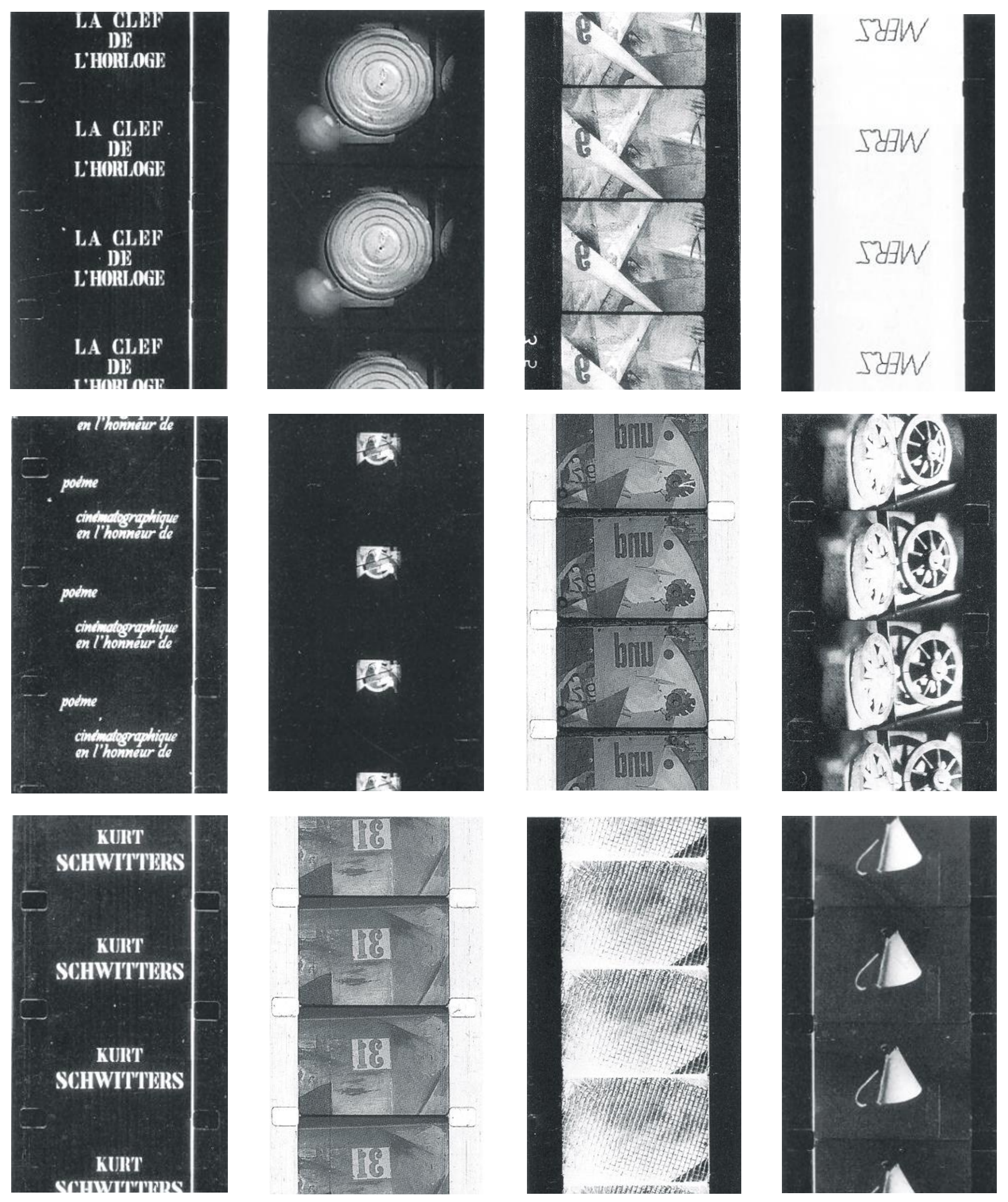
Camps de ble farcits de roselles i de blauets

en els panorames moderns de ciutats, la meua mirada circular

o horitzontal tan sols descobreix la nit.

Kurt Schwitters és un mussol que va pintar quadres;

excepcionalment a l'oli.

Kurt és un alemany que va nàixer el 20 de juny de 1887,

va viure fins al 8 de gener de 1948.

La seua obra, que encara està viva, em va commoure com la poesia.

(la pel·lícula que veureu...)

Marcel Broodthaers

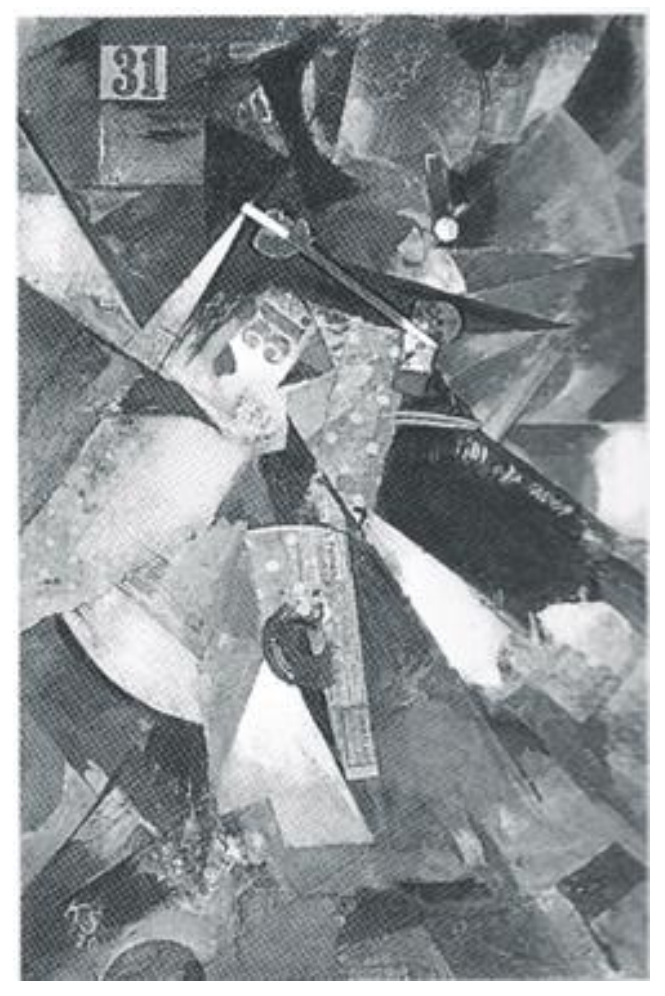

27

\section{La clau d'un rellotge}

Està aquest quadre amb una roda de carro sobre l'extrem d'una trajectòria.

Sorprés que no estiga pintada

Una roda de carro?

... És la roda de l'espai, una roda, germana dels rellotges, la meua roda sobretot, la immobilitat de la qual en l'espai del quadre va semblar haver de rompre's a cada moment i produir una rigorosa mecànica. En aquest moviment vaig percebre l'obra de K. Schwitters, que carrejava en lloc d'estrelles trossos de fusta, vells claus, bitllets d'autobús, tot allò que l'usuari de la Vida abandona en soterranis i en sostremorts, les andanes d'estació i els paviment dels carrers, com la marejada abandona el que resta d'un naufragi.

Marcel Broodthaers 
La inclusió d'objectes domèstics podia interpretar-se com una actualització del decorat de la faula però també com una apropiació de l'actualitat estètica. No obstant això, la juxtaposició entre els objectes i el text eliminava la significació primitiva de cada element. De la interacció entre els objectes i la paraula impresa sorgien nous vincles que donaven lloc a una altra faula, a una altra lliçó.

Per la projecció de la pel-lícula, Broodthaers dissenyà dues pantalles especials que duien imprés fragments del text del poema mateix. En projectar-hi la pel-lícula, la imatge se superposava a la paraula impresa i l'espectador es veia enfrontat a la dificultat de percebre la pel-lícula convencionalment i havia de fer-ne una lectura personal. La intenció era precisament dificultar una lectura ràpida com a oposició al fenomen del cinema com a nova esfera de consum.

La pel-lícula tenia un caràcter experimental però al mateix temps s'allunyava dels codis convencionals del cinema. Broodthaers va presentar-la en "Exprmntl 4", un festival de cinema experimental organitzat per la Cinemateca Reial de Bèlgica a Knokke-Le-Zoute, però hi fou admesa. Això no obstant, van projectar-la sobre una pantalla convencional i al marge del concurs. ${ }^{43}$ Posteriorment, Broodthaers decideix fer una edició incloent-hi la pel-lícula i emportar el conjunt a una galeria d'art.

\subsection{Les edicions i l'obra múltiple}

La presentació de l'edició Le corbeau et le renard en el context d'una galeria d'art constitueix ja un altre projecte, una exploració de noves formes de relació entre l'objecte, les belles arts, el cinema, la situació expositiva i l'espectador. Quant a l'esdevenir de la pel-lícula, Broodthaers declara:

La pel-lícula s'apropa al pop art, per dir-ho d'alguna manera, és un d'aquests múltiples dels què es parla últimament com a mitjans de difusió de l'art. Per això s'exposarà pròximament en una galeria què farà una tirada de quaranta exemplars, més les pantalles i els llibres. Així doncs, tot serà explotat com a objecte d'art de manera que cada exemplar comprendrà una pel-lícula, dues pantalles i un llibre gegant. ${ }^{44}$

L'edició del 1967 constava de tres objectes bàsics: la pel-lícula de $16 \mathrm{~mm}$ dins de la seua caixa metàl-lica, les dues pantalles especials i una caixa o llibre gegant. ${ }^{45}$ Així doncs, l'edició de la pel-lícula com a múltiple la situa ambiguament entre l'obra d'art i l'objecte industrial.

La caixa, per la seua part, estava folrada amb un paper fotogràfic que reproduïa parts del text i contenia els elements seguients: el text de Broodthaers reproduit íntegrament i la reproducció d'una versió d'aquest text escrita pel poeta Beni Umberto i il-lustrada amb quatre obres de Broodthaers. També hi havia dos rotllos folrats amb el paper fotogràfic, un retall de tela fotogràfica d'una obra titulada Moules pegat sobre un rectangle de feltre, un llenç reversible de paper fotogràfic que per una cara reproduïa una obra realitzada a partir d'una ampolla de llet i, per l'altra, un text manuscrit encapçalat amb el rètol Nota.

\footnotetext{
${ }^{43}$ Abans d'això, la pel-lícula va projectar-se íntegrament a París el 1967 i després, en les dependències del café Oud Knokke. Cf. "Comentaris sobre la pel-lícula Le Corbeau et le Renard". En Marcel Broodthaers. Cinéma; op. cit.: p. 52 - 57.

${ }^{44}$ Trépied (1968). "Interview de Marcel Broodthaers". En Marcel Broodthaers. Cinéma; op. cit.: p. 59.

${ }^{45}$ N'hi ha una altra edició complementària feta el 1972. Cf. "Comentaris sobre l'edició Le Corbeau et le Renard". En Marcel Broodthaers. Cinéma; op. cit.: p. 62 - 63.
} 
Broodthaers, com molts artistes plàstics, utilitza el múltiple com a suport creatiu aprofitant les seues possibilitats comunicatives i la seua versatilitat, però sobretot per a abordar la quiestió de la naturalesa objectual de l'obra.

29. Le corbeau et le renard (1968). Edició composta per: 1 caixa-llibre (29a), 1 pel-lícula (29b), 2 pantalles impreses $(29 c-d), 2$ texts poètics [1 de Broodthaers (29e) i 1 de Beni Umberto amb reproduccions d'obres de Broodthaers (29f)], 2 reproduccions [Objet écrit (29g), Moules (29h)] i manuscrit Note (29i).

\subsubsection{L'obra com a objecte}

La particularitat més notòria dels múltiples consisteix en la seua renúncia a la qualitat d'obra única i, per consegüent, a la tradició que la hi sustenta. D'altra banda, cal no confondre nocions com unicitat i originalitat, ja que multiplicitat i originalitat mai no són conceptes necessàriament antagònics.

Des d'una perspectiva històrica, però, l'obra múltiple constitueix una actualització de pràctiques de reproducció artística que tenen ja una llarga tradició. Entre les tècniques de reproducció emprades des de l'antiguitat es destaquen fondre i encunyar. Segles després, amb el desplegament de la impremta i de les tècniques gràfiques, es va fer possible la reproducció de l'escriptura, dels dibuixos i de la pintura. ${ }^{46}$ Mitjançant les edicions i les reproduccions, les obres d'art resultaven molt més accessibles que l'obra única, tant per la seua major distribució com pel seu menor cost.

La idea de concebre obres destinades especialment a la reproducció en sèrie apareix en l'època contemporània. El 1955, als artistes Yaacob Agam i Jean Tinguely va acudir-se'ls la idea de realitzar múltiples per el marxant d'art parisenc Denise René. El 1959, l'artista Daniel Spoerri fundà a París l'editorial Multiplication Arts Transformable (MAT). El taller de Spoerri va produir obres de Marcel Duchamp, Man Ray, Jean Tinguely i Víctor Vasarely, entre altres artistes interessats en l'àmplia difusió de les arts. La majoria dels projectes es realitzaven per encàrrec a causa dels limitats recursos del taller, que va assentar un precedent per la producció d'originals seriats. Cada edició constava d'unes cent còpies, la qual cosa feia possible una difusió més àmplia i permetria la seua comercialització a preus assequibles.

Durant els anys seixanta, els múltiples experimenta gran auge; la favorable relació entre costes de producció i rendibilitat el convertiren en un model molt atractiu tant per als artistes i per al públic en general com per als marxants d'art i per als col-leccionistes. Sovint, els artistes ja no opten per reproduir un original existent, sinó que es plantegen directament la creació d'obres alliberades de la noció d'originalitat. D'aquesta forma, i en teoria, podia arribar a realitzar-se la utopia avantguardista de la llibre circulació de l'art mitjançant una distribució i recepció més majoritària i menys d'elit.

La ràpida acceptació dels múltiples per part d'artistes i d'institucions no estigué exempta de polèmica; ja que, si ben bé la primacia de l'obra única desapareix, l'obra seriada continuava requerint de la signatura de l'artista com a senyal d'autenticitat. Per tant, l'original no s'extingia sinó que es multiplicava pel nombre d'exemplars produïts. En conseqüència, a mesura que l'obra existia en un major nombre d'exemplars, el seu preu podia ser menor que el d'un original, però també en podia deixar majors beneficis.

${ }^{46}$ Cf. W. Benjamin, "La obra de arte en la época de su reproductibilidad técnica". En Discursos Interrumpidos. Ma.: Taurus, 1973: p. 15-57. 


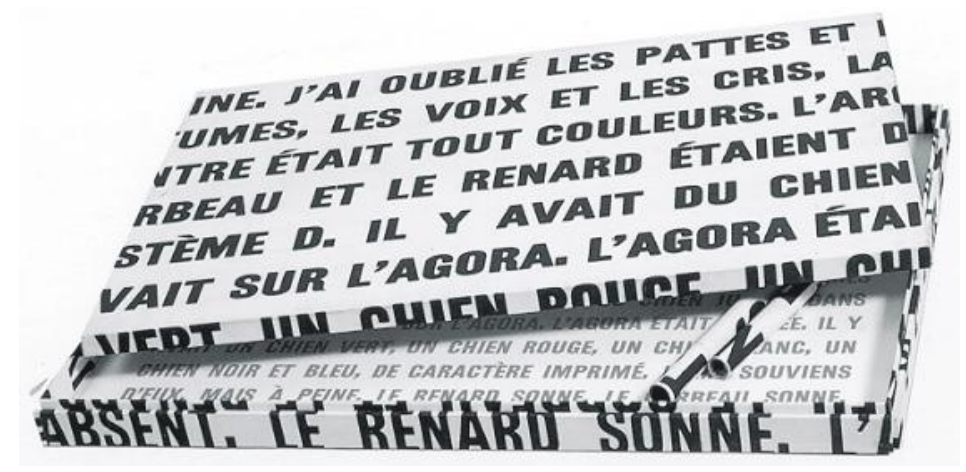

$28 a$

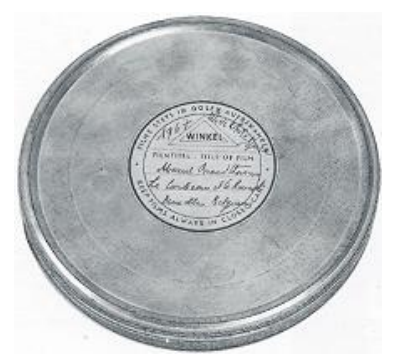

$28 b$

\section{ET LES COSTUMES, LES , MITÉ. LE PEINTRE ÉTAIT}

$28 c$

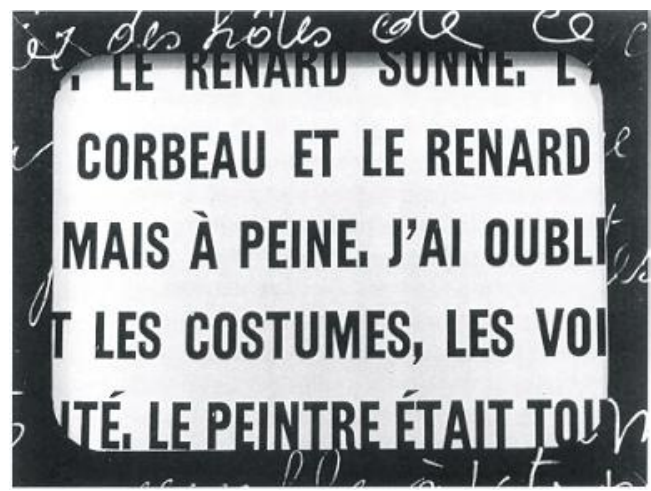


LE CORBEAU Et LE RENARD, LE CORBEAU SONNE, LE PEINTRE EST ABSENT, LE RENARD SONNE. L'ARCHITECTE EST ABSENT. MËME JEU, LE CORBEAU ET LE RENARD SONT ABSENTS. JE ME SOUVIENS D'EUX, MAIS A A PEINE, I'AI OUBLIE LES PATTES ET LES MAINS, LES JEUX ET LES COSTUMES, LES VOIX ET LES CRIS, LA FOURBERIE ET LA VANITÉ, LE PEINTRE ÉTAIT TOUT COULEURS. L'ARCHITECTE ÉTAIT EN PIERRE, LE CORBEAU ET LE RENARD ÉtAIENT DE CARACTÈres IMPRIMÉS. LE SYSTĖME D. IL Y AVAIT DU CHIEN JUSOUE DANS LA FOULE, IL PLEUVAIT SUR L'AGORA, L'AGORA ÉTAIT BONDÉE, IL Y AVAIT UN CHIEN VERT, UN CHIEN ROUGE, UN CHIEN BLANC, UN CHIEN NOIR ET BLEU, DE CARACTERE IMPRIMÉ, JE ME SOUVIENS D'EUX, MAIS A PEINE, LE RENARD SONNE, LE CORBEAU SONNE,

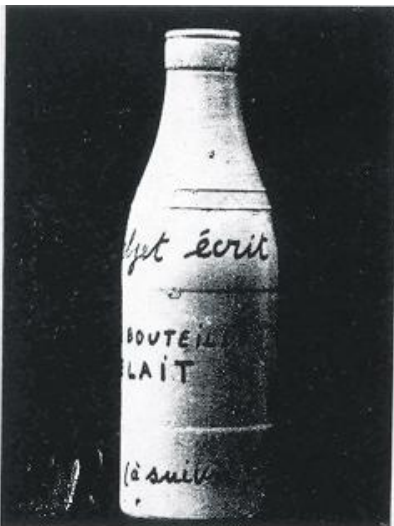

$28 g$
LE D EST PLUS GRAND QUE LE T. TOUS LES D DOIVENT AVOIR LA MÊME LONGUEUR, LE JAMBAGE ET L'OVALE ONT LA MÊME PENTE COMME DANS A. MODÈLES: LE CHIEN, LE RENARD, KOEKELBERG. LES CRIS. LES MAINS, L'ORCHIDEE, L'ARCHITECTE, LES PATTES, LES MAINS, PARIS. LA FOURBERIE, LES VOIX, LES CRIS, LE CARACTèRE, L'IMPRIMÉ, L'IMPRIMEUR، L'AGORA, LE BLEU, LE ROUGE, LE

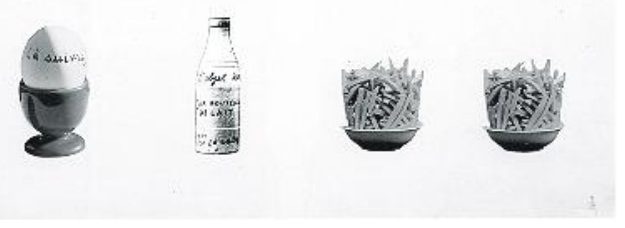

$28 f$

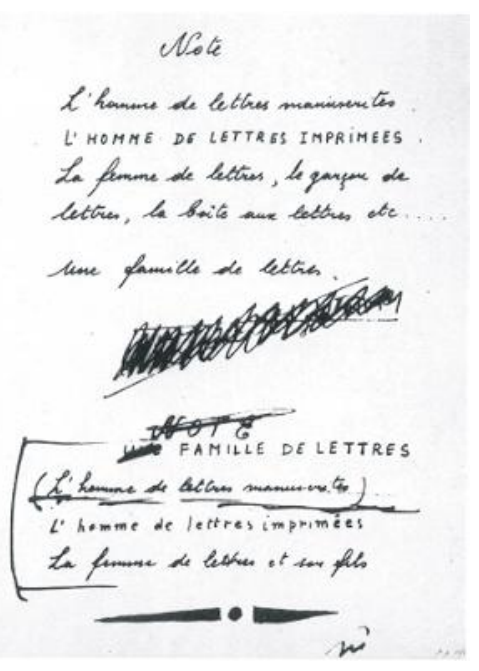

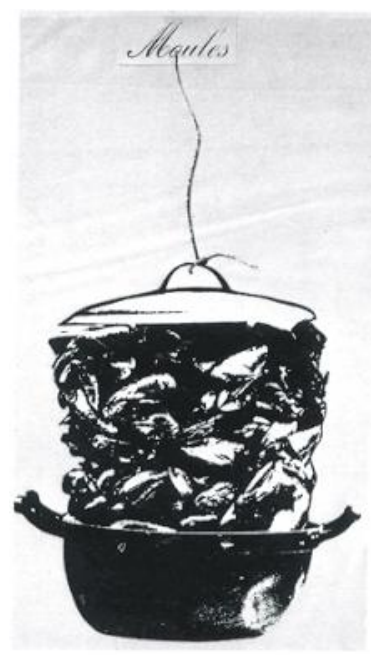

$28 h$ 
Les veus més crítiques advertien d'un canvi substancial en l'art i en la seua finalitat cap a l'àmbit de la producció d'objectes de consum. Broodthaers es va fer eco d'aquestes crítiques i, en aquest sentit, se serveix de la idea dels múltiples integrant-lo com un procediment per a explorar la condició objectual de l'obra, al temps que hi revela els seus aspectes menys filantròpics: la transformació de l'obra d'art en mercaderia.

És important aclarir que, per part de Broodthaers, aquestes crítiques mai no apunten contra la possibilitat que l'artista puga viure del seu treball ni tampoc contra l'existència d'un mercat de l'art, sinó contra el fet de supeditar els processos de producció, distribució i recepció artístiques cap a unes expectatives exclusivament econòmiques en detriment d'un valor d'ús de les arts i la cultura dins de la societat.

Respecte del projecte Le corbeau et le renard, inicialment, Broodthaers pretenia fer una edició il-limitada de la pel-lícula i de les pantalles i uns quaranta exemplars de la caixa, però la pel-lícula va tenir escassa demanda. De la caixa amb la resta d'elements solament van realitzar-se set exemplars a causa de l'elevat cost de fabricació.

Finalment, en l'exposició "Le corbeau et le renard" Broodthaers presenta la pel-lícula conjuntament amb els elements de l'edició, a més a més d'altres obres que hi estaven relacionades. La repetició de la idea de la pel-lícula en l'edició i en l'organització de l'exposició donava lloc a una mena de trencaclosques - un jeroglífic - que l'espectador havia de resoldre. La situació generada promovia una relació no convencional amb el cinema i amb les belles arts. Consegüentment, l'espectador deixava de ser un subjecte passiu, un simple consumidor, per participar de la producció de sentit i esdevenir-ne en colllaborador, en cocreador de l'obra.

\subsection{L'espai de Mallarmé}

En Mallarmé està la font de l'art contemporani... Inventa inconscientment l'espai modern [...] Un coups de dés. Podria ser un tractat sobre l'art. El més recent, el de Leonardo da Vinci, ha perdut la seua importància des que va concedir a les Arts Plàstiques un lloc massa gran, i ho endevinem avui, als seus mestres, (els Mèdici?). ${ }^{47}$

A poc a poc, els projectes de Broodthaers comencen a discriminar com a idees independents la qualitat objectual de l'obra i el sentit de la seua presentació dins de l'espai de l'art. Si inicialment s'apropiava objectes de la realitat per a introduir-los en quadres, escultures o pel-lícules, el trànsit de l'objecte a l'obra era producte d'una resignificació de l'objecte. Però, amb la assimilació dels múltiples, Broodthaers torna a assumir el paper d'editor i el procediment s'inverteix: el procés creatiu convergeix amb la producció objectual. No obstant això, Broodthaers evita atorgar a aquestes peces un caràcter autònom i per això comença a concebre-les com a fragments d'un discurs més complex. En aquest sentit el projecte Le corbeau et le renard va resultar una experiència important.

Un altre exemple especialment significatiu és una exposició anomenada "Exposition littéraire autour de Mallarmé", del 1969, on tots els elements estaven organitzats al voltant de la idea d'espai poètic de Mallarmé. El punt de partida va ser la reedició del llibre Un coup de

\footnotetext{
${ }^{47}$ M. Broodthaers (ca. 1969d). "Mallarmé es la fuente del arte contemporaneo...". En Marcel Broodthaers. Ma., op. cit.: pàg. 139.
} 
dés jamais n'abolira le hasard. Broodthaers va proposar-hi la comprensió del llibre i de la galeria com a suports espacials de l'experiència artística.

En el poema Un coup de dés de Mallarmé la disposició de les paraules i dels blancs en la pàgina del llibre dóna pas a l'espai. Segons va plantejar-ho el poeta mateix:

Ningú no es trobarà ací més que un espai de lectura. En una pàgina ordinària de poemes de vers curts, el blanc n'ocupa les dues terceres parts. D'aquesta proporció, però, faig una redistribució dels blancs que reemplaça la puntuació intervenint ja siga per operar una transmissió d'una nova imatge a una altra, ja per marcar-hi la relació més o menys directa dels grups de paraules subdivisió prismàtica de la idea - amb la frase central. ${ }^{48}$

Per la seua part, Broodthaers pren el poema Un coup de dés de Mallarmé per a rescriure'l substituint cadascun dels versos per línies negres de diferent gruix i longitud de manera que coincidien exactament amb les proporcions i la disposició del poema original. La substitució del text pels elements abstractes invalidava el contingut verbal del poema, però en canvi en feia prevaler l'aspecte visual i espacial. D'altra banda, Broodthaers inclou el text del poema com a pròleg del llibre, però com a prosa, és a dir, obviant la seua espacialització original.

Per a la reedició de Un coup de dés, Broodthaers va prendre com a model una publicació antiga. ${ }^{49}$ El llibre en qüestió, un exemplar de bibliòfil, també formava part de l'exposició de manera que l'espectador podia veure ambdós i adonar-se de les diferències que hi havia. Per exemple, en la portada de l'exemplar original apareixia la paraula Poème a continuació del títol però en l'exemplar reeditat n'havia sigut substituïda per la paraula Image. Ací mateix, el nom de Broodthaers estava imprés on apareixia originalment el de Mallarmé. Òbviament, les diferències feien referència al resultat obtingut de la substitució del contingut verbal pels elements abstractes, però també a la còpia i a la idea d'originalitat, o siga, a l'apropiació ja no del poema sinó de la idea d'espai de Mallarmé.

Inicialment, Broodthaers va concebre l'edició del llibre en dos suports diferents: sobre paper, guardant-ne molta similitud amb l'original, i sobre planxes d'alumini, com una matriu. De la versió impresa sobre paper foren impresos tres-cents exemplars els quals estaven destinats al públic de l'exposició. L'altra sèrie constava de dotze planxes d'alumini que tenien les mateixes dimensions de les pàgines dobles de l'original. La tirada d'aquesta sèrie no ultrapassà els deu exemplars a causa de l'elevat cost del procés.

Durant la correcció de les proves d'impremta, va sorgir la idea per a una tercera versió a partir de l'efecte de superposició que es produïa en la impressió sobre un paper ordinari. Aquests inesperats resultats van agradar molt a Broodthaers, qui va decidir aprofitar-los. La tercera sèrie tingué una tirada de noranta exemplars i estava impresa sobre un paper

\footnotetext{
${ }^{48}$ S. Mallarmé ["Preface". Un coup de dés jamais n'abolira le hasard] citat per E. A. Vigo "Continuidad de lo discontinuo" [document en línia]. En Marcha. La Plata, 1992 [última consulta: 2/12/2002]. Disponible en: http://www.eavigo.com.ar/escritos/continuidad_de_lo_discontinuo.htm. L'autor mateix analitza: "...la pàgina del llibre va ser fins llavors el contenidor natural de la poesia. [...] L'aparició del concepte d'espai poètic no és únicament l'alliberació formal sinó que la proposta ataca, a més, l'aspecte conceptual de la poesia. [...] El pla espacial farà possible utilitzar l'espai real, prendre volum mitjançant una lectura envoltant de la imatge on se sumarà a l'òptica el nostre cos en moviment al voltant d'un projecte concret. És l'anomenat objectiu poètic dels surrealistes [...] que lliga en textos de llargs títols els elements lingüístics que provenen dels somnis (allò oníric) amb elements materials."

${ }^{49}$ L'edició de Galimard, (París, 1914). El poema va ser escrit per Mallarmé el 1897.
} 
transparent. Broodthaers va agregar-los una cartolina blanca de les mateixes dimensions del foli, la qual cosa oferia a l'espectador l'opció de poder mirar cada pàgina sense la interferència de les anteriors o posteriors.

30. Portada del llibre de Broodthaers Un coup de dés jamais n'abolirá le hasard. Image (1969)

31. Detall d'una pàgina del llibre de Mallarmé Un coup de dés jamais n’abolirá le hasard. Poéme.

32. Detall de l'edició de Broodthaers Un coup de dés sobre planxes d'alumini.

Durant l'exposició, les tres versions de l'edició estaven col-locades al llarg de les parets de la galeria, sobre una espècie de pupitres i a una alçaria adequada. Broodthaers va fer pintar de negre el terra per escriure-hi el poema amb guix, encara que després va desestimar la idea. Per completar l'ambient, en l'interior de la galeria podia escoltar-se un enregistrament de la veu de Broodthaers fent una lectura del poema.

També formaven part del conjunt de l'exposició un vestit i tres camises sobre les quals es podien llegir fragments del poema de Mallarmé. En la paret del fons hi havia penjades quatre obres que representaven una pipa en combinació amb les lletres de l'alfabet. Aquestes peces, que podien semblar alienes al conjunt, portaven una nota esclaridora: "L'Alfabet és un dau amb 26 cares". La nota feia referència al conjunt de l'exposició com un projecte de relectura per a Un coup de dés.

33. Chers amis (2 / 12 / 1969), carta oberta distribuïda en la inauguració de l'exposició (p. següent)

34. Detall de l'espai de "Exposition littéraire autour de Mallarmé" (p. següent)

\subsubsection{Lectura de Mallarmé}

En el poema Un coups de dés jamais n'abolira le hasard de Mallarmé la fragmentació del text fa palpable la ruptura del vers, entés com a sequiència rítmica i visual, cosa que obri la multiplicitat de lectures. També s'hi fa sentir la perspectiva de profunditat espacial, de buit, i el sentit de no res que suggereix el poema mitjançant la ruptura sintàctica del vers i el protagonisme del blanc de la pàgina.

La singularitat de la lectura que fa Broodthaers de l'obra de Mallarmé pot interpretar-se com una resposta contestatària a determinada realitat estètica contemporània que afecta no solament la percepció de l'art sinó que remet a l'escissió de determinades formes estètiques modernistes, avantguardistes - de les idees que els vinculaven al seu context i a la seua realitat històrica; idees els continguts de les quals llavors eren formulats mitjançant plantejaments pràctics i programàtics. Però, l'efecte d'experimentació, de fragmentació, d'autoreferencialitat i d'objectualitat que es percep en la poesia i en les belles arts sembla estar lligat, no en el nivell estètic sinó en un nivell ideològic, a un descrèdit de la dimensió utòpica de la idea de l'obra d'art com a espai per exercir activament el propi judici i la llibertat creativa. En canvi, per a Broodthaers, tot això encara és possible i, a més a més, necessari.

Però, allò que possiblement pot explicar millor o apropar-nos a la lectura que va fer-ne Broodthaers és la sensació de suficiència que transmet el poema Un coup de dés, de cosa en si mateixa i al marge de cap referent extern. És una lectura que apunta cap a l'obra en tant llibrepoema-objecte i poema autoreferencial i que conflueix finalment amb la reflexió sobre la naturalesa de l'obra d'art.

Per a Broodthaers l'obra de Mallarmé encarna la idea de l'art com a espai d'alliberació espiritual: idea que va rescatar amb el mateix sentit però des d'un punt de vista diferent: 

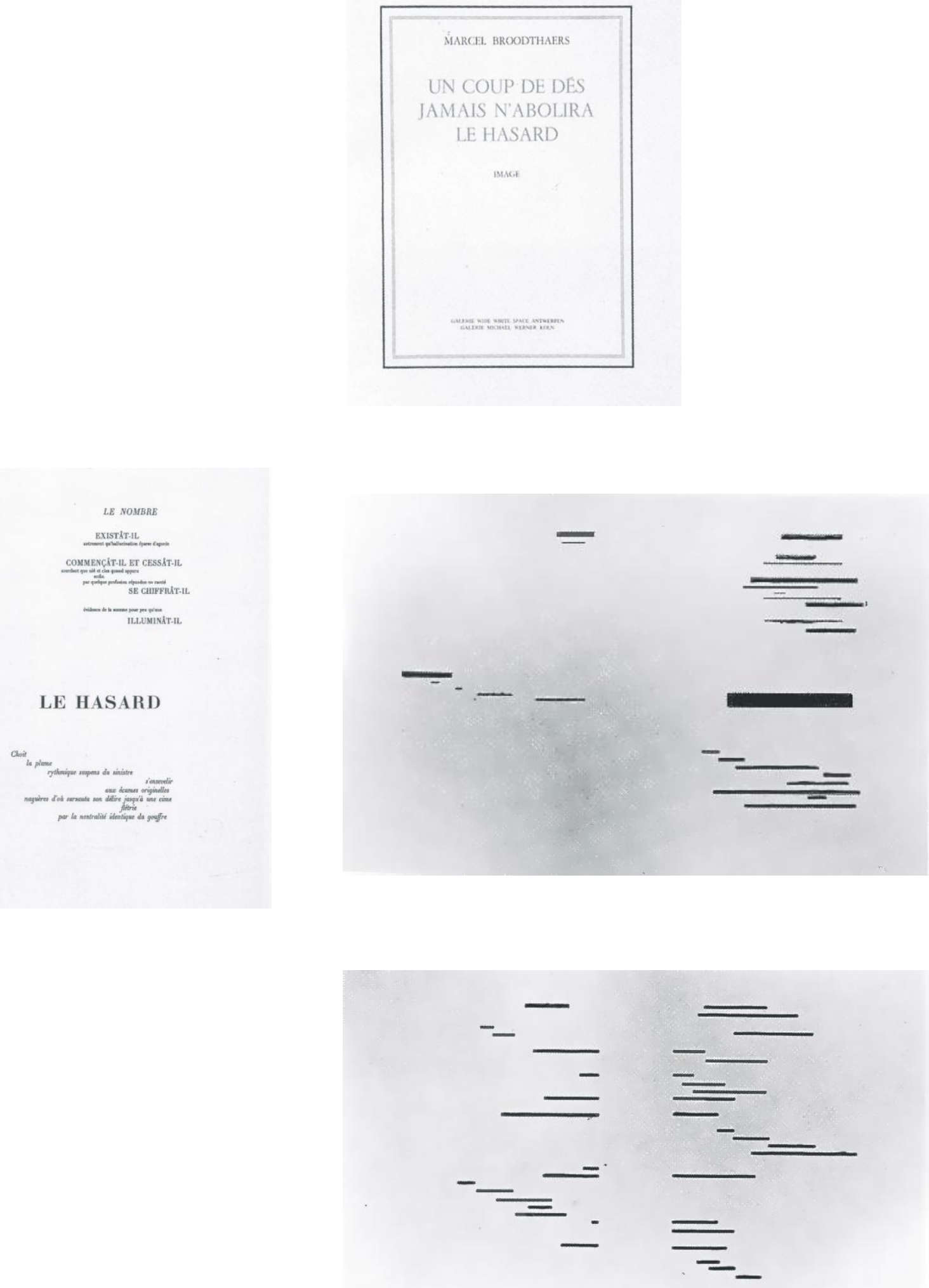
Antwerpen, 2 décenbre 169

chers anis,

Sur aluminium anodisé, des sillons gravés exactement dans le meme ordre et la méme dimension que la typographie du texte du poime: Un coup de Dés supports correspondant au papter Monval et au vélin d'Arches de 1'édition
originale. (1914) Le travall de copie a eté exécuté sur 1'exemplaire $\mathrm{n}^{\circ} 35$ appartenant à Monsieur Duboscq.

Pourquoi?

Sans doute, Magritte rencontré, il y a longtemps, $\mathrm{m}^{\prime}$ invite à néditer ce peème. Donc, J'oubliai, je méditai, ... aujourd' hui, je fais cette Image. dés. Artistes morts.

Nouveau! Nouveau?' Peut-etre. Excepté. Une constellation.

Un coup de Dés.

We Aussi Lacan. "Bcrits". . . dans une somne nallarmienne. Le derniex

"Le seul énoncé absolu a été dit par quil de droit: a savoir qu' aucun raison, dé dans le signifiant, n'y abolira jamais le hasard, - pour la tion de langage, et ce sous quelque aspect existe qu' en une deterninathine ou de rencontre.

volées à 1'alphabet.

Ceci a l'occasion d'une exposition (A voir aussi le poème de Mallarme ecrit. sur des chemises de la police de Dailas. I de ces plaques, de ces livres et d'une lecture sur le sujet par pierre Verstraeten.

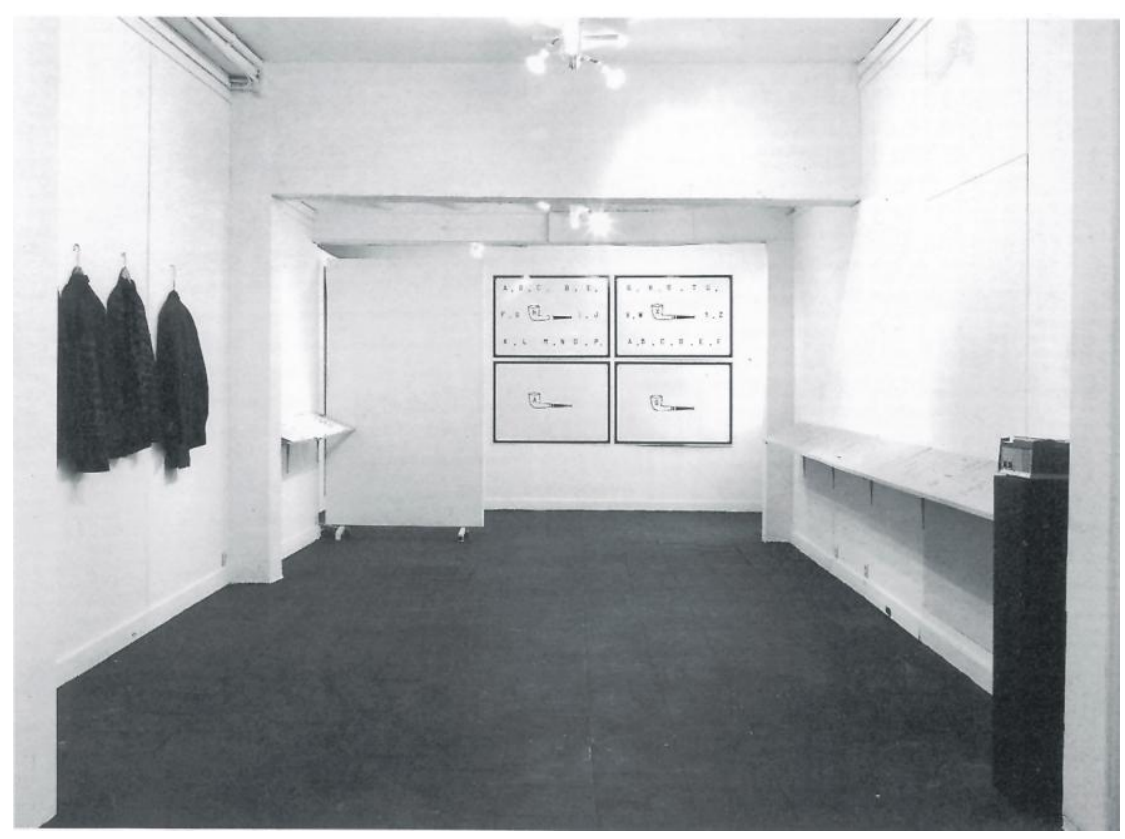


apunta cap a l'apropiació de l'espai, de la idea d'espai de Mallarmé, com a fonament per a la recerca d'un llenguatge personal i d'un valor d'ús de l'acte creatiu.

En la mostra "Exposition littéraire autour de Mallarmé" Broodthaers dissecciona el poema Un coup de dés a partir dels seus elements significants: la paraula i la imatge, i presenta cadascun independentment. Cada suport representava una part del poema però cap d'aquests era autosuficient. Llavors el significat de l'obra és unificat mitjançant l'exercici de lectura. A un altre nivell, d'igual manera que el llibre servia com a suport per a la representació de la imatge del vers, la galeria funcionava com a suport del llibre en tant objecte i de l'espacialització del poema.

Altrament, tant el llibre com la galeria són qüestionats fins al límit de les seues possibilitats en tant suports autònoms. Així doncs, Broodthaers proposa la comprensió d'ambdós, el llibre i la galeria, com a idees d'espai.

\subsection{La significació del moment expositiu}

En resum, per a Broodthaers l'espai expositiu no és un contenidor passiu sinó que representa un lloc de trobada, un espai de representació que interactua amb els elements de l'exposició. Per consegüent, el sentit de la seua obra no es troba definit enterament ni per l'objecte ni per l'espai, sinó que és construït a partir de la conjugació de les possibilitats enunciatives d'ambdós.

Globalment, els projectes i les exposicions de Broodthaers constitueixen una anàlisi de les circumstàncies de la producció artística i de la seua recepció. Un bon exemple d'això és l'exposició "MTL 13/3/70 - 10/4/70", en la qual Broodthaers presenta un recull dels seus quaderns de treball. En l'exposició es podien veure uns seixanta-set documents a més a més de dues carpetes, un certificat mèdic i un text pintat sobre l'aparador de la galeria. La mostra concloïa amb la presentació del catàleg i d'una pel-lícula rodada en la galeria mateixa durant l'exposició. La intenció de Broodthaers és vincular el procés de treball i l'exposició com a diferents moments del procés creatiu mateix entés en un sentit més ampli i, així, contradir la visió estancada i invariable d'aquests moments.

Altrament, aquest projecte constitueix potser el primer exemple en què apareix la idea de retrospectiva en el plantejament de les seues exposicions. Els elements que componen l'exposició "MTL 13/3/70 - 10/4/70" funcionen al mateix temps com a documents i com a documentació. Aquesta relació la hem resumida mitjançant el quadre següent.

35. Relació de documents en l'exposició "MTL 13/3/70 - 10/4/70" (quadre de text)

\begin{tabular}{ll}
\hline DOCUMENTS EXPOSATS & COM A DOCUMENTACIÓ DE $\square$ \\
\hline Papers, manuscrits, dibuixos... & $\square$ trajectòria poètica i artística de Broodthaers \\
Primera targeta d'invitació & $\square$ obertura de l'exposició, data i dades de l'artista \\
Pintura sobre l'aparador & $\square$ targeta d'invitació de l'exposició \\
Pel·lícula & $\square$ pintura sobre l'aparador i context de l'exposició \\
Segona targeta d'invitació & $\square$ estrena de la pel·lícula i clausura de l'exposició \\
Catàleg & $\square$ documents exposats i circumstància expositiva \\
\hline
\end{tabular}




\subsubsection{Els documents i la documentació}

El conjunt de papers i de manuscrits estava distribuït en tres panells independents que, darrerament, en el catàleg estaven identificats amb les lletres $A, B$ i $C$. No obstant això, tots tres constituïen una mateixa entitat. Cada panell presentava els folis desplegats i protegits amb una planxa de plexiglàs. El panell $A$ estava col-locat en sentit horitzontal, o siga, com una taula sobre dos suports, mentre que els $B$ i $C$ estaven penjats sobre la paret.

Els documents eren variats, dataven de diferents moments i comprenien un període de diversos anys. Entre aquests Broodthaers havia inclós textos manuscrits i mecanografiats, quasi tots amb anotacions i dibuixos. S'hi trobaven, per exemple, la transcripció del poema $U n$ coup de dés... així com uns altres apunts relacionats amb el projecte "Exposition littéraire autour de Mallarmé". No obstant això, la majoria de papers eren més antics: des d'un fragment del text Le corbeau et le renard fins als esborranys dels poemes reunits en els llibres PenseBête i La Bête Noire. En particular, es feia notar que els manuscrits dels poemes diferien dels publicats: estaven plens d'esborraments, d'anotacions marginals i de dibuixos, la qual cosa indicava que no es tractava dels poemes acabats, sinó de la documentació del procés creatiu. Així doncs, analitzats en conjunt, els papers reunits en l'exposició constituïen una espècie d'arqueologia de la producció no-plàstica de Broodthaers.

Si mitjançant la presentació dels esborranys, Broodthaers documenta exhaustivament l'obra en procés de configuració, alhora aquest procés és congelat per la circumstància expositiva. Així, bona part dels papers documentaven la trajectòria de Broodthaers com a poeta i com a artista, això no obstant, tant en la galeria com en el catàleg eren presentats com a originals i fins i tot com a obres d'art.

Darrerament, en el catàleg de l'exposició, Broodthaers presenta una relació raonada de tots els documents així com reproduccions i detalls particulars de cadascun. Cada element anava acompanyat d'una descripció textual dels procediments manuals aplicats en cada cas, a la manera d'una fitxa tècnica com les que porten les obres tradicionals en els catàlegs d'art, però els termes abreviats no eren correctes, per exemple: $t . d$. com a text mecanografiat, manu com a manuscrit, surch. com a subratlat, rat. com a ratllat, etc. Així doncs, l'inventari de procediments i l'interés pels detalls resultaven un absurd. Tota la informació del catàleg apareixia escrita en francés, en flamenc i en anglés.

El catàleg va ser presentat en concloure l'exposició i incloïa un plànol de l'exposició així com un text anomenat Nota sobre les intencions. Broodthaers va dissenyar-lo com un llibre i va concebre'l com a documentació i fins i tot com a prolongació del projecte.

36. Pàgines del llibre/ catàleg MTL 13/3/70 - 10/4/70.

37. Manuscrits presentats en l'exposició "MTL 13/3/70 - 10/4/70" (plego interior)

Pel que fa a la intervenció realitzada sobre l'aparador de la galeria, es tractava del text de la targeta d'invitació, el qual havia sigut pintat sobre el vidre. El text cobria quasi tota la superfície i estava escrit des de l'interior; calia estar dins de la galeria per llegir-lo. Des del carrer n'era il-legible perquè les lletres es veien del revés. Mitjançant la lectura, Broodthaers incorpora l'espai expositiu i inclusivament l'espectador com a part de l'obra.

Altrament, davant la funció estrictament informativa i publicitària del text, l'aparador pintat semblava un despropòsit i dificultava la seua percepció com a obra autònoma. Però, el fet que estiguera pintat, fet a mà, incitava a percebre'l com una obra d'art. Així doncs, el text atorga una doble dimensió temporal a la pintura: la del acte de llegir i la que resulta del sentit de la seua permanència. Un senyal fent l'ullet al Grand Verre de Duchamp? A partir del 
MARCEL BROODTHAERS

MTL

$13 / 3 / 70-10 / 4 / 70$

$35 a$
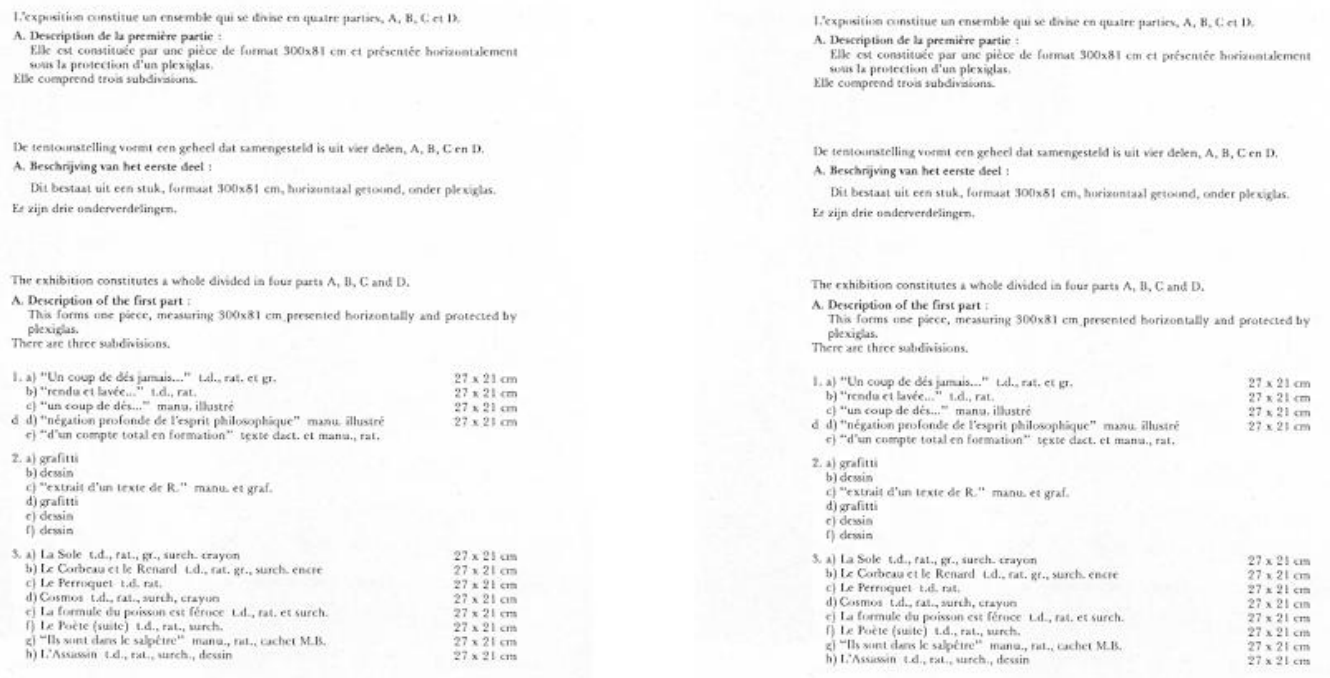


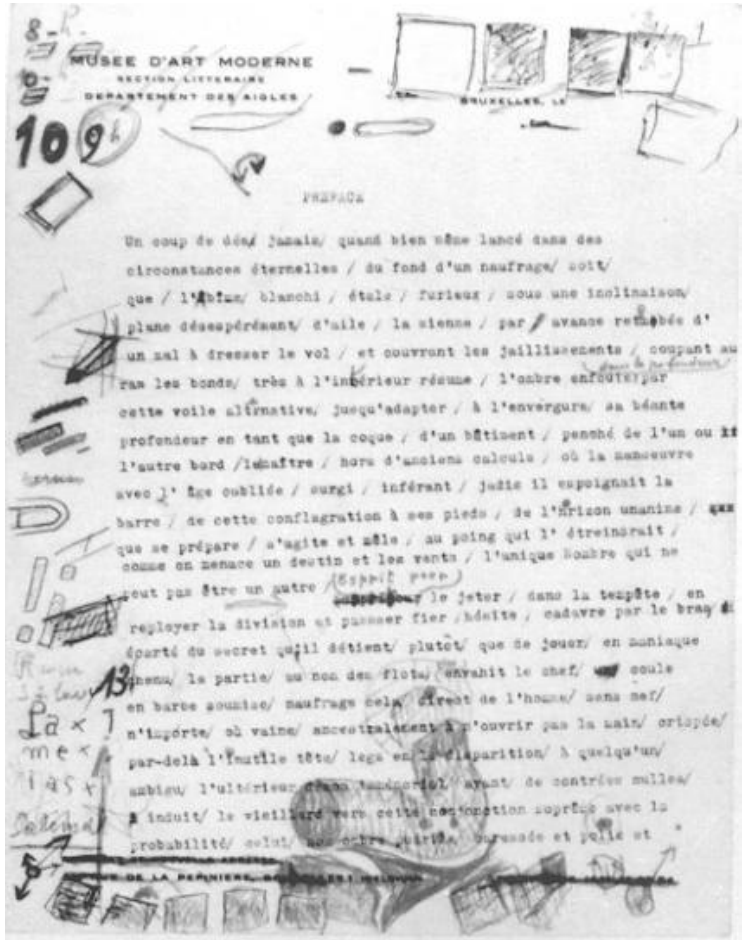

$37 a$
MUSEE DAAAT MODERNE

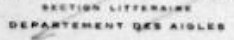

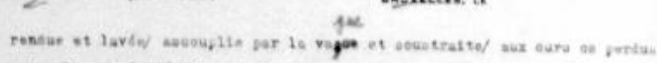

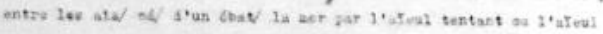

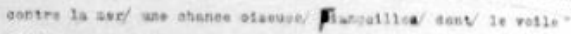

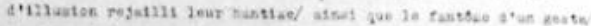

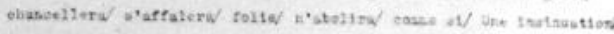

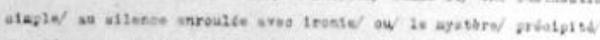

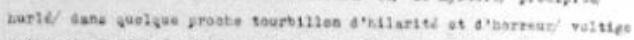

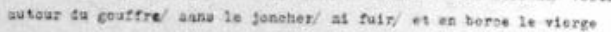

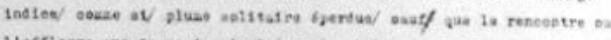

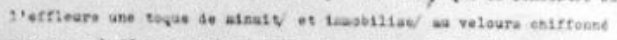

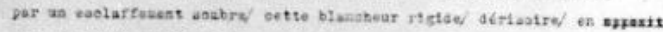

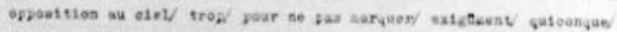

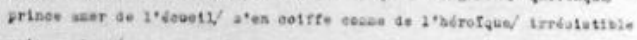

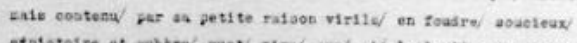

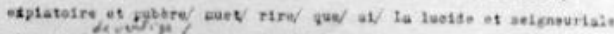

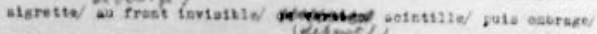

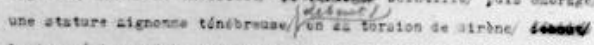

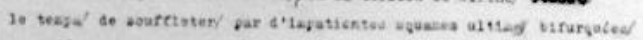

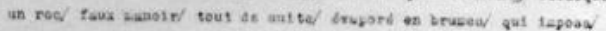

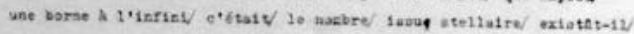

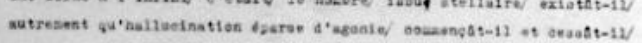

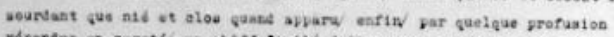
repondue on rarest as obirfrat-11/ bridence do la soswe pour peu

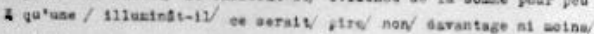

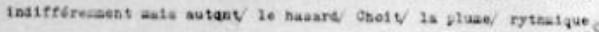

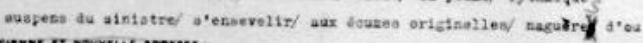

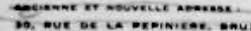




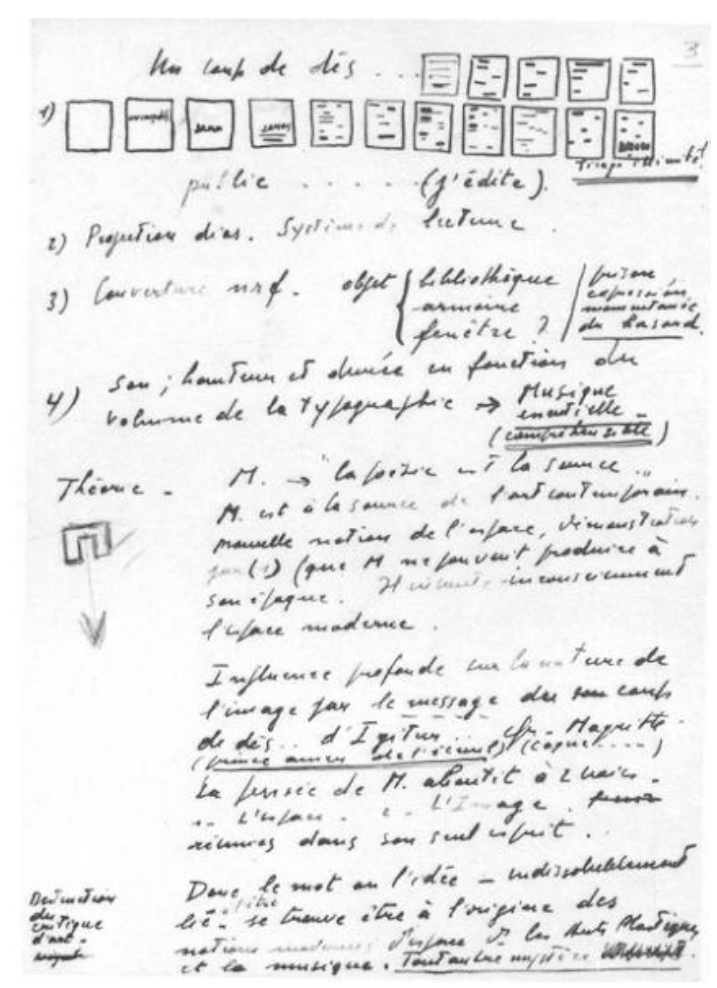

$37 c$

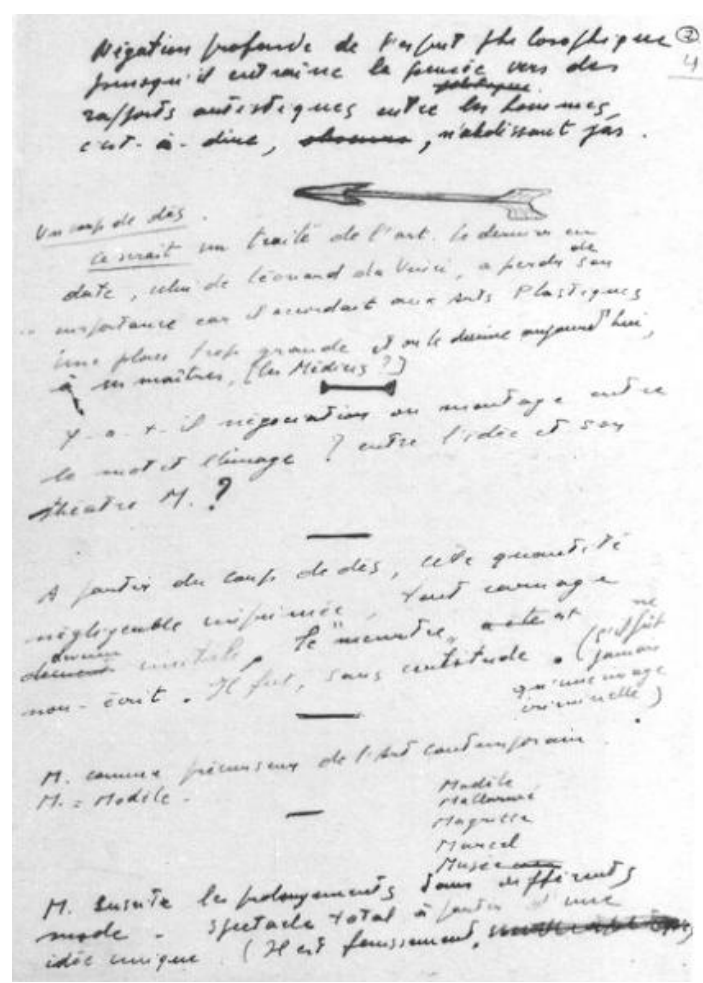

$37 d$

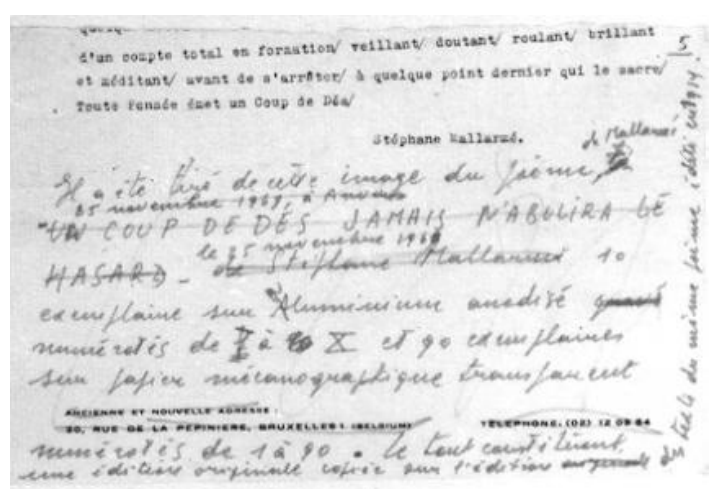

$37 e$ 

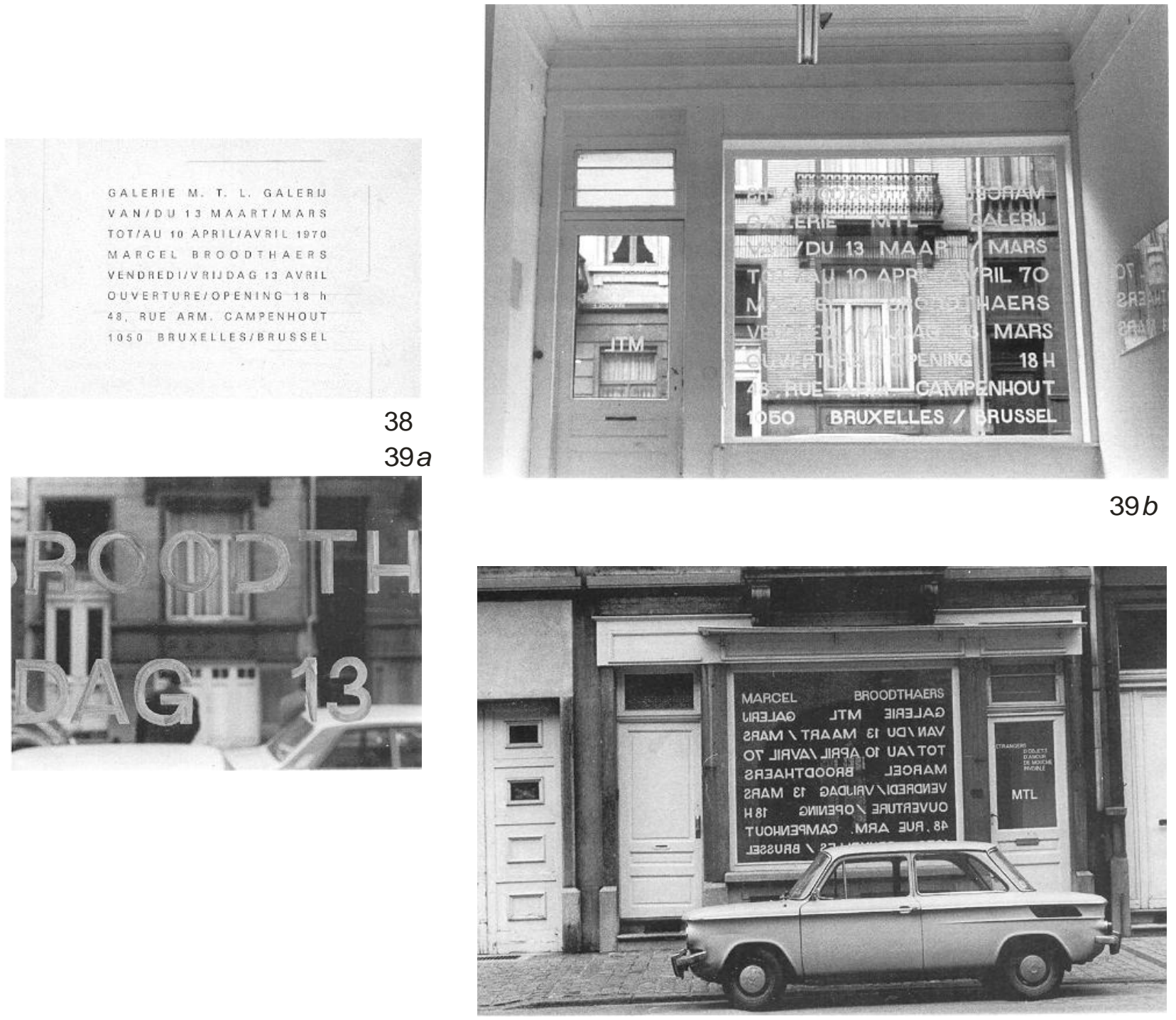

$39 c$
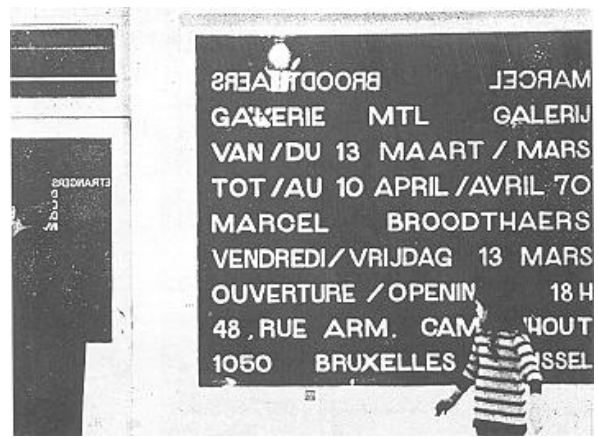
motiu pintat sobre el vidre, Broodthaers realitza una pel-lícula, és a dir, una altra obra, la qual cosa genera una nova documentació de l'exposició com a esdeveniment i alhora com una altra forma de durada.

38. MTL 13/3/70 - 10/4/70. Targeta d'invitació de l'exposició

39. Text pintat en l'aparador de la galeria

Quant al film, titulat MTL (DTH), la idea era dissociar les lletres de la informació que hi transmetrien. Per això, Broodthaers enfoca en primer pla detalls del text pintat sobre el vidre mentre en un segon pla podien veure's el carrer i el pas de la gent. En un altre moment de la pel-lícula, la càmera es desplaça de dreta a esquerra i viceversa com imitant l'acte de llegir. També hi apareixen les grafies $M T L$ i $D T H$ superposades a la imatge fílmica, com a elements abstractes, deslligades de tota referència a la paraula i a la seua significació original.

La projecció de la pel-lícula va coincidir amb el tancament de la mostra i per publicitar-la Broodthaers fa imprimir una altra targeta d'invitació. Aquesta segona targeta reproduïa una fotografia presa durant la inauguració de l'exposició: l'aparador de la galeria amb el text pintat de la primera targeta. Per a completar, Broodthaers utilitza el vidre de l'aparador mateix com a pantalla per a projectar la pel-lícula.

Tant la pintura sobre el vidre com la pel-lícula i la fotografia reproduïda en la segona targeta documenten, de diferents formes, la relació entre l'obra i la circumstància expositiva. Si les targetes d'invitació més prompte documenten el començament i el final de l'exposició, d'altra banda, Broodthaers fa coincidir el tancament de l'exposició amb l'estrena de la pel-lícula de manera que els processos de creació i de recepció són presentats com una seqüència, quedant-ne vinculats en un mateix espai. Finalment, amb la projecció de la pel-lícula sobre l'aparador, Broodthaers contraposa creació i recepció creant una espècie de bucle de l'obra com a procés i com a document.

Amb tot, la interacció que es produïa entre els elements de l'exposició negava la seua autonomia, cosa que duia a qüestionar el fet que qualsevol actuació sobre l'espai de la galeria poguera ser apercebuda com a art. Consegüentment, l'exposició utilitzava l'espai expositiu com a punt de trobada entre els processos de producció artística i de recepció, en els quals l'obra era presentada no com un objecte autònom sinó com un fragment del procés creatiu entés com a continuïtat.

40. MTL 13/3/70 - 10/4/70 II. Invitació per a l'estrena de la pel.lícula

41. Fotogrames de la pel-lícula MTL (DTH) (1970) (p. següent)

A banda de les seccions $A, B$ i $C$, també hi havia una altra carpeta, identificada en el catàleg amb la lletra $D$. La carpeta contenia els documents relacionats amb el projecte mateix, però en va estar tancada durant l'exposició, per tant el seu contingut no va estar a la vista de l'espectador. Així doncs, si els documents de les seccions $A, B$ i $C$, exhibien el procés creatiu, els de la carpeta $D$ guardaven relació amb el procés de recepció artística El fet d'enunciar l'existència d'un secret, una informació amagada en funció de determinades circumstàncies cercava, en realitat, demanar l'atenció de l'espectador i feia de la incògnita un element de complicitat i sobretot enunciava la necessitat d'una intervenció interpretativa.

Mitjançant el complex muntatge de l'exposició "MTL 13/3/70 - 10/4/70", Broodthaers presenta el conjunt d'elements - els papers, les carpetes, el text pintat sobre el vidre, les targetes d'invitació, la pel·lícula i el catàleg - com a documentació d'una sèrie d'accions 

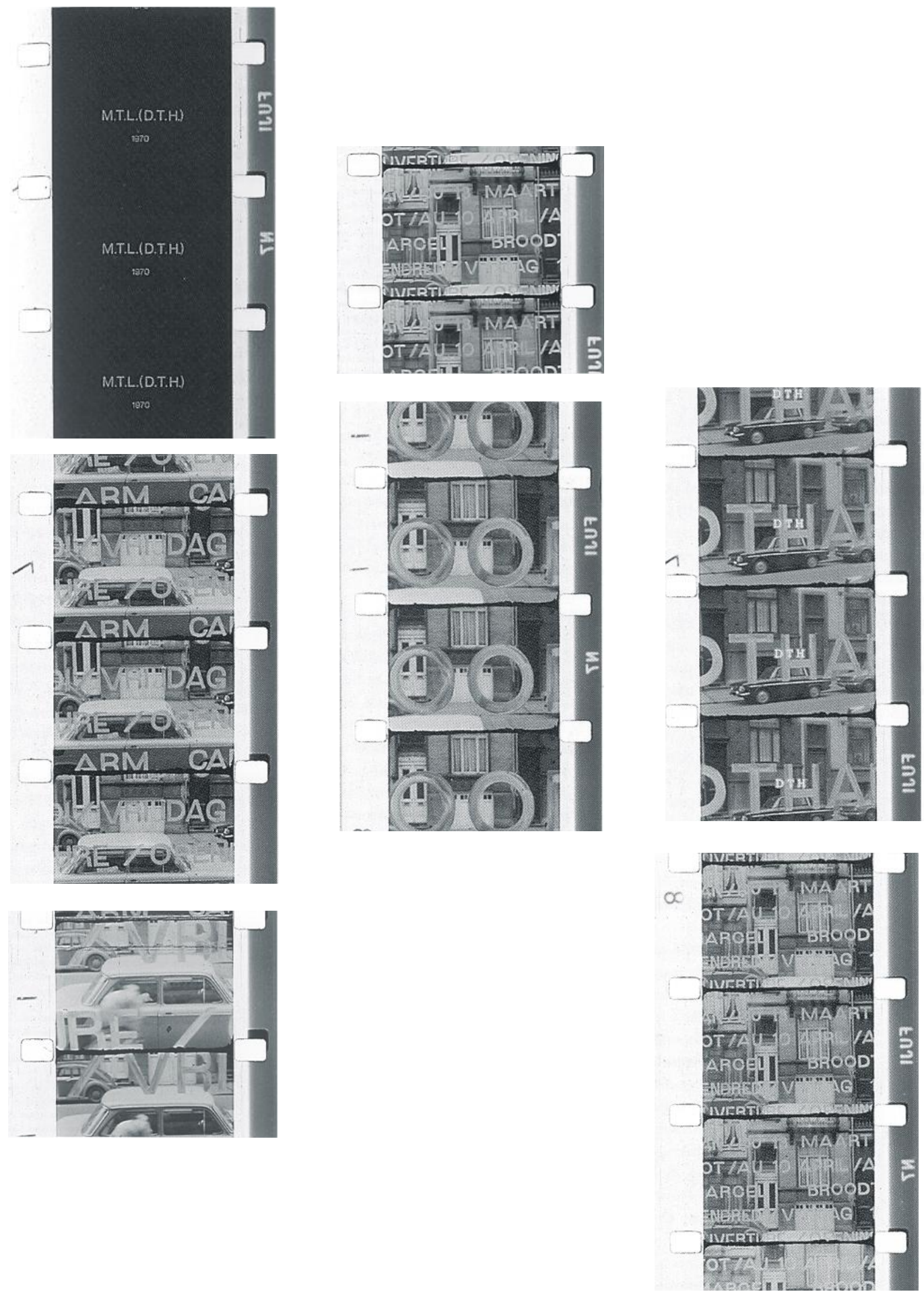
executades en funció d'assimilar l'espai expositiu i la durada en el temps com a part del procés creatiu. Així, cap d'aquests no hi eren autònoms ni constituïen un projecte teòric ni estètic coherents per si mateixos.

Amb tot això Broodthaers vol posar en qüestió la idea de l'autonomia de l'art, tant si es tracta de l'objecte com a art com si es tracta de la idea com a art. També qüestiona la idea d'autoria entesa com a institucionalització d'una definició d'art i, tanmateix, el paper legitimant de l'espai institucional, amb la qual cosa increpa directament els conceptes d'art i d'autoria fonamentats i instituïts a partir del llegat artístic de Duchamp. Així doncs, al temps que Broodthaers censura el paper legitimant dels espais instituits, el traspassa a l'espectador involucrant-lo en l'obra mitjançant l'exercici de lectura.

Altrament, proposa la utilització de la galeria com un element més de l'obra, o siga, com un element susceptible de ser manipulat per l'autor de manera que l'empremta de la subjectivitat recobra dimensió com a fonament de l'autoria. En un altre nivell, per a Broodthaers l'exposició representa únicament un fragment de la seua trajectòria com a artista, en la qual la mateixa circumstància expositiva queda integrada. 
3. L'ESPAI COM A SUPORT CREATIU 
CABINET DPS MIKISTRES DF LA CULTURE.

Ostende, le ? sept.1968

OUVERTURE

- - - - - - -

Noub avons de plaieir d'informer la olientèle et les ourieux

de l'inauguration du " Département des Aigles " du Kusée d'Art loderne.

Les travaux sont en coura; leur achèvement déterminera la date

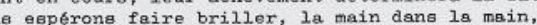
la poésie et les arts plastiques.

Nous espérons que notre formule " déaintéressement plus admixation " vous séduira.

30, rue de 2a Pépinière

Bruxelles 1 .
Pour 1'un des Ministres Marcel BRODTHAERS

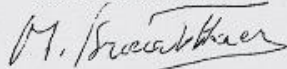

at bient8t, chers Amis,

OBJET METAL ESPRIT OBJET METAL ESPRIT OBJET METAL ESPRIT

OBJET METAL ISPRIT OBJET METAL BSPRIT OBJET MTTAL ESPRTT

OBJFT METAL BSPRIT OBJBT METAL ESPRIT OBJET MTTAL ESPRIT

OBJET METAL ESPRIT OBJBT MTTAL ESPRIT OBJET METAL ESPRIT

OBJET METAL ESPRIT OBJET METAL BSPRIT OBJET MTTAL ESPRIT

OBJET METAL ESPRIT OBJBT METAL ESPRIT OBJET METAL ESPRIT

OBJET MBTAL BSPRIT OBJET METAL ESPRIT OBJET METAL ESPRIT

OBJET METAL BSPRIT OBJPT METAL ESPRIT OBJET MITAL ESPRIT 
'origen del Musée d'Art Moderne Département des Aigles cal situar-lo en el context d'esdeveniments polítics i culturals viscuts a Europa durant el 1968. Aleshores, molts artistes i intel-lectuals d'esquerra dirigien la seua crítica cap al marc institucional en el qual es gestionava la pràctica artística. A Brussel-les un grup d'artistes va ocupar el Palau de Belles Arts com a part de les protestes. Durant tot un mes, els espais de la institució van ser l'escenari d'intervencions de tota mena: exposicions, performances, happenings, etc. Broodthaers va prendre part en l'ocupació i aquesta experiència li va conduir poc després, però de manera independent, a inventar-se el seu propi museu.

Per a Broodthaers el context del museu i de la galeria suplantava el significat de l'obra i per vindicar d'alguna manera els vincles de l'art amb el seu entorn sorgeix el Musée d'Art Moderne Département des Aigles: una institució altra, una ficció poètica, que parodia el funcionament de les institucions artístiques. Broodthaers assumeix el paper de director/ conservador de la institució i es proposa des de l'art indagar sobre les condiciones de veritat de la representació museística i reprendre el fill del debat, encara encés, sobre la condició de l'art i la funció de les institucions artístiques en la societat.

42. Ouvertures. Carta oberta al gabinet de ministres de cultura (7 de set. 1968). Section Littéraire

Per definir la naturalesa dels projectes que constitueixen les activitats del Musée d'Art Moderne Département des Aigles, el terme exposicions resulta una denominació inadequada. ${ }^{50}$ Es tracta d'espais i de situacions de ficció que alhora són reals i funcionen sota uns pressupostos determinats; són espais construïts. Més prompte, es tracta d'una sèrie de decorats.

Les diferents seccions del Musée d'Art Moderne i les darreres exposicions de Broodthaers que instrumentalitzen a dretcient la idea de Decor tenen en comú el fet de qüestionar el funcionament de les institucions artístiques així com l'art mateix entés com a idea autònoma. El caràcter efímer i artificial inherent a les manifestacions del Musée d'Art Moderne i a les diverses manifestacions del Decor remet a la idea de l'art com a decorat institucional, tant en l'espai del museu com en l'espai social.

\footnotetext{
50 "Doncs, en efecte, no es tractava de proposar un conjunt de treballs cadascun dels quals era una obra acabada i autònoma. Era més encertat considerar-ho com un environnement. Però aquesta noció solament és pertinent en la mesura que es relaciona amb una utilització de l'espai i no amb una construcció espacial amb vocació plàstica. Les manifestacions - per utilitzar el terme més neutre i obert possible - reunien sempre un nombre determinat d'objectes elegits pel seu contingut i mai no pel seu aspecte formal." J. Cladders. "Museo de Arte Moderno, Departamento de las Águilas, Sección siglo XIX". En Marcel Broodthaers. Ma., op. cit.: p. 294-295.
} 


\section{El Musée d'Art Moderne Département des Aigles: Obertura}

La inauguració del Musée d'Art Moderne Département des Aigles va ser concebuda per Broodthaers com un acte totalment formal i seguint el protocol dels museus oficials: la targeta d'invitació bilingüe francés/ flamenc, el discurs inaugural a càrrec d'una personalitat rellevant, el buffet per als invitats i finalment una intervenció sobre un tema d'actualitat per a obrir un debat amb el públic.

El discurs inaugural va ser a càrrec de Johannes Cladders, director del museu de Mönchengladbach, el rang $\mathrm{i}$ les funciones del qual apareixien en el text de la targeta d'invitació. Broodthaers va invitar Cladders perquè coneixia la seua compromesa postura respecte del museu com a institució pública i volia que l'exposara:

Parle sobre el seu Museu i sobre les dificultats per comunicar l'art i l'antimuseu a les autoritats oficials $i$ als homes amb sentit comú. ${ }^{51}$

Cladders va llegir el text d'un article que havia escrit per a un setmanari alemany on començava fent una anàlisi de la situació que travessaven els museus en aquells moments, els quals "com a institució es trobaven en el banc dels acusats, s'exposaven a la vergonya pública per causa de la seua decrepitud o, simplement, se'ls declarava morts." ${ }^{52}$ A continuació, Cladders va reivindicar el paper que havia jugat l'antiart en la renovació de l'art i va concloure al-legant a favor de l'existència de l'antimuseu com a resposta a la necessitat d'un contrapunt en el debat social.

Després, Broodthaers va prendre el seu torn de paraula per abordar la qüestió de les funcions i de la significació del museu dins de la societat, un tema aleshores polèmic. De seguida, va començar a parlar del seu projecte Musée d'Art Moderne, Département des Aigles i va establir un paral-lel entre la violència institucional que, en la seua opinió, exerceixen museus i galeries i la violència poètica que havia de definir el seu programa com a director/ conservador de la institució novella. Darrerament Broodthaers va obrir un debat amb el públic que va durar fins a la matinada on van discutir-se temes d'actualitat i problemes de la ciutat.

43. Discursos inaugurals del Musée d'Art Moderne, Département des Aigles a càrrec de Johannes Cladders i de Marcel Broodthaers. Brussel-les, 1968.

Amb la posada en marxa del Musée d'Art Moderne, Département des Aigles, el fet d'operar des d'uns límits clarament establerts dins de la ficció i parodiant el modus operandi dels museus oficials servia a Broodthaers per a posar en evidència allò que sovint passava per alt: l'existència d'espais legitimats socialment que regulen el funcionament del fet artístic.

\subsection{Els diferents emplaçaments}

Una de les característiques més singulars del Musée d'Art Moderne, Département des Aigles durant els seus quatre anys de funcionament va ser la seua localització en diferents espais. No es tractava de l'organització d'exposicions itinerants tal com podria fer-ho qualsevol altre museu, sinó que era la institució mateixa la què es desplaçava per diferents llocs. Era una situació que resultava prou atípica en relació a la concepció i al fonament de

\footnotetext{
${ }^{51}$ M. Broodthaers citat per J. Cladders; op. cit. [carta a J. Cladders; 15 set., 1968].

52 J. Cladders; op. cit.
} 


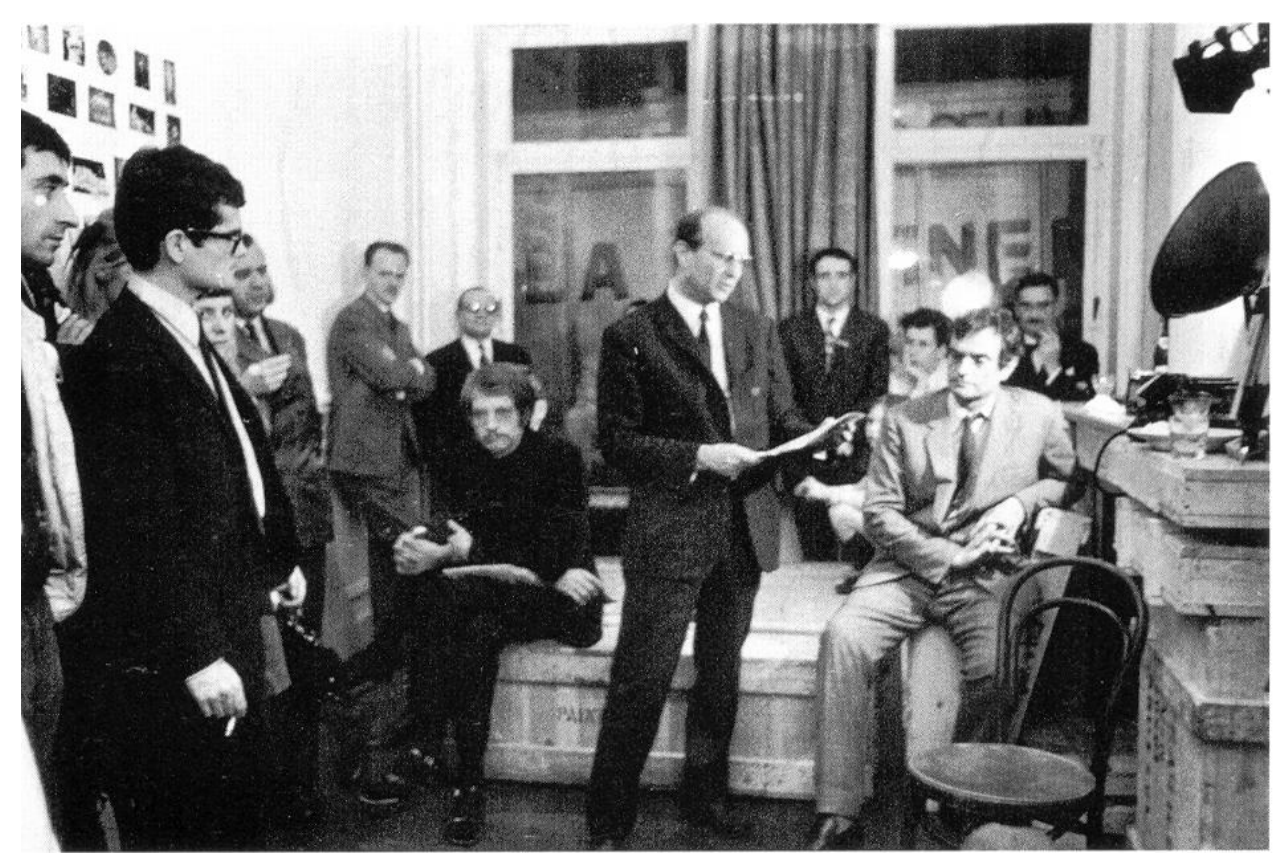

$43 a$

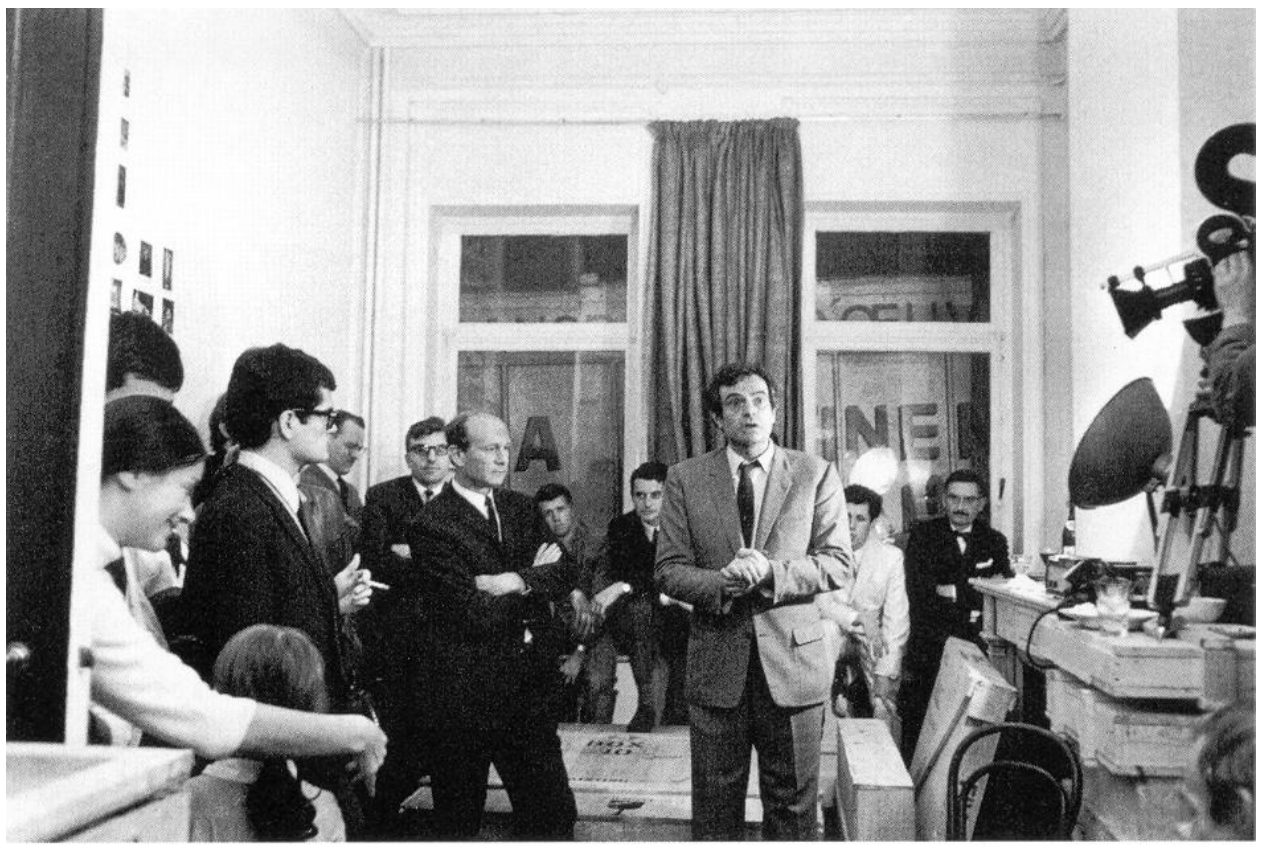




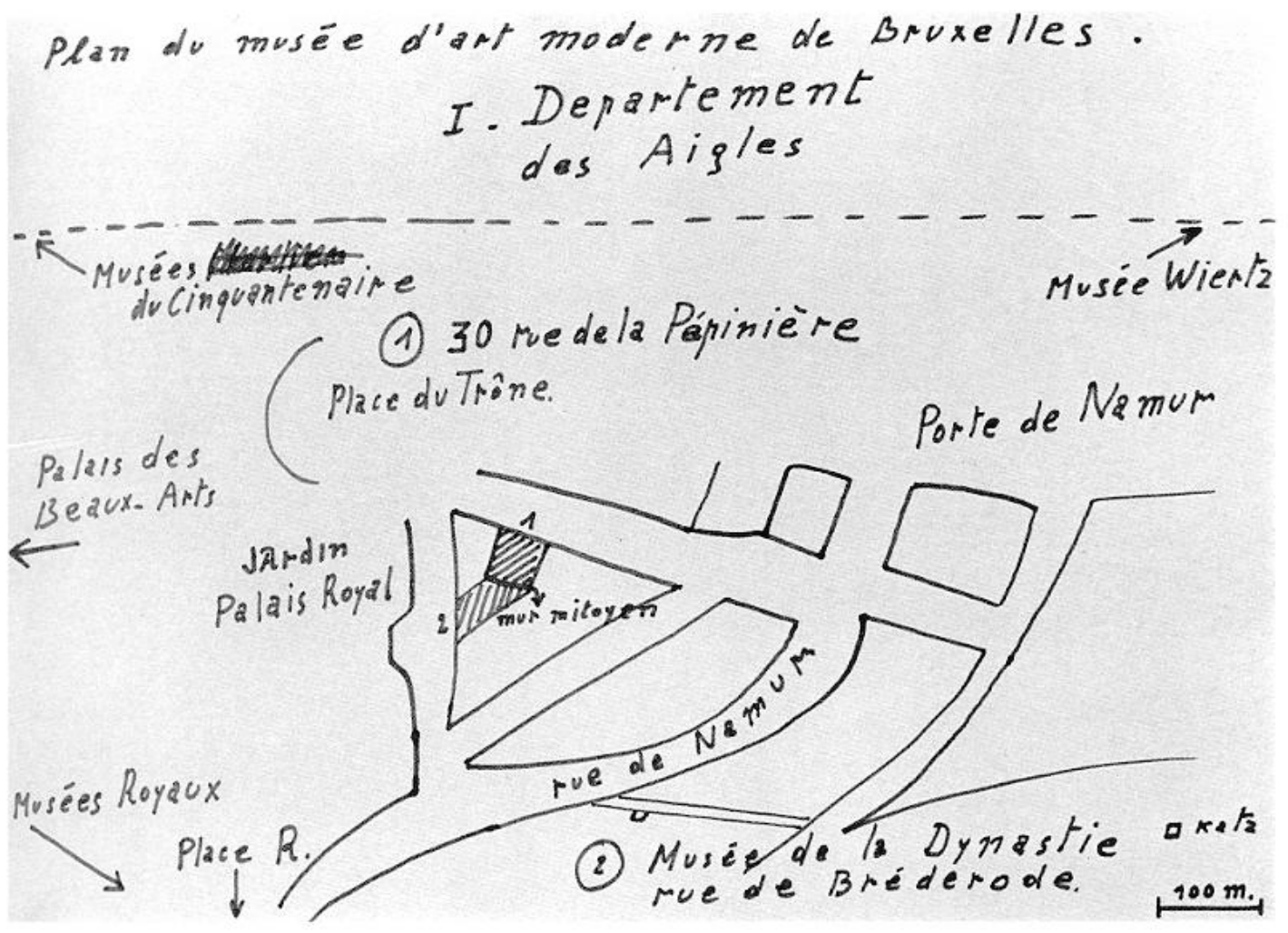


qualsevol museu oficial que, com a norma, són institucions de naturalesa sedentària i identificades majoritàriament amb una edificació concreta. Els diferents desenvolupaments i emplaçaments que va tenir originalment el Musée d'Art Moderne, Département des Aigles poden resumir-se en el quadre següent. ${ }^{53}$

44. Manifestacions del Musée d'Art Moderne Département des Aigles (quadre de text)

\begin{tabular}{|c|c|c|c|}
\hline Section Littéraire & & & $1968-1971$ \\
\hline Section XIXe siècle & 30 Rue de la Pépinière & Brussel-les & 27 setembre 1968 - 1969 \\
\hline $\begin{array}{l}\text { Poèmes Industriels } \\
\text { Cabinet des Estampes }\end{array}$ & $\begin{array}{l}\text { Llibreria Saint-Germain- } \\
\text { des-Prés }\end{array}$ & París & 29 octubre - 29 novembre 1968 \\
\hline Section Documentaire & Platja de Le Coq & Le Coq & agost 1969 \\
\hline Section XVIIe siècle & Espai A 379089 & Anvers & 27 setembre - 4 octubre 1969 \\
\hline $\begin{array}{l}\text { Section Folklorique, } \\
\text { Cabinet de Curiosités }\end{array}$ & Museu Zeeuws & Middelburg & ca. 1970 \\
\hline Section XIXe siècle (bis) & Städtische Kunsthalle & Düsseldorf & 14 i 15 febrer 1970 \\
\hline $\begin{array}{l}\text { Cinéma Modèle / } \\
\text { Section Cinéma }\end{array}$ & Burgplatz 12 & Düsseldorf & $\begin{array}{l}\text { novembre } 1970 \text { - gener } 1971 \\
\text { gener } 1971 \text { - } 1972\end{array}$ \\
\hline Section Financière & Galeria Michael Werner & Colònia & 5 - 10 octubre 1971 \\
\hline Section des Figures & Städtische Kunsthalle & Düsseldorf & 16 maig - 9 juliol 1972 \\
\hline Section Publicité & "Documenta V" & Kassel & 30 juny - 8 octubre 1972 \\
\hline Section d'Art Moderne & "Documenta V" & Kassel & 30 juny - 15 agosto 1972 \\
\hline Galerie du Xxe siècle & "Documenta V" & Kassel & 15 agost -8 octubre 1972 \\
\hline
\end{tabular}

Cal dir que la mobilitat del Musée d'Art Moderne no responia a un itinerari programat sinó que va fer-se sobre la marxa. Contrastant amb tot allò que tradicionalment caracteritza un museu, el Musée d'Art Moderne era una institució nòmada. Els diferents emplaçaments van succeir-se segons l'esdevenir del Museu mateix, si ben bé les diferents seccions sempre guardaven alguna relació amb el context i amb l'espai on van presentar-se.

Amb l'obertura del Musée d'Art Moderne s'inaugura la Section XIXe siècle, la qual va ser instal-lada en l'estudi de Broodthaers en 30 Rue de la Pépinière. Aquesta secció estava composta principalment per caixes, targetes postals i rètols, tots elements al-lusius a remeses i destinacions, a intercanvis i comunicació.

45. Pla del Musée d'Art Moderne Département des Aigles a Brussel-les (1969)

\subsubsection{Les manifestacions fonacionals 1968 - 1969}

Des de mitjans del 1968 fins al 1971 aproximadament, Broodthaers escriu una sèrie de cartes obertes dirigides a centenars de persones vinculades al món de l'art: artistes, directors de museus, galeristes o col-leccionistes, les quals van ser remeses des de diferents llocs: Brussel-les, Ostende, Anvers, París, Düsseldorf, Kassel, etc.

\footnotetext{
${ }^{53}$ Cf. "Museo de Arte Moderno Departamento de las Águilas 1968 - 1972: Documentos". En Marcel Broodthaers. Ma., op. cit: p. 167 - 231. Al llarg dels capítols següents s'analitzaran les diferents manifestacions. Ací mateix cal tenir en compte que algunes foren excloses darrerament del projecte-Museu per Broodthaers mateix. Més endavant abordarem els casos adients.
} 
Les cartes feien referència al Musée d'Art Moderne, comentaven els projectes i el funcionament de la institució, però essencialment el que feien era posar en circulació la idea i el nom del Museu. Els fulls de paper duien un segell amb la inscripció Département des Aigles o si no Section Littéraire. Segons Broodthaers mateix:

Aquestes cartes són un poc allò contrari d'un mitjà de comunicació, ja que més prompte comuniquen el nom del museu. En el rètol i en la situació d'aquest museu, s'oposen totalment a l'estil oficial i a la comunicació racional dels museus i dels organismes culturals existents. ${ }^{54}$

En octubre del 1968, al poc de temps d'inaugurar el Musée d'Art Moderne, Broodthaers presenta a París l'exposició "Multipl(i)é inimitable illimité, Exposition de tirages limités et illimités de poèmes industriels, M.U.SÉ.E D'.A.R.T. CAB.INE.T D.ES. E.STA.MP.E.S Département des Aigles". Aquestes obres senyalitzaven el nom del Museu, però eren totalment ambigües en tant que poemes i objectes industrials, escriptura $\mathrm{i}$ imatge alhora. Malgrat l'hermetisme, el llenguatge i l'aspecte estereotipat d'aquestes obres convidava l'espectador a desxifrar la seua significació. ${ }^{55}$

Per l'agost del 1969, al mateix temps que la Section XIXe siècle encara era instal-lada a Brussel-les, Broodthaers fa un altre emplaçament del Museu en la platja de Le Coq. Broodthaers i German Daled dibuixaren i excavaren la planta d'una edificació en la sorra de la platja. A continuació van plantar-hi pancartes amb diferents inscripcions bilingües, en francés $i$ en flamenc:

Prohibit absolutament tocar qualssevol objectes. ${ }^{56}$

Es prohibeix estrictament circular sobre les obres. ${ }^{57}$

46. Section Documentaire (1969). Muntatge fotogràtic.

L'emplaçament va fer estada no gaire temps, el temps que va demorar en pujar la marea i cobrir-ho tot. Finalment, la intervenció va quedar registrada com la Section Documentaire.

En setembre de 1969, un any després de l'obertura del Musée d'Art Moderne, Broodthaers cursa una altra invitació oficial amb l'anunci del tancament de la Section XIXe siècle i la inauguració de la Section XVIIe siècle:

Marcel Broodthaers prega [...] que tingueu l'amabilitat d'assistir a la cerimònia de clausura de la Section XIXe siècle del Département des Aigles, el dissabte 27 de setembre a les 18.00 hores. Hi està previst un servei d'autocar per emportar els invitats al local A 37 90 89, a Anvers [...] on tindrà lloc la inauguració de la Section XVIIe siècle, per P. K. Van Daalen, [...] Director del Museu Zeeuws. ${ }^{58}$

\footnotetext{
${ }^{54}$ L. Beckers (1969b). "Estas cartas son un poco lo contrario de un medio de comunicación..." (entrevista). En Marcel Broodthaers. Ma., op. cit:: p. 199.

${ }^{55}$ Sobre la sèrie d'obres denominada Poemes Industrials vegeu, en aquest treball, l'apartat 4.6.1 "La significació de l'espectador".

${ }^{56}$ M. Broodthaers (1969a). "Défense absolute... ". En Marcel Broodthaers. L'Architecte est absent...; op. cit.: p. 30.

${ }^{57}$ M. Broodthaers (1969b). "Il est strictement... ". En Marcel Broodthaers. L'Architecte est absent...; op. cit.: p. 30.

${ }^{58}$ M. Broodthaers (1968c). "Carta d'invitació per al tancament... ". En Marcel Broodthaers. Ma., op. cit: p. 200.
} 


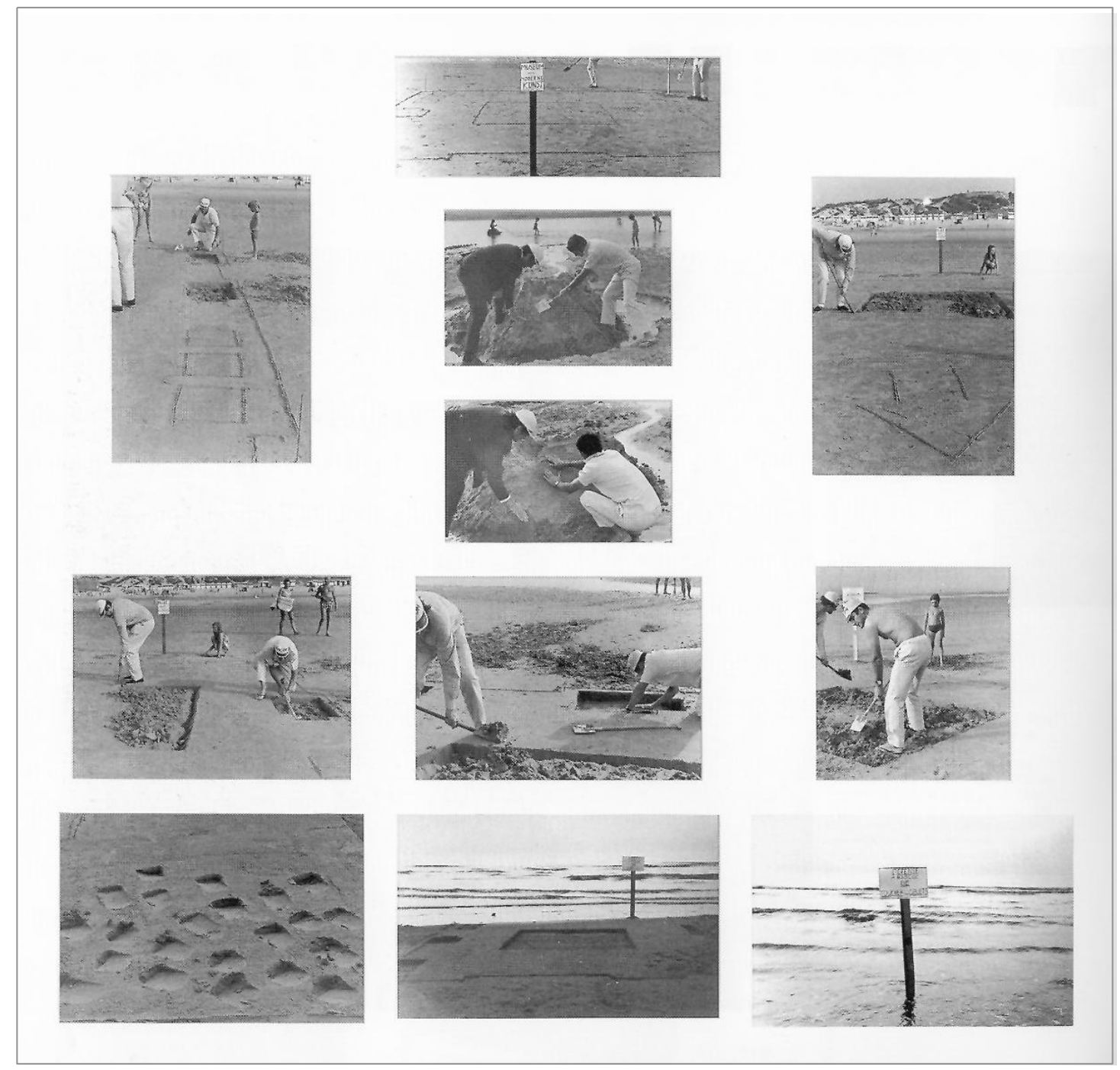



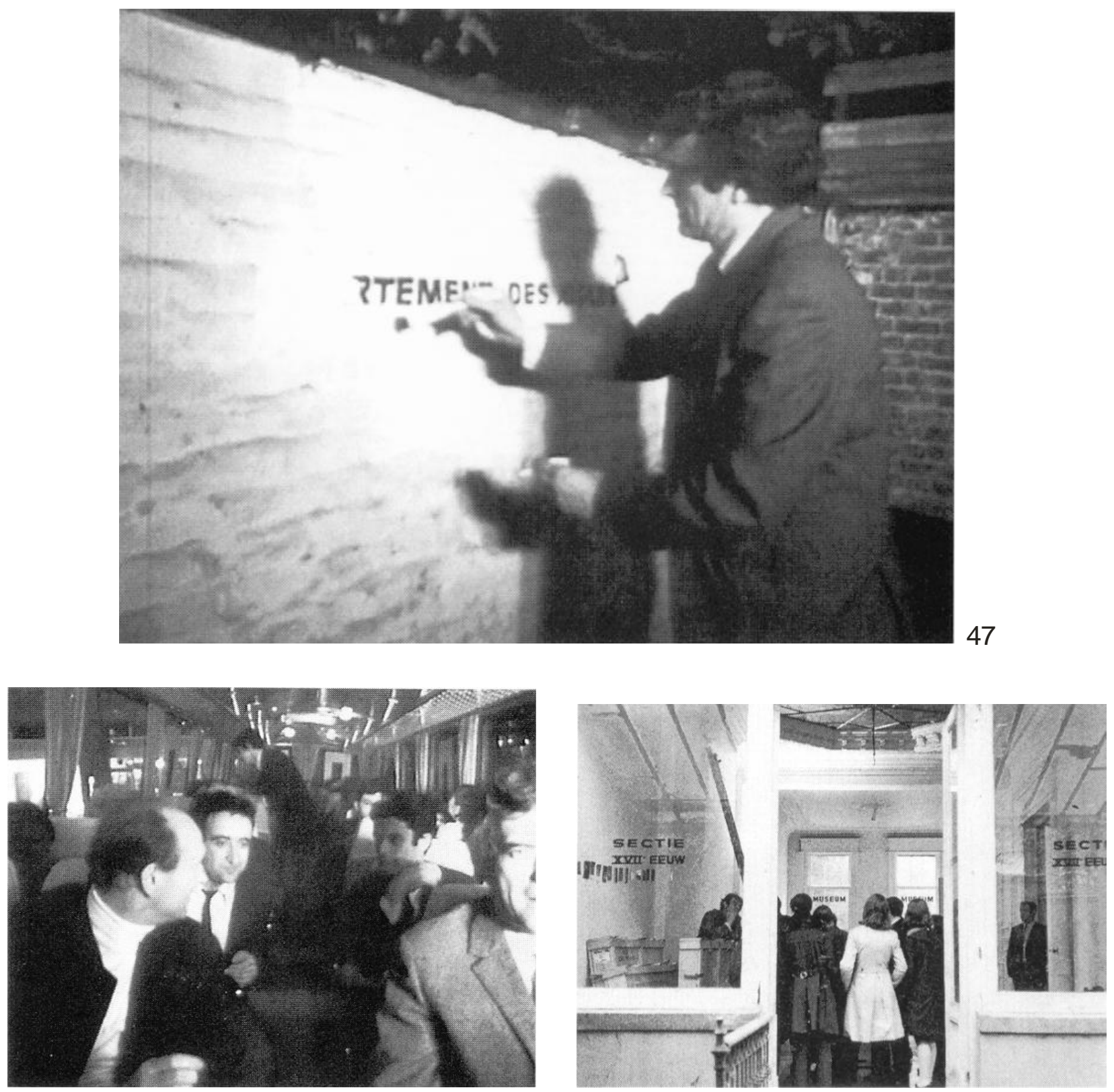

MUSEE * MUSEUM

Los thigh 
Com a part de l'acte de clausura Piet Van Daalen va dir un discurs i Broodthaers va eliminar la inscripció Département des Aigles que havia pintada en la paret del seu jardí. A continuació van col-locar-se les caixes i la resta d'elements en el camió de Menkes, que va fer el mateix recorregut que l'autocar dels invitats. A Anvers, el nou emplaçament del Museu era un espai alternatiu, anomenat A 3790 89, gestionat per Kaspar Koenig.

47. Broodthaers borra el rètol Département des Aigles de la paret. Brussel.les, 1969.

48. Viatge amb autobús Brussel-les - Anvers, 1969.

49. Inauguració de la Section XVIIe siècle. Anvers, 1969.

Poc després, Broodthaers fa donació a Van Daalen d'un canemàs brodat amb les paraules Musée - Museum. Les Aigles. La peça devia passar a formar part de la col-lecció del Departament Folklòric del museu Zeeuws. Altrament, Broodthaers també tenia la intenció d'editar un llibre-catàleg de la col-lecció del museu Zeeuws a partir d'una selecció de Van Daalen i de fotografies realitzades per Maria Gilissen; però el projecte no va arribar a terme. Això no obstant, la idea va quedar registrada com la Section Folklorique, Cabinet de Curiosités.

50. Musée - Museum. Les Aigles (ca. 1970). Bastidor brodat.

\subsubsection{Düsseldorf i Colònia 1970 - 1972}

En la primavera del 1969 Jürgen Harten, un dels directors de la Städtische Kunsthalle de Düsseldorf visita la Section XIXe siècle a Brussel-les. Harten invita Broodthaers a presentar el Musée d'Art Moderne, Département des Aigles dins del context d'un projecte anomenat Between què estava tenint lloc en la institució. Així doncs, l'any següent Broodthaers presenta a Düsseldorf la Section XIXe siècle (bis).

Harten i Broodthaers van fer els discursos inaugurals seguint els protocols. La novetat era que la Section XIXe siècle (bis) mostrava quadres vertaders de pintors alemanys del segle XIX juntament amb fotografies i diapositives que documentaven la Section XIXe siècle a Brussel-les. També va projectar-s'hi la pel-lícula Une Discussion Inaugurale, rodada durant la inauguració del Museu.

Des del 1970 fins al 1972, aproximadament, Broodthaers resideix a Düsseldorf on instal-la de manera independent, en el soterrani d'una casa ubicada en Burgplatz 12, unes altres manifestacions vinculades amb el Musée d'Art Moderne. De primer va instal-lar-se Cinéma Modèle i després la Section Cinéma.

L'espai de la Section Cinéma disposava de dues sales: una d'elles funcionava com a sala de cinema on tenia lloc la projecció d'un programa de pel-lícules i l'altra exhibia una col-lecció d'objectes com, per exemple: una pipa, un espill, un rellotge, un calendari, un cofre que contenia uns altres objectes, i un piano amb la inscripció Les Aigles, entre altres. La Section Cinéma va funcionar fins a mitjans del 1972.

51. Discurs inaugural de la Section Xixe siècle (bis) a càrrec de Jürgen Harten. Düsseldorf, 1970. (pàgina següent)

52. Broodthaers durant el muntatge de la Section Cinéma. Düsseldorf, ca. 1971-1972. (pàgina següent)

Paral-lelament, el 1971, Broodthaers presenta la Section Financière en l'espai de la galeria Michael Werner en el context de l'edició dinovena de la Fira d'Art de Colònia. La 
manifestació tenia dos projectes paral-lels. Un d'aquests consistia en l'edició d'una sobrecoberta per al catàleg general de la Fira amb la qual van embolcallar-se'n dinou exemplars. En la portada apareixia un text informant de la venda del Musée d'Art Moderne per causa de fallida, mentre que en la contraportada hi havia un dibuix de la silueta d'una àguila volant, la inscripció FIG.O i el vers "Ó Melancolie aigre château des aigles". ${ }^{59}$ En la solapa de la sobrecoberta hi havia una altra inscripció signada per Broodthaers i seguida d'una llista amb els noms de dinou artistes, escriptors i cineastes:

LES AIGLES / Amb la finalitat d'ordir una intriga, dedique aquesta sobrecoberta que recobreix el catàleg de la fira artística de Colònia a les persones imaginàries i reals els noms de les quals es donen a continuació. La majoria d'aquestes persones mai no s'haurien trobat. / Marcel Broodthaers [signatura i a continuació la relació dels noms] / Charles Baudelaire / J.B. Clement / Paul Colinet / Jacques Darché / Lucien Goldmann / Victor Hugo / J.D. Ingres / Buster Keatons / René Magritte / Edgar Poe / Jean Redon / Mark Rockho / Kurt Schwitters / Jonathan Swift / J.B. Uyttendaele / Gustave $* * * /$ Jean Vigo / Wiertz. $^{60}$

L'altre projecte de la Section Financière consistia en la venda regulada d'un lingot d'or estampillat amb la figura de l'àguila. El projecte incloïa una edició il-limitada del lingot d'or amb l'estampa de l'àguila així com la publicació d'un contracte amb les condicions de l'operació. Segons el contracte mateix, el preu de la peça es fixaria en el doble de la cotització de l'or en el mercat el dia de l'operació i la plusvàlua obtinguda estaria destinada a finançar el funcionament del Musée d'Art Moderne, Département des Aigles. Com a garantia, cada còpia de lingot havia de dur una carta d'autenticitat del conservador del Musée per tal d'evitar falsificacions. ${ }^{61}$ Aquest projecte no va dur-se a terme quan va ser concebut, el 1971, sinó que va editar-se pòstumament. ${ }^{62}$

53. Section Financière (1971). Sobrecoberta per al catàleg de la Fira d'Art de Colònia (plego interior)

54. Contracte per a la venda d'un quilo d'or en lingot (1971-1987). Facsímil (plego interior)

55. Detall del lingot amb l'estampa de l'àguila.

56. Museum - Museum. (1972) Díptic en serigrafia. En aquesta edició les reproduccions del lingot d'or s'acompanyen be amb el nom d'un artista (Mantegna, Bellini, Watteau, Ingres, Duchamp, Magritte, etc.), be amb els noms de diverses productes (mantega, or, coure, xocolata, sucre, petroli, tabac, etc.) o be amb les inscripcions IMITACIÓ, CÒPIA, FALS i ORIGINAL (tots en fr. i en al.).

L'any següent Broodthaers presenta en la Städtische Kunsthalle de Düsseldorf una de les manifestacions més conegudes del Museu: la Section des Figures, un projecte en què van col-laborar quaranta-quatre museus, a més a més de col-leccions privades. Van reunir-s'hi més de tres-centes peces de caràcter molt divers però que tenien com a element comú la representació de l'àguila. També hi eren part del projecte dues projeccions de diapositives amb exemples de l'àguila en la publicitat.

57. Portada del catàleg Section des Figures (1972) (p. següent)

\footnotetext{
${ }^{59}$ M. Broodthaers (1971a). "Section Financière... ". En Marcel Broodthaers. Cinéma; op. cit.: p. 194.

${ }^{60}$ M. Broodthaers $(1971 a)$. Íd.

${ }^{61}$ M. Broodthaers (ca. 1971b). "Concernant la vente d'un kilog d'or...". En Marcel Broodthaers. Ma. op. cit. p. 213.

${ }^{62}$ El 1987 la galeria Konrad Fischer va editar el Contrat i una reproducció fotogràfica del lingot d'or. Cfr. Marcel Broodthaers. Ma., op. cit.: p. 213.
} 


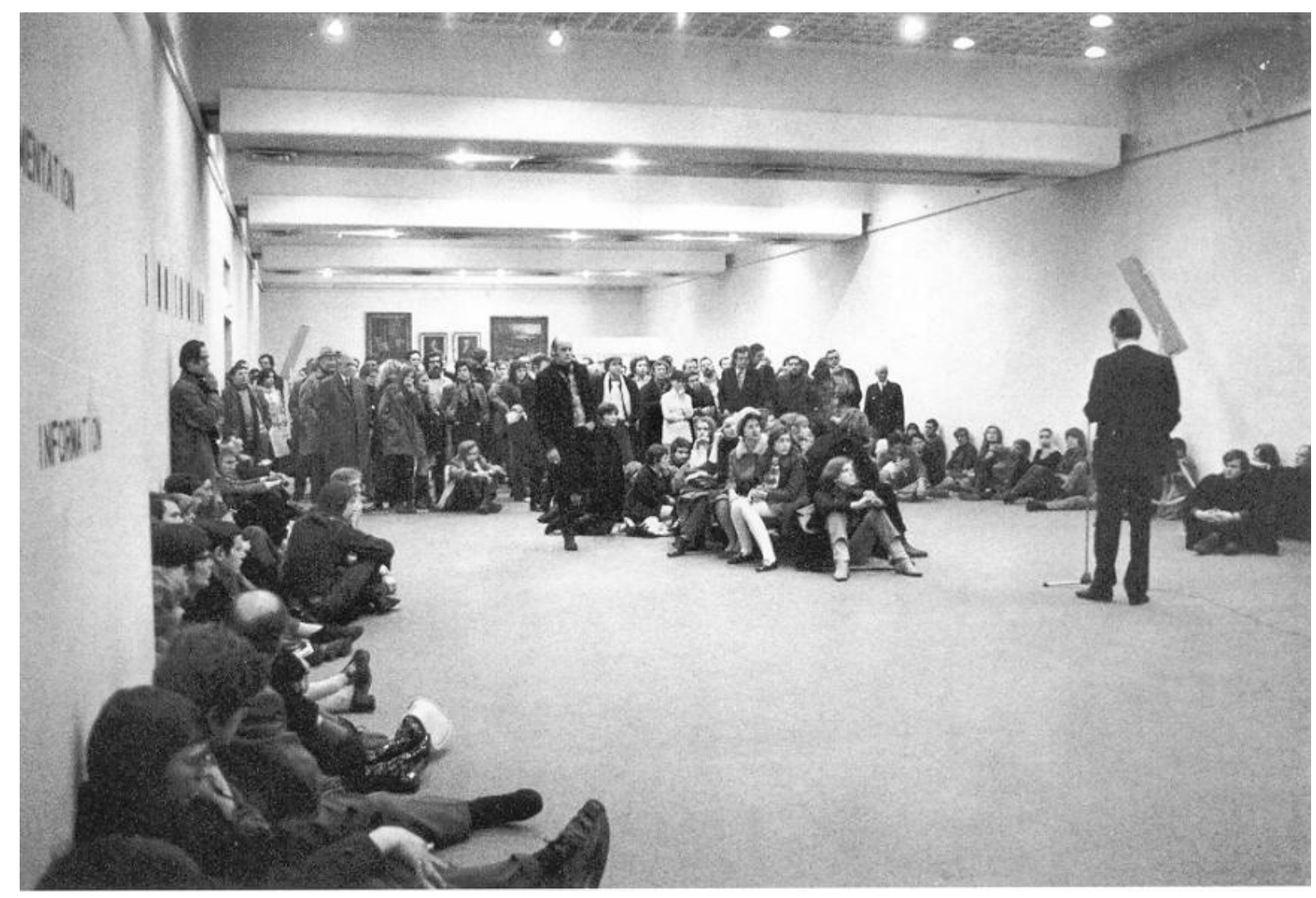

51

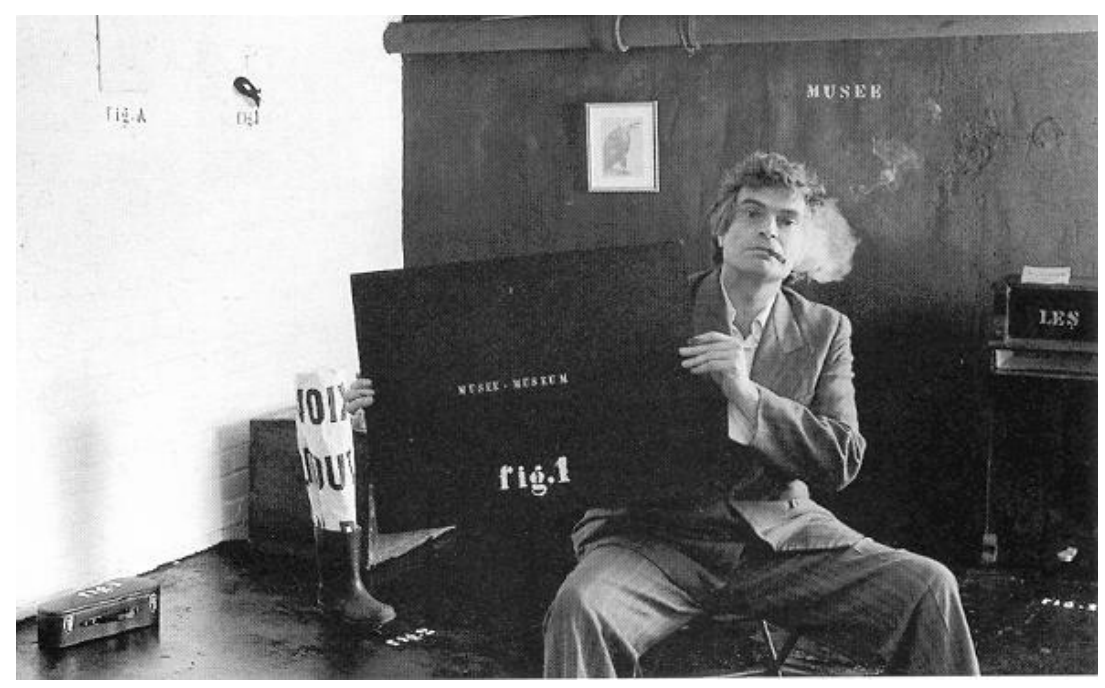

52 


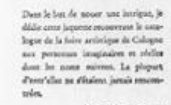

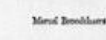

a. Nitancolic

aignes chateane des aigles
MUSEE

$\begin{array}{lllllllllllll}\text { D } & \text { A } & \text { R } & \text { T } & \text { M } & \text { O } & \text { D } & \text { E } & \mathbf{R} & \mathbf{N} & \mathbf{E}\end{array}$

A VENDRE

$1970-1971$

POUR CAUSE DE

FAILLITE
LES MGLES

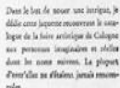

a. Nítancolic

aigre chateau des aighes
MUSEE

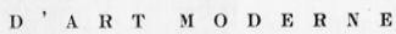

A VENDRE

1970-1971

POUR CAUSE DE

FAILLITE 


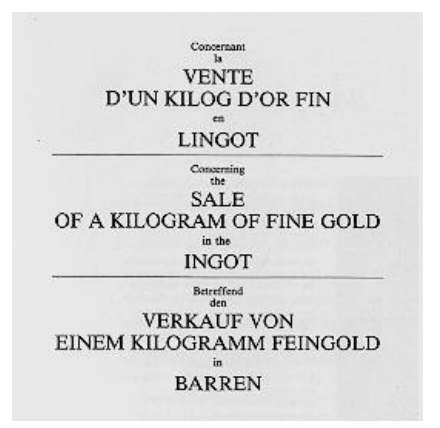

$54 a$

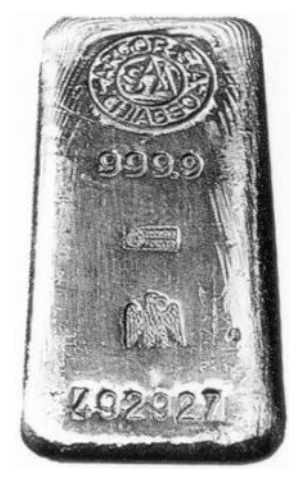

55

\section{MUSEUM}
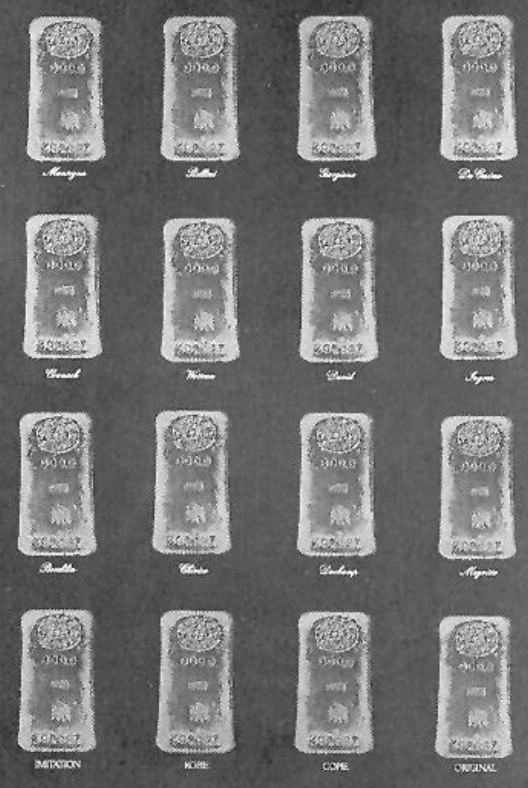

$56 a$

\section{CONTRAT}

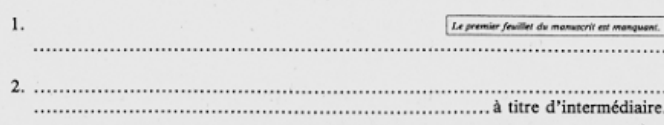

3. En cas de refus de perception de ces \% par les editions $\mathrm{K}$ ou les intermédiaires, ils

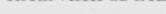

4. Le Kilog. d'or, en barre ou en lingot, en provenance d'une place au choix de l'acheteur - frais de déplacement à sa charge - est proposé en
"Tirage llimité".

5. Le prix est fixé au double du cours du jour. Paiement en devises, au comptant.

6. Chaque kilo d'or est estampillé d'un poinçon à l'aigle, marque du Musée d'Art Moderne, et accompagné d'une lettre manuscrite du conservateur afin d'éviter la fabrication de faux.

7. Il est loisible à l'acheteur de faire fondre son lingot ou sa barre afin d'effacer les marques, de braler la lettre d'identification afin de jouir pleinement de la pureté de la matière

8. Un exemplaire du tirage est déposé en banque, dans un coffre au nom du musée d'Art

9. Pour tous renseignements, écrire à: Monsieur le Conservateur du

Muste d'Art Moderne

Département des Aigles
12 Burgplatz -4 Düsseldorf

\section{$54 b$}

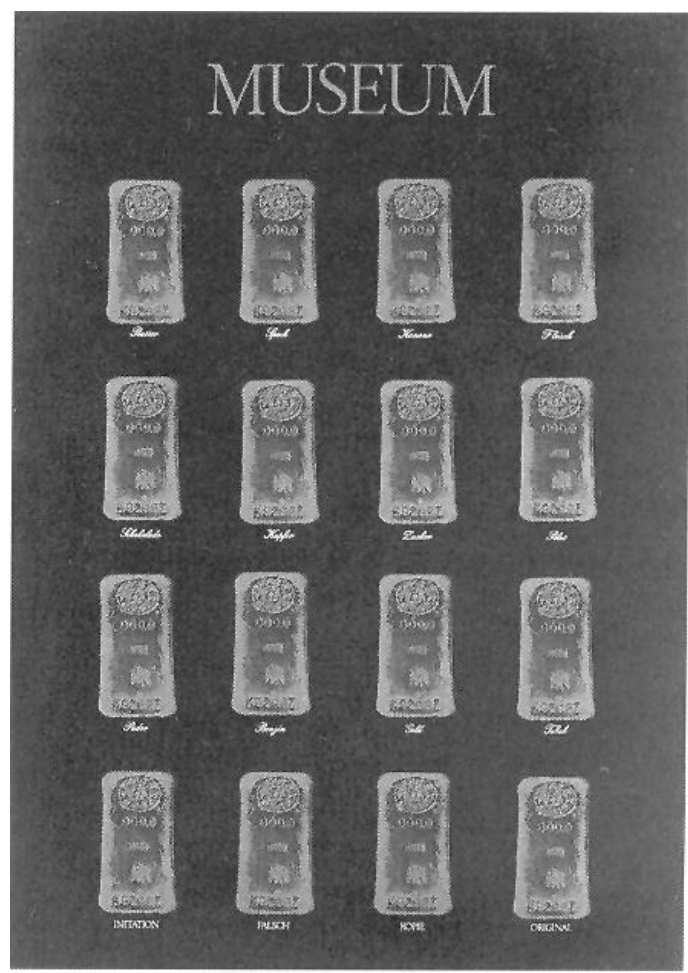

$56 b$ 


\section{MUSE U M}

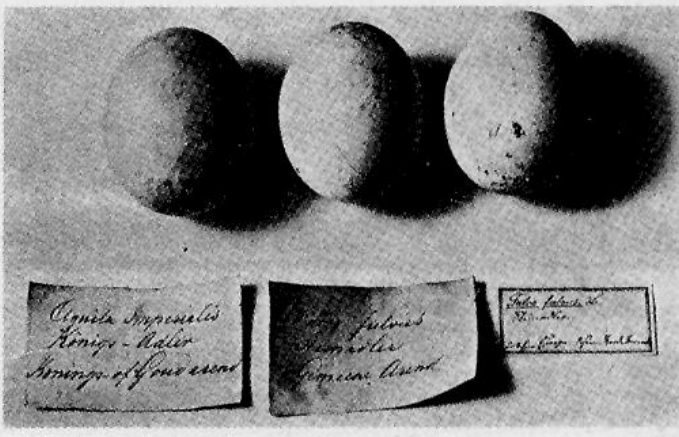

Kunstmuseum Basel Kupferstichkabinett

Staatliche Museen Stiftung Preußischer Kulturbesitz Berlin (West) Antikenabteilung, Kunstbibliothek, Kunstgewerbemuseum

Kupferstichkabinett, Museum für Islamische Kunst

Nationalgalerie, Skulpturenabteilung, Museum für Völkerkunde Abt. Amerikanische Archäologie

Staatliche Museen zu Berlin (Ost) Vorderasiatisches Museum

Akademisches Kunstmuseum der Universität Bonn

Musées Royaux d'Art et d'Histoire Brüssel

Département d'Antiquités Précolombiennes, Département de

Céramique, Département de Folklore, Département de Tapisserie Musée Royal d'Armes et d'Armures Brüssel

Musée Wiertz Brüssel

Hetjensmuseum Düsseldorf

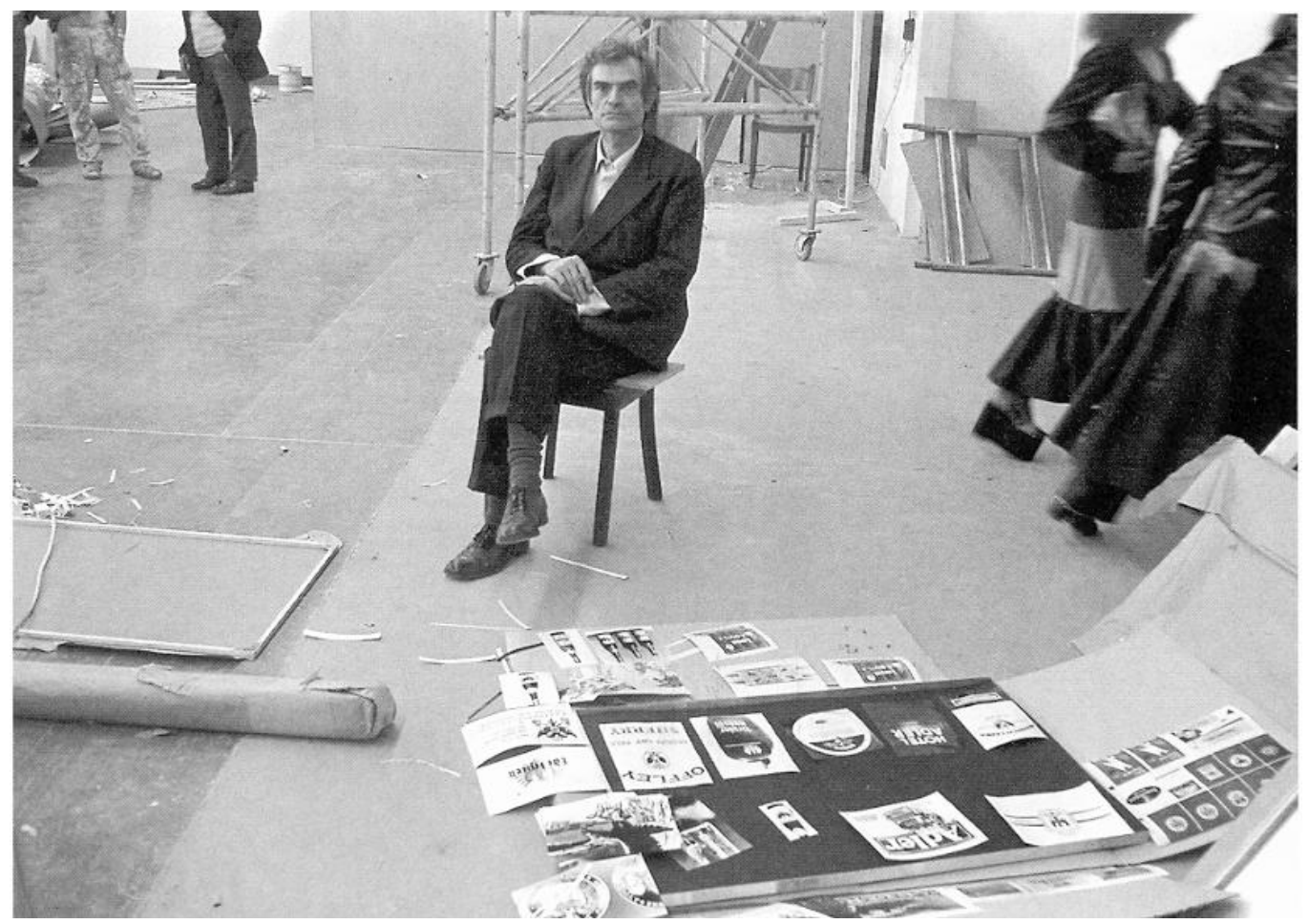




\subsection{3 "Documenta V" 1972}

$\mathrm{Al}$ poc de temps, Broodthaers presenta en "Documenta V" tres seccions del Museu en dos espais diferents. La Section Publicité va instal-lar-se en la planta baixa de l'edifici de la Nova Galeria, mentre que la Section d'Art Moderne i la Galerie du XXe siècle van instal-lar-se en la planta superior, ambdues en el mateix lloc, però en períodes diferents. En la Section Publicité Broodthaers presenta una espècie de resum de la Section des Figures, però donant més rellevància a la fotografia com a forma de documentació així com a la comparació de les imatges de l'àguila en la història de l'art i en la publicitat. Aquesta secció va mantenir-se sense grans canvis durant els tres mesos que durà la mostra.

58. Broodthaers durant el muntatge de la Section Publicité. Kassel, 1972 (p. oposada)

Altrament, en la Section d'Art Moderne Broodthaers construeix amb panells i rètols un espai-museu i al mig del terra va escriure Propietat Privada. Sis setmanes després Broodthaers desmunta la Section d'Art Moderne i transforma l'espai en el Musée d'Art Ancien, Département des Aigles, Galerie du XXe siècle. Així mateix, la inscripció en el terra va ser substituïda per una altra: Escriure, Pintar, Copiar, Figurar, Parlar, Formar, Somniar, Intercanviar, Fer, Informar, Poder.

En resum, l'esdevenir del Musée d'Art Moderne, Département des Aigles va estar estretament relacionat amb les circumstàncies dels seus diferents emplaçaments; no obstant això, va aconseguir ser un contrapunt en el debat social sobre el paper i les funcions de les institucions artístiques. Tanmateix, per a Broodthaers el Museu va funcionar com un instrument per escenificar la seua actitud compromesa.

\subsection{Els objectes en el Musée d'Art Moderne}

La configuració com a ficció de la institució Musée d'Art Moderne, Département des Aigles i dels seus espais està estretament vinculada amb els seus elements constitutius, o siga, amb els objectes que havien de representar la categoria d'art o el fenomen adient. Mitjançant l'objecte i la seua resignificació la ficció comença a prendre cos.

La Section XIXe siècle estava composta per rètols amb el mon del Museu, unes trenta caixes de transportar quadres amb diverses inscripcions - Picture, Tableau, Sculpture, Handle with care, Keep dry, Brussels, Painting, Fragile, Haut, Bas, etc. - un camió de Menkes (una coneguda empresa dedicada al transport d'obres d'art), així com unes cinquanta targetes postals què reproduïen obres d'artistes del segle XIX: Ingres, Wiertz, David, Courbet, Corot, Meissonier, Winterhalter, Puvis de Chavanne, etc.

Per a Broodthaers el fet d'apropiar-se obres vertaderes i atribuir-les un nou sentit com a objectes mai no podia ser alié a l'actitud iniciada per Duchamp, malgrat la diferència de propòsits. Però, la situació creada corria el risc de ser apercebuda per l'espectador com un nou plantejament estètic, cosa que n'invalidava la vertadera intenció. ${ }^{63}$ Aleshores, es tractava de trobar la manera d'incidir sobre els hàbits de percepció de l'espectador. La irrellevància dels

\footnotetext{
63 "Tots havien apercebut l'objecte com una expressió artística o com una curiositat. [...] Ningú tingué curiositat pel text. Ningú no es va emocionar per allò prohibit." Cf. I. Lebeer (1974); op. cit.
} 
objectes apropiats així com la seua funció dins del decorat-Museu subratllaven la intenció de polèmica del projecte Musée d'Art Moderne Département des Aigles. Cap dels objectes podia ser identificat com a obra d'art. Eren, segons Broodthaers mateix, "un munt de no res", que remetia a la ficció de la situació, a tot allò d'improvisat, de contestatari i de lúdic. ${ }^{64}$

59. Col·lecció de targetes postals en la Section xixe siècle. Brussel·les, 1968-1969.

60. Camió de transports de Menkes en la Section xixe siècle. Brussel-les, 1968-1969.

La sèrie d'elements fonacionals va repetir-se en la Section XVIIe siècle: els rètols del Museu, el camió de Menkes, les inscripcions, les caixes i les targetes postals; encara que ací les postals eren reproduccions de quadres de Rubens, un detall amb la ciutat natal de l'artista. L'únic element nou agregat al conjunt era una escala afermada en una de les parets i dirigida cap a una postal col-locada d'alt.

En la Section XIXe siècle (bis) la idea inicial de Broodthaers era traslladar a Düsseldorf tots els objectes que ja eren representatius del Museu, però després ho va desestimar i sols hi va utilitzar algunes postals. La repetició del nom i d'elements ja coneguts i representatius de la ficció del Museu feia que la nova manifestació fóra d'alguna manera previsible.

Les postals van ser presentades com a part d'una instal-lació anomenada Dokumentation Information. A banda d'això, hi havia fotografies i diversos documents de la Section XIXe siècle, de la Section XVIIe siècle i de la Section Littéraire; així com dues projeccions: una sèrie de diapositives titulada Caricatures et peintures du XIXe siècle i la pel-lícula Une Discussion Inaugurale, rodada el 1968 durant la inauguració del Museu. De l'altra part, hi havia vuit quadres originals del segle XIX d'autors representatius de l'Escola de Düsseldorf. Els quadres estaven ubicats en una paret prop de l'entrada i organitzats en dos nivells, segons la disposició convencional a l'ús en els museus del segle XIX. Al costat hi havia un panell gran amb el rètol Section XIXe siècle (bis).

El muntatge Dokumentation Information ocupava la major part de l'espai i resultà ser una bona solució que, a més a més, va atendre les expectatives del públic que ja tenia referències de l'existència i de la idea del Museu. Però, a poc a poc, els objectes del decorat-Museu que sustentaven la ficció començaven a ser apercebuts com a símbols. Altrament, la presència de quadres d'època va resultar inesperada i intrigant tenint en compte l'historial del Musée d'Art Moderne. També resultava prou atípica tant pel context d'un projecte alternatiu com era Between, com pel perfil institucional de la Kunsthalle.

La idea d'incloure quadres vertaders dins del museu fictici responia a una doble intenció. D'una banda, materialitzava una espècie de homenatge sincer i nostàlgic a l'art del segle XIX, que per a Broodthaers representava el cim de l'esperit modern. Però de l'altra banda, significava una demostració de revellia per part de Broodthaers davant la instauració i l'acceptació de les estètiques pràctiques. ${ }^{65}$ Això no obstant, Broodthaers assumeix i ressalta la descontextualització i l'objectualització dels quadres la qual cosa era inherent tant de la seua presència com del sentit de la seua apropiació.

${ }^{64}$ Cf. J. Harten i K. Schmidt. "Fragment d'un entretien avec Marcel Broodthaers". En A. Hakkens. Marcel Broodthaers par lui-même. Amsterdam: Ludion / Flammarion, ca. 1998: p. 80 - 83.

${ }^{65}$ Es tracta d'una categoria que aleshores servia per fer referència a una definició de l'obra d'art en tant objecte de reflexió teòrica així com la seua posterior transformació en objecte de contemplació estètica; una posició subscrita fonamentalment per l'art conceptual i justificada a partir del llegat artístic de Duchamp. 

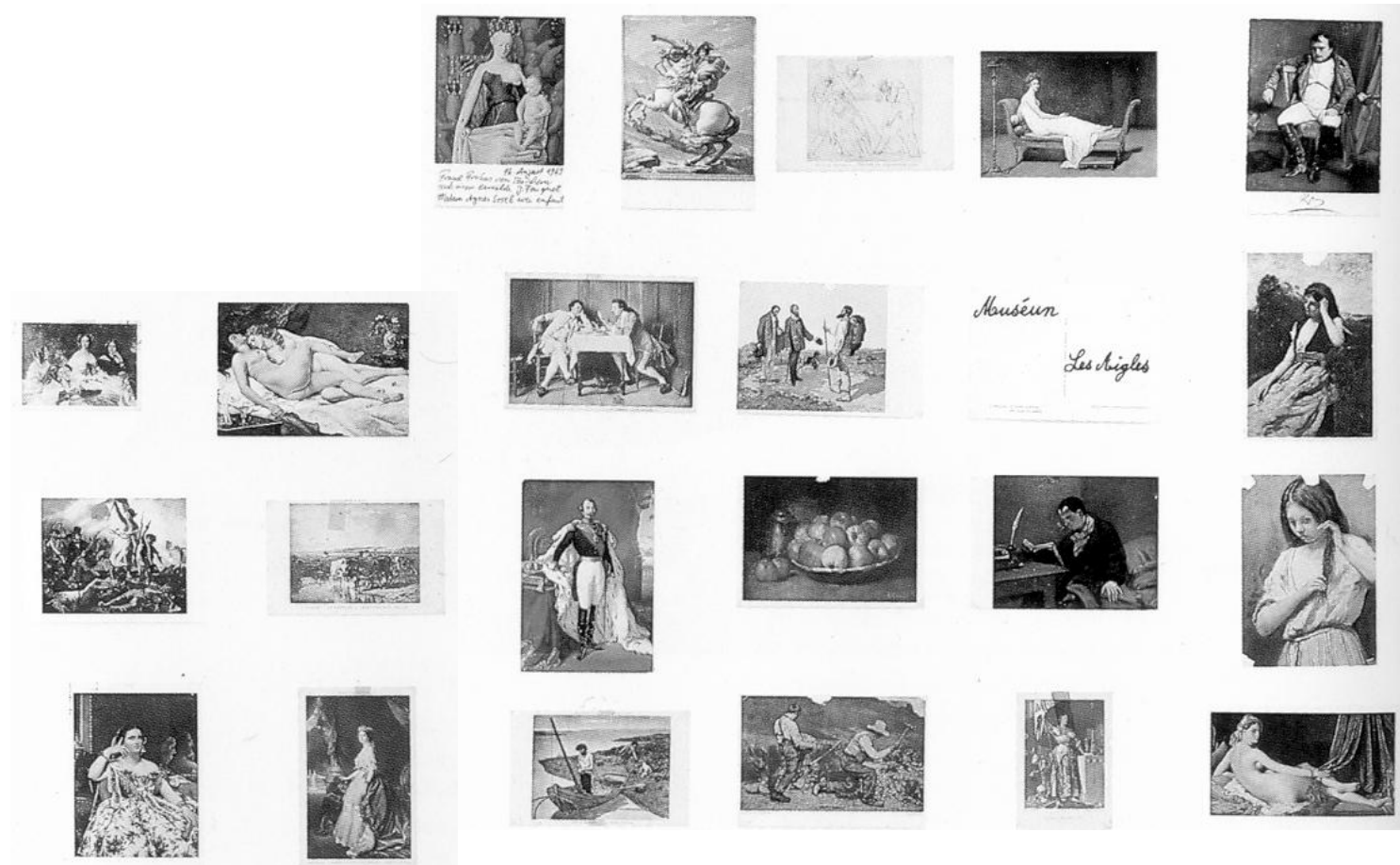

59

60

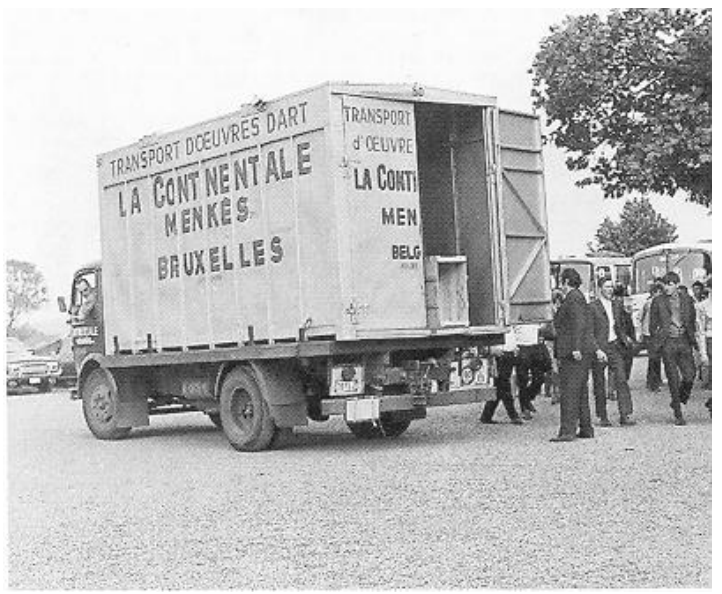



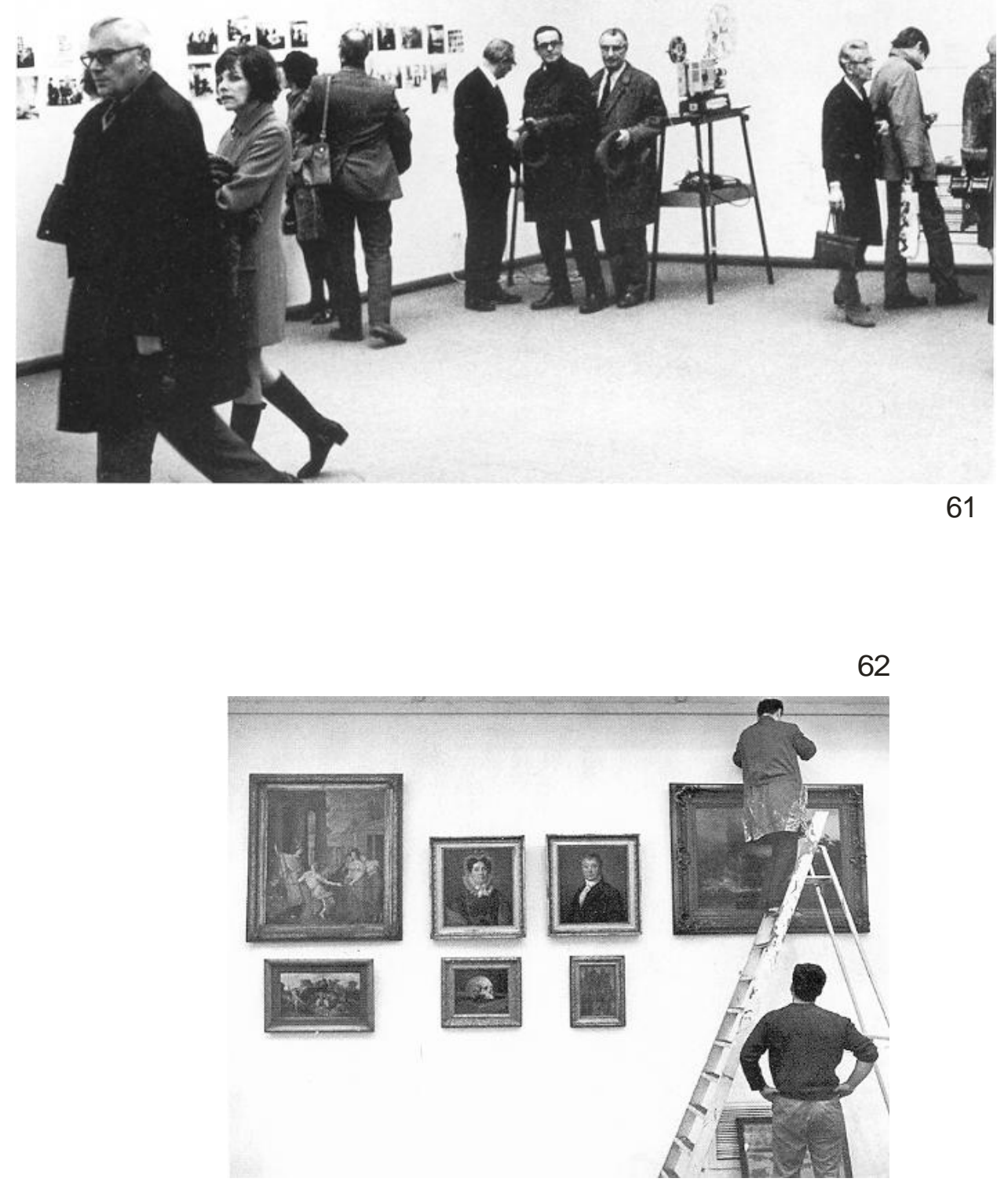
61. Dokumentation Information. Düsseldorf, 1970.

62. Quadres del segle XIX en la Section XIXe siècle (bis). Düsseldorf, 1970.

Darrerament, en la Section de Figures, Broodthaers assaja un mètode que li permet, segons va manifestar, "utilitzar els descobriments de l'art conceptual per donar una nova llum a objectes i quadres de l'antiguitat". 66

\subsection{La identitat de l'àguila}

Dos anys després de la Section XIXe siècle (bis) Broodthaers instal-la en la Kunsthalle de Düsseldorf la Section des Figures. Va presentar-se sota el títol "Der Adler vom Oligozän bis heute" (L'àguila des de l'oligocé fins als nostres dies), cosa que feia pensar en un projecte de caire enciclopèdic i que aplegava més de tres-centes peces procedents dels fons de col-leccions públiques i privades. Com abans, en la Section XIXe siècle (bis), Broodthaers va donar-hi rellevància, des del seu paper de director/ conservador del Musée d'Art Moderne, a les relacions de col-laboració amb les entitats que hi havien prestat les obres.

Broodthaers va realitzar una recerca per la història de l'art i l'antropologia i va reunir-hi objectes de tota mena: des de restes arqueològics, fins a representacions tretes de la publicitat, a més a més d'escultures, pintures i objectes diversos, tots en funció de documentar la simbologia de l'àguila en diferents èpoques i cultures. Així doncs, la col·lecció reunida revelava sorprenents coincidències: en diferents regions i en diferents contextos històrics, l'àguila apareixia representada com a espècie valuosa, com a símbol de grandesa, com a idea d'allò sublim o com a encarnació d'un esperit de conquista.

Per Broodthaers, els objectes reunits acomplien una funció didàctica: la de desemmascarar la imatge de l'àguila com a símbol de poder i de força. Segons va exposar en la presentació del catàleg:

La relació directa entre el fòssil de l'àguila trobat en unes excavacions efectuades en uns jaciments terciaris i les distintes formes sota les quals es presenta el símbol potser és dèbil, suposant que existeixa. [...] el símbol de l'àguila s'ha représ sense reflexió, sense haver sigut sotmés a discussió. [...] l'objectiu d'aquesta exposició, però, és treure-la [l'àguila] del cel imaginari on voleteja des de fa segles, amenaçant-nos amb els seus llamps. ${ }^{67}$

Cap de les representacions de l'àguila devia ser apercebuda com a obra d'art; però, la seua presentació en un context tan plural i cosmopolita com la Kunsthalle de Düsseldorf podia induir l'espectador a prendre's l'exposició com una proposta per ampliar els seus horitzons estètics.

Per evitar-ne equívocs, cada peca hi tenia assignada una placa amb un nombre i amb la inscripció Açò no és una obra d'art. Broodthaers declara haver obtingut aquesta sentència combinant, d'una banda, la definició d'obra d'art enunciada per Duchamp a partir de l'apropiació de l'objecte i, de l'altra, la dissociació entre l'objecte i la seua representació

\footnotetext{
${ }^{66}$ M. Broodthaers citat per J. Harten "Museo de Arte Moderno... ". En Marcel Broodthaers.Ma., op. cit.: p. 295296. [carta manuscrita 2 nov., 1972, signada: "Musée d'Art Moderne, Conservateur: Marcel Broodthaers"]

${ }^{67}$ M. Broodthaers (1972e). "Section des Figures". En Marcel Broodthaers. Pa., op. cit.: p. 220-221.
} 
enunciada per Magritte ${ }^{68}$ La intenció era separar la representació de la figura de l'àguila de la idea d'art. Al mateix temps, l'advertiment a l'espectador podia ser llegida com una apropiació - irònica - dels procediments analítics emprats per l'art conceptual. Broodthaers mateix ho explica:

El públic es veu confrontat als objectes artístics següents: àguiles de diferents classes, una part de les quals estan pesadament carregades de nocions simbòliques i històriques. El caràcter d'aquesta confrontació està determinat per la inscripció negativa açò no és... açò no és una obra d'art; la qual cosa no significa més que: públic, que cec estàs! Així, [...] o bé la informació ha acomplit un paper efectiu sobre allò que es diu l'art modern, [...] o bé la inscripció hi apareix com un pur absurd - és a dir que no està al nivell de la discussió sobre la validesa de les idees de Duchamp i de Magritte, per exemple, $-i$, en aquest cas, l'exposició obeeix una altra vegada als principis clàssics: l'àguila en l'art, en la història, en l'etnologia, en el folklore... ${ }^{69}$

Amb tot, els resultats de l'experiment no estaven garantits; Broodthaers mateix va reconéixer que no podia preveure els efectes que podia provocar-hi l'acumulació dels símbols de poder diví, de magnificència i de força; ni tampoc l'efecte de repetir-hi l'advertiment Açò no és una obra d'art. ${ }^{70}$

Així doncs, el reconeixement de la càrrega simbòlica de la figura de l'àguila així com l'entrecreuament de referències provocat per la disposició, per parelles o en sèries, dels objectes presentats en la Section des Figures i la repetició de l'efecte, produïen una neutralització de la mitificació de l'àguila. Paral-lelament, les diferents instrumentacions de la figura de l'àguila i de la seua simbologia al llarg de la història de l'art i de la civilització es proposaven desemmascarar la naturalesa de les relacions entre art i poder. No obstant això, el fet de desacreditar una lectura estètica de les peces i dur-les a la categoria d'objectes didàctics presentava la figura de l'àguila com la representació d'una ficció. Així va manifestar-ho Broodthaers en el segons catàleg de l'exposició:

L'àguila és, com el tigre de paper, un monstre frèvol. [...] Tot això es reflecteix també en el meu museu fictici fundat el 1968 i que vaig anomenar Département des Aigles. L'àguila de paper té un doble caràcter. D'una part acompleix el paper d'una paròdia social de les produccions artístiques, d'altra, el d'una paròdia artística dels fets socials. Els museus públics, com ara també totes les institucions culturals, no hi fan una altra cosa. Crec que un museu fictici com és el meu permet apropiar-se la realitat i d'allò que s'hi amaga. [...] El projecte de l'exposició es basa en la identitat de l'àguila en tant que idea i [en la identitat] de l'art com a idea. L'objectiu és proposar una reflexió crítica sobre la presentació de l'art en públic. ${ }^{71}$

63. Portada del volum II del catàleg Section des Figures. Düsseldorf, 1972.

64. Sales de l'exposició "Der Adler vom Oligozän bis heute". Düsseldorf, 1972.

65. Detalls de vitrines en l'exposició "Der Adler vom Oligozän bis heute".

66. Detall de plaques numerades amb la inscripció Açò no és una obra d'art.

${ }^{68}$ Cf. M. Broodthaers (1972b). "Méthode". En Marcel Broodthaers. Pa., op. cit.: p. 217; i també M. Oppitz. "Eagle; Pipe; Urinal". En B. Buchloh (ed.). Broodthaers. Writings, Interviews, Photographs. Cambridge; Massachusetts; London: The MIT Press, 1988: p. 155-156.

${ }^{69}$ M. Broodthaers (1972c). "Aigle. Idéologie. Public". En Marcel Broodthaers. Pa., op. cit.: p. 217.

${ }^{70}$ Cf. M. Broodthaers (1972d). "Reflexió sobre l'exposició L'Àguila...". En Marcel Broodthaers. Pa. op. cit.: p. 218.

${ }^{71}$ M. Broodthaers (1972e); op. cit. 


\section{USE UM}

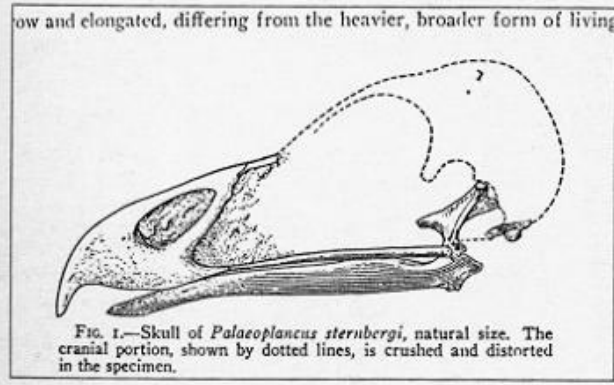

Kunstmuseum Basel Kupferstichkabinett

Staatliche Museen Stiftung PreuBischer Kulturbesitz Berlin (West) Antikenabteilung, Kunstbibliothek, Kunstgewerbemuseum

Kupferstichkabinett, Museum für Islamische Kunst Nationalgalerie, Skulpturenabteilung, Museum für Völkerkunde Abt. Amerikanische Archäologie Staatliche Museen zu Berlin (Ost) Vorderasiatisches Museum Akademisches Kunstmuseum der Universität Bonn Musées Royaux d'Art et d'Histoire Brüssel

Département d'Antiquités Précolombiennes, Département de Céramique, Département de Folklore, Département de Tapisserie Musée Royal d'Armes et d'Armures Brüssel Musée Wiertz Brüssel

Hetjensmuseum Düsseldorf

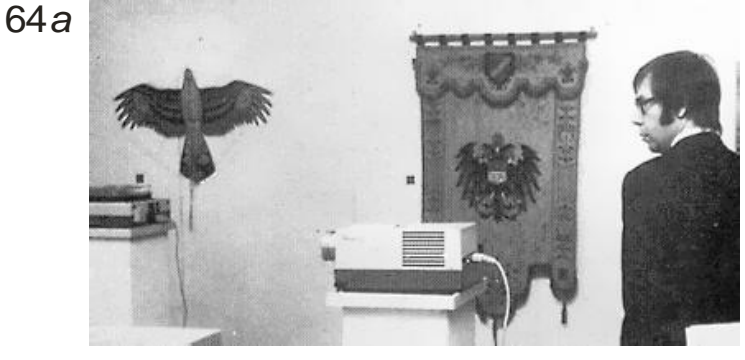

63

$65 a$

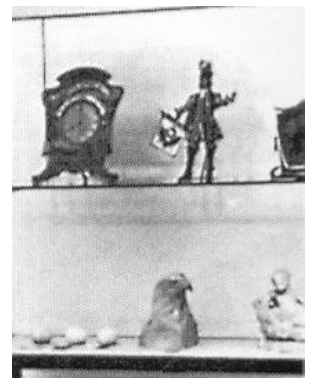

$64 b$

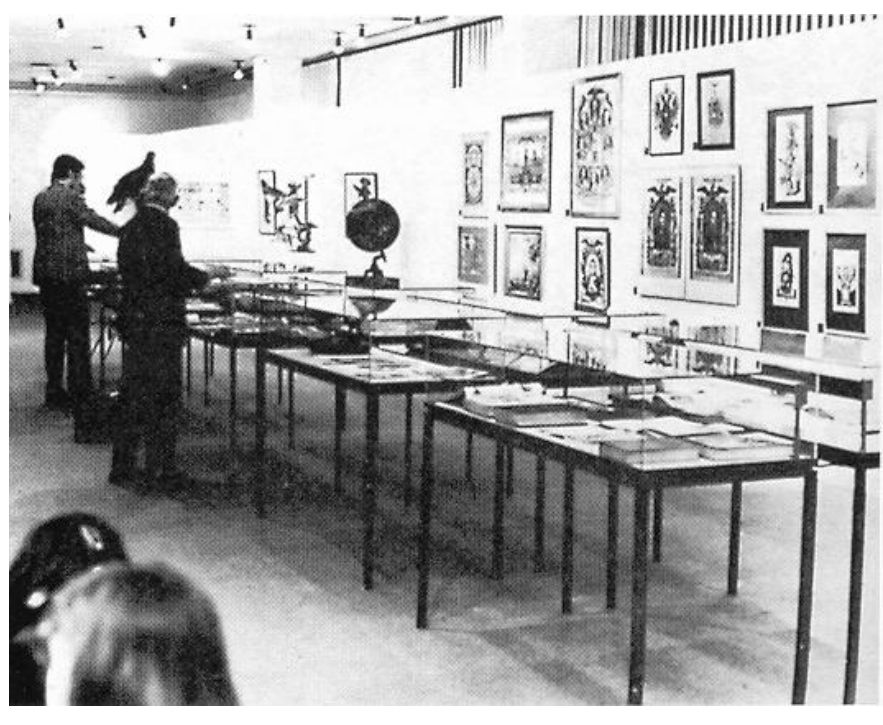

$65 b$
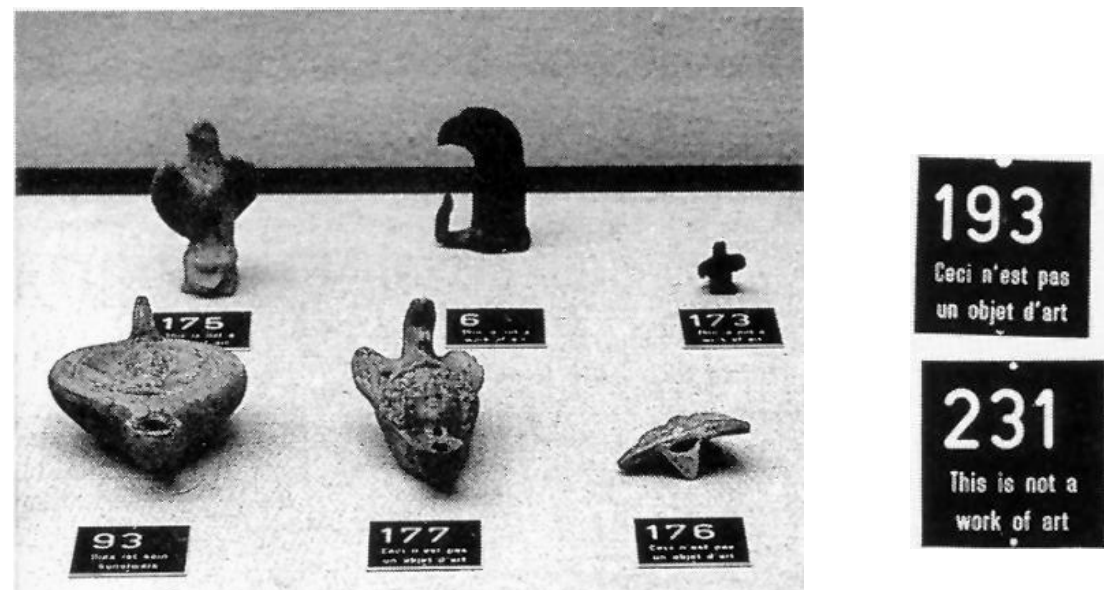


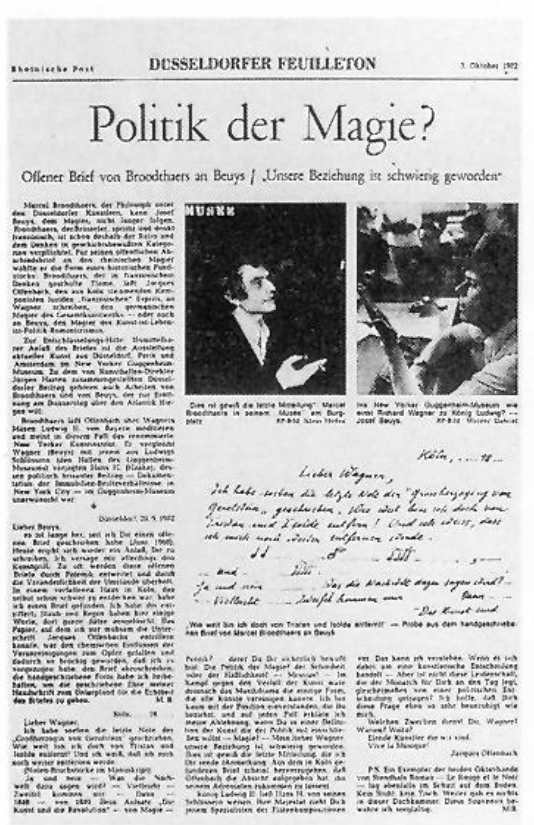

Article cxtrait du' Rheinische Post du 3 octobre 1972.

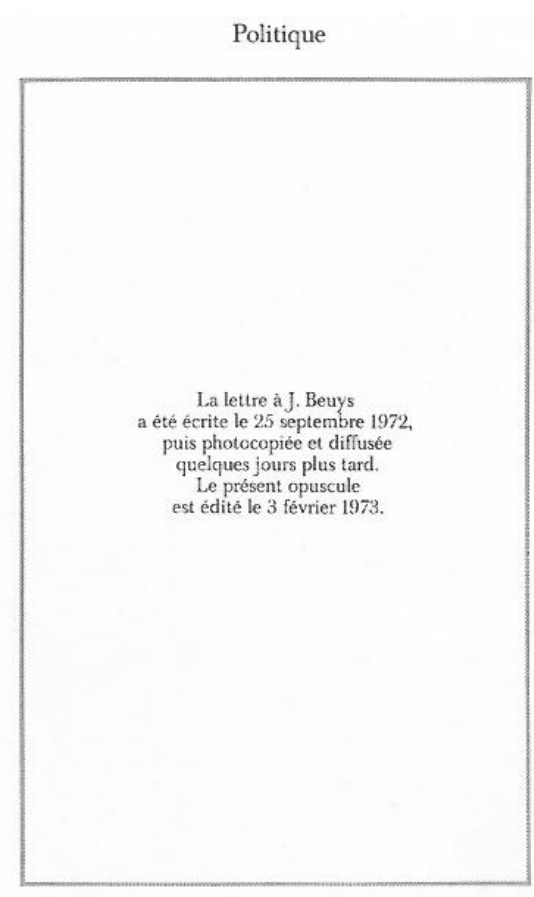

1.5

\section{Politique}

Mon cher Beuys,

Düsseldorf, le 2.5 sept. 72 Il y a longtemps, que je t'cere l'occasion de te faire signe, se précise. Je renoncerai cependant à ce véhicule. Les lettres ouvertes sont le plus souvent oblitérées par les négligences de plume et deviennent caduques avec le changement des circonstances.

Jai découvert dans un taudis délabrẻ de Cologne qui était lui-mème difficile à découvrir, une lettre. Je l'ai déchiffrée, poussières et pluies ont effacé cile à dôn ici, quelques mots, la quelques phrases entes. Victime du travail chimique des pollutions, le papier oủ à peine, j’ai pu lire la signature de Jacques Offenbach est devenu si fragile que j'ai préféré recopier la lettre en gardant toutefois cette forme manuscrite pour montrer sur l'honneur écrit de mon
écriture que cette lettre est véritablement authentique.

Mon cher Wagner,

Cologne, oct. 18 .. Je viens de mettre la dernière note à la "Grande Duchesse de Gérolstein". Que je suis loin de Tristan et Isolde. Et je sais que je m'en éloignerai encore. (Notes de musique)

et - Oui et Non...qu'en dira la postérité ?. Peut-ètre...le doute m'assaille... et - Oui et Non... qu'en dira la postérité ?... Peut-ètre... le doute m'assaille...
Alors !... 1848, de 1849. Ton essai "L'Art et la Révolution" de... magie... politique... dont tu ne parais guère avoir conscience... La politique, de la magie ?... De la beaute ou de la laideur ?... Messiah... Ha... Le drame musical, pour combattre la dégenérescence de l'Art serait la seule forme capable de réunir tous les Arts. Je suis peu d'accord avec cette position que tu assumes, en tout cas, j'exprime mon désaccord si tu inclus dans une définition de l'Art, celle de la politique... magie?... Mon cher Wagner, nos rapports sont malaisés. Et sans doute, est-ce le dernier message que je t'envoie.

(La lettre trouvé à Cologne semble indiquer que J. Offenbach ait renonce a la faire parvenir à son destinataire).

Le roi Louis Il éconduit Hans H. de ses châteaux. Sa Majestẻ te préfère à ce spécialiste des compositions à la fuute. Je comprends, s'il s'agit d'un choix artistique. Mais cette passion que le monarque nourrit à ton égard n'est. elle pas également motivée par un choix politique ? J'espère que cette question te troublera autant que moi. Wagner, a quelles fins servons-nous? Pourquoi ? Comment? Pauvres artistes que nous sommes!

Vive la Musique.

J. Offenbach

P.S. Un exemplaire en 2 volumes du roman de Stendhal - le Rouge et le Noir - (Levavasseur. Paris 1830) gisait aussi parmi les gravats répandus sur le plancher. $\mathrm{Ni}$ chaise - $\mathrm{Ni}$ table - C'est tout ce quil y avait dans cette mansarde. Je conserve précieusement ces reliques. 
En sentit general la idea de Broodthaers de revelar i desmuntar la mitologia de poder creada al voltant de la figura de l'àguila no passà desapercebuda en l'exposició i molt menys en el context alemany, encara que els emblemes històrics hi estaven representats molt discretament, com un exemple més, i sota una altra intenció. ${ }^{72}$ Altrament, l'embolic de quadres, escultures, animals dessecats, peces arqueològiques, decoratives i utilitàries, i etiquetes de productes de consum que presentava l'exposició pretenia centrar el debat en el tema de la legitimitat dels objectes per arribar-hi a la qüestió de l'autoritat del discurs cultural.

Tanmateix, la repercussió d'aquesta exposició en l'escena artística de la ciutat de Düsseldorf no estigué exempta de sorpreses. Un exemple és que l'espai de l'exposició fou escenari d'un episodi singular que tingué Joseph Beuys com a protagonista. Va succeir que Beuys va concedir una entrevista a la televisió i, per a l'ocasió, va elegir la sala de la Kunsthalle on estava instal-lada la Section des Figures com a decorat de fons.

La visió que va promoure Beuys dels objectes i de les imatges de l'exposició jugava a instrumentar la simbologia de l'àguila com una metàfora de la seua projecció artística. Així, van prevaler, una altra volta, els significats associats a l'àguila mítica, la qual cosa va incomodar Broodthaers. En aquest cas, però, el tema a tenir en compte va ser que no es tractava ni d'una anònima representació artística de l'àguila ni d'una exposició qualsevol.

La naturalesa essencial de les diferències entre ambdós artistes va aclarir-se poc després quan Broodthaers va publicar en un diari de Düsseldorf una carta oberta dirigida a Beuys on li comentava el descobriment d'una carta de Jacques Offenbach a Richard Wagner. Òbviament, la carta en qüestió era apòcrifa. La transcripció que en va fer Broodthaers posava de relleu no solament la passió compartida pel drama musical com a màxima aspiració artística, sinó també les divergents posicions ètiques i estètiques dels músics com una clara al-lusió als motius del desacord que s'hi havia produït.

67. "Politik der Magie?". Facsímil del article publicat originalment en el diari Rheinische Post (Düsseldorf, 1972) amb fotografies de Broodthaers i de Beuys. El facsímil va reproduir-se en "Magie. Art et Politique" (1973).

68. "Mon cher Beuys". Carta oberta a Joseph Beuys reproduïda en "Magie. Art et Politique" (1973); publicada originalment com a part de l'article en Rheinische Post.

\subsection{El Musée d'Art Moderne i els espais institucionals}

Sens dubte, la presentació de la Section des Figures i, abans, de la Section XIXe siècle en la Städtische Kunsthalle de Düsseldorf van redundar en major abast i difusió del projecte del Musée d'Art Moderne Département des Aigles. Però també va assolir un grau de reconeixement que podia contravenir els originals plantejaments programàtics.

De primer, quan Jürgen Harten, el comissari del projecte Between, invità Broodthaers, en qualitat de director/ conservador, a presentar el Musée d'Art Moderne Département des Aigles en la Kunsthalle de Düsseldorf, la principal preocupació de Broodthaers era precisament evitar confusions, és a dir, que la presència del Museu no fora apercebuda com una exposició

\footnotetext{
72 "El caràcter mític de la tirànica àguila imperial alemanya es dilueix, per exemple, en posar-hi juntament l'esmentat emblema nacional amb unes imitacions en colors borrosos de l'Associació Alemanya de Defensa de la Vida, de l'Associació Alemanya de Lligues de Futbol i del Club Alemany de l'Automòbil." M. Oppitz; op. cit.: p. 155-156.
} 
dins d'una altra institució. ${ }^{73}$ Cal fer menció que el projecte Between consistia en un programa d'intervencions artístiques de dos dies de durada intercalats dins del programa d'exposicions de la Kunsthalle. Així doncs, n'era un programa alternatiu i paral-lel que responia a l'interés de la mateixa institució de donar cabuda a propostes artístiques que d'alguna manera qüestionaven la Institució-Museu. Amb tot i això, la Kunsthalle de Düsseldorf havia trobat la manera de fer eco a la postura antinstitucional de molts artistes, de manera que els qüestionaments hi eren assumits com a autocrítica.

Broodthaers va ser invitat a exposar en Between 4: "Projecció para una idea del museu" (Projektion zur Idee des Museums) on els artistes participants, d'una forma o d'altra, treballaren sobre la idea de museu. Així doncs, acceptar participar-hi implicava per a Broodthaers tot un desafiament ja que des del seu punt de vista existia el risc que les circumstàncies de l'exposició restaren independència al seu projecte i neutralitzaren les seues intencions.

Quan finalment es va decidir a prendre part, va intentar fer encara més evident la ficció per subratllar l'autonomia del seu projecte. Així doncs, el panell gran amb la inscripció Musée d'Art Moderne Section XIXe siècle (bis) Département des Aigles, ubicat a l'entrada d'una de les sales de la planta superior de la Kunsthalle, establia una frontera que delimitava un altre domini perquè el públic poguera adonar-se que es tractava de la presentació del Museu dins d'un altre marc institucional.

69. Broodthaers i Harten amb el panell de la Section XIX siècle (bis). Düsseldorf, 1970.

Darrerament, la presentació de la Section des Figures en la Kunsthalle de Düsseldorf no va plantejar cap nou conflicte d'interessos al Musée d'Art Moderne sinó que Broodthaers va reutilitzar-hi i emfasitzar-hi les mateixes estratègies d'al-legoria i de distanciament. Però, a més de desmuntar la simbologia de l'àguila en les diferents representacions artístiques, Broodthaers demana l'atenció sobre com la simbologia de l'àguila i les representacions adients s'utilitzen dins del llenguatge de la publicitat:

Des de les obres d'art sumèries fins a les obres actuals, l'àguila parla el llenguatge estilístic de cada època. Les diapositives d'imatges publicitàries projectades en l'exposició posen de manifest una falta d'harmonia. La llengua de la publicitat fa presa de l'inconscient de l'espectador-consumidor i, amb aquests mitjans, es restitueix tota la seua puixança a l'àguila màgica. [...] Però, per agressiva que siga, l'àguila ix indemne de la publicitat. L'objecte artístic mai no s'hi pot aprehendre perquè està representat fora de les convencions que estructuren la vida artística. En la publicitat, l'art s'utilitza i té un èxit enorme, regna sobre radiants horitzons, encarna el somni de l'home. ${ }^{74}$

70. Detall d'una vitrina amb imatges de l'àguila en la publicitat. En "Der Adler vom Oligozän bis heute". Düsseldorf, 1972.

La conclusió que la figura del àguila representava l'entrada de la publicitat en l'art condueix a una altra idea: que la presència del Museu dins dels espais institucionals representava l'entrada de l'art en la publicitat. En aquest sentit, les conclusions de la Section des Figures són el punt de partida de la Section Publicité i en marquen el to polèmic de les manifestacions del Musée d'Art Moderne... en la Documenta.

\footnotetext{
${ }^{73}$ Cf. J. Harten; op. cit.: p. 295-296.

${ }^{74}$ M. Broodthaers (1972e); op. cit.
} 

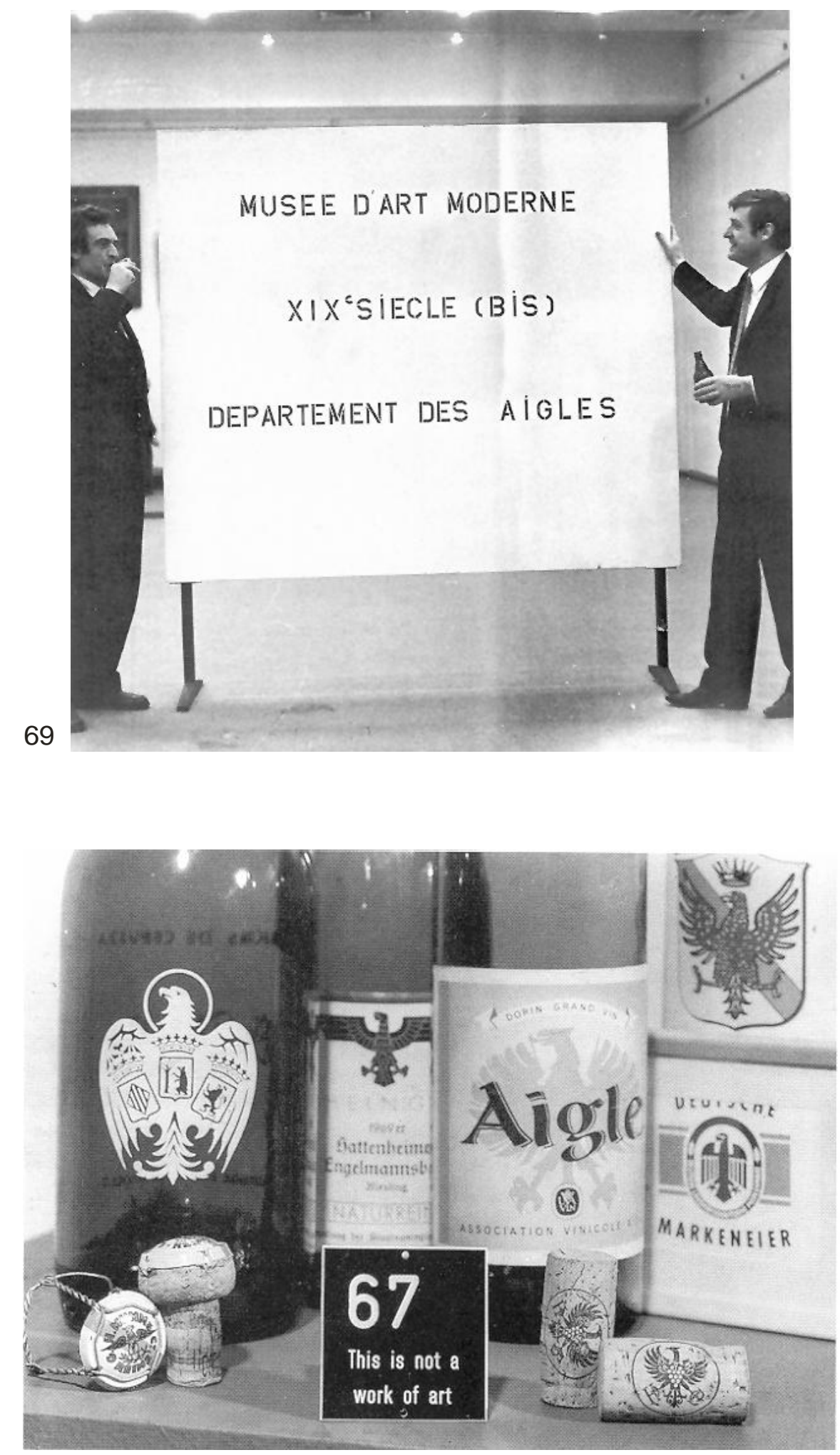


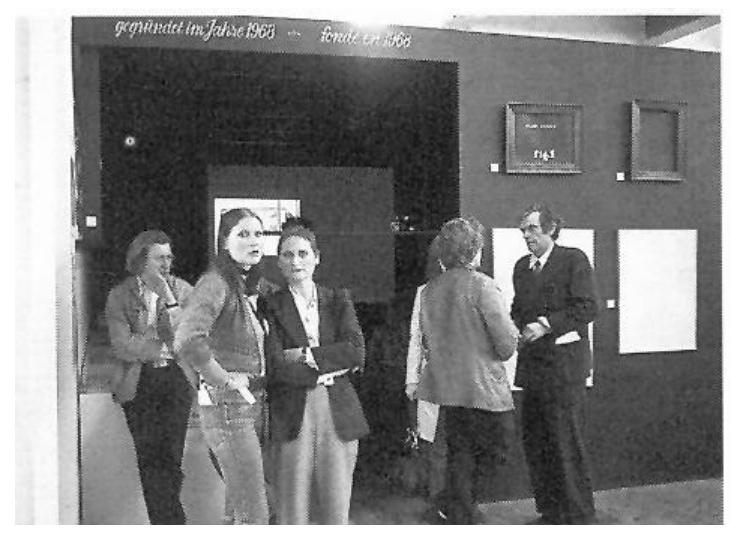

$71 a$

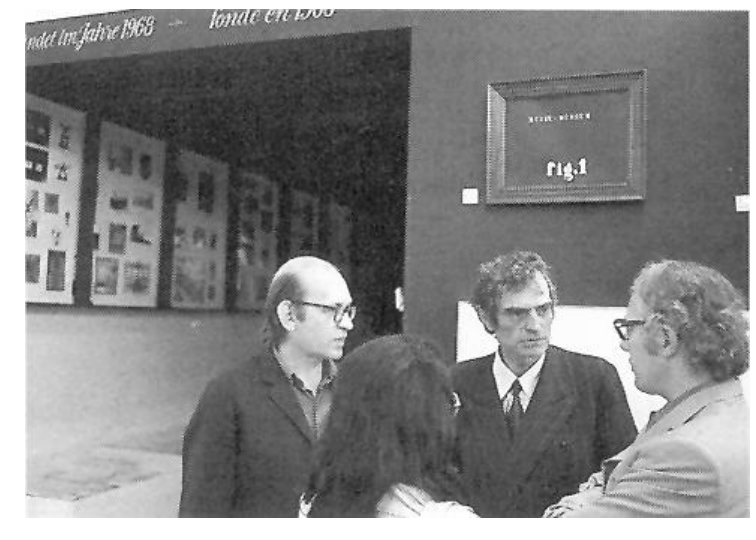

$71 b$

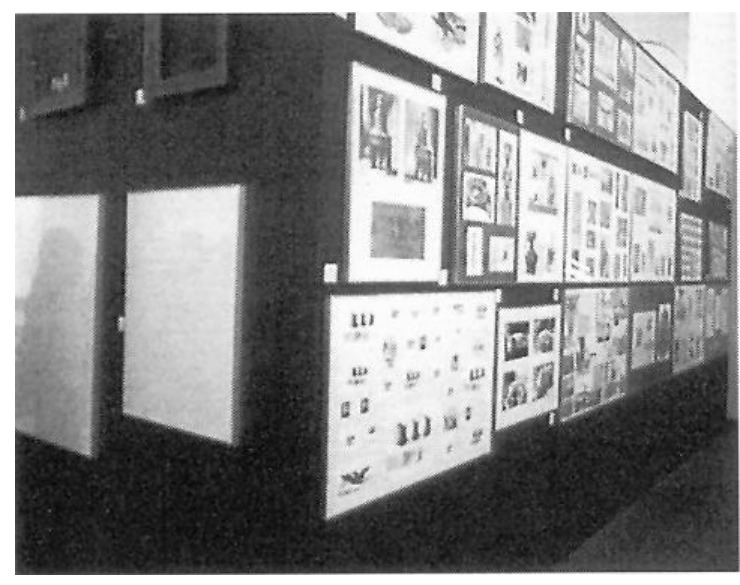

73

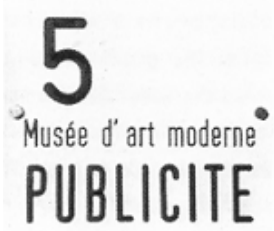

74 


\subsubsection{La Section Publicité}

Broodthaers va presentar en "Documenta V" tres manifestacions diferents del Museu instal-lades de forma independent: la Section Publicité, la Section d'Art Moderne i el Musée d'Art Ancien, Département des Aigles, Galerie du XXe siècle.

La Section Publicité era una sala construïda especialment i ubicada a la planta baixa de l'edifici de la Nova Galeria; estava composta bàsicament per fotografies, objectes, impresos, catàlegs i diversa documentació; i va ser presentada com un resum de la Section des Figures sota el títol "Fotos - Diapositives - Objectes. Àguiles des de l'any 3500 abans de J.C.". ${ }^{75}$ Les diapositives eren projectades en l'interior de la sala pintada de negre, mentre que en les parets exteriors podien veure's fotografies d'objectes de la Section des Figures muntades en uns panells; cadascun dels quals portava una placa amb un nombre i amb la inscripció Secció Publicitària.

Les diapositives documentaven, de forma paral-lela, diferents representacions de la figura de l'àguila en la història de l'art i en la publicitat. D'una banda mostraven diferents convencions representatives segons l'estil, l'època o la cultura d'on provenia l'objecte. De l'altra, il-lustraven com la publicitat utilitzava els llenguatges artístics en funció de sintetitzarne i esquematitzar-ne la representació. En ambdós casos, Broodthaers indueix a veure-hi que la identificació simbòlica i emblemàtica de l'àguila amb allò sublim o com a símbol de superioritat i de poder són producte de l'artifici.

Així doncs, Broodthaers presenta l'Àguila i el Museu com els vèrtexs poètic i polític d'una reflexió sobre l'art. En un primer nivell, el propòsit era documentar l'entrada de la publicitat en l'art mostrant-hi els diferents usos de la figura de l'àguila i de la seua simbologia. En un altre nivell, justifica irònicament la presència del Museu en la Documenta com l'entrada de l'art en la publicitat i, al mateix temps, ho assumeix com el final de l'empresa:

Aquest museu és un museu fictici. [...] fundat a Brussel-les el 1968 sota la pressió dels fets polítics del moment, tanca les seues portes amb la Documenta. Haurà passat d'un estat heroic i solitari a una situació propera a la consagració gràcies al suport de la Kuntshalle de Düsseldorf i de la Documenta. [...] Publicitat tant per l'art com per l'art de la publicitat. Qui repara, però, en l'acció màgica exercida per artistes anònims (gràcies al símbol de l'autoritat) al servei de la difusió dels productes de la indústria? Qui viu en el context de l'art i, aleshores, consideren l'art com a art; o solament qui li importa el context social d'aquestes produccions? Però què hi ve el públic, el gran públic i tots els que ven partits de futbol? ${ }^{76}$

71. Espai de la Section Publicité. Kassel, 1972.

72. Projecció de diapositives en l'interior de l'espai de la Section Publicité.

73. Detall d'un muntatge fotogràfic ubicat en l'exterior.

74. Detall de les plaques informatives en la Section Publicité.

\footnotetext{
${ }^{75}$ Cf. M. Broodthaers (1972g). "Pàgina de presentació del Museu en Documenta V". En Marcel Broodthaers. Ma., op. cit.: p. 224.

${ }^{76}$ M. Broodthaers (1972f). "Ce musée est un musée fictif ". En: Marcel Broodthaers. Pa., op. cit.: p. 227.
} 


\subsection{La clausura i les conclusions del Musée d'Art Moderne}

És un fet que el Museu va assolir prou de reconeixement institucional, sobretot arran de l'etapa de Düsseldorf i la invitació per participar en la Documenta era una de les maneres de constatar-ho. El Museu s'havia convertit en un fenomen autònom i Broodthaers s'adona que la situació començava a escapar del seu control, per la qual cosa calia revisar les estratègies. Llavors, l'anunci de la clausura del Museu en "Documenta V" va resultar la proposta més conseqüent per que el Museu poguera conservar la seua autonomia social i no una autonomia com a objecte.

Així doncs, les últimes manifestacions del Museu van ser concebudes a priori com un discurs de conclusions, però també com un escenari de discussió per mantenir el debat sobre la funció i la finalitat pública de l'art, donant-hi continuïtat als pressupostos originals del Museu.

El perfil de modernitat així com el crèdit institucional de la Documenta resultaven per a Broodthaers i pel Musée d'Art Moderne... un context prou complex en el sentit de mantenir la seua credibilitat com a institució fictícia. ${ }^{77}$ Llavors, Broodthaers esgrimeix l'expressió artística per defensar-hi una posició independent i, al mateix temps, el seu limitat abast:

La presentació d'una exposició depén de l'opinió que qui exposa tinga de l'art. La presentació oficial adopta les normes modernitzades de tot institut d'exposició. És a dir, que un mode d'exposició, sempre jeràrquic, constitueix la societat oficial juntament amb les institucions expositores (museus) i les restants institucions (hospitals, presons, etc.). D'això que qualsevol treball relatiu a una exposició s'emprenga, en la majoria dels casos, sobre la base d'un compromís (exemple: la Documenta 5 i H. Szeeman). Aleshores, constatem que la posada a escena dels objectes i de les imatges rarament resulta adequada i que, al contrari, en tota exposició existeix una tendència a la manipulació. [...] Les meues accions com a artista, és a dir, amb un significat tan indeterminat i tan mal definit, mai no podien situar-se sinó en els desenvolupaments marginals del comportament social. ${ }^{78}$

Pel que fa a la Section Publicité, fou provocadora perquè el Museu va presentar-la com una exposició promocional de si mateix. Altrament, la Section d'Art Moderne, resultà controvertida perquè mostrava el Musée d'Art Moderne com a objecte d'exposició.

La Section d'Art Moderne estava ubicada a la planta superior de la Nova Galeria, en el context d'una secció especial anomenada "Mitologies Individuals". Aquesta secció va ser ideada per Harald Szeemann, comissari general de "Documenta V" qui va encarregar la coordinació a Johannes Cladders, i pretenia reunir-hi i mostrar-hi diferents exemples d'una noció de l'art apercebuda com a microcosmos i de l'artista com a creador en el mateix sentit. ${ }^{79}$

\footnotetext{
${ }^{77}$ Respecte això, J. Cladders va detallar: "... jo tenia la impressió que a Broodthaers no li resultava fàcil concórrer [en "Documenta V" amb la secció "Mythologies Individuelles"] sense sentir-se perjudicat. [...] està clar que a Broodthaers li costà expressar-se en el marc de la Documenta. [...] sembla que no va tenir grans dificultats per instal-lar la Section Publicité, de la qual no hagué d'ocupar-me massa. Una altra cosa molt distinta resultà ser la Section d'Art Moderne." J. Cladders. "Museo de Arte Moderno, Departamento de las Águilas, Sección Publicidad; Sección de Arte Moderno; Galería del siglo XX". En Marcel Broodthaers. Ma., op. cit.: p. 299.

${ }^{78}$ M. Broodthaers (ca. 1972). "Le degré zéro". En Marcel Broodthaers. Pa., op. cit.: p. 231.

${ }^{79}$ L'organització fou a càrrec de Johannes Cladders i, a més a més de Marcel Broodthaers, "Mythologies Individuelles" va incloure artistes com Joseph Beuys, Daniel Buren i Robert Filliou. Cladders mateix va declarar: "...em limité a quatre artistes amb els quals ja havia treballat [...] Com que cadascun d'aquests tenia exigències conceptuals que no es podien satisfer si no es tenien afinitats particulars amb la seua obra, de seguida la resta de col·laboradors conegué la meua secció pel mot de difficult artist. J. Cladders; op. cit.: p. 299.
} 
Broodthaers va construir-hi una sala amb tres panells on va col-locar rètols, en alemany, en anglés i en francés; amb el nom del Museu i amb unes inscripcions indicatives: Direcció, Vestidor, Caixa i Secretaria. Al costat hi havia unes fletxes que assenyalaven cap a l'esquerra en els rètols d'alemany i cap a la dreta en els d'anglés i de francés. Al centre de l'espai Broodthaers va pintar un quadre negre en el terra i va escriure-hi Propietat Privada, també en les tres llengües. El quadre amb la inscripció estava resguardat per les quatre cantonades i envoltat amb una cadena.

Amb la inscripció Propietat Privada Broodthaers pretenia representar la subrepció que treia la institucionalització de qualsevol pronunciament individual. Els postulats de la Section d'Art Moderne simbolitzaven com qualsevol actitud artística podia ser patentada i darrerament instrumentada en aquest sentit. Quant a les maniobres de la institució Musée d'Art Moderne, Département des Aigles Broodthaers declara obertament:

Aquest museu és un museu fictici. De vegades fa el paper d'una paròdia política de manifestacions artístiques, i altres, el d'una paròdia artística dels esdeveniments polítics; allò que fan, per cert, els museus oficials i els organismes com la Documenta. Això si, amb la diferència que una ficció permet aprehendre la realitat i amagar-la alhora. ${ }^{80}$

Els panells que conformaven la Section d'Art Moderne estaven enfront d'una paret amb una finestra on Broodthaers havia posat unes altres inscripcions: FIG. O i Museum / Musée. La inscripció FIG. $O$ era més petita i sols podia llegir-se des de l'espai de la Section d'Art Moderne, mentre que la de Museum / Musée era més gran i estava invertida de manera que fora més visible i poguera llegir-se'n des de fora de l'edifici. Amb aquest joc d'inversions Broodthaers proposava una doble identificació: d'una banda, la de la institució dins de la institució i de l'altra, la del Musée d'Art Moderne... com a figura.

75. Espai de la Section d’Art Moderne. Kassel, 1972 / p. 94 (p. següent)

76. Detall amb inscripció Propietat Privada en el terra de l'espai la Section d'Art Moderne (p. següent)

77. Detall amb la inscripció Fig. 0 en la finestra de l'espai de la Section d'Art Moderne (p. següent)

Sis setmanes abans d'acabar "Documenta V", Broodthaers va desmuntar la Section d'Art Moderne: va pintar de negre els panells i va eliminar les inscripcions anteriors. En el seu lloc va escriure una altra amb lletres daurades: Musée d'Art Ancien, Département des Aigles, Galerie du XXe siècle. Aquest canvi representava l'exposició de la clausura del Musée d'Art Moderne Département des Aigles. Ací mateix, Broodthaers havia substituït la inscripció del quadre negre del terra per una altra, escrita solament en francés: escriure, pintar, copiar, figurar, parlar, formar, somniar, intercanviar, fer, informar, poder.

78. Detall amb la inscripció Museum / Musée en la façana de l'edifici de la Nova Galeria (p. següent)

79. Execució dels rètols Musée d’Art Ancien, Galerie du xxe siècle (1972) (p. següent)

80. Detall amb inscripció Escriure, Pintar, Copiar... en el terra (p. següent)

\footnotetext{
${ }^{80}$ M. Broodthaers (1972f); op. cit.
} 

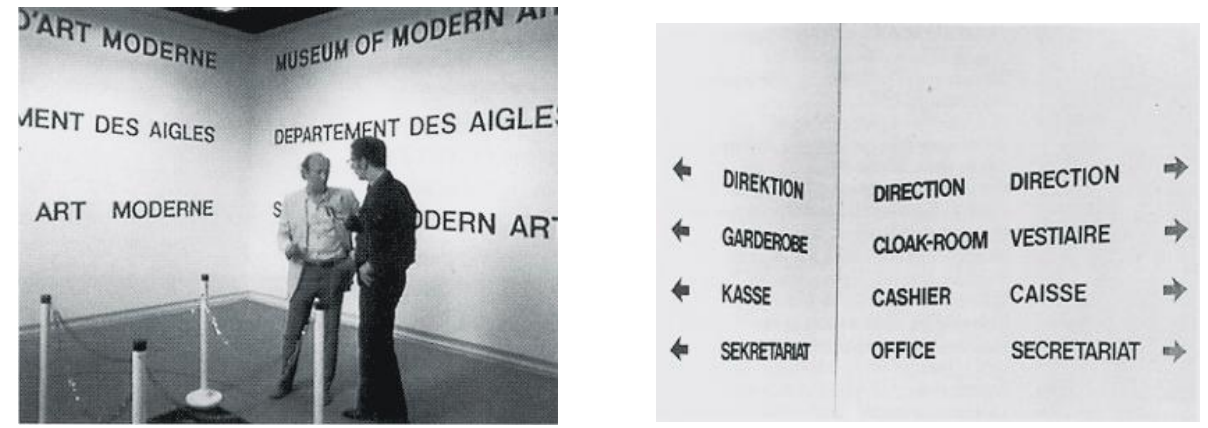

$75 c$

$75 a$

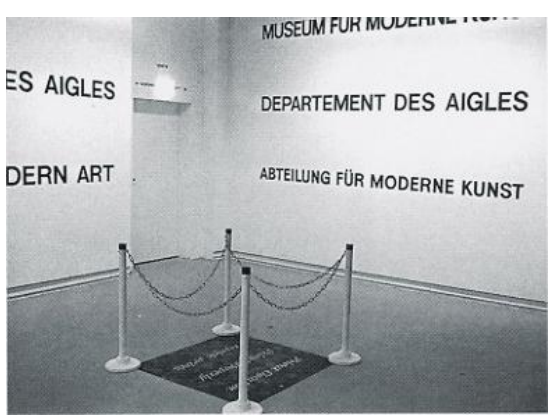

\section{$75 b$}
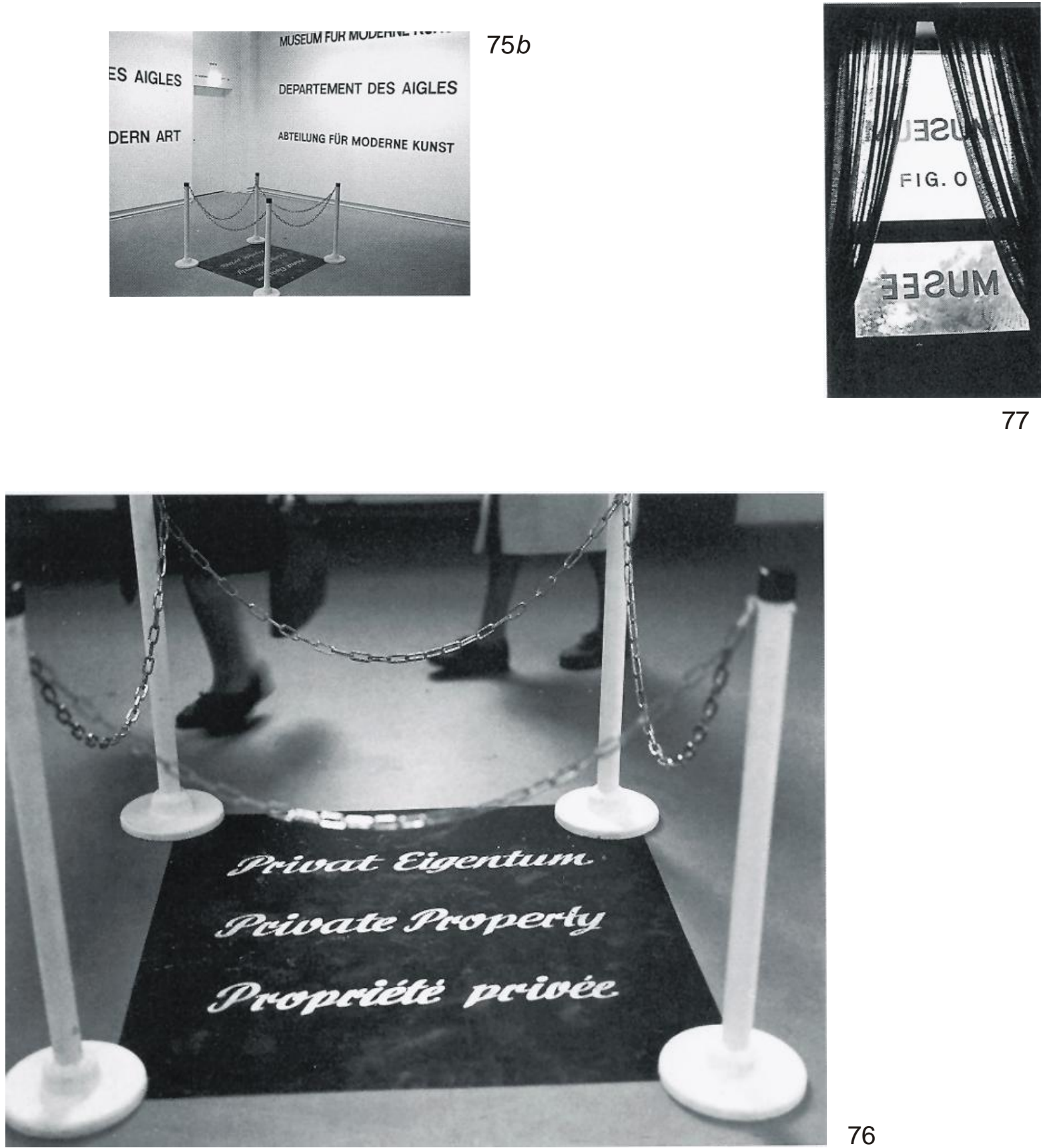

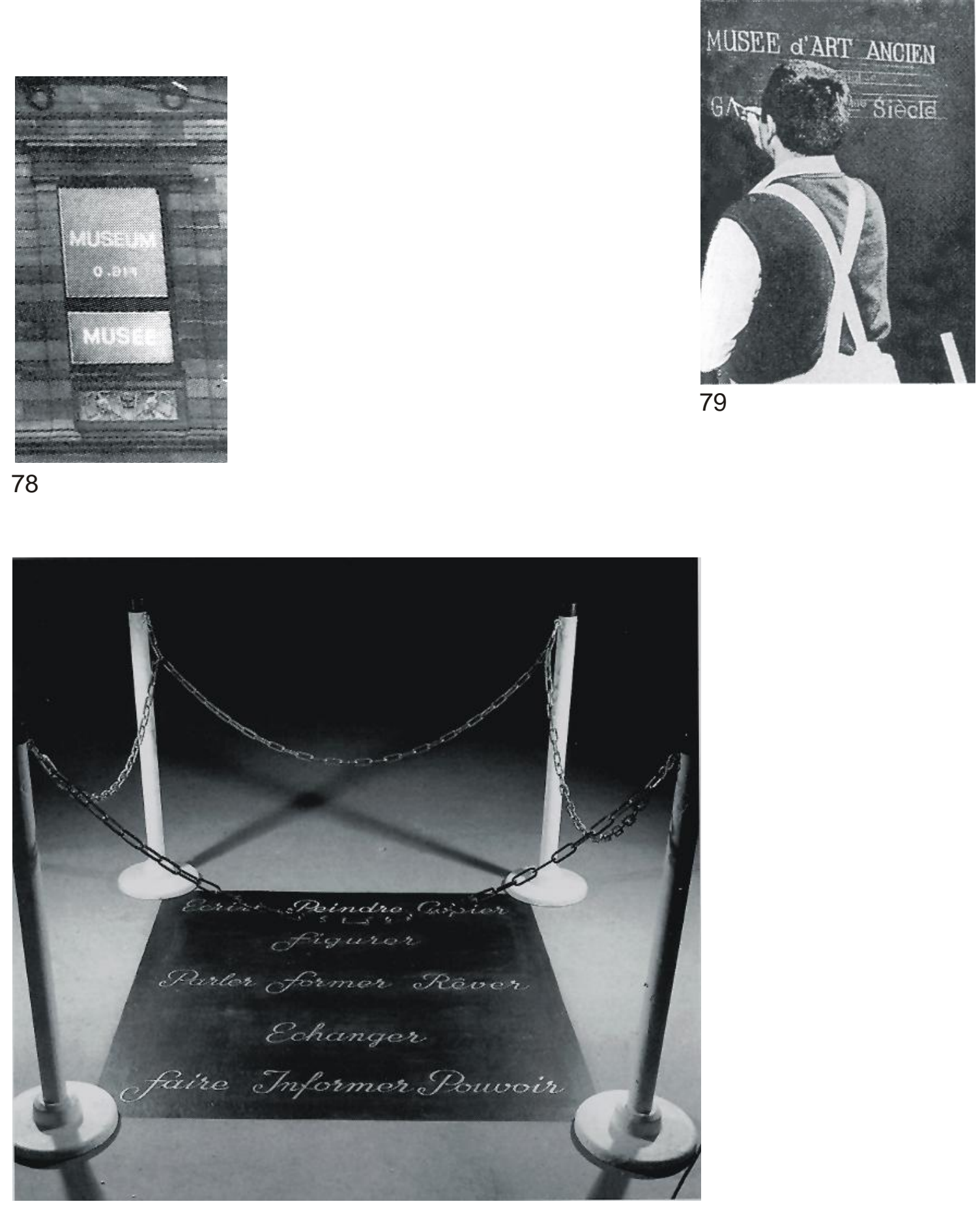
Aquest inventari de verbs és oposat a la inscripció anterior; és una eixida contestatària per a reivindicar l'expressió artística com a forma d'alliberament. En la mesura que la institució fictícia havia arribat a ser compresa pels mateixos mecanismes que eren objecte de les seues crítiques, Broodthaers ho assumeix com un minvament de l'efectivitat contestatària original del projecte. Per això, el Museu simbòlic havia de finir per a impedir la seua mitificació com un àguila més.

\subsection{Una altra volta de rosca: I'exposició com a Decor}

Vaig nàixer el 1924. Em faig artista el 1963. Vaig fundar un museu (Musée d'Art Moderne Département des Aigles) el 1968. Vaig soterrar aquest museu el 1972, en la Documenta, a Kassel. Aquest mateix any torne a convertir-me en artista. ${ }^{81}$

Després dels successius emplaçaments, l'ambient de provisionalitat del Musée d'Art Moderne, Département des Aigles gairebé havia arribat a convertir-se, paradoxalment, en un fenomen invariable i previsible. En conseqüència, les manifestacions i les situacions creades començaren a esgotar l'element sorpresa i a perdre part de la seua efectivitat original. Encara que el "treball analític (per oposició a un treball de tonalitat afectiva) sobre l'art" a què va lliurar-se Broodthaers va treure resultats; finalment, la presència del Museu en "Documenta $\mathrm{V}$ " havia posat en evidència la seua consagració $i$, per tant, el risc de transformar-se en un fenomen legitimat, un altre com tants, era un fet a considerar. ${ }^{82}$

Fent un balanç de la situació, Broodthaers mateix va reconéixer que:

L'aspecte ficció, és a dir fictici, es deslliga de l'empresa anomenada Musée d'Art Moderne, Département des Aigles d'una manera molt particular. L'aspecte irreal i el dispositiu, què inicialment no era més que un simple decorat, fou institucionalitzant-se gradualment [...] El dispositiu va perdre la seua significació decorativa, es va convertir en símbol del museu fictici. ${ }^{83}$

Malgrat això, el caràcter efímer i aparentment frívol inherent a la representació del Musée d'Art Moderne... com a decorat havia assolit posar en tela de judici la veracitat de les funcions representatives del museu com a institució social.

Cal dir que Broodthaers no deixà de fer altres projectes simultàniament al seu acompliment com a director/ conservador del Musée d'Art Moderne... i, si més prompte, les manifestacions del Museu van desenvolupar-se a partir de les situacions generades, hi havia en comú la reflexió al voltant de l'acte expositiu i de les circumstàncies que l'envolten.

Després del soterrament del Museu el 1972, el treball artístic de Broodthaers se centra en l'anàlisi de les implicacions derivades de la presentació institucional de l'obra d'art i en la reflexió sobre la funció de l'obra dins dels espais institucionals. El 1974 Broodthaers realitza a Brussel-les l'exposició "Catalogue - Catalogus" en la qual reuneix gairebé tota la seua producció artística des del 1964 sota una mirada entre la retrospectiva i l'antologia.

Sovint, la idea de retrospectiva es fa servir per a fer un discurs sobre el passat, mentre que la idea de l'antologia és atemporal i serveix per a fer reculls selectius. Això no obstant, la

${ }^{81}$ M. Broodthaers citat per B. Pelzer; op. cit.: p. 33. ["Kunst Heute". Szene Rhein-Ruhr'72. Essen: Museum Folkwang, 9 jul. -3 set., 1972]

${ }^{82}$ Cf. M. Broodthaers (1972a). "Presentació de la Secció de les Figures". En Marcel Broodthaers. Pa., op. cit.: p. 215.

${ }^{83}$ J. Harten i K. Schmidt (1972); op. cit. 
idea d'autoria de Broodthaers està molt lluny de complaure's en un recull narcisista o indulgent; sinó que més bé és l'excusa per a plantejar una visió crítica de l'acte creatiu mateix.

\subsubsection{L'exposició "Catalogue - Catalogus"}

Quan va dissenyar el muntatge de "Catalogue - Catalogus", Broodthaers va optar per adaptar-lo al caràcter de l'edifici del Palau de Belles Arts de Brussel-les. Es tractava d'una obra de l'arquitecte belga Víctor Horta, una de les figures més originals del modernisme, què destacà per crear edificis destinats a usos culturals i socials. Particularment en el Palau de Belles Arts de Brussel-les, projectat pels anys vint, Horta va utilitzar formes més clàssiques, desestimant les influencies pictòriques i cal-ligràfiques que havien caracteritzat la majoria de les seues conegudes construccions modernistes.

Llavors, Broodthaers decideix aprofitar unes vitrines de l'època modernista de què disposava la institució per mostrar una part de les seues obres. Ací hi exhibeix la majoria dels assemblages realitzats entre el 1964 i el 1967, els quals, en contra del que calia esperar, no estaven col-locats seguint un ordre cronològic. Tampoc no mostraven cap indici d'un criteri de selecció, sinó que, per l'efecte de trobar-se dins de les vitrines, els assemblages eren apercebuts com a objectes de museu. Aquesta presentació feia evident la pèrdua de referents que afectava l'obra d'art en el context del museu.

La distribució de les vitrines al llarg de les dues primeres sales guardava una disposició axial molt en consonància amb la composició i l'estructura arquitectònica de l'edifici. Altrament, en la tercera i última sala de l'exposició no hi havia cap vitrina i les obres es trobaven col-locades directament sobre les parets o sobre el terra; però hi havien sigut agrupades en conjunts.

Cada conjunt estava compost per obres que guardaven alguna relació o idea comuna, encara que cadascuna era independent. Per exemple, hi havia un, anomenat Briques, integrat per obres realitzades en diferents moments però que tenien com a tema comú la utilització de motius constructius: rajoles, murs, ferramentes, etc. També hi havia el conjunt Poèmes Industriels compost per part d'una sèrie de plaques de plàstic que van ser editades com a múltiples; així com un altre, anomenat Théorie des Figures, què estava integrat pels objectes de la Section Cinéma.

De la integració de les obres en conjunts i sota un títol diferent resultava una nova obra, tot $\mathrm{i}$ que les originals perdien la pròpia naturalesa. Per a Broodthaers aquest mètode d'exposició era més propi dels museus d'art contemporani, al temps que hi parodiava els seus mecanismes d'abstracció i de manipulació. Amb tot això Broodthaers pretenia posar en relleu com també les formes d'institucionalització alternatives desvirtuaven les pràctiques artístiques que implementaven algun tipus d'alternativitat.

81. Sales de l'exposició "Catalogue - Catalogus". Brussel-les, 1974 (p. següent).

Per resumir, en les dues primeres sales de l'exposició, on hi havia una clara intenció retrospectiva, Broodthaers mostra les seues obres com a objectes d'exposició; mentre que en la tercera sala els conjunts són presentats com a enunciats i al mateix temps com un catàleg antològic dels seus principals temes. Ambdós mètodes recorden els procediments didàctics de l'exposició de la Section des Figures on, d'una banda, les peces, reduïdes a la categoria d'objectes, eren aillades de qualsevol referència original; i de l'altra, les representacions de l'àguila en la història de l'art i en la publicitat s'hi confrontaven per neutralitzar el poder del símbol. 

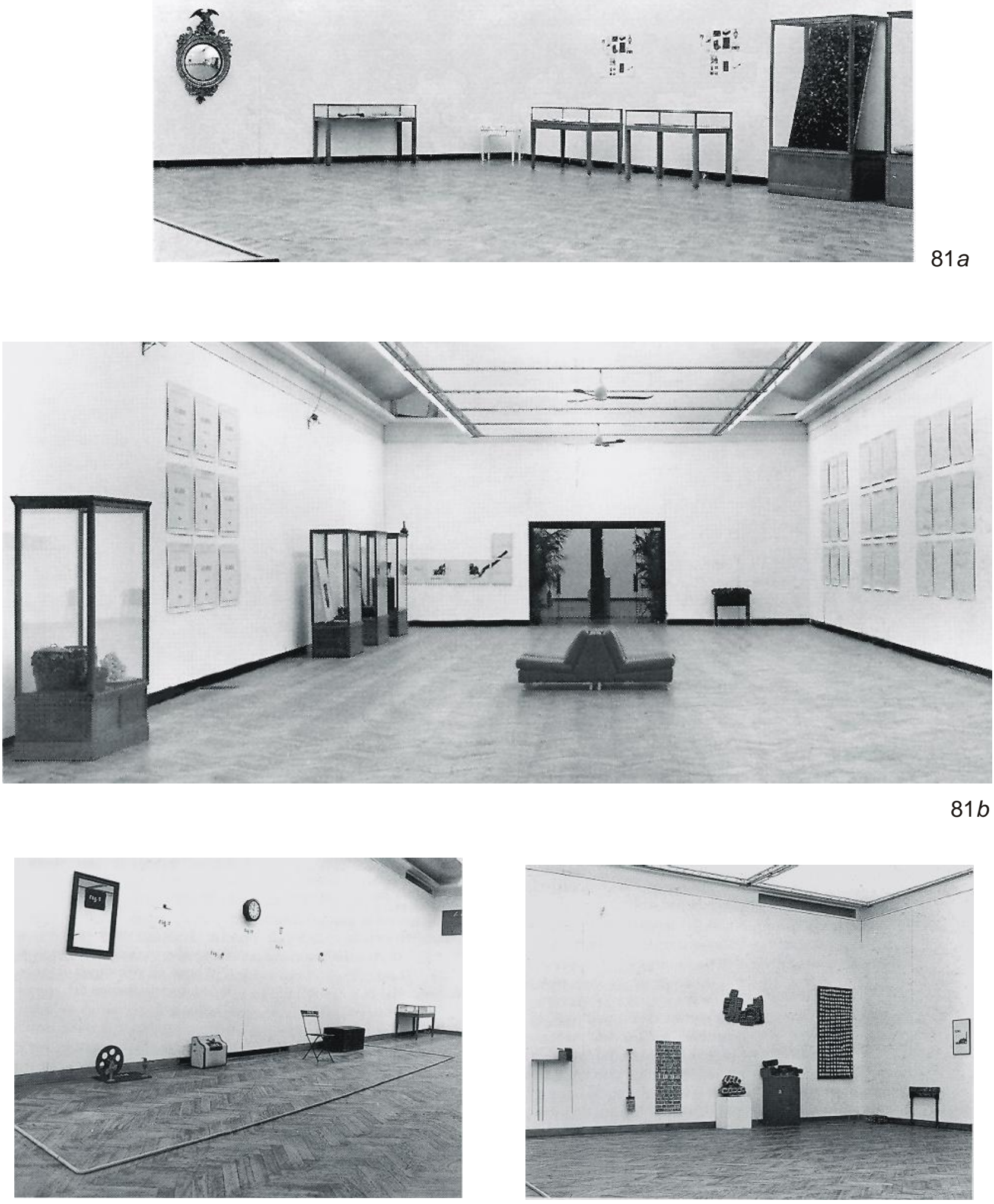

$81 c$ 
Així doncs, arran de les conclusions tretes de l'experiència del Museu, el treball de Broodthaers intenta emfasitzar l'acte expositiu com a construcció, o siga, com a creació i, consegüentment, cap dels elements exposats, siguen assemblages, pel-lícules, edicions o objectes, devien ser apercebuts com a obres en el sentit que convencionalment es dóna a l'obra d'art autònoma.

Però, tan la retrospectiva com l'antologia, en tant discursos, són ficcions. En aquest sentit, l'exposició "Catalogue - Catalogus" constitueix un muntatge en el qual l'exhibició de les peces està justificada com un procediment didàctic dins de la ficció que representa l'acte expositiu.

\subsection{L'acte expositiu i el projecte creatiu}

Amb tot, "Catalogue - Catalogus" no va ser la primera ni l'única exposició concebuda com a recull ni com a visió retrospectiva o antològica. Anteriorment, en exposicions com "MTL 13/3/70 - 10/4/70" i "Film als Objekt - Objekt als Film", Broodthaers va desenvolupar les idees a partir d'una catalogació i d'una nova lectura d'obres prèvies. ${ }^{84}$ Però, en exposicions darreres, com per exemple: "Invitation pour une expositon bourgeoise" i "L'Angélus de Daumier", Broodthaers empra sense ambigüitats obres prèvies en funció d'il-lustrar una ficció, de manera que l'acte expositiu esdevé la conclusió d'un projecte artístic.

Això no obstant, la finalitat del l'exposició és la situació per sí mateixa, per la qual cosa la seua entitat i el seus efectes són efímers i il-lusoris. Cal dir que en l'època moderna, els llocs comuns de la idea de Decor remeten tant a l'arquitectura d'interiors com a les arts escèniques i cinematogràfiques. Dins d'aquests contextos és possible combinar i integrar diverses disciplines, com per exemple: projectar, renovar, ambientar, pintar, etc. ${ }^{85}$ Ací mateix, els decorats també requereixen de tot un repertori d'elements accessoris com són: quadres, escultures, plantes, objectes, mobles, catifes, etcètera, segons siguen les necessitats i les particularitats del projecte.

Les manifestacions artístiques com l'escultura i la pintura tampoc no van ser autònomes, sobretot en l'època medieval, sinó que van estar considerades com a accessòries de l'arquitectura. Llavors, això mai no posava en dubte la qualitat de l'obra d'art ni molt menys el reconeixement de les obres magistrals. D'un mode diferent però, la relació de mútua dependència entre les arts va perdurar en el segle XX i inclusivament va arribar a conviure amb l'avantguarda: sia actualitzant-ne les formes tradicionals, sia plantejant-ne formes inèdites.

Els decorats de Broodthaers són com el Musée d'Art Moderne..., una forma de ficció, encara que també una manera més retòrica, però més directa, d'emplaçar les polítiques institucionals: des de dins del sistema mateix. Broodthaers fa servir la presència de les obres $\mathrm{i}$ l'organització espacial de l'exposició per a organitzar la lectura de l'espectador i introduir-hi noves idees. Amb tot i això, es tractava de crear una intenció discursiva i un llenguatge personal per emfasitzar el sentit públic i didàctic de la presentació d'una exposició i, al mateix temps, de subratllar el caràcter artificiós, exhibicionista i manipulador inherent a la presentació institucional.

\footnotetext{
${ }^{84}$ Sobre les exposicions "MTL 13/3/70 - 10/4/70" i "Film als Objekt - Objekt als Film", vegeu els capítols 2.7 "La significació del moment expositiu" i 4.4 "Les exposicions i el cinema", respectivament.

${ }^{85}$ Vegeu que pot haver-hi certa equivalència entre els procediments implicats en el Decor i l'inventari de verbs en la inscripció del terra en la manifestació Musée d'Art Ancien, Département des Aigles, Galerie du siècle XX.
} 
Així doncs, Broodthaers concep i assumeix les seues exposicions com a Decor amb la intenció d'abordar els temes que li interessen: la naturalesa de l'obra d'art i el paper de les institucions artístiques en el conjunt de relacions de la societat. En "L'Angélus de Daumier", la seua última exposició, Broodthaers presenta un altre recull d'obres de diferents èpoques, però més que d'una retrospectiva o una antologia, es tractava d'una successió de decorats.

\subsubsection{L'exposició "L'Angélus de Daumier"}

En el primer dels catàlegs editats per a l'exposició "L'Angélus de Daumier" s'incloïa un pla de les instal-lacions que detallava la planta de l'edifici i la ubicació de cada sala com un decorat independent amb una denominació pròpia. També hi havia una nota sobre cada decorat, però Broodthaers va abstenir-se de numerar les pàgines de manera que el lector havia de crear l'ordre. En canvi, s'hi repetia la instrucció nouveaux trucs, nouvelles combines per remarcar el caràcter mutant $\mathrm{i}$ la provisionalitat del Decor. ${ }^{86}$

82. Pàgina del catàleg de l'exposició "L'Angélus de Daumier". Paris, 1975.

83. Pla de l'exposició "L'Angélus de Daumier" amb la localització dels decorats.

Aquestes circumstàncies accentuaven en les obres i en els decorats la condició d'elements intercanviables, és a dir, que únicament com a part del decorat, o siga, dins d'un context museístic i arquitectònic - construït artificialment l'obra d'art aconseguia acomplir una funció real.

En la Salle des nuances Broodthaers va reunir obres de diferents èpoques però que tenien en comú la idea de la creació com a construcció: hi havia una escala, una pala, unes caixes d'embalatge i un quadre que representava una paret de rajoles amb la inscripció Arquitecte.

Enfront estava la Salle rose que fou el saló privat de la baronessa de Rothschild i que després va ser conservat com a тизеu per la institucióo ${ }^{87} \mathrm{~S}$ 'hi mantenien el mobiliari original de la mansió i els objectes personals de la baronessa. Broodthaers no va fer-hi cap modificació, simplement va aconseguir mostrar-lo al públic per primera vegada però com a part de la seua exposició.

Al final del passadís es trobava la Salle blanche, que era una reconstrucció a escala real de l'espai en 30 Rue de la Pépinière on començà a funcionar el Musée d'Art Moderne, Département des Aigles. Travessant-la estava la Salle outremer, on totes les obres exposades feien referència a viatges imaginaris, mapes simbòlics i naufragis.

D'altra banda, en travessar la Salle des nuances s'arribava a la Salle verte, un espai que obria al jardí de la mansió. Des d'ací s'accedia a altres sales més petites: la Salle rouge, on Broodthaers havia reunit obres concebudes com a edicions, així com llibres i obres amb referències a l'alfabet; la Salle noir, que era la sala de cinema i estava condicionada per a la projecció d'un programa de pel-lícules; i la Salle bleue, on Broodthaers havia penjat 12 calendaris que corresponien als anys que havia dedicat a les arts plàstiques, possiblement per simbolitzar que no hi hauria més temps.

\footnotetext{
${ }^{86}$ Cf. M. Broodthaers (1975b). "Notes sur le sujet"; en Marcel Broodthaers. Pa., op. cit.: p. 278

${ }^{87}$ Aquesta exposició tingué lloc a París en el Centre National d'Art Contemporain ubicat en una mansió del segle XVIII que va ser residència dels barons de Rothschild i aleshores seu de la Fundació Salomon de Rothschild.
} 
LES SALLES

Le moment de procéder à l'accrochage ne coīncide pas avec le temps employé pour l'impression d'un catelogue. C'est la première nison as avec le teups d'une seconde partie tentative de montrer par des photos, l'effet que donnera ch place. La seconde raison est la et des idées qui ont conduit à son arrangement puisqu'aujourd'hui l'artiste attache plus d'importance à la notion de DÉCOR qu'à telle ou telle pièce privilégiée.

Si son intention l'emporte, cette exposition ne sera pas une rétrospective mais une succession de \& décors » qui mènera ì la salle noire où un programme de films sera projeté. Nouveaux trucs, nouvelles combines
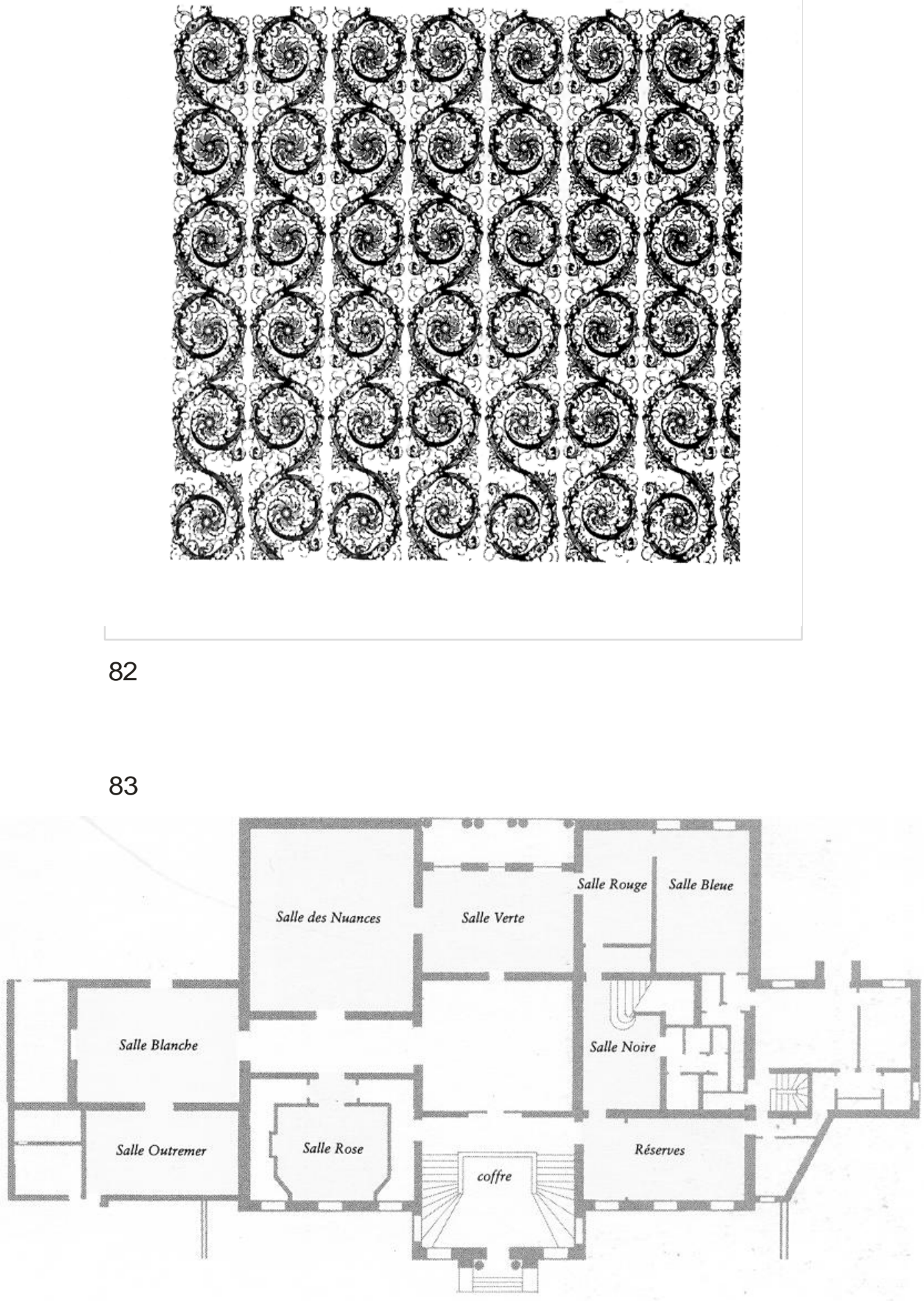

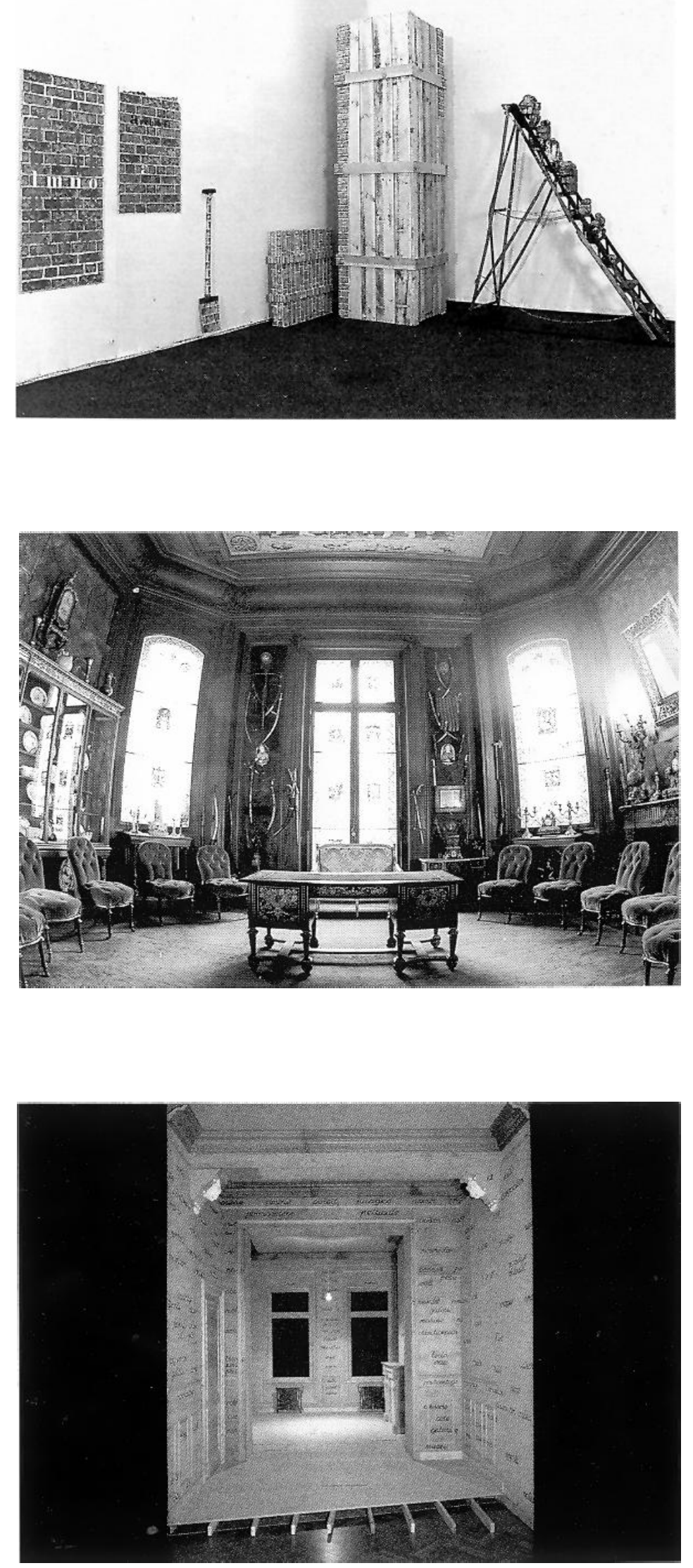
84. Salle des nuances en l'exposició "L’Angélus de Daumier".

85. Salle rose en "L’Angélus de Daumier".

86. Salle blanche en "L’Angélus de Daumier".

Indubtablement, la instrumentació del la noció de Decor en les últimes exposicions de Broodthaers obri una interrogació sobre la finalitat de l'art. La idea subjacent és proveir d'una funció real l'objecte exposat. Segons les seues paraules:

... la cosa més important va ser el Decor no tant en relació amb el lloc sinó amb el restabliment de l'objecte considerat en funció de la seua naturalesa: com a obra d'art, com a objecte decoratiu. ${ }^{88}$

Malgrat que els decorats acomplien el paper designat, el seu caràcter provisional i variable traslladava a les obres unes circumstàncies efímeres i problemàtiques. Però, és així com Broodthaers intenta habilitar una funció vertadera per a l'obra d'art i com finalment compren i projecta el seu paper en tant que artista.

L'analogia entre Museu i Decor començà per ser un comentari irònic sobre la descontextualització de les obres en l'espai institucional. Posteriorment, Broodthaers fa extensiva aquesta reflexió a la situació del museu mateix com a institució dins del conjunt de relacions de la societat. En definitiva, el Decor ironitza sobre la assimilació de la realitat per l'art, sobre el seu paper social i consegüentment en rendeix una definició no poc cínica:

Què és l'Art? Des del segle XIX es planteja aquesta pregunta contínuament tant a l'artista com al director de museu i a l'afeccionat. De fet, no crec que siga legítim definir l'Art i considerar la qüestió seriosament si no és per mitjà d'una constant: la transformació de l'art en mercaderia. [...] Si es tractés d'un fenomen de reificació, l'art seria una representació singular d'aquest fenomen, una forma de tautologia. Llavors, com a afirmació es justificaria i, al mateix temps, s'extrauria una existència nova. Però, aquesta utilitat de l'art està per demostrar-se, així com el valor d'aquesta definició. ${ }^{89}$

\footnotetext{
${ }^{88}$ S. Rona. "C'est l'Angelus qui sonne. Entretien avec Marcel Broodthaers" (1976).. En A. Hakkens. Marcel Broodthaers par lui-même. Amsterdam: Ludion / Flammarion, ca. 1998: p. 126 - 134.

${ }^{89}$ M. Broodthaers (1975a). "Être bien pensant ou ne pas être. Être aveugle". En Marcel Broodthaers. Pa., op. cit.: p. 268.
} 
4. L'ART ENTRE LA SUPERVIVÈNCIA I LA UTOPIA 
He fabricat instruments destinats al meu ús per a comprendre la moda en l'art, seguir-la, i finalment buscar una definició de la moda. No sóc pintor ni violinista. El que m'interessa és Ingres. I no Cézanne ni les pomes. ${ }^{90}$

es exposicions de Broodthaers constitueixen un nou tipus de textualitat que aconsegueix comprendre i representar el fenomen de la reificació de l'obra d'art i el paper de l'artista en la societat. Davant del repte de formular un discurs el sentit del qual no acabe assimilat i neutralitzat pels mateixos mecanismes als quals intenta oposar resistència, la seua intenció última és "proposar una reflexió crítica sobre la presentació de l'art en públic."91 En aquest sentit, el Musée d'Art Moderne Département des Aigles va ser un pretext, un amagatall. El Decor, en canvi, representa una instrumentació de l'art en la realitat social mitjançant l'apropiació de l'arquitectura i, al mateix temps, un model d'actitud davant el treball artístic i la seua finalitat. En el context d'un diàleg apòcrif amb Magritte apareix aquesta idea:

Què pensa vosté quant a deixar de considerar els seus quadres en funció dels títols, els quals consoliden la desorientació de l'espectador - abans ho ha declarat vosté mateix - i desplacen la imatge cap un domini intel-lectual on s'allunyen absolutament de qualsevol interpretació comuna. En canvi, redescobrir els esdeveniments de la vida, de la societat... és a dir, reconstruir en les seues obres l'entorn desaparegut. Aleshores, n'apareixerien com a testimonis de l'actualitat i mai no com a poemes. [...] Tan sols he traduït fidelment la meua posició en matèria d'art. Un punt de vista que podria ser interessant dirigit a instaurar una permanent critica de les imatges. Crec que això encara no s'ha fet. ${ }^{92}$

Broodthaers elabora respostes davant fet que la intenció crítica del seu treball acaba per formar part de la demagògia institucional i, al mateix temps, és conscient del pes dels convencionalismes artístics i dels hàbits que dificulten una lectura sense prejudicis. Així doncs, Broodthaers formula la noció de Decor apropiant-se dels mecanismes de reificació de l'obra d'art; però, en funció d'una permanent critica de les imatges i com a forma d'arrelament de l'art en la societat; és a dir, com un mitjà per inscriure el seu discurs en l'àmbit polític. Si les institucions artístiques i el mercat funcionen fent de les propostes desestabilitzadores els seus paradigmes, tal i com la indústria cultural va fer-ho amb el cinema i amb l'arquitectura, l'artista ha de definir conscientment el seu camí, la seua supervivència com a tal.

\footnotetext{
${ }^{90}$ I. Lebeer (1974); op. cit.

${ }^{91}$ Cf. M. Broodthaers (1972e). "Section des Figures", op. cit.

${ }^{92}$ M. Broodthaers (1967). "Intervieuw imaginaire de René Magritte". En Marcel Broodthaers. Ma., op. cit.: p. 104 -105 .
} 


\section{Notes sobre el paper social de l'artista}

Cal dir que el pensament al voltant del fet artístic com a succés social té lloc a partir de l'observació i de la comprensió dels vincles entre l'art i les circumstàncies històriques i socials. És un procés que es desenvolupa de forma paral-lela i complementària a la idea de l'autonomia de l'art ja des del naixement de l'estètica, moment en què les arts comencen a ser percebudes com a dominis propis. És també a partir d'aquest moment quan, paradoxalment, l'artista s'enfronta a un procés de desfiguració del seu paper social, arran de les profundes transformacions que tenen lloc a conseqüència de la revolució industrial.

El treball dels artistes - pintors, músics, arquitectes, actors, etc. - abans d'afectar-se per les relacions capitalistes, es percebia com una forma ideal de producció. S'hi idealitzava la llibertat de l'artista en comparar-la amb el conjunt d'activitats productives. ${ }^{93}$ Però, en minvar o desaparéixer els encàrrecs i els lligams, l'artista perd el seu perfil tradicional i es queda a la seua sort davant del pragmatisme i l'anonimat de la emergència burgesa i de les oscil-lacions del mercat. Llavors, la producció artística s'ha d'integrar dins de la producció de béns utilitaris o bé dins del mercat de l'art, que dóna lloc a l'escissió entre les arts decoratives i les belles arts.

Altrament, l'artista protagonitza dues situacions: bé s'integra dins del model de relacions capitalistes o bé intenta sostraure's per mitjà de diferents actituds. Si en l'esfera del pensament es parla de l'existència d'una consciència eficient articulada en la transformació social i econòmica, en l'esfera de l'art la presa de consciència implica un compromís i un exercici crític sobre la realitat que apel-le a les consciències individuals com a impulsió dels canvis. ${ }^{94}$

Pel segle XIX es consolida un nou tipus d'artista compromés amb el seu temps, és a dir que assumeix els canvis, la novetat $\mathrm{i}$ allò d'insòlit que apareix en la vida quotidiana. Però al mateix temps, l' artista modern intenta ser independent i defensar la seua subjectivitat, una actitud que s'enfronta clarament amb la tradició establerta de l'art que mira al passat, que reprodueix idees d'equilibri i d'estabilitat amb validesa general. És el retrat de l'artista que va fer Baudelaire com un subjecte que viu la confrontació entre allò transitori i allò etern $i$ immutable. ${ }^{95}$

En particular, l'actitud artística de Broodthaers conflueix amb la utopia de connectar l'art amb la realitat social - històrica, econòmica, científica... - com a context ideal, la qual cosa soscava els principis de l'autonomia de l'art. Però el compromís que assumeix Broodthaers reclama la possibilitat d'intervenir en la configuració d'aqueix context i mai no crear un nou ordre hegemònic ni restablir un ordre anterior. És un compromís indiferent i sense recompensa:

Amb l'art plàstic, solament he pogut comprometre'm a casa dels meus adversaris. Els arquitectes estan en la mateixa situació quan treballen pel seu compte. En la mesura d'allò que m'està permés, intente circumscriure el problema proposant poca cosa i això mateix, indiferent. [...] Crec que les meues exposicions han depés i encara depenen de records de l'època en què assumia la situació

\footnotetext{
${ }^{93}$ Però la distinció entre treball productiu i improductiu es va establir sols des del punt de vista del capitalista i no des del punt de vista de qui el realitza. Cf. K. Marx; F. Engels. "Historia crítica de la teoría de la plusvalía". En Textos sobre la producción artística. Ma.: A. Corazón, 1972. p. 84 y s.

94 "...els filòsofs s'han limitat a interpretar el món de distints modes; d'allò què es tracta és de transformar-lo." K. Marx citado por J. Brihuega. "Arte y sociedad. Genealogía de un parámetro fundamental". En V. Bozal, (ed.) Historia de las ideas estéticas y de las teorías artísticas contemporáneas. Ma.: Visor, 1996: vol. II, p.115. [1845: "Undécima tesis sobre Feuerbach"]

${ }^{95}$ Vegeu C. Baudelaire, "El pintor de la vida moderna", [s. ref. consultat en fotocòpies]
} 
creadora sota una forma heroica i solitària. Dit d'una altra manera: llegiu-hi, mireu-hi; en altra època. Avui: permeteu-me que us presente... ${ }^{96}$

\subsection{Poesia i arquitectura com a referents del Decor}

Si per a Broodthaers el Decor constitueix una forma d'aprehendre l'espai institucional i polític, l'arquitectura representa el codi i la instrucció que per excel-lència li permet projectarhi idees. L'interés de Broodthaers per l'arquitectura està lligat als espais públics: el museu, el carrer, la ciutat, i a les possibilitats d'interactuar-hi. Malgrat això, és conscient que la potestat de l'artista per a transformar la realitat a tal escala es troba considerablement limitada, quan no anul-lada. Fins i tot les revolucionaries idees del funcionalisme arquitectònic què van servir com a antecedent de la Bauhaus no van tardar a inspirar igualment els fenòmens d'urbanització descontrolada i d'especulació en les principals ciutats europees. Llavors, la figura de l'arquitecte-artista representa un ideal romàntic i queda relegada a la utopia.

Pel que fa al desenvolupament de formes alternatives d'interacció entre les arts impulsades pel moviment modern i per les avantguardes, un dels vèrtexs de la qüestió continua estant en els límits de l'arquitectura. D'una banda hi ha la voluntat artística d'ultrapassar els límits del quadre i de l'escultura, uns límits robats a l'arquitectura i, de l'altra, hi ha la voluntat de crear, d'assolir una altra definició d'espai. És la tensió de l'art d'existir com a representació o com a cosa en si mateixa i alhora la contradicció derivada d'instituir l'espai propi mitjançant la inscripció en l'espai immortal del museu i de la història. Mitjançant la instrumentació del Decor com a sistema d'exposició Broodthaers recrea l'entorn desaparegut de les seues obres actuant directament sobre l'espai arquitectònic i social. Igualment, la majoria dels desenvolupaments del Musée d'Art Moderne ja duien implícita una actuació des de l'arquitectura i cap a l'espai social entés com un camp expansionat. ${ }^{97}$

Un exemple d'això és una obra titulada Musée - Museum. Es tracta de l'edició d'un dibuix que detalla la instal-lació de la Section XIXe siècle utilitzant els plans arquitectònics del seu emplaçament a Brussel-les en l'estudi del 30 Rue de la Pépinière. La representació arquitectònica dota la institució fictícia d'una configuració real, d'un espai propi. Per la vora hi ha inserides targetes postals de quadres d'Ingres i de Courbet que havien sigut part dels objectes fonacionals del Museu.

Un altre tempteig relacionat amb la idea dels emplaçaments del Museu és el Project pour un musée sur une ille déserte, Îlle du Musée. L'illa del museu era, suposadament, una plataforma de formigó amb un contenidor que flotaven a la deriva acompanyats per música de Wagner - Das Rheingold - . Broodthaers ho descriu com "...una illa deserta sobre el Rin: Illa del Museu [...] Illa deserta amb arbre, tot de ciment" ${ }^{98}$ La maqueta representa una construcció tan desolada com absurda, que això no obstant, reflecteix la idea del sofisticat aïllament de l'art en el museu i del museu en la realitat social.

87. Musée - Museum. Où est l'original?/ Wo ist das original?, 1972. [anvers i revers] (pàgina següent)

88. Projet pour un musée sur une îlle déserte, îlle du Musée (1971) (pàgina següent)

\footnotetext{
${ }^{96}$ I. Lebeer (1974); op. cit.

${ }^{97}$ En el mateix sentit que R. Krauss va definir aquest concepte. Cf. R. Krauss "La escultura en el campo expandido". En H. Foster (comp.) La Postmodernidad. Ma.: Kairós, 1985; p. 59 - 74.

${ }^{98}$ M. Broodthaers (1971e). "Proyecto para una isla desierta...". En Marcel Broodthaers. Ma., op. cit.: p. 158.
} 


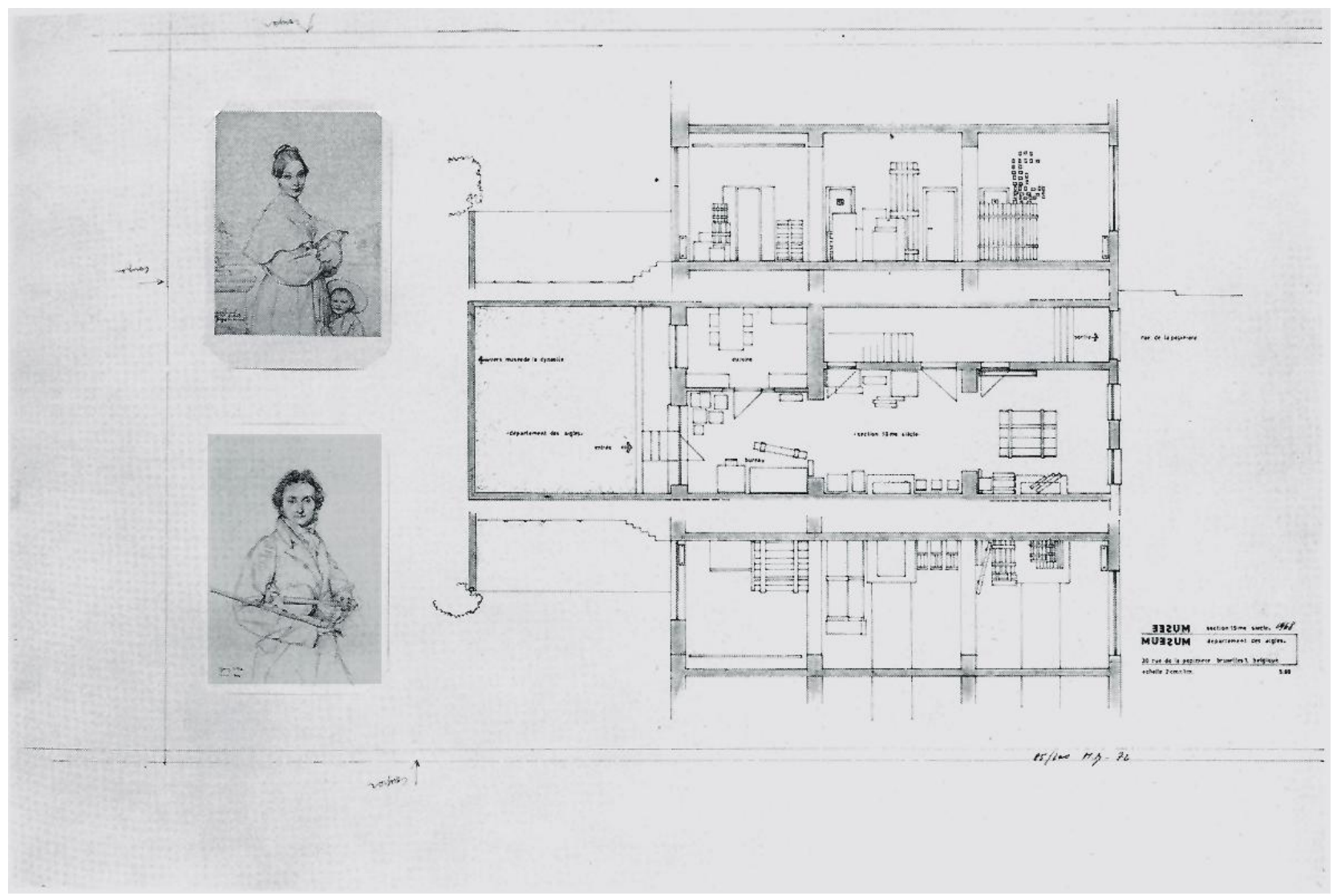

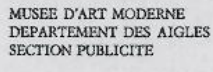

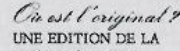

UNE EDITION DE LA ME MONCHENGLADBACI

OU EST LORIGINAL?

(CFCI NEST PAS UNE DEVINETTE.) LCEUVRE ORIGINALE SERATT CONSTITUEE PAR LES CARTES POSTALES INSBREES DANS UN PLAN

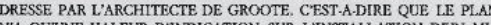
LES, REPRODUISANT DES GEVVES DU XIX'SIECLE, FAISAIENT PARTI AVEC DES CAISSES D'EMBALLAGE, DU MATERIEL D'EXPOSITION DE CE MUSEE. LE CONTRATE .ORIGINAL, DE CEL DE STHAMTON DE HABITUELS CE SONT DES CARTESIDFNTTOUTS CUT SUP LOPTENT IC LOYALEMENT, LE JAIDS DES SOUVENIRS, CELUI DE LA PEINTURE (LART CLASSE, TRADITIONNEL), ET CELUI D'UN CONCEPT SU OU EST LORIGLNAL? SOMBRE AU TROIS-QUARTS DANS LR PASS RATT ETRE CRITIQUE SI ELLE NETATT SIGNEE PAR L'AUTEUR. J'A M. BROODTHAERS

(1) SECTION XIXE SIECLE 1968 - 1969 BRUXELLES; SECTTON XIX D'ART ANCIEN (KASSEL 1972)

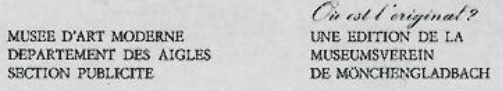

WO IST DAS ORIGINAL?

(DIES IST KEINE RATSELFRAGE), SIND DIE POSTKARTEN IM MU. SEUMSPLAN DES ARCHITEKTEN DE GROOTE DAS ORIGINAL? DE PLAN HAT DABEI NUR DIE FUNKTION, AUF DIE EINRICHTUNG EINES MUSECMS HINZUUEBISEN, WIE ES VON 1968 BIS 1969 IN BRUSSEL BE WERKEN DES 19, JAHEHUNDERTS ZUSAMASEN MIT VERPACKINGS MATERIALIEN AUSGESTELLT. IN DIESER ,ORIGINALEN" ZUSAM MENSIELLUNG ERSCHIENEN DIE REPSODL KTIONEN VER KRMDET DA SIE SICH WEDER AN EINEM POR SIE OBLICHEN ORT BE KUNSTPOSTKARTEN RUFEN BEIM BETRACHTER UNWILUORLCI VORSTELLUNGEN WACH VON DER (ALS KUNST ETABLIERTEN, TRA DITIONELLEN) MALERRI UND VON DER GESCCICHTE DER MALERE WO IST DAS ORIGINAL? DIE WERRKE DES 19 J JAIRHUNDERTS SIN WO IST DAS ORIGINAL? DIE WERKE DES 19 JAIRHUNDERTS SIND
HIER WEITGEHEND, WENN NICIT WOLLISTKNDIG, IN DIE NEBEL DER VERGANGENHEIT GEROCKT. HABEN WIR DAS ORIGINAL IN UNSERE T ES SICH UM EIN NEUES ORIG. NAL, DA MEINE SIGNIERUNG OBER FINE GEDANKLICHA AUSEINAN-

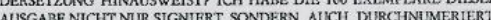
M BROODTHAERS

(1) SECTION XIXE SIECLE 1968 - 1969 BRUXELLFS; SECTION XIX D'ART ANCLEN (KASSTE 1972). 


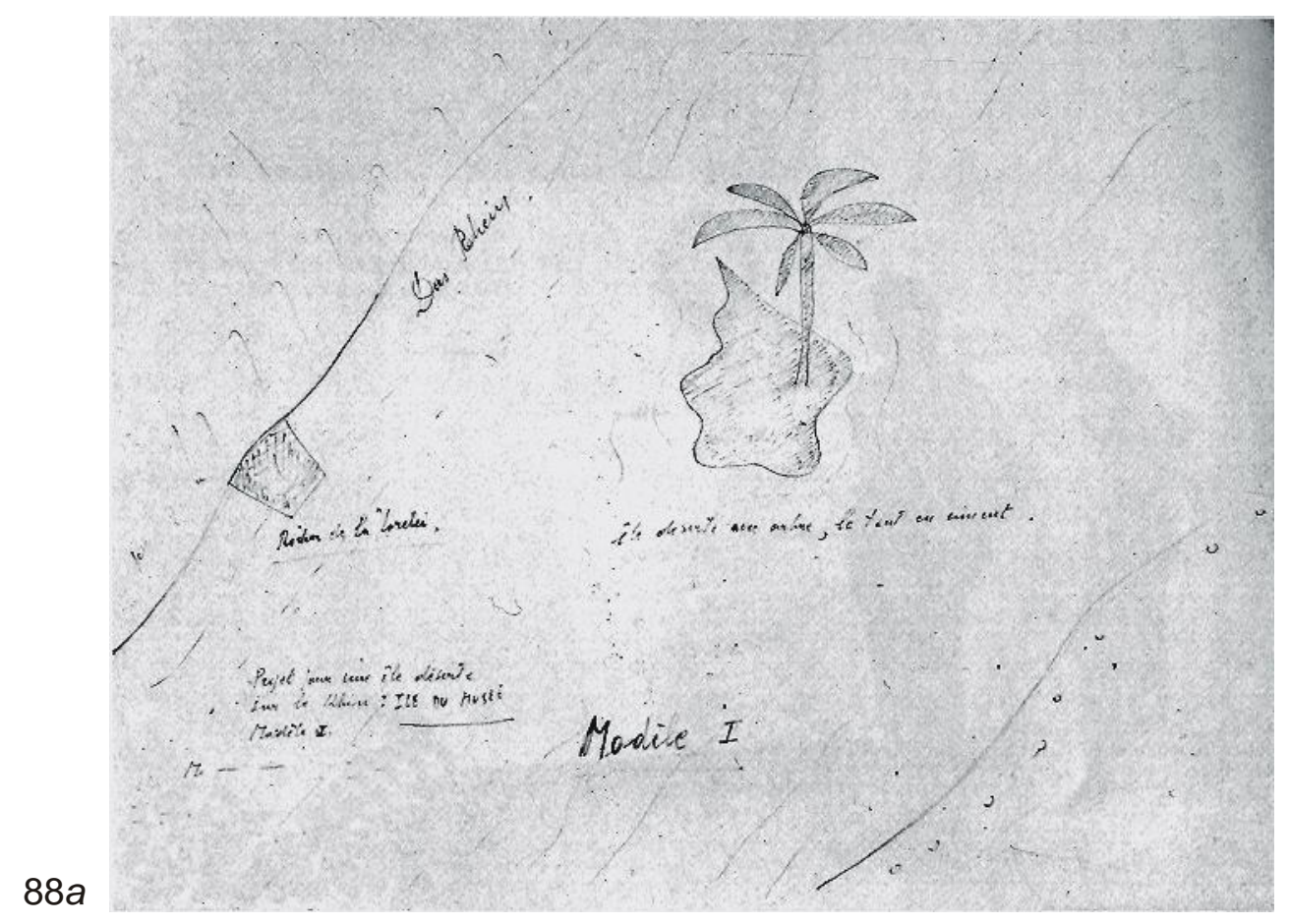

$88 b$

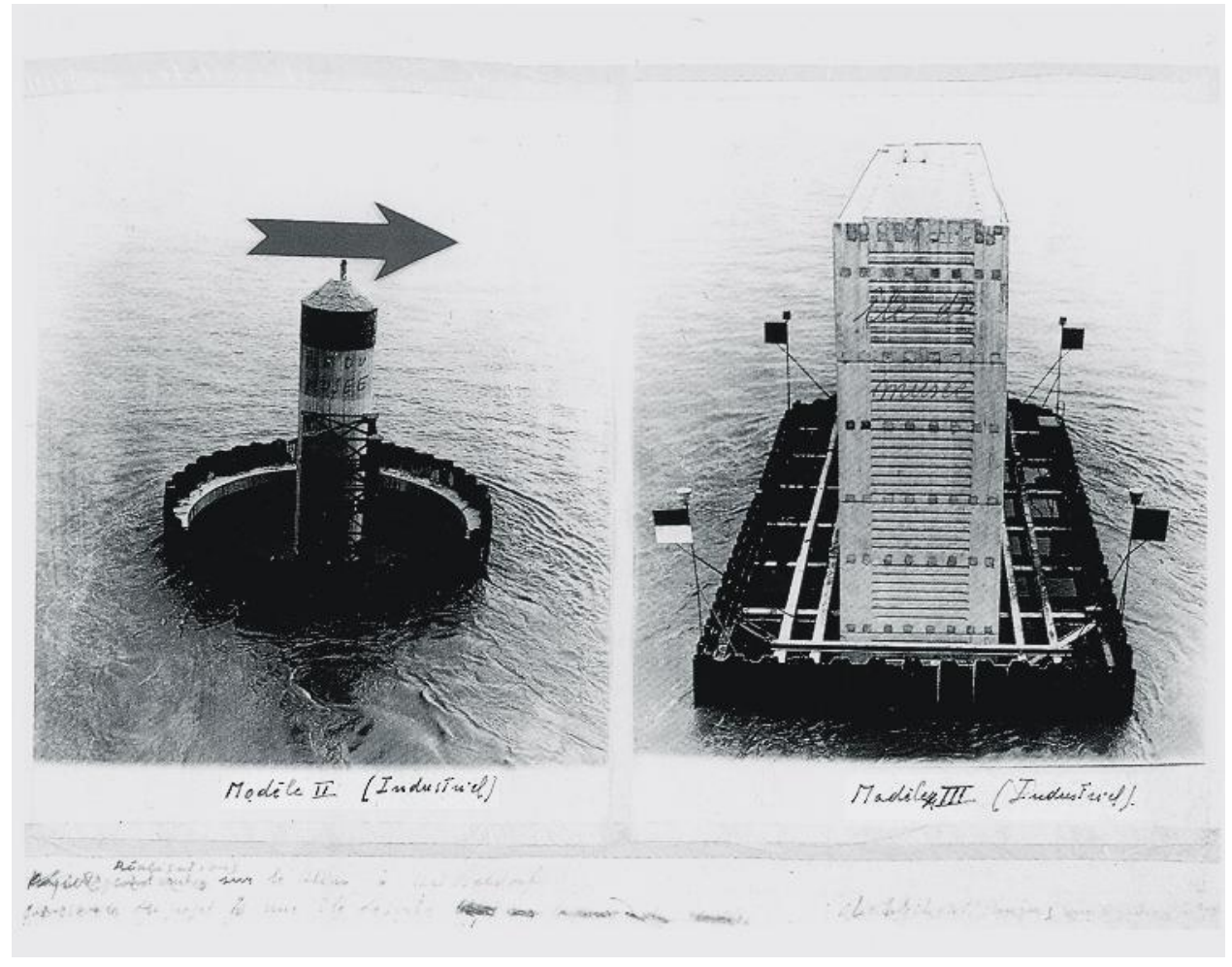


Però, el tema de la descontextualització i de la pèrdua de referents de l'obra d'art lligada a l'entorn del museu és primerenc en el treball de Broodthaers, a més a més de recurrent. Tocant això, cal recordar com en la pel-lícula La clef de l'horloge Broodthaers intenta reconstruir l'espai originari de l'obra de Schwitters. Els primers plans sobre els quadres exploren minuciosament la seua superfície i registren els objectes com a fragments evocadors. En canvi, no hi inclou cap referència visual de l'entorn dels quadres que llavors estaven exposats en el Palau de Belles Arts de Brussel-les. ${ }^{99}$ Solament, una veu en off hi esmentava la idea de presó i de desert; i un so com de maquinària es mesclava amb el tic-tac d'un rellotge imitat per la veu.

El 1971, al mateix temps que una gran exposició de Kurt Schwitters feia itinerari per varies institucions alemanyes, Broodthaers rescata la pel-lícula La clef de l'horloge per projectar-la a Düsseldorf com a part de la seua exposició "La figure 0". La presència de l'obra de Schwitters en el museu, que abans havia sigut condemnada mitjançant la càmera, ara era el tema de la seua reflexió:

Ja no és l'objecte el que recobreix el concepte sinó totalment a la inversa. [...] La matèria s'ha volatilitzat $\mathrm{i}$, això no obstant, els quadres de K. Schwitters constitueixen, encara avui, una bona inversió de pare de família. Una altra pregunta: per què els contemporanis de l'artista li van negar el seu suport financer i inclusivament el crèdit moral? Tenien, però, tots els motius per comprendre aquella brutal combinació de tristesa i poesia, ells què dormien en els llençols de la República de Weimar amb un somni amenaçat pels vampirs i pels soterradors. Van deixar traçada una figura nul.la en l'obscuritat de l'oblit. $100^{3}$

La interrogació que dirigeix Broodthaers al públic alemany convida a reparar en aspectes particulars de la vida de l'artista que van influenciar sobre la seua obra. Schwitters havia treballat en el projecte Merz des del 1923 fins a la seua mort, el 1948. El desenvolupament de la seua obra estigué subjecte als avatars de la guerra, les dificultats econòmiques i l'exili. Repetides vegades Schwitters parlava en la seua correspondència amb amics artistes i crítics de la significació que donava al Merzbau dins de la seua creació, major encara que la que atorgava als seus collages i quadres-Merz. Malgrat això, mai no obtingué el suport que necessitava i la seua obra gairebé no arribà a tenir reconeixement sinó després de la seua mort. Als pocs anys, és descoberta per les institucions i objecte d'ambicioses exposicions.

\subsubsection{Broodthaers i Schwitters}

Però, en què sentit l'obra de Schwitters pot representar per a Broodthaers una figura zero ? $^{101}$ Pocs artistes han instrumentat l'arquitectura ultrapassant els límits del quadre, de l'escultura i de la poesia d'una manera tan utòpica però tan clarivident com van fer-ho Broodthaers i Schwitters.

Schwitters trobà el terme Merz a partir de la fragmentació de la paraula Komerz, que en alemany significa comerç. El 1919 Schwitters va començar a donar la denominació Merzbild als seus quadres i a continuació va estendre la denominació Merz als poemes que venia realitzant des del 1917. Finalment, el terme es fa extensiu al conjunt de totes les seues

\footnotetext{
${ }^{99}$ Vegeu els apartats "La condició objectual de l'obra" p. 63 i "L'obra d'art i el seu context" p. 67.

${ }^{100}$ M. Broodthaers (1971d). "La Figure 0"; op. cit.

${ }^{101}$ És evident que per a Broodthaers el zero té unes connotacions de cosa originària, de punt de partida més que de cosa nul-la, encara que sovint li interessa jugar amb el doble sentit.
} 
activitats: "El meu objectiu és l'obra d'art total Merz que reuneix tots els tipus d'arts en una unitat artística." 102

De totes les arts, l'arquitectura era la que més s'identificava amb la idea Merz en el seu estat pur: la construcció amb vells materials i llenguatges d'una obra d'art nova. Inclusivament Schwitters va somniar la missió de la reestructuració artística de les ciutats: "...destruint-hi les parts més molestes [...] les grans ciutats podrien ser transformades en una obra d'art Merz gegantesca." ${ }^{103}$ Posteriorment, aquest afany de transformar construint s'interioritza: la idea Merz es trasllada a l'espai privat, un espai-caixa, capella, gruta, mausoleu... que l'artista podia (re)construir amb llibertat. Llavors, Schwitters planteja que "Merz és consequiència. Merz significa crear relacions entre totes les coses del món." ${ }^{104}$ És el punt de partida d'allò que es coneix de la seua obra; d'una cosa per naturalesa i per accident, permanentment inacabada.

Com Schwitters, Broodthaers troba en la poesia el seu primer refugi. Les motivacions d'ambdós artistes descobreixen el poeta com a artífex d'una obra expectant i ambiciosa, però alhora conscients de les seues limitacions. Així doncs, Broodthaers i Schwitters conflueixen amb la idea de l'art com a conseqüència.

Hi ha una notable versemblança entre la idea Merz d'aprofitar els vells materials, els objectes i els llenguatges obsolets en una nova obra d'art i la idea del Decor que desenvolupa Broodthaers. Però sobretot, ambdós coincideixen en el propòsit de circumscriure-hi la idea d'espai. També van compartir l'afecció per la lletra impresa, pels jocs semàntics i van formular, en algun moment, la utopia de l'obra total, revelant les seues creences en la capacitat crítica i redemptora de l'Art. El poeta hi és una figura recurrent.

Altrament, les circumstàncies que van cenyir les experiències d'ambdós artistes van ser molt diferents. Schwitters conegué la soledat, el desarrelament i la precarietat en l'exili. Va anomenar Catedral de la misèria eròtica (Kathedrale des Erotischen Elends) el seu primer Merzbau què va quedar abandonat en el seu taller de Hannover. Broodthaers, per la seua part, assumeix el Decor com a finalitat estetico-pràctica del projecte artístic i acaba per concebre'ls com a hivernacles: espais idíl-lics i ailllats en mig de les inclemències de la realitat. Per a Broodthaers l'analogia entre hivernacle i Decor pretén significar l'entorn real com a desert amb tota una carrega simbòlica adjacent:

Un desert real i simbòlic alhora, una il·lustració - a contrario - de la situació política i econòmica actual, però encara més, és la prevalència del desert, el desert de la societat, el desert de l'esglai i, al cap i a la fi, el desert del món de l'art... ${ }^{105}$

\footnotetext{
102 "... Merz significa essencialment la reunió de tots aquells materials imaginables destinats a fins artístics, així com, des d'un punt de vista tècnic, implica la pròpia valoració de cadascun d'aquests materials. [...] així doncs, no és gens important el fet que els materials emprats hagueren servit o no per a altres fins. [...] l'artista crea mitjançant la selecció, distribució i composició dels materials". K. Schwitters (1921). "Concepto de Merz". En F. Calvo Serraler i A. Gonzalez.. Escritos de Arte de Vanguardia. 1900 / 1945. Ma.: Itsmo, 1999: p. 223 i 224. Però, allò essencial de l'origen del concepte Merz és l'obtenció d'un element nou amb una significació nova a partir d'un element anterior [la paraula Komerzbank] però descontextualitzat. Cf. també H. Zeeman. "La inmortalidad no es un asunto de cualquiera". En Kurt Schwitters. València: IVAM, 1995: p. 425-435.

${ }^{103}$ K. Schwitters citat per H. Szeemann. Íd.

${ }^{104}$ K. Schwitters citat per H. Szeemann. Íd.

${ }^{105}$ F. De Vree (1974). "Entretien avec Marcel Broodthaers". En A. Hakkens; op. cit.: p. 103 - 107.
} 


\subsection{El jardí com a model de Decor}

... vaig escriure la paraula Museu en les finestres, Section XIXe siècle en la porta que dona al jardí i Départament des Aigles sobre el mur del fons del jardí. Així va nàixer aquest Museu... mai no d'un concepte sinó d'una circumstància; el concepte va arribar després. Tal i com va dir Marcel Duchamp: això és un objecte d'art, en essència, vaig dir: això és un museu. [...] vaig establir una relació entre la buidor de la pintura, [...] entre l'absència d'un significat i la buidor de les caixes, la buidor de les reproduccions. 106

Les analogies entre Museu i Decor són evidents i s'observen potser per primera vegada en la ubicació primitiva del Musée d'Art Moderne, Département des Aigles, en l'estudi de Broodthaers a Brussel-les. Per aquell temps, però, la relació entre el museu i el seu decorat es perfilava com a antitètica: era una circumstància que servia per a representar la violència poètica i per a ironitzar sobre l'estatut de l'obra d'art. Així doncs, els elements que aleshores conformaven el decorat del Museu, inclusivament el jardí, corroboraven la ficció a causa que el seu caràcter qüestionava el concepte mateix de museu. Aquesta experiència encara va perdurar d'una manera o d'altra en els diferents emplaçaments del Museu.

89. Espai museu en el jardí de l'estudi de Broodthaers. Brussel·les, 1968 - 69.

Posteriorment, Broodthaers va començar a utilitzar la idea de jardí com una ficció per si mateixa la qual cosa va servir per a configurar la noció de Decor. La instal-lació Jardin d'hiver, de la qual Broodthaers va fer versions diverses, va esdevenir un dels decorats més representatius i simbòlics. ${ }^{107}$

\subsubsection{Els decorats Jardin d'hiver}

El primer decorat Jardin d'hiver era una instal-lació composta, bàsicament, pels elements següents: setze gravats anglesos del segle XIX que procedien d'un llibre, sis reproduccions fotogràfiques dels originals, desenes de palmeres i de cadires de jardí, un monitor i una càmera de vídeo. Aquesta primera versió va ser realitzada el 1974 per a una exposició col-lectiva que tingué lloc a Brussel-les en el Palau de Belles Arts. ${ }^{108}$

Els gravats representaven diferents classes d'animals: ocells de diverses espècies, abelles, escarabats, paons i faisans; tots aquests en el seu entorn. També hi havia elefants i camells, tant en el seu estat salvatge com en convivència amb l'home. Els originals dels gravats s'hi podien veure dins d'unes vitrines, mentre que les ampliacions fotogràfiques estaven emmarcades i penjades de la paret. Les palmeres i les cadires, orientades cap a dins, formaven un cercle al mig de la sala simulant una glorieta. En un extrem de la sala hi havia una càmera de vídeo que registrava tot el conjunt i transmetia les imatges de la instal-lació en directe al monitor conformant un circuit tancat de televisió.

\footnotetext{
${ }^{106}$ F. De Vree (1969). "Entretien avec Marcel Broodthaers". En A. Hakkens; op. cit.: p. 68 - 73.

${ }^{107}$ Cal dir que no són els únics perquè hi ha més projectes de Broodthaers que d'alguna manera utilitzen la idea del jardí. Per exemple: la instal-lació L'entrée de l'exposition en l'exposició "Éloge du sujet" o una sèrie de diapositives amb el títol "Jardin d'hiver" composta per il-lustracions de llibres dels segles XVII i XIX, la qual formà part de l'exposició de pel-lícules de Broodthaers "Films, dias et photos" organitzat per la Kunsthalle de Düsseldorf del 23 al 25 de maig del 1975.

${ }^{108}$ Era l'exposició "Carl André, Marcel Broodthaers, Daniel Buren, Victor Burgin, Gilbert \& George, On Kawara, Richard Long, Gerhard Richter". Palau de Belles Arts, Brussel·les: 9 gener - 3 febrer, 1974.
} 


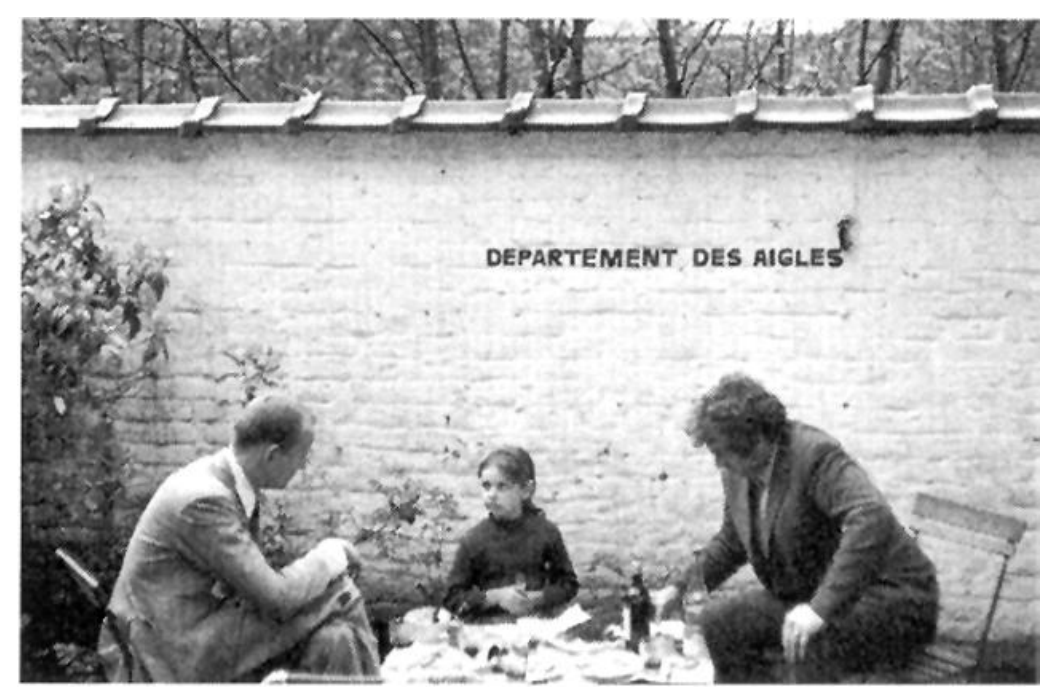

$89 a$

$89 b$

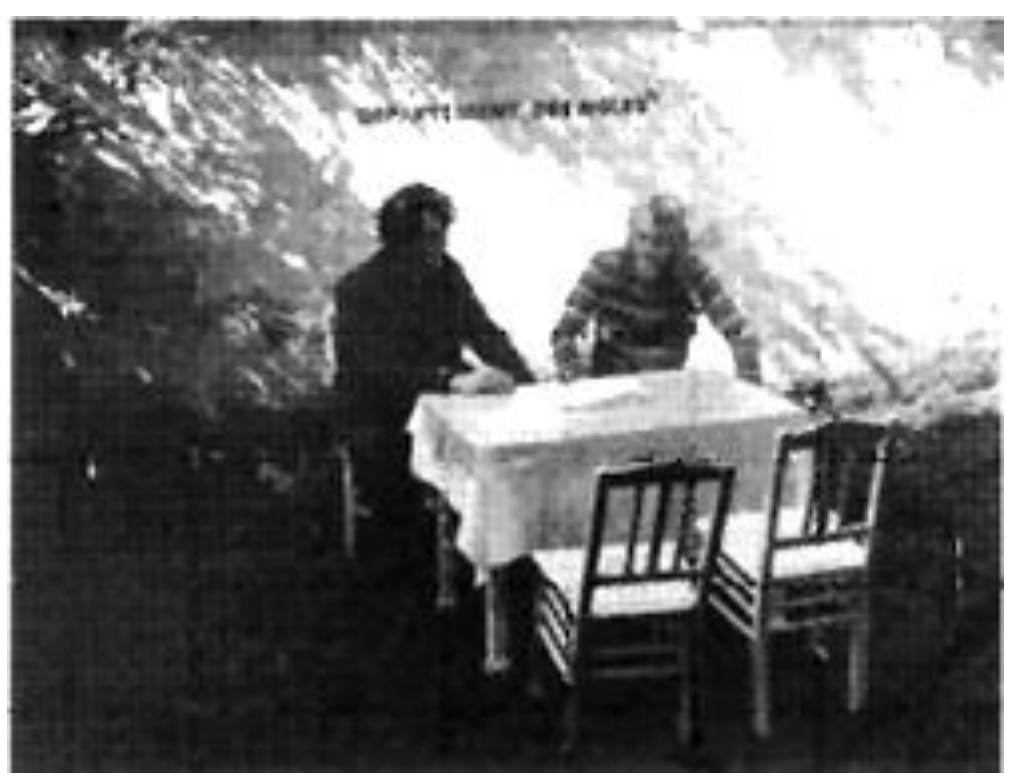



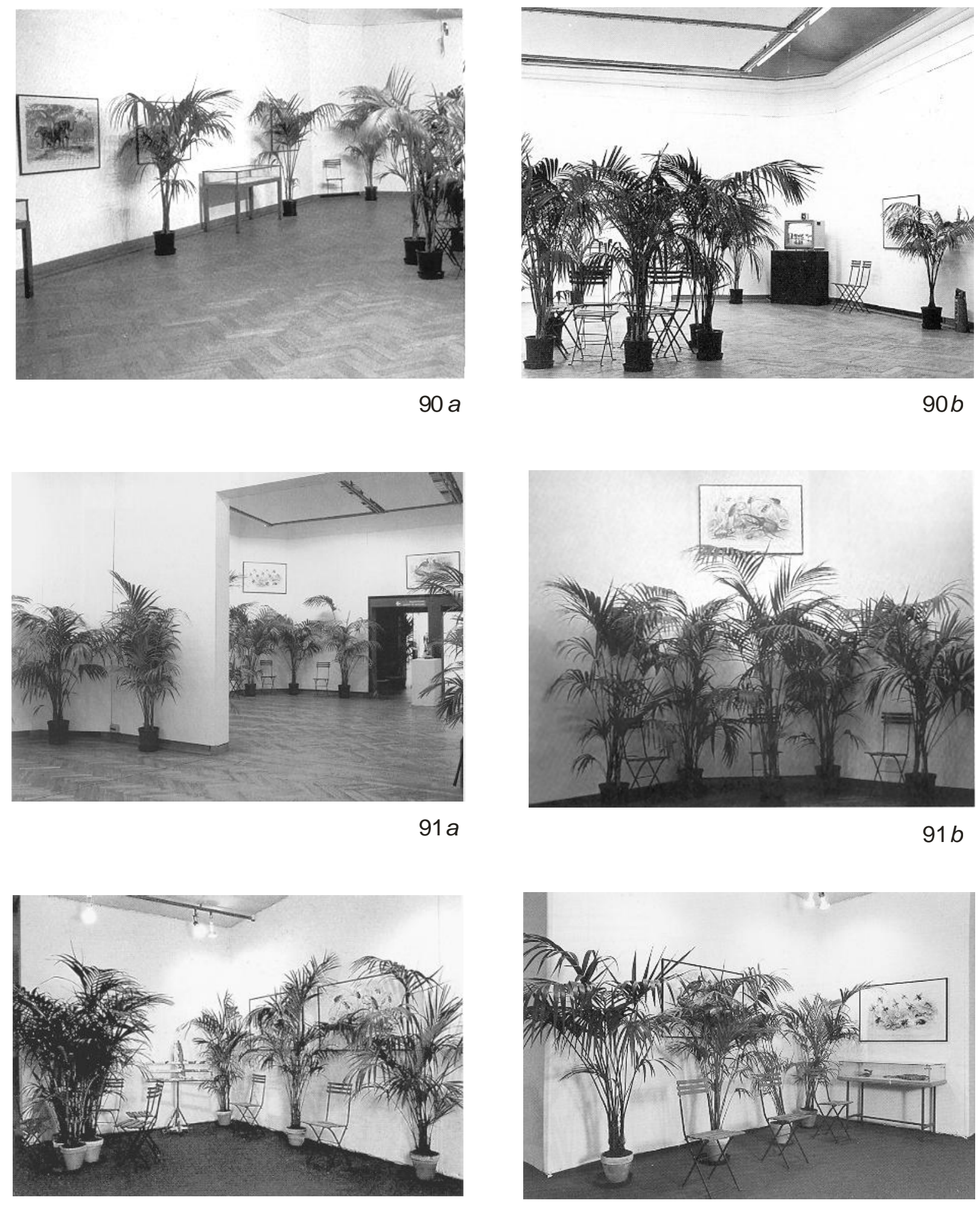

$92 a$ 
Broodthaers va acudir a la inauguració amb un camell del zoològic d'Anvers, al qual va conduir fins a l'entrada del museu. L'episodi fou filmat en vídeo i transmés en directe mitjançant el circuit tancat de televisió de manera que l'acció va poder veure's dins de la instal-lació a través del monitor. Finalment, Broodthaers va utilitzar les imatges filmades per a realitzar una pel-lícula. Al poc de temps, Broodthaers va presentar la segona versió, Jardin d'hiver II, en la mateixa institució però com a part de l'exposició "Catalogue - Catalogus". Ací no estaven els originals ni les vitrines, sinó solament les reproduccions dels gravats, a més a més de les palmeres i les cadires de jardí, que estaven col-locades al llarg de les parets. Durant l'exposició, va projectar-se la pel-lícula Jardin d'hiver $(A B C)$ com a part del decorat mateix.

La pel-lícula, per la seua part, mostrava imatges de l'exposició prèvia. S'hi veia el moment que el camell arribava a l'entrada del Palau de Belles Arts de Brussel-les, però de primer a través del monitor de vídeo ubicat en la sala i després l'acció en directe. A continuació, hi havia diferents preses de vista de la sala que incloïen detalls dels elements que conformaven el decorat, així com del públic i de Broodthaers mateix llegint el catàleg de l'exposició en les pàgines dedicades a la seua participació.

La tercera versió va ser presentada en l'exposició "L'Angélus de Daumier" com la Salle verte i va ser instal-lada en un saló amb grans finestres que obrien a un jardí vertader. Les reproduccions dels gravats també estaven penjades de les parets. Un conjunt de palmeres i de cadires, orientades cap a fora, formaven una altra glorieta, mentre que la resta estaven ubicades al llarg de les parets. No hi havia ni càmeres, ni monitor de vídeo, ni pel-lícula, però hi havia un faristol pintat de roig tot cobert de closques de musclos així com una vitrina amb dues serps dissecades.

90. Jardin d'hiver. Primera versió de la instal-lació. Brussel-les, 1974.

91. Jardin d'hiver II. Instal-lació en "Catalogue - Catalogus". Brussel-les, 1974.

92. La Salle verte en l'exposició "L'Angélus de Daumier". París, 1975.

En general, el jardí d'hivern o hivernacle pot considerar-se un jardí científic on les espècies exòtiques solen agrupar-se segon el seu origen geogràfic i perquè necessiten d'unes condicions ambientals òptimes per a la seua supervivència; unes condicions que, d'altra manera, no poden garantir-s'hi. Llavors, Broodthaers va representar aquests decorats com una espècie d'oasi o d'hivernacle de l'art i al mateix temps va desenvolupar una nova analogia: el jardí era per a la natura allò que el museu representava per a l'art. Així doncs, Broodthaers proposa la idea del Decor com a hivernacle i fins i tot l'existència i el funcionament de la institució museu com un oasi de la cultura. ${ }^{109}$

\subsubsection{Els objectes i el Decor}

Més o menys explícitament, la idea de l'hivernacle és part de la idea de Decor, la qual cosa justifica la recurrència d'alguns elements constitutius així com dels procediments que s'hi apliquen. Les palmeres apareixen en la majoria dels decorats de Broodthaers i simbolitzen allò exòtic encara que la seua presència circumscrita resulta totalment habitual. En l'exposició "Catalogue - Catalogus", per exemple, en formen part de tres muntatges: de L'entrée de l'exposition, de Tapis de sable i, a més a més, de Jardin d'hiver II. En tots tres Broodthaers utilitza les palmeres com a representació de la travessia de les obres pel museu.

\footnotetext{
${ }^{109}$ Vegeu F. De Vree (1974); op. cit.
} 
En la instal-lació L'entrée de l'exposition les palmeres es trobaven amuntegades en l'entrada de l'exposició i dificultant-hi el pas. A pocs metres del llindar, Broodthaers havia fet col-locar un panell que impedia veure des de fora l'interior de la sala. Hi havia una llarga fila de palmeres molt juntes davant la porta de manera que l'accés del públic a l'exposició quedava limitat a un únic espai lliure deixat a l'esquerra. Així doncs, aquest Decor constituïa una espècie d'avantsala de l'exposició que remarcava la delimitació i la significació de l'espai com a dins / fora, art / no-art, cultura / natura o privat / públic.

Per la seua part, la instal-lació Tapis de sable es trobava en l'última sala, juntament amb unes altres instal-lacions. En el centre de l'espai, hi havia un rectangle de sorra conformant una estora dins de la qual es trobava una palmera solitària. L'estora de sorra estava rivetejada amb les lletres de l'abecedari, amb la qual cosa Broodthaers pretenia significar l'abandonament de la natura i l'entrada en el món del llenguatge. Així doncs, la palmera solitària ja no era un objecte indiferenciat ni tampoc no era part de cap decorat sinó que hi conformava una obra d'art.

El recorregut de la palmera pels diferents espais de l'exposició simbolitzava la progressiva pèrdua de referents de l'obra d'art, de manera que acabava compartint el mateix destí que les obres exposades: en ser transformada en obra d'art, la palmera havia sigut abstreta de la seua funció com a objecte i havia sigut reificada com a icona. Però, també hi havia una tovallola de platja penjada en la paret que portava una palmera pintada d'una manera naif. Paradoxalment, en estar pintada sobre la tovallola de platja, la palmera recuperava la seua significació original i acomplia una funció decorativa dins d'un altre objecte.

93. L'entrée de l'exposition en l'exposició "Catalogue - Catalogus".

94. Tapis de sable. Instal-lació en l'última sala de l'exposició "Catalogue - Catalogus".

Altrament, les ampliacions fotogràfiques dels gravats del segle XIX així com els gravats originals i la pel-lícula funcionaven com a diferents representacions de la noció de jardí. D'altra banda, la pel-lícula funcionava en un altre nivell què feia referència al Decor com a posada a escena. Així doncs, cap d'aquestes obres hi tenia una funció pròpia. En canvi, els elements utilitaris i indiferenciats, com les palmeres i les cadires, sí hi acomplien la seua funció en tant que objectes.

En la pel-lícula Jardin d'hiver (ABC) Broodthaers articula diferents nivells de representació. D'una banda, estaven les imatges del camell en el monitor de televisió de la sala, les preses de vista en directe del camell en l'entrada de l'exposició i les representacions del camell que apareixien en les reproduccions fotogràfiques dels gravats. D'altra, hi estaven les imatges de l'exposició prèvia i de la instal-lació dins d'una altra instal-lació i d'una altra exposició que, això no obstant, es tractava essencialment del mateix decorat.

La presència del camell durant la inauguració de l'exposició en el Palau de Belles Arts, i després en la pel-lícula, resultava un poc inquietant, quan no desconcertant. Broodthaers l'elegeix com una figura simbòlica que desvela la intenció del decorat-jardí:

El parc zoològic va prestar-me un camell i me'l van traure fins al lloc on se celebrava l'exposició. Així vam poder filmar-lo relacionant-lo amb el jardí exòtic, veritat? com una relació entre dos exotismes, l'un al què estem acostumats i, d'altra part, un camell, que no està realment en el seu lloc, però que malgrat això, a Europa es considera un animal exòtic. És un animal associat al desert. [...] Per a mi el camell és la incomunicació. Jo diria que la resta no m'interessa. Em refereix 


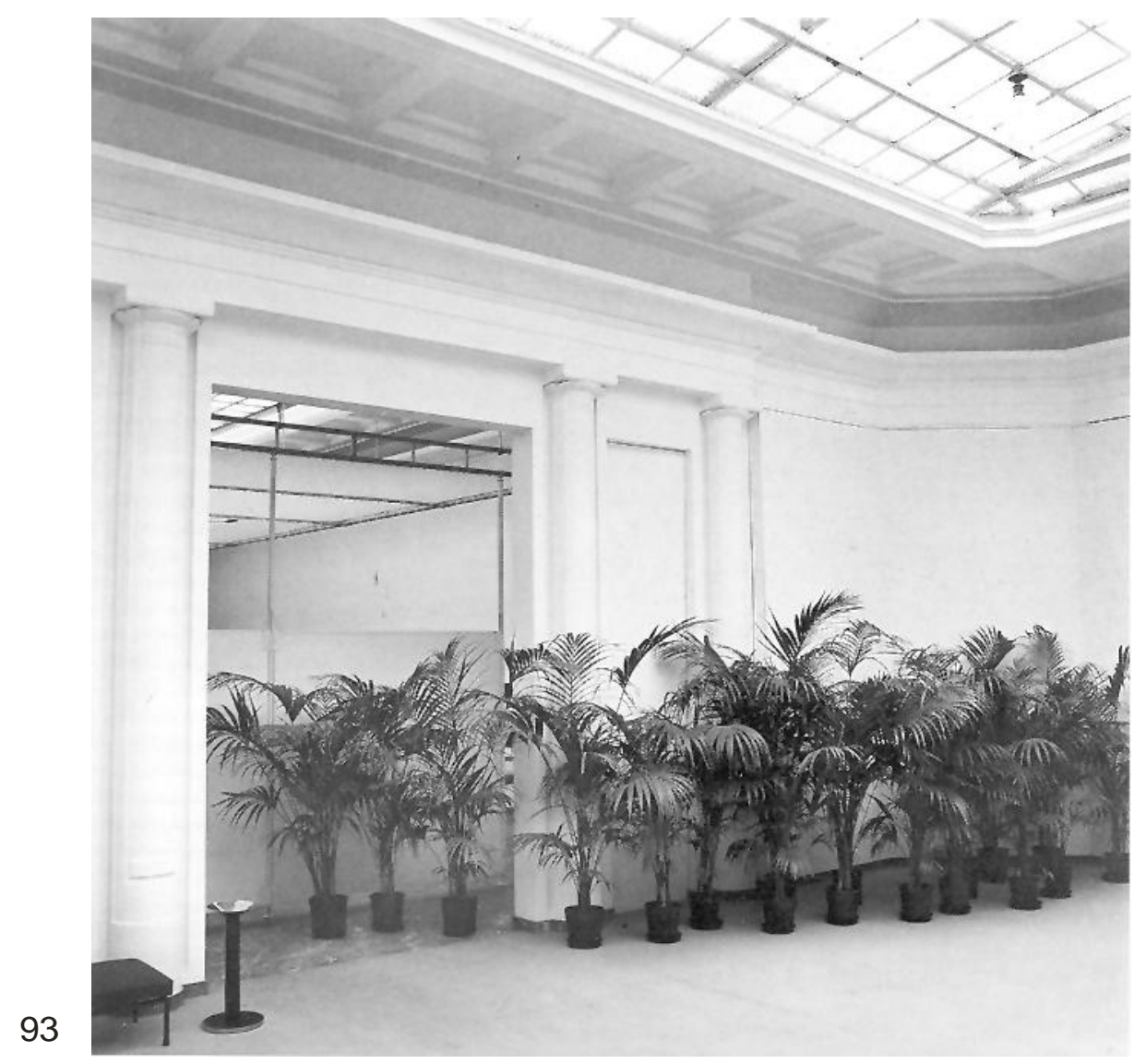

94

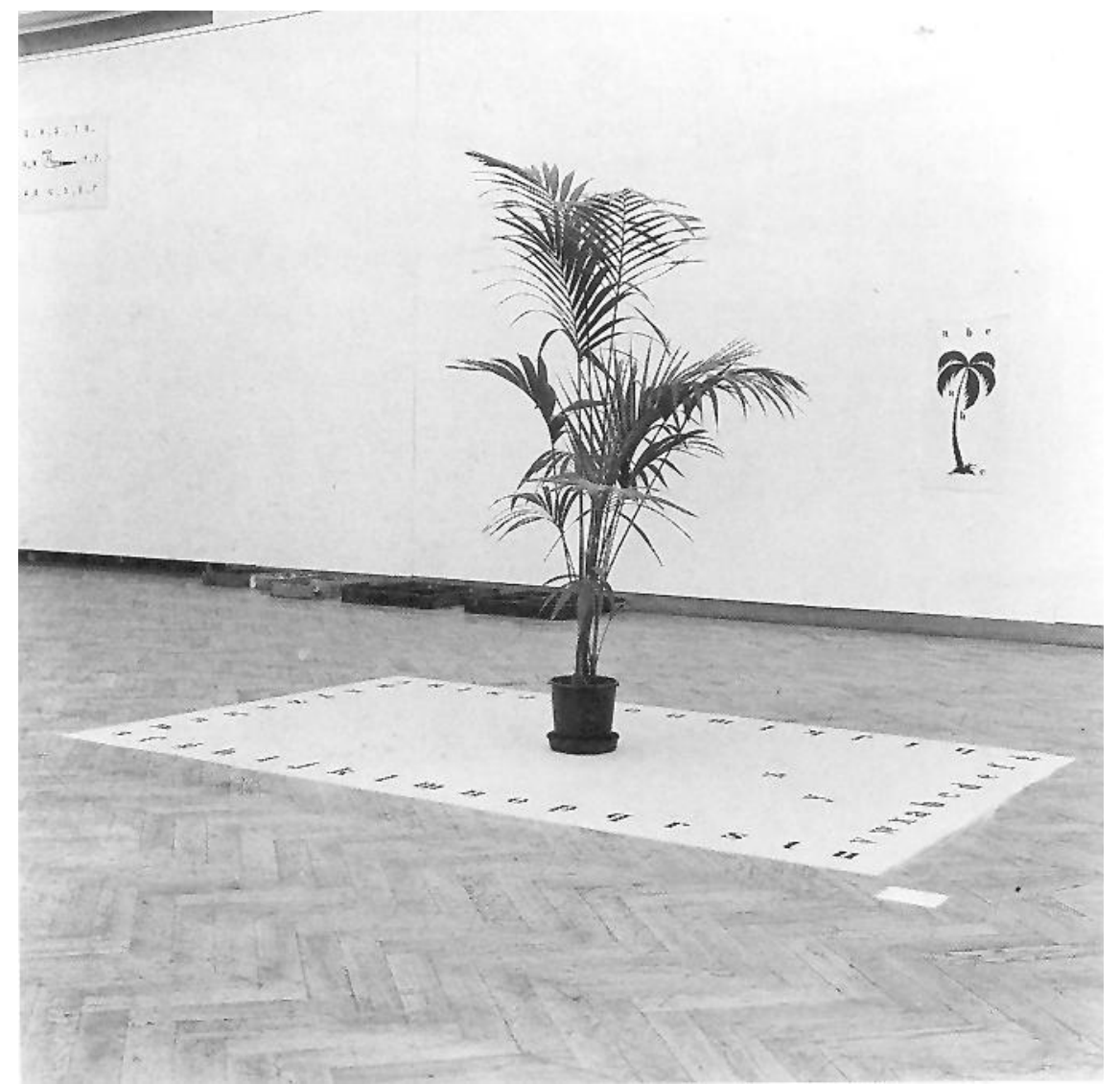




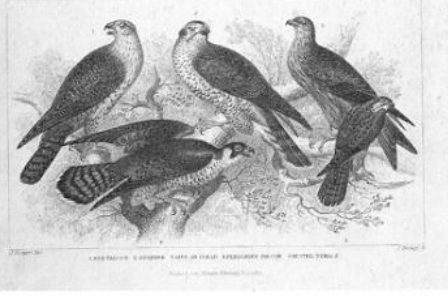

$95 a$
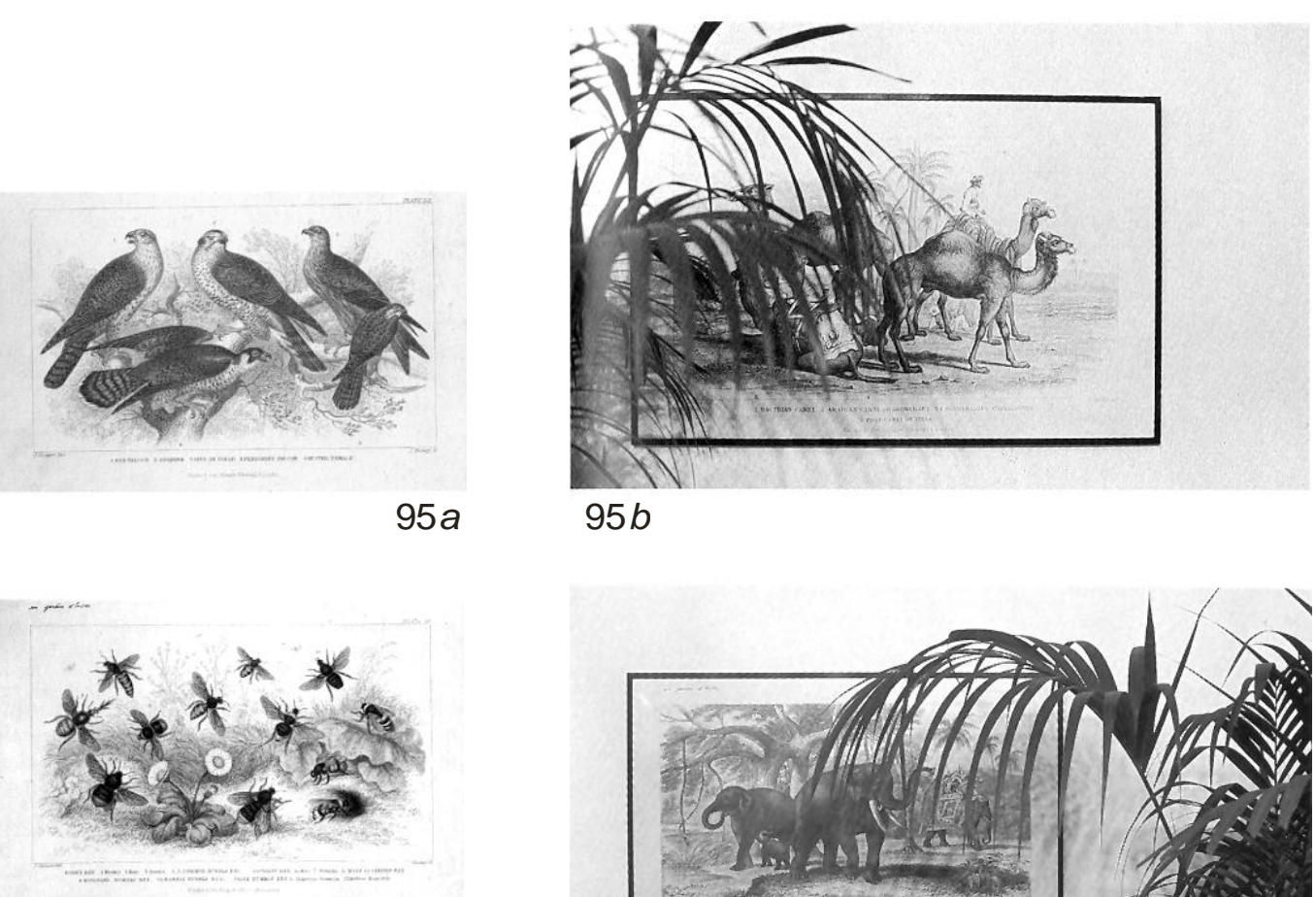

$95 c$

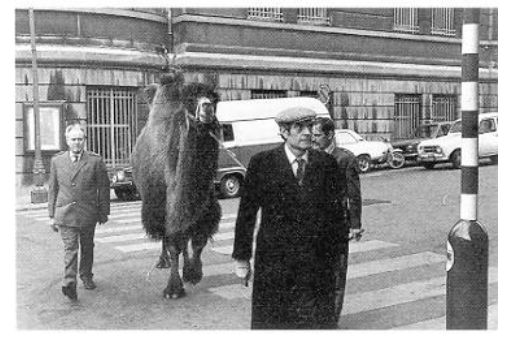

96
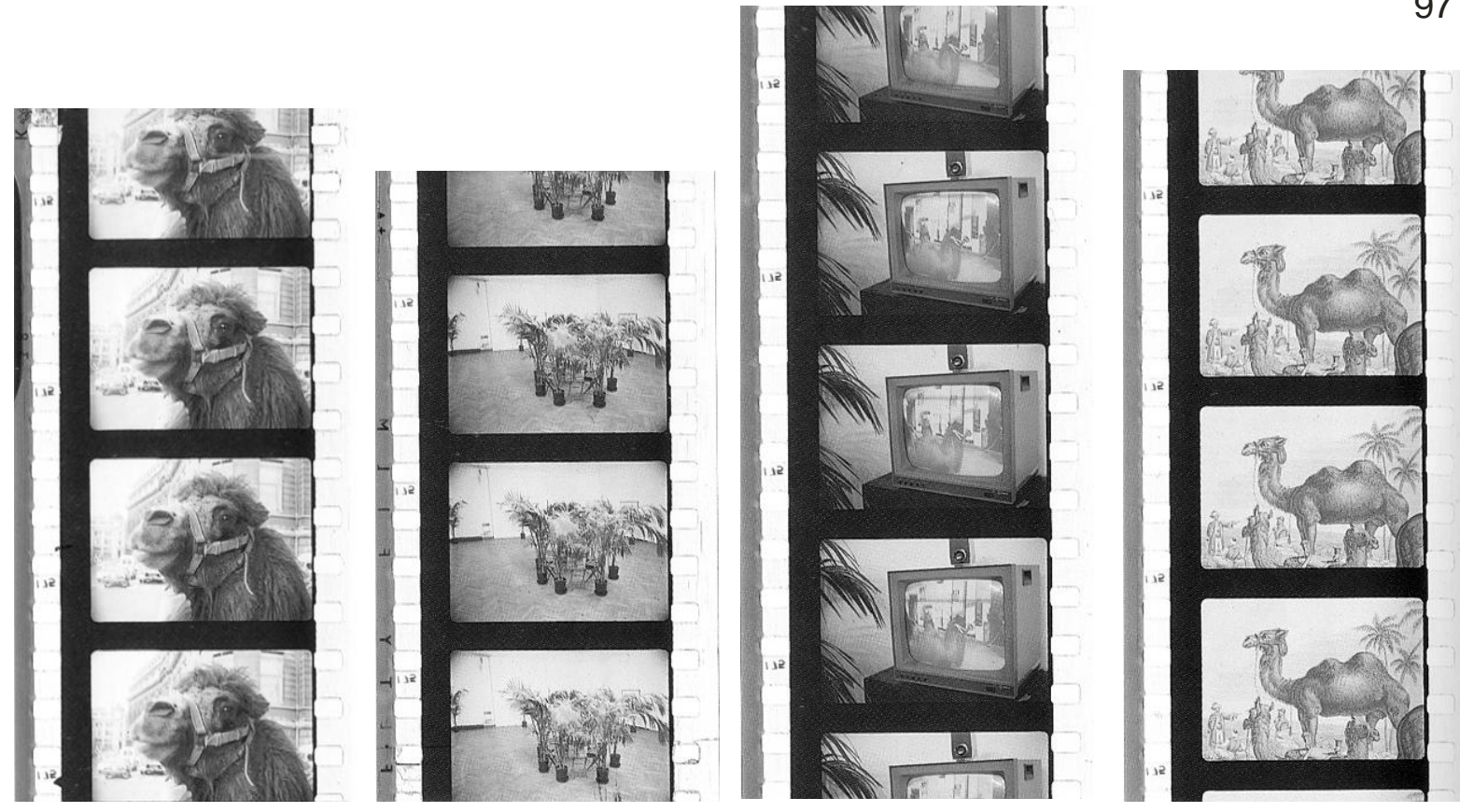
a la palmera, al museu. [...] Però per a mi, el camell és la meua bellesa, i la bellesa entesa com en el poema de Baudelaire: «Je suis belle, ô mortels, come un rêve de pierre». ${ }^{110}$

95. Reproduccions fotogràfiques dels gravats del segle XIX en Jardin d'hiver.

96. Camell pel carrer. Brussel-les, 1974.

97. Pel-lícula Jardin d'hiver $(A B C)$.

Sens dubte, el desenvolupament que fa Broodthaers de la idea del Decor i particularment del jardí com a decorat respon amb cinisme a la interrogació sobre la finalitat dels espais institucionals, assumint-los com una necessitat per a la supervivència de l'art, però representant-los com a món irreal i aïllat de la realitat.

Inicialment, l'analogia entre el jardí i el Musée d'Art Moderne... va ser un comentari irònic i crític sobre la construcció i l'ordenació d'un espai ideal. Però, el jardí com a Decor esdevé una idea recurrent: és una metàfora de l'acte expositiu i una representació del paper de l'art i fins i tot de la cultura com una natura morta en el context de la realitat social.

\subsection{El Museu i el cinema}

La relació entre el Musée d'Art Moderne Département des Aigles com a espai de representació i el cinema és un tema que cal tractar particularment. Des del començament, Broodthaers fa ús del cinema com a part del entramat del Museu fictici. Ací, per exemple, a partir de les imatges gravades durant la jornada inaugural, realitza el film Une Discussion Inaugurale, on combina allò documental amb els elements generats dins de la mateixa ficció Musée d'Art Moderne.... Darrerament, aquest film va estrenar-se com a part de la manifestació Section XIXe siècle (bis) presentada en la Städtische Kunsthalle de Düsseldorf com a part del projecte Between.

Poc després, pel novembre del 1970, Broodthaers inaugura a Düsseldorf una manifestació anomenada Cinéma Modèle, instal·lada en un soterrani llogat en Burgplatz 12. Es tractava d'un espai expositiu més o menys convencional però sense cap vincle institucional. Al poc de temps, pel gener del 1971, Broodthaers transforma l'espai de Cinéma Modèle en la Section Cinéma, una manifestació vinculada al Musée d'Art Moderne, Département des Aigles, la qual es mantingué en funcionament fins a l'octubre del 1972.

En Cinéma Modèle Broodthaers assaja una forma no estandarditzada d'exposició del cinema, al marge dels suports institucionals, on la posada en escena responia a la representació d'una idea del cinema com a reescriptura poètica. Aquesta manifestació estava organitzada en torn de la presentació d'un programa de pel·lícules titulat "Programme La Fontaine", on cadascun dels films feia referència a un artista o a un escriptor representats com a models. El programa estava compost pels títols següents.

\footnotetext{
${ }^{110}$ René Farabet (1975b). "Fragment d'una entrevista amb referència a la pel-lícula Jardin d'hiver (ABC)". En Marcel Broodthaers. Cinéma; op. cit.: p. 247.
} 
98. "Programme La Fontaine" presentat en Cinéma Modèle (quadre de text)

- La clef de l'horloge (Kurt Schwitters)

- Le corbeau et le renard (La Fontaine)

- La pipe (Rene Magritte)

- La pluie (Mallarmé)

- A film by Charles Baudelaire

Així doncs, s'hi produeix una confluència entre una actitud contestatària respecte de l'art i un interés per la percepció artística del cinema. Aquest assaig va funcionar durant cinc setmanes, encara que inicialment s'hi havia planejat per mantenir-se alguns mesos.

Altrament, en la Section Cinéma Broodthaers fa concórrer la ficció del Musée d'Art Moderne amb una idea del cinema. L'espai estava conformat en dues sales independents. La sala més gran era l'espai del cinema o Filmabteilung on tenia lloc la projecció de les pel-lícules. L'altra sala era l'espai Museu on s'hi trobaven una col-lecció d'objectes, diversa documentació i la direcció.

\subsubsection{La Section Cinéma}

En l'espai del cinema tenia lloc la projecció d'un programa de pel-lícules integrat per sis curtmetratges, dels quals tres havien sigut realitzats per Broodthaers i guardaven relació amb la Section XIXe siècle del Musée d'Art Moderne, Département des Aigles; mentre que els altres tres eren muntatges cinematogràfics que representaven diferents aproximacions a la realitat del cinema. Els títols eren els següents:

99. Programa de pel-lícules presentat en la Section Cinéma (quadre de text)

- Une Discussion Inaugurale

- Le Musée et la Discussion

- Un Voyage à Waterloo (Napoléon 1769-1969)

- Brüssel Teil II

- Belga Vox - Mode - 20 th Century Fox

- Charlie als Filmstar

Tant Une Discussion Inaugurale com Le Musée et la Discussion van ser realitzades a partir d'imatges preses durant la jornada inaugural del Museu, encara que constituïen diferents versions del mateix esdeveniment. El primer va projectar-se sobre la pantalla pintada en la paret, mentre que el segon va projectar-se sobre el mapamundi. Altrament, en la sequiència de títols inicials d'Un Voyage à Waterloo (Napoléon 1769-1969) aquest film figurava com la segona part d'una trilogia del Département des Aigles. ${ }^{11}$

\footnotetext{
${ }^{111}$ Une discussion inaugurale va estrenar-se en la manifestació Section XIXe siècle (bis) i possiblement alguns dels elements que apareixen en el film Un voyage a Waterloo (Napoléon 1769-1969) van formar part del muntatge Dokumentation Information. Cf. el capítol "Els objectes en el Musée d'Art Moderne".
} 
D'altra banda, Brüssel Teil II era un curt turístic sobre Brussel-les realitzat per les productores Globus Films i Filmoffice que va comprar Broodthaers en una botiga d'aficionats. El curt Charlie als Filmstar era un recull de sequiències d'una pel-lícula de Chaplin realitzat per la productora Globus Film, mentre que Belga Vox - Mode $-20^{\text {th }}$ Century Fox era un documental realitzat a partir de fragments de noticiaris exhibits en sales de cinema i de trossos de pel-lícula desaprofitats. ${ }^{112}$

Així doncs, el conjunt de pel-lícules del programa pretenia documentar els diferents aspectes del funcionament del Musée d'Art Moderne i del cinema com a indústria. D'una banda, els curtmetratges del Museu representaven la realitat de la institució fictícia i, de l'altra, els muntatges de les productores imprimien un matis de ficció a la realitat del cinema.

\subsubsection{L'espai del cinema}

En l'espai del cinema, Broodthaers rebutja la presentació convencional de les pel-lícules. Va començar per delimitar una gran superfície blanca en la paret com a pantalla de projeccions. A continuació hi va pintar uns rectangles negres amb inscripcions - fig.0, fig.l, fig.2, fig. 12 i fig. A - escampades per tot el requadre; i finalment va pintar de negre la resta de la paret. Tanmateix, la pantalla de projeccions no era un element neutral, sinó un suport que intervenia en la percepció de la pel-lícula ja que la imatge fílmica se superposava a les inscripcions. També hi havia un mapamundi polític que, circumstancialment, Broodthaers va utilitzar com a pantalla de projeccions.

En el centre de l'espai del departament de cine podia veure's el projector amb què es projectaven les pel-lícules i al costat de la pantalla hi havia dues cadires de director arrimades a la paret amb la inscripció fig. 2. En un racó de la sala hi havia una prestatgeria amb una bobinadora i una moviola; i al fons hi havia una taula on s'havia instal-lat un taller fotogràfic.

En projectar-se les pel-lícules sobre la pantalla pintada, la imatge fílmica se superposava a les inscripcions. La juxtaposició afectava la percepció de la imatge cinematogràfica, la desvinculava de la idea de moviment i l'associava a un sistema de lectura. Però el moviment de la imatge feia totalment inestable i arbitrària la designació. Totes les imatges quedaven deslligades del context de la pel-lícula i semblaven il-lustracions d'una abstracció.

100. Dibuixos preparatoris de la Cinéma Modèle i de la Section Cinéma (pàgina següent)

101. Pantalles de projeccions en l'espai del cinema (pàgina següent)

102. Detall de les pel-lícules projectades en la Section Cinéma (pàgina següent i plego interior )

\subsubsection{L'espai Museu}

Altrament, en l'espai Museu hi havia una exposició d'objectes diversos organitzats al llarg de dues parets contigües, una pintada de blanc i l'altra de negre. En la paret blanca hi havia pintades una sèrie d'inscripcions - fig.1, fig.2, fig.12, fig.1\&2, o fig.A - al costat de diferents objectes ordenats. Entre aquests hi havia un mirall, una pipa, una bomba de fum, un rellotge, un calendari, un antifaç, etc. Hi completaven el conjunt altres objectes que també portaven

\footnotetext{
${ }^{112}$ En les referències sobre el film Belga vox - Mode $-20^{\text {th }}$ century Fox no s'aclareix si va ser realitzat per Broodthaers o per les productores esmentades. Cf. "Section Cinéma, gener del 1971". En Marcel Broodthaers. Cinéma; op. cit.: p. 143-153.
} 


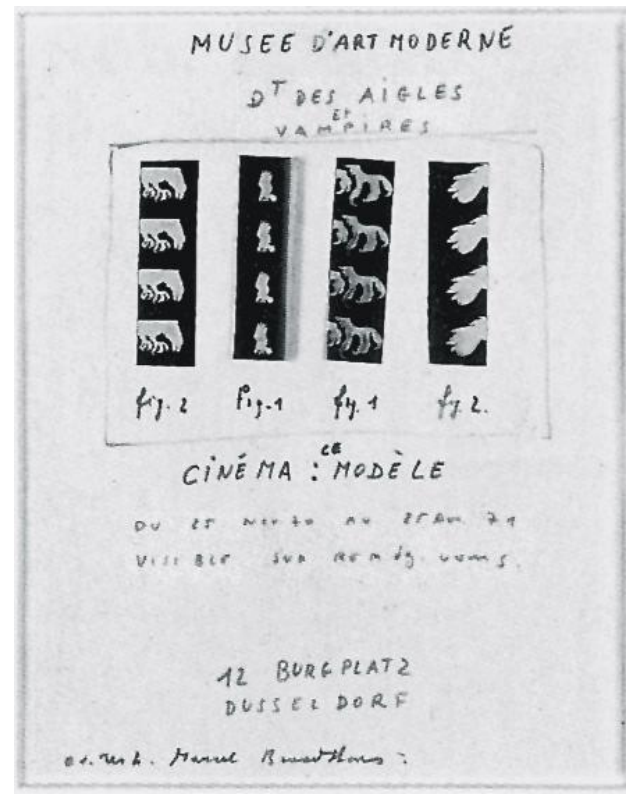

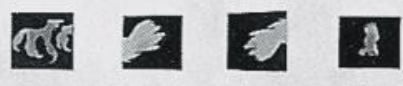

ige fir fis fige

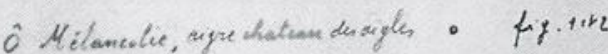

$\hat{o}$ bastense envol de camonds sandages. Hy sety

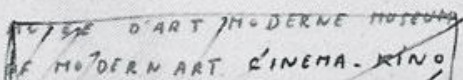

, YDÜSSESDORF

I2 BURGPLATZ BROODTHAERS ,

$100 a$

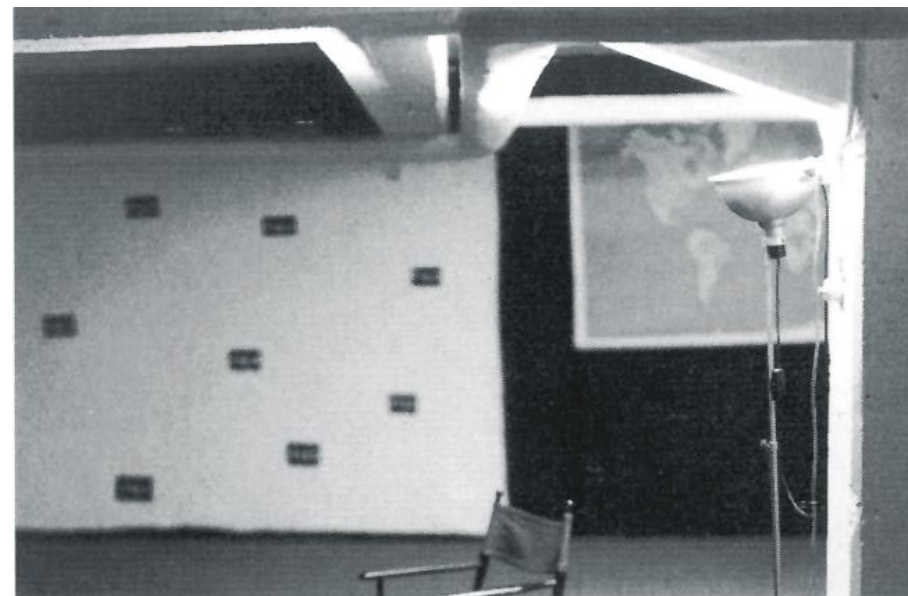

$101 a$

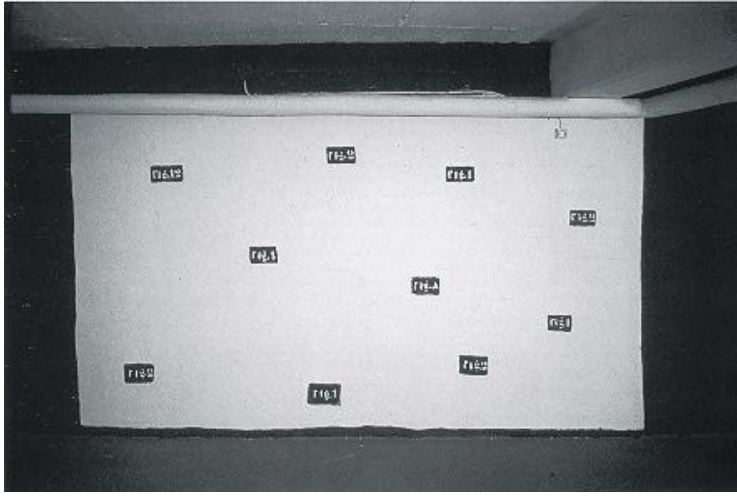


102a Une discussion inaugu rale
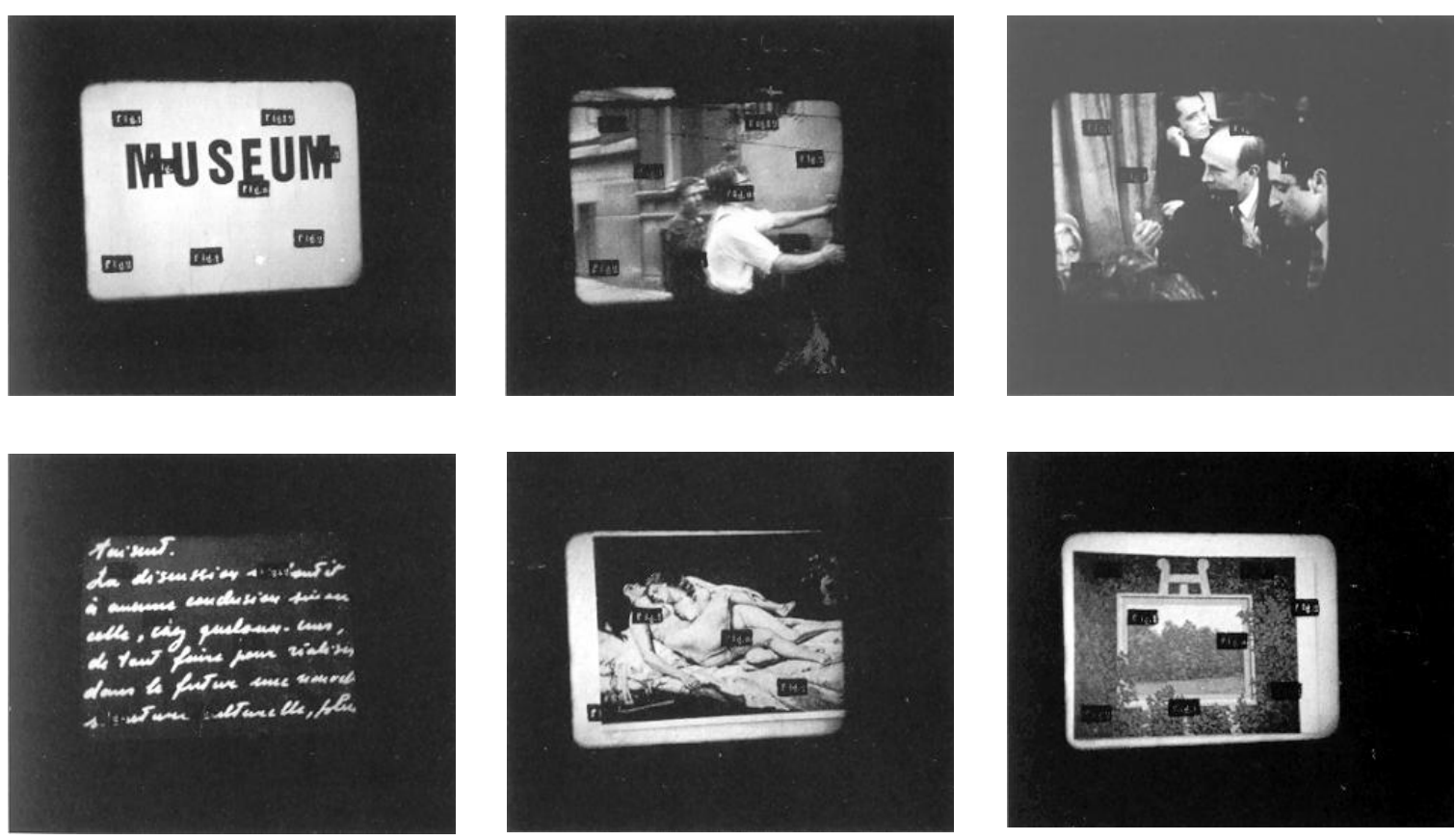

102b Le Musée et la discussion
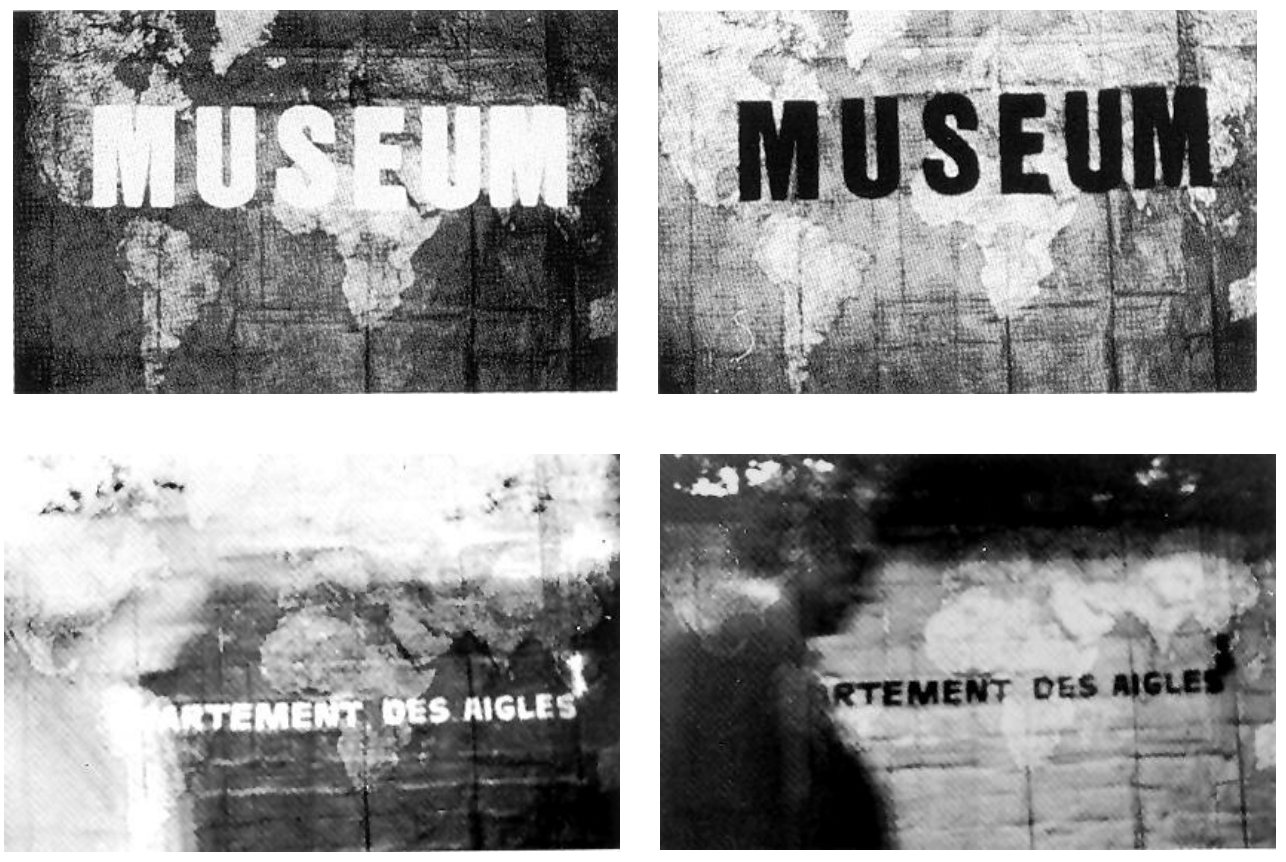
102c Un voyage à Wareloo (Napoléon 1769 - 1969)
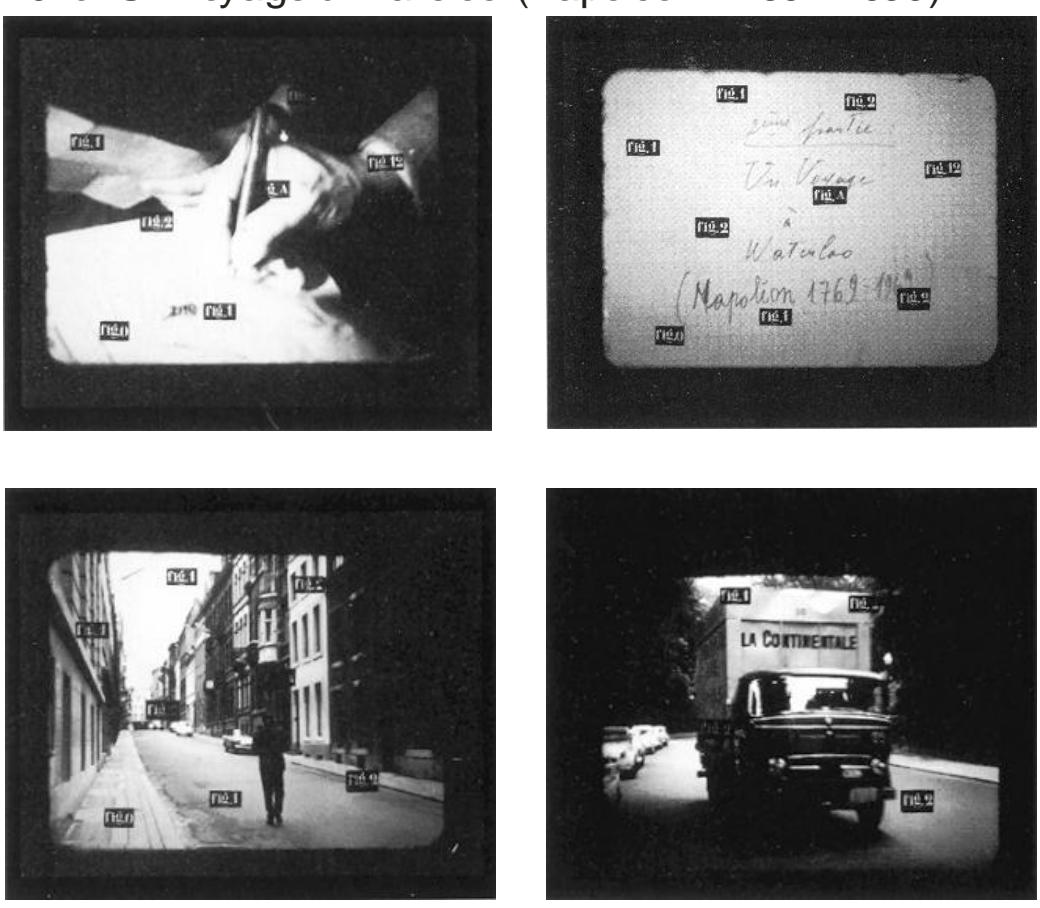

102d Brüssel Teil
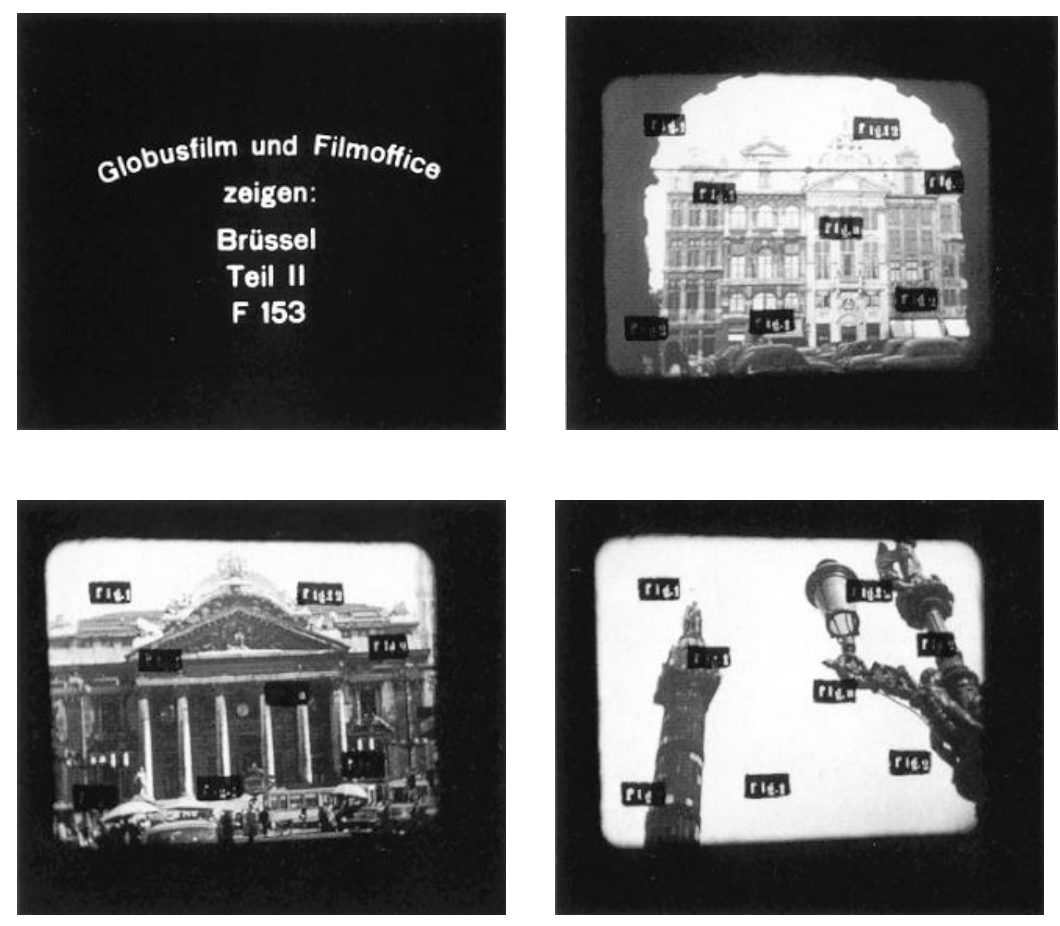
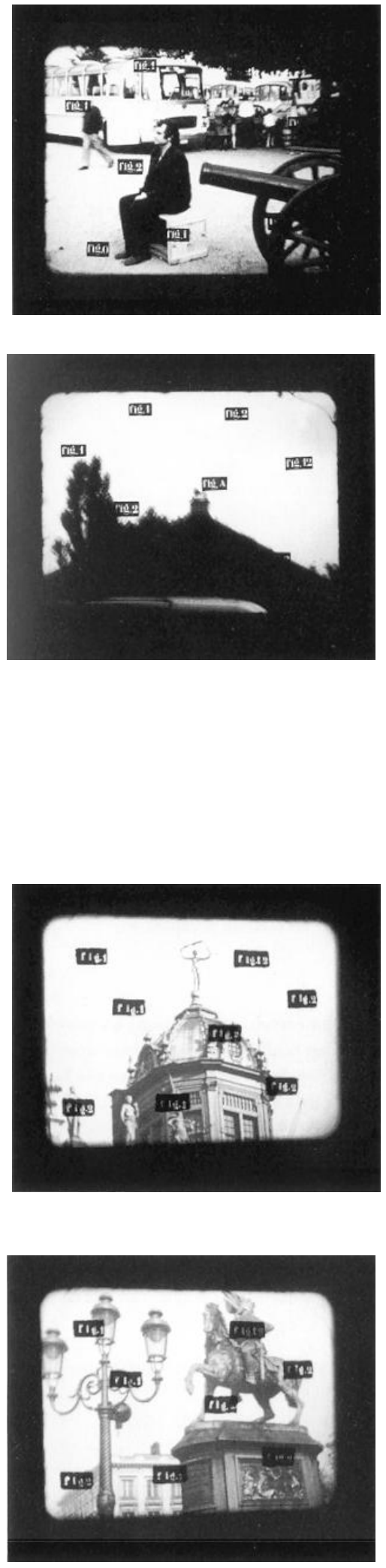
102e Belga vox - Mode - 20ht century Fox
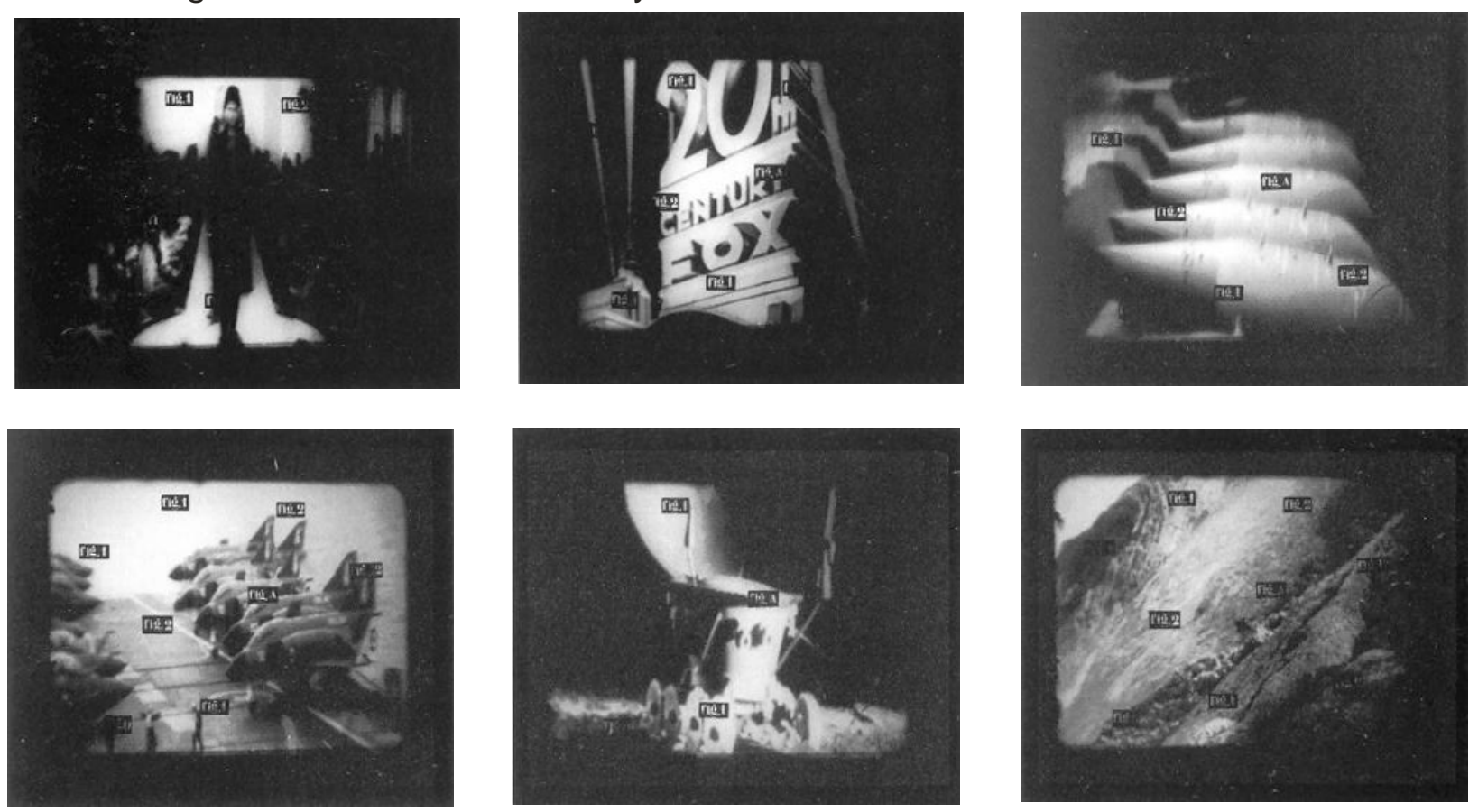

$102 f$ Charlie als Filmstar
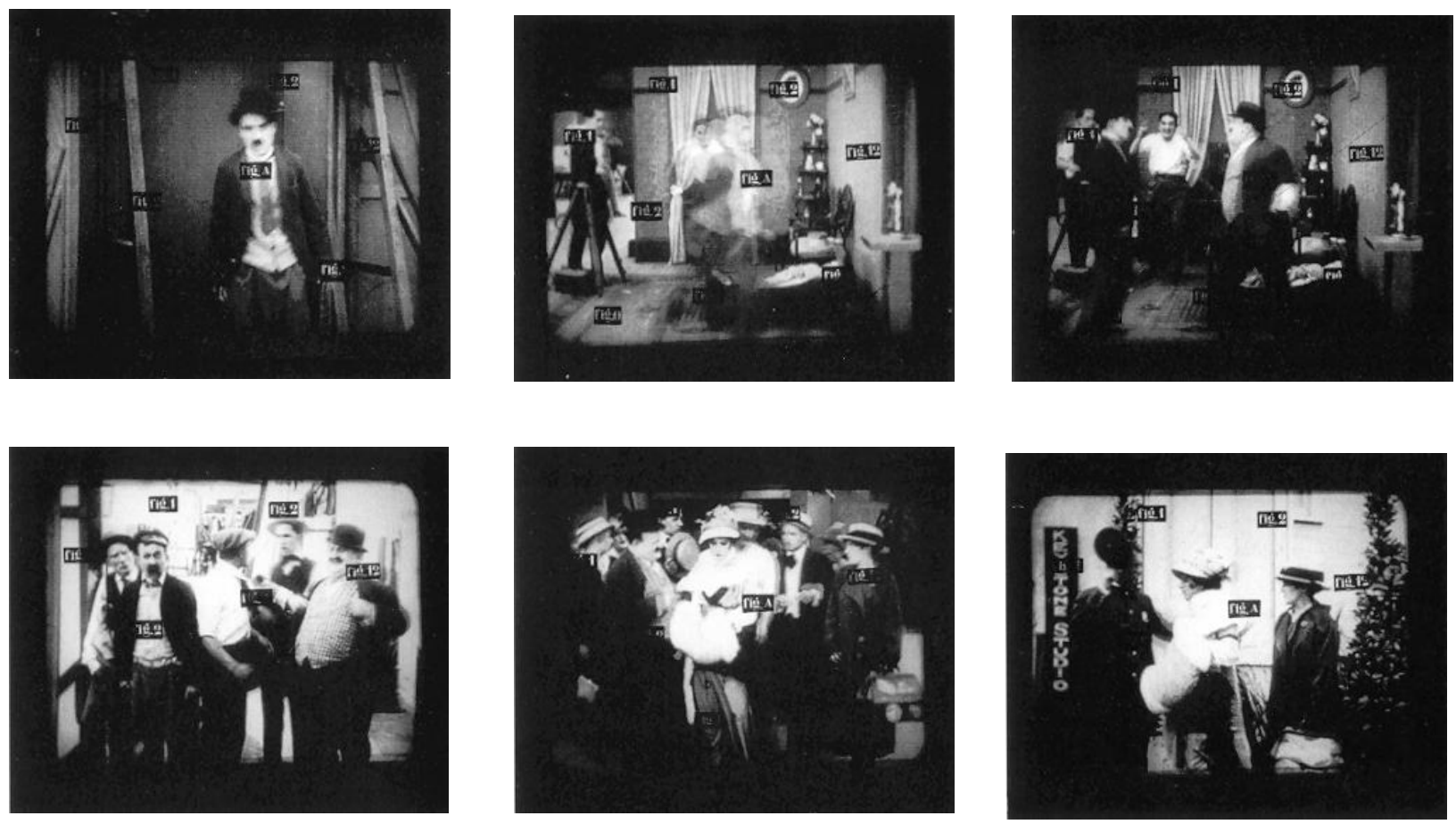

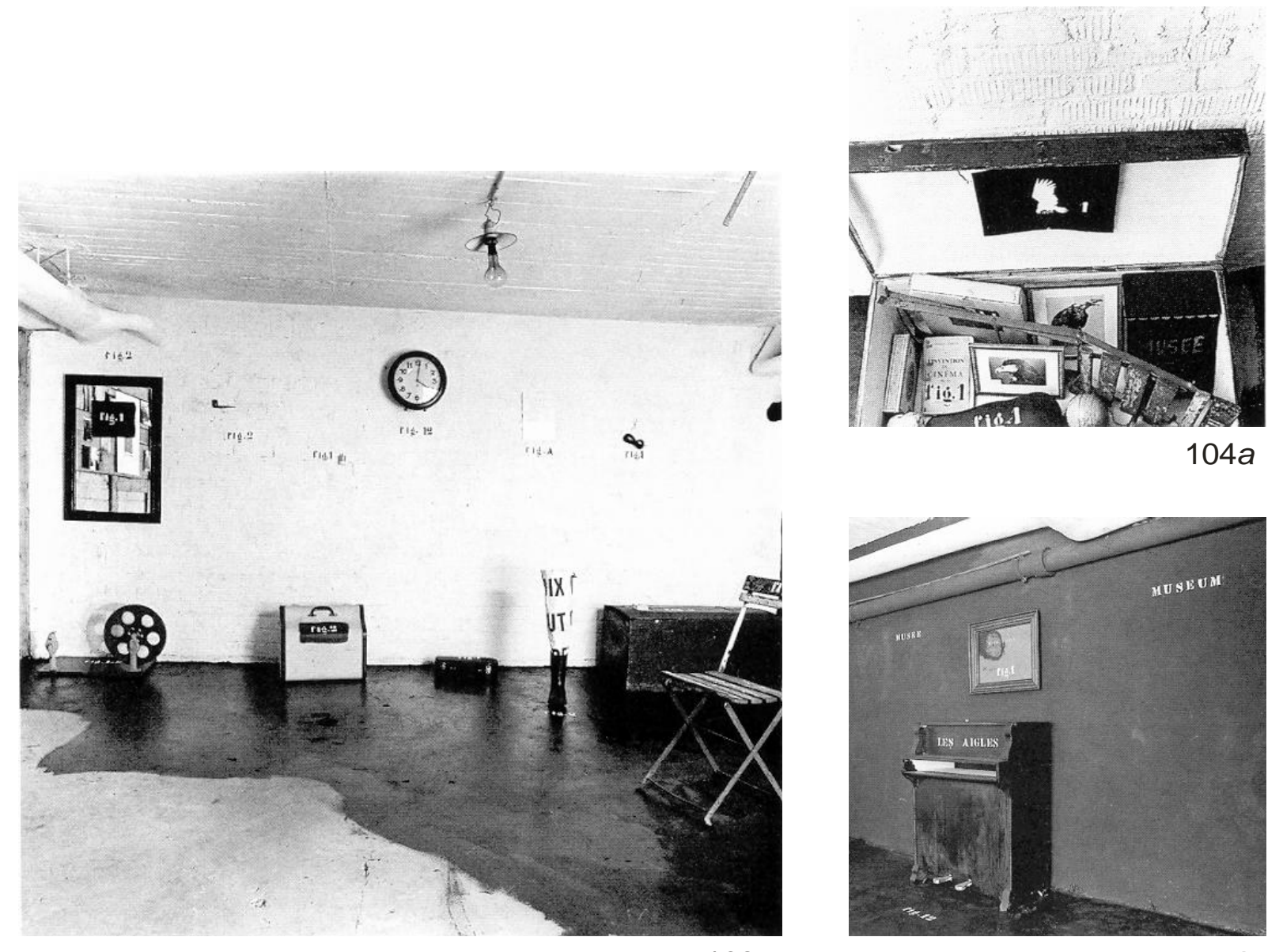

$$
103 a
$$
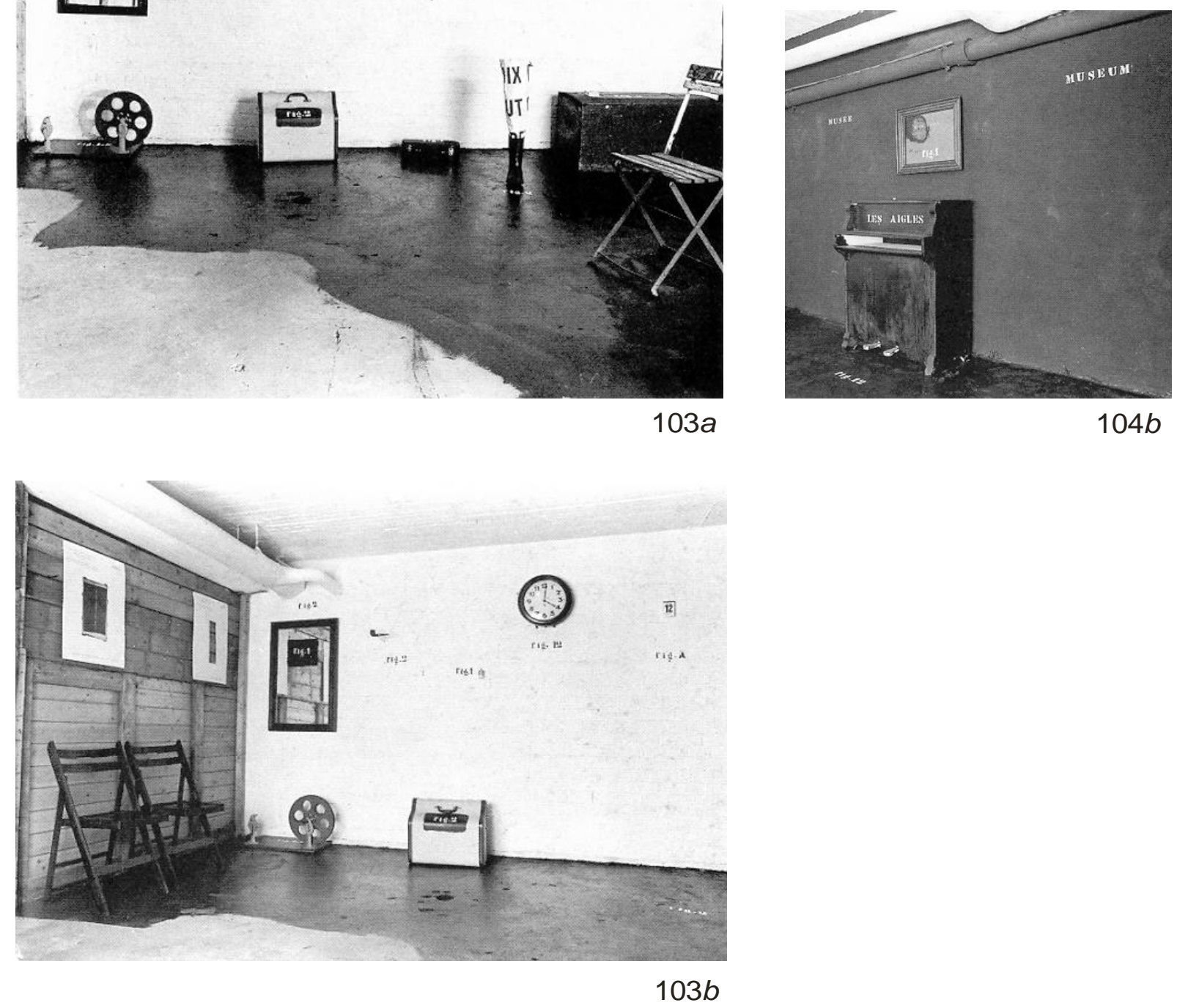
inscripcions: un cofre, un llum i un piano amb la inscripció Les Aigles. El cofre, per la seua part, contenia una altra sèrie d'elements: un dibuix de la silueta d'una àguila, una cadira plegable, un petit globus terraqüi, una caixa d'havans, una funda de violí, una caixa de cartó, el llibre de Georges Sadoul, L'invention du cinéma, etc.

Enfront de la paret negra hi havia un panell de fusta i una porta d'entrada que comunicava ambdós espais. Oposada a la paret blanca hi havia una altra prestatgeria on es trobava la documentació personal de Broodthaers, composta de pel-lícules així com de carpetes amb documents i fotografies.

L'exposició dels objectes s'estructura en dues composicions o conjunts de dotze elements cadascun. L'un és la sèrie d'objectes designats com a figures que estan escampats per tota la sala, i l'altre és el contingut del cofre i ell mateix. Però hi ha dos objectes que són part de ambdues composicions: el cofre i la cadira plegable. El cofre és simultàniament continent i contingut; la qual cosa, a un altre nivell, representa l'espai Museu mateix. D'altra banda, la cadira que igual podia estar plegada dins del cofre que desplegar-se en la sala estableix un intercanvi de representacions. Hi representa l'espectador i alhora el director què al mateix temps representa l'exposició. Així doncs, Broodthaers convida l'espectador a assumir-se com a director mitjançant l'exercici de lectura.

103. L'espai Museum en la Section Cinéma

104. Detall del contingut del cofre i de la paret de la dreta en l'espai Museum (Section Cinéma)

Els objectes s'hi exposen com una representació de si mateixos, la qual cosa trasllada la quiestió a l'espai, o siga, a les circumstàncies de la seua exposició. Per a Broodthaers, la relació entre els objectes mitjançant els nombres o la denotació com a figures els feia "intercanviables sobre l'escenari d'un teatre". ${ }^{113}$ Consegüentment, la seua significació no està únicament en aquests mateixos; més prompte en formen part d'un decorat el qual tampoc posseeix una entitat pròpia com a espai sinó que és construït en funció d'una espacialització de les idees, d'una representació del Museu i del cinema. Aquesta idea d'exposició com a espai de representació remet a la idea d'espai de Mallarmé. ${ }^{114}$

Broodthaers adverteix que els objectes privilegiats amb dues xifres són particularment significatius. ${ }^{115}$ Així doncs, en l'espai Museu la fig.12 designa el rellotge i el piano. Al costat del rellotge hi ha un calendari, designat amb la FIG. A, que s'ha detingut en el 12 de febrer. Aquesta fig. 12 és una referència a Mallarmé, al temps immòbil que per a Mallarmé representa l'hora de la mitjanit. Un rellotge marcant les dotze hores també apareix en unes plaques de plàstic amb la llegenda Cinéma Modèle.

Aquesta mitjanit suggereix a Broodthaers una idea d'excel-lència, de plenitud. És un temps detingut que connota, alhora, final i començament i que condensa l'espai: el fa present, el fa objecte. Broodthaers relaciona l'instant detingut de la mitjanit de Mallarmé amb les 24 imatges per segon que componen el moviment cinematogràfic mitjançant la duplicació de la xifra 12. Així doncs, cada remissió al mateix significant i cada repetició multiplica els significats i crea una cadena de connotacions.

\footnotetext{
${ }^{113}$ I. Lebeer (1974); op. cit.

114 Vegeu el capítol 2.6 "L'espai de Mallarmé" i també J.C. Royoux. "Project pour un texte: El modelo cinematográfico en la obra de Marcel Broodthaers". En Marcel Broodthaers. Cinéma; op. cit.: p. 300.

${ }^{115}$ Cf. F. Spillemaeckers (ca. 1971). "Comentaris sobre la Section Cinéma". En Marcel Broodthaers. Cinéma; op. cit:: p. 159.
} 
Una altra volta, la designació com a figures podia donar als objectes una funció il-lustrativa mentre que la numeració semblava una forma d'ordenació. No obstant això, la repetició dels mateixos nombres i del mateix procediment hi resultava arbitrari i incomprensible. Broodthaers ho explica amb detall referint-se a l'ordenació de l'espai Museu:

1. Es plantegen dos sistemes:

a) un joc de dotze referents que es manifesta mitjançant la mostra del contingut del cofre, podríem dir l'exposició, perquè és l'únic conjunt que s'ofereix com un enigma a resoldre;

b) aquest mateix cofre està contingut en una sèrie de figures que no s'ofereixen com a figures, sinó únicament en forma de repeticions successives. [...] si eixim del circuit tancat [la part anomenada «a)»] i si ens tornem cap allò que deuria ser la seua motivació - allò que constitueix la motivació, ja que es tracta d'un conjunt d'objectes, o més exactament, un joc d'objectes inventat en el recinte d'un museu de ficció (Musée d'Art Moderne, Département des Aigles) i alimentat per ella (aqueix joc d'objectes no és un element constitutiu del museu) constatem que, en aquest nivell, l'objecte del món ja sols està present com a figura en un sistema binari (quasi perfecte) de significació (fig.l i fig.2; mescla de fig.l i de fig.2 en fig. 12 i en fig. 1 \& 2). La referència última resulta ser, doncs, imatge en si mateixa. [...]

2. Hem considerat que la fig. A quedava més o menys fora del sistema i que els objectes privilegiats amb dues xifres eren particularment significatius. En aquest simbolisme dels nombres el cinc és l'únic; [...] tornem a trobar-lo sobre l'únic objecte que manca de tota implicació cultural o simbòlica: és una caixa de cartó que no hi aporta cap d'informació, una caixa dins d'una altra. És que hi ha un sistema de relació entre la informació del nombre i la informació de la figura? És que la redundància i la informació de la imatge i el nombre es troben en raó inversa? Sí, aquest signe de desordre obriria també un nou sistema. [...]

3. Hem indicat, doncs, algunes possibilitats de la cadena de referències, la relació eventual entre la informació i la redundància [...] i l'ús de la similitud i la contigüitat com a principis d'associació. Els objectes estan aillats, la repetició reforça l'aïllament tornant-los idèntics a si mateixos d'un mode absolut. És un univers discontinu ja que cada objecte està solament com a representació, com a figura [...] Queda la matriu lingüística (joc sobre el concepte mateix de continent i de contingut), que es registrarà com un lament hipòcrita de la destrucció de l'objecte per la lingüística, així com un intent de relacionar la figura com a representació visual d'una forma amb la figura com a representació del llenguatge. ${ }^{116}$

Pel juny del 1972 el conjunt d'objectes de la Section Cinéma va ser venut per mitjà de la galeria Wide White Space i adquirit pel museu de Mönchengladbach, la qual cosa va traure algunes transformacions en l'espai. En llevar els objectes de l'espai Museu, Broodthaers va rescriure amb lletres més grans el rètol fig.12 que estava assignat al rellotge. La resta d'inscripcions de la paret va deixar-les igual. També va posar Département des Aigles, 24 imatges / segon en un dels taulons de la prestatgeria. Altrament, en l'espai del cinema, Broodthaers va escriure la paraula silenci sobre la paret en quatre llocs diferents; sobre una biga va posar una sèrie de nombres $21 / 12$ / 0 / 2 i va pintar en roig el rètol Section Cinéma de l'entrada. La nova ordenació va mantenir-s'hi fins a l'octubre del 1972 quan va tancar.

105. L'espai modificat arran de la venda dels objectes de l'espai Museum en la Section Cinéma (1972).

${ }^{116}$ F. Spillemaeckers (ca. 1971); op. cit. 

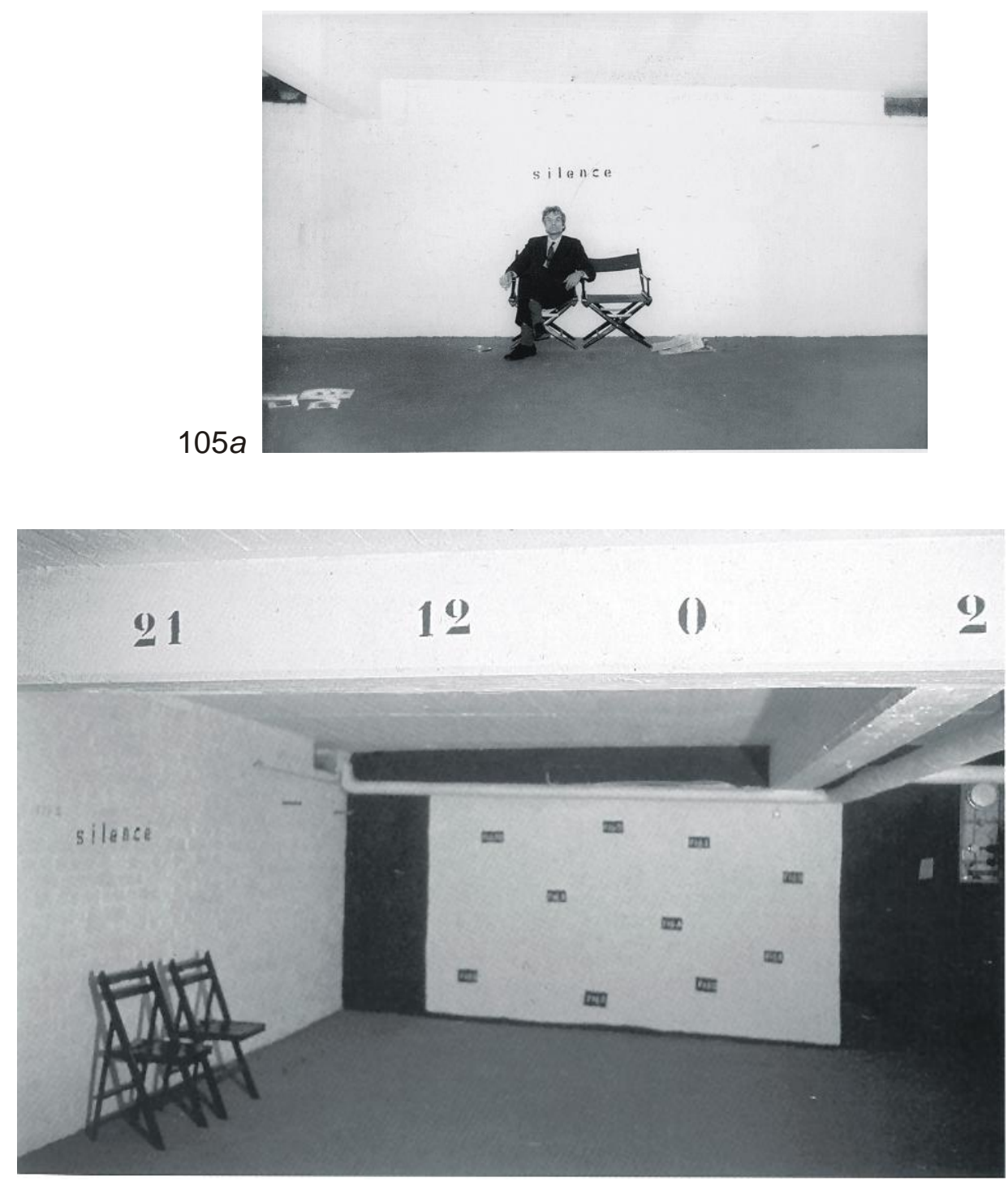

$105 b$

$105 c$

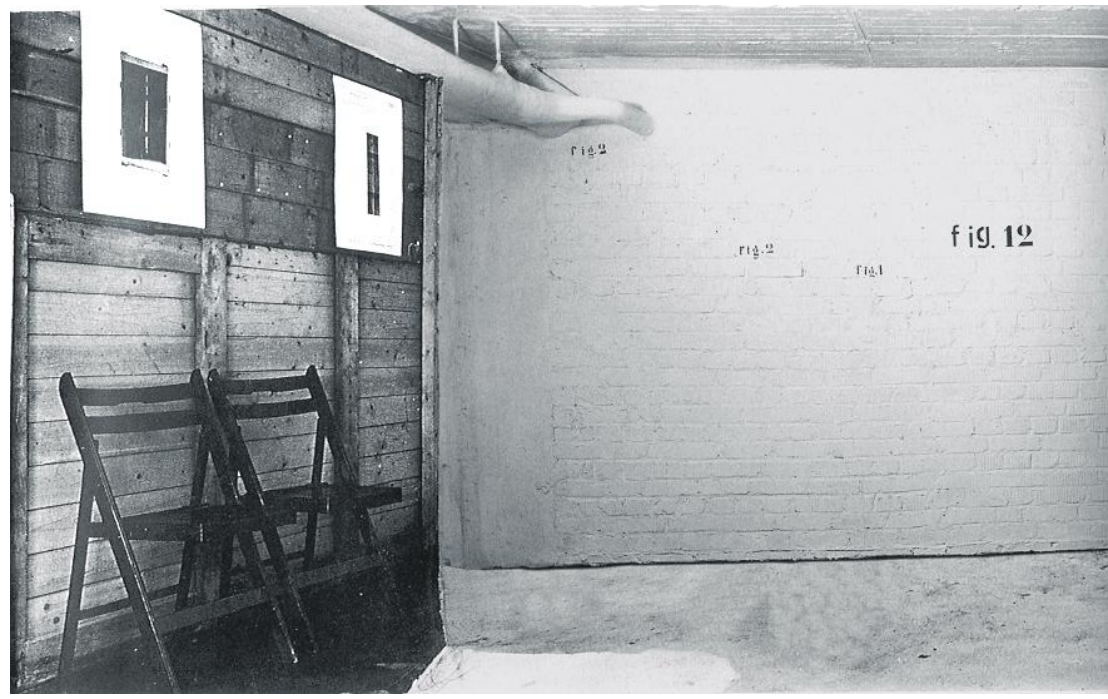


Consegüentment, sembla que més que d'una col-lecció d'objectes, es tracta d'un sistema subjecte a unes determinades condicions d'exposició generades a partir de la ficció del Museu. D'una banda, el desfasament de l'objecte amb la seua designació suspén la relació entre significant i significat $i$, de l'altra, remet a la qüestió de la representació plantejada per Magritte. Però, Broodthaers no hi aporta cap representació, ni verbal ni visual, sinó que procedeix directament a crear un sistema instrumental propi.

En aquest sistema, la significació dels objectes ha sigut abolida i resulta impossible explicar-los ailladament. Sembla que els objectes es remeten els uns als altres com a referents d'un text criptografiat. Broodthaers mateix justifica aquest joc d'objectes com "una trobada esperada de funcions diferents". ${ }^{117}$ L'ordenació espacial i la textura llegible que articula els objectes moral i materialment indueix a pensar que el conjunt d'objectes de l'espai Museu ha de percebre's com un assemblage abans que com una col-lecció i que, alhora, està subjecte als mateixos procediments de representació i d'intercanvi que qualsevol altre objecte. ${ }^{118}$

En resum, el propòsit de Broodthaers en la Section Cinéma és fer confluir la idea del Museu i una idea del cinema. Si el cinema representava un procediment i una forma de llenguatge, el Museu representava un espai de confrontació i d'intercanvi d'idees, un espai de comunicació. Malgrat tot, Broodthaers és conscient de la "dificultat de construir una imatge el sentit de la qual no siga un reflex de la mateixa màquina i del mateix mecanisme". ${ }^{119}$

Tanmateix, les pel-lícules de Broodthaers ultrapassen els estàndards cinematogràfics i la manifestació Section Cinéma era, sobretot, un ambient subjectiu què s'apropava més a la noció de Decor que no a la idea de Museu. De fet, va acabar per independitzar-se del projecte global del Musée d'Art Moderne Département des Aigles. ${ }^{120}$

\subsection{Les exposicions i el cinema}

En els projectes de Broodthaers, l'organització de la situació expositiva en funció de l'obra cinematogràfica implica, en principi, un reforçament de la idea del cinema com a art enfrontada a una noció del cinema com a espectacle d'entreteniment. Alhora, el caràcter instrumental del cinema de Broodthaers abasta de manera particular la percepció de la pel-lícula, a més a més de l'exploració de les possibilitats discursives del cinema, amb la qual cosa, el marc de presentació constitueix una circumstància significativa.

Per l'octubre del 1971 Broodthaers va fer una exposició anomenada "Film als Objekt Objekt als Film" en el museu estatal de Mönchengladbach on va presentar un recull de les seues pel-lícules juntament amb diapositives, objectes i obres que hi estaven relacionades. Broodthaers s'hi proposa la lectura d'ambdues manifestacions, la projecció i la l'exposició, com a il-lustracions a partir de la presentació de les pel-lícules i dels objectes com a elements intercanviables, com a accessoris de la representació.

\footnotetext{
${ }^{117}$ Vegeu I. Lebeer (1974); op. cit.

${ }^{118}$ Sobre la idea de col·lecció en l'organització de l'espai de la Section Cinéma, vegeu J. C. Royoux; op. cit.: p. 303 i 309 .

${ }^{119}$ M. Broodthaers citat per C. David "El museo del signo". En Marcel Broodthaers.Ma., op. cit.: p. 17 - 22. [L. Beckers. "Gesprek met Marcel Broodthaers". Museumjournaal, 15 febrer, 1970: p. 66-71 (Entrevista amb M. Broodthaers (13 / 12 / 1969)]

${ }^{120}$ Finalment, Broodthaers va eliminar la Section Cinéma del conjunt de manifestacions del Museu. En el catàleg de l'exposició "Catalogue-Catalogus" va publicar la "Genealogia de les activitats del Musée d'Art Moderne, Département des Aigles" i no hi apareixia la Section Cinéma. Cf. J. C. Royoux; op. cit.: p. 308.
} 
La mostra ocupava quatre sales independents i cada espai representava una projecció diferent. N'hi havia dues per a la projecció de les pel-lícules i altres dues per a les diapositives. Un dels espais estava condicionat com a sala de cinema amb un pati de butaques i una pantalla blanca convencional. S'hi va projectar el programa següent.

106. Pel-lícules en la sala amb pantalla convencional. Exposició "Film als Objekt - Objekt als Film".

- La clef de I'horloge (Kurt Schwitters)

- Une seconde de eternité (Ma signature)

- La pluie (Project pour un texte)

- $M T L(D T H)$

- La pipe (Rene Magritte)

- Un film de Charles Baudelaire (Carte politique du monde ou systéme de signification)

- Histoire de amour (Dr. Huysmans)

- Le poisson (Le poisson)

107. Pel.lícules projectades sobre les pantalles plegables. Exposició "Film als Objekt - Objekt als Film".

- Section XIXe siècle (Musée d'Art Moderne, Département des Aigles)

- Fig.0, Fig.1, Fig.2, Fig. A (This and others films)

- Le corbeau et le renard (La Fontaine)

En l'altra sala relacionada amb el cinema la projecció de les pel-lícules s'allunyava dels estàndards. Els films corresponents al programa de la Section Cinéma es projectaven sobre una pantalla plegable que portava les inscripcions fig.O, fig.1, fig.2 i fig.A. Igualment, la pel-lícula Le corbeau et le renard es projectava sobre una altra pantalla plegable amb un text pintat. Ambdues pantalles estaven penjades en la paret, l'una sobre l'altra, i es desplegaven de forma alternativa. En les parets d'ambdues sales podien veure's obres i objectes relacionats amb les pel-lícules. ${ }^{121}$

En un altre espai tenia lloc la projecció d'una sèrie de diapositives de reproduccions de quadres del segle XIX que feia servir com a pantalla una caixa de fusta de les que s'empren per al transport de quadres; mentre que en la paret hi havia una sèrie de targetes postals de quadres del segle XIX. En l'últim espai hi havia tres projectors de diapositives projectant la signatura de Broodthaers sobre tres obres emmarcades. ${ }^{122}$

Broodthaers hi inverteix la significació dels elements: exposa les pel-lícules i les diapositives com a documents al temps que disposa les obres i els objectes com a elements d'un decorat. Però, en la visualització de les imatges projectades resultava que els objectes i les obres funcionaven com a parament de les pel-lícules i de les diapositives. Llavors, les imatges esdevenien alhora documentació i escenificació.

\footnotetext{
${ }^{121}$ D'objectes hi havia una pipa i un rellotge els quals apareixien en el film Le pipe i també una arruixadora, una cadira de jardí i un cofre com els utilitzats en el film La pluie. La majoria d'aquests objectes també formaven part del conjunt de la Section Cinéma. Entre les obres hi havia uns dibuixos sobre la idea de la pel-lícula Une seconde d'éternité, així com Carte politique du monde per Un film de Charles Baudelaire i les pantalles especials de l'edició Le corbeau et le renard, a més a més d'esbossos i d'anotacions per al muntatge de les pel-lícules.

${ }^{122}$ Es tractava de les obres: Où est la signature? (1971), Signatur? (1971) i Projektion (1971).
} 
Tanmateix, en la mesura que la pel-lícula se serveix de l'exposició com a espai de representació, està subjecta a les circumstàncies de l'acte expositiu. La pel-lícula esdevé un altre element de l'escenificació que fa referència a una abstracció. Per exemple, la pel-lícula MTL $(D T H)$ gira entorn al text de la targeta d'invitació d'una exposició, el qual estava pintat sobre el vidre de l'aparador de la galeria. ${ }^{123}$ Així doncs, la pel-lícula funciona com a documentació de la circumstància expositiva i alhora com la seua representació. Finalment, el film devia projectar-se sobre l'aparador mateix, era l'esdeveniment que assenyalava el tancament de la mostra.

108. Sales de l'exposició "Film als Objekt - Objekt als Film". Mönchengladbach, 1971.

109. Sales amb pantalles especials de projeccions en l'exposició "Film als Objekt - Objekt als Film".

110. Projeccions de diapositives en les altres dues sales de l'exposició.

Altrament, la relació que construeix Broodthaers entre l'exposició i la pel-lícula il·lustra els processos de creació artística i de recepció no com a moments estancats sinó com una sequiència, però també com a elements intercanviables. En un altre nivell, amb la presentació dels elements com a signes intercanviables Broodthaers intenta mostrar que tant el cinema com les belles arts representen productes culturals susceptibles de ser resignificats socialment.

Broodthaers va concloure que la realitat del cinema no era molt diferent de la de les arts plàstiques. A propòsit, va declarar:

...el cinema és un infortuni major que el teatre i menor que la televisió. Vull dir que l'infortuni està en funció d'un públic cada vegada més nombrós, en benefici de l'increment de la recaptació. La qual cosa no deixa de ser una fortuna. ${ }^{24}$

Consegüentment, la intenció de Broodthaers és alterar la percepció tradicional tant del cinema com de les belles arts per a promoure la reflexió de l'espectador sobre les circumstàncies que condicionen la recepció de les arts en els espais socialment circumscrits.

\subsubsection{La pel-lícula com a objecte}

Quan Broodthaers comença a fer cinema va provar de presentar les seues pel-lícules en certàmens de cinema experimental. ${ }^{125}$ També va organitzar en el Palau de Belles Arts de Brussel-les, el 1959, un programa de pel-lícules experimentals anomenat Poésie-Cinema. Això no obstant, el curtmetratge Le corbeau et le renard no va ser admés a concurs pel jurat d'Exprmntl 4 què va veure massa complicat instal-lar les pantalles especials per projectar un film de set minuts de durada. Malgrat tot, en el context del festival no van faltar oportunitats per projectar-lo al públic en locals privats. ${ }^{126}$ A continuació, Broodthaers aconsegueix presentar la pel-lícula en una galeria d'art com a part d'una edició d'objectes.

\footnotetext{
${ }^{123}$ Sobre la relació entre la pel-lícula $M T L(D T H)$, l'espai expositiu i l'exposició vegeu el cap. 2.7 La significació del moment expositiu i també "MTL 13/3/70 - 10/4/70. Comentaris sobre l'exposició". En Marcel Broodthaers. Cinéma; op. cit.: p. 102.

${ }^{124}$ M. Broodthaers (1974a). "Comentari sobre Un film de Charles Baudelaire i sobre Jardin d'hiver". En Marcel Broodthaers. Cinéma; op. cit.: p.121.

${ }^{125}$ La pel-lícula La clef de l'horloge va estrenar-se el 1958 en "Filmexprmntlfilm" a Brussel-les i Le corbeau et le renard va presentar-se el 1968 en "Exprmntl 4" a Knokke-Le-Zoute.

${ }^{126}$ Cf. A. de Decker "Comentario sobre el proyecto Le corbeau et le renard". En Marcel Broodthaers. Ma., op. cit.: p. $118-121$.
} 

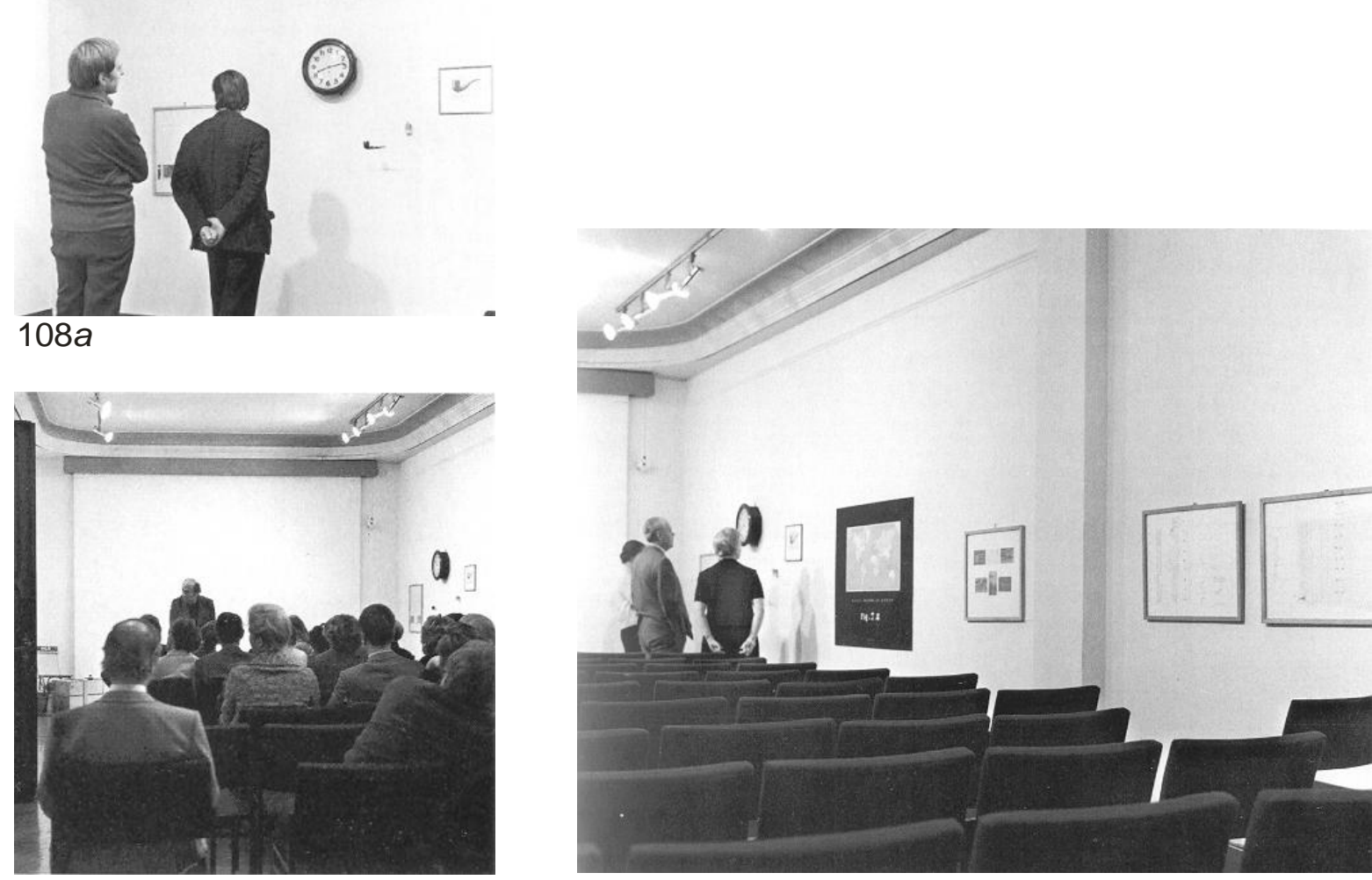

$108 b$

$108 c$

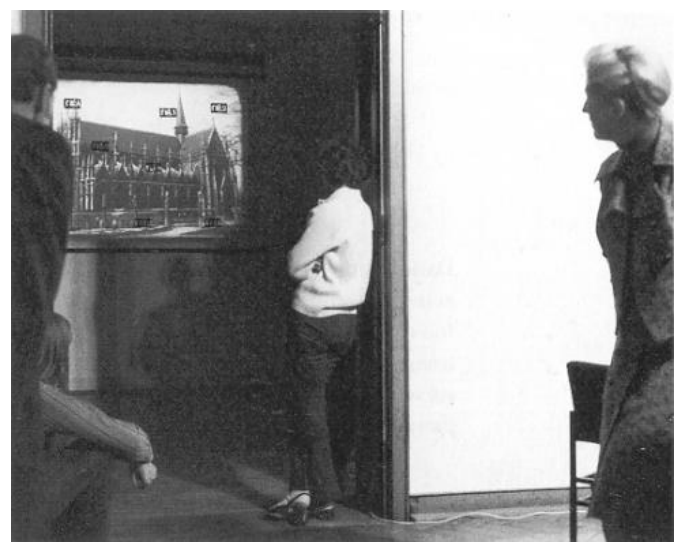

$109 a$

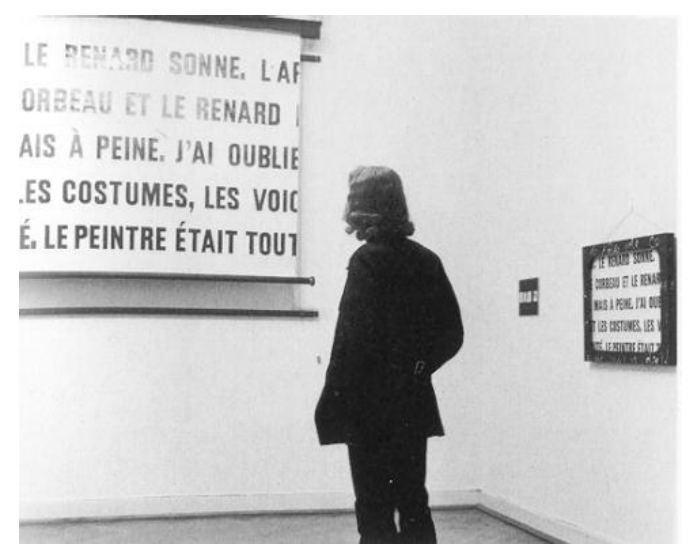

$109 b$
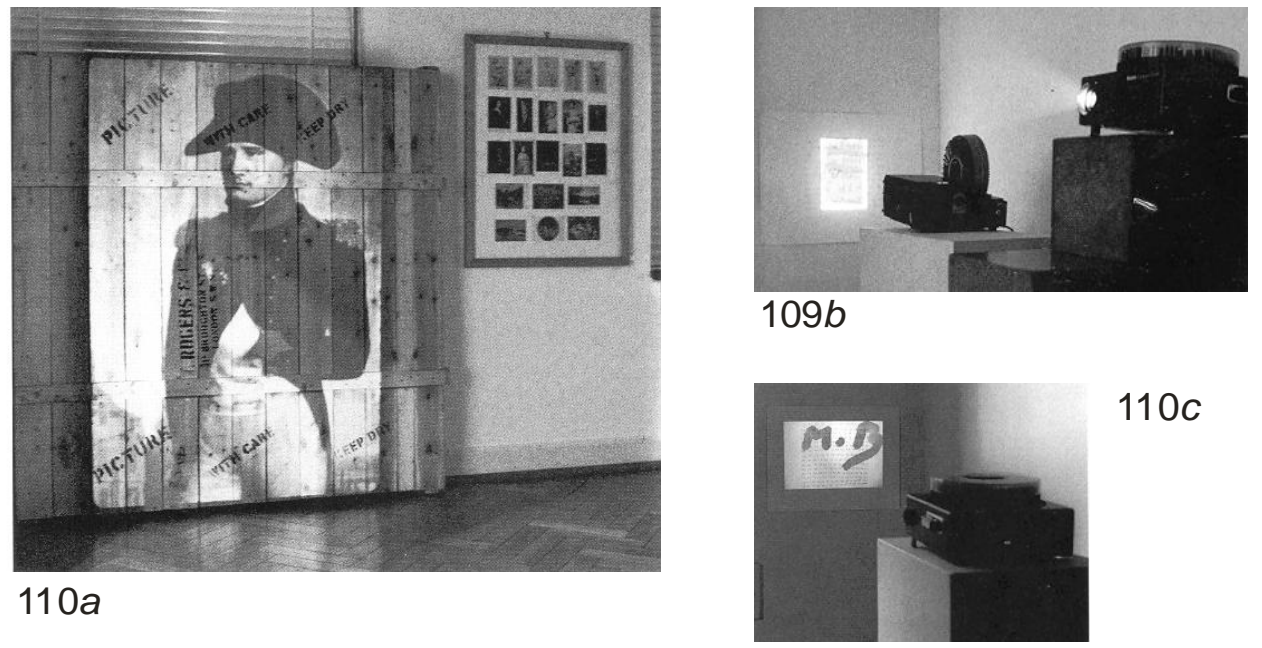

$110 c$ 


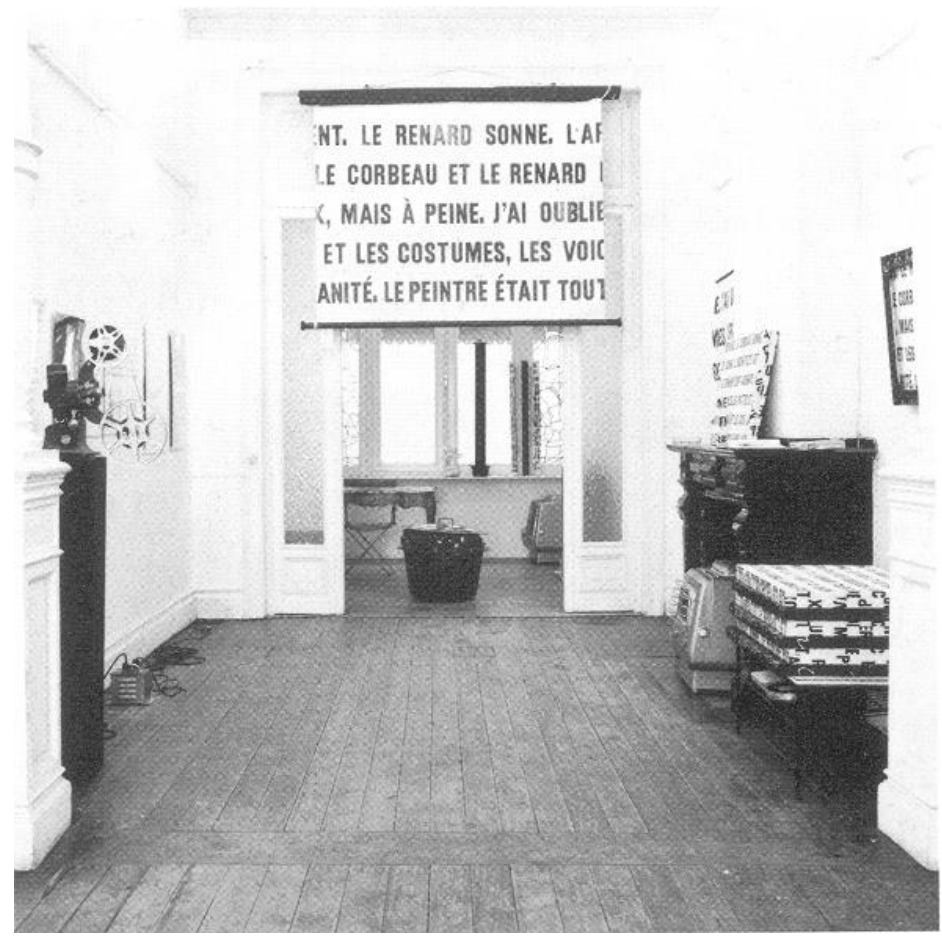

$111 a$
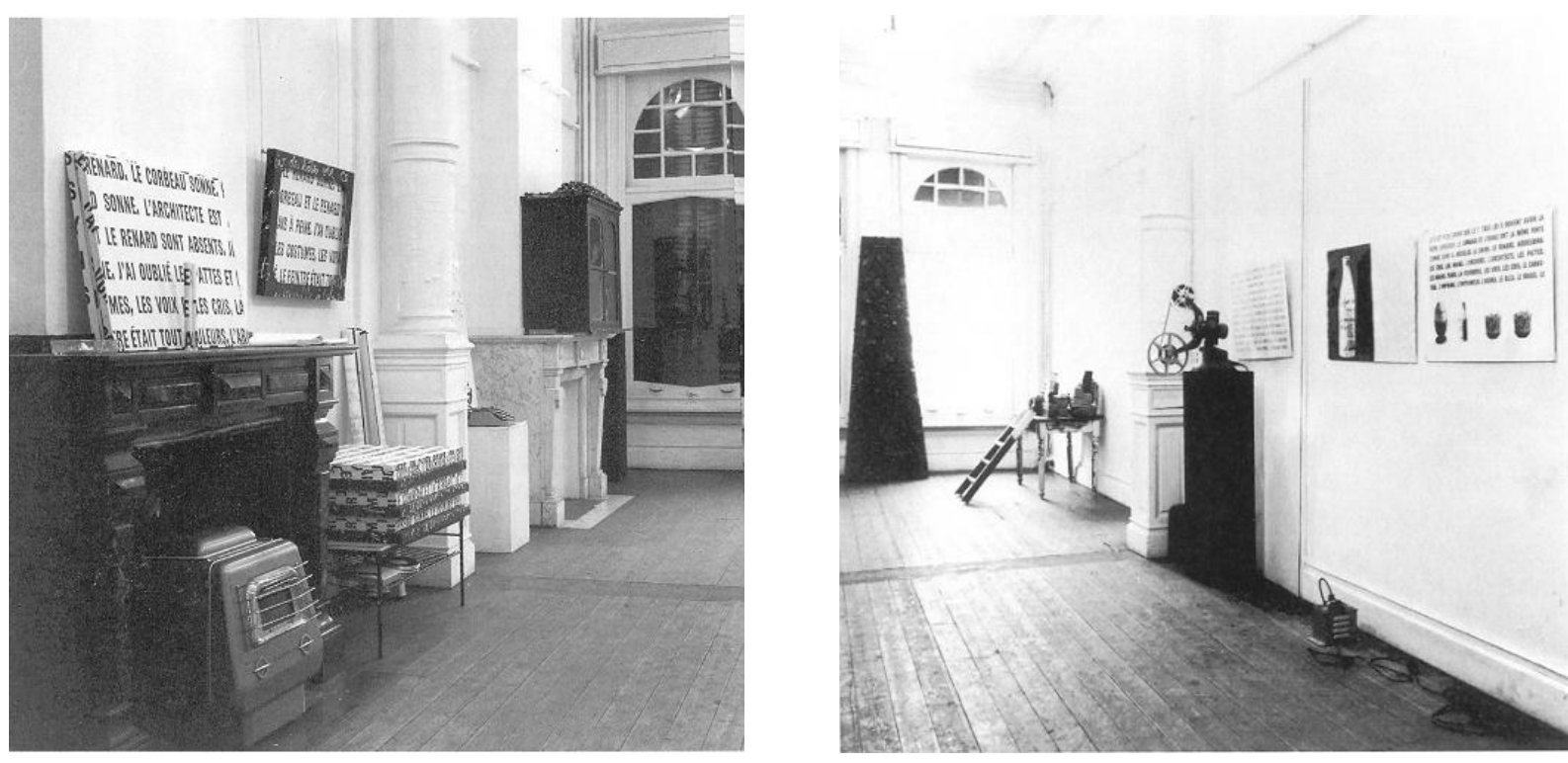

$111 b$ 
En la galeria, la pel-lícula va projectar-se sobre una pantalla plegable de grans dimensions què duia pintat un fragment del text. Aquesta pantalla també va ser realitzada per a la pel-lícula Le corbeau et le renard encara que no era part de l'edició. ${ }^{127}$ La caixa-llibre estava recolzada damunt d'una fumera i les dues pantalles especials estaven pels costats penjades en la paret com si foren quadres. La resta d'exemplars de la caixa i d'una de les pantalles estaven apilats sobre una taula baixa que hi havia a un costat de la fumera.

\section{Disposició dels objectes en l'espai de l'exposició "Le corbeau et le renard"}

En la paret d'enfront estaven penjats la reproducció del text de Broodthaers i la del text de Beni Umberto il-lustrat amb obres de Broodthaers, a més a més del panell que reproduïa una obra realitzada a partir d'una ampolla de llet i el manuscrit titulat Nota. També es podien veure alguns assemblages - Le corbeau et le renard, Planche à charbon, Grande caserole de moules i Briques - així com el projector cinematogràfic. Els comentaris de Broodthaers arran de la naturalesa i de l'esdevenir de Le corbeau et le renard són prou aclaridors:

...la meua pel·lícula ultrapassa el marc d'una pel·lícula ordinària. En principi, no està destinada a les sales de cinema, o almenys no exclusivament, perquè per veure-hi i poder entendre l'obra total que he volgut realitzar no solament fa falta que la pel-lícula es projecte sobre la pantalla impresa sinó que, a més a més, l'espectador ha de posseir el text. [...] Per això s'exposarà pròximament en una galeria. [...] És un environnement. ${ }^{128}$

La idea d'environnement o d'ambient desenvolupada a partir de la pel-lícula Le corbeau et le renard va resultar una experiència tan rellevant com la pel-lícula mateixa. Mitjançant l'exposició Broodthaers transforma l'edició en una obra espacial; no obstant això, tant la pel-lícula com la resta d'elements exposats mancaven d'autonomia. En aquesta primitiva idea d'ambient es troba el punt de partida de les manifestacions Cinéma Modèle i Section Cinéma i, sobretot, d'allò que, posteriorment, constitueix el Decor. És a dir, la idea d'ambient i la noció de Decor fan servir l'exposició com a escenari en funció de l'espacialització de la pel-lícula, de la representació d'una idea d'espai.

\subsection{El cinema com a simulació}

...m'agradaria dir que no sóc cineasta. Per a mi, la pel·lícula és la prolongació del llenguatge. Vaig començar per la poesia, després la plàstica i finalment el cinema el qual reuneix diversos elements de l'art. És a dir: l'escriptura (la poesia), l'objecte (la plàstica) i la imatge (la pel-lícula). La cosa més difícil és, òbviament, l'harmonia entre tots els elements. ${ }^{129}$

El cinema constitueix el primer tempteig de Broodthaers d'independitzar el text de la poesia, de l'Art en el sentit platònic, i de vincular els fonaments del text i de l'escriptura al camp de les arts espacials i representatives: les belles arts, el cinema, l'arquitectura $\mathrm{i}$ el teatre. Tanmateix, en aquest assaig primerenc ja apareix l'encadenament d'elements heterogenis textos, objectes, paraules, fragments, imatges... - com a signes intercanviables que caracteritza la generalitat del treball de Broodthaers.

\footnotetext{
${ }^{127}$ Aquesta altra pantalla també va utilitzar-se en l'exposició "Film als Objekt - Objekt als Film".

${ }^{128}$ Trépied (1968). "Interview de Marcel Broodthaers"; op. cit. ${ }^{129}$ Íd.
} 
En l'espai la juxtaposició i la combinació d'aquests signes com un text estructurat justifica l'exposició i, darrerament, el Decor, mentre que en la pel-lícula aquests procediments s'integren en la instrumentació del concepte de muntatge.

\subsubsection{Muntatge}

Per exemple, en la seua primera pel-lícula, La clef de l'horloge, Broodthaers arreplega de la superfície dels quadres tota la seua matèria - "tot allò que l'usuari de la Vida abandona" juxtaposant-hi els elements com en un collage Merz amb efectes que recorden el cinéma pur dels anys vint per recrear d'una manera més fidel l'atmosfera de l'obra de Schwitters. ${ }^{130}$ Així doncs, el muntatge assoleix un grau més genèric que tècnic, és més procediment que procés. El resultat no responia a cap classificació: era una pel-lícula experimental, en blanc i negre, i amb un llenguatge cinematogràfic anacrònic. ${ }^{131}$

Certament, Broodthaers no fa ús del procés de muntatge per a articular un discurs cinematogràfic en tota regla, sinó que se serveix del cinema com un mitjà d'apropiació de la realitat a partir de la recollida i del reciclatge d'imatges. La imatge documental és presa com a objecte i deslligada de la seua font per a representar idees abstractes. Llavors, aquestes imatges també representen una paraula-zero.

En particular, en el curtmetratge Le chant de ma génération, del 1959, del qual sols es conserva el guió, Broodthaers utilitza fragments de noticiaris així com fotografies preses per ell mateix. Imatges documentals de la guerra en els anys 1940-1945 i fotografies d'esdeveniments d'actualitat s'articulen, mitjançant el guió, en un relat subjectiu que pretén integrar la memòria col-lectiva amb la vida quotidiana.

També és un bon exemple una altra pel-lícula prou singular, Bruegel et Goya, journalistes, del 1964, que Broodthaers no tornà a projectar. Era un muntatge fet a partir d'un guió narratiu curosament elaborat amb imatges immòbils de gravats d'ambdós artistes. Broodthaers revela la semblança d'actituds dels artistes davant els esdeveniments polítics i la censura i proposa recuperar-los com a "testimonis del seu temps, com a cronistes, com a periodistes". Les diferents èpoques estaven representades mitjançant la diferència d'estils, cosa que la pel-lícula ressaltava. Respecte això, Broodthaers declara que "sols el cinema pot fer possible tal confrontació"; així doncs, n'hi proposa equiparar el gravat i el cinema amb la premsa contemporània en tant que suports per a la informació i per a la polèmica. ${ }^{132}$

Broodthaers comença per fer servir el cinema com un llenguatge de la memòria, com a evocació de l'art del passat i d'un temps en què la poesia i les arts compartien el mateix públic i el mateix espai. Broodthaers mateix va expressar-ho aviat:

La meua memòria és una pel·lícula en colors amb una tècnica superior a la de les pel-lícules comercials. [...] Aleshores, vaig al cinema quan ho desitje, però més prompte m'avorreix aquesta complaença cinematogràfica. Prefereix els instants que la imatge s'extingeix en mi, i la confusió s'espesseix. ${ }^{133}$

\footnotetext{
${ }^{130}$ V. M. Broodthaers (1971c). "La clef de l'horloge...". En Marcel Broodthaers. Cinéma; op. cit.: p. 24.

${ }^{131}$ Vegeu B. Jenkins. "Un Peu Tard: Cita en el cine de Marcel Broodthaers". En Marcel Broodthaers. Cinéma; op. cit.: p. 289-295

${ }_{132}$ Cf. M. Broodthaers (1964c). "Bruegel et Goya, journalistes". En: Marcel Broodthaers. Cinéma; op. cit.: p. 34.

${ }^{133}$ M. Broodthaers (1958b). "Ma mémoire est un film...". En Marcel Broodthaers. Cinéma; op. cit.: p. 26.
} 
La poètica cinematogràfica de Broodthaers es refugia en el moment que el cinema assoleix la categoria d'art, però encara no havia sigut segrestat per la indústria i pel mercat de l'esglai. ${ }^{134}$ Però, aquesta mena d'exili és, sobretot, una utopia, una forma de vindicar un model de pràctica artística al marge de la lògica de l'intercanvi de mercaderies i un lloc propi en l'escenari de la societat.

La idea d'alliberament i de redempció és el motiu que es repeteix en moltes pel-lícules, el mateix que condueix la recerca i l'aplegada de signes que representen l'Art i que remeten als models de Broodthaers - Baudelaire, Mallarmé, Magritte, etc. - propiciant diàlegs imaginaris i una lectura còmplice.

\title{
4.5.2 Jeroglífic
}

Altrament, l'especificitat del llenguatge cinematogràfic com a muntatge serveix a Broodthaers per a empresonar el text i per a desplaçar-lo espacialment en una altra dimensió. Això s'il-lustra significativament en la pel-lícula Le corbeau et le renard: la juxtaposició de la lletra impresa amb els objectes cancel-lava la significació original dels elements, al temps que obria altres possibilitats de comprensió. Broodthaers s'hi refereix amb aquests termes:

\begin{abstract}
Vaig prendre el text de La Fontaine i vaig transformar-lo en allò que jo anomene una escriptura personal (poesia). Enfront de la tipografia d'aquest text vaig col-locar objectes quotidians (botes, telèfon, ampolla de llet) el destí dels quals consisteix a establir una estreta relació amb els caràcters impresos. És un intent de negar, tant com siga possible, el sentit de la paraula, així com el de la imatge. En finalitzar el rodatge, vaig adonar-me que la projecció sobre la pantalla normal, és a dir, la simple tela blanca, no reflectia exactament la imatge que volia compondre. L'objecte era massa exterior al text. Per a integrar text $\mathrm{i}$ objecte, la pantalla havia de dur impresos els mateixos caràcters tipogràfics que el film. La meua pel-lícula és un jeroglífic que és menester voler desxifrar. És un exercici de lectura. ${ }^{135}$
\end{abstract}

112. Preparació i filmació del film Le courbeau et le renard (1967).

113. Detall dels objectes i del text filmats en la pel-lícula Le courbeau et le renard (pàgina següent)

114. Fotografies de la pel.lícula Le courbeau et le renard projectada sobre una de les pantalles impreses (1967) (pàgina següent)

Broodthaers hi parla de "negar, tant com siga possible, el sentit de la paraula i el de la imatge" i després "d'un exercici de lectura". En projectar-se la pel-lícula sobre les pantalles impreses, la imatge fílmica se superposava al text, s'hi repetia l'efecte de juxtaposició i s'hi dificultava més fer-ne una lectura convencional. Tanmateix, la interacció de tots els elements devia aportar alguna clau per trobar-hi un sentit inèdit.

La definició del text com a escriptura personal i de la pel-lícula com a jeroglífic, ambdós trets de la rondalla, se centren en la idea de missatge, de transmesa, d'apropiació. Però, la impossibilitat de percebre l'obra d'una manera convencional, d'aprendre el seu significat, hi subverteix la idea de missatge.

\footnotetext{
${ }^{134}$ Per aprofundir en el tema de la relació del cinema Broodthaers amb el passat vegeu B. Jenkins; op. cit.

${ }^{135}$ Trépied (1968); op. cit.
} 


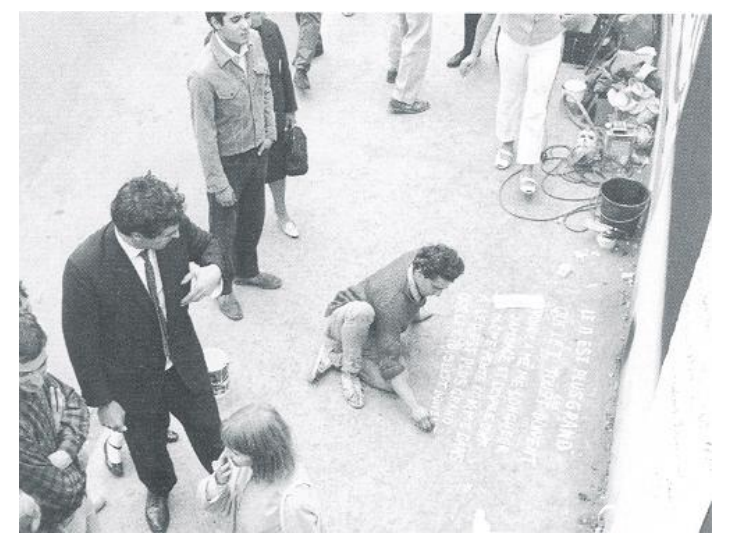

$112 a$

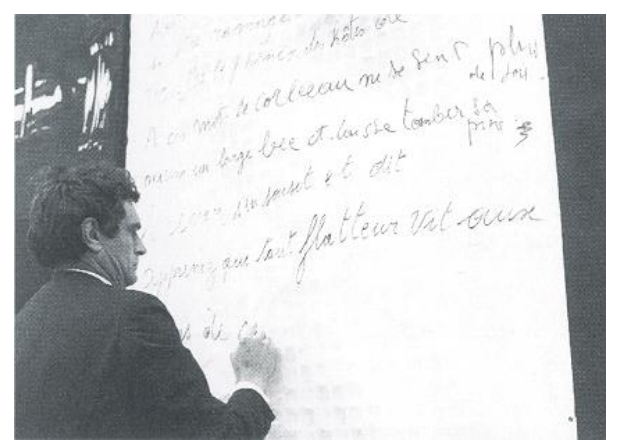

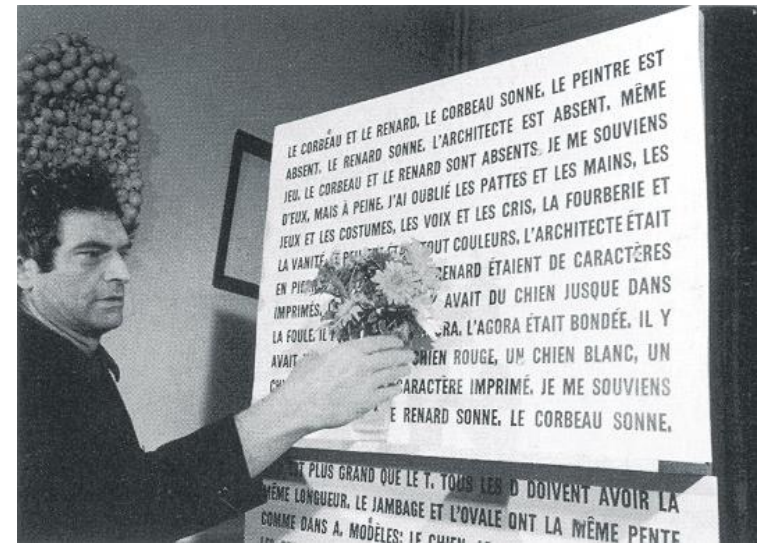

$112 c$

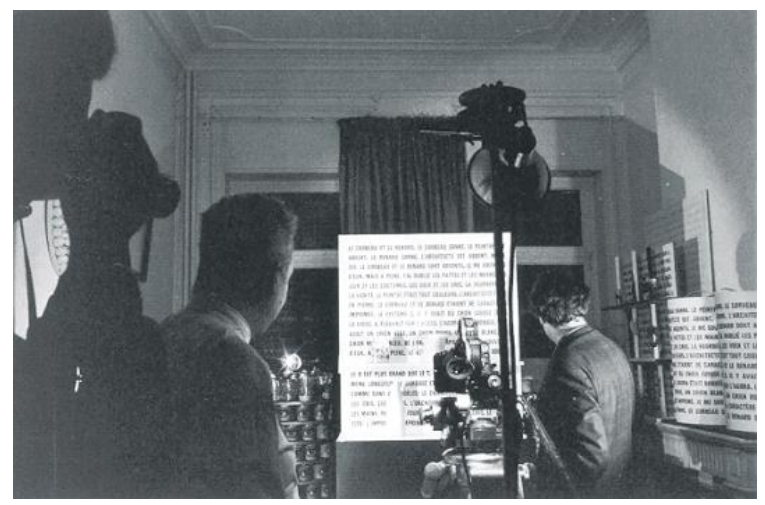

$112 d$

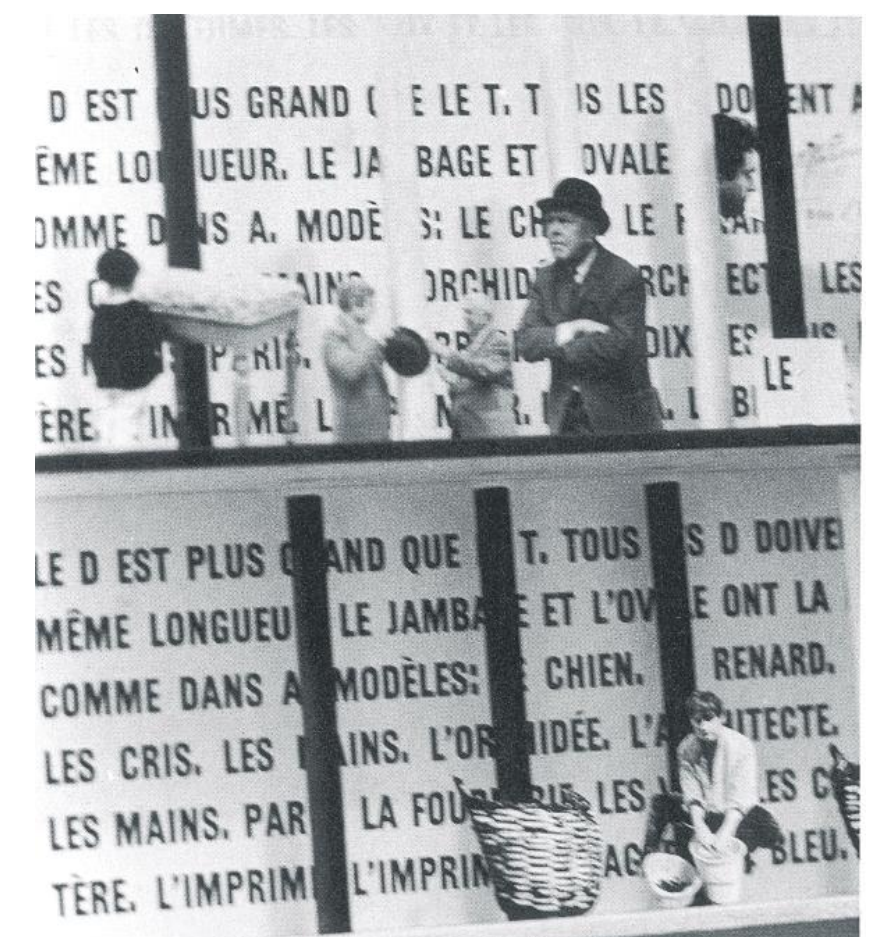

LE D EST LUS GRAND UE LE T, TOUS LES D DON MÊME L GUEUR. LE ] ABAGE ET LOVALE ONT U COMME INS A. MOY SS: LE CHIEN, LE RENARO LES CRI LES M S SIDEE. L'ARCHITECTI 

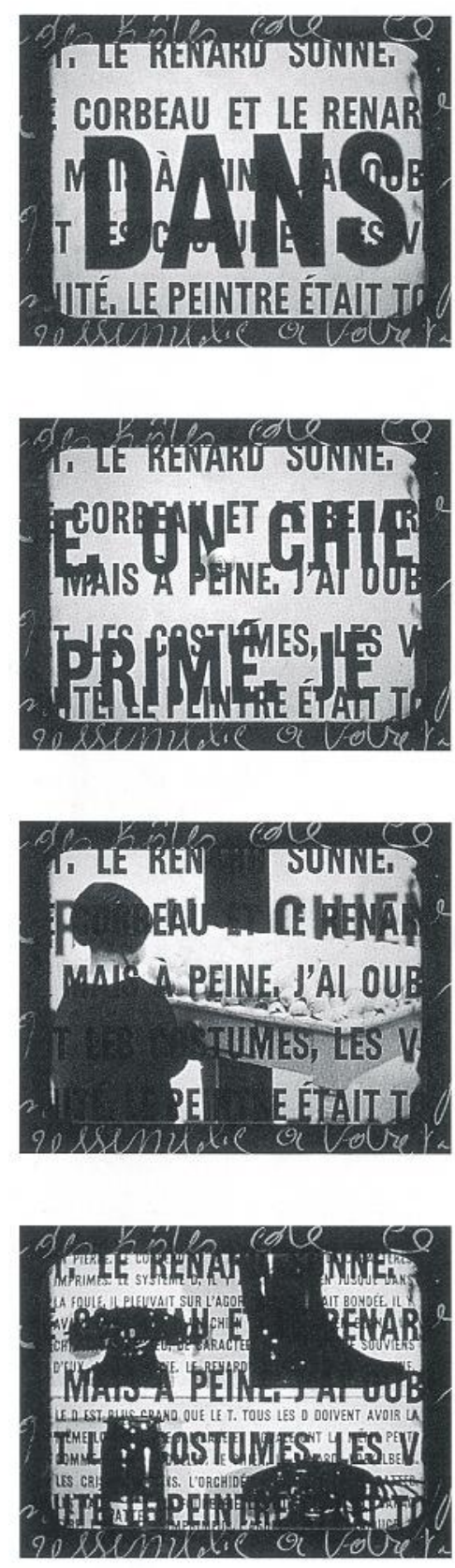
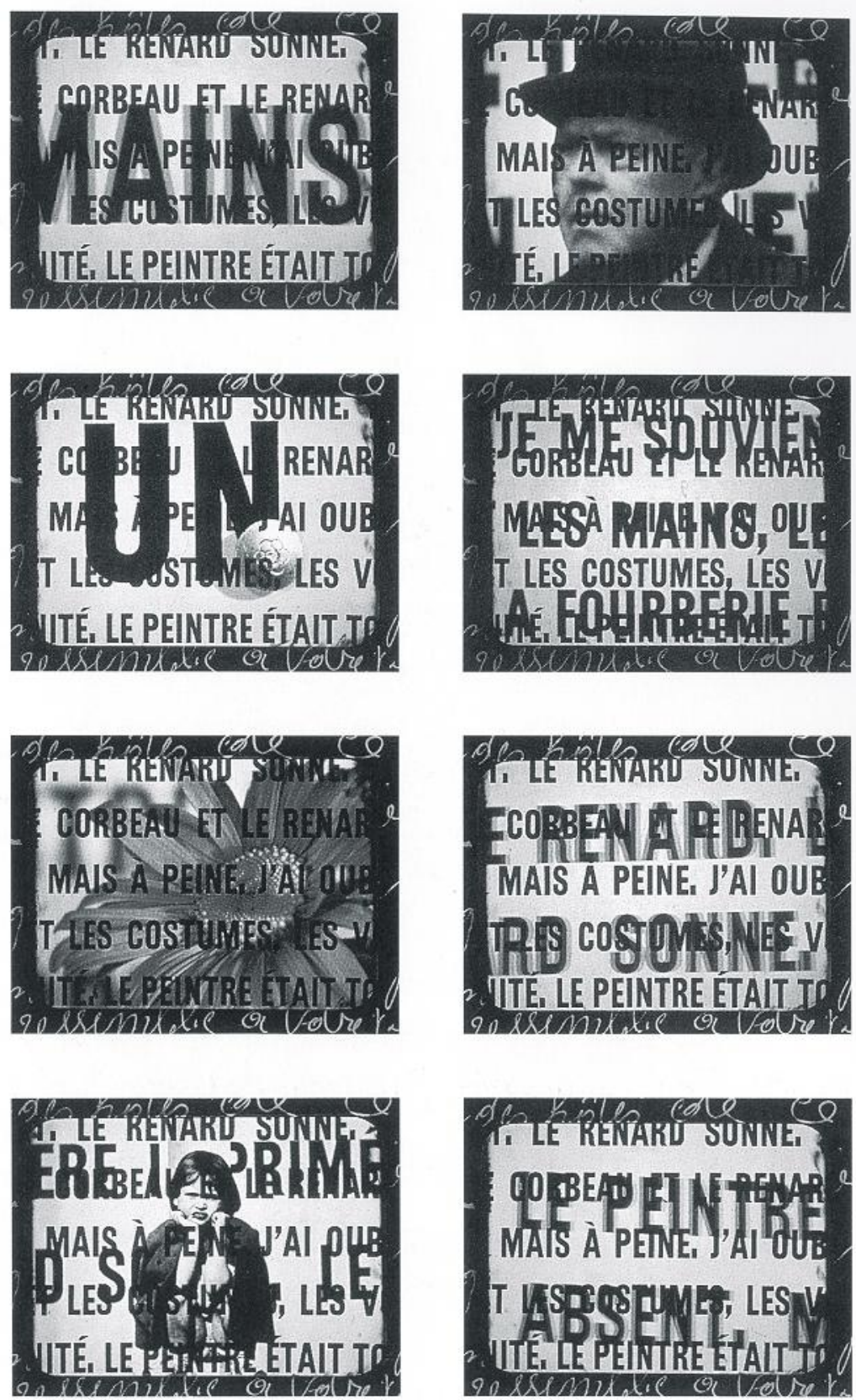
Broodthaers eludeix a dretcient qualsevol forma d'enunciació i, respecte això, declara:

Al meu parer, no pot haver-hi relació directa entre art i missatge, i encara menys si aqueix missatge és polític, sota risc de cremar-se com un foc d'artifici. D'anar-se'n en orri. [...] Des que vaig començar a fer art, el meu, el que he copiat, l'explotació de les conseqüències polítiques d'aquesta activitat (la teoria de la qual sols pot ser descoberta fora del seu àmbit) m'ha paregut ambigua, sospitosa, massa angèlica. Si el producte artístic és cosa de la cosa, la teoria es converteix en propietat privada. ${ }^{136}$

Així doncs, Broodthaers proposa una resignificació de l'obra artística com a text. De primer, calia traure del poema el fonament textual, emportar-lo a l'espai com a representació, però després calia mirar de canviar l'enunciat de l'obra com a cosa de la cosa, com a mercaderia. Finalment, fa coincidir l'apropiació del text com a objecte i la proposta de la pel-lícula com a exercici de lectura, i ambdós, com a signes intercanviables.

La idea d'una pel-lícula com a text consisteix a crear un simulacre de missatge de manera que l'exercici de lectura i la recerca de sentit constitueixen el vincle amb l'espectador i el fonament de l'obra. Altrament, la idea d'escriptura personal i de jeroglífic alliberen el codi de lectura, la qual cosa ofereix la possibilitat d'implicar l'espectador en el procés de producció de sentit.

\subsection{L'exercici de lectura}

Broodthaers assumeix la disciplina cinematogràfica amb un sentit instrumental, com a prolongació del llenguatge $\mathrm{i}$, en aquest sentit, n'hi fa servir la pel-lícula com un suport experimental i els recursos cinematogràfics estàndards com a components d'una sintaxi privada.

Quant a la pel-lícula Le corbeau et le renard Broodthaers apunta:

Experimental en aquest sentit

1 Correlació entre 2 imatges una de les quals és superfície (la imatge de la paraula

i la foto)

i l'altra un volum - l'objecte -

canal de invencions extracinematogràfiques.

Exercici de lectura poètica

vinculat al moviment cinematogràfic clàssic.

El cinema és utilitzat com a

procediment, com la foto en

pintura fotogràfica. 137

\footnotetext{
${ }^{136}$ I. Lebeer (1974); op. cit.

${ }^{137}$ M. Broodthaers (ca. 1967a). "Expérimental en ce sens...". En Marcel Broodthaers. Cinéma; op. cit. p. 54.
} 
Però paradoxalment, Broodthaers rebutja la categoria experimental per definir les seues realitzacions. Això respecte, cal comentar que en el context dels anys seixanta i setanta del segle $\mathrm{XX}$, s'identificava amb el rètol d'experimental quasi tota la producció cinematogràfica que s'exhibia i es distribuïa pels circuits no-comercials o alternatius. Broodthaers, però, no subscrivia el compromís dels cineastes europeus com tampoc va sentir-se especialment atret per les possibilitats del videoart. ${ }^{138}$ Així mateix, mai no considera els seus films com antipel-lícules, sinó que més prompte intentava eixir-se de qualsevol catalogació estricta.

A mode de dissertació, Broodthaers enumera una sèrie d'opcions davant la creació cinematogràfica explorant les seues possibilitats de reformulació, encara que, aparentment, les desestima:

Si faig una pel-lícula per a un cinema definit encara com a disciplina del moviment he de repetir el vers de Baudelaire, o si no...

1. ... no fer la pel-lícula i alhora acceptar el valor de la pel-lícula verge, la pàgina en blanc del cineasta $[\ldots]$

2. ...fer una pel-lícula a costa de l'avorriment. Per exemple, una pel-lícula d'amor. Heu ací una idea molt seductora, però amb risc de servir de bandera a múltiples mercaderies [...]

3. ... excloure els problemes del llenguatge específic del cinema considerant la pel-lícula simplement com una referència a alguna abstracció. [...] Però, el tema no es veurà sotmés per aquesta insignificància de l'estil de transmissió, quan no absorbit i convertit en un film documental d'idees trillades, de vegades original?

...les noves tècniques de la imatge $[. .$.$] permeten trobar-hi una solució - em tem que momentània -$ certament interessant.

No obstant això cal estar molt endinsat en el món tecnològic per a utilitzar amb èxit aquest tipus de mitjà. Heu-me ací, dividit cruelment entre allò immòbil què ja ha sigut escrit i el moviment còmic que anima les 24 imatges per segon. ${ }^{139}$

Definitivament, Broodthaers no exposa cap solució, cap enunciació directa, sinó que la resposta cal cercar-la en el valor de plantejar-se la qüestió i en l'exploració mateixa del medi cinematogràfic que constitueix el seu treball.

La instrumentació del cinema representa l'exercici d'escriptura poètica, la qual cosa trau, en primer lloc, una altra definició de pel-lícula. Alhora, també defineix la seua finalitat i la forma d'interacció amb l'espectador. Respecte això, Broodthaers aclareix:

L'origen de les meues intencions està en un punt de vista sobre el cinema que descarta la noció de moviment. La pel-lícula és un lloc de conservació de les idees - una llauna de conserves d'un model particular - (M'agrada el cinema no com a disciplina privilegiada, sinó com a mitjà capaç d'arribar a gran nombre d'espectadors.) [...] El text cerca una poesia de caràcter teòric. L'edició d'aquest text en cartolina de format... no es va concebre com una pàgina destinada a afavorir la lectura, sinó com a imatge de valor plàstic. És un poema? És un quadre? La pel-lícula Le corbeau et le renard és un exercici de lectura. En què consisteix el caràcter experimental de la pel-lícula? No m'agrada definir-la com a experiment. Espere haver realitzat una pel-lícula d'artista. ${ }^{10}$

\footnotetext{
${ }^{138}$ Broodthaers va emprar el vídeo com a part de la instal-lació Jardin d'hiver què va presentar-se en una exposició organitzada pel Palau de Belles Arts de Brussel-les i dedicada als nous aspectes de l'avantguarda en les arts plàstiques. Sobre Jardin d'hiver, vegeu l'apartat 4.2.1 "Els decorats Jardin d'hiver" i la conversa de Broodthaers amb F. De Vree (1974); op. cit..

${ }_{139}$ M. Broodthaers (ca. 1969a). "Projet pour un texte". En Marcel Broodthaers. Cinéma; op. cit: p. 91.

${ }^{140}$ M. Broodthaers (ca. 1967b). "Le D est plus grand que le T". En Marcel Broodthaers. Cinéma; op. cit: p. 58.
} 
L'hermetisme de la pel-lícula es converteix en motivació per a l'exercici de lectura. Llavors, és l'espectador qui produeix el missatge.

\subsubsection{La significació de l'espectador}

Broodthaers reserva a l'espectador un lloc preeminent no sols en la pel-lícula sinó en la generalitat del seu treball. L'espectador representa per a Broodthaers un lligam real però singularitzat entre l'obra i el context, entre el fet artístic i la realitat social. Així doncs, l'experiència comunicativa que resulta de la trobada de l'obra i l'espectador representa l'alternativa del vincle social de l'art.

Broodthaers no s'identifica com a cineasta, sinó com a espectador:

Una cadira. Seure's sobre una cadira. No moure's. [...] Comoditat per pensar en l'escriptura. [...] Faig cinema com a espectador. Cal que pagueu el preu de l'entrada? La meua llibertat equival a aquesta qüestió? Això mai no serà qüestió de diners entre nosaltres, ni de política, gens de política, cap política sinó la cadira. [...] Ara no estic construint. [...] No puc construir sense desfer. ${ }^{141}$

La seua intenció és fer cinema com a poeta. Això no obstant, sempre va desmarcar el seu treball d'una estreta catalogació com a cinema d'autor i va mantenir un distanciament. Les seues pel-lícules no deixen de ser les d'un afeccionat, les d'un poeta obsessionat per l'espai.

La noció de jeroglífic que havia aplicat sobre el seu cinema també serveix com a emblema d'una sèrie d'obres identificades com a Poèmes Industriels. ${ }^{142}$ Ací, la denominació poema fa referència al text, és a dir, a la conjunció entre paraula i imatge, mentre que el qualificatiu d'industrial fa referència tant a l'objecte que constitueix l'obra com als mitjans tecnològics que hi estan implicats. Aquest conjunt d'obres van sorgir al voltant del projecte Musée d'Art Moderne, Département des Aigles. Com les inscripcions, les cartes obertes i la resta d'objectes, els Poemes Industrials servien, originalment, per a posar en circulació una noció de Museu, per a definir una ficció.

115. Academie. (1968) Positiu i negatiu.

116. Porte $A$ (1969). Positiu i negatiu.

117. Cinéma Modèle. (1970). Positiu i negatiu.

El material plàstic amb què estan fets així com les característiques de la tècnica del termoformat duien a simplificar-ne els signes gràfics. No sense cinisme, Broodthaers declara sentir-se atret pel condicionament a la tècnica i al material:

Em va semblar que la matèria plàstica m'alliberava del passat, quan aquesta matèria no existia. La idea va agradar-me tant que vaig oblidar que el material ja havia sigut ennoblit, segons sembla, en els pannells de les galeries i dels museus sota la signatura dels Nouveaux Réalistes i dels Pop americans. El fet que m'interessava era la malaptesa que aportava el material a la representació. ${ }^{143}$

\footnotetext{
${ }^{141}$ M. Broodthaers (1960). "Enquête au pays du rêve". En Marcel Broodthaers. Cinéma. op. cit: p. 30 - 33.

${ }^{142}$ Inicialment aquestes plaques estaven relacionades amb la ficció del Museu, però després van funcionar de manera independent. Broodthaers estableix la denominació Poemes Industrials arran de l'exposició "Catalogue Catalogus", el 1974. Però, cal recordar que les primeres d'aquestes obres van ser exposades el 1968 sota el títol "Multipl(i)é inimitable illimité, Exposition de tirages limités et illimités de poèmes industriels, M.U.SÉ.E D'.A.R.T. CAB.INE.T D.ES. E.STA.MP.E.S Département des Aigles".

${ }^{143}$ I. Lebeer (1974); op . cit.
} 
4. L'art entre la utopia i la supervivència

175

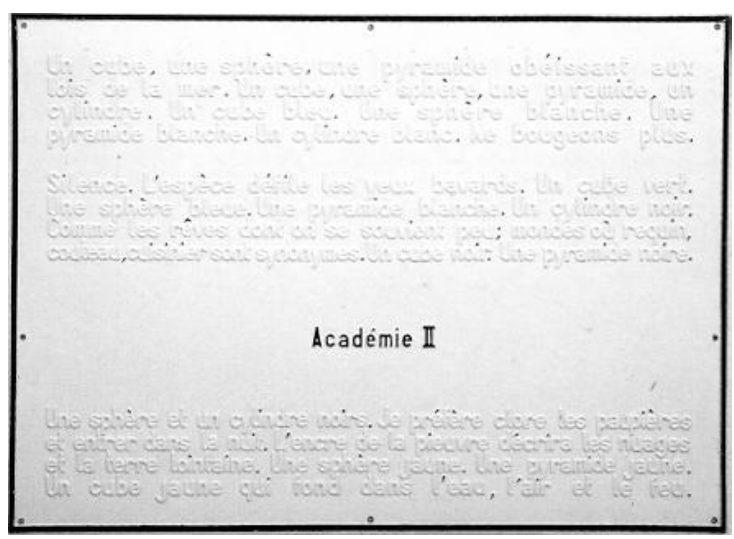

$115 a$

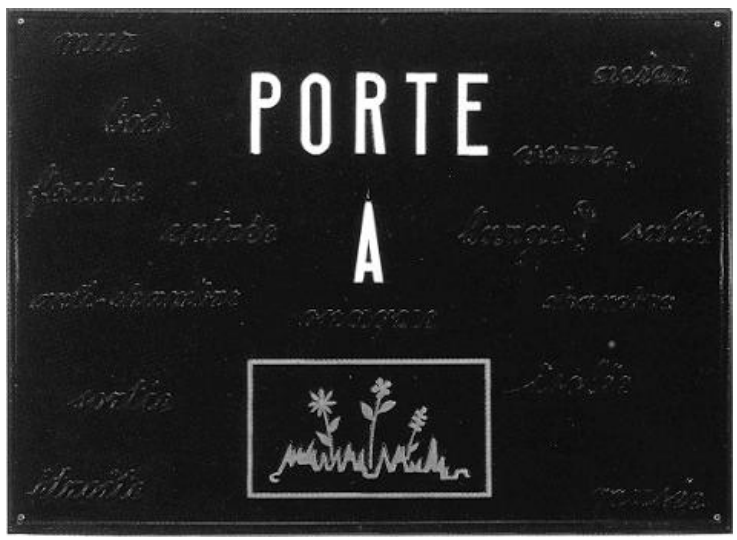

$116 a$

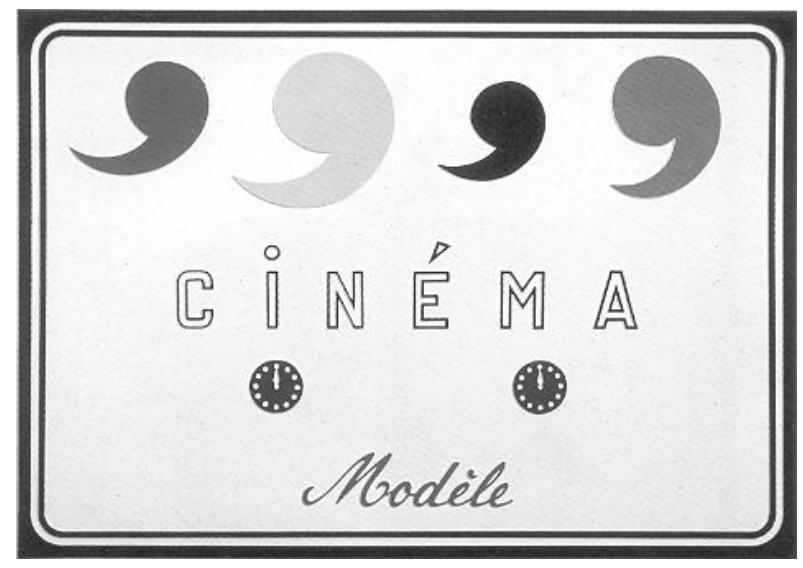

$117 a$

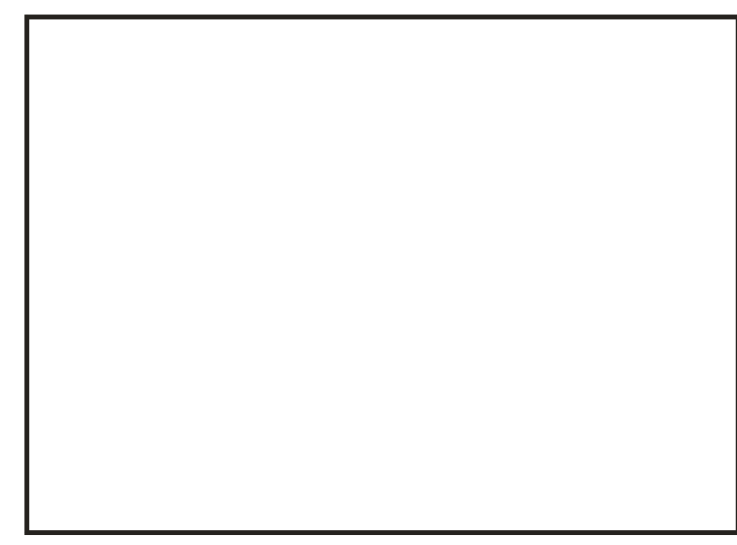

$115 b$

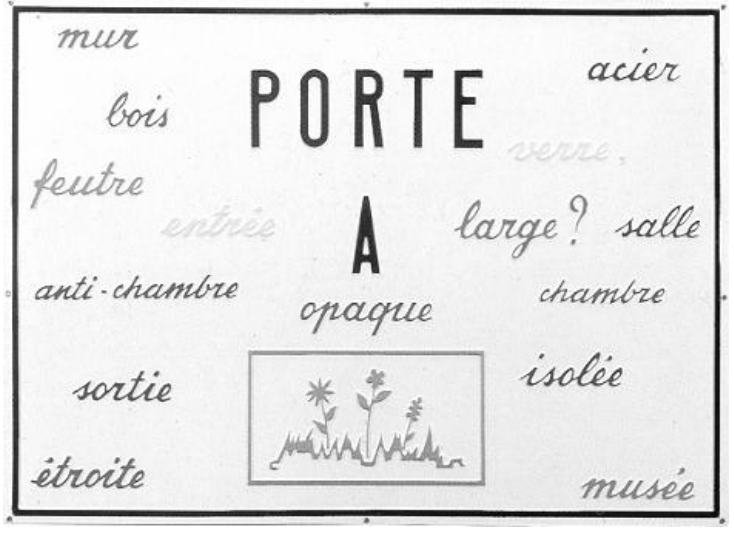

$116 b$

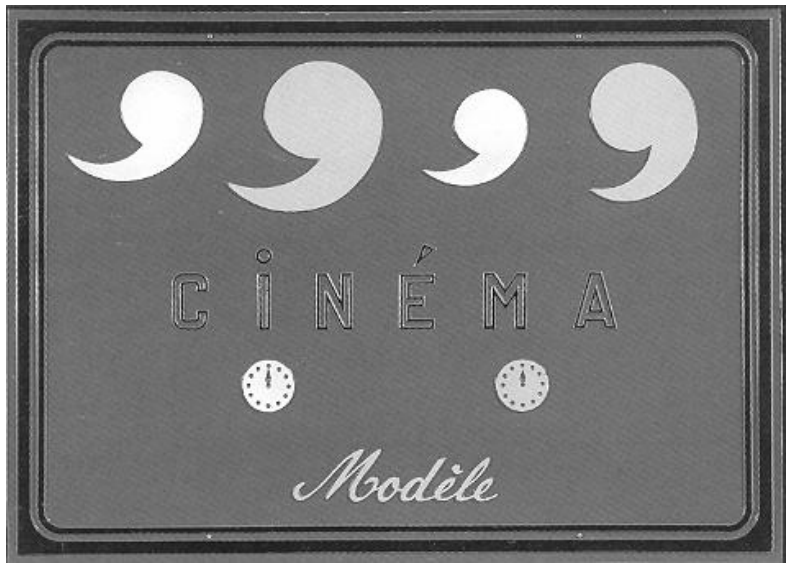

$117 b$ 

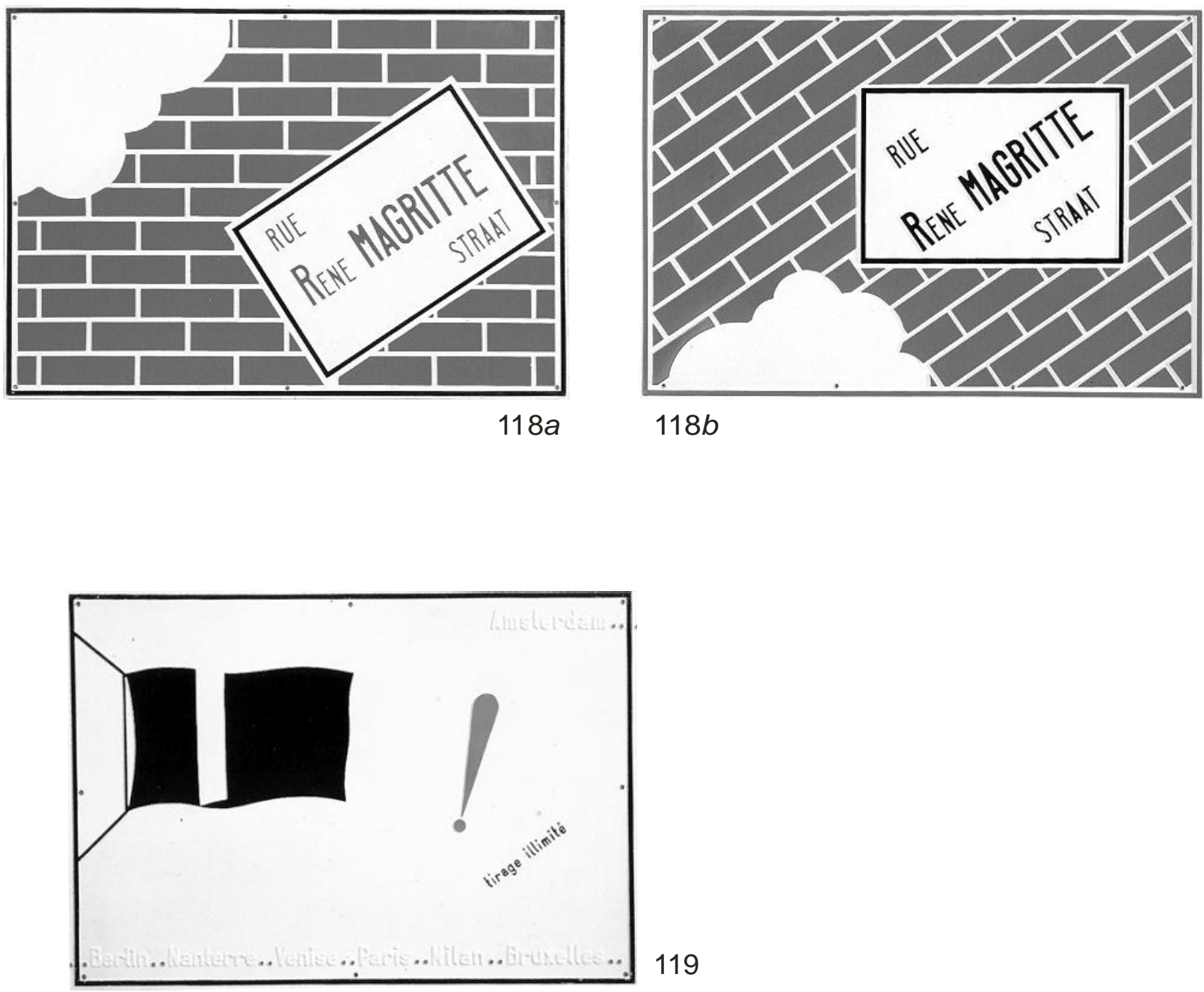

119

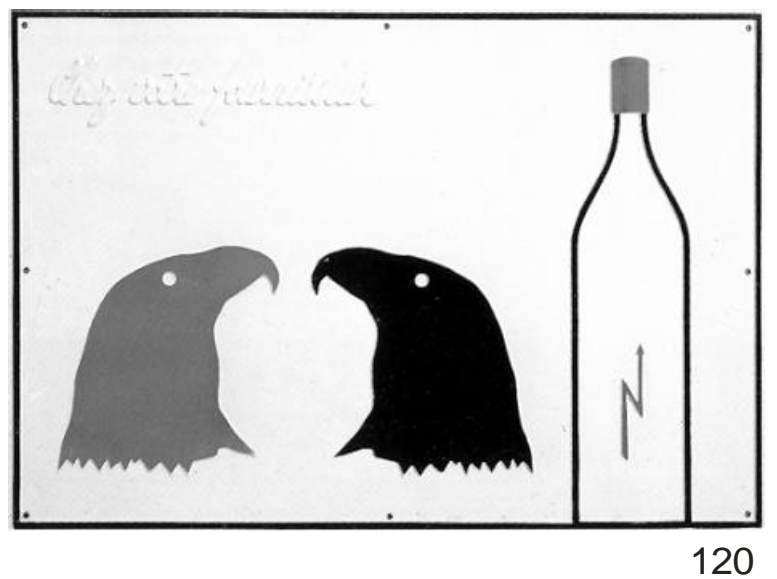


Altrament, encara que el material plàstic atorgava una factura freda i versemblant, el significat de les inscripcions desafiava l'espectador. Aquestes composicions semblen senyals públics, però instrumenten la poesia, remeten a allò prohibit alhora que a la superació de les seues limitacions, a la conquesta de l'espai. Es troben entre l'escriptura i la imatge, entre el quadre $\mathrm{i}$ el poema, però en territori de ningú, al mateix temps que adopten un distanciament d'ambdós mitjans. És tracta de senyals ambigus i seductors amb signes senzills i estereotipats.

Del llenguatge d'aquestes obres, Broodthaers diu que és jeroglífic i ho argumenta:

...la lectura proposada depén d'un doble nivell, cadascú dels quals pertany a una actitud negativa que em sembla apropiada a l'actitud artística. No col-locar el missatge íntegrament en una de les dues parts, imatge o text. És a dir, rebutjar el lliurament d'un missatge clar com una comesa que no incumbeix l'artista ni, per extensió, tothom productor interessat econòmicament. ${ }^{144}$

Així, Broodthaers hi planteja una oposició entre missatge i sentit de manera que l'exercici de lectura forma part del procés de construcció de l'obra. La juxtaposició i la reversibilitat entre la paraula i la imatge fan impossible una lectura lineal que desorienta l'espectador. Però, per a l'espectador desxifrar el jeroglífic implica entendre el desafiament de l'artista $\mathrm{i}$ correspondre'l acceptant un paper actiu enfront de l'obra, convertir-se'n en lector, i conseqüentment en coautor.

Així doncs, Broodthaers intervé especialment sobre la noció d'intercanvi com a moment intermedi entre la producció i el consum. La idea de l'art com a producció s'actualitza com a producció de sentit per mitjà del fonament textual de l'objecte. L'hermetisme del text impedeix una apropiació directa del missatge i subverteix el sentit de l'intercanvi. D'aquesta manera, l'examen del text i el procés de lectura per part de l'espectador constitueix la conclusió de l'obra.

Altrament, Broodthaers rebutja qualsevol responsabilitat davant "dels que prenen aquestes plaques per quadres i les pengen en la paret"; no accepta assumir la bona fe de l'espectador, ni tampoc la seua mala fe. ${ }^{145}$ Els Poèmes Industriels representen una connivència entre l'obra d'art i l'objecte industrial, entre poesia i mercaderia, alhora que li en permeten constatar com "els hàbits i les fixacions personals impedeixen una lectura sense prejudicis." ${ }^{146}$

Al cap i a la fi, és la seducció que exerceix la imatge, allò d'original i allò d'excèntric, i mai no l'estructura textual de la simulació, el fet que li atorga una vertadera realitat, un valor d'ús, ja que aquesta realitat material és el fonament de la seua existència com a mercaderia.

És a dir, que únicament com a mercaderia l'obra acompleix totes les seues funcions. El punt de distanciament està justament en l'escenificació de l'abstracció i de l'alienació del valor d'ús social i cultural de l'obra sotmesa al judici del valor de canvi.

118. Tirage illimité (Le Noir et le Rouge) (1968).

119. Rue Rene Magritte Straat (1968-69).

120. Chez votre fournisseur (Le vinaigre des aigles) (1968).

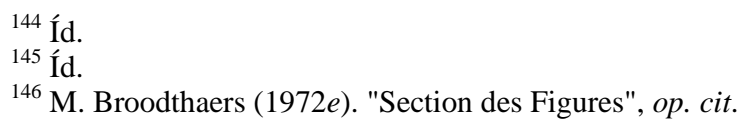




\subsection{La signatura de l'artista}

Globalment, podem concloure que l'escenificació programàtica de la identificació entre obra d'art i mercaderia, així com la decisió d'instrumentalitzar la seua presentació pública com a Decor duen implícites dues qüestions principals: la finalitat de l'art i el paper del artista. Broodthaers relaciona la reificació de l'obra com a mercaderia amb el grau d'establiment social del discurs artístic personal i desvela una paradoxa: la legitimitat del discurs artístic és avalada per la signatura de l'artista. La vàlua social de la signatura instrueix i fonamenta, al mateix temps, la doctrina de l'autonomia de l'art.

Així, en la portada del catàleg de l'exposició "Court-circuit" es veu una correcció sobre el rètol del nom de Broodthaers escrit malament. La situació il-lustra amb molt d'enginy la comèdia del significat transcendental i publicitari de la signatura com a representació de l'autoria. En el mateix sentit, Broodthaers fa notar la fàtua importància de la pròpia imatge $\mathrm{i}$ conclou que "quan hom es fica en l'art no fa sinó fer tombs de catàleg a catàleg." 147

121. Portada del catàleg de l'exposició "Court-circuit" (1967).

\subsubsection{La signatura i l'autonomia de l'art}

Llavors, Broodthaers pren la signatura com a representació d'una abstracció per posar en qüestió l'autonomia de l'art. Però cap plantejament artístic constitueix una esfera aïllada. De fet, la instrumentació d'una definició d'art particular relaciona estretament la pràctica artística amb el seu context i la integra dins d'un sistema d'idees estètiques, de modes i de gustos, encara que represente una transgressió del sistema mateix. En aquest sentit, la crítica de l'autonomia de l'art va estar en el nucli del debat sobre la relació art i societat durant els anys seixanta i setanta del segle XX. Així mateix, cal dir que aquestes idees van tenir el marxisme com a principal marc teòric de referència pel fet que moltes qüestions relatives a la relació entre art i societat es trobaven enunciades en la tesi sobre la història i l'economia política, encara que de forma dispersa. ${ }^{148}$

Pel que fa a la instrumentació de l'obra d'art com a mercaderia, la proposta de Broodthaers implica una crítica als mecanismes de circulació artística i de representativitat, així com al paper de l'artista dins del sistema de la Institució Art. ${ }^{149}$ Però, en general, en la mesura que els plantejaments artístics, inclusivament els més crítics, assoleixen certa presencia pública, comencen a integrar-se dins del teixit d'idees dominants conjuntament amb la resta d'actituds que hi coexisteixen. ${ }^{150}$

\footnotetext{
${ }^{147}$ M. Broodthaers (1972f). "Ce musée est un musée fictif "; op. cit.

${ }^{148}$ D'altra banda, crec necessari puntualitzar dues coses. La primera és que la reflexió sobre el tema art i societat té un variat suport al llarg del seu esdevenir. La segona és que el pensament filosòfic de K. Marx és prou eclèctic: recull i sintetitza diferents fonts filosòfiques i, a més a més, abasta diferents àmbits de reflexió. Però, indubtablement, comprendre el plantejament de la crítica de l'autonomia de l'art resulta difícil sense advertir els punts de trobada d'ambdues referències. Cf. J. Brihuega. "Arte y sociedad... ". En V. Bozal; op. cit.: p. 109-126.

${ }^{149}$ El terme Institució Art va ser encunyat per fer referència tant als mecanismes de distribució i promoció de les arts com a la producció artística i al conjunt d'idees dominants que hi influeixen. Vegeu P. Bürger. "La historicidad de las categorías estéticas". En Teoría de la vanguardia. Bar.: Península, 1987: p. 62.

150 P. Bürger parla de la "constatació del caràcter històric del llenguatge [artístic]" i planteja el concepte d'historització com a reflexió que capta mitjançant un llenguatge, la historicitat del discurs mateix. Cf. P. Bürger; op. cit.: p. 51.
} 


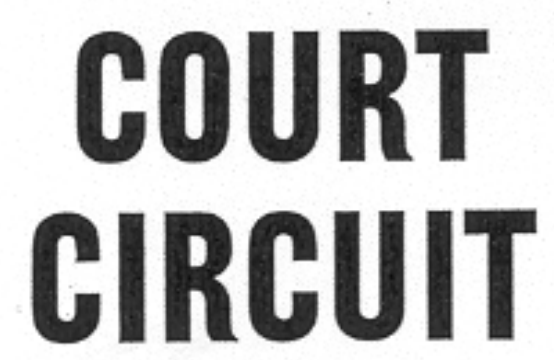

Palais des Obeaux-Suts

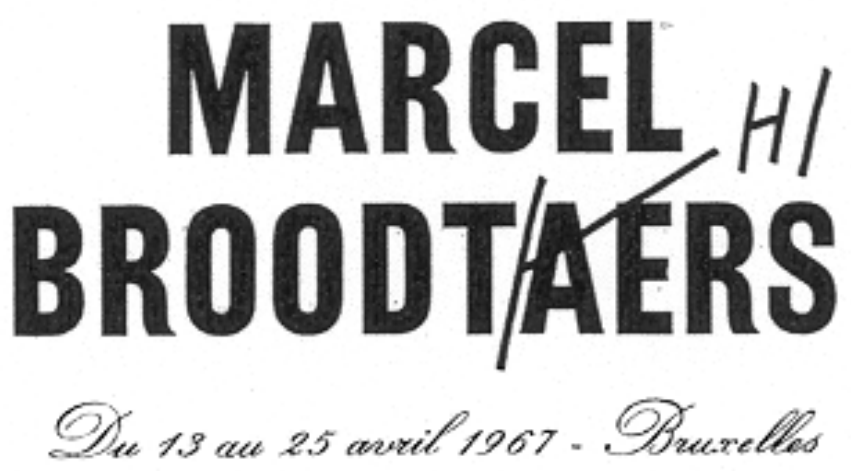




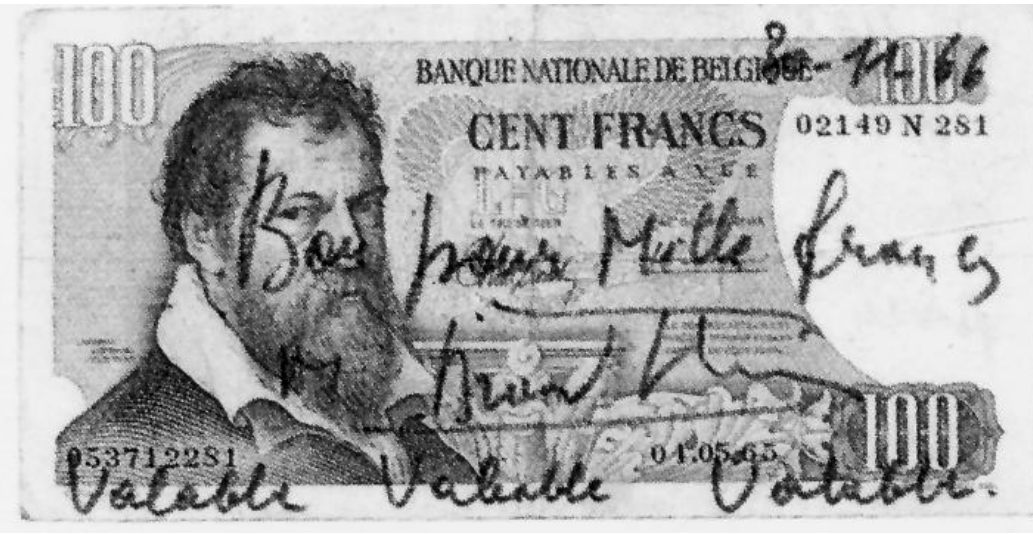

$122 a$

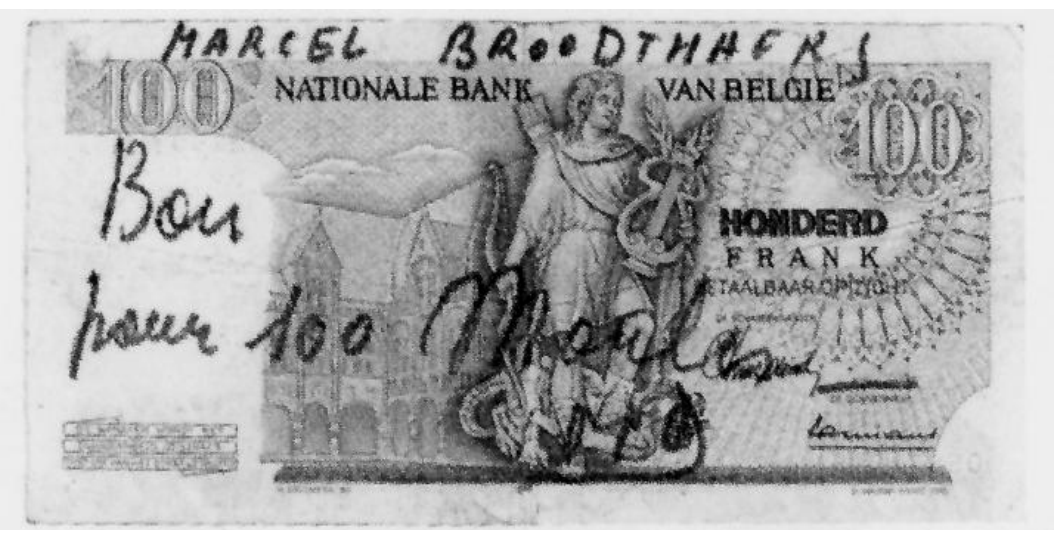

$122 b$ 
Broodthaers és conscient que la instrumentació d'un projecte artístic que soscave els basaments de tot un sistema ha de dur implícites les seues estratègies de supervivència. En aquest sentit, el seu anàlisi del procediment ready-made trau una lectura prou esclaridora sobre les circumstàncies que determinen l'esdevenir de l'obra. Respecte això, Broodthaers declara:

Poc importa que es tracte d'un urinari signat $R$. Mutt (1917) o d'un objecte trobat, qualsevol objecte pot elevar-se a la categoria d'obra d'art. L'artista el defineix de tal manera que el seu destí depén tan sols del museu. Des de Duchamp, l'artista és l'autor d'una definició. ${ }^{151}$

Després de l'impacte inicial, l'entrada de l'objecte en l'art ultrapassa la seua intenció primitiva i s'institucionalitza l'actitud. La transcendència del gest de Duchamp en virtut de la seua originalitat censura el seu potencial subversiu. Sense desestimar la significació desmitificadora dels ready-mades, Broodthaers revela la ingenuïtat d'aquesta definició, els efectes secundaris de la qual van inaugurar una privatització del concepte d'art i van propiciar, a posteriori, la seua assimilació com a fonament de noves icones. ${ }^{152}$

Aleshores, no és gens d'accidental que l'objecte siga el principal significant en l'obra de Broodthaers. L'objecte és la base de l'intercanvi. La seua elecció sempre és culpable per a Broodthaers, mentre que el seu destí, en tant que obra d'art, és indiferent. Tot el seu treball se suporta en l'apropiació de l'objecte. Hi ha una obra que fa servir els diners com a objecte que és un exemple significatiu.

Broodthaers posa una llegenda, Xec per mil francs, sobre un bitllet de curs legal per valor de 100 francs belgues i li afegeix la seua signatura. Es tracta d'una declaració arbitrària, però totalment legitima des d'una perspectiva artística. L'operació confronta dues abstraccions, el valor del paper com a dinés i el valor de l'objecte com a art, alhora que escenifica l'arbitrarietat de la relació entre el valor d'ús i el valor de canvi

122. S/T (1966). Bitllet: anvers i revers.

Però alhora Broodthaers es planteja una altra qüestió de supervivència què és com fer visible en l'obra allò que no és mercaderia i, d'altra banda, com camuflar la seua finalitat política És a dir, com concretar el valor d'ús: la dimensió textual de l'obra? La solució que apunta és certament interessant:

Si encara volem apropar-nos a una actitud revolucionària en art queda solament una postura possible, que és declarar-se secret i hermètic a partir d'una plataforma burgesa. En altres paraules, no comunicar-se excepte amb uns pocs, tan sols tan com siga de necessari per a sobreviure. ${ }^{153}$

\footnotetext{
${ }_{151}^{151}$ M. Broodthaers (1972b). "Méthode". En Marcel Broodthaers. Pa., op. cit.: p. 217.

${ }^{152}$ No obstant això, veig interessant assenyalar que Duchamp mateix s'adona... "del perill que podia haver-hi d'usar sense cap discriminació aquesta forma d'expressió. [...] vaig decidir limitar la producció de ready mades a una petita quantitat cada any. [...] «l'art és una droga d'hàbit» i vaig voler protegir els meus ready-mades contra una contaminació de tal gènere." M. Duchamp. "A propósito de los ready-mades". En Escritos. Duchamp du signe. Bar.: Gustavo Gili, 1978: p. 164.

${ }^{153}$ M. Broodthaers citat per J. C. Royoux; op. cit.: p. 304. ["Meuwisen ou n'importe qui". MTL Magazine, novembre 1970. Conversa entre Marcel Broodthaers, Wim Meuwisen, Herman Daled, Jacques Duquesne, Maria Gilissen i Fernand Spillemaeckers]
} 


\subsubsection{Legitimació i subversió de l'objecte mitjançant la signatura}

La trobada amb Piero Manzoni, el 1962 a Brussel-les, fou molt important per a Broodthaers perquè li va permetre adonar-se de la subversió implícita en fer servir la signatura com a legitimació d'una actitud artística.

Per a Manzoni la signatura és una ferramenta i l'obra, un producte de l'artista. En el context de l'intercanvi d'idees que tingué lloc entre ambdós, Manzoni va declarar Broodthaers obra d'art estenent-li un certificat d'autenticitat amb la seua signatura. Si l'artista és un productor d'art, la presentació del productor com a producte actualitza el procediment readymade al temps que subverteix radicalment el significat de l'autoria.

En canvi, Broodthaers pren la signatura com a autorepresentació per burlar-se de la idea d'autonomia de l'art. L'obra, l'autoria i la signatura es remeten l'una a l'altra i aquesta reversibilitat redueix qualsevol finalitat a la tautologia. Així, la signatura és el motiu d'una sèrie d'obres i particularment d'una pel-lícula titulada Une seconde d'eternité i presentada com "la més curta del món". ${ }^{154}$

Aplicant les tècniques del cinema d'animació, Broodthaers va descompondre el monograma del seu nom en els vint i quatre moviments per segon de la imatge fílmica. A continuació, va filmar cada quadre obrint l'obturador de la càmera en cada moment de la sequiència. Finalment, en va muntar el final amb el principi de la pel-lícula, creant-hi un bucle, per projectar-la de forma ininterrompuda.

Però, en el segon de durada de la pel-lícula era impossible apercebre-hi el moviment de l'escriptura i, en canvi, amb la repetició contínua d'aqueixa unitat d'un segon s'aconseguia crear un ritme i una il.lusió de moviment en una imatge totalment abstracta. Interrogat sobre el tema d'aquest curtmetratge, Broodthaers declara:

És un film molt curt, d'un segon, el títol del qual és Une seconde d'eternité. Vull plasmar una determinada realitat artística d'una manera artística. No és més important que es tracte de la meua signatura o de la d'un altre: és més important el fet mateix de la signatura. Crec que la creació artística reposa sobre una impulsió narcisista. [...] Em va agradar molt fer aquesta pel-lícula on el grafisme que no dura més que un segon constitueix al mateix temps una ficció. ${ }^{155}$

123. Dibuix preparatori per al film Une seconde d'éternité (ca. 1970).

124. Edició de la pel-lícula sobre paper.

Juntament amb la projecció del curtmetratge, que va tenir lloc en una galeria d'art, Broodthaers exposa el film com un objecte independent, a més a més de dues plaques de plàstic que reproduïen, en positiu $\mathrm{i}$ en negatiu, l'últim fotograma, o siga, l'escriptura completada del monograma. Així doncs, amb la confrontació de les diferents representacions de la signatura s'invertien els seus sentits. Si mitjançant la projecció de la pel-lícula es representava el procés de l'escriptura, d'altra banda, l'exposició dels vint-i-quatre fotogrames del film constituïa la representació del mitjà cinematogràfic. D'igual manera, les plaques mostraven la signatura com a obra i, alhora, com a model: positiu i negatiu, còpia i patró.

\footnotetext{
154 "La galeria Folker Skulima presenta el film més curt del món: Une seconde d'éternité...". En Marcel Broodthaers. Cinéma; op. cit.: p. 128.

${ }^{155}$ F. de Vree (1971). "Entretien avec Marcel Broodthaers". En A. Hakkens; op. cit.: p. 75 - 79.
} 
4. L'art entre la utopia i la supervivència 183

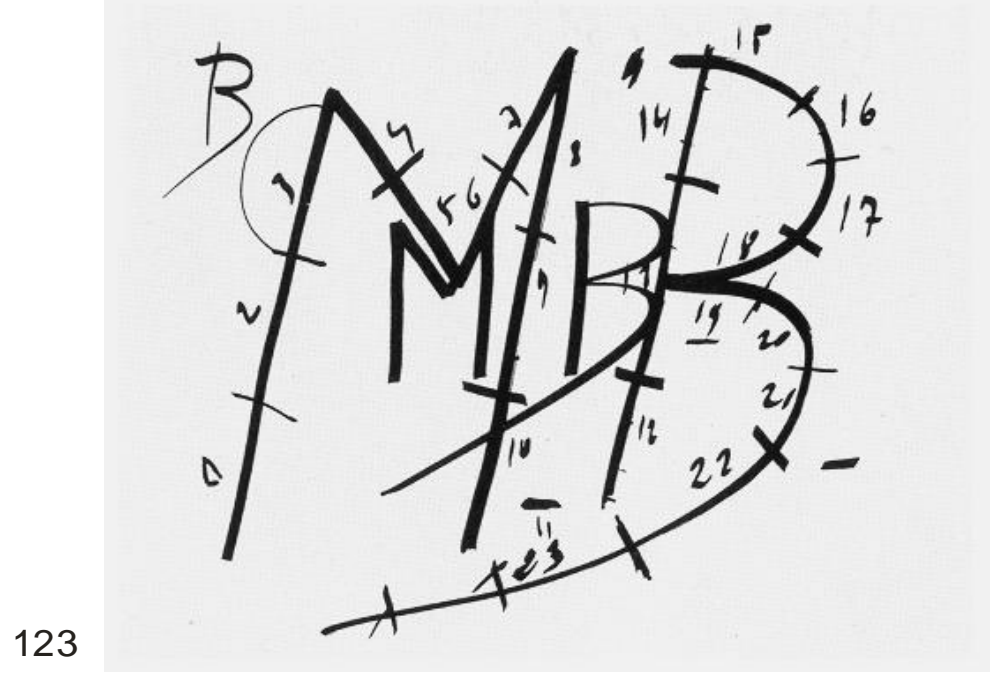

124

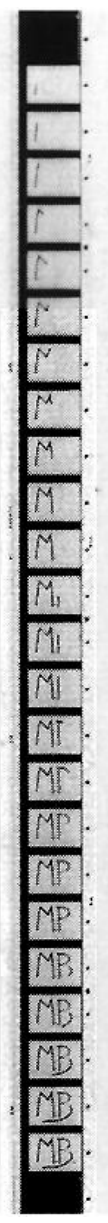




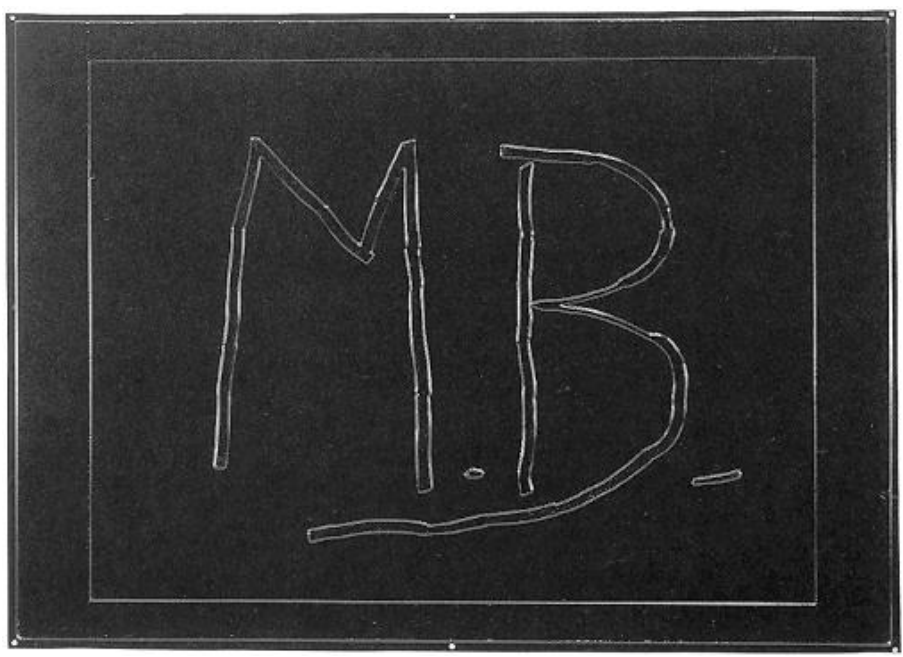

$125 a$

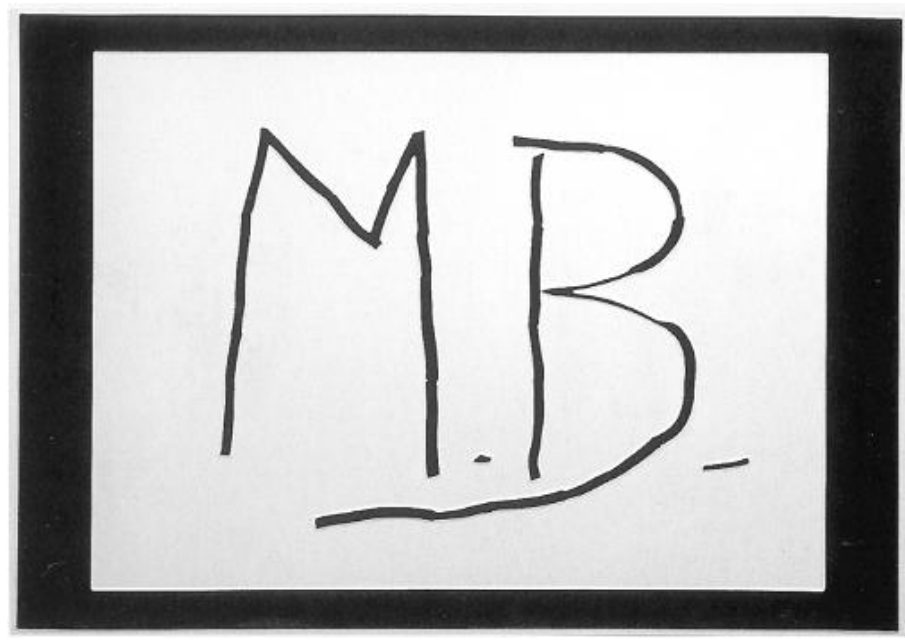

$125 b$

1 segon per a Narcís

ja és el temps de l'eternitat.

Narcís ha repetit

indefinidament el temps

de $1 / 24^{\circ}$ de segon.

En Narcís, la persistència retiniana

tenia una durada eterna.

Narcís és l'inventor del cinema.

Marcel Broodthaers

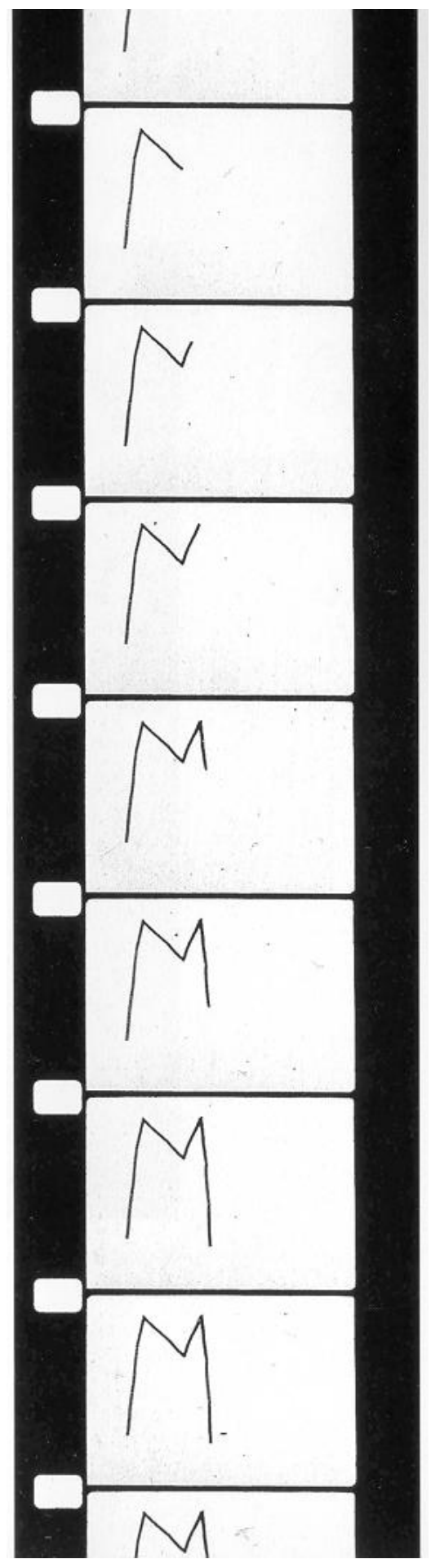


125. Ma signature (1970) [positiu i negatiu].

126. "Un segon per a Narcís..." poema (ca. 1970)

127. Fotogrames de la pel-lícula Une seconde d'eternité (1970).

L'acceleració del moviment de l'escriptura i la immobilitat cinematogràfica imprimien a la pel-lícula certa comicitat, mentre que la volatilitat de la imatge i la reversibilitat de la lectura il-lustraven el protagonisme efímer de la signatura com a emblema de l'obra autònoma i de la mercaderia lliurada a la continuïtat del intercanvi. És tracta, però, d'una ficció sobre la signatura o de la signatura de l'artista com a ficció? Això respecte, Broodthaers replanteja la qüestió:

La signatura de l'autor - pintor, poeta, cineasta - em sembla el principi d'un sistema de mentides, el sistema que qualsevol poeta, qualsevol artista intenta establir per defendre's... contra què exactament, ho ignore. ${ }^{156}$

${ }^{156}$ F. de Vree (1971); op. cit.. 
CONCLUSIONS 


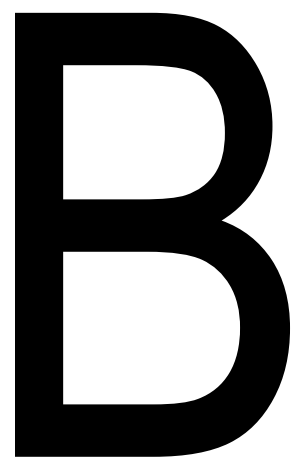

ROODTHAERS assumeix la pràctica artística amb un sentit instrumental i mai no com una finalitat en sí mateixa, la qual cosa revela l'existència d'una autoria complexa. Els resultats d'aquesta investigació permeten deduir unes conclusions globals que, contrastades amb els tres objectius bàsics formulats originalment, verifiquen la hipòtesi de la utopia pervinguda com un model en l'autoria de Broodthaers.

Així, la revisió de la seua trajectòria artística com una praxi ha revelat, en primer lloc, que la seua entrada en les belles arts respon a un intent de conjugar l'acció simbòlica inherent a l'acte creatiu amb una acció social que aleshores no havia aconseguit mitjançant la poesia. En segon lloc, l'examen de l'autoria de Broodthaers per mitjà de l'anàlisi sistemàtic detallat de diferents projectes ha permés observar com l'arreglament de la seua pràctica artística com un llenguatge es correspon amb la intenció simbòlica i comunicativa del procés creador; mentre que la contemplació de l'espai com un suport creatiu representa l'intent de circumscriure l'art com una acció social no exempta de polèmica. Per últim, la síntesi de les principals idees derivades de l'anàlisi de l'autoria ha confirmat que Broodthaers planteja una visió prou crítica de l'acte creatiu així com del paper de l'art i de l'artista en la societat; però en canvi, instrumentalitza la praxi artística com una forma d'influir sobre l'individu i sobre la societat lluny de la complaença, del narcisisme o de la voluntat de poder.

Altrament, els resultats obtinguts al llarg del desenvolupament de la investigació han tret també moltes més qüestions d'interés. En aquest ordre, l'examen i el seguiment de les diferents experiències artístiques (procediments i resultats que es corresponen amb l'objectiu 1) han revelat que Broodthaers intenta servir-se de la creació artística per a construir un discurs que puga incidir sobre allò real, sobre l'àmbit social i polític que concerneix l'art. Com ho pervé? Cercant i trobant formes de compromís individual i conscient i formes d'expressió conseqüents. Així doncs, no és gens d'estrany que la primera forma trobada fóra la poesia, l'Art per excel-lència.

Així mateix, ha quedat evident que el pas de Broodthaers pel moviment surrealista i pel partit comunista belgues va constituir un assaig i un exercici amb molta més significació de la que les investigacions precedents han estimat fins ara. L'orientació ideològica progressista i la significació alliberadora dels moviments surrealista i comunista així com les contradiccions inherents a aquests valors en l'época de la postguerra van ser experiències que portaren Broodthaers al convenciment que el compromís polític en art consisteix fonamentalment a assumir una postura individual.

Quant a la recerca de formes de expressió, pot dir-se que linterés de Broodthaers per la fotografia documental constitueix el seu primer apropament a la imatge. Però, malgrat la impecable factura i la poesia d'aquestes imatges, mai no han de veure's com una obra amb finalitat independent sinó com a part d'un text. El mateix sentit tenen les seues primeres 
pel-lícules. No obstant això, la singularitat del mitjà cinematogràfic permet la juxtaposició entre text i imatge i afavoreix, des del principi, que les pel-lícules de Broodthaers siguen un model textual.

El seu apropament a les arts plàstiques té lloc, inicialment, mitjançant l'exploració de la condició objectual de l'obra com a fonament de la seua alienació com a mercaderia o com a peça de museu. Però aquesta etapa d'aproximació i d'exploració es produeix encara a través de la producció textual. Finalment, Broodthaers descobreix la ductilitat del suport objectual, els seus avantatges sobre el poema i sobre el comentari crític de la realitat artística, així com les possibilitats discursives que ofereix. Així doncs, l'entrada en les Belles Arts no és més que una altra empremta en la seua experiència.

És menester subratllar que els assemblages de Broodthaers marquen, objectivament, un punt d'inflexió. La majoria d'investigadors, en canvi, ha traçat una línia virtual la qual cosa ha configurat una mena de passat gairebé inconnex pel que fa a la producció plàstica en sentit estricte. De tot això cal destacar, però, que allò més significatiu és que, mitjançant els assemblages, Broodthaers va veure-hi la creació artística com un instrument per a l'apropiació simbòlica d'allò real. Llavors, comença a plantejar-se conscientment l'exercici artístic com a recerca d'un llenguatge. Això respecte, l'examen de les obres i dels procediments de l'autoria (procediments i resultats que es corresponen amb l'objectiu 2) ha permés analitzar i comparar diferents projectes i valorar la repercussió en el desenvolupament general de la seua pràctica artística.

Cal fer menció específica dels resultats de l'anàlisi de la relació de Broodthaers amb l'escultura i amb la pintura. S'ha de partir del fet que el procediment de l'assemblage com a reciclatge i reunió d'objectes, fragments i deixalles trets de la realitat i la seua recomposició com a obra d'art va remoure i va transgredir les fronteres de l'escultura i de la pintura. Això no obstant, Broodthaers s'absté de definir els seus assemblages com a oposició o com a transgressió d'aquests gèneres. Les seues composicions més bé sorprenen i desconcerten l'espectador per la presència d'elements compromesos amb el llenguatge de l'escultura i de la pintura (bases, pedestals i la mateixa paraula escultura com a títol, així com també textures pictòriques, pinzellades i la paraula pintura com a títol, respectivament). D'aquestes observacions es deriva que les al-lusions implícites o explícites mai no tenen res a veure amb el gènere, sinó que remeten a l'escultura i a la pintura com a llenguatges. Els antecedents de la investigació de Broodthaers es troben en la reflexió lingüística sobre la pintura iniciada per René Magritte.

Igualment, s'ha investigat la relació de l'obra de Broodthaers amb el nouveau réalisme i amb el pop art i els resultats condueixen a insistir novament sobre la utilització de l'assemblage i, tanmateix de l'estètica de l'objecte, com a exercici d'apropiació d'allò real, aleshores en referència a la realitat artística del moment. Cal tenir en compte que, en qualitat de pràctica objectual, l'assemblage va arribar a ser el signe característic dels artistes circumscrits al nouveau réalisme i al pop art. En aquest sentit, Broodthaers intenta que les seues obres siguen il-lustratives tant del fenomen artístic assemblage com del fenomen social de la proliferació de pràctiques objectuals en benefici de l'art com a nova indústria, però des d'una postura crítica.

A més dels assemblages, les edicions de llibres, d'obra gràfica, de pel-lícules i d'objectes ocupen un lloc destacat dins la producció artística de Broodthaers. Allò comú de totes aquestes manifestacions és la reflexió entorn de la condició objectual de l'obra, que apareix com una constant al llarg de tot el seu treball. Per a Broodthaers, les possibilitats discursives del suport objectual de l'obra plàstica permeten accedir a l'espai i superar les limitacions comunicatives del poema. En aquest sentit, l'autoria de Broodthaers es fonamenta en l'anàlisi de les circumstàncies de la producció artística i de la seua recepció. 
Mitjançant l'examen de les obres i dels procediments de l'autoria s'ha observat que la reflexió de Broodthaers al voltant de la condició objectual de l'obra profunditza sobre ambdues circumstàncies: sobre la producció i sobre la recepció artística. Així doncs, s'han diferenciat dos procediments bàsics: l'apropiació d'objectes procedents de la realitat i el reciclatge de la seua obra mateixa en qualitat d'objecte. En els assemblages Broodthaers ironitza la proliferació de pràctiques objectuals mitjançant les seues sèries d'acumulacions de deixalles del consum: closques de musclos, cascares d'ous, ossos, etc. El seu propòsit és posar en relleu una buidor en la memòria que inhabilitava el desafiament original que va significar l'entrada de l'objecte en l'art a través del collage i del ready-made. En altres projectes, en canvi, la idea d'antologia o de retrospectiva li permet mostrar peces de museu autèntiques o bé la seua obra mateixa com a objectes d'exposició. Altres vegades presenta conjuntament obres plàstiques, objectes i pel-lícules com a elements intercanviables sobre l'escenari expositiu. D'aquesta manera Broodthaers desvela com la legitimitat de l'objecte en tant que art i de la idea en tant que art es troben circumscrites a la seua presència en l'espai institucional. Per consegüent, el Decor com a idea d'exposició qüestiona l'autonomia de l'art i, alhora, impugna qualsevol projecte d'autoria basat en la privatització d'una definició d'art justificada a partir del llegat artístic de Duchamp.

Altrament, la investigació sobre la definició d'art de Broodthaers i l'enfocament des de la seua autoria han dut directament a una altra qüestió no menys important: el seu punt de vista sobre el paper de les entitats que representen l'activitat artística en una societat, per exemple, els museus, les col-leccions, les galeries, les biennals, etc. i com hi és la seua relació. A partir del punt d'inflexió que marquen els primers assemblages, Broodthaers utilitza l'exposició de la seua obra com a mise en scène i la galeria d'art com a fòrum fingint desconéixer, de cara al públic, la vertadera funció dels espais instituïts. La seua intenció és apel-lar directament a l'espectador, a la seua condició d'artífex i, d'aquesta manera, censurar el paper legitimant de les institucions artístiques. En canvi, l'espai expositiu juga en els seus projectes el paper de suport de la idea i funciona com un lloc de representació que interactua amb els elements de l'exposició. Consegüentment, la naturalesa dels projectes de Broodthaers mai no està definida absolutament ni per les obres o objectes exposats ni per l'espai, sinó que depén de la conjugació de les possibilitats enunciatives d'ambdós i, sobretot, de l'activitat de l'espectador, de l'exercici de lectura.

Un dels projectes que millor resumeix el punt de vista de Broodthaers sobre el paper de les institucions artístiques és el Musée d'Art Moderne Département des Aigles: un dispositiu que va nàixer com un lloc de discussió i d'intercanvi d'idees vinculat als esdeveniments de protesta antinstitucional del 1968. Aquest museu és un assaig sociològic i, alhora, una ficció poètica. El seu desenvolupament mateix va afavorir un funcionament gairebé autònom fins a acabar convertit en un símbol més per a les institucions artístiques. En Documenta $V$ Broodthaers anuncia el tancament del seu museu i en les conclusions ressuscita la qüestió del paper de les institucions llançant l'interrogant d'una altra manera: pot arribar a ser quelcom autèntic i sincer l'activitat artística en el si dels espais institucionals, és a dir, circumscrita a galeries, museus, projectes alternatius, macroexposicions i col-leccions?

Broodthaers defineix el Musée d'Art Moderne Département des Aigles com un engany que descobreix les mentides del museu autèntic. Això no obstant, mitjançant el seu museu, Broodthaers pervé apropiar-se simbòlicament del valor d'ús de l'experiència artística com un procés instituït per subvertir l'ineludible fenomen de la reificació. En l'anàlisi de les distintes manifestacions del projecte Museu s'ha observat que cap d'aquestes, ni tan sols el projecte general mateix, estaven regides per una directriu traçada d'avant mà: ben prompte es va anar construint en la mesura de les circumstàncies. Així doncs, l'engany, és a dir, les respostes de Broodthaers a la institucionalització progressiva del Museu, està implícit en la successiva 
redefinició de la ficció i en la invenció d'un nou engany: el decorat (Decor) com a idea d'exposició i com a justificació última de l'acte creatiu.

En els estudis precedents sobre Marcel Broodthaers que s'han revisat al llarg d'aquesta investigació no s'ha registrat cap relació entre el Decor i el Musée d'Art Moderne Département des Aigles sobre el basament d'una similitud d'estratègies d'enunciació [de fet, solament hi ha un autor, Jean-Cristophe Royoux, que a propòsit de la seua anàlisi de la pel-lícula com a part del Décor, ha donat crèdit a la significació que Broodthaers atorga als decorats com a reconstrucció en l'obra del seu entorn desaparegut, és a dir, com una forma de supervivència de l'art en la societat]. Per veure-hi la similitud d'estratègies entre ambdues idees, el Museu i el Decor, és important observar el Decor, en un primer nivell, com a conseqüència del desenvolupament d'una sèrie d'enunciats que conformen l'autoria de Broodthaers i no únicament com una definició comuna per a una sèrie d'exposicions.

L'existència d'enunciats que apareixen reiteradament s'ha pogut verificar mitjançant la síntesi de les principals idees derivades de l'anàlisi detallat dels projectes i de l'autoria (procediments i resultats que es corresponen amb l'objectiu 3). Per il-lustrar aquesta afirmació s'hi presenta un extracte tan concret com és possible dels enunciats globals tenint en compte que ja han quedat de manifest al llarg d'aquesta argumentació de conclusions.

- la reflexió entorn de la condició objectual de l'obra d'art;

- la relació entre la naturalesa simbòlica de l'obra i la seua finalitat polèmica;

- la instrumentació de l'espai com a suport i, al mateix temps, com a entorn de l'obra;

- la significació de l'espai i la significació de l'espectador com a artífexs de l'exercici de lectura;

- la relació dels projectes amb els espais socialment instituïts i, paral-lelament, la instrumentació de lectures codificades.

També s'ha observat mitjançant l'examen comparat de diferents obres i projectes, en particular del Museu i del Decor, que hi existeix una relació de successió o de progressió que concerneix especialment a les manifestacions de cadascun d'aquests enunciats segons les circumstàncies dels projectes. És a dir, que expressen idees i inquietuds permanents que fan efecte sobre l'autoria desenvolupant un encadenament de preguntes i de respostes. En la pràctica artística, aquesta relació de progressió dels enunciats es manifesta com una reiteració de formulacions i d'observacions. Això no obstant, és important esclarir dues coses. Primera: que amb un punt de vista diferent al d'aquesta investigació es podrien trobar uns altres enunciats vista la multiplicitat de lectures i d'interpretacions que autoritza el treball de Broodthaers. Segona: que la relació de successió/progressió observada mai no es pot generalitzar; o siga, que encara que es verifique la reiteració mai no es pot resumir tota l'obra de Broodthaers com una successió/progressió ja que sempre restarien molts elements fora de la cadena. Així doncs, crec que aquesta conclusió sols resulta vàlida per enfocar i donar llum sobre aspectes concrets i per aplicar-la circumstancialment.

En un altre nivell, el Decor com a idea d'exposició se serveix, reiteradament, d'obres i d'objectes com a elements intercanviables; però, alhora, instal-la un model de perpètua redefinició de l'acte creatiu, Noveauxs trucs, nouvelles combines, com un recurs davant la inevitable reificació de l'obra. A través de la persistent metàfora de l'hivernacle (Jardin d'hiver), representada una vegada i una altra en diferents exposicions, Broodthaers mostra la incomunicació de l'obra en el museu i del museu amb la realitat. Però, a més a més, l'examen detallat de diferents projectes i dels procediments de l'autoria ha posat en relleu que la idea de Decor ja apareix circumstancialment en l'apropiació simbòlica de l'espai com a suport de 
l'obra que ocorre per raó de la construcció d'ambients (environments) en diverses exposicions. Així doncs, es pot concloure que el projecte Museu constitueix una altra forma de Decor.

Com a justificació de l'acte creatiu, el Decor s'inscriu també dins la recerca d'un llenguatge que codifica la pràctica artística subjecta ineludiblement al procés d'intercanvi com a producció de sentit (el contrapunt necessari de la producció de mercaderies) ja que, com bé aclareix Broodthaers, el decorat mai no és un fi per si mateix. En els decorats té lloc una conjunció d'elements de diversa naturalesa que s'articulen com a fragments d'una sintaxis personal, però allò més sorprenent d'aquesta instrumentació és que s'inspira en el concepte de muntatge cinematogràfic. Paral-lelament, la pel-lícula com a part del decor pervé una dimensió de textualitat i de representació que la sostrau de la seua ordinària condició de mercaderia.

Aleshores, el Decor, el cinema i les arts plàstiques conflueixen com a prolongació del llenguatge i com a temptatives de circumscriure una idea d'espai. De manera especial, tant en el Decor com en les manifestacions del Museu, en les exposicions, en els projectes i en les pel-lícules, l'experimentació de Broodthaers - els sistemes d'objectes, l'autoreferencialitat i la intercanviabilitat dels elements en tant que signes - respon a la recerca d'una dimensió utòpica de l'art que, inicialment, Broodthaers localitzava en el pla ideològic i subjectiu i que, finalment, pervé formular amb excel-lència en el pla estètic. Al mateix temps, l'experimentació de Broodthaers condueix a la idea de l'art com a espai, com a domini per exercir la llibertat creativa i el judici crític d'una forma desinteressada i, alhora, compromesa.

Després del soterrament del Museu, sobreviu el Decor en qualitat d'instrumentació de la ficció sota la forma d'exposicions retrospectives i antològiques a costa del beneplàcit institucional guanyat amb el Musée d'Art Moderne Département des Aigles. Ceguetat o suficiència? Això no obstant, mitjançant l'aparent vacuïtat de la instrumentació del Decor Broodthaers aconsegueix condensar els seus enunciats i estendre la seua confrontació a l'àmbit social que engloba les institucions. Voluntat de poder o utopia pervinguda?

Broodthaers posa de manifest l'entramat d'interessos econòmics i polítics que sobrevenen al fet artístic i assenyala les conseqüències que recauen sobre l'art, la cultura i l'individu. Però, són els mateixos pressuposts que hi ha en els seus enunciats com a director/conservador del Museu, com a artista plàstic, com a crític d'art, com a fotògraf, com a cineasta i com a poeta. Així doncs, la seua utopia mai no és una entelèquia sinó que pervé instrumentar la pràctica artística com un marc per formular preguntes, com un terreny de maniobres, com una forma d'incidir sobre la societat i sobre l'individu i, sobretot, una postura personal respecte a l'art les conseqüències de la qual s'estenen a l'àmbit d'allò social i d'allò polític.

Al llarg de trenta anys molts artistes reconeguts i caracteritzats per la seua actitud crítica i compromesa han considerat Broodthaers un referent modèlic. Actualment resulta paradoxal el grau d'assimilació institucional que ha aconseguit Broodthaers al temps que tants artistes contemporanis continuen fent-se les mateixes preguntes i sense triomfar.

Aleshores, en quins termes es pot parlar de l'impacte de l'obra de Broodthaers en el segle XXI? Això mai no té una mesura absoluta sinó que caldria partir, en primer lloc, d'una anàlisi i d'una delimitació de les circumstàncies que dibuixen el segle XXI i, després, fer una hipòtesi de valoració predictiva. Tanmateix, ací hi ha preguntes i respostes per fer una altra Tesi Doctoral.

Però, quina és la significació del treball de Broodthaers que ha volgut destacar aquesta TESI DOCTORAL? Justament la que no és possible aprehendre només confiant en el missatgeimpacte i fent-se l'eco, a més a més de tot el que ja s'ha exposat al llarg del desenvolupament de l'escrit i d'aquestes conclusions. És menester remarcar, una altra volta, que aquesta TESI DOCTORAL mai no ha tingut per finalitat fer una valoració de la significació de l'obra de Broodthaers ni en termes d'impacte ni de transcendència. Tanmateix, això no vol dir que no 
n'existeixa. És a dir, la significació del treball de Broodthaers que s'hi ha volgut destacar és la que és capaç de connectar amb les nostres preguntes com a creadors, com a espectadors i, sobretot, remarcar el valor d'allò que Broodthaers va definir com l'exercici de lectura. Cal llegir Broodthaers, treure un compte i portar-lo a la nostra experiència com a creadors, com a individus. Per tant, mai no pot haver-hi una resposta. En aquest sentit, els resultats i les conclusions d'aquesta TESI DOCTORAL són una de les lectures possibles; i exposen, modestament, un punt de vista que mai no intenta ni exercir càtedra ni constituir l'última paraula sinó moure el pensament. 


\section{ANNEX 1. BIOGRafia RAONADA DE MARCEL BROODTHAERS}

Les fonts utilitzades per a escriure el present annex són les següents. Llibres sencers: Marcel Broodthaers (Nova York / Minneapolis, 1989); Marcel Broodthaers. Oeuvres 1963-1975 (De Vree, Fredy, 1990); Marcel Broodthaers (París, 1991); Marcel Broodthaers (Madrid, 1992); Marcel Broodthaers. Katalog der Editionen Graphik und Bücher (Hannover: 1996) i Marcel Broodthaers. Cinéma (Barcelona, 1997). Capítols de llibres: "Elementos biográficos" (Compton, Michael); "Biography and bibliography" (Dichoff, Wilfried); "Éléments biographiques" (Hakkens, Anna); "Marcel Broodthaers antes de 1964" (Marcel Broodthaers); "Bibliography" (Gildemyn, Marie-Pascale) i "Biographie" (Marcel Broodthaers. Katalog der Editionen...). Tanmateix, els detalls de les fonts esmentades figuren en l'apartat de TEXTOS SOBRE MARCEL BROODTHAERS del capítol de REFERÈNCIES BIBLIOGRÀFIQUES d'aquesta TESI DOCTORAL.

La tasca d'investigació ha permés observar que, tal i com es constata en l'enumeració anterior, la majoria d'estudis monogràfics sobre Marcel Broodthaers ha vist la necessitat d'incloure, d'alguna manera, dades objectives en relació amb la trajectòria artística de Marcel Broodthaers amb valor de context. Així mateix, s'ha observat que la informació inclosa en cadascuna de les fonts esmentades està en relació amb el tipus d'exposició o d'estudi que va realitzar-se. Això no obstant, els punts de vista d'aquests estudis mai no coincideixen, en cap cas, amb els objectius d'aquest treball de tesi. De fet, tota la informació referent a les exposicions de Broodthaers des del 1976 fins a l'actualitat, la qual es pot trobar en les fonts esmentades, no hi ha sigut inclosa ja que s'ha considerat que està fora del context temàtic d'aquesta tesi; és a dir, que excedeix el marc de l'autoria de Marcel Broodthaers.

Finalment, cal remarcar que les fonts utilitzades per a escriure el present annex no han sigut copiades passivament sinó que han sigut contrastades, avaluades i aprofitades com allò que són: com a fonts. Consegüentment, és menester remarcar també que la recerca de les fonts així com l'anàlisi, la selecció, el contrast i la verificació de les dades que finalment s'ofereixen en l'annex s'ha considerat una part de la investigació d'aquesta tesi. Aquestes dades han sigut un dels basaments fonamentals per a desenvolupar la investigació i l'escriptura del treball i s'ha estimat incloure-les com un annex en qualitat de context específic de l'objecte d'estudi. 


\section{Exposicions col-lectives}

\section{4}

"Laureats du Prix Jeune Sculpture Belga". Palau de Belles Arts, Brussel-les, 1-12 febrer, 1964.

"Le Retour... des choses". Galeria SaintLaurent, Brussel·les, agost - 30 set., 1964.

\section{5}

"Pop Art, Nouveau Réalisme, etc.". Palau de Belles Arts, Brussel-les, 5 febrer - 1 març, 1965.

\section{6}

"2e Salon International des Galeries Pilotes Lausanne / Artistes et découvreurs de notre temps". Museu cantonal de Belles Arts, Palau de Rumine, Lausanne, 12 juny -2 oct., 1966. [Cat.]

"Des Salles / Raüme". Galeria Saint-Laurent, Brussel-les, 9 juliol -15 set.,1966. [Cat.]

"An 10". Galeria New Smith, Brussel-les, 4-21 oct., 1966.

\section{7}

"Reportage. Interuniversitaire tentoonstelling". Brussel-les, Lovaina, Gante, Lieja, Anvers, 30 oct. 1967- 1968. [Cat.]

\section{8}

"Three Blind Mice. De Collecties Visser, Peeters, Betch". Stedelijk van Abbemuseum, Eindhoven, 6 abril -19 maig, 1968; Abbaye Saint-Pierre, Gante, 15 juny 15 agost, 1968. [Cat.]

"Wide White Space Galery au parkhotel Hessenland". Documenta 4, Kassel, 26 juny - 5 juliol, 1968.
"Eerste Triennale voor Plastische Kunst in Belgie". Stadshallen, Bruges, 11 juliol - 8 set., 1968. [Cat.]

"Lignano Biennale I. Rassegna Internazionale d'Arte Contemperanea". Lignano, 25 agost 6 oct., 1968. [Cat.]

"Prospect 68". Städtische Kunsthalle, Düsseldorf, 20-29 set., 1968. [Cat.]

\section{9}

"Triennale der Zuiderlijke Nederlanden / Jonge Kunst uit Zuid-Nederland en Vlaanderen (2)". Stedelijk van Abbemuseum, Eindhoven, 3 abril -18 maig, 1969; Koninklijk Museum voor Schone Kunsten, Anvers, 1 juny - 13 juliol, 1969. [Cat.]

"Between 2". Städtische Kunsthalle, Düsseldorf, 20-22 juny , 1969.

"Konzeption / Conception". Städtisches Museum i Schloos Morsbroich, Leverkusen, oct. - nov., 1969. [Cat.]

"An 12 ou Vingt ans après". Galeria New Smith, Brussel'les, 8-26 d'oct., 1966.

\section{0}

"Between 4". Städtische Kunsthalle, Düsseldorf, 14-15 febrer, 1970.

"Paris 18 IV 70". 66 de la Rue Mouffetard, París, abril - maig, 1970. [Cat.] 
"La Métamorphose de l'object. Art et anti-art 1910-1970". Palau de Belles Arts: Brussel-les, 22 abril - 6 juny, 1970; Museu Boymansvan Beuningen: Rotterdam, 27 juny -15 agost, 1971; Galeria nacional: Berlín, 11 set. - 7 nov., 1971; Palau Reial: Mailand, 15 des., 1971 - 10 febrer, 1972; Kunsthalle: Bâle, 4 març - 22 abril, 1972; Museu d'Arts Decoratives: Paris, maig juny, 1972. [Cat.]

"3e Salon International des Galeries Pilotes Lausanne / Artistes et découvreurs de notre temps". Museu cantonal de Belles Arts i Palau de Rumine: Lausanne, 21 juny - 4 oct., 1970; Museu d'Art Modern de la Vila de Paris: 28 oct. - 6 des., 1970. [Cat.]

"Information". Museu d'Art Modern: Nova York, 2 juliol - 30 agost, 1970. [Cat.]

"Letterlijk en Figuurlijk". Zeeuws Museum in de Vleeshal van het Stadthuis: Middelburg, 10 juliol - 30 agost, 1970. [Cat.]

"Between 5". Städtische Kunsthalle i Kunstverein für die Rheinlande und Westfalen: Düsseldorf, 9-18 oct., 1970.

\section{1}

"Multiples. The First Decade". Museu d'Art de Filadèlfia: Filadèlfia, 5 març - 4 abril, 1971.

"2e Biennale Nürnberg 1971 - Was die Schönheit sei, das weiss ich nich, Künstler - Theorie - Werk". Kunsthalle Nürnberg, Nüremberg, 20 abril - 1 agost, 1971. [Cat.]

"Tweede Triennale Brugge". Provincie WestVlaanderen, Stad Brugge Hallen, Bruges, 15 jul.-15 set., 1971.

"Kölner Kunstmarkt '71". Kunsthalle Köln: Colònia, 5-10 oct., 1971. [Cat.]

"Prospect '71 / Projection". Städtische Kunsthalle, Düsseldorf, 8 - 17 oct., 1971.

\section{2}

"Documenta 5: Befragung der Realität Bildwelten heute". Galeria Nova i Museu Fridericianum: Kassel, 30 juny - 8 octubre, 1972. [Cat.]

"Amsterdam - Paris - Düsseldorf". Museu Solomon R. Guggenheim: Nova York, 5 octubre - 26 nov., 1972. [Cat.]
"Peintres et Sculpteurs Belges Contemperains / Hedendaagse belgische Schilders en Beeldhouwers". Palau de Belles Arts, Brussel.les, 26 oct. - 3 nov., 1972; Museu Cantini: Marsella, nov. - des., 1972. [Cat.]

"Actualité d'un bilan". Galeria Yvon Lambert, Paris, 29 octubre - 5 des., 1972. [Cat.]

\section{3}

"Bilder - Objekte - Film - Konzepte". Städtische Galeria: Lenbachhaus, Munic, 3 abril - 13 maig, 1973. [Cat.]

"Medium Fotografie, Fotoarbeiten bildender Künstler von 1910 bis 1973". Städtisches Museum / Schloss Morsbroich: Leverkusen, 18 maig - 5 agost, 1973. [Cat.]

"M. Broodthaers, J. Charlier, J. Geys, B. Lohaus, G. Mees, Panamarenko, M. Roquet". Palau de Belles Arts: Brussel-les, 25 maig - 24 juny, 1973. [Cat.]

"Prospect '73 - Maler - Painters - Peintres". Städtische Kunsthalle: Düsseldorf, 28 set.7 oct., 1973.

"30 Internationale Künstler in Belin - Gäste des Deutschen Akademischen Austauschdienstes, Berliner Künstlerprogramm". Beethoven - Halle: Bonn, 14-27 des., 1973. [Cat.]

\section{4}

"Carl André, Marcel Broodthaers, Daniel Buren, Victor Burgin, Gilbert \& George, On Kawara, Richard Long, Gerhard Richter". Palau de Belles Arts: Brussel-les, 9 gener3 febrer, 1974. [Cat.]

"3e Triennale Brugge". Provincie WestVlaanderen, Stad Brugge Beurrshalle, Bruges, 22 juny-1 set., 1974. [Cat.]

"Kunst Bleibt Kunst. Projekt '74 Köln. Aspekte internationaler Kunst am Anfang der 70er Jahre". Kunsthalle: Colònia, 6 juliol - 8 set., 1974. [Cat. p. 148-151]

\section{5}

"Funkties van Tekenen / Functions of Drawing". Rijksmuseum Kröller - Müller , Otterlo, 24 maig - 4 agost, 1975. [Cat.]

"Ceci Cela ou Rien / This that or nothing... During six months". Nigel Greenwood Ltd.: Londres, juliol 1975 - gener 1976. 
"Von Pop zum Konzept. Kunst unserer Zeit in belgischen Privatsammlungen". Galeria Nova - Sammlung Ludwig, Aix - la Chapelle, 4 oct. - 9 nov., 1975. [Cat.]

\section{Exposicions individuals}

\section{4}

"Moi aussi, je me suis demandé si je ne pouvais pas vendre quelque chose..." Galeria Saint-Laurent: Brussel-les, 10-25 abril, 1964.

\section{5}

"Objets de Broodthaers / Voorwerpen van Broodthaers". Galeria Aujourd-hui, Palau de Belles Arts: Brussel·les, 2-24 abril, 1965.

\section{6}

"M.B." Galeria J.: París, 8-21 març, 1966.

"Moules Oeufs Frites Pots Charbon". Galeria Wide White Space: Anvers, 26 maig - 26 juny, 1966. [Cat.]

"Peinture à l'Oeuf. Je retourne à la matière. Je retrouve la tradidition des primitifs". Galeria Cogeime: Brussel-les, 27 set. - 9 oct., 1966.

\section{7}

"Marcel Broodt(h)aers / Court Circuit". Palau de Belles Arts: Brussel-les, 13-15 abril, 1967. [Cat.]

"Marcel Broodthaers". Kasteelke, Mullem, 18 nov. -9 des., 1967.

\section{8}

"Le corbeau et le renard". Galeria Wide White Space: Anvers, 7-24 març, 1968.

"Marcel Broodthaers". Galeria Rudolf Zwirner: Colònia, set., 1968.

"Section XIXe siècle. Musée d'Art Moderne, Département des Aigles". 30, rue de la Pépinière: Brussel·les, 27 set. 1968 - 27 set. 1969.

"La collection privée de Marcel Broodthaers". Galeria 44: Brussel·les, tardor del 1968.
"Multipl(i)é inimitable illimité, Exposition de tirages limités et illimités de poèmes industriels, M.U.SÉ.E D'.A.R.T. CAB.INE.T D.ES. E.STA.MP.E.S Département des Aigles". Llibreria Saint-Germain-des-Prés: Paris, 29 oct. - 19 nov.,1968.

\section{9}

"Broodthaers". Galeria Gerda Bassenge i Benjamin Katz: Berlín, març - abril, 1969 i Galeria Fitzroy: Brussel-les, 23 abril - 7 maig, 1969.

"Naar een onbeduidende Kunst? Vers un art sans impertance?" Galeria Richard Foncke: Gante, 19 agost - 10 set., 1969.

"Section XVIIe siècle. Musée d'Art Moderne, Département des Aigles". Espai A 3790 89, Anvers, 27 set. -4 oct., 1969.

"An 12 ou Vingt ans après". Galeria New Smith: Brussel.les, 8-26 oct., 1969.

"Exposition littéraire autour de Mallarmé. Marcel Broodthaers à la Deblioudeblious / S". Galeria Wide White Space: Anvers, 2-20 des., 1969 .

\section{0}

"Exposition littéraire et musicale autour de Mallarmé". Galeria Michael Werner: Colònia, 22 gener - 20 febrer, 1970.

"Section XIXe siècle (bis). Musée d'Art Moderne, Département des Aigles". Städtische Kunsthalle: Düsseldorf, 14-15 febrer, 1970. [En "Between 4"]

"MTL 13/3/70 - 10/4/70". Galeria MTL, Brussel.les, 20 febrer - 13 març, 1970.

"Modèle / M. Broodthaers". Galeria Michael Werner: Colònia, 4-15 set., 1970. [projecció del film Der Fisch]

"Cinéma Modele. Musée d'Art Moderne, Département des Aigles". Burgplatz 12: Düsseldorf, 15 nov. 1970 - gener 1971.

\section{1}

"Section Cinéma. Musée d'Art Moderne, Département des Aigles". Burgplatz 12: Düsseldorf, gener 1971- hivern 1972.

"Département des Aigles. Proyection d'un film du Musée d'Art Moderne. Exposition de 40 dessins". Galeria Michael Werner: Colònia, 16 gener - 15 febrer, 1971. 
"Marcel Broodthaers: Relieftafeln-Film". Galeria Ernst: Hannover, 6-25 març, 1971.

"Figures anciennes et modernes". Galeria Wide White Space: Anvers, 27 set. - 27 octubre, 1971.

"Section Financière, Musée d'Art Moderne à vendre 1970 - 1971 pour causa de faillite". Galeria Michael Werner: Feria d'Art de Colònia, 5-10 oct., 1971.

"Film als Objekt - Objekt als Film". Städtische Museum: Mönchengladbach, 21 octubre - 7 nov., 1971. [Cat.]

\section{2}

"Marcel Broodthaers (sic): Zeichungen, Dias, Film". Galeria Heiner Friedrich: Munic, 6-25 maig, 1972.

"Section des Figures (Der Adler vom Oligozän bis heute) Musée d'Art Moderne, Département des Aigles". Städtische Kunsthalle: Düsseldorf, 16 maig - 9 juliol 1972.

"MTL 18/5/72 - 17/6/72". Galeria MTL: Brussel'les, 18 maig - 17 juny, 1972.

"La porte est ouverte 27-8-1901 M.B. M.B. M.B..." Galeria Michael Werner: Colònia, 15 juny - 4 juliol, 1972. [Cat.]

"Le Corbeau et le Renard (1967-1972)".Galeria Wide White Space: Anvers, 17-30 juny, 1972. [Cat.]

"Section Publicité. Musée d'Art Moderne, Département des Aigles". Nova Galeria: Kassel, 30 juny - 8 octubre, 1972 [Documenta 5].

"Section d'Art Moderne. Musée d'Art Moderne, Département des Aigles". Nova Galeria: Kassel, 30 juny - 15 agost, 1972 [Documenta 5].

"Galeria du XXe siècle. Musée d'Art Ancien, Département des Aigles". Nova Galeria: Kassel, 15 agost- 8 oct., 1972 [Documenta 5].

"Marcel Broodthaers. La Signature de l'Artiste". Galeria Grafikmeyer: Karlsruhe, 20 octubre - 16 nov., 1972.

"Marcel Broodthaers". Galeria Jack Wendler: Londres, 1-22 des., 1972.
1973

"Programme". Galeria Wide White Space: Anvers, 15 gener - 15 febrer, 1973. [selecció de projeccions, films i diapositives]

"Marcel Broodthaers. Rétrospective (octobre 1963 - mar. 1973)". Art \& Project: Amsterdam, 17 març -14 abril, 1973. [Cat.]

"Petrus Paulus Rubens". Galeria MTL, Galeria Le Bailli, 195 avenue Louise i 13 avenue des Éperons d'Or, simultàniament: Brussel.les, març, 1973. [com a part del projecte Art \& Project: Amsterdam, març abril, 1973].

"Rendez-vous mit Jacques Offenbach". Städtische Galeria en Lenbachhaus: Munic, 13 abril - 13 maig, 1973.

"A, B, C, - Paysage d'Automne". Galeria Yvon Lambert: París, 14-20 juny, 1973.

"Fumer-Boire-Copier-Parler-Écrire-PeintreFilmer, 1821-1867, 1846-1870, 1869-1951, 1871-1945, 1898-1967, 1972". Galeria Françoise Lambert: Milà, juny, 1973.

"Peintures Littéraires 1972-1973". Galeria Rudolf Zwirner: Colònia, set., 1973.

"Jeter du poisson sur le marché de Cologne". Galeria Michael Werner: Colònia, 7 set. - 10 oct., 1973.

"Marcel Broodthaers. Oeuvres impertantes depuis 1963". Galeria New Smith: Brussel|les, 7 nov. - 1 des., 1973.

\section{4}

"Reclame pour la Mer du Nord". Galeria / Édition Seriaal: Amsterdam, 12 abril- 6 maig, 1974.

"M.B." Galeria Folker Skulima: Berlín, 16-30 juny, 1974.

"Zeichnungen". Galeria Michael Werner: Colònia, 1-30 juliol, 1974.

"Ne dites pas que je ne l'ai pas dit-Le Perroquet / Zeg niet dat ik het niet gezegd heb-De Papegaai". Galeria Wide White Space: Anvers, 19 set., 1974; Galeria Le Bailli: Brussel-les, 25 set., 1974.

"Culture Internationale". Galeria MTL: Brussel-les, 27 set.- 24 oct., 1974.

"Catalogue - Catalogus". Palau de Belles Arts: Brussel.les, 27 set.- 3 nov., 1974. [Cat.] 
"Éloge du Sujet". Kunstmuseum: Basilea, 5 oct. - 3 nov., 1974. [projecció del film Éloge du Sujet en la Sala Lumière]

"1833 - 1974 Marcel Broodthaers. Das Manuskript in der Flaschel / The manuscript on a Botle / Le Manuscrit trouvé dans une bouteille 1833/1974". Galeria René Block: Berlín, 12 octubre - 12 nov., 1974.

\section{5}

"Invitation pour une exposition bourgeoise". Galeria Nacional: Berlín, 25 febrer - 6 abril, 1975.

"Le privilège de l'Art". Museu d'Art Modern: Oxford, 26 abril - 1 juny, 1975.

"Films, dias et fotos. (Une contradiction entre le mouvement et le statisme de l'image)". Städtische Kunsthalle: Düsseldorf, 23-25 maig, 1975.

"Décor: A Conquest by Marcel Broodthaers". ICA (Institute of Contemperary Art) Nova Galeria: Londres, 11 juny - 6 juliol, 1975.

"Voyages autour de la mode". Galeria Grafikmeyer: Karlsruhe, 15 juny - 31 juliol, 1975.

"L'Angélus de Daumier". Centre National d'Art Contemperain, Hôtel Rothschild: París, 2 octubre - 10 nov., 1975. [Cat.]

"Les Poissons - De Vissen". Galeria MTL i Lebeer Hossmann: Brussel-les, 4 des. 1975 - 10 gener 1976.

\section{6}

"Marcel Broodthaers". Galeria Marzona: Düsseldorf, 15 gener - 16 febrer, 1976. [Cat.]

\section{Pel·lícules}

\section{7}

La Clef de l'Horloge (Poème cinématografique en I'honeur de Kurt Schwiters). $16 \mathrm{~mm}$, blanc i negre, so, 7 min. Brussel·les, 1957.

\section{9}

Le Chant de ma Génération. $35 \mathrm{~mm}$, blanc i negre, so. Brusselles, 1959.[No se'n conserva més que el guió. Muntatge a partir de fragments de documentals de l'època]
Actualités reconsidérées. $16 \mathrm{~mm}$, blanc i negre, so. Brussel-les, 1959.[No se'n conserva més que el guió. Muntatge a partir de fragments de seqüències d'actualitats exhibides en sales de cinema. Potser va projectar-se'n en la mostra Poesie-Cinéma]

\section{4}

Bruegel et Goya, Journalistes. $35 \mathrm{~mm}$, blanc i negre, so, $20 \mathrm{~min}$. Brussel $\cdot$ les, 1964.

\section{7}

Le Corbeau et le Renard (d'après La Fontaine). $16 \mathrm{~mm}$, color, $17 \mathrm{~min}$. Brussel.les, 1967. [pel-lícula que cal projectar sobre una pantalla especial. Despés en va formar part d'una edició i va exposar-se'n en una galeria d'art]

Objet. $16 \mathrm{~mm}$, blanc i negre, $10 \mathrm{~min}$., Brussel.les, 1967.

\section{8}

Une Discussion Inaugurale. $16 \mathrm{~mm}$, blanc i negre, $8 \mathrm{~min}$. / $10 \mathrm{~min}$. / $30 \mathrm{seg}$. (vàries versions). Brussel-les, 1968.

Signalisation. $16 \mathrm{~mm}$, blanc i negre, $3 \mathrm{~min}$., Brussel.les, 1968. [muntat per Maria Gilissen i Jean-Lois Dewert, 1985]

\section{9}

Le Musée et la Discussion. $16 \mathrm{~mm}$, blanc i negre, 12 min. Brussel-les, 1969.

Un Voyage à Waterloo (Napoleón 1769-1969). $16 \mathrm{~mm}$, blanc i negre, $13 \mathrm{~min}$. Brussel.les, 1969.

Le temps d'une journée. The past. The time. 16 $\mathrm{mm}$, blanc i negre. Brussel-les, 1969. [inacabada]

La Pluie (Projet pour un texte). $16 \mathrm{~mm}$, blanc i negre, 2 min., Brussel les, 1969.

La pipe satire. $35 \mathrm{~mm}$, blanc i negre, $2 \mathrm{~min}$., Brussel.les, 1969.

Défense de Fumer. $35 \mathrm{~mm}$, blanc i negre, 28 seg., Brussel-les, 1969-70.

Ceci ne serait pas une pipe (Un Film del Musée d'Art Moderne). $35 \mathrm{~mm}$, blanc i negre, 2 min. 20 seg., Brussel-les, 1969-71.

La Pipe (Gestalt, Abbildung, Figur, Bild) 16 $\mathrm{mm}$, blanc i negre i virat en blau, $4 \mathrm{~min} .20$ seg., Brussel-les, 1969-72. [quatre versions] 
1970

MTL (DTH). $16 \mathrm{~mm}$, color, $5 \mathrm{~min}$., Brussel·les, 1970.

Un film du Musée d'Art Moderne. $35 \mathrm{~mm}$, blanc i negre, 4 min., Brussel les, 1970.

Musée-Museum. $16 \mathrm{~mm}$, blanc i negre, 12 min., Brussel-les, 1970. [en projectat sobre un mapa del món]

La lune. $35 \mathrm{~mm}$, color, 2 min 30seg., Brussel.les, 1970

Un Film de Charles Baudelaire (Carte politique du monde). $35 \mathrm{~mm}$, color, so, $6 \mathrm{~min} .30$ seg., Brussel·les i Paris, 1970.

Un Film de Charles Baudelaire (Carte politique du monde ou système de signification). 35 $\mathrm{mm}$, color, so, 6 min. 30 seg., Brussel.les i Paris, 1970. [segona versió]

La Signatura (Une Seconde d'Eternité). 35 i 16 mm, blanc i negre, 1 seg., Berlin, 1970.

Une Seconde d'Eternité (D'après une idée de Charles Baudelaire). $35 \mathrm{~mm}$, blanc i negre, 1 seg., Brussel·les, 1970.

\section{1}

Projet pour un Poison (Projet pour un Film) 35 $\mathrm{mm}$, blanc i negre, 9 min., Brussel.les i Colònia, 1970-71.

Crime à Cologne. 35 min., blanc i negre, so, 1 min. 30 seg., Colònia, 1971.

Au-delà de cette limite vos bilets ne sont plus valables. $16 \mathrm{~mm}$, blanc i negre, $7 \mathrm{~min} .30$ seg., Paris i Berlin, 1971.

C'est-je-parole-regret. $16 \mathrm{~mm}$, color, so, $7 \mathrm{~min}$., Colònia, 1971.

Histoire d'amour (Dr. Huysmans). $16 \mathrm{~mm}$, color, so, 3 min, Brussel les, 1971.

Section Cinéma: Charlie als Filmstar. $16 \mathrm{~mm}$, blanc i negre, 2 min 30 seg., 1971. [curt muntat per la productora Globus Film]

Section Cinéma: Brüssel Teil II. 16 mm, blanc i negre, 2 min 20 seg., 1971. [curt muntat per les productores Globus Film i Filmoffice]

Section Cinéma: Belga Vox - Mode - 20th Century Fox. $16 \mathrm{~mm}$, blanc i negre, $8 \mathrm{~min}$. 30 seg., 1971.

O-X. $16 \mathrm{~mm}$, blanc i negre, $3 \mathrm{~min}$., Düsseldorf, 1971.

Paris (Carte postale). $16 \mathrm{~mm}$, color, $2 \mathrm{~min}$., Paris, 1971.
1972

Tableau Magritte. $35 \mathrm{~mm}$, blanc i negre, $3 \mathrm{~min}$., Brussel-les, 1972.

Mauretania (Avec mer). 16mm, color, 2 min., Düsseldorf, 1972. [dues versions: Mauretania (AOX-XOA) i Mauretania (Fig.O - Figures Fig.A)]

Ah, que la chasse soit le plaisir des Rois. 16 mm, color, 8 min., Brussel·les, 1972.

Die Farbe / La Couleur / The Colour. 16 mm, color, 2min., Düsseldorf, 1972.

Chère petite soeur (La Tempête). $16 \mathrm{~mm}$, blanc i negre i virat, 4 min., Brussel.les, 1972.

Rendez-vous mit Jacques Offenbach. $16 \mathrm{~min}$, blanc i negre, so, $18 \mathrm{~min} .30$ seg., Brussel·les i Düsseldorf, 1972.

Speakes Corner. $16 \mathrm{~mm}$, blanc i negre, $8 \mathrm{~min}$., Londres, 1972.

Musée d'Art Moderne. Département des Aigles. Section Publicité et Section d'Art Moderne. $16 \mathrm{~mm}$, blanc i negre, $12 \mathrm{~min}$., Kassel, 1972. [muntat per Maria Gilissen i JeanLois Dewert, 1986]

Musée d'Art Ancien. Dé partement des Aigles. Galeria du XXe siècle. $16 \mathrm{~mm}$, color, $7 \mathrm{~min}$., Kassel, 1972. [muntat per Maria Gilissen i Jean-Lois Dewert, 1984]

Kassel Wilhelmshöhe (Hercules mit Kaskadern). $16 \mathrm{~mm}$, blanc i negre, $5 \mathrm{~min} 30$ seg., Kassel, 1972. [muntat per Maria Gilissen i Jean-Lois Dewert, 1982]

\section{3}

Deux Films. 16 mm, color, 12 min., Brussel·les, 1973.

Analyse d'une Peinture. $16 \mathrm{~mm}$, color, $6 \mathrm{~min}$, Brussel.les, 1973.

Une peinture d'amateur découverte dans une boutique de curiosités. $16 \mathrm{~mm}$, color, $7 \mathrm{~min}$, Brusel'les, 1973. [versió a partir del film Analyse d'une Peinture]

Le méme fiml, revu après critiques. $16 \mathrm{~mm}$, color, 5 min., Brussel-les, 1973. [versió a partir del film Analyse d'une Peinture]

The Last Voyage. $16 \mathrm{~mm}$, color, $4 \mathrm{~min}$., Londres, 1973-74. 
1974

A Voyage on the North Sea. $16 \mathrm{~mm}$, color, 4 min. 15 seg., Brussel-les i Londres, 197374.

Eau de Cologne 1974. 35 mm, color, so, 2 min., Colònia, 1974.

Un Jardin dHiver (ABC). $35 \mathrm{~mm}$, color, so, 6 min., Brussel.les, 1974.

Les nouvelles aventures des Pieds Nickelés (Nouveaux trucs - Nouvelles combines). 35 $\mathrm{mm}$, color, 1974. [sense acabar-ne]

Berlin oder ein Traum mit Sahne. $35 \mathrm{~mm}$, color, so, 10 min., Berlín, 1974.

Monsierur Teste. $35 \mathrm{~mm}$, color, $2 \mathrm{~min}$., Brussel.les i Paris, 1974-75.

Figures of Wax (Jeremy Bentham). $35 \mathrm{~mm}$, color, so, 15 min., Londres, 1974.

\section{5}

Slip-test (Dissolves). $16 \mathrm{~mm}$, color, 6 seg., Londres, 1975.

La Bataille de Waterloo. $35 \mathrm{~mm}$ i $16 \mathrm{~mm}$, color, so, 11 min. 20 seg., Londres, 1975.

\section{Intervencions, happenings, projeccions, debats, conferències}

\section{0}

"Vente Publique. Bibliothèques d'Amateurs. Autographes. Editions originales - Beaux Livres Illustrés - Histoire Héraldique Hoppologie - Littérature moderne et Beaux livres en langue allemande". (Marcel Broodthaers - Libraire). Galeria Thémis: Brussel|les, 25 març, 1950.

\section{8}

"Film Exprmntl Film 1958". Festival de cinema experimental de Knokke Le-Zoute: juny agost, 1958. [Presentació del film La Clef de L'Horloge. 16 mm, B/N, so, 7' 1957]

\section{9}

"Poésie-Cinéma". Palau de Belles Arts: Brussel·les, 1965.
1964

"Sophisticated Happening by Marcel Broodthaers. Peinture Sculpture Musique Nature Critique Poésie Instinct Clarté Dada Pop Trap op". Galeria Smith: Brussel-les, 23 juliol, 1964. [Lectura d'un article aparegut en premsa sobre la noció d'art i de diners. Acaba pegant-hi un quadre negre i unes ulleres gegants]

"Exposition surprise". Parc du Mont des Arts: Brussel.les, set., 1964. [Exposició improvisada en un lloc públic amb la col·laboració d'un grup de músics negres]

\section{5}

"Debat sobre el Pop Art en què van prendre part Marcel Broodthaers, Pierre Restany, Jean Dypréau i Bob Claessens". Palau de Belles Arts, Brussel les, 12 març, 1965.

"Le Pop'Art. Palau de Belles Arts: Brussel-les, 22 març, 1965. [Debat públic en què van participar Marcel Broodthaers, Marcel Baugniet, Jean Dypréau i Jacques Meuris en concloure-hi l'exposició "Pop Art, Nouveau Réalisme, etc."]

\section{6}

"Au Pied de la lettre". Rue de la Pépinière: Brusselles, 8 des., 1966. [Happening on van participar cinc membres del grup musical de Paul Lambert a més i a més de Walter Swennen, Eliane de Schutter i Marcel Broodthaers]

"Grandville \& M.B". Club de Jazz: Gante, ca. 1966 i Galeria Smith: Brussel-les, 1966. [Projecció de diapositives juntament amb una audició de jazz a càrrec de Léo Keuten, Paul Feyaerts i Henri van den Abeele]

"Happening". Rue de la Pépinière, Brussel·les, 1966.

\section{7}

"Film Exprmnntlfilm 4". Festival de cinema experimental de Knokke Le -Zoute: 25 dic. 1967-2 gen. 1968. [Projecció del film Le corbeau et le renard]

"Le Corbeau et le Renard". Torre del Rellotge: París, 1967 [projecció pública de la pel'lícula Le corbeau et le renard]. 
1968

"Manifestation Publiques". Palau de Belles Arts: Brusselles, 31 gener, 1968 [Conferència sobre René Magritte a càrrec de Marcel Broodthaers i Bob Claessens dins del cicle "Joventut i Arts Plàstiques"].

"Le Mec Art et l'Art du l'Object". Palau de Belles Arts: Brussel'les 6 març, 1968 [Conferència de Marcel Broodthaers i Otto Hahn dins del cicle "Joventut i Arts Plàstiques"]

"Al voltant de la polèmica". Palau de Belles Arts: Brussel.les, 8 des., 1968. [Debat públic amb Marcel Broodthaers, Pierre Restany i Jean Dypréau]

"Section Littéraire, Musée d'Art Moderne, Département des Aigles". Cartes obertes: Ostende, Brussel.les, Anvers, París, Düsseldorf1, Colònia, etc. 1968-70.

\section{9}

"Section Documentaire. Musée d'Art Moderne, Département des Aigles". Platja de Le Coq: (Bèlgica) agost, 1969.

"An 12 ou Vingt ans après". Galeria Louise, Salle Arlequin: Brussel-les, 13 d'oct., 1966. [Broodthaers va dedicar i va signar els primers 75 exemplars del llibre Vingt ans après d'Alexandre Dumas en el marc de la 2a Feria d'Art Actual]

"L'anàlisi de la relació entre les làmines mallarmeanes de Broodthaers i la tirada de dades mallarmeà". Espai A 3790 89: Anvers, 2 de des., 1969. [Conferència pronunciada pel professor de filosofia Pierre Verstraeten en l'inauguració de la mostra "Exposition littéraire autour de Mallarmé. Marcel Broodthaers à la Deblioudeblious / S".]

\section{0}

"MTL-DTH". Galeria MTL: Brussel·les, $20.30 \mathrm{~h}$, 10 d'abril, 1970. [estrena del film MTL-DTH sobre l'escaparata de la galeria l'últim dia de l'exposició]

"Section Folklorique, Cabinet des Curiosités. Musée d'Art Moderne, Département des Aigles". Departament Folklòric del Museu Zeeuws: Middelburg, 1970.
"Une Seconde d'Éternité (d'après une idée de Charles Baudelaire)". Galeria FolkerSkulima: Berlín, 1970. [projecció del film La Signature (Une Seconde d'Éternité)]

\section{1}

"Au-delà de cette limite vos billets ne sont plus valables". Galeria Yvon Lambert: París, 15 dic., 1971. [projecció de la pellícula]

\section{2}

"Au-delà de cette limite vos billets ne sont plus valables". Galeria François Lambert: París, Milan 19 d'abril, 1972. [Íd.]

"Fig.1. Fig.2. Fig.0. Fig.12. Programme de Films". Agència d'Art Modern: Nàpols, 18 març, 1972.

"Rendez-vous mit Jacques Offenbach, Marcel Broodthaers. Films". Palau de Belles Arts: Brusselles, 7 des. 1972. [conferència i presentació d'un programa de diversos films i d'un debat amb el públic]

\section{3}

"L'Art et son contexte culturel". La Cambre: Brussel-les, 1-3 juliol, 1973. [Congres internacional sobre art contemporani organitzat per Fernand Spillemaeckers (Galeria MTL). Participants: Art \& Languaje Institute (Philip Pilkington, David Rushton), Carl André, Marcel Broodthaers, Daniel Buren, Hans Haacke, John Latham, Caderé, Sol Lewit i Lawrence Weiner]

"Analyse eines Bilde / Analyse d'une peinture". Projecció del film durant la inauguració de I"exposició "Peitures Littéraires 1972 1973". Galerie Rudolf Zwirner: Colònia, 7 sep., 1973.

"Internationale Colloquium zur Vorbereitung Wersktatt Berlin für Experimentele Kunst". Academia d'art de Berlín: 13 octubre, 1973.

"Fig.1. Fig.2. Fig.0. Fig.12. Fig.A. (Film von Marcel Broodthaers)". Academia d'art de Berlín, 13 oct., 1973 i Galeria René Bloch: Berlín, 14 oct., 1973.

"M.B. Film". Galeria Loehr: Frankfurt, 15 octubre, 1973. 
"Deux films de Marcel Broodthaers: 1. Une peinture d'amateur découverte dans une boutique de curiosités; 2 . Le même film revu après critiques". Galeria Yvon Lambert: París, 6 nov., 1973.

\section{4}

"A Voyage on the North Sea". Petersburg Press, Londres, 28 gener, 1974. [llançament del llibre $A$ Voyage on the North Sea i estrena d'un film amb el mateix nom]

"Un film de Charles Baudelaire (1970)". Cine Estudi Arenberg: Brussel.les, des de 31 gener, 1974. [projecció de la pel-lícula com a part de l'exposició "Carl André, Marcel Broodthaers, Daniel Buren, Victor Burgin, Gilbert \& George, On Kawara, Richard Long, Gerhard Richter"]

"L'Image d'Épinal et I'Image Théorique. Diapositives sur un matériel du XIXe siècle (illustration de levres, lithographies, etc....) et un matériel prisé dans l'art immediatement contemperain". Palau de Belles Arts: Brussel-les, 28 març, 1974. [conferència-exposició dins del cicle "Joventut i Arts Plàstiques]

"Eau de Cologne 74". Projecció del film en les sales de cinema Melville (París), Pullman i Uni Center (Colònia), juny, 1974.

"Prix Robert Giron 1974". Palau de Belles Arts, Rotonde, 24 set., 1974. [intervenció de Marcel Broodthaers en rebre el premi d'Arts Plàstiques "Robert Giron"]

"Éloge du sujet". Projecció del film en la sala Lumière: Bâle, 5 oct. -3 nov., 1974.

\section{5}

"Berlin oder ein Traum mit Sahne". Projecció del film. Galeria Nacional: Berlín, 25 de febrer, 1975.

"Figures of Wax (Jeremy Bentham)". The Slade School of Fine Arts, Col-legi Universitari: Londres, 10 des., 1975. [projecció del film Figures of Wax (Jeremy Bentham)]

\section{Llibres i edicions d'artista}

\section{0}

Vente Publique. Bibliothèques d'Amateus. Autographes. Editions originales - Beaux Livres Illustrés - Histoire Héraldique Hoppologie - Littérature moderne et Beaux livres en langue allemande. (Marcel Broodthaers - Libraire). Brussel-les: Galeria Thémis, 25 març, 1950. [targeta d'invitació]

\section{7}

Mon livre d'ogre. Ostende: à l'Enseigne de l'Arquebuse du Silence, 1957. [llibre de poemes]

\section{8}

Photographies de Julien Coulommier. Brussel-les: Galeria Aujourd'hui, Palau de Belles Arts, 4-18 oct., 1958. [targeta d'invitació de l'exposició]

\section{0}

Minuit. Brussel|les: George Houyoux (ed.), 1960. [llibre de poemes]

\section{1}

La Bête Noire. Brussel'les, Marcel Broodthaers (ed.), 1961. [llibre de poemes]

\section{3}

Pense-Bête. Brussel'les: Marcel Broodthaers (ed.), 1963. [llibre de poemes]

\section{4}

Moi aussi, je me suis demandé si je ne pouvais pas vendre quelque chose...". Brussel.les: Galeria Saint-Laurent, 10-25 abril, 1964 [targeta d'invitació de l'exposició].

La faute d'ortographe (Mea culpa). Brussel-les: galeria Smith, 1964. [Butlletí d'inscripcions d'edicions litogràfiques de la galeria Smith on el nom de Broodthaers apareix escrit malament i rectificat a mà per ell mateix. Trenta exemplars numerats i signats i vint proves d'artista] 


\section{5}

Pop Art?. Objets de Broodthaers / Voorwerpen van Broodthaers. Brusselles: Galeria Aujourd-hui, Palau de Belles Arts, 2-24 abril., 1965. [targeta d'invitació de l'exposició]

\section{6}

Phantomas, $n^{\circ} 62$, any 13 . Brussel-les: febrer, 1966. [nombre especial de la revista a càrrec de Marcel Broodthaers. Tirada limitada de 500 exemplars]

Moules Oeufs Frites Pots Charbon. Anvers: Galeria Wide White Space, 1966. [cat. de l'exposició a càrrec de Mrcel Broodthaers]

Je retourne à la matière. Je retrouve la tradidition des primitifs. Peinture à l'Oeuf. Peinture à l'Oeuf. Brussel-les: Galeria Cogeime, 27 set. - 9 octubre, 1966. [targeta d'invitació de l'exposició]

\section{7}

Court Circuit / Marcel Broodt(h)aers. Brussel-les: Palau de Belles Arts, 13-15 abril, 1967. [cat. de l'exposició a càrrec de Broodthaers]

Allo!! Pierre Restany? II est absent. Mullem, Kasteelke, 18 nov. - 9 des., 1967. [targeta d'invitació de l'exposició "Marcel Broodthaers"]

\section{8}

Le corbeau et le renard. Anvers: Galeria Wide White Space, 1967. [Llibre gegant amb film]

\section{9}

Un museu d'Art Moderne A Brussel/les... . Belín: Galeria Gerda Bassenge i Benjamin Katz, març - abril, 1969 i Brussel-les: Galeria Fitzroy, 23 abril - 7 maig, 1969. [anunciament de l'exposició "Broodthaers"]

Naar een onbeduidende Kunst? Vers un art sans impertance? Gante: Galeria Richard Foncke, 19 agost - 10 set., 1969. [targeta d'invitació de l'exposició]

La signature série 1. Marcel Broodthaers (ed.), 1969. Serigrafia sobre paper de calco. Tirada illimitada, seixanta exemplars signats però no numerats.
Vintg ans après. Brussel-les: Richard Lucas, 1969. [Edició d'una banda de sobrecoberta per a 75 exemplars d'Alexandre Dumas. Vintg ans après. París, Galimard, 1961. Le livre de Poche Clássique. Vol. I datat i signat per Richard Lucas i vol. II datat i signat per Marcel Broodthaers. S'hi inclou un diàleg entre ambdós pegat en la pàgina de portadeta]

Un coup de dés jamais n'abolira le hasard. Image. Anvers: Galeria Wide White Space, 1969. [Edició formada per: 10 exemplars de 12 plaques d'alumini enumerades del I al X; 90 exemplars del llibre sobre paper transparent; 300 exemplars del llibre sobre paper blanc com a catàlegs de l'exposició. En presentats com a part de l'exposició "Exposition littéraire autour de Mallarmé. Marcel Broodthaers à la Deblioudebliou / S."]

\section{0}

MTL 13/3/70 - 10/4/70. Brussel·les: Galeria MTL, 1970. [catàleg de l'exposició. Dotze pàgines numerades, dues addicionals en numerades tretze i catorze, dues més sense en numerar com a annex i una "Note sur les intentions"]

M.B., 24 images / seconde. Galeria FolkerSkulima, 1970. Pel-lícula de $35 \mathrm{~mm}$ amb 24 fotogrames sobre cartolina. Cincuanta exemplars numerats i signats i deu proves d'artista numerades amb xifres romanes.

\section{1}

Section Financière, Musée d'Art Moderne à vendre 1970 - 1971 pour causa de faillite. Colònia: Galeria Michael Werner, 1971 [Sobrecoberta per a 19 exemplars del catàleg gereral de la Fira d'Art de Colònia.]

\section{2}

Six lettres ouvertes, "Avis". Hamburg: Griffelkunst Vereiningung, 1972. [sis fulls impresos en offset en diferents colors sobre paper blanc. Tirada de cent exemplars sesnse numerar i signats en cada full]

Chère petite soeur. Colònia: Galeria Michael Werner, 1972. [full imprés en offset. Tirada de cent exemplars numerats i signats] 
Ein Eisenbahnüberfall. Munic: Galeria Heiner Friedrich, 1972. [tirada de cent exemplars numerats, signats i individualitzats amb les inscripcions fig. 1, fig. 2, fig. a manuscrites]

Correspondance. Briefwechsel. Düsseldorf: Marcel Broodthaers/ Städtische Kunsthalle, 1972. [tirada de tres-cents exemplars, alguns numerats, signats $\mathrm{i}$ amb el segell del Département des Aigles pel revers]

MTL 18/5/72 - 17/6/72 (Tractatus LogicoCatalogicus ou l'art de vendre). Brussel les: Galeria MTL, 1972. [reimpressió del catàleg de l'exposició "MTL 13/3/70 - 10/4/70" presentat en l'exposició "MTL 18/5/72 17/6/72"]

Tractatus Logico-Catalogicus. Brussel-les: Galeria MTL, 1972. [Póster a partir dels clixés en negatiu del catàleg "MTL 18/5/72 - 17/6/72". Tirada de 100 exemplars]

Plan vert. La porte est ouverte. Colònia: Galeria Michael Werner, 1972. [Edició d'un llibrecatàleg, 50 exemplars d'eixida, enumerats i signats per Broodthaers]

Musée-Museum. Où est l'original? Wo ist das Original?. Mönchengladbach: Museumsverein, 1972. [Dos pósters amb el pla de la "Secció segle XIX" del Musée d'Art Moderne, un dels quals reproduïa targetes postals d'obres d'Ingres i l'altre de Courbet. Ambdós pósters incloïen un text darrere]

\section{3}

Rébus. París: Galeria Yvon Lambert, 1973. [fuul imprés en blau i en roig. Tirada de cent exemplars numerats i signats pel revers]

Comment va la mémoire et La Fontaine. París: Galeria Yvon Lambert, 1973. [full imprés en offset sobre papel color camuza. Tirada de cent exemplars nunerats i signats]

Charles Baudelaire. Je hais le mouvement qui déplace les lignes. Hamburgo: Hossmann, 1973. [llibre d'artista amb nota de Marcel Broodthaers: "El llibre té el seu origen en el seminari de Lucien Goldman sobre Baudelaire, què tingué lloc a Brussel-les I'hivern del 1969 - 1970 i al què havia sigut invitat com a "artista".]

Magie. Art et Politique. París: Multiplicata, 1973. [llibre d'artista.Tirada de 400 exemplars signats per Broodthaers en roig o en blau]
Jeter du poisson sur le marché de Cologne. Colònia: Galeria Michael Werner, 1973. [Llibre d'artista amb dibuixos utilitzats per a la pel-lícula Projet pour un Poisson (1971)]

A Voyage on the North Sea. Londres: Petersburg Press, 1973. [Llibre-pel-lícula d'artista. Trenta huit pàgines sense tallar, numerades pel revers i signades. Els 100 exemplars d'eixida anaven acompanyats de la pel.lícula Un voyage en Mer du Nord (16mm, 4' 15", color, sense so). Tirada de 1100 exemplars.

Un voyage en Mer du Nord. Brussel-les: Hossmann i Londres: Petersburg Press, 1973. [Llibre-pel-lícula d'artista. Trenta huit pàgines sense tallar $\mathrm{i}$ numerades pel revers, deu dels exemplars amb xifres romanes i acompanyats de la pel-lícula Un voyage en Mer du Nord (16mm, 4' 15", color, sense so). Tirada de 1000 exemplars. Nota de Broodthaers en revers de portada: "Abans de tallar els fulls, el lector hauria de desconfiar del ganivet que hi manipule. Vull que renuncie a aquest gest i que guarde aquesta arma amb ell, aquest punyal, aquest objecte d'escriptori que de sobte, com un llamp, podria transformar-se en cel erm. Es deixa al lector curiós la tasca de descobrir la raó que ha dut a publicar el present volum. S'ayudarà, si cal, amb algunes lectures tretes de l'abundant produciió actual. Prohibit tallar les pàgines."]

Eine Reise auf der Nordsee. Colònia: $m$. Dumant i Londres: Petersburg Press, 1973. [Llibre-pel-lícula d'artista. Trenta huit pàgines sense tallar $\mathrm{i}$ numerades pel revers. Tirada de 1000 exemplars.

\section{4}

A Voyage on the North Sea. Londres: Petersburg Press, 1974. [Llibre, tirada total de 1100 exemplars. Els 100 exemplars d'eixida anaven acompanyats de la pel-lícula Un voyage en Mer du Nord. (Brussel·les, Hossmann, 1973)]

A Voyage on the North Sea. Londres: Petersburg Press, 28 gener, 1974. [Invitació de l'estrena de la pel-lícula i llançament del libre-pel·lícula d'artista] 
Citron-Citröen (Réclame pour la Mer du Nord. Amsterdam: Seriaal, 1974. Impresió offset i serigrafia. Tirada de 100 exemplars numerats i signats.

Les animaux de la ferme. Heildelberg: Staeck, 1974. Impresió offset sobre cartó. Dues llàmines. Tirada de 100 exemplars numerats i signats.

The Manuscript 1833 (Le manuscrit trouvé dans une bouteille). Berlín: René Block, 1974. [Ampolla de vi de vidre transparent amb la inscripció The Manuscript 1833 envoltada en un full de paper de seda amb un text imprés i guardada en una caixa de cartó amb la inscripció El manuscrit trobat dins d'una ampolla en tres llengues (fr., al. i an.) i les dates $1833-1974$. Tirada de 120 exemplars numerats i signats en el full de paper de seda.

C'éstait comme une semaine de bonté. Colònia: Galeria Thomas Borgmann, 1974. [Conjunt de sis illustracions per a una novel la (s. ref.). Tirada de 25 exemplars enumerats i signats per Broodthaers, cadascú amb una anotació diferent]

Jardin d'Hiver. Brussel-les: Societé des Expositions i Londres: Petersburg Press, 1974. [Carpeta amb 4 litografies Tirada de 120 exemplars enumerats i rubricats amb la següent nota: "tan sols el punt de vista de l'autor i el meu (aquest opuscle) podria servir de comentari al decorat Jardin d'Hivern, plantat en gener del 1974 en el Palau de Belles Arts de Brussel-les." Signat per Yves Gevaert]

Moules Oeufs Frites Pots Charbon Perroquets. Anvers: Galleria Wide White Space, 1974 [tarjeta d'invitació de l'exposició].

Moules Oeufs Frites Pots Charbon Perroquets. Anvers: Galleria Wide White Space, 1974. [reedició del catàleg de l'exposició "Moules Oeufs Frites Pots Charbon". Ambdós exemplars van ser presentats dins d'una vitrina en aquesta exposició com a part del decorat Ne dites pas que je ne l'ai pas dit.]

Charles Baudelaire. Pauvre Belgique. París i Nova York, 1974. [llibre d'artista. Tirada de 44 exemplars en paper de proves, quatre exemplars estan marcats de $\mathrm{A}$ a $\mathrm{D}$ i la resta enumerats de l'1 al 40, en signats per Broodthaers]
Racisme végétal. La Séance. Film de Marcel Broodthaers. Colònia: Benjamin H.D. Buchloh, 1974. [Llibre d'artista. Publicat com a contribució original en "Revue des Travaux Théoriques et Practiques". Edició d'eixida 50 exemplars enumerats i signats, a més i amés de 300 sense signar-ne.]

\section{5}

La soupe de Daguerre. Nova York, Múltiples, 1975. [Dotze fotografies muntades sobre una cartolina amb el títol imprés en serigrafia. Pel revers de la cartolina hi ha la reproducció de fotos de set artistes i la inscripció Artists and photographs. edició de 60 exemplars numerats $\mathrm{i}$ signats pel revers.

En lisant la Lorelei. Wie ich die Lorelei gelesen habe. Munic: Galeria Heiner Friedrich i París: Galeria Yvon Lambert, 1975. [Edició de 17 illustracions. Tirada de 116 exemplars: 100 en enumerats de 1 a 100; 10 en enumerats de I a X; i 6 marcats de la A a la F]

Garniture symbolique. Marcel Broodthaers ed., 1975. [Dotze sèries de fotografies muntades en línia horitzontal sobre paper blanc fins a una llargària de $150 \mathrm{~cm}$ aproximadament. Les fotos són detalls del text del poema de Mallarmé Un coup de dés (París: Gallimard, 1914). Edició de 12 exemplars numerats: de l'1 al 4 amb la signatura de Broodthaers i del 5 al 12 amb el segell Estatja M. Broodthaers]

La Conquête de l'espace. Atlas à l'usage des artistes et des militaires. Brussel.les: Lebeer Hossmann, 1975. [Llibre d'artista. Edició de 50 exemplars numerats i cinc proves d'artista numerades amb xifres romanes i amb el segell: "Estatja Marcel Broodthaers"]

Altlas. Brussel-les, Lebeer Hossmann, 1975. [Póster. Tirada de 50 exemplars numerats: de l'1 al 22 signats i del 23 al 50 amb el segell Estatja M. Broodthaers"] 


\section{Textos}

\section{5}

"L'île sonnante". Le Ciel bleue, (Brussel-les) n07, 5 abril, 1945.

"Le Ploblème alemand. Le Salut Public (Hebdomadaire de précision politique et littéraire), 1945. [Signat: Marcel Canal]

"Jules Barbey d'Aurevilly ou la perte-drapeau". Le Salut Public (Hebdomadaire de précision politique et littéraire), 1945. [Signat: Marcel Canal]

"La Taverne de la Jamaïque". Le Salut Public (Hebdomadaire de précision politique et littéraire), 1945. [Signat: Marcel Canal]

"Le rêve d'un jeune homme malheureux ou l'anarchiste anodin". Le Salut Public (Hebdomadaire de précision politique et littéraire), (Brussel-les) 1945-1946.

\section{6}

"Respuesta a una entrevista de René Magitte", Le savoir vivre, (Brussel·les) 1946.

\section{8}

"Project pour un film". Le Surréalisme révolutionnaire, (París) n¹, març - abril, 1948, pág. 4.

\section{4}

"Adieu, Police". Phantomas, (Brussel-les) n², abril, 1954, p. 15. [Signat: Château d'If]

"Le Roi Midi". Phantomas, n³, set., 1954, p. 6. [Signat: Château d'Af]

\section{6}

"Poème". Phantomas, n 07 - 8, invierno, 1956, p. 29.

\section{7}

"Lui écrire une letre (Hommage à Marcel Havrenne)". Phantomas, n9, tardor, 1957, p. 7.

"Les confesions du siècle". Le Patriote ilustré, (Brussel-les) no 50, 15 des., 1957, vol.73, p. 13-15.

\section{8}

"Un autre monde". Le Patriote Illustré, no 10, 9 març, 1958, vol.74, p. 389.
"La Clef de L'Horloge". Film Exprmntl Film 1958. Knokke Le-Zoute, The International Festival of Independent Film, 1958, p. 34.

"À propos de Julien Coulommier" (1957). Photographies de Julien Coulommier. Brussel'les, Galeria Aujourd'hui, Palau de Belles Arts, 4-18 oct., 1958.

\section{9}

"Le Jardin de la prison". Edda, (Brussel.les) $n^{0}$ 2, març, 1959.

"Le ballon ce n'est pas fait pour se tuer!" Germinal, (Brussel-les) 29 set. 1959, p. 1-6.

\section{0}

"Climat". Phantomas, no 15-16, gener, 1960, p. 93.

1961

"Un poète en voyage... à Londres". Journal des Beaux-Arts, (Brussel.les) $n^{0}$ 931, 7 abril, 1961, p. 12.

"Un poète en voyage... à Londres". Journal des Beaux-Art, nº 933, 21 abril, 1961, p. 13.

"Un poète en voyage... à Bruxelles". Journal des Beaux-Arts, n 936, 12 maig, 1961, p. 11.

"Un poète en voyage... à Londres". Journal des Beaux-Arts, n 937, 19 maig, 1961, p. 10.

"Un poète en voyage... à Londres". Journal des Beaux-Arts, n 941, 16 juny, 1961, p. 10.

"Un poète en voyage... à Londres". Journal des Beaux-Arts, n 942, 23 juny, 1961, p. 11.

\section{2}

"À la Galeria Aujourd-hui. Un précurseur: Livinus." Journal des Beaux-Arts, nº 959, 5 gener, 1962, p. 5.

"Le mur de Fernand Lerin". Journal des BeauxArts, $n^{\circ}$ 974, 20 abril, 1962, p. 8.

"Deux peintres: Paul Delvaux et Ėmile Salkin et un de leurs élèves: Charles Deroux". Journal des Beaux-Arts, n 967, 2 març, 1962, p. 12.

"Une créatrice de bijoux pleinement satisfaite". Germinal, 14-20 juny., 1962, p. 5. [sense signar, dedicat a Francine Salkin]

"Un club Antonin Artaud vient d'être créé à Bruxelles. À propos de la solitude". Journal des Beaux-Arts, n 984, 29 juny, 1962, p. 12. 


\section{3}

"Les remords". Architecture, (Brussel-les) gener - febrer, 1963, p. 62-63.

"Un tombeau". Architecture, maig - juny, 1963, p. 175.

"Le format des livres diminue...les lectures augmentent". Le Magazine du temps présent, (París) ca. 1963. [full semanal publicat i distribuït per diaris de provincias como L'Echo d'Oran, La Voix du Nord, etc.]

"Quand la poule au pot se paie par chèque...". Le Magazine du temps présent, ca. 1963.

"En plein ville 'un prisonnier de la tour' veille sur la pollution de l'air". Le Magazine du temps présent, 5 maig, 1963.

"Comme un sou neuf". Journal des Beaux-Arts, no 1025, 17 oct., 1963, p. 9.

"Gare au D'fi! Le Pop Art, Jim Dine et l'influence de René Magritte". Journal des Beaux-Arts, no 1029, 14 nov., 1963, p. 9.

\section{4}

"Gérard Ruymen? Non: l'alto". Journal des Beaux-Arts, nº 1045, 14 març, 1964, p. 5.

\section{5}

"À la Galeria Aujourd'hui: Marcel Broodthaers par Marcel Broodthaers". Journal des Beaux-Arts, no 1086, 1 abril, 1965, p. 5.

"Évolution ou l'Oeuf film". Phantomas, n 51-61, des., 1965, p. 111-113.

"Comme du beurre dans un sandwich". Phantomas, $n^{0}$ 51-61, des., 1965, p. 295297.

\section{6}

"Ma Rhétorique". Moules Oeufs Frites Pots Charbon. Anvers, Galeria Wide White Space, 26 maig - 26 juny, 1966. [poema inclós en el catàleg de l'exposició]

"Poème". Moules Oeufs Frites Pots Charbon. Anvers, Galeria Wide White Space, 26 maig - 26 juny, 1966. [Íd.]

"Le Perroquet". Moules Oeufs Frites Pots Charbon. Anvers, Galeria Wide White Space, 26 maig - 26 juny, 1966. [Íd.]

"Théorèmes". Moules Oeufs Frites Pots Charbon. Anvers, Galeria Wide White Space, 26 maig - 26 juny, 1966. [íd.]
"Venise: une biennale discutée". Journal des Beaux-Arts, no 1135, 23 juny, 1966, p. 6.

"Manifestation poétique". Journal des BeauxArts, n 1137, 6 oct., 1966, p. 17.

"À propos d'une émission de Jean Antoine sur Giorgio de Chirico". Journal des Arts Plastiques, $n^{0} 28,1966$.

\section{7}

"À propos du Prix Jeune Peinture Belge 1966". Journal des Arts Plastiques, no 31,1967. [Signat: Louis Annecour]

"Interview imaginaire de René Magritte". Journal des Arts Plastiques, gener, $\mathrm{n}^{\circ} 30$, 1967.

"Interview d'un collectionneur: Hubert Peeters par Marcel Broodthares". Journal des Arts Plastiques, (Brussel.les) n 32, 1967.

"J'attends ton coup de fil, Marcel!". En BROODTHAERS, Marcel. Marcel Broodt(h)aers. Court Circuit. Brussel-les: Palau de Belles Arts, 1967.

"Interview". Phantomas, nº 67-68, juliol 1967, p. 84. [entrevista imaginaria a Marcel Lecomte]

"Reportage". En Reportage. Interuniversitaire tentoonstelling, Brussel.les, Lovaina, Gante, Lieja, Anvers, oct. 1967.

1968

"L'Exprimntl 4". Trépied (Tribune mensuelle de cine-jeune), nº 2, febrer 1968, p. 6-7.

\section{9}

"Musée d'Art Moderne - Section xixe siècle Département des Aigles, 25 août 1969". En Konzeption /Conception. Leverkusen: Städtisches Museum, Schloos Morsbroich, 1969.

\section{0}

"À MTL ou à BCD" (1970). Belgische Kunst 1969-1977. Ooidonk, 1978, p. 97.

"Dédicace". MTL Art Actuel, (Brussel·les) març, 1970. 
"Note sur les intentions". MTL 13/3/70 10/4/70. Brussel-les, Galeria MTL, 1970. [el text va ser inclós en el catàleg en un full apart i més tard va ser reeditat en MTL 18/5/72 - 176/72 (Tractatus LogicoCatalogicus ou l'art de vendre). Brussel.les, Galeria MTL, 1972, p. 12]

\section{1}

"Museum noir museum blanc". Artworker Star, (Anvers) $n^{0} 1$, Art Worker Foundation, 1971.

"Musée à vendre, Fig. 0. Ma Collection". Artworker Star, n², Art, 1971.

"Die Null-Figur". En Kurt Schwitters. Düsseldorf: Städtische Kunsthale; Berlín: Akademie der Künste; Stuttgart: Staatsgalerie; Bâle: Kunsthale, 1971, p. 15. ["La Figure 0", versió original en francés amb motiu de la projecció del film La Clef de l'Horloge en l'exposició "La Figure 0"]

\section{2}

"Musée d'Art Moderne, Département des Aigles". En Section des Figures. Der Adler vom Oligozän bis heute. Düsseldorf, Städtische Kunsthalle, 1972, vol. I, p. 4.

"Methode". En Section des Figures. Der Adler vom Oligozän bis heute. Düsseldorf, Städtische Kunsthalle, 1972, vol. I, p. 13.

"Adler - Ideologie - Publicum". En Section des Figures. Der Adler vom Oligozän bis heute. Düsseldorf, Städtische Kunsthalle, 1972, vol. I, p. 16.

"Musée d'Art Moderne. Section des Figures". En Section des Figures. Der Adler vom Oligozän bis heute. Düsseldorf, Städtische Kunsthalle, 1972, vol. II, p. 4.

"Section des Figures". En Section des Figures. Der Adler vom Oligozän bis heute. Düsseldorf, Städtische Kunsthalle, 1972, vol. II, p. 18 -19.

"Mon cher Beuys". En BRoodthaers, Marcel. Magie. Art et Politique. París: Multiplicata, 1973: p. 5. [Carta oberta Düsseldorf, 25 / 09 172

"Politik der Magie?". Rheinische Post; Dusseldorfer Feuilleton, 3 d'oct. del 1972.

"Plan vert". La porte est ouverte. Colònia: Galeria Michael Werner, 1972.
"Le Musée d'Art Moderne Département des Aigles est tout simplement un mesonge...". (Text reunit per J. Cladders a partir d'una entrevista realitzada el 28 de gener de 1972 (fr., an. i al.) que, en principi, havia de ser part del catàleg de Documenta 5 , però sols se'n van incloure com a fulls annexos. En MARCEL BROODTHAERS. París: Galerie Nationale du Jeu de Paume, ca. 1991: p. 229). Documenta V. Kassel, 1972.

Documenta 5: Befragung der Realität Bildwelten heute. Kassel, 1972, p. 131.

"Kunst Heute". En Szene Rhein - Ruhr - 72. Essen, Museum Folkwang, 1972.

"Ma collection. A Daniel Buren". Amsterdam París - Düsseldorf. Nova York: Museu Solomon R.Guggenheim, 1972.

"II parle". Actualité d'un bilan. París: Galeria Yvon Lambert, 1972, p. 34-37.

\section{3}

"Museum für moderne Kunst. Werbeabteilung". Heute Kunst., n 1, abril 1973, p. 20.

"Der Nullpunkt". Heute Kunst., n 1 , abril 1973, p. 20.

"Projeck für den Kaufvertrag". Heute Kunst., ${ }^{0}$ 1, abril 1973, p. 20.

"Museum für moderne Kunst - Abteilung die Adler". Heute Kunst., (Milán) $n^{0} 1$, abril 1973, p. 22-23.

"Changement de Propiéte?". Interfunktionen, (Colònia) nº 10, 1973, p. 76-80.

"Marcel Broodthaers zu Gufo Reale". Interfunktionen, $\mathrm{n}^{\circ} 10,1973$,.

"Allgemeine Theorie der Kunst und der Sammlung / Théorie générale de l'Art et de la Collection". En Bilder - Objekte - Film Konzepte. Munic: Galeria d'Art Lenbachhaus, 1973, p. 50.

"Rendez-vous mit Jacques Offenbach". BilderObjekte - Film - Konzepte. Munic: Galeria d'Art Lenbahhaus, 3 abril - 13 maig, 1973.

"J'ai construit une théorie". Deurle 11 / 7 / 73. Deurle: Museum Dhondt - Dhaenens, 11 jul.-12 agost, 1973.

"Être Narcise. Être Artiste". Magie. Art et Politique. París, Multiplicata, 1973, p. 18.

\section{4}

"A-ne pas-jeter sur la voie publique". Fausses Clés pour les arts, (Brussel-les) 1974. 
"Éloge du désespoir". En Hamilton, Richard. Flower Pieces Progressives. Londres: 1974.

"Un film de Charles Baudelaire". Cine Culture, (Brussel-les) no 105, 1974.

"Wiertz Museum. Musée Wiertz". Studio International, n 970, (Londres) 1974, vol. 188. [portada]

"Feuilleton". Studio International, (Londres) $\mathrm{n}^{0}$ 966, 1974, vol. 187 , p. $240-241$.

"Avis - Ansich - View". Interfunktionen, (Colònia) nº 11, juliol - set., 1974. [portada]

"Jardin d'hiver". Palau de Belles Arts, Brussel-les, 1974. [Text imprés en l'exposició "Carl André, Marcel Broodthaers, Daniel Buren, Victor Burgin, Gilbert \& George, On Kawara, Richard Long, Gerhard Richter". Palau de Belles Arts, Brusselles, 1974. En DE VREE, Freddy (1974). "Entretien avec Marcel Broodthaers". En HAKkENS, Anna. Marcel Broodthaers par lui-même. Amsterdam: Ludion / Flammarion, ca. 1998: p. 104.]

"Racisme végétal. La Séance. Film de Marcel Broodthaers". Interfunktionen, (Colònia) $n^{0}$ 11, juliol - set., 1974, p. 60-73.

"Dorf bleibt Dorf". + - 0, n $n^{0}$, set. 1974, p. 1517.

"D'un prix et de son usage". En Catalogue Catalogus. Brusselles: Palau de Belles Arts, 1974, p. 1.

"Musée d'Art Moderne". En Catalogue Catalogus. Brussel-les, Palau de Belles Arts, 1974, p. 26.

"Wiertz Museum. Musée Wiertz". Studio International, (Londres) no 970, 1974, vol. 188, p. 114. [i portada de Marcel Broodthares]

"Note". En Charles Baudelaire. Pauvre Belgique. París i Nova York: Herman Daled i Yves Gevaert, 1974. [París: pàgina 1 de portada; Nova York: pàgina 4 de portada]

\section{5}

"Das Wort Film?". En Invitation pour une exposition bourgeoise. Berlín: Nationalgalerie, 1975.

"A book by Marcel Broodthaers". Studio International, (Londres) $n^{0} 974$, març - abril, 1975, vol. 189, p. 107-115.
"To be a straight thinker or not to be. To be blind". En Le privilège de l'Art. Oxford: Museu d'Art Modern, 1975.

"Marcel Broodthaers über die Kunst". En "Kunst und Literatur... welches Gesicht wird verbogen?". Magazin Kunst, (Maguncia) $n^{0}$ 2, 1975, p. 73-74.

"Notes sur le sujet". En L'Angélus de Daumier. París, Centre National d'Art Contemperain, Hôtel Rothschild, 1975, vol. II, p. 3.

"En lisant la Lorelei. Wie ich die Lorelei gelesen habe". En lisant la Lorelei. Wie ich die Lorelei gelesen habe. Munic: Galeria Heiner Friedrich i París: Galeria Yvon Lambert, 1975.

\section{Entrevistes}

\section{5}

VLAEMINCKX, Jean-Michel. "Entretien avec Marcel Broodthaers". Degré Zéro, (Brussel-les) n 1, 1965.

\section{6}

Restany, Pierre. "Marcel Broodthaers et Pierre Restany parlent de peinture et de braconnage". Journal des Beaux-Arts, $\mathrm{n}^{\circ}$ 122, 17 març, 1966, p. 6.

\section{8}

TRÉPIED (Tribune mensuelle de cine-jeune). "Interview de Marcel Broodthaers". (Brussel-les) nº 2, febrer 1968, p. 4-5.

CHARLIER, Jacques. Entrevista amb Marcel Broodthaers, 1969. [manuscrit inèdit]

LUCAS, Richard; BROODTHAERS, Marcel. "Vingt ans après". En Vintg ans après. Brussel-les, Richard Lucas i Galeria New Smith, 1969. [Conversa entre l'autor i l'editor impresa i inclosa amb cada exemplar]

\section{9}

DE VREE, Freddy (1969). "Entrevista amb Marcel Broodthaers". En HAKKENS, Anna. Marcel Broodthaers par lui-même. Amsterdam: Ludion / Flammarion, ca. 1998: p. $68-73$. 
1970

BEKKERS, Ludo. "Greprek met Marcel Broodthaers". Museumjournaal, (Amsterdam) 15 febrer, 1970, p. 66-71.

DALED, Herman et. al. "Meuwissen ou n'imperte qui". MTL Magazine, nov. 1970, p. 4-12. [conversa entre Marcel Broodthaers, Herman Daled, Maria Gilissen, Jacques Duquense, Wim Meuwissen i Fernand Spillemackers.

1971

DE VREE, Freddy. "Entrevista amb Marcel Broodthaers". En HAKKENS, Anna. Marcel Broodthaers par lui-même. Amsterdam: Ludion / Flammarion, ca. 1998: p. 75 - 79.

\section{2}

HARTEN, Jürgen i SCHMIDT, Katharina. "Auszug aus einem Gespräch mit Marcel Broodthaers". En el dossier de premsa de l'exposició Section des Figures (Der Adler vom Oligozän bis heute). Düsseldorf, Städtische Kunsthalle, 1972, p. 6. [extracte d'una entrevista realitzada originalment en francés i en alemany pel maig del 1972.]

ADÉ, George. "Entrevista amb Marcel Broodthaers". En BUCHLOW, Benjamin i GILISSEN, Maria (ed.) Section Publicité du Musée d'Art Moderne Département des Aigles. Marcel Broodthaers. Nova York: Marian Goodman, 1995. p. 11. [Entrevista de l'1 d'oct. del 1972 durant la filmació d'un documental sobre Documenta 5 per a Radio y Televisió belga. Dir. CORNELIS, Jef]
1973

HARTEN, Jürgen i SCHULDT, Herbert. "Die Kunst bleibt zu einer Hoffnung gezwungen". Kunstjahrbuch 3, (Hannover) 1973. P. 63 68.

BUCHLOH, Benjamin i OPPITZ, Michael. "Analysis of a Painting". En Marcel Broodthaers. Cinéma. Barcelona: Fundació Antoni Tàpies, p. 300 - 301. [entrevista publicada com a panflet en l'exposició en la Galeria Rudilf Zwirner. Colònia, octubre, 1973]

\section{4}

Lebeen, Irmeline. "Dix mille francs de récompense". En BROODTHAERS, Marcel. Catalogue-Catalogus. Brussel-les: Palau de Belles Arts, 1974: p. 64 - 68.

Verstraeten, Marianne. "Entretien avec Marcel Broodthaers à l'occasion de l'installation Jardin d'hiver". En HAKKENS, Anna. Marcel Broodthaers par lui-même. Amsterdam: Ludion / Flammarion, ca. 1998: p. 108 110.

DE VREE, Freddy. "Entrevista amb Marcel Broodthaers". En HAKKENS, Anna. Marcel Broodthaers par lui-même. Amsterdam: Ludion / Flammarion, ca. 1998: p. 103 107.

\section{6}

RoNA, Stéphane (1976). "C'est I'Angelus qui sonne. Entretien avec Marcel Broodthaers". + - 0. № 12, feber 1976. 


\section{AnNeX 2. ReCUlL DE textos de Marcel BROOdthaers}

El propòsit d'incloure un annex amb un recull de textos de Marcel Broodthaers ha sigut posar a l'abast d'altres investigadors una sèrie de fonts directes que no són de fàcil accés. Gran part dels assaigs i dels texts poètics escrits per Broodthaers i de les entrevistes que van fer-li tan sols han sigut publicats en francés (llengua original), en alemany i, excepcionalment, en anglés. Certament, alguns textos i unes poques entrevistes han sigut publicats en castellà dins dels catàlegs monogràfics Marcel Broodthaers (Madrid, 1992) i Marcel Broodthaers. Cinéma (Barcelona, 1997). En el transcurs de la investigació, però, s'han generat diversos dubtes que finalment s'han resolts consultant les fonts en la llengua original i, sobretot, estenent l'estudi a totes les fonts existents. De tot això, però, només s'hi ha inclós un recull fonamentat en l'adequació al tema i als objectius d'aquesta tesi doctoral (cf. introducció: pàgines 23 i 29).

Quant als textos en francés que formen part d'aquest annex, és menester defensar-los particularment. En primer lloc, s'ha estimat que són un luxe que ni les editorials ni la majoria d'institucions ens ofereixen, sempre al tant d'altres prioritats. Una tesi doctoral, en canvi, té altres objectes i pot assumir-ho encara que això represente prou de treball addicional i una despesa econòmica major. En segon lloc, més enllà del propòsit d'obtenir un grau acadèmic, la investigació és un treball altruista; oferir els seus fruits a qui siga capaç de valorar-los també és un luxe i, a més a més, una satisfacció. Finalment resta dir que, dels textos en francés, s'han digitalitzat les fotocòpies realitzades en centres de documentació degudament autoritzats (la Fundació Antoni Tàpies i el MACBA, ambdós a Barcelona), amb la qual cosa no s'ha faltat als drets de reproducció.

Altrament, cal aclarir que les traduccions al valencià no han sigut copiades passivament de cap publicació; és a dir, fins al moment d'acabar la investigació (juny del 2003) no hi havia cap text de Broodthaers publicat en valencià $i$, en aquest sentit, es poden considerar textos inèdits. És important remarcar també que les traduccions han sigut fetes especialment per a conformar l'annex, dins del context del treball de tesi i, sobretot, tenint cura de fer-ho professionalment. La tasca de traducció ha estat a càrrec de Milagros Feria i de Tanya Angulo. Consegüentment, els treballs de recerca bibliogràfica, d'anàlisi i de selecció de les fonts, així, com la tasca de traducció es consideren una part del treball d'investigació i de tesi. 


\title{
Espere la teua telefonada, Marcel!
}

\author{
Marcel Broodthaers, 1967. [Diàleg apòcrif amb Pierre Restany] Traducció: Milagros Feria i Tanya Angulo.
}

Broodthaers es pronuncia Brotars: quatre lletres fonèticament inútils en l'ortografia d'un nom. Hi ha tela per a inspirar una vocació de filòleg, d'arxiver-paleolèg, d'etnògraf-explorador. Broodthaers és tot això i qualsevol altra cosa alhora. Com Marat revisat per Sade, cultiva curosament l'èczema del llenguatge. Els fronteres del món de les paraules i els contrabandistes del món dels objectes, els traficants de l' $A$ a la $Z$ tots tenen punts en comú.

Dimarts 21 de març del 1967: som tot dos, Marcel i jo, en el meu despatx a París. Parlem poc, per perífrasis. M'ensenya algunes fotos. I de sobte el corrent passa fins al curtcircuit. El segle dinou va produir un excés de carbó. Sabem fins on es va arribar en el terreny del transport públic, de la calefacció, de la química del carboni. La nostra Segona Revolució Industrial en el segle vint va produir un excés d'informació $i$ de reclams visuals. La diferència entre poesia $i$ arts plàstiques es difumina davant del problema de l'excés d'imatges, ja es tracte de sensibilitzar, d'humanitzar, d'individualitzar, abans de res. Banyat fins al coll des de fa quaranta tres anys dins de la saturació dels mass media, Broodthaers cerca desesperadament la seua realitat que potser és l'art dels altres, al cap i a fi. L'art dels altres, pres com la realitat per si mateixa, és un poc com el tresor de Tutankhàmon revelat intempestivament $\mathrm{a}$ Carter $\mathrm{i}$ a Lord Carnarvon.

El 9 de març del 1967 em trobava en el taller de Marcel a Brussel·les, en el carrer del Planter. Un antre de llibertat, una caverna de misèria i d'assossec en el si d'un abellar d'oficines ultramodernes i de frenètica activitat. Deu meu! Què penós pot resultar suportar la tasca dels altres! Els meus ulls púdics i fatigats s'acosten a terra: hi trobe un inefable camp de fulles entre capes de pols i d'oblit. Així s'esclareix la veritat de Broodthaers: el realisme duu a l'anonimat com l'electricitat al curtcircuit. Per a ell es tracta d'imaginar plàsticament, tangiblement els límits de la comunicació, tan necessaris i tan suficients com la inevitable anarquia del llenguatge. La imatge, en el límit de la no-imatge, s'instal la en la nostra memòria amb la transparència dels símbols definitius: el telèfon sord, ofegat pel cotó, és un clixé de la civilització.

Ell: Parles! em diu Marcel. Vaig tenir el telèfon molt tard en la meua pobre vida de pobre. Però des del dia que vaig tenir el meu telèfon, ja mai no vaig voler separar-me'n. Durant mesos vaig espiar el timbre, telefonava els amics per motius fútils. Encara avui passe dels deutes urgents les quals no puc satisfer però pague el telèfon.

Jo: Hom no es passa la vida al voltant del telèfon, col·lega, i t'has ficat en un món que espera de tu... productes de bellesa. Fixat, tal i com dius, li agrades tant als homes com a les dones. Eres una mica dolent $i$ despenjat però tu tens mena, és a dir tens estil i encant sens dubte. Ningú t'obliga a fer el maleït. Simplement no vas aprendre a fer el que cal. Per tant fes-te el simpàtic (a la teua manera) i no bades boca. Però com tots els obsessos del prim fill de la comunicació et creus el funàmbul de Zaratustra.

Ell: Ara ja se què és un color i què és un volum, després de tres anys. Ja no crec en el clixé de l'antiart. 
Jo: Molt bé, Marcel. Ho podràs demostrar als teus amics d'ací a uns dies a Brussel·les, en el Palau de Belles Arts. Telefona'm per a descriure'm l'ambient de la inauguració: quina roba portava A? En quina pel-lícula pensava B mirant el sostre amb un aire absent? Al final $\mathrm{C}$ va tornar a temps de Luxemburg? A quina hora exacta va fer entrada l'escamot en espessa colla: els dos $\mathrm{D}$, el lleó vell i el jove Turc, el somrient director E i després F n ${ }^{\circ} 1$ flanquejat per Quadrumà, la xica mona de torn G. H., l'altre F beneït que no benèvol, Mestre I eternament disfressat de caputxí, el venerable $\mathrm{J}$ confinat en una altra cultura, els enviats de l'ambaixada gantesa i després tots els amics que t'estimen, que veritablement ens consideren i per als quals tu, Marcel Broodthaers, i jo, Pierre Restany, vam triar, romàntics incorregibles com som, dur fins al final la nostra residual $i$ anacrònica existència, tu com a artista (individual) $\mathrm{i}$ jo com a crític (d'art). Espere la teua telefonada, Marcel!

\section{Estimat Pere:}

La inauguració va ser tot un èxit. A, B, C, D, E, F, G-H, F, I, J, van estar tal i com tu t'imaginaves, els altres van ser absents. Sens dubte, la dificultat va ser les comunicacions. Vaig estar maco a la meua manera i vaig estar callat. Pere, recorda-te'n, ara ja coneix el món del volum.

$\cos$

\section{Entrevista de Trepied a Marcel Broodthaers}

Trepied, 1968. Traducció: Milagros Feria i Tanya Angulo.

Marcel Broodthaers, el seu currículum ens indica que vosté no es dedica exclusivament al cinema. Llavors, què representa la pel-lícula per a vosté?

Abans de respondre la seua pregunta, m'agradaria dir que jo no soc cineasta. Per a mi la pel·lícula és la prolongació del llenguatge. Vaig començar per la poesia, després la plàstica i finalment el cinema, el qual reuneix diversos elements de l'art. És a dir: l'escriptura (la poesia), l'objecte (la plàstica) i la imatge (la pel·lícula). La cosa més difícil és, òbviament, l'harmonia entre tots els elements.

Com va aconseguir obtenir l'harmonia en Le corbeau et le renard?

Vaig prendre el text de La Fontaine i vaig transformar-lo en allò que jo anomene una escriptura personal (poesia). Enfront de la tipografia d'aquest text, vaig col·locar objectes quotidians (botes, telèfon, ampolla de llet) el destí dels quals consisteix a establir una estreta relació amb els caràcters impresos. És un intent de negar, tant com siga possible, el sentit de la paraula així com el de la imatge. En finalitzar el rodatge vaig adonar-me que la projecció sobre la pantalla normal, és a dir, la simple tela blanca, no reflectia exactament la imatge que volia compondre. L'objecte era massa exterior al text. Per a integrar text i objecte, la pantalla havia de dur impresos els mateixos caràcters tipogràfics que la pel·lícula. La meua pel·lícula és un jeroglífic que és menester voler desxifrar. És un exercici de lectura.

Aleshores, no és tracta d'una pel-lícula clàssica o comercial, sinó més prompte d'una pel-lícula experimental. Es podria considerar una antipel·lícula?

Si i no, perquè una antipel·lícula continua sent una pel·lícula, tal i com l'antinovel·la mai no pot evitar del tot el marc del llibre i de l'escriptura. Però, la meua pel·lícula ultrapassa el marc d'una pel·lícula ordinària. En principi, no està destinada a les sales de cinema, o al menys no exclusivament, perquè per veure-hi i poder entendre l'obra total que volgut realitzar no solament fa falta que la pel·lícula es projecte sobre la pantalla impresa sinó que, a més, l'espectador ha de posseir el text. La pel-lícula s'apropa al pop art, per dir-ho d'alguna manera, 
és un dels múltiples dels què es parla últimament com a mitjans de difusió de l'art. Per això s'exposarà pròximament en una galeria què farà una tirada de quaranta exemplars, més les pantalles i els llibres. Així doncs, tot serà explotat com a objecte d'art de manera que cada exemplar comprendrà una pel-lícula, dues pantalles i un llibre gegant. És un environnement.

Aixi doncs, vosté no es dirigeix al gran públic. Aleshores, com concep el paper de l'artista?

Actualment, d'una forma conscient o inconscient, l'artista està compromés. El problema és... estar-ne conscientment... autènticament... mai no ser objecte del compromís d'uns altres. El compromís aparent me molesta, com el de Godard i el d'altres. A Europa, l'artista no té una funció definida que puga acceptar o desafiar. El seu èxit o el seu fracàs depenen de l'atzar. L'artista és excèntric en la societat. Això és verificable sobretot a Bèlgica; allí mai no se li deprecia, faltaria més. En tot cas, mai no se li aporta cap ajuda eficaç, l'ajuda que li en permetria desafiar l'atzar.

On li agradaria viure?

Als Estats Units, el país més industrialitzat, el país d'on procedeix el Living Theater entre altres coses que, al meu parer, influirà sobre qualsevol temptativa artística; siga la què siga. És tracta, abans de res, d'una opció d'artista i mai no de polític.

Quins són els seus futurs projectes?

Introduir més realitat en els meus esforços i realitzar una pel-lícula sobre el Vietnam basada en l'ús del signe de l'escriptura. A Knokke no s'ha presentat res en aquesta línia últimament.

Creu que el cinema té futur encara?

No crec en el cinema, no més que en cap altre art. Tampoc no crec ni en l'artista únic ni en l'obra única. Crec en els fenòmens $i$ en els homes que reuneixen idees.

\section{GS}

\section{Projecte per a un text}

\section{Marcel Broodthaers, 1969. Traducció: Milagros Feria i Tanya Angulo.}

- Avorreix el moviment que desplaça les línies -

Si faig una pel-lícula per a un cinema definit encara com a disciplina del moviment he de repetir el vers de Baudelaire; o si no...

1. ... no fer la pel-lícula $\mathrm{i}$ alhora acceptar el valor de la pel-lícula verge, la pàgina en blanc del cineasta, i pregar per a que altres la facen;

2. ... fer una pel·lícula a costa de l'avorriment. Per exemple, una pel·lícula d'amor. Heu ací una idea molt seductora, però amb risc de servir de bandera a múltiples mercaderies, - pel·lícules publicitàries, pel·lícules propagandístiques, pel·lícules pornogràfiques, pel·lícules prohibides.

3. ... excloure els problemes del llenguatge específic del cinema considerant la pel-lícula simplement com una referència a alguna abstracció. D'aquest mode, en determinats aspectes de l'art conceptual sovint la pel-lícula és un intermediari sense importància on la idea juga el paper de tema principal. Però, el tema no es veurà sotmés per aquesta insignificància de l'estil de transmissió quan no absorbit i convertit en un film documental d'idees trillades, de vegades original?

... Les noves tècniques de la imatge, més que del cinema (el làser?), permeten trobar una solució, em tem que momentània, certament interessant. 
No obstant això cal estar molt endinsat en el món tecnològic per a utilitzar amb èxit aquest tipus de mitjà. Heu-me ací dividit cruelment entre allò immòbil què ja ha sigut escrit i el moviment còmic que anima les 24 imatges per segon.

PROJECTE PER A UN PEIX

$\cos$

\section{Conversa de Freddy de Vree amb Marcel Broodthaers (I)}

Freddy De Vree, 1969. Traducció: Milagros Feria i Tanya Angulo.

Marcel, vosté sempre sembla estar ansiós i tens quan li posen davant un micròfon, per què??

Perquè se que allò que diga serà reproduït i que ja mai no serà un secret.

Això potser té una relació amb els esborraments dels seus texts $i$ dels seus quadres, amb les siluetes $i$ amb la buidor dels seus objectes?

Deu ser mes o menys la mateixa cosa. Al cap i a la fi, sí, no pense que haja una diferència entre un micròfon, un full de paper un blanc o una superfície que es vulga mostrar a algú.

$D^{\prime}$ on ve aquesta vacil-lació en mostrar als altres les coses que ha fet?

Aquest dubte prové, probablement, d'una contradicció. Crec que tinc tendència, a causa d'una consciència política del món, a voler donar solament informacions objectives sobre el món. D'altra banda, tinc una tendència natural al narcisisme, a la subjectivitat, a expressar-me tal i com soc... i és això el que vull ocultar.

Pot indicar-me com és que aquesta dualitat apareix des del principi en les seues obres plàstiques?

Potser poguera aclarir el que acabe de dir sobre la meua tendència a l'objectivitat a partir de l'elecció del material, del plàstic, un material familiar que coneix tothom, i que fa entendre que es tracta d'un missatge sobre el món material d'avui dia. Aquest missatge, aquesta imatge, aquest text és subjectiu - al menys una de cada dues vegades. La imatge pot ser la representació d'un poema, una al·lusió a la història de l'art - tant en el passat com alguna cosa que m'haja impressionat - per exemple, Magritte.

Plaques de plàstic amb un tros de cel, un llenç de paret amb la inscripció Carrer Magritte... Unes plaques amb una pipa d'on ix fum o un equivalent tipogräfic, una coma... en què consisteix aquest lligam amb Magritte?

He reflexionat molt sobre l'art actual i he descobert que l'obra de Magritte és una de les fonts principals de l'art plàstic contemporani. Alhora, en Magritte podem trobar el missatge de Mallarmé... en la mesura que s'hi puga parlar de missatge. També vaig adonar-me que ara Magritte comença a gaudir d'una celebritat pòstuma immensa. Aquesta celebritat és particularment sospitosa ja que està lligada essencialment a la apujada de preus del seus quadres, encara que, de fet, la seua obra es veu enfosquida per aquesta glòria. Inicialment, el seu treball es va veure esfosquit per la ignorància, pel menyspreu i pel desconeixement. Avui podem parlar del cas contrari: és tan extraordinàriament cèlebre que molt poca gent ha tingut l'oportunitat de veure-hi un Magritte realment. No crec que m'haja servit del seu llenguatge. Pel contrari, en les plaques de plàstic amb la pipa i amb la inscripció del seu nom el que vaig intentar és desplegar el seu llenguatge. Utilitze els mateixos elements, però els done una altra orientació d'alguna manera, una orientació realista. No vaig limitar-me a les idees de poesia i de Misteri, més prompte vaig servir-me de la distorsió d'allò gran i d'allò menut, de l'objecte i de la seua representació per a desvelar la realitat sociològica.

A partir d'aquest punt de vista, com ve vosté avui les seues primeres exposicions, les acumulacions de cascares de musclos, d'ous $i$ d'ulls? 
Sí, era un debut. No hi veig gens del que renegar. Llavors vaig intentar, mitjançant objectes banals, quotidians, construir una relació entre l'objecte i la imatge d'aquest objecte... i introduir aquesta doble idea, és a dir, espai pla i volum en una mateixa entitat.

No es pot parlar d'acumulacions com en l'obra d'Arman, però és una imatge que m'acudeix al pensament quan parle d'aquest musclos i d'aquests ulls... però Arman, em sembla, pren qualsevol objecte. Vosté se serveix d'objectes que, en psiquiatria, tenen certes connotacions més subjectives. En les seues plaques de plàstic, vosté fa referència a la dualitat del somni (Magritte) i d'allò real. Quan vosté retranscriu tot això a una sola formula, aquesta dualitat subsisteix sempre, malgrat la ruptura entre l'objecte banal i el seu significat més profund?

Sí, evidentment, però mai no ho he fet conscientment. En treballar aquests conceptes vaig adonar-me que la meua producció encaixaria prou bé en la perspectiva clínica, diguem-ne. De primer vaig estar molt disgustat, vertaderament enfadat, fins que vaig començar a sentir més prompte allò contrari. Vaig arribar a la conclusió que era molt important per a l'artista i, de fet, per a l'art en general, que aquest aspecte clínic - que potser constitueix el vertader objecte de l'art - mai no quede ocult. Com a persona hom té una tendència natural a amagar-ho, al cap i a la fi mai no voldria passar per un malalt mental... i tanmateix... l'anàlisi de l'art des del punt de vista clínic és necessari. Això conduiria cap una altra forma de desmitificació, es tracta però d'una qüestió molt delicada. De fet, no es tracta de fer declaracions del tipus "és conseqüència d'un desordre mental", "és demència", "la societat to té res a veure amb això", sinó que això potser ens permetrà restablir l'equilibri trencat que va existir entre la societat i el boig tenint en compte que el considere com un element positiu de la societat.

Vosté parla de desmitificació $i$ això és precisament el que volia aconseguir amb el Musée d'Art Moderne, Département des Aigles. Vosté va instal-lar aquest museu en les seues dependències durant un any. Avui n'bi ha desaparegut. En essència, qual va ser l'objectiu d'aquesta empresa? A més, es tracta d'una empresa o és més prompte un simple...

Potser seria més senzill remuntar-se als inicis. El 1968, després de la ratxa de reivindicacions que vam viure, alguns amics - artistes, col·leccionistes, habituals de galeries $-i$ jo vam reunir-nos per intentar analitzar el que no marxava ben bé en el món artístic belga, per analitzar les ponències Art-Société. Vam xarrar i finalment van acordar reunir-nos en el meu estudi. Vam parlar molt sobre nosaltres i esperava, com a poc, seixanta o setanta persones. No obstant això el meu estudi estava buit pràcticament, no hi havia més que dues o tres cadires... on podia seure la gent? Aleshores vaig tenir la idea de telefonar una empresa de transports, Menkès molt coneguda a Brussel·les - i llogar algunes caixes per a que els visitants pogueren seure. Va semblar-me totalment logic fer-los seure sobre aquests signes que feien referència al fet d'embalar l'art, caixes on es transporten pintures $i$ escultures. Vaig rebre aquestes caixes $i$ finalment les vaig col-locar d'una manera molt particular, com si de fet foren les obres d'art mateixes. Aleshores vaig dir-me: però si és això, després de tot, el museu és això. Heus ací, llavors, la noció de museu. Vaig agregar targetes postals i vaig adornar aquest decorat amb obres del segle dinou. Ho vaig fer en part per provocació i en part per a crear un contrast amb les plaques de plàstic que vaig realitzar a partir d'aquest moment, i per a indicar una distancia. Tot seguit, vaig escriure la paraula Musen en les finestres, Section XIXè siècle en la porta que dona al jardí i Département des Aigles sobre el mur dels fons del jardí. Així va nàixer aquest Museu... mai no d'un concepte sinó d'una circumstància; el concepte va arribar després. Com va dir Marcel Duchamp: això és un objecte d'art, en essència, vaig dir: això és un museu. Hi ha una diferència: després d'un any vaig reembalar tot el material i el Museu va desenvolupar-se. De fet, vaig establir una relació entre la buidor de la pintura, - que mai no la faig servir com un concepte pejoratiu necessàriament - entre l'absència d'un significat i la buidor de les caixes, la buidor de les reproduccions. El Museu implicava evidentment una crítica a l'Estat belga i a la seua política per gestionar els museus i una crítica a les seues institucions culturals. Però allò essencial - sobretot en el nostre país - és la qüestió del llenguatge d'aquesta crítica, de la formulació, de l'exposició dels diversos problemes i conceptes - la noció de pintura, la noció històrica de museu. 


\title{
Conversa de Freddy de Vree amb Marcel Broodthaers (II)
}

\author{
Freddy De Vree, 1971. Traducció: Milagros Feria i Tanya Angulo.
}

Marcel Broodthaers, pot descriure'm el Museu que vosté té ací, a Düsseldorf, $i$ donar-me algunes explicacions sobre la seua funció?

En aquest moment, té el Museu davant els seues ulls i preferiria que comencés per donar-me la seua impressió ja que, de fet, es tracta d'una estructura de ficció i no tinc ni idea de com funciona per als altres. Visc l'aventura del museu, la ficció, a la meua manera, subjectivament. Això va començar fa quatre anys en el meu taller a Brussel·les. Vaig crear un museu fictici amb caixes de transport buides, amb reproduccions d'obres d'art en targetes postals i amb inscripcions que indicaven que hom es trobava en un museu. Ací revise la situació però amb altres elements, altres formes $\mathrm{i}$ altres idees. De tota manera, no estic totalment segur, tanmateix, que el visitant experimente la sensació de trobar-se en un museu, és a dir, en un lloc semblant a un hospital, a una presó i, al mateix temps, en una ficció...

Com interpreta vosté l'obsessió pel Museu? És l'obsessió per escapar d'un passat romàntic sense abandonar la idea que l'art sempre està lligat a la vida mateixa?

Puc respondre personalment: per a mi el Museu sempre ha sigut un lloc on m'ha gustat anar de jove perquè mai no hi havia ningú.

Vol reconstruir aquesta soledat o transmetre-la al visitant?

Més prompte voldria rompre aquesta soledat, però mai no ho aconsegueix ja que ací no hi ha cap multitud. Així de sobte, em resulta difícil donar una resposta teòrica a la seua pregunta sobre el visitant. Això si: sempre estaré feliç de veure arribar visitants amics i coneguts perquè sempre naix un contacte directe. Però també m'agrada el visitant casual encara que és provable que vinga seguint el consell d'un amic o d'un conegut. La meua relació amb el visitant és una relació personal; però em pregunte si no és gràcies als contactes personals que el Museu pot seguir existint, gràcies a la bona voluntat dels visitants que, senzillament, accepten la meua ficció. I allò que m'inquieta és la reacció d'algú que es trobe fora d'aquest entramat personal. Pot abstraure's de la nostra comunicació verbal i posar-se a observar? Després li pregunte: que hi veu? Això és un Museu, és ficció? S'ha aconseguit cap objectiu?

És difícil! Hi veig un museu consagrat al tema del cinema. Hi ha una absència evident d'algunes figures $i$ una reducció de les figures a simbols. Aquest simbolisme indefinit està distribuit per tot l'espai i evoca la classificació pròpia d'un museu. El soterrani és un poc angoixant ja que em veig obligat-per a trobar-m'bi més o menys a gust, en el sentit psicologic - a recórrer a la meua imaginació $i$ a imaginar alguna cosa més a banda dels reduïts elements que estan presents en aquest Museu.

Sí, però això sense dubte està condicionat per la nostra relació personal. Crec que puc acabar l'aventura objectivant la ficció i, en aquest sentit, és que accepte exposar el meu Museu de ficció en l'interior del Museu vertader, ací en la Kunsthalle de Düsseldorf. Crec que així acabarem amb les interferències dels contactes personals i de les impressions subjectives, que desapareixeran tant la seua impressió com la meua, i crec que podria ser interessant si aquesta aventura romàntica es resol per un malguany romàntic...

Marcel Broodthaers, una pregunta totalment diferent: alhora té una exposició a Anvers en la galeria Wide White Space $i$ en altres dues galeries de Colònia. Quina és la seua actitud respecte d'una fira on es ven l'art?

Ai, jo em trobe molt més còmode en la fira de Colònia que no en el meu Museu mateix, doncs en el Kunstmarkt ens troben de ple en la realitat de la societat contemporània, en el centre mateix del seu sistema, el qual es revela com a fonament comercial.

I per què s'bi troba més còmode? 
Perquè és la vida de tothom, l'existència de pràcticament tots els artistes, dels directors de museus i dels galeristes. Fonament comercial - no vull dir que totes aquestes persones siguen detestables o viles, sinó que allí l'art es ven com una mercaderia menyspreable.

Vosté es troba a mercè del mercat en el Kunstmarkt o és de l'opinió que, per la naturalesa mateixa, la seua obra es liura d'aquest tipus de comerç?

Intente, particularment en les obres que s'exposen en la fira de Colònia, introduir algun aspecte que incloga la negació d'aquesta situació, una situació que ja m'esperava. Hi ha dos o tres objectes que podrien passar per mercaderia menyspreable, però espere que, per la seua estructura o per les paraules que els envolten, contemplen una advertència que indique: "estic ací, no és la meua culpa..." espere que no siga perquè jo ho diga, sinó perquè l'objecte mateix ho indique.

Vosté està present en "Prospekt", la secció cinematogräfica de la Fira amb una pel-licula - la projecció d'un bucle sobre el qual estan inscrites les seues inicials.

És un film molt curt, d'un segon, el títol del qual és Une seconde d'éternité. Vull plasmar una determinada realitat artística d'una manera artística. No és més important que es tracte de la meua signatura o de la d'un altre: és més important el fet mateix de la signatura. Crec que la creació artística reposa sobre una impulsió narcisista. Une seconde d'éternité s'inspira més o menys en Charles Baudelaire. Va ser un gran plaer fer aquesta pel-lícula on el grafisme que no dura més que un segon constitueix al mateix temps una ficció. La signatura de l'autor - pintor, poeta, cineasta - em sembla el principi d'un sistema de mentides, el sistema que qualsevol poeta, qualsevol artista intenta establir per defendre's... contra què exactament, ho ignore.

\section{$\cos$}

\section{Mètode}

Marcel Broodthaers, 1972. Traducció: Milagros Feria i Tanya Angulo.

\section{Duchamp}

Poc importa que es tracte d'un urinari signat R. Mutt (1917) o d'un objecte trobat, qualsevol objecte pot elevar-se a la categoria d'obra d'art. L'artista el defineix de tal manera que el seu destí sols depén del museu. Des de Duchamp, l'artista és l'autor d'una definició.

De primer, la iniciativa de Duchamp apuntava a desestabilitzar el poder de jurats i d'escoles; avui - esdevinguda en l'ombra de sí mateixa - domina tot un sector de l'art contemporani sostinguda per col-leccionistes i marxants: ambdós aspectes s'hi il luminen.

Per mostrar que aquesta iniciativa continua viva recordem que en un passat molt recent alguns artistes han aplicat la definició d'allò que és art a la definició mateixa - al llenguatge de la definició - $\mathrm{i}$ així han fet sorgir tota una infraliteratura.

\section{Magritte}

Llegiu el text de Michel Foucault Ceci n'est pas une pipe. 


\title{
Conversa de Jürgen Harten i Katarina Schmidt amb Marcel Broodthaers
}

\author{
J. Harten i K. Schmidt, 1972. Traducció: Milagros Feria i Tanya Angulo.
}

\section{J. H.: Viure amb l'atzar. És això, no?}

Sí, trobar-lo.... perquè es volatilitza en un instant! Mai no s'hi pot circumscriure, a ell, mai no. L'atzar és, al final, l'única cosa, l'únic fulgor d'esperança que existeix en una empresa com aquesta, té un efecte alliberador i et permet, alhora, alliberar-te'n i prendre consciència d'allò que s'ha emprés d'un mode infreqüent...

\section{J. H.: I quina relació ve vosté entre el seu Musée d'Art Moderne, Département des Aigles fundat el 1968 i un museu tradicional?}

Ho veuré millor quan s'haja acabat, de moment encara és viu. Tanmateix, tinc la meua idea sobre l'assumpte, però no està clar del tot perquè l'experiència no ha acabat. Malgrat això, no tindria cap problema d'aprehendre aquesta relació. De primer, és molt estreta ja que la invenció del Musée d'Art Moderne, Département des Aigles s'ha expressat, en principi, en un dispositiu compost de caixes, de targetes postals i d'inscripcions. Aquesta invenció - un munt de no res - estava, pel seu caràcter, lligada als esdeveniments polítics que coneixien tots els països.

\section{J. H.: Com cal entendre'l?}

Pot entendre's com un canvi que ha intervingut sobre la consciència, especialment la de la joventut, cosa que ha repercutit inevitablement sobre el terreny artístic. Aquest canvi ha fet sorgir la pregunta següent: què és l'art i quin paper acompleix l'artista en la societat? He portat la reflexió un poc més lluny plantejant la qüestió següent: qual és, en general, el paper d'allò que representa la vida artística en una societat - a saber, un museu? En principi, es tractava de fer balanç de la situació. Inicialment vaig pensar en els dispositius dels quals he parlat com d'un lloc de discussió, d'intercanvi d'idees; però de seguida l'empresa va conéixer nous desenvolupaments i va deslligar-se d'aquest context immediat (no és la definició més adequada), sociològic (això està millor). Es va deslligar per emprendre una existència autònoma; el clàssic fenomen de l'art, al cap i a la fi. S'inventa una cosa que es creu estretament lligada a un esdeveniment real que es produeix en la societat i, llavors, la cosa comença a dur una vida autònoma, a evolucionar i a produir les seues pròpies cèl·lules. Aleshores es desencadena en l'art una espècie de procés biològic que l'artista controla amb molta dificultat. En la meua opinió, aquest procés mai no es controla sinó durant un lapsus de temps molt curt i de manera molt general; després se li escapa. Les idees comencen a desenvolupar-se, com a cèlllules vives.

L'aspecte ficció, és a dir fictici, es deslliga de l'empresa anomenada Musée d'Art Moderne, Département des Aigles d'una manera molt particular. L'aspecte irreal i el dispositiu, què inicialment no era més que un simple decorat, fou institucionalitzant-se gradualment, per a mi i per a la gent propera a mi. Aquest museu va fer-se realitat per al meu cercle de relacions - amics, personalitats que s'ocupaven de l'art, al cap i a fi, - i per a gent arribada de l'estranger què n'havien oït parlar i el volien visitar. Al voltant d'aquest nou Musée d'Art Moderne, Département des Aigles va començar a germinar un sistema de relacions totalment nou, malgrat el seu caràcter efímer. El dispositiu va perdre la seua significació decorativa, es va convertir en símbol del museu fictici, és a dir que les postals, pel fet mateix de la seua relació amb aquesta situació especial, van adquirir valor de símbol. La pregunta que es planteja relacionada amb allò que ens ocupa, les Àguiles què provenen d'altres museus; hi intervé una espècie d'atzar! Parlava d'una ficció què descansava en el simbolisme de les caixes i en la representació del punt de vista mitjançant targetes postals. Ara, parle de ficció en relació amb les àguiles que expose sota el mateix rètol Musée d'Art Modern. Què ocorre? Doncs que l'àguila mateixa és, al 
cap i a la fi i des de l'origen, una ficció els continguts sociològics i polítics de la qual són cada vegada més difícils de comprendre segon ens remuntem en la història.

Com explicar totalment el naixement de l'àguila com a símbol i com a mite sense tots els coneixements arqueològics dels que hi disposem? Crec que l'exposició mostra fins a l'evidència que l'àguila i la seua representació són una ficció en sí mateixes. Dues ficcions s'hi reuneixen; això ha de ser provocatiu. L'exposició extrau la seua realitat del fet que, finalment, arribem a una consciència de la realitat més forta que la realitat mateixa - entenent per realitat la realitat d'una idea - gràcies a la trobada d'aquestes ficcions.

J. H.: Es tracta, en últim terme, de la relació amb una realitat transformada $i$ amb els objectes que existeixen realment. Si considerem els objectes amb una consciència transformada, sembla que canvien de caràcter; però, com a objectes continuen portant una existència independent. Per exemple, els objectes sumeris o medievals que es van col-leccionar en el marc d'un museu. Però, aquest marc ha canviat de significat sociologic $i$ crec que amb el seu mètode - la ficció com a mètode - no es percep aquest canvi suficientment.

Vosté parla de mètode. De ser possible preferiria afermar-me sobre la situació que he creat. L'impuls del canvi, què potser fa efecte quan s'hi veu aquesta exposició de les àguiles, procedeix més prompte de la situació de ficció, de la creació d'una situació, no tant d'un mètode.

J. H.: Parlant clar, vosté encara espera veure com es desenvoluparà l'exposició.

Òbviament . No estic gens segur de quina cosa eixirà d'ací. Malgrat això, he afirmat que una ficció s'ajuntaria amb una altra. Per a començar, és una idea solament.

K. S.: Però en tot cas, vosté considera l'exposició com un lloc de debat, com quan va fundar el Musée d'Art Moderne, Département des Aigles?

Sí; però un debat totalment diferent en el sentit que els debats, de moment, no poden sorgir lliurement. Aquesta exposició s'ha convertit més prompte en un projecte; s'invita al visitant a aprendre'l. Si no hi participa directament, no encaixa amb la idea d'un debat; no és cert? En un debat tots participen, intervenen, argumenten. Per ser més precisos, l'exposició s'ha convertit en un projecte de debat $i$ ara m'inquieta la idea que el meu projecte puga entendre's com una presa de posicions.

$\cos$

\section{Àguila. Ideologia. Públic}

\section{Marcel Broodthaers, 1972. Traducció: Milagros Feria i Tanya Angulo.}

En quina mesura les informacions sobre l'art contemporani han arribat a la consciència del públic? El públic és vosté, soc jo, són els altres.

El públic es veu confrontat pels següents objectes artístics: àguiles de diferents classes, una part de les quals estan pesadament carregades de nocions simbòliques i històriques. El caràcter d'aquesta confrontació està determinat per la inscripció negativa: açò no és... açò no és una obra d'art, la qual cosa no significa més que: públic, què cec estàs!

Així doncs, d'una manera o d'altra, o bé la informació ha acomplit un paper efectiu sobre allò que es diu l'art modern $\mathrm{i}$, en aquest cas, tota àguila està pura i simplement integrada en un mètode; o bé la inscripció apareix com un pur absurd - és a dir que no està al nivell de la discussió sobre la validesa de les idees de Duchamp i de Magritte, per exemple, - i, en aquest cas, l'exposició obeeix una altra vegada als principis clàssics: l'àguila en l'art, en la història, en l'etnologia, en el folklore... Sens dubte jo no seria més afortunat amb la serp, el lleó, el bou. 


\section{Secció de les Figures}

Marcel Broodthaers, 1972. Traducció: Milagros Feria i Tanya Angulo.

\section{Figura 1}

Si no es dotara l'àguila, en la idea que hom se'n fa, d'una força màgica suficient per propulsar un Déu o una nau espacial (Apol·lo 11), ningú s'interessaria per ella. Sobre el mateix ocell hi ha idees equívoques. La majoria dels naturalistes el descriuen amb paraules patètiques; Konrad Lorenz no és una excepció. L'àguila és estúpida - diu essencialment - té por inclusivament d'una bicicleta.

\section{Figura 0}

Tals representacions són perilloses. De vegades porten a una espècie d'anestèsia de la qual és impossible despertar-se. Estar-hi molt espantat. No saber-hi. Finalment, admirar incondicionalment la representació majestuosa de l'art i de l'àguila; tot allò molt sublim des de l'oligocé fins avui. Per què l'oligocé? La relació directa entre el fòssil de l'àguila trobat en unes excavacions efectuades en uns jaciments terciaris i les distintes formes sota les quals es presenta el símbol potser és dèbil, suposant que existeixa. La geologia, però, hauria de fer-se entendre en el títol (sensacional), afegir-li una punxa de cientisme fals que revelaria que el símbol Àguila s'ha représ sense reflexió, sense haver sigut sotmés a discussió. L'àguila no és una carlota; l'objectiu d'aquesta exposició, però, és treure-la del cel imaginari on voleteja des de fa segles, amenaçant-nos amb els seus llamps - ja siga de pedra, de fusta circumdada d'or o d'acer inoxidable.

\section{Figura 2}

Seguir el seu rastre a través dels boscos d'imatges ens emportarà a considerar distints punts de vista en quant al significat del símbol; significat sempre idèntic siga qual siga el nivell considerat anàleg als cercles que descriu l'ocell: grandesa, autoritat, puixança. Esperit diví. Esperit de conquista. Imperialisme.

\section{Figura 2}

L'àguila és, com el tigre de paper, un monstre frèvol. Nia en els museus públics. Tot això es reflecteix també en el meu museu fictici fundat el 1968 i que vaig anomenar Département des Aigles. L'àguila de paper té un doble caràcter. D'una part acompleix el paper d'una paròdia social de les produccions artístiques, d'altra el d'una paròdia artística dels fets socials. Els museus públics, com ara també totes les institucions culturals, no hi fan una altra cosa. Crec que un museu fictici com és el meu permet apropiar-se de la realitat i d'allò que s'hi amaga. La Section des Figures, tal i com apareix en l'exposició de Düsseldorf, acompleix aquest desplaçament de l'objectiu. Un procés de negació, un procés ple de contradiccions, com està representat en la Kunsthalle? Hi veiem que no hi ha diferències capitals entre les meues intencions i la seua realització en l'exposició. El mètode triat prega reconéixer l'eficàcia de les idees de Duchamp i de Magritte. Al meu parer, el mètode fa èmfasi sobre un problema - com tota manifestació artística que s'anuncia com a tal - i en aquest aspecte està amenaçat per la seua mateixa insuficiència de pertinència social. Per això, s'afegeix davall un text de Michael Oppitz, titulat Aigle Pipe Urinoir, què profunditza el meu mètode des d'un punt de vista teòric.

\section{Figura 0}

El projecte de l'exposició es basa en la identitat de l'Àguila en tant que idea i en la identitat de l'art com a idea. L'objectiu és proposar una reflexió crítica sobre la presentació de l'art en 
públic. Pel que respecta a la percepció de l'art pel públic, hi verifique que els hàbits i les fixacions personals impedeixen una lectura sense prejudicis. Malgrat això, el rètol amb la inscripció Açò no és una obra d'art hi acompleix un paper: pertorba la projecció narcisista del visitant sobre l'objecte que contempla, encara que no arribe a la seua consciència.

\section{Figura 1}

Des de les obres d'art sumèries fins a les obres actuals, l'àguila parla el llenguatge estilístic de cada època. Les diapositives d'imatges publicitàries projectades en l'exposició posen de manifest una falta d'harmonia. La llengua de la publicitat fa presa de l'inconscient de l'espectadorconsumidor i, amb aquests mitjans, es restitueix tota la seua puixança a l'Àguila màgica. Michael Oppitz s'endinsa en el meu sentit quan escriu que he arrencat algunes plomes a l'àguila mítica. Però, per agressiva que siga, l'àguila ix indemne de la publicitat. L'objecte artístic mai no s'hi pot aprehendre perquè està representat fora de les convencions que estructuren la vida artística. En la publicitat, l'art s'utilitza i té un èxit enorme, regna sobre radiants horitzons, encarna el somni de l'home.

MARCEL BROODTHAERS

$\cos$

\section{El Musée d'Art Moderne Département des Aigles és simplement una mentida}

Marcel Broodthaers, 1972. Traducció: Milagros Feria i Tanya Angulo.

El Musée d'Art Moderne, Département des Aigles és simplement una mentida, un engany. Sobreviu, però, des de fa quatre anys en el si de les més diverses manifestacions: publicacions, xerrades, postals, vertaders objectes artístics, quadres, escultures i en els publicity objects.

Parlar del meu Museu és equivalent a parlar de l'art i de la manera, és analitzar l'engany. El museu normal i els seus representants simplement posen a escena una forma de veritat. Parlar d'aquest Museu és equivalent a discórrer sobre les condicions d'aquesta veritat.

Hi ha una veritat en la mentida que és la que determina la meua consciència.

Quan una obra d'art troba la seua condició en la mentida o en l'engany, és una obra d'art? No tinc la resposta.

Un museu que és un engany té alguna cosa que ocultar, la mentida personal té un component freudià. Però, allò que el museu personal vol ocultar és el museu vertader.

Sincerament, la motivació de qualsevol artista és el narcisisme i potser també la voluntat de poder (Nietzsche); però per a mi la motivació és molt menys interessant que el tema en si mateix.

El museu fictici intenta saquejar l'autèntic museu, l'oficial, per conferir més poder i més versemblança a la seua mentida. Així mateix, és important descobrir si el museu fictici llança noves llums sobre els mecanismes de l'art, del món i de la vida de l'art. Amb el meu museu jo planteig la qüestió. Per això no he de donar la resposta.

Jo ja haguera pogut vendre el meu museu, però no puc fer-ho, de moment. Mentre hi trobe refugi i m'hi identifique no puc, o al menys és el que pense ara. Mai no em deixaré atrapar. M'arreplege en el meu amagatall del museu. En aquest sentit el museu és un pretext.

Potser l'única possibilitat que tinc de ser un artista siga ser un mentider perquè, al cap i a la fi, tots els productes econòmics, el comerç i la comunicació són mentides, i la majoria dels artistes ajusten la seua producció al mercat com si es tractés de productes industrials.

MARCEL BROODTHAERS 


\title{
Aquest museu és un museu fictici
}

\author{
Marcel Broodthaers, 1972. Traducció: Milagros Feria i Tanya Angulo.
}

Aquest museu és un musen fictici. De vegades fa el paper d'una paròdia política de manifestacions artístiques, $i$ altres, el d'una paròdia artística dels esdeveniments politics; allò que fan, per cert, els museus oficials $i$ els organismes com la Documenta. Això si, amb la diferència que una ficció permet aprehendre la realitat $i$ amagar-la alhora. Aquest museu, fundat a Brussel-les el 1968 sota la pressió dels fets politics del moment, tanca les seues portes amb la Documenta. Haurà passat d'un estat heroic $i$ solitari a una situació propera a la consagració gràcies al suport de la Kuntshalle de Düsseldorf $i$ de la Documenta.

Aixi doncs, és lògic que en l'actualitat estiga aturat en el tedi. Tanmateix, és un punt de vista romàntic, però què puc fer jo. Ja es tracte de Sant Joan l'Evangelista o de Walt Disney, el simbol de l'àguila en l'àmbit del fet escrit té un pes substancial. Això no obstant, escric aquestes linies; és a dir que entenc el romanticisme com una nostàlgia de Déu. Constatem com de difícil és mantenir al Déu a distancia quan es tracta d'art, tan difícil com liiurar-se de les trampes de les galeries $i$ de les institucions oficials.

Intente recollir alguns texts $i$ entrevistes contradictòries relacionades amb les diferents seccions del Départament des Aigles. Endavant es podrà trobar una entrevista del Dr. J. Cladders a propòsit de la Section d'Art Moderne $i$ un text teòric de M. Oppitz sobre l'exposició de les Figures a Düsseldorf. Cal assenyalar que en ocasió d'aquesta exposició ha sigut editat un cataleg amb una introducció de J. Harten (les traduccions en llengua francesa vindran a continuació).

Encara és prompte per a descriure les intencions que m'ban dut a la realització de la Section Publicité. Com que la imatge en coincideix amb l'apareguda en la part publicitària del catàleg de la Documenta, m'estalviarà llargs discurs. Quan hom es fica en l'art, no fa sinó fer tombs de catàleg a catäleg. En aquestes condicions encara és important la cultura? Al meu parer, sí, i encara més si el pensament s'incorpora dins d'un marc de referència que li puga ajudar a defensar-se de les imatges i dels texts transmesos per la publicitat i pels mitjans que determinen les nostres normes de comportament i la nostra ideologia.

Aquest musen fictici pren com a punt de partida la identitat de l'art i de l'àguila..., era evident que s'bavia d'estampillar l'Urinoir (1917) de Duchamp amb el signe de l'aguila, o siga, mostrar entre molts altres documents la foto de l'objecte santificat per la bistòria de l'art.

Publicitat tan per a l'art com per a l'art de la publicitat. Qui repara, però, en l'acció màgica exercida per artistes anònims (gràcies al símbol de l'autoritat) al servei de la difusió dels productes de la indústria? Qui viu en el context de l'art i, tanmateix, considera l'art en qualitat d'art. O qui solament li importa el context social de les produccions. Però, què hi ve el públic, el gran públic i tots els que ven partits de futbol?

MARCEL BROODTHAERS

$\cos$

\section{El grau zero}

Marcel Broodthaers, 1973. Traducció: Milagros Feria i Tanya Angulo.

La presentació d'una exposició depén de l'opinió que qui exposa tinga de l'art. La presentació oficial adopta les normes modernitzades de tot institut d'exposició. Es a dir, que un mode d'exposició, sempre jeràrquic, constitueix la societat oficial juntament amb les institucions 
expositores (museus) i la resta d'institucions (hospitals, presons, etc.). D'això que qualsevol treball relatiu a una exposició s'emprenga, en la majoria dels casos, sobre la base d'un compromís (exemple: la Documenta 5 i H. Szeeman). Aleshores, constatem que la posada a escena dels objectes i de les imatges rarament resulta adequada i que, al contrari, en tota exposició existeix una tendència a la manipulació. En quant a mi, l'estiu passat vaig mostrar l'exposició "L'Aigle de l'oligocène jusqu'à nos jours" en la Kunsthalle de Düsseldorf. Les meues accions com a artista, és a dir, amb un significat tan indeterminat $i$ tan mal definit, mai no podien situar-se sinó en els desenvolupaments marginals del comportament social. És fàcilment comprovable que allò que jo volia era neutralitzar el valor d'ús del símbol de l'àguila i reduir-lo al seu grau zero per a introduir dimensions crítiques en la història i en l'ús del símbol.

MARCEL BROODTHAERS

$\cos$

\section{Conversa de Freddy de Vree amb Marcel Broodthaers (III)}

Freddy De Vree, 1974. Traducció: Milagros Feria i Tanya Angulo.

Marcel Broodthaers, en aquesta exposició belga dedicada als aspectes de l'avantguarda en les arts plàstiques hi ha, com a exemple, una obra prou sòbria que per si mateixa aconsegueix abastar tota una sala. No parle de la seua sala sinó de la creu de sorra de Richard Long. Vosté que opina d'aquest tipus d'obres?

Admire molt aquesta obra de Richard Long però mai no se m'acudiria denominar-la una creu, encara que ho siga evidentment, o un signe de multiplicació. Hi veig simplement una cosa poètica expressada mitjançant el material vegetal i no res més. Una poesia natural amb un grau alt d'intensitat. Prefereix Richard Long més que altres artistes. Les seues obres m'arriben més que les d'alguns altres perquè són menys accessibles. Únicament puc explicar-me la seua obra dins d'una relació personal amb l'obra mateixa, en l'interior d'un sistema tancat.

\section{I en l'interior d'un museu.}

Estic convençut que Richard Long no té consciència d'aquest problema. Deu semblar-li tan natural fer una obra com mostrar-la ací. Richard Long no planteja qüestions polítiques sinó aquesta única pregunta indirecta: què fa la poesia en el nostre món?

Quina creu que és la seua funció?

Crec que és alterar els còdex amb els que s'elaboren explicacions. En la mesura que la poesia queda sense explicació pertorba els hàbits vigents en un món on sempre s'intenta explicar tot i on sempre i en qualsevol circumstància s'intenta posar ordre.

$V$ osté ha instal-lat aci un Jardin d'hiver, ple de plantes tropicals i la primera idea que m'acut al pensament com una associació és: això evoca un desert.

Sí, la imatge d'un desert. És una mena d'imatge suplementària, me n'alegre doncs mai no es troba en allò que s'exhibeix - palmeres, cadires, reproduccions... - però, efectivament, és la idea fonamental: el desert...

L'absència....

L'absència, i l'absència del desert. Un desert real i simbòlic alhora, una il·lustració - a contrario - de la situació política i econòmica actual, però encara més, és la prevalència del desert, el desert de la societat, el desert de l'esglai i, al cap i a la fi, el desert del món de l'art...

$V$ osté va escriure un text com a afegiment.

Sí. Un text curt: 
Un hivernacle

seria un A B C D E F de la diversió, un art de la diversió.

G H I J K L M N O P Q R S T U V W X Z

Per a oblidar. Per a dormir, rellent, tranquil.

Es dibuixen nous horitzons.

Veig venir cap a mi nous horitzons i l'esperança d'un altre

alfabet (vegeu catàleg)

Aleshores és un text amb el que vull oposar-me a una sèrie d'idees i de teories que actualment estan de moda en el món de l'art; és un text, però, prou difícil des del punt de vista de la comunicació. Tot sembla desenvolupar-se en cercles i veig la necessitat de definir la meua conformitat amb tot el que s'hi exposa - l'estora de coure de Carl André, el baldaquí de Buren, l'escultura plana de Richard Long, l'alfabet cromàtic de Gerhard Richter, etc. - quan compare aquest recull amb tot l'art tradicional tal i com es manifesta en aquest país (i se li dóna suport). Des d'aquesta òptica s'esborren els matisos entre els que exposen ací i el monument a la indiferència que tota societat erigeix amb l'art que assimila. Fa de tot això un pilar de l'Estat i ho assimila com a tal en les presons i en els hospitals. Però els matisos dels què parle en el meu text... fan referència als matisos d'altres artistes en el si d'aquest extremadament estret món de l'avantguarda. Però quant més estret n'és, més em sembla una caixa de ressonàncies que reflecteix veritablement els esdeveniments que es desenvolupen a escala mundial. És paradoxal, però aquest microcosmos funciona amb molta eficàcia.

Des del meu punt de vista, voldria replantejar les coses de la manera següent: es tracta de la creació d'un front instrumentat contra la propensió a l'biperrealisme abans d'una manifestació de simpatia cap a l'art conceptual.

Evidentment! L'hiperrealisme mai no significa únicament la consagració d'una determinada idea de la pintura en el nucli de l'art en general, sinó també la consagració de totes les concepcions reaccionàries. El missatge de l'hiperrealisme comporta la idea de confort, l'absència absoluta de canvis, l'exaltació dels diners en el si d'un mon que ha dissimulat tots els seus problemes.

L'hiperrealisme - potser amb l'excepció del seu Jardin d'biver, Marcel - li permet per primera vegada al burgés d'avui dia trobar un ordre, una identitat en l'art contemporani. Són pintures fetes a partir d'una fotografia, aixi doncs, a partir d'una peşa d'identitat.

Sí, però quan pense en l'hiperrealisme també pense en Meissonier; és més o menys la mateixa cosa, exceptuant que la llibertat que encara existia en l'època de Meissonier ha desapareguda. En la nostra època, tota temptativa artística equival a un ordre: fer això en compte d'una altra cosa. En l'època de Meissonier almenys es podien tenir idees divergents i representar una altra cosa. La llibertat d'expressió esculpida en el frontó de totes les nostres institucions és avui purament formal. Mentre que abans al menys existia encara una llibertat, escassa això si, en un domini més general. Vosté no s'ha allunyat massa del Jardin d'hiver doncs vaig pensar en un hivernacle d'aquest tipus quan el vaig concebre.

Una neteja per mitjà de la buidor? Com els esborraments del text del poema de Mallarmé?

Sí, una cosa pareguda. En el llibre menut sobre Mallarmé procedeix a separar el text i la imatge del text, la tipografia. Vaig reimprimir el text com una introducció a la seua imatge. Avui dia el llenguatge de Mallarmé s'utilitza també més enllà de l'art, per exemple en psicoanàlisi per Jacques Lacan. La seua obra Ecrits se serveix del llenguatge de Mallarmé però centrat en allò real, la psicoanàlisi, que apassiona Lacan i els seus lectors.

Voldria comentar alguna cosa sobre les pel-lícules en què treballa actualment?

Treballe en The last voyage, una sèrie de diapositives de finals del segle dinou. De fet no són diapositives sinó fotos colorades a mà, molt belles per cert. Un pare és mort en un decorat especialment burgés, ha mort amb la companyia de la seua filla i del seu gendre i deixa veure 
amb un gest etern el vaixell que passa i que s'emporta la seua ànima. És la primera part de la pel-lícula. En la segona part s'hi veu la Nova York actual sota la forma del Temps, del Temps i de la Mort.

Marcel, allò que m'impressiona ara és que sovint mostra els seus personatges en relació amb la mort. També em recorde de la seua sèrie de reproduccions amb el vaixell que va desapareixent $i$ de la jove que escriu: "Estimada germaneta..."

Sí però, estic malalt. Pateix d'una malaltia llarga i penosa que tan sols pot tenir un desenllaç fatal. Però a llarg termini, crec, ja que tinc molta cura... i voldria dir als lectors que s'interessen per la meua existència... vull dir... que no es preocupen massa!

$\cos$

\title{
Deu mil francs de recompensa. Entrevista a Marcel Broodthaers
}

\author{
Entrevista d'Irmeline Lebeer, 1974. Traducció: Milagros Feria i Tanya Angulo.
}

\section{Objectes}

Per a vosté els objectes funcionen com a paraules?

Jo utilitze l'objecte com una paraula zero.

En principi no es tracta d'objectes literaris?

Se'ls podria denominar així sempre que els objectes més recents escapen d'aquesta denominació què té una reputació pejorativa (em pregunte per què). Aquests objectes recents porten, d'una manera sensacional, l'empremta d'un llenguatge: paraules, numeracions, signes inscrits sobre l'objecte mateix...

Des del començament de la seua activitat seguia una direcció tan precisa?

M'obsessionava un quadre de Magritte, aquell en què figuraven paraules. En Magritte hi ha una contradicció entre la paraula pintada i l'objecte pintat, una subversió del signe del llenguatge i de la pintura en benefici d'una precisió de la noció de tema.

Encara té afecció per alguns objectes?

Sí, per alguns. Són poètics, és a dir, són culpables dins de l'art com a llenguatge i innocents dins del llenguatge com a art. Per exemple, els què li vaig a descriure: un fémur tricolor, Fémur d'bomme belge, i un antic retrat de general trobat en no sé quin mercat d'objectes usats. $\mathrm{He}$ practicat un foradet en la boca frunzida del general per a introduir una burilla de pur. En aquest objecte-retrat hi ha una encertada harmonia de tons: el quadre és d'un color marró prou passat, la burilla també. Qualsevol pur no li aniria a la boca d'un general qualsevol... el calibre del pur, el format de la boca...

En açò consisteix l'art del retrat?

Prefereix pensar que es tracta d'un objecte pedagògic. Cal desvelar - si és possible - el secret de l'art: el general mort fuma un pur apagat. Així doncs, juntament amb el fèmur jo he fet dos objectes útils. M'hauria agradat fer alguns més que m'hagueren donat tanta satisfacció, però vaig sentir desconfiança del génere. Em sembla que el retrat i el fèmur tenen la virtut de corroir la falsificació inherent a la cultura. En el fèmur es reuneixen nacionalisme i estructura, el militar no està lluny.

Hi ha moltes closques de musclos i d'ous en la seua producció. Són acumulacions? 
El tema és, abans de res, la relació que s'instal la entre les closques d'ou i l'objecte que les suporta: taula, cadira o olla. Una taula és el lloc on se serveix un ou, però sobre la meua taula, on hi ha massa ous, falten el ganivet, la forqueta i el plat; absències necessàries per a què l'ou parle en la taula o per a què l'espectador tinga una idea original de la gallina.

I els musclos, són un somni sobre la Mar del Nord? Un musclo amaga un volum.

El desbordament dels musclos en l'olla mai no segueix les lleis de l'ebullició sinó que segueix les regles de l'artifici per arribar a la construcció d'una abstracció.

Aixi doncs, vosté se sent prop d'un sistema acadèmic?

D'una retòrica que s'alimenta del nou diccionari de les idees tòpiques. Més que objectes i idees, allò que organitze és la trobada de funcions diferents que remeten al mateix món: la taula $\mathrm{i}$ l'ou, el musclo i l'olla a taula i en l'art, en el motlle i en la gallina.

És el món del imaginari o el de la realitat sociològica?

Això és el que Magritte no parava de reprotxar-me. Em trobava més sociòleg que artista.

\section{Senyalitzacions industrials}

Les plaques de plàstic responen a aquesta realitat sociologica?

Em va semblar que la matèria plàstica m'alliberava del passat, quan aquesta matèria no existia. La idea va agradar-me tant que vaig oblidar que el material ja havia sigut ennoblit, segon sembla, en els pannells de les galeries i dels museus sota la signatura dels Nouveaux Réalistes i dels Pop americans. El fet que m'interessava era la malaptesa que aportava el material a la representació.

Es van editar set exemplars?

Jo mateix definí la tirada perquè, en aquell moment, cap galeria volia assumir el risc de l'edició. El sector privat va ajudar-me a resoldre-ho.

I el llenguatge d'aquestes plaques?

Podríem denominar-lo jeroglífic; i el tema, una especulació sobre una dificultat de lectura arrossegada per l'ús d'aquest material. Aquestes plaques es fabriquen com a xurros.

Aquestes plaques són també difícils de desxifrar?

La lectura es veu obstaculitzada per l'aspecte d'imatge del text i a la inversa. El caràcter estereotipat del text $\mathrm{i}$ de la imatge ve definit per la tècnica del plàstic; i la lectura proposada depén d'un doble nivell, cadascú dels quals pertany a una actitud negativa que em sembla apropiada de l'actitud artística. No col-locar el missatge íntegrament en una de les dues parts, imatge o text. És a dir, rebutjar el lliurament d'un missatge clar com una comesa que no incumbeix l'artista ni, per extensió, tot productor interessat econòmicament. Això podria ser el començament d'una polèmica. Al meu parer, no pot haver-hi relació directa entre art i missatge, i encara menys si aquest missatge és polític, sota risc de cremar-se com un foc d'artifici. D'anar-se'n en orri. Prefereix signar enganya-badaires sense utilitzar aquesta garantia.

Quina classe de badaires enganya amb les plaques?

Diguem que els que prenen les plaques per quadres i les pengen en la paret. D'altra banda, cap cosa pot demostrar que el badaire no siga l'autor, que s'ha cregut lingüista saltant per damunt de la barra significant/significat i que, de fet, no ha fet més que jugar a ser professor.

\section{Les figures}

Se situa vosté en una perspectiva surrealista?

Me ho sé de memòria: “Tot duu a creure que existeix un punt en l'esperit des del qual la vida i la mort, allò real i allò imaginari, el passat i el futur, allò comunicable i allò incomunicable, allò alt i allò baix cessen de ser apercebuts com a contradictoris." Espere no tenir gens d'això en 
l'esperit. Magritte està menys còmode amb Ceci n'est pas une pipe; però, de tota manera, era massa Magritte. És a dir, que no bastava amb Ceci n'est pas une pipe; jo he inventat l'aventura a partir d'aquesta pipa.

\section{Un exemple?}

En el museu de Mönchengladbach pofrà veure una caixa de cartó, un rellotge, un mirall, una pipa i també una màscara, una bomba de fum i algú que altre objecte, dels quals ja no em recorde, tots acompanyats de les inscripcions figura 1 o figura 2 o figura 0 pintades en la paret, bé al costat o bé sota cadascú dels objectes. Si hom es fia del sentit de la inscripció, l'objecte pren un caràcter il·lustratiu què es refereix a una espècie de novel·la de la societat. Aquests objectes, el mirall i la pipa (o bé la caixa de cartó, el rellotge i la cadira), sotmesos a la mateixa enumeració es converteixen en elements intercanviables en l'escenari d'un teatre. El seu destí ja està sentenciat. D'aquesta manera obtinc una trobada esperada entre funcions diferents articulada moralment i material mitjançant una doble assignació i una textura llegible - fusta, vidre, ferro, teixit -. Jo mai no haguera pogut abastar tant de complexitat amb els objectes tecnològics la unicitat dels quals condueix l'esperit a la monomania: art minimal - robot ordinador.

Els nombres 1, 2 i 0 apareixen amb un sentit literal i l'abreviatura fig. es concilia malament amb el seu sentit. Aquesta és la premissa per què vosté es trobe bé en la seua condició?

Allò que em tranquil·litza és l'esperança que qui mira corre el risc - per un instant - de no trobarse tant a gust amb la seua condició. No deixe d'anar al museu de Mönchengladbach.

Però, l'espectador podria confondre's i veure-bi una expressió comparable a la del Nou Realisme dels anys 60?

Els meus primers objectes i imatges - 1964 -1965 - mai no podien donar lloc a tal confusió. La literalitat vinculada amb l'apropiació d'allò real no m'interessava, ja que traduïa una acceptació pura i simple del progrés en l'art i... fora de l'art. Deixant clar això, cap cosa li pot impedir a un espectador equivocar-se, si s'empenyora, i jo no assumeix ni la bona fe de l'espectador (o del lector), ni la seua mala fe.

\section{Partia vosté d'una visió elaborada del seu projecte?}

Ignore allò que el meu inconscient haja pogut fabricar, vosté no m'obligarà a dir-ho. He fabricat instruments destinats al meu ús per comprendre la moda en l'art, seguir-la i finalment buscar una definició de la moda. No soc ni pintor ni violinista; el que m'interessa és Ingres i no Cézanne ni les pomes.

Per què no ha utilitzat llibres o revistes? No troba a faltar elements d'informació d'aquest tipus?

Succeeix que aprehenc més fàcilment les dades conceptuals o altres mitjançant la informació que dóna el producte específic (particularment el meu) que no mitjançant l'intèrpret de la seua teoria. Capte menys fàcilment les coses i allò que impliquen a través de la lectura de llibres, encara que el llibre és l'objecte que em fascina perquè per a mi significa l'objecte d'una prohibició. La meua primerenca proposta artística duu l'empremta d'aquest malefici. El saldo d'una edició de poemes escrits per mi va servir-me de material per a una escultura.

Un objecte en l'espai?

Vaig escaiolar a mitges un paquet de cinquanta exemplars d'una recopilació de poemes, Pense-Bête. L'embalatge de paper desfet deixava veure, en la part superior de l'escultura, els cantells dels llibres (ja que la part inferior estava oculta per l'escaiola) de manera que no es podia llegir el llibre sense destruir l'aspecte plàstic. Aquest gest concret remetia la prohibició a l'espectador o al menys això creia jo; però, per a la meua sorpresa, la reacció va ser molt distinta. Tothom hi havia apercebut l'objecte com una expressió artística o com una curiositat. - Mireu, uns llibres escaiolats! -. Ningú va tenir curiositat pel text, ignorant si es tractava del soterrament d'una prosa, d'una poesia, de tristesa o de plaer. Ningú es va emocionar per allò prohibit. Fins aquell moment, jo vivia pràcticament aillat des del punt de vista de la comunicació; el meu públic era fictici. De sobte, el públic va esdevenir real en la mesura que és qüestió d'espai i de conquista. 


\section{Hi ha una diferencia entre ambdós puiblics?}

Avui dia el llibre de poesia ha trobat certa audiència sota noves formes, la qual cosa no impedeix que la indiferència persisteixa. El segon públic ignora l'abast del primer. Si l'espai és vertaderament l'element fonamental de la construcció artística (forma de llenguatge o forma material) jo no podria, després d'aquesta singular experiència, sinó oposar-lo a la filosofia d'allò que està escrit amb sentit comú.

L'espai què amaga? No és un joc com allò de "llop estàs ací?"?

Efectivament, el llop sempre diu que està en altra part i, no obstant això, està ací i se sap que se'n girarà $i$ atraparà algú. La recerca constant d'una definició d'espai no serviria més que per a ocultar l'estructura essencial de l'art, un procés de reificació. En percebre cada individu una funció de l'espai, tant millor si és convincent, se l'apropia mentalment o econòmicament.

Quines són les seues idees polítiques?

Des que vaig començar a fer art, el meu, el què he copiat, l'explotació de les conseqüències polítiques d'aquesta activitat (la teoria de la qual solament pot ser descoberta fora del seu àmbit) m'ha paregut ambigua, sospitosa, massa angèlica. Si el producte artístic és cosa de la cosa, la teoria es converteix en propietat privada.

Vosté ha fet art compromés?

Abans sí i eren poemes, signes de compromís concrets perquè no tenien recompensa. Llavors, el meu treball consistia en escriure, quan menys, millor. Amb l'art plàstic, solament he pogut comprometre'm a casa dels meus adversaris; els arquitectes estan en la mateixa situació quan treballen pel seu compte. Intente, en la mesura d'allò que m'està permés, circumscriure el problema proposant poc i això mateix indiferent. L'espai no pot conduir sinó al paradís.

Hi hauria alguna diferència entre l'art plàstic i un compromís desinteressat?... [Silenci]. A partir de què moment es fa art indiferent?

A partir del moment en què hom és menys artista, en què la necessitat del fer no enfonsa els seus arrels més que en el record. Crec que les meues exposicions han depés i encara depenen de records de l'época en què assumia la situació creadora sota una forma heroica i solitària. Dit d'una altra manera, en altra época: llegiu, mireu. Avui: permeteu-me que us presente...

L'activitat artística - precisem: en el context d'una circulació per les galeries, per les col-leccions i pels museus, és a dir, quan els altres arriben a conèixer-la - seria la màxima expressió d'allò no autèntic?

Potser, allò no autèntic es troba en la tàctica triada per emprendre la maniobra sobre el terreny, en una forma autèntica de replantejar l'art, la seua circulació, etc.; la qual cosa, indistintament i sota tots el punts de vista, justifica la continuïtat i l'expansió de la producció. És a dir, l'art com a producció.

En aquesta ruleta, vosté com salva l'apostament?

Encara queda un risc no menys interessant, en tercer o quart grau, i hom mai no està obligat a cremar-se. És... ${ }^{157}$

\section{La figura de l'Àguila}

Aquesta manera de pretendre abastar formes artístiques tan allunyades com poden estar-ho un objecte d'un llenc tradicional, no fa pensar en la trobada d'una màquina de cosir i d'un paraigües sobre una taula de disseccions? 15710000 francs de recompensa per al lector que aconsegueixa reemplaçar els punts suspensius per una formula
adient. 
Una pinta, un llenç tradicional, una màquina de cosir, un paraigües, una taula poden tenir el seu lloc en el museu en seccions diferents segon una classificació. Hi veiem les escultures en un espai reservat, les pintures en un altre, les porcellanes i les maiòliques... els animals dessecats... Cada espai, compartimentat alhora, pot estar destinat a una secció - les serps, els insectes, els peixos, els ocells - i susceptible d'estar dividida en departaments - els periquitos, els ocells peixaters, les àguiles...

El Musée d'Art Modern a Brussel-les el 1968, amb caixes d'embalar de les utilitzades per transportar d'obres d'art $i$ que emportaven les inscripcions $i$ els senyals dels llocs de destinació, era la secció del segle XIX inaugurada amb un discurs del Dr. J. Cladders de Mönchengladbach?

Les peregrinacions i transformacions d'aquest museu estan documentades en distintes publicacions. L'etapa de Düsseldorf el $1972{ }^{158}$ hi posa el punt final. La secció de les figures hi reunia escultures i objectes procedents de nombrosos museus. Cada peça hi anava acompanyada de la menció Açò no és un objecte d'art - tant si era un vas sumeri procedent del Louvre com si era un tòtem del British Museum o si era publicitat retallada d'un periòdic (totes les peces representaven l'àguila).

Ceci n'est pas un objet d'art és una fórmula obtinguda per la contracció d'un concepte de Duchamp i d'un concepte antitètic de Magritte la qual cosa m'ha servit per a decorar l'urinari de Duchamp amb la insígnia de l'àguila fumant en pipa. Crec haver-hi subratllat el principi d'autoritat que converteix el símbol de l'Àguila en el coronel de l'Art.

Aquest museu continua sense ser un objecte d'art, una pipa?

Ceci n'est pas un objet d'art: la fórmula és una Figura 0. Cada peça d'aquesta exposició de Düsseldorf és una Figura 1 o una Figura 2; cada etapa d'aquest museu entra igualment en el sistema rudimentari. Tornant sobre això que he descrit abans, una caixa de cartó s'hi torna equivalent a una màscara, etc. Un mirall rematat per un àguila - antiguitat de finals del XVIII - és possessió d'una associació museogràfica de Gante. Mirall oficial, podria dir-se'n, que reenvia la imatge virtual d'aquestes àguiles que amb els seus múltiples caps conten la història de les armes, el punt de vista de l'Art. Aquest mirall és el contrasentit, encara que està rematat pel missatger de Júpiter, és un mirallet per a aloses.

Finalment, vosté de quin museu és conservador?

De ningú, excepte si poguera definir el paper i el contingut d'un museu l'estatut del qual no es llija en les aventures dels Pieds-Nickelés de Forton o en la imatge de El Bosco que descriu com s'extirpa una pedra del cap de les persones que pateixen malenconia.

(Avui dia, l'instrument científic ha reemplaçat el martell que portaven en la mà els Paracelsos del segle XVI).

Aleshores, el Museu d'Art Modern seria el museu del sentit. Restaria saber si l'art existeix en cap lloc que no siga un pla negatiu.

${ }^{158} \mathrm{Amb}$ el suport de K. Ruhrberg i de J. Harten, i de la direcció de la Kunsthalle. 


\title{
Ser un home de bé o no ser. Estar cec
}

\author{
Marcel Broodthaers, 1975. Traducció: Milagros Feria i Tanya Angulo.
}

Què és l'art? Des del segle XIX es planteja aquesta pregunta contínuament tant a l'artista com al director de museu i a l'afeccionat.

De fet, no crec que siga legítim definir l'Art i considerar la qüestió seriosament si no és per mitjà d'una constant: la transformació de l'art en mercaderia. Aquest procés s'accelera avui dia fins al punt que els valors artístics i els comercials se superposen. Si es tractés d'un fenomen de reificació, l'art seria una representació singular d'aquest fenomen, una forma de tautologia.

Llavors, com a afirmació es justificaria i, al mateix temps, s'extrauria una existència nova.

Però, la utilitat de l'art està per demostrar-se, així com el valor d'aquesta definició. De fet, és segur que el comentari sobre l'art segueix el moviment econòmic. Ens sembla incert que aquest comentari puga ser polític. Presoner dels seus fantasmes, i de la seua utilització màgica, l'Art adorna les nostres parets burgeses com un signe de poder - acompanya les peripècies de la nostra història com un joc d'ombres artístiques - cosa que dubtem. En llegir tot allò que de bizantí s'escriu al respecte, pensem en el sexe dels àngels, en Rabelais i en els debats en la Sorbonne.

Actualment, Tel Quel i les investigacions lingüístiques intempestives es confonen en una mateixa glosa que els seus autors voldrien que fora crítica. Art i Literatura... de les cares de la lluna, quina està oculta? Quants núvols i imatges efímeres...

Res, no he descobert res, ni tan sols l'Amèrica. Elegeix considerar l'art com un treball inútil, apolític i poc moral. Captivat per una innoble inspiració, mai no ocultaré que si les errades estan de la meua part experimentaria una certa joia. Joia culpable perquè dependria de les víctimes, els que van creure que tenia raó.

Monsieur de La Palice és un dels meus clientes. Li agraden les novetats. Ell, que fa riure a tothom, alhora pren el meu alfabet com a pretext per riure's.

El meu alfabet està pintat. Tot és fosc, els lectors estan invitats a entrar en aquesta nit per llegir una teoria i per experimentar sentiments fraternals, aquests que uneixen els homes, en particular els cecs.

MARCEL BROODTHAERS, 1975.

$\cos$

\section{Notes sobre el tema}

Marcel Broodthaers, 1975. Traducció: Milagros Feria i Tanya Angulo.

M'hauria agradat que aquesta nota fora més florida o al menys que faça olor al perfum deliciós que emana d'un cel de cul d'ampolla, però és L'Àngelus de Daumier i he d'acomplir el meu deure ja que ho anuncie sota el títol de nota en la primera part del catàleg. Hi parle d'una mena d'estupefacció. Efectivament, davant la quantitat de Títols que cobreixen la institució on he instal·lat les meues maletes i baguls. Únicament resta saber que ací estem en la fundació Salomon de Rotschild. Simplement, no és més que nostàlgia d'un ús de les definicions exactes de la paraula just. No oblideu que soc belga d'origen. Ni tampoc l'admiració que provoca París en un estranger. $\mathrm{Fa}$ dos anys, com a poc, que no hi he sigut. Tot això explica aquesta exposició què precedirà un comentari treballat a la manera d'un lingüista. En primer lloc, el bagul de vímet que figura en el 
ball de la mansió conté missatges meus remesos per l'Estat d'un altre hemisferi. Estan ocults seguint el principi de la Carta robada i del Manuscrit trobat en una ampolla. Passem, però, a les conclusions; ací no hi ha lloc per a una retranscripció.

\section{Idees i motivacions}

És part del paper d'un artista encara en actiu estendre's sobre el tema de les motivacions? Es tracta d'un fonament sospitós. De ciència certa, per a un futur amenaçat és millor deixar que els crítics d'art s'equivoquen els primers. Siga com siga, una paraula més sobre la intenció de l'exposició. És la quarta d'aquest génere amb el qual he intentat articular de diferent manera objectes i quadres realitzats en dates que s'escalonen entre el 1964 i l'any present fins a conformar unes sales a la manera d'un decor. És a dir, es tracta de restituir a l'objecte o a la pintura una funció real; ja que el decorat mai no es un fi en si mateix.

\section{Art i política}

La política que crec defendre - en art - és feble, individual abans de res i submisa a les pressions i a la influència d'un públic especialitzat entre el que figuren, en un lloc privilegiat, els intermediaris i els colleccionistes. Actualment són rars els afeccionats i es troben a faltar d'una manera dolorosa. Si estic exagerant la importància d'aquesta situació que Daumier em faça justícia. Siga com siga, una relació pràctica/teòrica en Art em sembla Futurista o il·lusòria. En l'art estem en un terreny movedís comparable al de la moda o al de la monomania, ja es tracte de parany o d'emergir.

No obstant això, la necessitat d'una actitud política, encara que siga feble, és ineludible avui dia. Espere que el lector, qui hi salude finalment, llija les paraules següents les quals van ser posades a disposició dels visitants des de la inauguració, el 2 d'octubre.

Per voluntat de l'artista, com a gest simbòlic de solidaritat amb els demòcrates espanyols, la inanguració de l'exposició s'interromprà mitja hora abans de l'horari habitual.

N. B.

Una exposició d'aquest tipus necessita del concurs d'ajudes de tots els horitzons, tant en el pla de les idees com en el del treball manual. Ho agraeix tot a cadascun.

Entre els objectes recents i inèdits figura la gran construcció de fusta tota coberta de paraules i el recull d'algunes teles sobre el tema de l'alfabet.

La diferència entre projecte i realització s'expressa, crec que suficientment, en la data que separa l'aparició de les dues parts del catàleg.

MARCEL BROODTHAERS

\section{$\cos$}

\section{És l'Àngelus qui somnia. L'última entrevista a Marcel Broodthaers}

Entrevista de Stéphane Rona, 1975. Traducció: Milagros Feria i Tanya Angulo.

En acabar aquest número ens hem assabentat de la mort de Marcel Broodthaers. Amb ell se'n ha anat l'artista belga més important després de Magritte. Al llarg de la seua vida va perseguir el seu ideal sense fer concessions. Durant anys, massa temps, ningú li va fer cas. Va ser molt més tard quan va trobar reconeixement internacional. Massa tard perquè la malaltia que ja portava des 
de la joventut havia minvat la seua salut. Tothom que el va freqüentar els últims anys sap quant va lluitar. Quant plena de projectes era la seua existència, quant nombroses van ser les darreres realitzacions. Cap cosa està més lluny de la nostra intenció que els judicis atropellats. Aquesta entrevista va arribar-nos fa unes setmanes. En les circumstàncies actuals adquireix valor de missatge. Broodthaers mateix va elegir el títol d'aquesta conversa. Fem saber aquest detall per evitar interpretacions dolentes en un moment tan penós. Hem deixat la conversa tal i com va ser la nostra intenció de publicar-la, respectant el que pensem era la voluntat de Broodthaers.

En l'anterior número de + - $O$ (n¹1) Otto Hahn va concedir-nos una entrevista on li preguntàvem sobre Marcel Broodthaers en tant que home i artista. En no estar d'acord amb algunes idees emeses, Marcel Broodthaers va sol·licitar precisar el seu punt de vista.

És curiós el nom que va donar vosté a la seua última exposició a París: L'Angélus de Daumier.

Vertaderament és un lapsus que ni tan sols Millet s'esperava. D'una part va ser una feliç coincidència que immediatament després hi haguera una gran exposició de Millet. En dir això, m'agradaria que parlarem de l'article d'Otto Hahn que van publicar amb motiu de la recent exposició que vaig fer en el CNAC a París. ${ }^{159}$ En primer lloc, Otto Hahn no representa tot París, és una veu entre altres. Per una vegada m'ha agradat un dels seus articles perquè em disgusten els que sovint semblen estar marcats per una censura interior que lamentablement no solament és privilegi d'un crític com Otto Hahn sinó de la majoria de persones vinculades al periodisme. A París és molt difícil escapar d'aquesta regla. No crec que ningú ho admetria perquè la llibertat d'expressió està molt a la moda, però no estic tan segur. Malgrat tot, m'ha agradat molt l'article d'Otto Hahn. El conec des de fa temps, estava més prompte decebut pel que havia escrit sobre mi, però pel ton i per l'estil de les respostes d'aquest text, finalment he trobat alguna cosa que em motive a polemitzar sobre els diferents punt de vista. És cert que no estic d'acord amb que soc peresós (perquè, d'altra banda, no sé si soc peresós, cosa que poguera ser certa). Però el revés de la qüestió podria ser: perquè tal individu és treballador? En les definicions de peresa i de treball prenen part molts factors. Sovint la peresa pot ser, com altrament l'alcoholisme, signe o indicador d'una inadaptació a una societat cada vegada més tecnològica. No vull insistir massa en aquest tema perquè no és l'objectiu d'una publicació d'art com la vostra, però de tota manera hi és menester cridar l'atenció. Ho esmente perquè l'artista peresós i alcohòlic era una imatge permesa fa uns cinquanta anys, particularment en temps de Montparnasse, era una cosa legitimada profundament. La qual cosa ja no succeeix avui dia! I és estrany, com si ara tots els artistes foren treballadors i es begueren una ampolleta de Perrier. De tota manera, aquest clixé correspon únicament a representacions fetes per una burgesia que compra art i que es fa una determinada imatge de l'artista. L'artista..., altrament, no dic que es rente les mans, no perd d'ull. Què es pot esperar? Jo diria que actualment fa alguna cosa més que mirar. En el cas de l'avantguarda, l'artista pren part més que mai en l'estructura comercial i en el marketing de l'art. De tota manera, em va agradar molt el seu article perquè se de bona tinta que no és un amant d'aquest tipus de procés que, precisament per a Otto Hahn, es troba massa al límit d'un tipus de literatura i d'art plàstic. Ell prefereix obres més clares, més definides.

Llavors, es tracta de l'acudit guanyaràs el pa amb la teua suor. Podria existir cap equivalència obrer-artista?

No, no crec que es puga concebre en aquest nivell. Potser la relació siga la següent. L'artista, com l'obrer, és un simple productor, però siga com siga, encara que es trobe en mal moment l'artista és conscient de la seua vàlua, coneix el seu lloc, i quan arriba a ser un productor

159 Nota del redactor: es tracta d'una entrevista de Stéphane Rona a Otto Hahn. 
reconegut es tracta d'obrer de luxe. Un artista viu en una magnitud diferent totalment de la d'un obrer siga qual siga el país, no?

\section{L'alcoholisme i la peresa, no es tracta d'un assumpte privat?}

Aquest comportament mai no és privat perquè tot allò que fa l'artista és xiuxiuejat pels racons.

Tanmateix es tracta d'un subjecte el paper del qual és donar lloc a la fabricació d'un mite. La peresa, l'alcoholisme o el dejú, l'aigua mineral, són una inadaptació al medi. L'adaptació s'aconsegueix, per norma general, per mitjà dels diners. A propòsit d'aquesta adaptació, hi ha una espècie d'alcoholisme modern, la droga, que és exactament la mateixa cosa. Ara fem servir altres ginys que emporten l'artista a episodis més penosos que els de l'alcoholisme d'antany. Ser inadaptat socialment significa estar en una condició secundària i vorejant la qüestió d'allò real. És una contradicció perquè tothom tendeix cap a la norma i per pervenir-ho està obligat lliurar alguns poemes per ací, algunes obres d'art per allà. Al menys en la mesura que les coses són clares. Per clar entenc l'obscur període que no et conec ningú, que tothom et deixa al mig del carrer. Però aquesta mai no és la resposta a la pregunta que és tan important, al meu parer. Tot això no solament concerneix a l'art, als escriptors, sinó al cap i a la fi a tothom que no està inscrit dins d'aquesta directriu que és la tecnologia. Cada vegada més resulta menys divertit viure en aquestes condicions; cada vegada més tenim més necessitat d'existir per mitjà d'una cultura capaç d'omplir-nos. Ans al contrari. Estem assetjats per la televisió, pels diaris, pel blue movies, per tot allò mecanitzat que acaba per transformar l'home en robot. Només escapem amb penes $\mathrm{i}$ treballs. Només ara moltes persones començaran a sentir les dificultats d'adaptació a la societat. O bé prendran la decisió, és el cas de la majoria, de resignar-se mentre que altres es veuran obligats a manifestar-se d'una manera o d'altra.

Respecte de la peresa, el que succeeix és que no entenc molt bé el treball. De jove mon pare m'obligava a fer un munt de coses per les quals mai no vaig sentir-me motivat i que, a banda d'això, mai no arribava a comprendre. Al final, lògicament, vaig tenir problemes. És el mateix cas de tothom que està a disgust amb el seu treball, siga de la banda que siga. Tot això comporta pertorbacions importants i té validesa tant per a qui es troba mirant el sostre com per a qui es troba davant d'una màquina que en essència no abasta a comprendre. La gent no té més opció que guanyar-se la vida. Jo, a contra cor, m'apanyava més o menys, siga fent la punyeta a mon pare, siga contrariant a uns $\mathrm{i}$ a altres. Llavors vaig tenir algunes experiències de treball dins de la classe obrera mateixa inqüestionablement, poca cosa, en total huit o nou mesos. Jo sé què representa això i com mutila a una persona. I avui dia, això és aparentment quotidià. Caldria fer una enquesta entre les botigueres que pateixen Musik by Musak al llarg de set hores seguides i que acaba agradant-les.

Es pot concebre el treball sens que comporte sacrifici?

Em fa acudir al pensament els monjos de clausura entre les seues quatre parets. No fan mal a ningú. Ells mateixos treballen la seua terra... Però en el cas que mai no haguera res a fer seria un poc fotut, una mena de vacances perennes, en bata de casa, o bé cavalcant tot el dia, fent el flâneur... Jo mai no he dit que el treball em desagrade particularment, i no és que jo siga un monjo sinó un flâneur, però quan en alguna part hom té algun desig d'inscriure el seu nom, encara que per pura vanitat, per deixar veritablement alguna cosa als altres homes, és molt difícil separar ambdues actituds. Supose que la vida d'un monjo és més neta que la del flâneur. Hi ha una renúncia voluntària que tendeix notablement a desaparèixer avui dia.

Hom diria llavors que per a vosté el crític no fa sinó equivocar-se.

I tant!, la seua comesa ha esdevingut com la de l'artista d'antany, extremadament minvada pel marketing, per la pressió de grups conformats no tant per artistes com per determinades persones amb les quals estan vinculats els col·leccionistes. El paper del crític s'ha vist molt més reduit que el del artista. L'artista sempre té la possibilitat de sacar-se un as de la màniga per a alterar la situació. El crític mai no té aquesta possibilitat perquè el diari el deixaria al mig del carrer. Ah, però si se n'ix, aleshores és molt diferent: la crítica d'art es desenvolupa i 
envaeix ràpidament altres dominis com, per exemple, les possibilitats de lectura. Pense en Walter Benjamin, magnífic crític d'art alemany, mort el 1940 als Pirineus en una escaramussa entre espanyols i francesos. Va suïcidar-s'hi. M'explane parlant d'ell perquè crec que en aquesta antiga zona francesa ningú coneix el seu nom. Pel que jo sé pràcticament no hi ha traduccions dels seus textos, però va escriure profusament sobre l'art en sèrie, sobre el naixement del cinema, sobre el futurisme. Heu ací un model significatiu de crític d'art que mai no s'ha fer servir. Pense després en Georg Lukács. Estic llegint-lo ara mateix, aprenent d'ell. Tinc la clara sensació que valora les coses en la seua mesura justa. A més i a més he treballat amb un dels seus deixebles, Goldman, durant un seminari on vaig participar no sense interessar-me alhora per la resta.

Tornem, si li sembla bé, a les seues exposicions.

De manera general, tinc en compte el lloc geogràfic on em trobe. A París es tractava d'una fundació, la Fundació Salomon de Rothschild. Recentment vaig fer una exposició Londres des d'on es va veure el Mall durant el Trooping the colour. La meua exposició estava impregnada d'aquesta situació i d'alguns costums anglesos. No veig la necessitat de veure-hi una altra cosa. Ara quan parle de tot això, puc adonar-me'n però és cert que també se m'escapen molts detalls. Com a definició d'art sempre he valorat especialment la d'una amiga científica: l'art i la ciència mai no han de mesclar-se. Per a mi l'art és un capritx. La qual cosa evidentment mai no impedeix fer una lectura científica de l'art. No sé a quin sant ve tanta història. És que va ser la intenció de Balzac descriure la seua societat? No està gens clar, calia allargar les pàgines, hi havia deutes i s'havien de pagar. Els límits són imprecisos. I això precisament és el que no m'agrada del rigor que avui dia professen algunes persones en l'art d'avantguarda. A no ser que aquesta necessitat de rigor fatu siga corresponent, una altra volta, amb l'expressió del seu temps. Podrien trobar en l'art d'avantguarda prou de tecnologia i d'altres elements que suggereixen autopistes. És per això que em sent tan aillat i que actualment tinc tan poc de contacte amb altres artistes.

Cite un fragment del seu catàleg: "M'hauria agradat que aquesta nota fora més florida o al menys que oliera al perfum deliciós que emana d'un cel de cul d'ampolla. Però és L'Angélus de Daumier $i$ he d'acomplir la meua obligació perquè ho anuncie en la primera part d'aquest catàleg." En el moment de muntar una exposició, és vosté qui canvia o és la circumstància?

Les dues coses, les circumstàncies i jo mateix. És per això que el catàleg està previst com a dues parts, un projecte i després una segona part que reflecteix millor la realitat. Per exemple, de primer es tractava de fer un reconstrucció del primer museu que havia construït a Brussel·les. Durant la realització vaig fer un aturament i vaig servir-me d'una part del material per a canviar-li el context. En lloc d'un museu, la construcció va esdevenir una llotja perfectament petit-burgesa on suren les paraules. A més i a més, per ara m'opose a la noció de reproducció. No crec que en faça cap o en tot cas, no en signaré cap. Vaig afanyar-me molt en fer les cinc exposicions retrospectives d'aquest any, en articular les peces amb un sentit invers. Així doncs, en l'última exposició parisenca, la cosa més important va ser el decor no tant en relació amb el lloc sinó amb el restabliment de l'objecte considerat en funció de la seua naturalesa: com a obra d'art, com a objecte decoratiu. És a dir, el decor mai no és una finalitat per si mateixa, sinó que és part tant d'una peça de teatre com d'una connexió. Amb el mateix sentit vaig fer tres pel-lícules que s'adapten perfectament des del punt de vista de les idees.

L'Angélus de Daumier és un lapsus. Què pensa dels que intenten justificar aquest títol?

No saben què és un lapsus, llavors es trenquen el cap. Durant aquesta exposició va passar que algunes persones van preguntar on està l'exposició de Daumier, on està L'Angélus de Millet. Va haver-hi qui s'ha irritat i va haver-hi qui se'l ha pres molt bé i que va rebre amb humor totes les coses que mai no havia vist abans. Va ser sorprenent un grup de senyores majors del barri que venien buscant L'Angélus i en el seu lloc van descobrir el saló de la baronessa de 
Rothschild per primera vegada. Elles anaven a la seua. Van continuar mirant la resta de coses que hi havia encantades de passar-hi la vesprada.

Vosté va afegir una nota política en aquesta exposició.

Per feble que siga la meu veu, i dins del domini de l'art, intente manifestar una opció malgrat la pressió que hi haja. Aquesta nota del 20 d'octubre del 1975, dia de la inauguració, va ser escrita durant la jornada de protesta en defensa dels afusellats espanyols. Vaig prendre individualment la decisió d'escriure una nota segon la qual em solidaritzava amb els demòcrates espanyols. D'altra manera, en general evite els matisos polítics. Potser estén subjacents però mai no d'una manera clara. Abans d'acabar encara voldria insistir sobre el punt següent. En l'entrevista concedida per Otto Hahns hi ha una interpretació d'un conflicte segon la qual jo vaig oposarme als comisaris de l'exposició. No he sigut jo qui ho ha dit. La meua posició ja la he dita i, a més i a més, amb tota certesa és correspon amb gran part de la veritat. Els últims dies vaig desitjar treballar absolutament a soles. És la meua posició i la mantinc malgrat tot, i pel que fa a això no desig polemitzar més. 
TEXTOS ORIGINALS EN FRANCÉS 


\section{Projet pour un film 160}

Une mouche a pénétré dans le

paysage immobile

Les feuillages frémissent à son

passage, les oiseaux ressuscitent et

brusquement le moulin à aubes s'est

remis à tourner.

L'école est lâchée.

Le professeur chancelant s'engouffre

dans un buisson.

\section{TROIS POEMES DE L'ILE DESERTE}

On recontre des Indiens, son père, sa mère: on rapporteles continents disparus derrière l'horizon pour céer une vie en profondeur.

Un soir, en rentrant chez moi, comme je montais les escaliers, les formations para-surréalistes glissaient de l'autre côté de la rampe et sur le dernier palier était assis Jonny Joes qui philosophait tout seul.

Un bossu émergea de l'étang et vint. Son nez à ma porte. Une rage terrible me commanda d'écraser sa bose. J'en tirai plusieurs seaux de chlorophyle avec laquelle je peignis mon intérieur et la face de ceux que je recontrai.

Le nisorèvre apporte ses châteaux-arrières en bois de chêne comme ceux des anciens vaisseaux. Ils me font l'effet d'un balancement au-dessus d'une imagination désertique. 


\section{Art poétique 161}

Le goût du secret et la practique de l'hermétisme, c'est tout un et pour moi, un jeu favori. Mais ici, je veux dévolier les sources de mon inspiration, cette fois, abandonnant toute pudeur.

Les ouvrages juridique, souvent, exitèrent mon imagination. La place que le mot y occupe est une place nette. L'ambiguïté du Doit tient sans doute à l'interprétation du texte; à l'esperit et non à la letre.

Le mot dans les codes bille comme un solitaire. En bien, voilà qui me passionna depuis que je sus lire. Pasion dangereuse, passion obsédante dont voici un résultat maigre, queluqe poèmes détournés de leur nature de gens et de choses.

Voici un extrait de mon livre de chevet.

161 Publicat originalment en Pense-Bête. Brussel·les: Marcel Broodthaers ed., 1963. En B. Buchloh (ed.). Broodthaers. Writings, Interviews, Photographs. Cambridge, Massachusetts, London: The MIT Press, 1988: p. 14. 


\section{J'attends ton coup de fil, Marcel!}

Diàleg apòcrif amb Pierre Restany. Marcel Broodthaers (1967). En HAKKENS, Anna. Marcel Broodthaers par lui-même. Amsterdam: Ludion / Flammarion, ca. 1998: p. 54 - 57.

Broodthaers se prononce Brotars: quatre lettres phonétiquement inutiles dans l'orthographe du nom. Il y a de quoi inspirer une vocation de philologue, d'archiviste-paléographe, d'ethnographe-explorateur. Broodthaers est tout cela à la fois, et quelque chose d'autre. Cornme Marat revu par Sade, il cultive soigneusement l'eczéma du langage. Les frontaliers du monde des mots et les contrebandiers du monde des objets, les passeurs clandestins de l'en-soi au pour-soi ont entre eux des signes de reconnaissance.

Mardi 21 mars 1967: nous sommes tous les deux, Marcel et moi, dans mon bureau à Paris. Nous parlons peu, par périphrases. Il me montre quelques photos. Et voilà que le courant passe, jusqu'au court-circuit. Le dix-neuvième siècle produisai un excès de charbon. On sait ce ça à donné, sur le plan des transports en cornmun, du chauffage, de la chimie du carbone. Notre Seconde Révolution Industrielle au vingtieme siècle produit un excès d'information et de sollicitations visueIles. La différence entre poésie et arts plastiques s'estompe devant le problème de cet excès d'images, qu'il s'agit avant tout de sensibiliser, d'humaniser, d'individualiser. Plongé jusqu'au con depuis 43 ans dans ce bain de saturation des mass media, Broodthaers cherche désespérément sa réalité, qui est peut-être, finalement, l'art des autres. L'art des autres conçu comme la réalité en soi, c'est un peu le trésor de Tout-Anch-Amon soudainement révélé à Carter et à Lord Carnarvon.

Le 9 mars 1967 j'étais dans l'atelier de Marcel à BruxeIles, rue de la Pépinière. Un antre de liberté, une caverne de crasse et de repos au sein d'une ruche de bureaux ultra-moderne et bourdonnante d'activité. Dieu! Que le labeur des autres est pénible à supporter! Mes yeux, pudiques et lassés, se baissent aterre: j'y découvre un champ de fouilles ineffable, entre deux couches de poussiere et d'oubli. Ainsi se dégage la vérité de Broodthaers: le réalisme melle à l'anonymat, aussi sûrement que l'électricité au court-circuit. Il s'agit pour lui de figurer plastiquement, tangiblement les limites de la cornmunication, nécessaires et suffisantes tout cornme l'inévitable anarchie du langage. L'image à la limite de la non-image, s'inscrit dans notre mémoire avec l'acuité des symboles définitifs: le téléphone sourd obstrué par le coton est un cliché de la civilisation.

Lui: Tu parles! me dit Marcel. Je n'ai eu le téléphone que très tard dans ma pauvre vie de pauvre.

Mais depuis le jour où j'ai eu mon téléphone, je n'ai plus voulu m'en séparer. Pendant des mois je guettais la sonnerie, je téléphonais aux amis pour des motifs futiles. Maintenant encore, je laisse courir toutes les dettes pressantes auxquelles je ne puis faire face, mais je paie le téléphone.

Moi: On ne passe pas sa vie au téléphone, mon vieux Broodthaers, et tu es plongé dans un monde qui attend de toi... des produits de beauté. Remarque, cornme tu en conviens d'ailleurs toi-même, tu plais assez aux hornmes et aux femmes. Tu es un peu sale et débraillé mais tu as un genre, c'est-à-dire du style et sans doute du charme. Personne ne te force ajouer le maudit. Seulement tu n'as pas appris à donner dans le beau conçu à l'état de valeur. Sois donc beau (à 
ta façon) et tais-toi. Mais cornme tous les obsédés du fil ténu de la cornmunication, tu te prends pour le danseur de corde de Zarathoustra.

Lui: Je sais maintenant ce que c'est qu'une couleur et un volume, depuis trois ans queje m'y suis mis. Je ne crois plus au cliché de l'anti-art.

Moi: Eh bien Marcel, tu vas en donner la preuve à tes amis dans quelques jours, à Bruxelles, au Palais des Beaux-Arts. Téléphone-moi pour me décrire l'ambiance du vemissage: quelle robe portait A? A quel film pensait $B$ en contemplant le plafond d'un air absent? Est- ce que $C$ est rentrée à temps du Luxembourg? A quelle heure exacte à fait son entrée le peloton de tête, en cohorte serrée: les deux $\mathrm{D}$, le vieux lion et le jeune Turc, le directorial et souriant $\mathrm{E}$ et puis $\mathrm{F}$ $n^{\circ} 1$ encadré dans Quadrum, la paire muséarde G. H., l'autre F bénit et non benoit, Maître I étemellement déguisé en capucin, le vénérable Je délégué à l'autre culture, les envoyés de l'ambassade gantoise et puis tous les amis qui t'aiment, qui nous aiment bien et parmi lesquels toi Marcel Broodthaers et moi Pierre Restany nous avons choisi, incorrigibles romantiques que nous sommes, de mener jusqu'au bout notre existence résiduelle et anachronique, toi d'artiste (individuel) et moi de critique (d'art). J'attends ton coup de fil, Marcel!

\section{Mon cher Pierre,}

Ce vemissage était réussi. A, B, C, D, E, F, G-H, F, I, J, se sont conformés à ta vision, les autres étaient absents. Les communications étaient sans doute défectueuses. J'étais beau à ma façon et je me suis tu. Souviens-toi, Pierre, je connais à présent le monde du volume.

\section{$\cos$}

\section{Interview de Marcel Broodthaers}

Trepied (1968). En MARCEL BROOdTHAERS. CINÉMA. Barcelona: Fundació Antoni Tàpies, 1997: p. 59.

Votre curriculum vitae nous indique, Marcel Broodthaers, que vous ne vous occupez pas exclusivement du cinéma. Que représente alors le film pour vous?

Avant de répondre à votre question je voudrais dire que je ne suis pas cinéaste. Le film pour moi, c'est le prolongement du langage. J'ai commencé par la poésie, puis la plastique et finalement le cinéma qui réunit plusieurs éléments de l'art. C'est-à-dire: l'écriture (la poésie), l'objet (la plastique) et l'image (le film). La grande difficulté, c'est évidemment l'harmonie entre ces éléments.

Comment avez-vous obtenu cette harmonie dans Le Corbeau et le Renard?

J'ai repris le texte de La Fontaine et je l'ai transformé en ce que j'appelle une écriture personnelle (poésie). Devant la typographie de ce texte, j'ai placé des objets quotidiens (bottes, téléphone, bouteille de lait) dont la destination est d'entrer dans un rapport étroit avec les caractères imprimés. C'est un essai pour nier autant que possible le sens du mot comme celui de l'image. Le tournage terminé, je me suis aperçu que la projection sur l'écran normal, c'est-à-dire la simple toile blanche, ne reflétait pas exactement l'image que je voulais composer. L'objet restait trop extérieur au texte. Il fallait pour intégrer texte et objet que l'écran soit impressionné par les mêmes caractères typographiques que ceux du film. Mon film est un rébus qu'il faut avoir le désir de déchiffrer. C'est un exercice de lecture.

Alors ce n'est pas un film classique ou commercial, mais plutôt un film expérimental. Peut-être même un film "anti-film"?

Oui et non, car anti-film reste quand même film, comme l'anti-roman ne peut échapper completement au cadre du livre et de l'écriture; mais mon film élargit le cadre d'un film "ordinaire". Il n'est pas principalement ou du moins pas exclusivement destiné aux salles de cinéma. Car pour voir et pouvoir comprendre l'oeuvre totale que j'ai voulu réaliser, il faut non seulement que le film soit projeté sur l'écran imprimé mais encore que le spectateur possède 
aussi le texte. Ce film se rapproche si vous voulez du "Pop-art". C'est l'un de ces "Multiples" dont on parle depuis quelques temps comme moyen de diffusion de l'art. C'est pourquoi il va être exposé prochainement dans une galerie qui en fait tirer 40 exemplaires plus les écrans et les livres. Il sera donc exploité comme objet d'art, dont chaque exemplaire comporte un film, deux écrans, et un livre géant. C'est un environnement.

Vous ne vous adressez. donc pas au grand public, comment concevez-vous le rôle de l'artiste?

Aujourd'hui consciemment ou inconsciemment l'artiste est engagé. Le problème... c'est d'être engagé consciemment... authentiquement... ne pas être l'objet de l'engagement des autres. L'engagement apparent m'agace comme celui d'un Godard et de bien d'autres. L'artiste n'a plus en Europe, une fonction définie qu'il peut accepter ou défier. Son succès ou son échec dépend du hasard. Il est excentrique à la société. C'est particulierement vrai pour la Bélgique; c'est tout juste si elle ne lui méprise pas. En tout cas, elle ne lui apporte aucune aide efficace, c'est-à-dire une aide qui lui permettrait de déjouer le hasard.

Où voudriez-vous vivre?

Aux Etats-Unis, le pays le plus industrialisé, le pays d'où est venu entre autres le Living Theater, qui à mon avis influencera toute tentative artistique quelle qu'elle soit. C'est là, bien sûr, le choix de l'artiste et non de l'homme politique.

Quels sont vos projets d'avenir?

Introduire plus de réel dans mes efforts et réaliser un film sur le Vietnam, basé sur l'emploi du signe d'écriture. Récemment, à Knokke, rien n'a été présenté dans ce domaine.

Croyez-vous que le cinéma ait encore un avenir?

Je ne crois pas au cinéma, pas plus qu'a un autre art. Je ne crois pas non plus en l'artiste unique ou à l'oeuvre unique. Je crois à des phénomenes et des hommes qui réunissent des idées.

$\cos$

\section{Projet pour un texte - Projet pour un poisson}

Marcel Broodthaers (1969). En MARCEL BROOdTHAERS. CINÉMA. Barcelona: Fundació Antoni Tàpies, 1997: p. 91.

- Je hais le mouvement qui déplace les lignes -

Si je fais un film, pour un cinéma encore défini comme discipline du mouvement, il me faut répéter le vers de Baudelaire, à moins que ...

1. ... ne pas faire de film et en même temps accepter la valeur du film vierge, cette page blanche du cinéaste et prier pour que d'autres le fassent.

2. ... faire un film au pri.x de la haine. Un film d'amour par exemple. Voilà qui est très séduisant mais risque de servir de pavillon à bien des marchandises, - films publicitaires, films de propagande, films pornographiques, films interdits.

3. ... écarter les problèmes de langage spécifique au cinéma en considérant le film comme une simple référence à quelque abstraction. Aussi dans certains aspects du conceptual Art, souvent le film est un intermédiaire banal où l'idée joue le rôle principal de sujet. Mais le sujet n'est-il pas réduit par cette platitude du style de transmission, sinon absorbé et rejeté dans un documentaire des idées reçues, parfois original?

... Les nouvelles techniques de l'image plus que du cinéma (le laser?) permettent de trouver une solution - momentanée, je le crains - intéressante, certainement.

Encore faut-il être bien né dans un monde technologique pour utiliser ce genre de moyen avec succès. Et me voici cruellement partagé entre quelque chose d'immobile qui a déjà été écrit et le mouvement comique qui anime 24 images par seconde.

PROJET POUR UN POISSON 
$\cos$

\section{Entretien avec Marcel Broodthaers I}

Freddy De Vree (1969). En HAKKENS, Anna. Marcel Broodthaers par lui-même. Amsterdam: Ludion I Flammarion, ca. 1998: p. 68 - 73.

Marcel, vous prétendez toujours être anxieux et tendu quand on vous présente un microphone. Pourquoi?

Parce que je sais que ce que je dis sera reproduit et que je ne pourrai plus le cacher... (éclate de rire)

Est-ce que cela à un rapport avec ces ratures de vos textes et tableaux, avec les silhouettes et le vide de vos objets?

Ça doit être quelque chose du même ordre. En fin de compte, oui, je ne pense ras qu'il y ait une différence entre un micro, une feuille de papier blanche ou une surface qu'on veut montrer à quelqu'un...

$D^{\prime}$ ou vient cette hésitation à montrer à d'aulres les choses que vous avez faites?

Elle provient probablement d'une contradiction. Je crois que j'ai tendance, suite à une conscience politique du monde, à ne vouloir donner que des informations objectives sur le monde. D'autre part, j'ai une tendance naturelle au narcissisme, à la subjectivité, à m'exprimer moimême..., et c'est cela que j'entends cacher.

Pouvez-vous indiquer comment cette dualité apparaît des le départ dans vos ouvres plastiques?

Je pourrais peut-être clarifier ce que je viens de dire à propos de ma tendance à l'objectivité à partir du choix de ce matériau, du plastique, un matériau familier, que tout le monde connait, et qui permet de comprendre qu'il s'agit d'un message sur le monde matériel d'aujourd'hui. Ce message, cette image, ce texte, est subjectif - du moins une fois sur deux. Cette image peut être la représentation d'un poème, une allusion à l'histoire de l'art - aussi bien le passé que quelque chose qui m'a touché - Magritte par exemple.

Des plaques de plastique avec un morceau de ciel, un pan de mur avec l'inscription «Rue Magritte»... Des plaques avec une pipe d'où monte de la fumée, ou un équivalent typographique, une virgule... en quoi consiste ce lien avec Magritte?

J'ai beaucoup réfléchi à l'art actuel, et découvert que l'oeuvre de Magritte est l'une des sources principales de l'art plastique contemporain. Dans Magritte on peut retrouver à son tour le message de Mallarmé... pour autant qu'on puisse parler de message. Ce que j'ai également remarqué, c'est que Magritte commence maintenant à jouir d'une célébrité posthume immense. Cette célébrité est particulièrement suspecte, car elle est essentiellement liée à la flambée des prix de ses tableaux, si bien que son art est en fait obscurci par cette gloire. D'abord son art à été obscurci par l'ignorance, le mépris, la méconnaissance. Aujourd'hui on peut parler du contraire absolu: il est si extraordinairement célebre que peu de gens ont eu l'occasion de voir réellement un Magritte. Je ne crois pas que je me sois servi de son langage. Au contraire, dans ces plaques de plastique avec des pipes et l'inscription de son nom, j'ai essayé de déployer son langage. J'utilise si l'on veu les mêmes éléments mais je leur donne une autre orientation, une orientation réaliste. Je ne me suis pas attaché aux idées de poésie et de Mystere, je me suis plutôt servi de cette distorsion du grand et du petit, de l'objet et de sa re répresentation, pour faire apparaître la réalité sociologique.

Comment voyez-vous aujourd'bui, à partir de ce point de vue, vos premières expositions, ces accumulations de coquilles de moules, d'oeufs, d'yeux?

Oui, c'était un début. Je ne veux rien en renier. Déja alors, j'ai essayé, par le biais d'objets banals, quotidiens, de constituer une liaison entre l'objet et l'image de cet objet... et d'insérer cette double idée, donc espace plane et volume, dans une même entité.

Je ne sais pas si je peux parler d'accumulations comme dans l'oeuvre d'Arman, mais c'est une image qui me vient à l'esprit lorsque je parle de ces coquilles de moules et de ces yeux... mais Arman, me semble-t-il, prend n'importe 
quel objeto Vous, vous prenez toujours des objets qui, au sens psychiatrique, ont certaines résonances plus subjectives. Dans vos plaques de plastique, vous faites référence à la dualité du rêve (Magritte) et du réel. Quand vous retranscrivez tout cela en une seule formule, subsiste toujours malgré tout cette blessure, cette rupture entre l'objet banal et la signification profonde?

Oui. Mais je n'ai évidemment pas fait cela consciemment. Tout en travaillant avec ces concepts, je me suis rendu compte que ma production cadrerait très bien dans une perspective clinique, disons. J'en ai d'abord été très mécontent, j'étais vraiment fâché, jusqu'au moment où j'ai commencé à ressentir plutôt le contraire. Je suis arriveé à la concision qu'il était important por l'artiste, en fait pour l'art en general, que cet aspect clinique - qui constitue peut-êrte le véritable sujet de l'art - ne soit pas caché. En tant que personne, on à naturellement toujours tendance à l'occulter, en fin de compte on n'a pas envie de passer pour un malade mental... et cependant... cette analyse de l'art d'un point de vue clinique est nécessaire. Elle conduirait à une autre forme de démystification, mais cela reste une question très délicate. Il ne s'agit pas en effet de faire des déclarations du genre «c'est la conséquence d'un trouble mental», «c'est de la démence», «la société n'a rien à voir là-dedans», mais cela nous permettrait peut-être au contraire de rétablir l'équilibre rompu qui à existé entre la société et le fou, étant entendu que je considere ce dernier comme un élément positif de la société.

Vous parlez de démystification et c'est précisément ce que vous vouliez atteindre avec le Musée d'Art Moderne, Département des Aigles. Vous avez installé ce musée pendant une année chez. vous. Aujourd'bui il à disparu. Quel était en fait le but de cette entreprise? S'agit-il d'ailleurs d'une entreprise ou est-ce plutôt un simple...

Le plus simple serait peut-être bien de remonter au tout début. En 1968, après cette vague de contestation que nous avons connue, quelques amis - artistes, collectionneurs, gens de galerie et moi nous sommes réunis pour tenter d'analyser ce qui n'allait pas dans le monde artistique beIge, pour analyser les rapports Art-Société. Nous avons bavardé puis nous avons finalement convenu d'une réunion dans mon atelier. On en à beaucoup parlé autour de nous et j'attendais au moins soixante à soixante-dix personnes. Or, mon atelier est assez vide, il n'y à que deux ou trois chaises... ou ces gens devaient-ils s'asseoir? L'idée m'est alors venue de téléphoner à une entreprise de transport, Menkes - assez connue à Bruxelles - et de louer quelques caisses pour que les visiteurs puissent s'asseoir. Cela me paraissait tout à fait logique de les faire prendre place sur ces «signes» qui font référence au fait d'emballer de l'art, caisses dans lesquelles on transporte des peintures et des sculptures. J'ai réceptionné ces caisses et je les ai installées ici d'une maniere finalement assez particuliere, en fait comme si elles étaient elles-mêmes des oeuvres d'art. Alors je me suis dit: mais au fond c'est ça, le musée c'est ça. Voilà donc pour la notion de musée. J'ai ajouté les cartes postales et orné ce décor d'oeuvres du dix-neuvieme siecle. Je l'ai fait en partie par provocation, et en partie pour créer un contraste avec ces plaques de plastique que j'ai faites à partir de ce moment-la, et donc pour indiquer une distance. Ensuite, j'ai écrit le mot «Musée» sur les fenêtres, «Section XIXème siècle» sur la porte donnant sur le jardin et «Département des Aigles» sur le mur au fond du jardin. C'est ainsi que ce Musée est né... non pas d'un concept, mais d'une circonstance; le concept est venu après. Comme Marcel Duchamp disait: «Ceci est un objet d'art». au fond, j'ai dit: «Ceci est un musée». Il y a une différence: après un na j'ai remballé tout ce matériel, et le Musée s'est développé. En fait, j'établissais un rapport entre le vide - ce queje n'emploie pas nécessairement comme un concept péjoratif - de la peinture, entre l'absence d'une signification et le vide des caisses, le vide des reproductions. Le Musée comportait évidernrnent aussi une critique del'Etat belge et de sa politique des musées, de ses instances culturelles. Mais l'essentiel- dans notre pays avant toute autre chose - c'est le problème du langage de cette critique, de la formulation, de l'exposition de divers problèmes et concepts - la notion de peinture, la notion historique de musée. 
$\cos$

\section{Entretien avec Marcel Broodthaers II}

Freddy De Vree (1971). En HAKKENS, Anna. Marcel Broodthaers par lui-même. Amsterdam: Ludion / Flammarion, ca. 1998: p. $75-79$.

Marcel Broodthaers, pouvez-vous décrire le Musée que vous avez ici à DüsseldorJ et donner quelques explications quant à sa fonction?

Vous avez en ce moment le Musée sous les yeux et je préférerais que vous cornmenciez par me donner votre impression, car il s'agit en fait d'une structure de fiction etje n'ai aucune idée de la façon dont cela fonctionne chez les autres. Je vis cette aventure du musée, cette fiction, à ma propre manière, subjectivement. Il y a trois quatre ans, cela à commencé dans mon atelierhabitation à Bruxelles, où j'ai créé un musée fictif avec des caisses de transport vides et des reproductions d'oeuvres d'art sur des cartes postales, et avec des inscriptions indiquant qu'on se trouvait dans un musée. Je revis cette situation ici, mais avec d'autres éléments, d'autres formes, d'autres idées. Je ne suis toutefois pas tout à fait sur que le visiteur éprouve également la sensation de se trouver dans un musée, je veux dire dans un endroit qui ressemble à un hôpital, à une prison, et en même temps dans une fiction...

Mais comment interprétez-vous vous-même cette obsession du Musée? Cette obsession aussi de la façon d'échapper à un passé romantique sans abandonner l'idée que l'art reste toujours lié à la vie même?

Au niveau personnel, je peux répondre: le Musée à toujours été pour moi un lieu où j'aimais aller durant ma jeunesse parce qu'il n'y avait jamais âme qui vive.

Et est-ce que vous voulez reconstruire cette solitude, ou la transmettre au visiteur?

Je voudrais plutôt rompre cette solitude, mais ça ne marche pas, car il n'y a pas foule ici. Et il m'est difficile de donner au pied levé une réponse théorique à votre question sur le visiteur. Disons ceci: je suis toujours heureux de voir arriver ici des amis ou des visiteurs que je connais, car il naît toujours un contact direct. Mais j'aime aussi le visiteur de hasard, bien qu'il vienne le plus souvent sur le conseil d'un ami ou d'une connaissance. Mon rapport au visiteur est un rapport personnel, maisje me demande si ce n'est pas grâce à ces contacts personnels que ce Musée peut continuer à exister, grâce à la bonne volonté des visiteurs qui acceptent tout simplement ma fiction. Et ce qui m'inquiète, c'est la réaction possible de quelqu 'un qui se trouve entièrement en dehors de ce réseau personnel. Pouvez-vous faire abstraction de notre communication verbale et vous mettre à regarder? Ensuite, i je vous demande: Que voyezvous? Est-ce un Musée, est-ce une fiction? Est-ce qu'un but est atteint?

Pas facile! Je vois un musée consacré au thème «cinéma». Il y a une absence nette de certaines figures, et des réductions de figures à des symboles. Ce symbolisme vague est distribué dans tout l'espace et évoque la classification propre à un musée. La cave à quelque chose d'angoissant pour moi parce que je suis contraint pour me sentir plus moi parce que je suis contraint - pour me sentir plus ou moins à l'aise ici, au sens psychologique - de faire appel à mon imagination et d'imaginer plus que les éléments réduits qui sont présentés dans ce Musée.

Oui, mais cela tient sans doute à notre relation personnelle. Je crois que je peux terrniner cette aventure en objectivant la fiction, et c'est dans ce gens que j'ai accepté d'exposer mon Musée de fiction à l'intérieur du véritable Musée, ici à la Kunsthalle de Düsseldorf. Je crois que nous mettrons fin ainsi aux interférences des contacts personnels et des impressions subjectives et qu'elles disparaîtront, la vôtre comme la mienne, et je crois que cela peut devenir intéressant si cette aventure romantique se solde par un échec romantique...

Marcel Broodthaers, une question tout à fait différente: vous avez également une exposition personnelle à la Wide White Space Gallery à Anvers et dans deux galeries de Cologne. Quelle est votre attitfide à l'égard d'une foire ou l'on vend de l'art? 
Ah, mais je me sens bien plus à l'aise à la foire de Cologne que dans mon propre Musée, car sur le Kunstmarkt nous nous trouvons en plein dans la réalité de la société contemporaine, au beau milieu de son systeme, qui se révèle être bassement commercial.

Et pourquoi vous y sentez-vous plus à l'aise?

Parce que c'est la vie de chacun, l'existence de pratiquement tous les artistes, des directeurs de musée et des galeristes. Bassement commerciale - je ne veux pas dire que tous ces gens sont odieux, ou vils, mais que l'art est vendu la comme une marchandise méprisable.

Est-ce que vous vous sentez, marchandé sur un tel Kunstmarkt ou êtes-vous d'avis que, par sa nature même, votre oewure échappe à cette sorte de commerce?

J'essaie, particulièrement dans les oeuvres qui sont montrées ici à la foire de Cologne, d'introduire guelque chose qui comprenne la négation de cette situation, une situation à laquelle je m'attendais. Il y a ici deux ou trois objets qui peuvent passer pour une marchandise méprisable, mais j'espère que, par leur structure ou par les mots qui les entourent, ils contiennent un avertissement qui indique: «Je suis là, ce n'est pas de ma faute»... j'espère que ce n'est pas moi qui le dis, j'espère que l'objet lui-même l'indique.

Vous êtes présent dans Prospekt, la section cinématographique de la Foire, avec un film - la projection d'une «boucle» sur laquelle sont inscrites vos initiales.

C'est un film très court, une seconde, le titre est d'ailleurs Une seconde d'éternité. Je veux, de façon artistique, témoigner une certaine réalité artistique. L'important n'est pas qu'il s'agisse de ma signature ou de celle d'un autre: c'est le fait même de la signature. Je crois que la création artistique repose sur une impulsion narcissique. Une seconde d'éternité s'inspire plus ou moins de Charles Baudelaire. J'ai pris plaisir à faire ce film; le graphisme qui ne dure qu'une seconde constitue en même temps une fiction. La signature de l'auteur - peintre, poete, cinéaste... m'apparaît être le début d'un système de mensonges, le système de chaque poète, chaque artiste essaie d'etablir pour se défendre... contre quoi exactement, je l'ignore.

$\cos$

\section{Méthode}

Marcel Broodthaers (1972). En MARCEL BROOdTHAERS. París: Galerie Nationale du Jeu de Paume, ca. 1991: p. 217.

\section{Duchamp}

Peu importe qu'il s'agisse d'un urinoir signé R. Mutt (1917) ou d'un objet trouvé, n'importe quel objet peut être élevé au rang d'oeuvre d'art. L'artiste définit cet objet de telle manière que son avenir ne relève plus que du musée. Depuis Duchamp l'artiste est l'auteur d'une défition.

A ses débuts l'initiative de Duchamp visait à ébranler la puissance des jurys et des écoles, aujourd'hui - devenue l'ombre d'elle-même - elle est dominante dans tout un secteur de l'art contemporain, soutenue par des collectionneurs et des marchands: ces deux aspects sont mis ici en lumière.

Pour montrer que cette initiative est toujours vivante rappelons que dans un passé trés récent des artistes ont appliqué la définition de ce qu'est l'art à la définition elle-même - au langage de la définition - et ont fait surgir ainsi toute une infra-littérature.

\section{Magritte}

Lisez le texte de Michel Foucault Ceci n'est pas une pipe. 


\section{Fragment d'un entretien avec Marcel Broodthaers}

Jürgen Harten i Katarina Schmidt (1972). En HAKKENS, Anna. Marcel Broodthaers par lui-même. Amsterdam: Ludion / Flammarion, ca. 1998: p. 80 - 83

\section{J. H: ... vivre avec le hasard, malgré tout?}

Oui, aller au devant du hasard, car il vous file entre les doigts dans l'instant même! On ne peut pas baliser le hasard, pas le hasard. Finalement le hasard est la seule, la seule lueur dans une entreprise cornme celle-ci. I1 vous libère et fait qu'on continue son chemin dans la direction empruntée, de sorte qu'on devient conscient, d'une façon tout à fait particulière, de ce qu'on à entamé.

J. H: Et comment voyeq-vous la relation entre votre Musée d'Art Modeme, Département des Aigles, qui à été fondé en 1968, et un musée traditionnel?.

Je verrai cette relation plus clairement lorsque l'entreprise sera parvenue à son terme, actuellement elle est encore bien vivante. j'ai sans doute mon idée à ce sujet, mais ce n'est pas encore tout à fait clair parce que l'expérience n'est pas terminée. Pourtant, je n 'aurais pas de difficulté à situer cette relation. En premier lieu, il s'agit d'une relation étroite, car l'invention du Musée dArt Moderne, Département des Aigles - au début un simple arrangement de caisses, cartes postales et inscriptions: trois fois cien - était liée aux événements de 1968, c'est-à-dire à l'espèce d'événements politiques qui se produisaient à ce moment-là dans tous les pays.

\section{J. H.: Qu'est-ce que cela implique?}

Il faut se représenter un grand changement des consciences, surtout chez les jeunes, et ce changement s'est inévitablement prolongé aussi dans le domaine de l'art. Une question surgissait à nouveau: Qu'est-ce que l'art? Quel rôle l'artiste joue-t-il dans la société? J'ai fait encore un pas supplémentaire en posant la question: Quel est à la limite le rôle de ce qui dans notre société représente la vie artistique, c'est-à-dire: quel est le rôle du musée? Il importait en premier lieu de faire un relevé de la situation. Et ces arrangements dont j'ai parIé étaient pour moi un lieu où discuter et échanger des idées. Mais toute l'entreprise à évolué rapidement et s'est dégagée de ce contexte imrnédiat ou plutôt: sociologique, et à commencé à vivre d'une vie autonome. Bref, c'est le phénomène classique de l'art. Vous concevez quelque chose, une chose dont vous croyez qu'elle est en rapport étroit avec un événement déterminé qui se produit dans la société, et puis cela se met tout à coup à vivre sa propre vie, à grandir et à produire des cellules. A ce moment-là naît dans l'art une sorte de biologie sur laquelle l'artiste lui-même n'a pratiquement plus aucun contrôle. D'après moi, l'artiste ne peut contrôler ce processus que pendant un temps bref et de plus, de façon très générale. Ensuite, il perd son emprise. Les idées cornmencent à se multiplier cornme des cellules vivantes.

L'aspect «fiction», le fictif, s'est détaché de façon très particulière de l'entreprise portant le nom de Musée d'Art Moderne, Département des Aigles. Le côté irréel, l'arrangement, qui n'était rien de plus au départ qu'un simple décor, s'est progressivement institutionnalisé à mes yeux et à ceux de mon entourage irnmédiat. Ce musée est devenu réalité pour mes connaissances bruxelloises mes amis, des personnes qui s'occupaient d'art - et ensuite des personnes qui venaient de l'étranger pour voir, parce qu'ils en avaient entendu parler. C'est ainsi qu'a germé autour de ce Musée d'Art Moderne, Département des Aigles, malgré son caractere fugitif, un système de relations entièrement nouveau. L'arrangement cessait d'avoir une fonction de décor, il devenait le symbole d'un musée fictif, c'est-à-dire: les cartes postales prenaient une valeur symbolique précisément par leur relation avec cette situation spéciale. Pour ce qui est de la question qui se pose par rapport à ce qui nous occupe, les aigles, là, il y à une sorte de hasard qui intervient! j'ai parlé d'une fiction basée sur le symbolisme des caisses et dont le point de vue était rendu par les cartes postales. Maintenant je parle de fiction en rapport avec les aigles que j'expose sous la même étiquette Musée d'Art Moderne, Département des Aigles. Que se passe-t-il? Il apparaît 
en fin de compte que l'aigle est lui-même, dès le début, de la fiction... fiction dont le contenu sociologique et politique est de plus en plus difficile à comprendre au fur et à mesure qu'on remonte dans le passé.

Cornment peut-on expliquer pleinement la naissance du symbole et du mythe de l'aigle sans la connaissance archéologique que nous avons à ce sujet? Je crois que cette exposition peut faire comprendre que l'aigle et la façon dont il est représenté relevent de la fiction. Deux fictions vont ici s'opposer, ce qui à certaine- ment un effet de provocation. Il est essentiel pour cette exposition que nous acquérions, grâce à cette confrontation des fictions, une conscience plus vigoureuse de la réalité, de la réalité d'une idée, bien entendu.

J. H: Il s'agit finalement d'une relation entre une consciente modifiée et des objets qui existent réellement. Si l'on regarde ces objets avec cette consciente modifiée, on à l'impression qu'ils changent de nature, mais en tant qu'objets ils mènent une vie autonome. Par exemple, des objets sumériens, médiévaux, étaient exposés les uns à côté des autres avec un musée comme contexte. Ce contexte toutefois changeait sa signification sociologique et je crois que grâce à votre méthode - la «méthode fiction» - nous devenons maintenant conscients de ce processus.

Vous parlez de méthode. Je préférerais peut-être me baser sur la situation que j'ai créée. L'impulsion au changement qui émane peut-être également de cette exposition d'aigles vient plutôt de cette «situation de fiction» que d'une méthode déterminée.

JH: En termes concrets: Vous attendez, encore de voir comment l'exposition se présentera.

Evidernment. Je ne suis pas du tout sûr du résultat. Pourtant j'ai affirmé qu'on en arrivera à une confrontation de fictions. Pour l'instant, ce n'est qu'une façon de se représenter les choses.

K. S.: En tout cas, voyez-vous cette exposition comme un lieu de discussion, tout comme précédemment, lorsque vous avez fondé le Musée d'Art Modeme, Département des Aigles?

Oui, mais une discussion d'un caractère totalement différent. En ce sens que cette fois le débat ne peut pas se développer en toute liberté. Le visiteur est interpellé, mais il ne prend pas une part directe à la discussion. Donc, cela ne correspond pas à ce que nous entendons par discussion. Quand il y à discussion, tout le monde participe, intervient, avance des arguments. Pour être précis: cette exposition est donc en fait une proposition de discussion. Pendant que je pense à ces choses, je m'inquiete à l'idée que mon invitation pourrait être interprétée cornme une prise de position.

$\cos$

\section{Aigle. Idéologie. Public}

Marcel Broodthaers (1972). En MARCEL BROODTHAERS. París: Galerie Nationale du Jeu de Paume, ca. 1991: p. 217.

Dans quelle mesure les informations sur l'art contemporain ont-elles fait leur chemin dans la conscience du public? Le public, c'est vous, c'est moi, ce sont les autres.

Le public est confronté aux objets d'art suivants: différentes sortes d'aigles dont une partie est lourdement chargée de notions symboliques et historiques. Le caractère de cette confrontation est déterminé par l'inscription négative: "Ceci n'est pas... ceci n'est pas une oeuvre d'art". Ce qui ne signifie rien d'autre que: public, comme tu es aveugle! .

Ainsi d'une façon ou d'une autre: ou bien l'information à joué un rôle effectif sur ce qu'on appelle I'art modeme, alors tout Aigle est purement et simplement intégré à une méthode; ou bien l'inscription apparait comme un pur non sens - c'est-à-dire qu'elle n'est pas au niveau de la discussion sur la validité des idées, par exemple, de Duchamp et de Magritte - dans ce cas l'exposition obéit de nouveau aux principes classiques: l'Aigle dans l'art, en histoire, en ethnologie, dans le folklore... Je ne serais sans aucun doute pas plus chanceux avec le serpent, le lion, le taureau.

MARCEL BROODTHAERS 


\section{Section des Figures}

Marcel Broodthaers (1972). En MARCEL BROOdTHAERS. París: Galerie Nationale du Jeu de Paume, ca. 1991: p. 220 - 221.

\section{Figure 1}

Si on n'attribuait pas à l'aigle, dans l'idée qu'on s'en fait, une force magique, suffisante pour propulser un dieu ou un vaisseau spatial (Appolo 11), personne ne s'intéresserait à lui.

De l'oiseau lui-même on se fait une idée erronée. La plupart des naturalistes le décrivent avec des mots pathétiques. Konrad Lorenz fait exception. L'aigle est bête, dit-il en substance. Il à peur même d'une bicyclette.

\section{Figure 0}

De telles représentations sont dangereuses. Elles vous plongent parfois dans une sorte d'anesthésie dont il est impossible de se réveiller. Être très profondément effrayé. Ne pas savoir. Finalement admirer sans réserve. La représentation majestueuse de l'art et la représentation majestueuse de l'aigle. Tout cela très sublime - de l'oligocène jusqu'à nos jours. Pourquoi l'oligocène? Le rapport direct entre le fossile de l'aigle trouvé lors de fouilles effectuées dans les couches du tertiaire et les différentes formes sous lesquelles se présente le symbole est peut-être faible, à supposer qu'il existe seulement. Mais la "géologie" devrait se faire entendre dans le titre (sensationnel), lui ajouter une pointe de fausse scientificité qui révèle que le symbole Aigle à été repris sans réflexion, sans avoir été soumis à discussion. L 'aigle n'est pas une carotte; mais l'objectif de cette exposition est de l'arracher de ce ciel imaginaire où il tournoie depuis des siècles, nous menaçant de ses éclairs- qu'il soit de pierre, de bois cerclé d'or ou en acier inoxydable.

\section{Figure 2}

Suivre ses traces à travers la forêt des images nous amènera à envisager différents points de vue: quant à la signification du symbole, à la signification toujours identique quel que soit le niveau considéré - analogue aux cercles que décrit l'oiseau: grandeur, autorité, puissance. Esprit divin. Esprit de conquête. Impérialisme.

\section{Figure 2}

L'aigle est, comme le tigre de papier, un monstre chétif. 11 niche dans les musées publics. Cela se reflète aussi dans mon musée fictif que j'ai fondé en 1968 et auquel j'ai donné le nom de "Département des Aigles". L'aigle de papier à un caractère double. D'une part il joue le rôle d'une parodie sociale des productions artistiques, d'autre part celui d'une parodie artistique de faits sociaux. Les musées publics, comme d'ailleurs toutes les institutions culturelles, ne font rien d'autre. Je crois qu'un musée fictif comme le mien permet d'avoir prise sur la réalité comme sur ce qu'elle cache. La "Section des Figures", telle qu'elle est montrée à l'exposition de Düsseldorf, accomplit ce déplacement de l'objectif. Processus de déni. Processus plein de contradictions comment est-il représenté dans la Kunsthalle? On voit bien ici qu'il n'y à pas de différences capitales entre mes intentions et leur réalisation dans l'exposition. La méthode choisie invite à reconnaitre l'efficacité des idées de Duchamp et de Magritte. Elle met à mon avis l'accent sur un problème - comme toute manifestation artistique qui s'annonce comme telle - et elle est à cet égard menacée par sa propre insuffisance de pertinence sociale. C'est pourquoi j'ajoute en-dessous un texte de Michael Oppitz portant le titre Aigle Pipe Urinoir, qui approfon- dit ma méthode d'un point de vue théorique. 


\section{Figure 0}

Le projet de l'exposition se base sur l'identité de l'Aigle en tant qu'idée et de l'art comme idée. L'objectif est de proposer une réflexion critique sur la présentation de l'art en public. Pour ce qui est de la perception de l'art par le public, je constate que les habitudes et les fixations personnelles empêchent une "lecture" sans préjugés. Malgré tout, la plaquette portant l'inscription "Ceci n'est pas une oeuvre d'art" joue un certain rôle. Elle perturbe la projection narcissique du visiteur sur I'objet qu'il contemple, mais elle n'atteint pas sa conscience.

\section{Figure 1}

Des oeuvres d'art sumériennes aux oeuvres actuelles, l'Aigle parle le langage stylistique de chaque époque. Les diapositives d'images publicitaires projetées dans l'exposition font ressortir un manque d'harmonie. La langue de la publicité à pour cible l'inconscient du spectateurconsommateur; par là l'Aigle magique se voit restituer toute sa puissance. Michael Oppitz abonde dans mon sens quand il écrit que j'ai arraché quelques plumes à l'aigle mythique. Mais dans la publicité il s'en sort indemne, aussi agressive soit-elle. L'objet d'art ne peut être saisi ici car il est représenté hors des conventions qui structurent la vie artistique. Dans la publicité, l'art est utilisé et reçoit un énorme succès. Il règne sur des horizons radieux. Il incarne le rêve de l'homme.

MARCEL BROODTHAERS

\section{$\cos$}

\section{Le Musée d'Art Moderne Département des Aigles est tout simplement un mesonge}

Marcel Broodthaers (1972). En MARCEL BROODTHAERS. París: Galerie Nationale du Jeu de Paume, ca. 1991: p. 229.

Le "Musée d' Art Moderne Département des Aigles" est tout simplement un mensonge, une tromperie. Mais il survit depuis déja quatre ans au sein de manifestations les plus diverses; dans des publications, des entretiens, des cartes postales, de véritables objets d'art, des tableaux, des sculptures et dans des publicity objects.

Parler de mon musée équivaut à parler de l'art et la manière, à analyser la tromperie. Le musée normal et ses représentations mettent simplement en scène une forme de vérité. Parler de ce musée équivaut à discourir sur les conditions de cette vérité.

Il y à une vérité du mensonge. C'est elle qui détermine ma conscience. Quand une oeuvre d'art trouve sa condition dans le mensonge ou la tromperie, est-ce alors encore une oeuvre d'art? Je n'ai pas de réponse.

Un musée qui est une tromperie à quelque chose à cacher. Le mensonge personnel à un aspect freudien. Mais ce que le musée personnel veut cacher, c'est le vrai musée.

La motivation de tout artiste est à vrai dire le narcissisme, peut-être aussi la "volonté de puissance" (Nietzsche). Mais pour moi la motivation est beaucoup moins intéressante que le thème lui-même.

Le musée fictif essaie de piller le musée authentique, officiel, pour donner davantage de puissance et de vraisemblance à son mensonge. Il est également important de découvrir si le musée fictif jette un jour nouveau sur les mécanismes de l'art, du monde et de la vie de l'art. Avec mon musée je pose la question. C'est pourquoi je n'ai pas besoin de donner la réponse.

J'aurais déja pu vendre mon musée. Mais ça ne m'est pas possible pour l'instant. Tant que j'y trouve refuge et que je m'identifie à lui, je ne le puis pas. C'est du moins ce que je pense pour le moment.

Je ne me laisserai pas attraper. Je me replie dans la cachette du musée. En ce sens le musée est un prétexte. 
Peut-être la seule possibilité pour moi d'être un artiste est-elle d'être un menteur, parce qu'en fin de compte tous les produits économiques, le commerce, la communication sont des mensonges. La plupart des artistes ajustent leur production au marché, comme si c'étaient des marchandises industrielles.

MARCEL BROODTHAERS

\section{$\cos$}

\section{Ce musée est un musée fictif}

Marcel Broodthaers (1973). En MARCEL BROODTHAERS. París: Galerie Nationale du Jeu de Paume, ca. 1991: p. 227.

[Ce musée est un musée fictif. Il joue une fois le rôle d'une parodie politique des manifestations artistiques, une autre fois celui d'une parodie artistique des événements politiques. Ce que font d'ailleurs les musées officiels et les organes comme la Documenta. Avec toutefois la différence qu'une fiction permet de saisir la réalité et en même temps ce qu'elle cache. Fondé en 1968 à Bruxelles, sous la pression des vues politiques du moment, ce musée ferme ses portes avec la Documenta. Il sera passé d'une forme héroïque et solitaire à une forme voisine de la consécration grâce à l'aide de la Kunsthalle de Düsseldorf et celle de la Documenta.

Il est donc logique qu'à présent il se rige dans l'ennui. Certes, voilà un point de vue romantique; mais qu'y puis-je? Qu'il s'agisse de saint Jean l'Évangéliste ou de Walt Disney, le symbole de l'aigle au niveau de l'écrit pèse d'un poids singulier. Or, j'écris ces lignes, c'est-à-dire que j'entends le romantisme comme une nostalgie de Dieu.] Constatons donc combien iI est difficile de garder le dieu à distance dès qu'il s'agit d'art, aussi difficile que d'échapper aux pièges des galeries et des institutions officielles.

J'essaye de réunir quelques textes et des interviews contradictoires concemant les différentes sections du Département des Aigles. Déjà on pourra lire plus loin une interview du Dr. J. Cladders à propos de la Section Art Modeme et un texte théorique de M. Oppitz sur l'exposition des Figures à Düsseldorf. Signalons qu'un catalogue avec une introduction de J. Harten à été édité à cette occasion (les traductions en langue française suivront).

Il est un peu tôt pour décrire les intentions qui m'ont guidé dans la réalisation de la Section Publicité. Comme l'image de celle-ci coïncide avec celle parue dans la partie publicitaire du catalogue de la Documenta, elle me dis- pensera de longs discours. A s'occuper d'art, on ne tombe jamais que d'un catalogue à l'autre]. Dans ces conditions, la culture est-elle encore importante? A mon avis, oui, d'autant plus si elle incorpore la pensée dans un cadre de référence qui peut vous aidera à vous défendre contre les images et les textes véhiculés par les média et par la publicité qui déterminent nos règles de comportement et notre idéologie.

Ce musée fictif prend pour point de départ l'identité de l'art et de l'Aigle..., il allait de soi d'estampiller l'Urinoir de Duchamp (1917) du signe de l' Aigle, plus exactement, la photo de l'objet sanctifié par l'histoire de I'art, montrée ici avec beaucoup d'autres documents.

Publicité pour l'art et pour l'art de la publicité. Mais qui remarque l'action magique exercée par des artistes anonymes (grâce au symbole de l'autorité), au service de la diffusion des produits de l'industrie? Ceux qui vivent dans le contexte de l'art et considèrent ainsi I'art en tant qu'art. Et seuls ceux à qui importe le contexte social de ces productions. Mais que voit le public, le grand public et tous ceux qui regardent des matchs de football?

MARCEL BROODTHAERS 


\section{Le degré zéro}

Marcel Broodthaers (1973). En MARCEL BROODTHAERS. París: Galerie Nationale du Jeu de Paume, ca. 1991: p. 231.

La présentation d'une exposition dépend de l'opinion que l'exposant officiel se fait de l'art. La présentation officielle adopte les normes "modernisées" de tout institut d'exposition. C'est-à-dire qu'un mode d'exposition toujours hiérarchique constitue avec les institutions exposantes (musées) et les autres institutions (hôpitaux, prisons, etc.) la société officielle. De ce fait, tout travail d'exposition est la plupart du temps entrepris sur la base d'un compromis (exemple: la Documenta 5 et $\mathrm{H}$. Szeeman). Nous constatons donc que la mise en scène des objets et des images est rarement adéquate mais qu'il y à, pour toute exposition, tendance à la manipulation. J'ai montré poul ma part l'été demier) l'exposition "L'Aigle de l'oligocène jusqu'à nos jours" à la Kunsthalle de Düsseldorf. Comme artiste, cela veut dice, avec une signification aussi peu déterminée et aussi mal définie, mes actions ne pouvant être sirutées que dans les formations marginales du comportement social. Il est aisément constatable que je voulais neutraliser la valeur d'usage du symbole de l'Aigle et la réduire à son degré zéro pour introduire des dimensions critiques dans l'histoire et l'usage de ce symbole.

MARCEL BROODTHAERS

$\cos$

\section{Entretien avec Marcel Broodthaers III}

Freddy De Vree (1974). En HAKKENS, Anna. Marcel Broodthaers par lui-même. Amsterdam: Ludion / Flammarion, ca. 1998: p. $103-107$.

Marcel Broodthaers, dans cette exposition bruxelloise consacrée à des aspects de l'avant-garde dans les arts plastiques, on voit par exemple une oewvre assez sobre qui à elle seule remplit toute une salle. Je ne parte pas de votre salle, mais de la Croix de sable de Richard Long. Que trouvez- vous de ce genre d'oeuvres d'art?

J'aime vraiment beaucoup cette oeuvre de Richard Long, mais jamais l'idée ne me serait venue de l'appeler une croix, bien que ce soit une croix, évidemment, ou un signe de multiplication. J'y vais tout simplement quelque chose de poétique qui s'exprime à travers le matériau végétal, et rien de plus. Une poésie naturelle d'un haut degré d'intensité. Je préfere Richard Long à beaucoup d'autres artistes, ses oeuvres me touchent plus que celles de certains autres parce qu'elles sont moins accessibles. On ne peut pas expliquer son oeuvre, sinon dans un rapport personnel à elle-même, à l'intérieur d'un système clos.

Et à l'intérieur d'un musée.

Je suis convaincu que Richard Long n'est pas conscient de ce problème. Ça doit lui paraittre aussi naturel et évident de réaliser une telle reuvre que de la montrer ici. Richard Long ne pose pas de questions politiques, sinon cette seule question indirecte: que vient faire la poésie dans notre monde?

Que croyez-vous qu'elle vient faire?

Je crois qu'elle trouble les codes avec lesquels on élabore des explications. Dans la mesure où la poésie reste inexplicable, elle dérange les habitudes en vigueur dans un monde où l'on essaie toujours de tout expliquer et oò l'on veut toujours et partout mettre de l'ordre.

Vous avez installé ici un Jardin d'hiver, plein de plantes tropicales, et pourtant ma premiere idée a été, comme une association: ceci évoque un désert. 
Oui, l'image d'un désert. Ce genre d'image supplémentaire me réjouit, car elle ne se trouve pas dans ce qui est montré - palmiers, chaises, reproductions... - et pourtant c'est, en effet, l'idée fondamentale: le désert...

L'absence...

L'absence, et l'absence du désert. Un désert à la fois réel et symbolique, une illustration $-a$ contrario - de la situation politique et économique actuelle, mais plus encare, la prédominance du désert, le désert de la société, le désert des loisirs, le désert, finalement, du monde de l'art...

Vous avez écrit un texte d'accompagnement.

Oui. Un petit texte:

Un jardin d'hiver

Ce serait un A B C D E F du divertissement, un art du divertissement.

GHIJ KLMN O PQRSTUVWXYZ

Pour oublier. Pour dormir, serein, bien pensant.

De nouveaux horizons se dessinent.

Je vais venir à moi de nouveaux horizons et l'espoir d'un autre alphabet (voir catalogue)

C'est donc un texte par lequel je veux m'opposer à une série d'idées et de théories qui sont actueIlement en vague dans le monde de l'art, mais c'est un texte assez difficile au point de vue «communication». Tout semble se dérouler en cercles, etje tiens à préciser que je suis d'accord avec ce qui est exposé ici - le tapis de cuivre de Carl Andre, le baldaquin de Buren, la sculpture plane de Richard Long, l'alphabet chromatique de Gerhard Richter, etc. - lorsque je compare cet ensemble avec tout l'art traditionnel tel qu'il se manifeste dans ce pays (et y est encouragé). Dans cette optique, les nuances s'effacent entre ceux qui exposent ici et le «monument du laissez-aller» que toute société érige avec l'art qu'elle assimile. Elle en fait un pilier de l'Etat et l'assimile ainsi aux prisons et aux hôpitaux. Mais les nuances dont je parle dans mon texte... s'adressent aux nuances des autres artistes au sein de ce monde extrêmement étroit de l'avant-garde. Mais plus ce monde est étroit, plus il me parait être une caisse de résonance véritable des événements qui se déroulent à l'échelle du monde. C'est paradoxal, mais ce microcosme fonctione de façon très efficace.

Je voudrais, de mon point de vue à moi, reformuler les choses comme suit: ce serait moins une maniJestation de sympathie à l'égard de l'art conceptuel que la formation partielle d'un front contre la tendance à l'byperréalisme.

Evidemment! L'hyperréalisme ne signifie pas seulement la consé- cration d'une certaine idée de la peinture a l'intérieur de l'ensemble de l'art, mais également la consécration de toutes les conceptions réactionnaires. Le message de l'hyperréalisme comprend l'idée de confort, l'absence absolue de changement, l'exaltation de l'argent au sein d'un monde qui a dissimulé tous ses problèmes.

L'byperréalisme - et je quitte peut-être votre Jardin d'hiver, Marcel - permet pour la première fois au bourgeois d'aujourd'bui de trouver également un ordre, une identité dans l'art contemporain. Ce sont des peintures faites d'apres une photographie, d'après une pièce d'identité donc.

Oui, mais lorsque je pense a l'hyperréalisme, je pense aussi à Meissonier, c'est à peu près la même chose, sauf que la liberté qui existait encare à l'époque de Meissonier a disparu. A notre époque, toute tentative artistique équivaut à un ordre: il faut faire ceci, faire cela et pas autre chose. A l'époque de Meissonier, on pouvait au moins encare avoir des idées divergentes et représenter autre chose. Cette liberté d'expression qui est sculptée au fronton de toutes nos institutions est aujourd'hui purement formelle. Tandis qu 'autrefois, il existait quand même encore une liberté, fût-elle étroite, dans un domaine plus général. Vous ne vous êtes pas tellement éloigné du Jardin d'biver, cal c'est à cette sorte de serre que je pensais, lorsque je l'ai conçu. 
Un nettoyage par le vide? Comme le raturage du texte dans le poème de Mallarmé?

Oui, quelque chose de ce genre. Dans ce petit livre sur Mallarmé, j'opère une séparation entre le texte et l'image du texte, la typograhie. J'ai réimprimé le texte comme une introduction à l'image du texte. Aujourd'hui, le langage de Mallarmé est utilisé également en dehors de l'art, par exemple en psychanalyse, par Jacques Lacan. Son ouvrage Ecrits comprend le langage de Mallarmé, mais centré sur le réel, la psychanalyse, qui passionne Lacan et ses lecteurs.

Voulez-vous dire un mot également des films sur lesquels vous travaillez en ce moment?

Je travaille sur The last voyage, une série de diapositives de la fin du siècle précédent [XIX]. Ce ne sont en fait pas des diapositives mais des photos coloriées a la main, très beIles d'ailleurs. Un père meurt dans un décor particulierement bourgeois, il meurt, entouré de sa fille et de son beau-fils... et il montre, dans un geste étemel, le bateau qui passe et qui emportera son âme. C'est la première partie du film. Dans la seconde partie, on voit le New York actuel, sous la forme du Temps, du Temps et de la Mort.

Marcel, ce qui me frappe maintenant, c'est que vous mettez si souvent vos personnages en rapport avec la mort. Je pense également à votre série de gravures avec le bateau qui sombre et la jeune fille qui ecrit: "Chère petite soeur... »

Oui mais, je suis malade. Je souffre d'une maladie longue et pénible, qui ne peut avoir qu'une issue fatale. Mais dans très longtemps, je crois, carje me soigne très bien... et je voudrais dire aux lecteurs qui prennent intérêt à mon existence... enfin... de ne pas trop s'en faire!

$\cos$

\section{Dix mille francs de récompense}

I. Lebeer (1974). En Marcel Broodthaers. París: Galerie Nationale du Jeu de Paume, ca. 1991: p. 248 - 251.

\section{Objets}

Les objets fonctionnent-ils, chez vous, comme des mots?

J'utilise l'objet comme un mot zéro.

Ce n'étaient pas d'abord des objets littéraires?

On pourrait les nommer comme cela, alors que les objets plus récents échappent à cette dénomination qui a réputation péjorative (je me demande bien pourquoi?). Ces objets récents portent, à la manière sensationnelle, les marques d'un langage. Mots, numérotations, signes inscrits sur l'objet lui-même.

Au début de votre activité vous aveź, suivi une direction aussi précise?

J'étais hanté par une certaine peinture de Magritte, celle-là où figurent des mots. Chez Magritte, il y a contradiction entre le mot peint et l'objet peint, subversion du signe du langage et de la peinture au bénéfice d'un resserrement de la notion de sujet

$Y$ a-t-il des objets auxquels vous tenez encore?

Oui, quelques-uns. Ils sont poétiques, c'est-à - dire coupables dans "L'Art comme langage" et innocents dans le langage comme Art. Par exemple, ceux que je vais vous décrire. Un fémur tricolore, Fémur d'bomme belge. Et un vieux portrait de général ramassé dans je ne sais plus quel marché aux puces. J'ai fait un petit trou à la place de la bouche pincée du général pour y introduire un mégot de cigare. Dans cet objet-portrait, il y a une heureuse harmonie de tons. La peinture est brune, assez pisseuse, le mégot également. N'importe quel cigare n'irait pas dans n'importe quelle bouche de général... le calibre du cigare, le format de la bouche.

Est-ce cela l'art du portrait?

Je préfère croire qu'il s'agit d'un objet pédagogique. Il est nécessaire de dévoiler - quand il se peut - le secret de l'art, le général mort fume un cigare éteint. J'ai fait ainsi, avec le fémur, deux objets utiles. J'aurais voulu en faire d'autres qui m'eussent donné autant de satisfaction. Mais je 
me suis méfié du genre. Le portrait et le fémur me paraissent avoir la vertu de ronger la falsification inhérente à la culture. Avec le fémur, nationalité et structure de l'être humain sont réunies. Le soldat n'est pas loin.

Ily a beaucoup de coquilles, de moules et d'oeufs dans votre production. Des accumulations?

Le sujet est davantage le rapport qui s'installe entre les coquilles et l'objet qui les supporte. Table, chaise ou casserole. C'est sur une table que l'on sert un oeuf. Mais sur ma table où il y a trop d'oeufs il y manque le couteau, la fourchette et l'assiette. Absences nécessaires pour faire parler l'oeuf à table ou pour que le spectateur ait une idée originale de la poule.

Et les moules, un rêve sur la mer du Nord? Une moule cache un volume.

Le débordement des moules de la casserole ne suit pas les lois de l'ébullition, il suit les règles de l'artifice pour aboutir à la construction d'une forme abstraite.

Donc, vous êtes proche d'un système académique?

D'une rhétorique se nourrissant au nouveau dictionnaire des idées reçues. Plus que d'objets et d'idées, j'organise la rencontre de fonctions différentes qui renvoient au même monde: la table et l'oeuf, la moule et la casserole à la table et à l'art, à la moule et à la poule.

Le monde de l'imaginaire?

Ou celui de la réalité sociologique. C'est ce que Magritte ne manquait pas de me reprocher. Il me trouvait plus sociologique qu'artiste.

\section{Signalisations industrielles}

Les plaques en matière plastique correspondentelles à cette réalité sociologique?

J'ai cru que la matière plastique me libérait du passé, alors que cette matière n'existait pas. Cette idée m'avait tant plu que j'oubliai que ce matériau fut déja "ennobli" par son apparition aux cimaises des galeries et des musées sous la signature des Nouveaux Réalistes et des Pop américains. Ce qui m'intéressait, c'était le gauchissement que le matériau apportait à la représentation.

Elles étaient éditées à 7 exemplaires?

J'ai défini moi-même leur tirage car aucune galerie ne voulait assumer à ce moment-là le risque d'édition. Pour le faire, je fus aidé par le secteur privé.

Et le langage de ces plaques?

Disons des rébus. Et le sujet, une spéculation sur une difficulté de lecture entraînée par l'emploi de ce matériau. Sachez que l'on fabrique ces plaques comme des gaufres.

Ces plaques sont-elles si malaisées à déchiffrer?

La lecture est contrariée par l'aspect image du texte et l'inverse. Le caractère stéréotypé du texte et de l'image est défini par la technique du plastique. Et la lecture proposée dépend d'un double niveau - appartenant chacun à une attitude négative qui me parait être le propre de l'attitude artistique. Ne pas situer le message entièrement d'un coté, image ou texte. C'est-à-dire refuser la délivrance d'un message clair comme si ce rôle ne pouvait incomber à l'artiste et par extension à tout producteur économiquement intéressé. Il y aurait ouverture, ici, d'une polémique. À mon sens, il ne peut y avoir de rapport direct entre l'art et le message et encore moins si ce message est politique sous peine de se brûler à l'artifice. De sombrer. Je préfère signer des attrapes-nigauds sans me servir de cette caution.

Quel genre de nigands attrapez-vous avec vos plaques?

Eh bien! ceux qui prennent ces plaques pour des tableaux et les accrochent aux murs. Rien ne dit d'ailleurs que le nigaud ne soit leur auteur qui a cru être linguiste en sautant la barre de la formule Signifiant/Signifié et qui, en fait, n'aurait que joué au professeur.

\section{Les figures}

Vous situez-vous dans une perspective surréaliste? 
Je connais ceci par coeur: "Tout porte à croire qu'il existe un point de l'esprit d'où la vie et la mort, le réel et l'imaginaire, le passé et le futur, le communicable et l'incommunicable, le haut et le bas cessent d'être perçus contradictoirement." J'espère n'avoir rien de cet état d'esprit. Magritte avec "Ceci n'est pas une pipe" est moins aisé. Mais encore, il était trop Magritte. C'est-à-dire qu'il n'était pas assez "Ceci n'est pas une pipe". C'est à partir de cette pipe que j'ai tenté l'aventure.

Un exemple?

Vous verrez au musée de Mönchegladbach une boîte en carton, une horloge, un miroir, une pipe et aussi un masque et une bombe fumigène, l'un ou l'autre objet encore dont je ne me souviens plus, accompagnés de l'expression Fig. 1 ou Fig. 2 ou Fig. 0 peinte sur la cloison endessous ou a coté de chacun d'eux. Si l'on se fie au sens de l'inscription, l'objet prend un caractère illustratif se référant à une sorte de roman de la société. Ces objets, le miroir et la pipe, soumis à cette même numérotation (ou la boîte en carton et l'horloge et la chaise), deviennent les éléments interchangeables sur la scène d'un théatre. Leur destin est miné. J'obtiens, ici, une rencontre espérée de fonctions différentes. Une double assignation et une texture lisible - bois, verre, fer, tissu - les articulent moralement et matériellement. Je n'aurais pu atteindre cette complexité avec les objets technologiques dont l'unicité voue l'esprit à la monomanie: minimal art - robot - ordinateur.

Les numéros 1, 2, $O$ apparaissent figuralement. Et les abréviations Fig. mal dans leur sens. Est-ce la condition pour que vous vous sentiez, bien dans le vôtre?

Ce qui me rassure, c'est l'espoir que celui qui regarde court le risque - un instant - de ne plus se trouver si bien dans le sien. Ne manquez pas de passer au musée de Mönchengladbach.

Mais le spectateur pourrait se méprendre et voir là une expression comparable à celle du Nouveau Réalisme des années 60 ?

Mes premiers objets et images - 1964-1965 - ne pouvaient donner lieu à cette confusion. La littéralité liée à l'appropriation du réel ne me convenait pas car elle traduisait une acceptation pure et simple du progrès dans l'art et... ailleurs. Ceci dit, rien ne peut empêcher un spectateur de se méprendre, s'il y tient. Et je n'assume ni la bonne foi du spectateur ou du lecteur ni sa mauvaise foi.

Etes vous parti d'une vision élaborée de votre projet?

Je ne sais ce que mon inconscient a pu fabriquer, vous ne me le ferez pas dire. J'ai fabriqué des instruments destinés à mon usage pour comprendre la mode en art, la suivre et chercher finalement une définition de la mode. Je ne suis ni peintre, ni violoniste. Ce qui m'intéresse, c'est Ingres. Ce n'est pas Cézanne et les pommes.

Pourquoi ne vous êtes-vous pas servi de livres ou de revues?. Il ne manque pas d'éléments d'information de ce genre?

Il se fait que j'appréhende plus facilement les données conceptuelles ou autres par l'information que donne le produit spécifique (particulièrement le mien) que par le truchement de sa théorie. Je saisis moins facilement les choses et ce qu'elles impliquent par la lecture de livres, à ceci près que le livre est l'objet qui me fascine, car il est pour moi l'objet d'une interdiction. Ma toute première proposition artistique porte l'empreinte de ce maléfice. Le solde d'une édition de poèmes, par moi écrits, m'a servi de matériau pour une sculpture.

Un objet dans l'espace?

J'ai plâtré à moitié un paquet de cinquante exemplaires d'un recueil, le "Pense-Bête". Le papier d'emballage déchiré laisse voir, dans la partie supérieure de la "sculpture", les tranches des livres (la partie inférieure étant donc cachée par le plâtre). On ne peut, ici, lire le livre sans détruire l'aspect plastique. Ce geste concret renvoyait l'interdiction au spectateur, enfin je le croyais. Mais à ma surprise, la réaction de celui-ci fût tout autre que celle que j'imaginai. Quel qu'il fût, jusqu'à présent, il perçut l'objet ou comme une expression artistique ou comme une curiosité. "Tiens; des livres dans du plâtre!" Aucun n'eut la curiosité du texte, ignorant s'il s'agissait de l'enterrement d'une prose, d'une poésie, de tristesse ou de plaisir. Aucun ne s'est 
ému de l'interdit. Jusqu'à ce moment, je vivais pratiquement isolé du point de vue de la communication, mon public étant fictif. Soudain, il devint réel, à ce niveau où il est question d'espace et de conquête.

$Y$ a-t-il une différence entre les publics?

Aujourd'hui, le livre de poèmes sous des formes nouvelles a trouvé une certaine audience, ce qui n'empêche pas la différence de persister. Du premier public, le second ignore la visée. Si l'espace est bien l'élément fondamental de la construction artistique (forme de langage ou forme matérielle), je ne pourrais, apres cette singulière expérience, que l'opposer à la philosophie de ce qui est écrit avec un sens commun.

Que cache l'espace? N'est-ce pas un jeu comme celui du Loup es-tu là?

En effet, le loup dit chaque fois qu'il est ailleurs, et cependant il est là. Et l'on sait qu'il va se retourner et attraper quelqu'un. La recherche constante d'une définition de l'espace ne servirait qu'à cacher la structure essentielle de l' Art, un processus de réification. Chaque individu percevant une fonction de l'espace, et d'autant plus si elle est convaincante, se l'approprie mentalement ou économiquement.

Quelles sont vos idées politiques?

Dès que j'ai commencé à faire de l'art, le mien, celui que j'ai copié, l'exploitation des conséquences politiques de cette activité (dont la théorie ne peut être repérée qu'en dehors de son champ) m'est apparue ambiguë, suspecte, trop angélique. Si le produit artistique est chose de la chose, la théorie devient une propriété privée.

Avez-vous fait de l'art engagé?

Auparavant. Et c'était des poèmes, signes concrets d'engagement, car sans récompense. Mon travail consistait alors à en écrire le moins possible. Avec l'art plastique, je n'ai pu m'engager que chez mes adversaires. Les architectes sont dans la même situation, quand ils travaillent à leur compte. J'essaie autant qu'il m'est permis de circonscrire ce probleme en proposant peu et de l'indifférent. L'espace ne peut conduire qu'au paradis.

Il y aurait une différence entre l'art plastique et un engagement désintéressé?... [Silence]. À partir de quel moment fait-on de l'art indifférent?

À partir du moment où l'on est moins artiste, où la nécessité du faire ne plonge ses racines que dans le souvenir. Je crois que mes expositions ont dépendu, et dépendent encore des souvenirs de l'époque où j'assumais la situation créatrice sous une forme héroïque et solitaire. Autrement dit - Autrefois: Lisez, regardez - Aujourd'hui: Permettez-moi de vous présenter...

L'activité artistique - précisons: dans le contexte d'une circulation dans les galeries, les collections et les musées, c'est-à-dire quand les autres en prennent connaissance - serait le comble de l'inauthenticité?

L'on retrouve, peut-être, dans la tactique choisie pour engager la manoeuvre sur le terrain, une forme authentique de remise en question de l'art, de sa circulation, etc. Ce qui, indistinctement à tous les points de vue, justifie la continuité et l'expansion de la production. Reste, l'art comme production.

À cette roulette, comment sawvez-vous la mise?

Il y a encore un risque non moins intéressant, au 3è ou 4è degré. Et l'on n'est pas obligé de se brûler - C'est...162

16210000 francs de récompense au lecteur qui remplacera les points de suspension par une formule convenable. 


\section{La figure de l'Aigle}

Cette façon de prétendre embrasser des formes artistiques aussi éloignées les unes des autres qu'un objet peut l'être d'une toile traditionnelle ne fait-elle pas penser à la rencontre d'une macbine à coudre et d'un parapluie sur une table de vivisection?

Un peigne, une toile traditionnelle, une machine à coudre, un parapluie, une table peuvent prendre place au musée dans des sections différentes selon un classement. Nous voyons les sculptures dans un espace réservé, les peintures dans un autre, les porcelaines et les faïences..., les animaux empaillés... Chaque espace, à son tour compartimenté, peut être destiné à une section- les serpents, les insectes, les poissons, les oiseaux - susceptible d'être divisée en départements -les perroquets, les oiseaux-pêcheurs, les aigles.

Musée d'Art Moderne à Bruxelles, en 1968, avec des caisses d'emballage ayant servi au transport d'oenvres d'art et portant les inscriptions et marques des lieux de destination - c'était la section XIXè siècle inangurée par un discours du Dr. J. Cladders de Mönchengladbach?

Les pérégrinations et transformations de ce musée sont documentées dans différentes publications. L'étape de Düsseldorf en $1972{ }^{163}$ fait le point. La section des figures y regroupait des peintures, des sculptures et des objets en provenance de nombreux musées. Chaque pièce était accompagnée de la mention: Ceci n'est pas un objet d'art - qu'il s'agisse d'un vase de Sumer en provenance du Louvre ou d'un totem du British Museum ou d'une publicité découpée dans un journal (chaque pièce représentant l'aigle).

"Ceci n'est pas un objet d'art" est une formule obtenue par la contraction d'un concept de Duchamp et d'un concept antithétique de Magritte. Ce qui m'a servi à décorer l'urinoir de Duchamp de l'insigne de l'Aigle fumant la pipe. Je crois avoir souligné le principe d'autorité qui fait du symbole de l'Aigle le colonel de l'Art.

Ce musée continue à ne pas être un objet d'art, une pipe?

"Ceci n'est pas un objet d'art": la formule est une Figure 0. Chaque pièce de cette exposition de Düsseldorf est une Figure 1 ou une Figure 2. Chaque étape de ce musée entre dans ce système rudimentaire également. Reportons-nous à ce que nous avons décrit plus haut, la où une boîte en carton devient l'équivalent d'un masque, etc. Un miroir surmonté d'un aigle - antiquité de la fin du XVIIIème siècle - est en possession d'une association muséographique gantoise. Miroir officiel, si l'on peut dire, qui renvoie l'image virtuelle de ces aigles racontant par leurs têtes multiples l'Histoire des armes le point-de-vue de l'Art. Ce miroir est celui du contresens. Bien que surmonté par le messager de Jupiter, c'est un miroir aux alouettes.

De quel musée êtes-vous finalement le conservateur?

D'aucun, sauf si je pouvais définir rôle et contenu d'un musée dont le statut ne se lirait plus dans les aventures des Pieds-Nickelés de Forton ou dans cette image de Bosch décrivant comment l'on extirpait une pierre de la tête des gens souffrant de mélancolie.

(Aujourd'hui, l'outil scientifique a remplacé le marteau qui était aux mains des Paracelse du XVIè siècle).

Le Musée d'Art Moderne serait alors celui du sens. Il resterait alors à savoir si l'art existe ailleurs que sur un plan négatif.

${ }^{163}$ Avec l'appui de K. Ruhrberg et de J. Harten, et du bureau de la Kunsthalle. 


\section{Être bien pensant ou ne pas être. Être aveugle}

Marcel Broodthaers (1975). En MARCEL BROODTHAERS. París: Galerie Nationale du Jeu de Paume, ca. 1991: p. 268.

Qu'est-ce que l'Art? Depuis le xixè siècle, la question est sans cesse posée tant à l'artiste, qu'au directeur de Musée, qu'à l'amateur.

En fait, je ne crois pas qu'il soit légitime de définir l'Art et de considérer la question sérieusement, sinon au travers d'une constante, à savoir: la transformation de l'Art en marchandise. Ce processus s'accélère de nos jours au point qu'il y a superposition des valeurs artistiques et commerciales. S'il s'agit du phénomene de réification, l'Art serait une représentation singulière de ce phénomene, une forme de tautologie.

Il se justifierait alors comme affirmation et du même coup y puiserait une existence nouvelle.

Mais cette utilité de l'Art reste à prouver et la valeur d'une telle définition. En fait, il est certain que le commentaire sur l'Art suit le mouvement économique. Il nous paraît incertain que ce commentaire puisse être politique. Prisonnier de ses fantasmes et de son usage magique, l'Art orne nos murs bourgeois comme signe de puissance - il accompagne les péripéties de notre histoire comme un jeu d'ombres artistiques, l'on s'en doute. A tire tout ce qui s'écrit de byzantin sur le sujet, on pense au sexe des anges, à Rabelais et aux débats en Sorbonne.

Actuellement "Tel Quel" et les recherches linguistiques intempestives se confondent dans une même glose que ses auteurs voudraient critique. Art et littérature. . . des faces de la lune, laquelle est cachée? Que de nuages et d'images éphémères. .

Je n'ai rien, rien découvert, pas même l'Amérique. Je fais le choix de considérer l'Art comme un travail inutile, apolitique et peu moral. Une ignoble inspiration me poussant, je ne cacherai pas que si les torts sont de mon côté, j'en éprouverai une sorte de jouissance. Jouissance coupable puisqu'elle dépendrait des victimes - ceux qui out cru que j'avais raison.

Monsieur de La Palice est de mes clients. Il aime les nouveautés. Lui qui fait rire les autres prend prétexte de mon alphabet pour rire à son tour.

Mon alphabet est peint. Tout cela est obscur, les lecteurs sont invités à entrer dans cette nuit pour y lire une théorie ou éprouver des sentiments fraternels, ceux-là unissent les hommes et particulierement les aveugles.

MARCEL BROODTHAERS

$\cos$

\section{Notes sur le sujet}

Marcel Broodthaers (1975). " En MARCEL BROOdTHAERS. París: Galerie Nationale du Jeu de Paume, ca. 1991: p. 278.

J'aurais voulu que celle-ci soit plus fleurie ou sente au moins le délicieux parfum qui émane d'un ciel en cul de bouteille, mais c'est l'Angélus de Daumier, et je dois remplir mon devoir puisque je l'annonce dans la premiere partie de ce catalogue sous le titre de note. J'y parle d'un certain étonnement. Certes, devant le nombre de Titres qui couvre l'institution où j'ai installé mes valises et mes malles. Il n'y manque que de savoir que nous sommes, ici, a la fondation Salomon de Rotschild. Peu de choses, tout cela, sinon une nostalgie d'un emploi des définitions exactes du mot "juste". N'oubliez pas que je suis Belge de franche origine. Ou encore de l'étonnement que donne Paris à un étranger. Il y a deux ans au moins que je n'y ai plus séjoumé. Voici l'explication de celle exposition, qui précédera un commentaire fouillé a la façon d'une linguistique. La malle en osier, d'abord, figurant dans le hall de l'hôtel. Elle contient des messages à moi confiés par l'État d'un autre hémisphère. Ils sont cachés là selon les principes de la "Lettre Volée" et du 
"Manuscrit trouvé dans une Bouteille". Mais passons aux conclusions, la place, ici, pour une retranscription, fait défaut.

\section{Idées motivations}

Est-ce bien dans le rôle d'un artiste encore en activité de s'étendre au sujet de ses motivations? Voilà une source suspecte. Il vaut mieux certainement pour un futur menacé de laisser d'abord se tromper les critiques d'art. Toutefois encore un mot sur l'intention de cette exposition. Elle est la quatrième de ce genre, où j'ai tenté d'articuler différemment des objets et des tableaux réalisés à des dates s'échelonnant entre 1964 et cette année, pour former des salles dans un esprit "décor". C'est-à-dire de restituer à l'objet ou à la peinture une fonction réelle. Le décor n'étant pas une fin en soi.

\section{Art et politique}

La politique que j'entends défendre - en art - est faible, individuelle d'abord et soumise aux pressions et à l'influence d'un public spécialisé où figurent en bonne place les intermédiaires et les collectionneurs. Actuellement, les amateurs sont rares et font cruellement défaut. Si j'exagere l'importance de cette situation, que Daumier me fasse justice. De toute façon une liaison pratique/théorie en Art me parait "Futuriste" ou illusoire. Nous avec l'art sommes sur un terrain mouvant à comparer à celui de la mode ou de la monomanie, qu'il s'agisse de colle ou de surface.

Cependant, bien que faible, la nécessité d'une attitude politique est nécessaire, aujourd'hui. Je souhaite que le lecteur qu'ici enfin je salue, lise les quelques mots qui suivent, qui ont été mis à la disposition des visiteurs lors du vemissage le 2 octobre.

Selon le souhait de l'artiste, comme geste symbolique de solidarité avec les Démocrates Espagnols, le vernissage de l'exposition sera interrompu une demi-heure avant l'heure habituelle.

N.B.

1. Une exposition du type de celle-ci nécessite un concours d'aides de tour horizon, tant sur le plan des idées que sur celui du travail manuel. Je remercie tout un chacun.

2. Parmi les objets récents et inédits, figure la grande construc- tion en bois couverte de mots. Et une réunion de quelques toiles sur le theme de l'alphabet.

3. La différence entre projet et réalisation s'exprime, je crois, suffisamment par celle qui sépare les dates de parution des deux parties du catalogue.

MARCEL BROODTHAERS

$\operatorname{Cos}$

\section{C'est l'Angélus qui sonne}

Entretien de Stéphane Rona (1975). En HAKKENS, Anna. Marcel Broodthaers par lui-même. Amsterdam: Ludion / Flammarion, ca. 1998: p. 126 - 134.

Au moment de terminer ce numéro, nous apprenons la mort de Marcel Broodthaers. Avec lui disparait l'artiste beige le plus important depuis René Magritte. Il a poursuivi son idéal sans concession pendant toute sa vie. Pendant des années, trop longtemps, il ne fut écouté de personne. C'est beaucoup plus tard qu'il connut enfin une renommée internationale. Trop tard, parce que la maladie contractée déjà pendant le jeune âge, l'avait miné. Tous ceux qui l'ont approché dans ces dernières années, savent cambien il a lutté. Cambien sa vie était pleine de projets, combien nombreuses furent ses dernières réalisations. Nous sommes loin des jugements hâtifs. Il y a quelques semaines, nous avons recueilli cette dernière interview. Elle prend dans ces circonstances valeur de message. C'est Broodthaers lui-même qui avait choisi le titre de cet entretien. Nous ajoutons ce détail pour qu'en ces pénibles moments, il n'y ait pas de mauvaises 
interprétations. Nous laissons cette conversation dans l'état où nous avions l'intention de la publier, respectant ce que nous pensons être une des volontés de Broodthaers.

Dans le dernier numéro de +-0 ( $\left.\mathrm{n}^{\circ} 11\right)$, Otto Hahn nous accordait une interview où nous avions posé quelques questions sur Marcel Broodthaers en tant qu 'homme et artiste. Marcel

Broodthaers, n 'étant pas très heureux de certaines idées émises, a souhaité préciser son point de vue.

Curieuse rencontre que le nom que vous avez donné à votre derniere exposition à Paris: L'Angélus de Daumier?

A vrai dire, c'est un lapsus qui ne visait même pas Millet. C'est d'ailleurs une heureuse coïncidence qu'il y ait eu immédiatement après une grande exposition Millet. Ceci dit, je voudrais vous parler de l'article d'Otto Hahn que vous avez publié à l'occasion de cette récente exposition que j'ai faite au CNAC à Paris. (Ndlr: il s'agit en fait d'une interview d'Otto Hahn par Stéphane Rona). Tout d'abord, Otto Hahn ne représente pas tout Paris, il est une voix parmi d'autres. Pour une fois, j'ai beaucoup aimé un de ses articles parce que je regrette ceux qui me paraissent souvent marqués par une censure intérieure qui malheureusement n'est pas seulement l'apanage d'un critique cormme Otto Hahn mais de la plupart des gens qui s'occupent de journalisme. Il est très difficile à Paris d'échapper à cette regle. Je crois que personne ne le reconnaitra parce que la liberté d'expression est fort à la mode mais moi je n'y crois pas. Malgré cela, j'aime beaucoup l'article d'Otto Hahn. Je le connais depuis longtemps, j'étais plutôt déçu par ce qu'il écrivait sur moi; tandis que ceci, par le ton et le style des réponses, enfin voilà quelque chose qui prête à des divergences de point de vue. Il est certain que je ne suis pas d'accord d'être "paresseux» (parce queje ne sais pas sije suis paresseux d'ailleurs, cela se pourrait bien). Mais la question inverse peut se poser aussi: pourquoi un tel est-il travailleur. Il entre beaucoup de composantes dans ces définitions de la paresse et du travail. La paresse peut très souvent, cornrne l'alcoolisme d'ailleurs, être le signe d'une inadaptation à une société de plus en plus technologique. Je ne veux pas insister trop à ce sujet, ce ne serait pas l'objet d'un journal d'art comme le vôtre mais il est tout de même bon de rappeler ceci. J'en parle, parce que l'artiste paresseux et alcoolique a servi d'image il y a cinquante ans, particulièrement au temps de Montparnasse, c'était quelque chose de profondément admis. Ce ne l'est plus aujourd'hui! Ce qui est bizarre, cornrne si tous les artistes maintenant étaient des travailleurs et buvaient du quart remero De toutes façons, ce cliché ne corres- pondjamais qu'à des projections faites par une bourgeoisie qui achète de l'art et qui se fait une certaine image de l'artiste. L'artiste quant à lui, je ne dis pas qu'il s'en lave les mains, il regarde. Que voulez-vous? Actuellement, je dirais qu'il fait plus que regarder. Dans le cas de l'avant-garde, il participe plus étroitement qu'auparavant dans la structure commerciale et au marketing de l'art. En tous cas, j'ai beaucoup aimé son article parce queje sais pertinernrnent bien qu'il n'apprécie pas particulièrement ce genre de démarche qui certainement pour Otto Hahn se trouve trop à la limite d'une certaine littérature et des arts plastiques. Il préfère des oeuvres plus tranchées, plus définies.

$C^{\prime} e s t$ donc de la morale, il faut gagner son pain à la sueur de son front. Ne peut-on imaginer une équivalence ouvrier-artiste?

Non, je ne crois pas que nous pouvons l'entendre sur ce plan-là. Le rapport est peut-être celui-ci. L'artiste cornme l'ouvrier est simplement producteur, mais de toute façon, même s'il est dans la dèche, l'artiste sait très bien ce qu'il vise et quand il devient producteur reconnu, il s'agit d'un ouvrier de grand luxe. Un artiste vit d'une manière autrement large qu'un ouvrier de n'importe quel pays, non?

L'alcoolisme et la paresse, n'est-ce-pas une affaire privée?

Ce comportement n'est pas privé parce que tout ce que fait l'artiste est chuchoté dans les coins. Il est de toute façon quelqu'un dont le rôle est de prêter à la fabrication d'un mythe. Avec la paresse, l'alcoolisme ou avec le jêune, l'eau minérale, il s'agit d'une inadap- tation au départ. L'adaptation se faisant en général par l'argent. A propos de cette adaptation, il y a une sorte d'alcoolisme moderne, la drogue, c'est exactement la même chose. On utilise maintenant 
d'autres machins qui conduisent l'artiste encore à des accidents plus pénibles que l'alcoolisme de naguère. Être inadapté socialement signifie qu'on est dans un état second et à côté de la question du réel. C'est une contradiction parce que tout hornme tend vers la norme et pour y arriver, parfois, il est bien obligé de laisser derrière lui, là, quelques poèmes, là, quelques oeuvres d'art. Du moins tant que les choses sont pures. Par pures, j'entends, cette période très noire où personne ne vous connait, où tout le monde vous met à la porte. Mais ça ne fait néanmoins pas le tour de cette question qui est assez importante à mon sens. Elle concerne non seulement l'art, les écrivains, mais finalement tous ceux qui ne s'inscrivent pas dans cette direction qu'est la technologie. Cela devient de moins en moins marrant de vivre ainsi; on a besoin de plus en plus d'exister par l'imagination d'une certaine culture suffisante. Sinon, on est coincé par la TV, les jounaux, le blue movies, par tout ce qu'il y a de mécanique et qui finit par transformer l'homme en robot. On n'échappe que très difficilement. C'est maintenant que beaucoup commenceront à sentir les difficultés d'adaptation à la société. Ou bien, ils prendront le parti, c'est le cas de la plupart, de se résigner tandis que d'autres se croiront obligé de manifester d'une manière où d'une autre. Quant à la paresse, c'est que je ne comprends pas le travail. Quand j'étais jeune mon père m'obligeait à faire des tas de choses pour les quellesje n'étais pas motivé et queje ne comprenais d'ailleurs pas. Finalement j'ai donc eu des difficultés. C'est le cas de tous ceux qui ont des ennuis avec leur travail, de n 'importe quel bord soient-ils. Cela entraîne des perturbations importantes, c'est valable aussi bien pour l'homme qui regarde le plafond que pour celui qui est devant une machine et dont il ne voit pas la finalité. Les gens sont bien obligés de gagner leur vie. Moi, à mon corps défendant, je m'arrangeais plus ou moins en emmerdant mon père, soit en emmerdant l'un ou l'autre. J'ai fait par ailleurs quelques expériences de travail tout a fait social dans la classe ouvriere même, très peu, au total, huit à neuf mois. Je sais ce que cela représente et que cela mutile quelqu'un. Et aujourd'hui, c'est toujours pareil. Il faudrait aller poursuivre l'enquête chez les vendeuses de magasin qui subissent Musik by Muzak pendant sept heures de suite et qui finissent même par aimer cela.

\section{Pourrait-on imaginer le travail sans le réaliser vraiment?}

Vous me faites penser aux moines enfermés entre leurs quatre murs. IIs ne causent de dommage personne. IIs cultivent eux-mêmes leurs champs... Mais s'il ne fallait rien faire ce serait un peu emmerdant, ces espèces de vacances perpétuelles, en robe de bufe ou bien à cheval toute la joumée, être flâneur... Je ne dis pas que je détesterais personellement, je ne dis pas d'être moine, mais d'être flâneur; mais quand il y a quelque part quelque désir de pure vanité d'inscrire son nom soit celui vraiment de dire quelque chose aux autres hommes, il est très difficile de départager les deux choses. Je suppose que la vie du moine est plus nette que celle du flâneur. Il y a la un retranchement volontaire qui disparait beaucoup aujourd'hui.

On dirait que pour vous le critique ne peut que se tramper.

Bien sûr, son role est devenu comme celui de l'artiste d'ailleurs, extremement réduit par le marketing, la puissance de groupes formés non plus par des artistes mais par des gens auxquels certains collectionneurs sont liés. Le role du critique s'est amenuisé beaucoup plus encore que celui de l'artiste. Celui-ci a toujours la réserve de sortir une carte qui va déranger le jeu. Le critique n'a ras cette possibilité parce que le joumalle met tout de suite a la porte. Ah, s'il échappe a tout cela, alors c'est très différent, la critique de l'art se développe et déborde rapidement sur d'autres terrains sur son mode de lecture par exemple. Je pense à Walter Benjarnin, magnifique critique d'art allemand qui est mort en 1940 quand il s'est fait coincer sur les Pyrénées entre les Espagnols et les Français. Il s'est suicidé la, j'en parle ainsi longuement parce queje crois que dans cette ancienne zone française personne ne connait son nom. A ma connaissance, il n'existe pratiquement ras de traduction de ses textes. Mais il a écrit tant de choses sur l'art de série, sur la naissance du cinéma, sur le futurisme. Il y a là un modele de critique d'art très important qui n'a jamais servi. Ensuite je pense à Georg Lukács. Je suis occupé à le lire, à l'apprendre. J'ai nettement le sentiment qu'il touche très souvent le point 
avec justesse. J'ai d'ailleurs travaillé avec un de ses disciples, Goldman, lors d'un séminaire où j'ai dû participer non sans intérêt parfois pour les autres.

Revenons si vous le voulez, bien a vos expositions.

D'une maniere générale,je tiens compte du lieu géographique où je me trouve. A Paris c'était une fondation, la fondation Salomon de Rothschild. J'ai fait récemment une exposition à Londres qui donnait sur le Mall au moment du Trooping the Colour. Mon exposition était teintée de la situation et de certaines habitudes anglaises. Je ne pense pas qu'il faille y voir autre chose. Mainte- nant je dis bien tout cela, mais je me rends compte aussi combien beaucoup m'échappe. Comme définition de l'art,j'ai beaucoup apprécié celle d'une amie scientifique: l'art et la science, ça ne se mélange pas. Pour moi, l'art est un caprice. Ce qui n'empêche - pas évidemment de pouvoir faire une lecture scientifique de l'art. Je ne sais pas pourquoi on fait tant d'histoires. Etait-il vraiment dans les intentions de Balzac de décrire sa société. Ce n'est pas certain, il fallait allonger les pages, il y avait les dettes, il fallait les payer. Tout cela reste très fragile. C'est précisément ce que je n'aime pas dans cette rigueur d'aujourd'hui, que d'aucuns professent dans l'art d'avant-garde. A moins que ce besoin de fausse rigueur corresponde de nouveau à une expression du temps. On y retrouverait assez bien de technologie, assez bien de choses qui ressemblent à des autoroutes. C'est pour cela que je me gens assez isolé pour ce qui est des contacts que j'ai actuellement avec les artistes.

Je cite une partie de votre catalogue: "J'aurais voulu que celle-ci soit Plus fleurie on sente au moins le délicieux parfum qui s'émane d'un ciel en cul de bouteille. Mais c'est L'Angélus de Daumier, et je dais remplir mon devoir puisque je l'annonce dans la premiere partie de ce catalogue.». Au moment du montage d'une exposition, est-ce vous qui changez ou bien les circonstances?

Les deux, les circonstances et moi-même. C'est pourquoi le catalogue a été prévu en deux parties, un projet et puis une se conde partie reflétant au mieux la réalité. Par exemple, il s'agissait d'abord de faire une reconstitution du premier musée que j'avais fabriqué à Bruxelles. En cours de réalisation, j'ai arreté tout cela et je me suis servi d'une partie du matériel et j'en ai changé le contexte. A la place du musée, c'est devenu un rezde-chaussée parfaitement petitbourgeois où flottent les mots. D'ailleurs pour l'instant,je suis très opposé à l'esprit de reconstitution. Je crois que je n'en ferai pas ou en tout cas, je n'en signerai aucun. Je me suis efforcé en faisant les cinq rétrospectives de cette année, d'articuler les pieces dans des sens différents, ici, dans la derniere exposition parisienne, l'intention étant le décor, non pas tellement en relation avec le lieu mais avec la restitution de l'objet considéré en soi comme oeuvre d'art, comme objet décoratif, c'est-à-dire le décor non pas cornme une fin en soi, mais devant me servir soit à une pièce de théâtre soit a un fil. Dans cet esprit-là, j'ai réalisé trois films parfaitement adaptés du point de vue des idées.

L'Angélus de Daumier est un lapsus. Que pensez-vous de ceux qui essaient de justifier ce titre?

Ils ne savent pas que c'est un lapsus, alors ils cherchent. Il est arrivé au cours de cette exposition, que des gens viennent demander où est cette exposition de Daumier; où est L'Angélus de Millet. Certains se fâchaient. Il y en a qui le prenaient très bien et que toutes ces choses qu'ils n'avaient jamais vues mettaient de bonne humeur. Il y eut cette surprise, un groupe de vieilles clames habitant le quartier qui venaient pour $L^{\prime}$ Angélus et qui au lieu de cela ont découvert pour la première fois le salon de feu la baronne de Rothschild. Elles étaient toutes a leur affaire. Elles ont continué à regarder le reste tout à fait ravies de leur après-midi.

Vous avez ajouté une note politique à cette exposition.

Si faible que soit ma voix et dans le domaine intérieur de l'art, je tiens à manifester une option sous la pression des événements. Cette note gui date du 20 octobre 1975, jour du vernissage, fut écrite lors de la joumée de protestation en faveur des fusillés espagnols. Individuellement, j'ai pris la décision d'écrire une note selon laquelle je me solidarisais avec les démocrates espagnols. Sinon en général, j'aurais évité le sujet politique. Il se serait peut- être trouvé là mais sousjacent, pas de manière nette. Avant de terminer, je souhaite faire encore la mise au point suivante. Dans l'interview donnée par Otto Hahn se trouve une interprétation d'un conflit 
m'ayant opposé aux cornmissaires de l'exposition. Ce n'est pas moi qui l'ai dit. Ma position est celle-ci et correspond d'ailleurs certainement à la plus grande part de vérité. Je suis capricieux et les derniers dix jours, j'ai désiré travailler absolument seul. Je m'en tiens là et je ne désire pas polémiquer à ce sujet. 
REFERENCIES BIBLOGRÀFIQUES 


\section{Textos de Marcel Broodthaers. Referències comentades}

BROODTHAERS, Marcel (1948). "Projet pour un film". En MARCEL BROODTHAERS. CINÉMA. Bar.: Fundació Antoni Tàpies, 1997: p. 17. [Le Surréalisme revolutionnaire, març - abril, 1948, núm. 1: p. 4]

- $\quad$ (1954a). "Adieu, Police". En MARCEL BROODTHAERS. Ma.: MNCARS, 1992: p. 36. [Signat: Château d'If. Phantomas (Brussel·les) abril, 1954, núm. 2: p. 15]

- (1954b). "Le Roi Midi". En MARCEL BROODTHAERS. Ma.: MNCARS, 1992: p. 36. [Signat: Château d'Af. Phantomas, set., 1954, núm. 3: p. 6]

- $\quad$ (1957a). "La Clef de l'Horloge" En MARCEL BROOdTHAERS. CINÉMA. Bar.: Fundació Antoni Tàpies, 1997: p. 22 (p. 314 trad. cast.). [Parlament en la banda sonora de la pel.l. La Clef de l'Horloge]

- $\quad$ (1957b). "Les confesions du siècle". En MARCEL BROODTHAERS. L'ARCHITECTE EST ABSENT. LE MAÇON. Imschoot; Uitgevers: Foundation pour l'architecture, 1991: p. 113 (facs.) [Le Patriote illustrée, (Brussel les) 15 des., 1957, núm. 50: p. 1989 - 1991]

- (1958a). "Un autre monde". En MARCEL BROODTHAERS. L'ARCHITECTE EST ABSENT. LE MAÇON. Imschoot; Uitgevers: Foundation pour l'architecture, 1991: p. 111 (facs.) [Le Patriote illustrée, 9 març, 1958, vol. 74, núm. 10: p. 389.]

- (1958b). "Ma mémoire est un film en couleur...". En MARCEL BROOdTHAERS. CINÉMA. Bar.: Fundació Antoni Tàpies, 1997: p. 26-27 (p. 315 trad. cast.). [Text poètic]

- (1959). "Le Chant de ma Génération. Montage d'Actualités. Période 40 - 45 a 59". En MARCEL BROODTHAERS. CINÉMA. Bar.: Fundació Antoni Tàpies, 1997: p. 29 (p. 315 trad. cast.). [Facs.]

- (1960). "Enquête au pays du rêve". En MARCEL BROOdTHAERS. CINÉMA. Bar.: Fundació Antoni Tàpies, 1997: p. 30 - 33 (p. 315 - 316 trad. cast.). [Text poètic]

- $\quad$ (1961a). "Un poète en voyage... à Londres". En MARCEL BROODTHAERS. Ma.: MNCARS, 1992: p. 44. [Facs.. Journal des Beaux-Arts, (Brussel·les) 3 abril, 1961, núm. 941: p. 10]

- $\quad$ (1961b). "Un poète en voyage... à Londres". En MARCEL BROODTHAERS. Ma.: Ministerio de Cultura, MNCARS, 1992: p. 47. [Facs.. Journal des Beaux-Arts, 23 juny, 1961, núm. 942: p. 11]

- $\quad$ (1962). "Le mur de Fernand Lerin". En MARCEL BROODTHAERS. L'ARCHITECTE EST ABSENT. LE MAÇON. Imschoot, Uitgevers: Foundation pour l'architecture, 1991: p. 91 (facs.) [Journal des Beaux-Arts, 20 abril, 1962, núm. 974: p. 8]

- (1963a). "Un tombeau". En MARCEL BROOdthaERS. L'ARCHITECTE EST ABSENT. LE MAÇON. Imschoot, Uitgevers: Foundation pour l'architecture, 1991: p. 11 (facs.). [Architecture, 1963, núm. 52: p. 175]

- $\quad$ (1963b). "En pleine ville Un prisonnier de la tour veille sur la pollution de l'air". En MARCEL BROODTHAERS. L'ARCHITECTE EST ABSENT. LE MAÇON. Imschoot, Uitgevers: Foundation pour l'architecture, 1991: p. 116 - 117. [Le Magazine du Temps Présent, (París) 5 maig, 1963]

- (1963c). "Gare au Défi! Le Pop Art, Jim Dine et l'influence de René Magritte". En MARCEL BROODTHAERS. Ma.: MNCARS, 1992: p. $52-53$ (facs.). [Journal des Beaux-Arts, 14 nov., 1963, núm. 1029: p. 9]

- $\quad$ (1964a). "Moi aussi, je me suis demandé si je ne pouvais pas vendre quelque chose...". En MARCEL BROODTHAERS. Ma.: MNCARS, 1992: p. 56. [targeta d'invitació de l'exposició "Moi aussi, je me suis demandé...". Galeria Saint-Laurent, Brussel|les: 10-25 abril, 1964] 
- (1964b). "XVle siècle. Navires et gravures...". En MARCEL BROODTHAERS. CINÉMA. Bar.: Fundació Antoni Tàpies, 1997: p. 35 - 40 (p. 317 - 318 trad. cast.). [Parlament en la banda sonora de la pel.l. Bruegel et Goya, journalistes]

- (1964c). "Bruegel et Goya, journalistes". En MARCEL BROODTHAERS. CINÉMA. Bar.: Fundació Antoni Tàpies, 1997: p. 34 (p. 316 - 317 trad. cast.). [Text per al comunicat de premsa]

- (1965a). "À la galerie Aujourd'hui. Marcel Broodthaers par Marcel Broodthaers". En MARCEL BROODTHAERS. Ma.: MNCARS, 1992: p. 70 (facs.). [.Journal des Beaux-Arts, 1 abril, 1965, núm. 1086: p. 5]

- $\quad$ (1965b). "¿Pop Art? Preguntádselo a Jean Dypréau...". En MARCEL BROODTHAERS. Ma.: MNCARS, 1992: p. 69. [Text imprés en la targeta d'invitació de l'exposició "Objets de Broodthaers I Voorwerpen van Broodthaers". Galeria Aujourd-hui, Palau de Belles Arts, Brussel·les: 2-24 abril, 1965]

- $\quad$ (1965c). "Evolution ou I'Oeuf film". En MARCEL BROOdTHAERS. CINÉMA. Bar.: Fundació Antoni Tàpies, 1997: p. 43 (p. 318 - 319 trad. cast.). [Phantomas, des., 1965, núm. 51-61: p. 111 - 113]

- $\quad$ (1965d). "Como la mantequilla en un sandwich". En Marcel Broodthaers. Ma.: MNCARS, 1992: p. 71 72. [Phantomas, des. 1965, núm.51-61: p. 295 - 297]

- (ca. 1965). "L'Oeuf film". En MARCEL BROODTHAERS. CINÉMA. Bar.: Fundació Antoni Tàpies, 1997: p. 42 (p. 318 trad. cast.). [Text poètic]

- (1967). "Intervieuw imaginaire de René Magritte". En MARCEL BROODTHAERS. Ma.: MNCARS, 1992: p. 104-105 (facs.). [Journal des Arts Plastiques, gener, 1967, núm. 30]

- (1967) "J'attends ton coup de fil, Marcel!". En HAKKENS, Anna. Marcel Broodthaers par lui-même. Amsterdam: Ludion / Flammarion, ca. 1998: p. 54 - 57. [Originalment en BROODTHAERS, Marcel. Marcel Broodt(h)aers. Court-Circuit. Brussel-les: Palau de Belles Arts, 1967]

- (ca. 1967a). "Expérimental en ce sens...". En MARCEL BROODTHAERS. CINÉMA. Bar.: Fundació Antoni Tàpies, 1997: p. 54 (p. 319 trad. cast.). [Comentari poètic a propòsit de la pel·. Le corbeau el le renard]

- $\quad$ (ca. 1967b). "Le D est plus grand que le T". En MARCEL BROODTHAERS. CINÉMA. Bar.: Fundació Antoni Tàpies, 1997: p. 58 (p. 319 trad. cast.). [Comentari a propòsit de la pel·l. Le corbeau el le renard]

- (1967-68). "Le corbeau et le renard. Le corbeau sonne...". En Marcel Broodthaers. L'Architecte est absent. Le Maçon. Imschoot; Uitgevers: Foundation pour l'architecture, 1991: p. 68. [tipografia impresa i pintada sobre tela i fusta: $56 \times 75 \mathrm{~cm}$. Coll. particular]

- $\quad$ (1968a). "Le Cinéma Expérimental et les fabules de La Fontaine. La raison du plus fort". En MARCEL BROODTHAERS. CINÉMA. Bar.: Fundació Antoni Tàpies, 1997: p. 60 - 61 [Fragment] (p. 320 - 321 trad. cast.).

- $\quad$ (1968b). "Primero escenifiqué los objetos de la realidad cotidiana...". En MARCEL BROODTHAERS. Ma.: MNCARS, 1992: p. 133. [Carta dirigida a l'ed. de la revista Art International i als dir. de la Lignano Biennale I. Arreplegada darrerament com una carta oberta datada el 27 d'agost del 1968]

- $\quad$ (1968c). "Carta d'invitació per al tancament de la Section XIXe siècle i la inauguració de la Section XVIII siècle". En MARCEL BROODTHAERS. Ma.: MNCARS, 1992: p. 200. [s. ref.]

- (ca. 1968a). "Imatges en noir et blanc et en couleurs ou Le corbeau et le renard". En MARCEL BROODTHAERS. CINÉMA. Bar.: Fundació Antoni Tàpies, 1997: p. 67 (p. 321 trad. cast.). [Breu reflexió sobre la pel.l.]

- (ca. 1968b). "C'est le procédé qui m'interesa...". En MARCEL BROOdTHAERS. CINÉMA. Bar.: Fundació Antoni Tàpies, 1997: p. 66 (p. 321 trad. cast.). [Reflexions sobre la pel·. Le corbeau el le renard]

- (ca. 1968c). "En principe le film est divisé en 4 parties...". En MARCEL BROODTHAERS. CINÉMA. Bar.: Fundació Antoni Tàpies, 1997: p. 73 (p. 322 trad. cast.). [Text utilitzat per a l'escriptura en negatiu que apareix en la pel.l. Une discussion inaugurale]

- $\quad$ (1969a). "Défense absolute de toucher aux objets / Streng verboden de woorwerpen aan te raken". En MARCEL BROODTHAERS. L'ARCHITECTE EST ABSENT. LE MAÇON. Imschoot; Uitgevers: Foundation pour l'architecture, 1991: p. 30 [rètol manuscrit sobre cartó. Fotografia de GILISSEN, Maria] 
- $\quad$ (1969b). "Il est strictement interdit de ciculer sur les travaux / Streng verboden op de Werken te Gaan". En MARCEL BROODTHAERS. L'ARCHITECTE EST ABSENT. LE MAÇON. Imschoot; Uitgevers: Foundation pour l'architecture, 1991: p. 30 [rètol manuscrit sobre cartó. Fotografia de GILISSEN, Maria]

- (ca. 1969a). "Projet pour un texte". En MARCEL BROOdTHAers. CINÉMA. Bar.: Fundació Antoni Tàpies, 1997, p. 91(p. 322 trad. cast.).

- $\quad$ (ca. 1969b). "En Juillet 1969 Le Département des Aigles du Musée d'Art Moderne a fait un voyage itinéraire à Waterloo...". En MARCEL BROODTHAERS. CINÉMA. Bar.: Fundació Antoni Tàpies, 1997, p. 82 (p. 322 trad. cast.). [Fragment d'una carta oberta a Jacques Charlier]

- $\quad$ (ca. 1969c). "This wouldn't be a pipe". En MARCEL BROODTHAERS. CINÉMA. Bar.: Fundació Antoni Tàpies, 1997: p. 96 (p. 322 trad. cast.). [Text poètic]

- (ca. 1969d). "Mallarmé es la fuente del arte contemporaneo...". En MARCEL BROODTHAERS. Ma.: Ministerio de Cultura, MNCARS, 1992: p. 139. [Text d'un manuscrit presentat en l'exposició "MTL 13/3/70 - 10/4/70". Galeria MTL, Brussel·les: 1970. L'original en fr. citat per RoRIMER, A. "The exhibition at the MTL Galery in Brussels". En BUCHLOH, B. (ed.). Broodthaers. Writings, Interviews, Photographs. Cambridge; Massachusetts; Londres: The MIT Press, 1988: p. 110-111.

- $\quad$ (1970a). "Musée d'Art Moderne. Section Litteraire. Département des Aigles. Preface". En MARCEL BROODTHAERS. CINÉMA. Bar.: Fundació Antoni Tàpies, 1997, p. 105. [Facs. d'una transcripció del text del poema Un coup de dés... de Mallarmé i manuscrits del projecte d'edició exposades en l'exposició "MTL. 13/3/70 - 10/4/70". Galeria MTL, Brussel-les: 1970]

- $\quad$ (1970b). "Lecture du catalogue MTL...". En MARCEL BROODTHAERS. CINÉMA. Bar.: Fundació Antoni Tàpies, 1997: p. 110 - 111(p. $322-325$ trad. cast.). [Transcripció textual d'un enregistrament de la lectura del catàleg de la exposició "MTL 13/3/70 - 10/4/70" com si fora una entrevista de Broodthaers a sí mateix]

- (ca. 1970a). "1 seconde pour Narcisse...". En MARCEL BROODTHAERS. CINÉMA. Bar.: Fundació Antoni Tàpies, 1997: p.126 i (p.325 trad. cast.). [Poema i comentari]

- (ca. 1970b). "24 Images, film d'une seconde, a un double sujet..." En MARCEL BROODTHAERS. CINÉMA. Bar.: Fundació Antoni Tàpies, 1997: p.127 (p.325 trad. cast.). [Comentari i poema]

- $\quad$ (1971a). "Section Financière, Musée d'Art Moderne à vendre 1970 - 1971 pour causa de faillite". En MARCEL BROODTHAERS. CINÉMA. Bar.: Fundació Antoni Tàpies, 1997: p. 194. [Sobrecoberta del catàleg de la Fira d'Art de Colònia. Colònia: Galerie Michael Werner, 1971]

- $\quad$ (1971b). "La Clef de l'Horloge: K. Schwitters". En MARCEL BROODTHAERS. CINÉMA. Bar.: Fundació Antoni Tàpies, 1997: p. 24 (p. 314 trad. cast.). [Fragment d'un manuscrit]

- (1971c). "La Clef de l'Horloge: poème cinématographique en l'honneur de Kurt Schwitters". En MARCEl BROOdTHAERS, CINÉMA. Bar.: Fundació Antoni Tàpies, 1997: p. 24 (p. 314 trad. cast.). [Manuscrit que fa ref. a l'exposició de Schwitters en el Palau de Belles Arts de Brussel.les]

- $\quad$ (1971d). "La Figure 0". En MARCEL BROODTHAERS. CINÉMA. Bar.: Fundació Antoni Tàpies, 1997: p. 25 (p. 314 - 315 trad. cast.). [Text publicat originalment en alemany "Die Null-Figur". En Kurt Schwitters. Düseldorf: Städtische Kunsthale; Berlín: Akademie der Künste; Stuttgart: Staatsgalerie; Bâle: Kunsthale, 1971: p. 15]

- $\quad$ (1971e). "Proyecto para una isla desierta sobre el Rin: Isla del Museo". En MARCEL BROODTHAERS. Ma.: MNCARS, 1992: p. 158-159. [Dos dibuixos, dos muntatges fotogràfics i un text manuscrit "Projet pour un musée sur une île déserte, Île du Musée"]

- $\quad$ (ca. 1971a). "2 types de projections...". En MARCEL BROODTHAERS. CINÉMA. Bar.: Fundació Antoni Tàpies, 1997: p.192 (p. 328 trad. cast.). [Comentari sobre l'exposició "Film als Objekt - Objekt als Film"]

- (ca. 1971b). "Concernant la vente d'un kilog d'or fin en lingot". En MARCEL BROODTHAERS. Ma.: MNCARS, 1992, p. 213. [Edició pòstuma segon el projecte del Musée d'Art Moderne, Section Financière, Département des Aigles. Düseldorf: Galeria Konrad Fischer, 1987]

- (ca. 1971c). "Interview (mots màgiques, mots sans espérance)". En Marcel Broodthaers. Ma.: MNCARS, 1992: p. 213. [Edició pòstuma segon el projecte del Musée d'Art Moderne, Section Financière, Département des Aigles. Düseldorf: Galeria Konrad Fischer, 1987] 
- $\quad$ (1972a). "Presentació de la Section des Figures". En MARCEL BROODTHAERS. Ma.: MNCARS, 1992: p. 215. [Originalment en BROODTHAERS, Marcel. Section des Figures (Der Adler vom Oligozän bis heute). Düseldorf: Städtische Kunsthalle, 1972: vol. I, p. 4 (al..)]

- (1972b). "Méthode". En MARCEL BROODTHAERS. Pa.: Galerie Nationale du Jeu de Paume, ca. 1991: p. 217. [Originalment "Methode". En BROODTHAERS, Marcel. Section des Figures (Der Adler vom Oligozän bis heute). Düseldorf: Städtische Kunsthalle, 1972, vol. I, p. 13 (al.)]

- (1972c). "Aigle. Idéologie. Public". En MARCEL BROODTHAERS. Pa.: Galerie Nationale du Jeu de Paume, ca. 1991: p. 217. [Originalment "Adler - Ideologie - Publikum". En BROODTHAERS, Marcel. Section des Figures (Der Adler vom Oligozän bis heute). Düseldorf: Städtische Kunsthalle, 1972: vol. I, p. 16 (al.)]

- $\quad$ (1972d). "Musée d'Art Moderne. Section des Figures". En MARCEL BROODTHAERS. Pa.: Galerie Nationale du Jeu de Paume, ca. 1991: p. 218. [Originalment "Musée d'Art Moderne. Section des Figures". En BROODTHAERS, Marcel. Section des Figures (Der Adler vom Oligozän bis heute). Düseldorf: Städtische Kunsthalle, 1972: vol. II, p. 4 (al.). Presentació del segon volum del catàleg de l'exposició]

- $\quad$ (1972e). "Section des Figures". En MarCel BROOdThaeRs. Pa.: Galerie Nationale du Jeu de Paume, ca. 1991: p. 220 - 221. [Originalment "Section des Figures". En BROODTHAERS, Marcel. Section des Figures (Der Adler vom Oligozän bis heute). Düseldorf: Städtische Kunsthalle, 1972, vol. II, p. 18-19]

- $\quad$ (1972g). "In der Empfangshalle der Neuen Galerie...". En MARCEL BROODTHAERS. Ma.: MNCARS, 1992: p. 224. [Originalment en DOCUMENTA 5. BEFRAGUNG DER REALITÄT - BILDWELTEN HEUTE. Kassel, 1972 (s. p.). Pàgina corresponen al Musée d'Art Moderne en el catàleg de Documenta V]

- (1972h). "Le Musée d'Art Moderne Département des Aigles est tout simplement un mesonge...". En MARCEL BROODTHAERS. Pa.: Galerie Nationale du Jeu de Paume, ca. 1991: p. 229. [Conclusions del Musée d'Art Moderne Département des Aigles. Text reunit per J. Cladders a partir d'una entrevista realitzada el 28 de gener de 1972 (fr., an. i al.) que, en principi, havia de ser part del catàleg de Documenta 5, però sols se'n van incloure com a fulls annexos]

- $\quad$ (1972j). "Mon cher Beuys, Düsseldorf, le 25 set. 72". En MARCEL BROODTHAERS. Ma.: MNCARS, 1992: p. 178. [Carta oberta. En BroOdTHAERS, Marcel. Magie. Art et Politique. Pa.: Multiplicata, 1973: p. 5]

- (1972k). "Politik der Magie?". En MarCel BROOdTHAERS. Ma.: MNCARS, 1992: p. 178-179. [Facs. de l'article publicat en Rheinische Post; Düseldorf: 3 d'oct. del 1972. En BROODTHAERS, Marcel. Magie. Art et Politique. Pa.: Multiplicata, 1973: p. 14]

- (1972/). "Il parle. Le sujet. La conquête de l'espace". En MARCEL BROOdTHAERS. CINÉMA. Bar.: Fundació Antoni Tàpies, 1997: p. 93. [Facs. del text publicat en l'exposició "Actualité d'un bilan". Galeria Yvon Lambert, Pa.: oct. 29 - des. 5, 1972: p. 37]

- $\quad(1972 m)$. "Musée - Museum. Où est l'original? Wo ist das Original?". En MARCEL BROODTHAERS. L'ARCHITECTE EST ABSENT. LE MAÇON. Imschoot; Uitgevers: Foundation pour l'architecture, 1991: $p$. 36. [Mönchengladbach, Museumsverein, 1972. Text en fr. i en alemany imprés en el revers del pla de la Section XIX siècle del Musée d'Art Moderne que també incloïa targetes postals de reproduccions de pintures i de dibuixos d'Ingres i de Courbet]

- (1973a). "Ce musée est un musée fictif... ". En MARCEL BROODTHAERS. Pa.: Galerie Nationale du Jeu de Paume, ca. 1991: p. 227. [Originalment "Museum für moderne Kunst - Abteilung die Adler". Heute Kunst. №1, (Milà), abril, 1973: p. 20 - 23. En al. excepte els fragments entre corxets que van ser publicats en fr. en el comunicat de premsa de Documenta $V$.]

- $\quad$ (1973b). "Projet pour le contrat d'achat". En MARCEL BROODTHAERS. Pa.: Galerie Nationale du Jeu de Paume, ca. 1991: p. 231. [Originalment "Projekt für den Kaufvertrag". Heute Kunst. N01, (Milà), abril, 1973: p. 20 - 23]

- (1973c). "Le degré zéro". En MARCEl BROOdTHAERs. Pa.: Galerie Nationale du Jeu de Paume, ca. 1991: p. 231.[ Originalment "Der Nullpunkt". Heute Kunst. №1, (Milà), abril, 1973: p. 20 - 23] 
- $\quad$ (1973d). "Être Narcise... Être Artiste". En MARCEL BROODTHAERS. Ma.: MNCARS, 1992: p. 179. [Fasc. originalment en BROODTHAERS, Marcel. Magie. Art et Politique. Pa.: Multiplicata, 1973: p. 18]

- $\quad$ (1974a). "Comentari sobre Un film de Charles Baudelaire i sobre Jardin d'hiver". En MARCEL BROODTHAERS. CINÉMA. Bar.: Fundació Antoni Tàpies, 1997: p.121 (facs.). [Fragment d'una declaració de Broodthaers a Ciné culture, (Brussel·les) febrer, 1974, núm. 105]

- (1974b). "Musée Wiertz". En MARCEL BROODTHAERS. L'ARCHITECTE EST ABSENT. Le MAÇON. Imschoot, Uitgevers: Foundation pour l'architecture, 1991: p. 92. [Originalment en Studio International, oct., 1974, vol. 188, núm. 970: p. 114]

- (1975a). "Être bien pensant ou ne pas être. Être aveugle". En MARCEL BROODTHAERS. Pa.: Galerie Nationale du Jeu de Paume, ca. 1991: p. 268. [Originalment "To be a straight thinker or not to be. To be blind". En BROODTHAERS, Marcel. Le privilège de l'Art. Oxford: Museum of Modern Art, abril 26 - juny 1, 1975: n. p. (trad. del fr.)]

- $\quad$ (1975b). "Notes sur le sujet" En MARCEl BROOdTHAERS. Pa.: Galerie Nationale du Jeu de Paume, ca. 1991: p. 278. [Originalment en BROODTHAERS, Marcel. L'Angelus de Daumier. Pa.: Centre National d'Art Contemporain, oct. 2 - nov. 10, 1975; vol. II, p. 3]

\section{Entrevistes}

ADÉ, George (1972) "Entrevista amb Marcel Broodthaers". En BUCHLOW, Benjamin i GILISSEN, Maria (ed.) Section Publicité du Musée d'Art Moderne Département des Aigles. Marcel Broodthaers. Nova York: Marian Goodman, 1995. p. 11. [Entrevista de l'1 d'oct. del 1972 durant la filmació d'un documental sobre Documenta 5 per a Radio y Televisió belga. Dir. CORNELIS, Jef]

BECKERS, Ludo (1969a). "1968. El nacimiento del museo marca de hecho una ruptura con el Nuevo Realismo..." . En MARCEL BROODTHAERS. Ma.: MNCARS, 1992: p. 189 p. 47. [Fragment d'una entrevista realitzada en fr. el 13 de des. del 1969. "Gesprek met Marcel Broodthaers". Museumjournaal, (Amsterdam) 15 febrer, 1970: p. 66-71]

- $\quad$ (1969b) "Estas cartas son un poco lo contrario de un medio de comunicación...". En MARCEL BROODTHAERS. Ma.: MNCARS, 1992: p. 199. [Fragment d'una entrevista realitzada en fr. el 13 de des. del 1969. "Gesprek met Marcel Broodthaers". Museumjournaal, (Amsterdam) 15 febrer, 1970: p. 66-71]

LeBEER, Irmeline (1974). "Dix mille francs de récompense". En MARCEL BROODTHAERS. Pa.: Galerie Nationale du Jeu de Paume, ca. 1991: p. 248 - 251. [En BroOdTHAERS, Marcel. CatalogueCatalogus. Brussel-les: Palau de Belles Arts, 1974: p. 64 - 68]

- $\quad$ "Diez mil francos de recompensa". En MARCEL BROODTHAERS. Ma.: MNCARS, 1992: p. 248 - 251.

DE VREE, Freddy (1969). "Entrevista amb Marcel Broodthaers". En HAKKENS, Anna. Marcel Broodthaers par lui-même. Amsterdam: Ludion / Flammarion, ca. 1998: p. 68 - 73.

- (1971). "Entrevista amb Marcel Broodthaers". En HAKKENS, Anna. Marcel Broodthaers par luimême. Amsterdam: Ludion / Flammarion, ca. 1998: p. 75 - 79.

- (1974). "Entrevista amb Marcel Broodthaers". En HAKKENS, Anna. Marcel Broodthaers par luimême. Amsterdam: Ludion / Flammarion, ca. 1998: p. 103 - 107.

FARABET, René (1975a) "Fragment d'una entrevista amb referència la pel-lícula Monsieur Teste". En Marcel Broodthaers. Cinéma. Bar.: Fundació Antoni Tàpies, 1997: p. 266 (p. 332 trad. cast.). [Atelier de création radiophonique. France Culture, 1975]

- $\quad$ (1975b). "Fragment d'una entrevista amb referència a la pel·lícula Jardin d'hiver (ABC)". En Marcel Broodthaers. Cinéma. Bar.: Fundació Antoni Tàpies, 1997: p. 247 (p. 331 trad. cast.). [Atelier de création radiophonique. France Culture, 1975]

HARTEN, Jürguen i SCHMIDT, Katarina (1972). "Fragment d'un entretien avec Marcel Broodthaers". En HAKKENS, Anna. Marcel Broodthaers par lui-même. Amsterdam: Ludion / Flammarion, ca. 1998: p. 80 - 83. ["Auszug aus einem Gespräch mit Marcel Broodthaers". En Section des Figures. Der Adler vom Oligozän bis heute. Düseldorf: Städtische Kunsthalle, 1972. Fragments d'una conversa en fr. i en al., pel maig del 1972 publicada originalment en el dossier de premsa de l'exposició] 
- $\quad$ "Conversa de Jürgen Harten i Katarina Schmidt amb Marcel Broodthaers ". En Marcel Broodthaers. Ma.: MNCARS, 1992: p. 222-223 (cast.).

LUCAS, Richard (1969). "Vingt ans après". En MARCEL BROODTHAERS. Ma.: MNCARS, 1992: p. 137. (fr.) [Facs. del diàleg imprés en la sobreportada del exemplars de Vintg ans après. Brussel.les: Richard Lucas / Galeria New Smith, 2a Fira d'Art Actual, 1969]

RoNA, Stéphane (1976). "C'est l'Angelus qui sonne. Entretien avec Marcel Broodthaers". En HAKKENS, Anna. Marcel Broodthaers par lui-même. Amsterdam: Ludion / Flammarion, ca. 1998: p. 126 - 134. [+ - 0. Brussel.les i Ginebra]

SPILlEMAECKERS, Fernand (ca. 1971). "Comentaris sobre la Secció Cinema". En Marcel Broodthaers. Cinéma. Bar.: Fundació Antoni Tàpies, 1997: p. 159 (fr.; p. 327 trad. cast.).

TRÉPIED (1968). "Interview de Marcel Broodthaers". En Marcel Broodthaers. Cinéma. Bar.: Fundació Antoni Tàpies, 1997: p. 59 (fr.; p. 319-320 trad. cast.). [Trépied (Tribune mensuelle de cine jeune), (Brussel·les) febrer, 1968, núm. 2: p. 4-5]

VerstRAETEN, Marianne (1974). "Entretien avec Marcel Broodthaers à l'occasion de l'installation Jardin d'hiver". En HAKKENS, Anna. Marcel Broodthaers par lui-même. Amsterdam: Ludion / Flammarion, ca. 1998: p. $108-110$.

VLAEMINCKX, Jean-Michel (1965). "Entretien avec Marcel Broodthaers". En HAKKENS, Anna. Marcel Broodthaers par lui-même. Amsterdam: Ludion/ Flammarion, ca. 1998: p. 43 - 47. [Degré Zero, (Brussel·les) 1965.]

\section{Textos sobre Marcel Broodthaers}

Ashton, Dore. "Ten entr'actes from the tragedy of the Hôtel du Grand Miroir". En DicHOFF, Wilfried (ed.). Marcel Broodthaers. Colònia: Tinaia 9, 1994: p. 189 - 201.

BARKER, Barry. "Decorado. Una conquista por Marcel Broodthaers. Preparativos para una película". En MARCEL BROODTHAERS. Ma.: MNCARS, 1992: p. 274 - 275.

"Biography and bibliography". En DICHOFF, Wilfried (ed.). Marcel Broodthaers. Colònia: Tinaia 9, 1994: p. $273-276$.

"Biographie". En MARCel BROOdTHAeRs. KatAlog der EDITIONEN GRAPHIK UND BÜCHER. (Pròleg: NoBIS, Norbet i MEYER, Werner). Hannover: Cantz, ca. 1996: p. 81 - 99 (fr. al. i an.)

BORGEMEISTER, Rainer. "La signature, l'artiste". Trad. de l'al.: TREICHER, Caroline. En MARCEL BROODTHAERS. OEUVRE GRAPHIQUE. ESSAIS. Ginebra: Centre genevois de gravure contemporaine, 1991: p. 42 - 52.

- $\quad$ "Section des figures: The Eagle from the oligocene to the present." En BUCHLOH, Benjamin (ed.). Broodthaers. Writings, Interviews, Photographs. Cambridge /Massachusetts/ London: The MIT Press, 1988: p. 135 -151.

BUCHLOH, Benjamin H. D. "Open leters, industrial poems". En BUCHLOH, Benjamin (ed.). Broodthaers. Writings, Interviews, Photographs. Cambridge/ Massachusetts/ London: The MIT Press, 1988: p. 67 $-100$.

- "Contemplatingt publicity: Marcel Broodthaers's Section Publicité". En GILISSEN, Maria i BUCHLOW, Benjamin (ed.) Marcel Broodthaers. Section Publicité du Musée d'Art Moderne. Dt. des Aigles. Nova york: Galeria Marian Goodman, ca. 1995: p. 86 - 99.

"Ce merveilleux musée où il n'y a que des caisses". En MARCEL BROODTHAERS. Ma.: MNCARS, 1992: p. 300-301. [Facs. de Special, 8 d'oct. 1969]

"Cinéma Modèle". En MARCEL BROODTHAERS. CINÉMA. Bar.: Fundació Antoni Tàpies, 1997: p. 132.

CLADDERS, Johannes. "Museo de Arte Moderno, Departamento de las Águilas, Sección siglo XIX". En MARCEL BROODTHAERS. Ma.: MNCARS, 1992: p. 294 - 295.

- $\quad$ "Museo de Arte Moderno, Departamento de las Águilas, Sección Cine". En MARCEL BROODTHAERS. Ma.: MNCARS, 1992: p. 296 - 297.

- $\quad$ Museo de Arte Moderno, Departamento de las Águilas, Sección Publicidad; Sección de Arte Moderno; Galería del siglo XX". En MARCEL BROODTHAERS. Ma.: MNCARS, 1992: p. 299. 
- "Musée-Museum". Trad. de l'al.: Parmelin, Jean Claude. En Marcel Broodthaers. OeuvRe GRAPHIQUE. ESSAIS. Ginebra: Centre genevois de gravure contemporaine, 1991: p. 55 - 63.

"Comentaris sobre la pel·l. Le corbeau et le renard". En MARCEL BROODTHAERS. CINÉMA. Bar.: Fundació Antoni Tàpies, 1997: p. 52 - 57.

"Comentaris sobre l'edició Le corbeau et le renard". En MARCEL BROODTHAERS. CINÉMA. Bar.: Fundació Antoni Tàpies, 1997: p. 62 - 63.

"Comentaris sobre l'exposició Le corbeau et le renard". En MARCEL BROODTHAERS. CINÉMA. Bar.: Fundació Antoni Tàpies, 1997: p. 64 - 65.

COMPTON, Michael "The rhetoric of Marcel Broodthaers". En DICHOFF, Wilfried (ed.). Marcel Broodthaers. Colònia: Tinaia 9, 1994: p. $213-227$.

- $\quad$ "Les editions de Marcel Broodthaers". Trad. de l'an.: DuBoIS, Thierry. En MARCEL BROODTHAERS. OEUVRE GRAPHIQUE. ESSAIS. Ginebra: Centre genevois de gravure contemporaine, 1991: p. 27- 32.

- $\quad$ "Elementos biográficos". En MARCEL BROODTHAERS. Ma.: MNCARS, 1992: p. 302.

CUENAT, Philippe. "L'oeuvre graphique dans le décor: L'Entree de l'Exposition". En MARCEL BROODTHAERS. OEUVRE GRAPHIQUE. ESSAIS. Ginebra: Centre genevois de gravure contemporaine, 1991: p. 64 - 80.

CULOT, Maurice. "L'arquitect est absent". En MARCEL BROODTHAERS. L'ARCHITECTE EST ABSENT. LE MAÇON. Imschoot, Uitgevers: Foundation pour l'architecture, 1991: p. 7 - 9.

DAVID, Catherine. "El museo del signo". En MARCEL BROODTHAERS. Ma.: MNCARS, 1992: p. 17 - 22.

DE DECKER, Anny. "Comentario sobre el proyecto Exposition littéraire autour de Mallarme: Marcel Broodthaers à la Deblioudebliou / S". En MARCEL BROODTHAERS. Ma.: MNCARS, 1992: p. 140 - 141.

- $\quad$ "Comentarios sobre el proyecto Le corbeau et le renard". En MARCEL BROODTHAERS. Ma.: 1992: p. $118-121$.

DE VREE, Freddy. "Feuilleton from Marcel Broodthaers, Marcel Broodthaers". En DICHOFF, Wilfried (ed.). Marcel Broodthaers. Colònia: Tinaia 9, 1994: p. 205 - 211.

- $\quad$ "Introducció". En DE VREE, Fredy. Marcel Broodthaers. Oeuvres 1963-1975. Brussel-les: Isy Branchot (ed.) 1990: p. 5 - 14.

DiCHOOFF, Wilfried "La valeur plastique du langage". En DiCHOFF, Wilfried (ed.). Marcel Broodthaers. Colònia: Tinaia 9, 1994: p7 - 17

HAKKENS, Anna. "Éléments biographiques". En HAKKENS, Anna. Marcel Broodthaers par lui-même. Amsterdam: Ludion/ Flammarion, ca. 1998: p. 135 - 137.

"Film als Objekt - Objekt als Film". En MARCEL BROODTHAERS. CINÉMA. Bar.: Fundació Antoni Tàpies, 1997: p. 190. [Comentari sobre l'exposició]

GEVAERT, Yves. "Un Jardin d'hiver. Un bibelot d'inanité sonore" (amb colllaboració de VAN BALBERGHE, Émile). En MARCEL BROODTHAeRs. OeuVRE GRAPHIQUe. ESSAIS. Ginebra: Centre genevois de gravure contemporaine, 1991: p. 81 - 94.

- $\quad$ "Pauvre Belgique: An asterisk in history". En BUCHLOH, Benjamin (ed.). Broodthaers. Writings, Interviews, Photographs. Cambridge; Massachusetts; London: The MIT Press, 1988: p. 183 - 197.

- $\quad$ "Catalogue-Catalogus. La exposición retrospectiva de Marcel Broodthaers. Comentarios acerca de algunas de las obras". En MARCEL BROODTHAERS. Ma.: MNCARS, 1992: p. 236 - 247.

GILDEMYN, Marie-Pascale. "Bibliography". En BUCHLOH, Benjamin (ed.). Broodthaers. Writings, Interviews, Photographs. Cambridge; Massachusetts; London: The MIT Press, 1988: p. 198 - 210.

HARTEN, Jürgen. "Museo de Arte Moderno, Departamento de las Águilas, Sección siglo XIX (bis)". En MARCEL BROODTHAERS. Ma.: MNCARS, 1992: p. 295-296.

- $\quad$ "Museo de Arte Moderno, Departamento de las Águilas, Sección de las Figuras". En MARCEL BROODTHAERS. Ma.: MNCARS, 1992: p. 297-299.

JenkInNS, Bruce. "Un Peu Tard: Cita en el cine de Marcel Broodthaers". En MARCEL BROODTHAERS. CINÉMA. Bar.: Fundació Antoni Tàpies, 1997: p. 289 - 295.

- $\quad$ "CB: Cinéma Broodthaers". En MARCEL BROODTHAERS. New York; Minneapolis: Walker Art Center, Rizzoli, 1989: p. 51.

KRAUSS, Rosalind. "A voyage on the North Sea. Art in the age of the post-medium condition". Londres: Thames \& Hudson, ca. 2000. ISBN 0500282072. 
"La galerie Folker Skulima présente le film plus court du monde: Une seconde d'Éternité...". En MARCEL BROODTHAERS. CINÉMA. Bar.: Fundació Antoni Tàpies, 1997: p.128. [Facs. de la invitació de l'exposició]

MARí, Bartomeu. "Musée - Museum". En MARCEL BROODTHAERS. L'ARCHITECTE EST ABSENT. Le MAÇON. Imschoot, Uitgevers: Foundation pour l'architecture, 1991: p. 29.

- "Les projets de M. B.". En MARCEL BROODTHAERS. L'ARCHITECTE EST ABSENT. LE MAÇON. Imschoot, Uitgevers: Foundation pour l'architecture, 1991: p. 94 - 95.

"Marcel Broodthaers antes de 1964". En MARCEL BROODTHAERS. Ma.: MNCARS, 1992: p. 34-53.

MeISTER, Helga. "Descripció de l'espai de la Section Cinéma". En MARCEL BROODTHAERS. CINÉMA. Bar.: Fundació Antoni Tàpies, 1997: p. 156. [Fragment de "Fiktives Museum. Marcel Broodthaers gibt einen Denkanstob". Düsseldorfer Nachrichten 31, 6 febrer, 1971]

"MTL 13/3/70 - 10/4/70. Comentaris sobre l'exposició". En MARCEL BROODTHAERS. CINÉMA. Bar.: Fundació Antoni Tàpies, 1997: p. 102.

"MTL (DTH). Comentaris sobre la pel-licula". En MARCEL BROODTHAERS. CINÉMA. Bar.: Fundació Antoni Tàpies, 1997: p. 109.

"Museo de Arte Moderno Departamento de las Águilas 1968 - 1972: Documentos". En MARCEL BROODTHAERS. Ma.: MNCARS, 1992: p. 167 - 231.

OpPITZ, Michael. "Eagle; Pipe; Urinal". En BuCHLOH, Benjamin (ed.). Broodthaers. Writings, Interviews, Photographs. Cambridge/ Massachusetts/ London: The MIT Press, 1988: p. 155 - 156.

"Les pel-lícules del Musé d'Art Moderne. Section Xixe siècle. Département des Aigles". En MARCEL BROODTHAERS. CINÉMA. Bar.: Fundació Antoni Tàpies, 1997: p. 145. [Comentari sobre les pel lícules del Museu projectades en la Section Cinéma]

Pelzer, Birgit. "Los indicios del intercambio". En MARCEL BROODTHAERS. Ma.: MNCARS, 1992: p. 24 - 33.

- "Recourse to the letter". En BuCHLOH, Benjamin (ed.). Broodthaers. Writings, Interviews, Photographs. Cambridge/ Massachusetts/ London: The MIT Press, 1988: p. 157 - 181.

QUAST, Antje "Qui songe a des mains simples or what does poetry have to do with the wold? Marcel Broodthaers and Stephane Mallarmé". En DICHOFF, Wilfried (ed.). Marcel Broodthaers. Colònia: Tinaia 9, 1994: p. $251-271$.

RORIMER, Anne. "Le tractatus logico-catalogicus". Trad. de l'an.: DUBoIs, Thierry. En MARCEL BROODTHAERS. OEUVRE GRAPHIQUE. ESSAIS. Ginebra: Centre genevois de gravure contemporaine, 1991: p. $53-56$.

- $\quad$ "The exhibition at the MTL Galery in Brussels". En BUCHLOH, Benjamin (ed.). Broodthaers. Writings, Interviews, Photographs. Cambridge/ Massachusetts/ London: The MIT Press, 1988: p. 101 -125.

RoYOuX, Jean-Cristophe. "Project pour un Texte: El modelo cinematográfico en la obra de Marcel Broodthaers". En MARCEL BROODTHAERS. CINÉMA. Bar.: Fundació Antoni Tàpies, 1997: p. 297 310.

SCHWARZ, Dieter. "Mea culpa. De la fonction de l'art graphique dans l'oeuvre artistique de Marcel Broodthaers". Trad. de l'al.: ZAJAC. Magdalena. En MARCEL BROODTHAERS. OEUVRE GRAPHIQUE. ESSAIS. Ginebra: Centre genevois de gravure contemporaine, 1991: p. 33 - 40.

- "Look! Books in plaster!". En BUCHLOH, Benjamin (ed.). Broodthaers. Writings, Interviews, Photographs. Cambridge/ Massachusetts/ London: The MIT Press, 1988: p. 57 - 66.

"Section Cinéma, gener del 1971". En Marcel Broodthaers, Cinéma. Bar.: Fundació Antoni Tàpies, 1997: p. $143-153$.

"Section Cinéma, juny - oct. del 1972". En MARCEL BROODTHAERS. CINÉMA. Bar.: Fundació Antoni Tàpies, 1997: p. $162-169$.

SNAUWAERT, Dirk. "The figures". En BUCHLOH, Benjamin (ed.). Broodthaers. Writings, Interviews, Photographs. Cambridge/ Massachusetts/ London: The MIT Press, 1988: p. 127133.

UMBerto, Beni. "Le D est plus grand que le T...". En MARCEL BROODTHAERS. CINÉMA. Bar.: Fundació Antoni Tàpies, 1997: p. 53. [Poema a partir del text de Broodthaers - a partir de la rondalla de La Fontaine - que darrerament va ser part de l'edició Le corbeau el le renard]

"Jardin d'hiver (ABC)". En MARCEL BROODTHAERS. CINÉMA. Bar.: Fundació Antoni Tàpies, 1997: p. 240. [Comentari sobre la pel'l. i sobre els decorats Jardin d'hiver] 
ZWEITE, Armin. "Comentaris a propòsit de A Film by Charles Baudelaire". En MARCEL BROODTHAERS. CINÉMA. Bar.: Fundació Antoni Tàpies, 1997: p. 123.

ZWIRNER, Dorothea. "Mirror, Mirror on the wall... The puzzle of representation in Marcel Broodthaers". En DICHOFF, Wilfried (ed.). Marcel Broodthaers. Colònia: Tinaia 9, 1994: p. 229 - 249.

\section{Monografies sobre Marcel Broodthaers}

BROODTHAERS, Marcel. En lisant la Lorelei. Wie ich die Lorelei gelesen habe. Ginebra: CUENAT, Philippe (ed.) Musée d'Art Moderne et Contemporain, 1997 (reimpressió/ s. ISBN 1a ed. Munic/ Paris: Galeria Heiner Friedrich i Galeria Yvon Lambert, 1975).

Broodthaers, Marcel. Magie Art et Politique. Colònia: Dichoff, Wilfried (ed.) Tinaia 9, 1994 [reimpresió 400 còpies 1a ed. París: Multiplicata, 1973].

Cuenat, Philippe (ed.). Marcel Broodthaers autour de la Lorelei. Ginebra: Musée d'Art Moderne et Contemporain, 1997 [cat. S. ISBN]

DE VREE, Fredy. Marcel Broodthaers. Oeuvres 1963-1975. Brussel-les: Isy Branchot (ed.) 1990. ISBN 2903004005.

DiCHOFF, Wilfried (ed.). Marcel Broodthaers. Projets. Colònia: Tinaia 9, 1994. [Inclou: "Projet pour un film", "Projet pour un traite de toutes les figures", "Projet pour un texte - Project pour un poisson" i vint dibuixos]

DICHOFF, Wilfried (ed.). Marcel Broodthaers. Colònia: Tinaia 9, 1994. ISBN 3930740001. [catàleg i caixa amb reimpresions i edició d'obres de Broodthaers]

GILISSEN, Maria i BUCHLOW, Benjamin (ed.) Marcel Broodthaers. Section Publicité du Musée d'Art Moderne. Dt. des Aigles. Nova York: Galeria Marian Goodman, ca. 1995 (no IBSN).

HAKKENS, Anna. Marcel Broodthaers par lui-même. Amsterdam: Ludion/ Flammarion. ca. 1998. ISBN 9055441368.

Marcel BRoodthaers. CinÉmA. Comissaris: BorJa-VIllel, Manuel J. i Compton, Michael en col·laboració amb GILISEN, Maria. Bar.: Fundació Antoni Tàpies, 1997. ISBN: 8488786-16-6.

MARCEL BROODTHAERS. Katalog DER EDITIONEN GRAPHIK UND BÜCHER. Pròleg: NoBIS, Norbet (Sprengel Museum Hanover) i MEYER, Werner (Städtische Galerie Göppingen). Hannover: Cantz, ca. 1996. ISBN 3893228365.

MARCEL BROODTHAERS. L'ARCHITECTE EST ABSENT. LE MAÇON. Imschoot, Uitgevers: Foundation pour l'architecture, 1991. ISBN: 90-72191-60-9.

MARCEL BROODTHAERS. Ma.: MNCARS, 1992. ISBN: 84-8026-003-3. [Comissaria: DAVID, Catherine].

MARCEL BROODTHAERS. Nova York/ Minneapolis: Walker Art Center, Rizzoli, ca. 1989. ISBN 0847810518.

MARCEL BROODTHAERS. OEUVRE GRAPHIQUE. ESSAIS. Ginebra: Centre genevois de gravure contemporaine, 1991 (no IBSN).

MARCEL BROODTHAERS. Pa.: Galerie Nationale du Jeu de Paume, ca. 1991. ISBN 2908901056.

\section{Referències generals. Subdivisió per matèries}

\section{Referències sobre altres artistes i escriptors}

BERNÁLDEZ, Carmen. Joseph Beuys. Guipúscoa: Editorial Nerea, 1999. Col $\cdot$. Arte Hoy. ISBN 89569320.

DuCHAMP, Marcel. Escritos. Duchamp du signe. Versió: ELIAS Josep i HESSE Carlota. Revisió bibliogràfica: RomAGUERA, Joaquim. Bar.: Gustavo Gili, 1978. Comunicación Visual. Serie Clásicos. ISBN 8425207045.

GUASH, Anna Maria. "Joseph Beuys y la escena artística de Düsseldorf". En El arte del siglo XX en sus exposiciones. 1945-1995. Bar.: Ediciones del Serbal, 1997: p. $232-240$.

KURT SCHWITTERS. València: IVAM. Centre Julio Gonzalez, 1995.

MALLARMÉ, Stéphane. Obra poética. Traducció: SILVA-SANTIESTEBAN, Ricardo. Ma.: Hiperión, 1994. (ed. bilingüe fr. i cast.). 
- Dos poemas dramáticos: La siesta de un fauno. Las nupcias de Herodías. Traducció: SILVASANTIESTEBAN, Ricardo. Bar.: Tusquets, 1972. (ed. bilingüe fr. i cast.).

MAULPOINT, Jean-Michel. Stéphane Mallarmé: Portait du poète en araignée [document en línia]. 1998. [última consulta: 29 / 07 / 2003] Disponible en: http://www.maulpoint.net/mallarme.html.

PUNTS DE CONFLUĖNCIA. JOSEPH BEUYS, DUSELDORF 1962-1987. Bar.: Caixa de Pensions, 1988. ISBN

SAn MARTín, Francisco Javier. Piero Manzoni. Ma.: Nerea, 1998. Arte Hoy. ISBN 84-89569-22-3.

SCHNEEDE, Uwe M. René Magritte. Bar.: Labor, 1978. ISBN 8433575600.

SzEEMANN, Haraald. "La inmortalidad no es un asunto de cualquiera". En Kurt Schwitters. València: IVAM. Centre Julio Gonzalez, 1995: p. 425-435.

VIGo, Edgardo A. "Continuidad de lo discontínuo" [document en línia]. En Marcha. La Plata, 1992 [última consulta: 2 / 12 / 2002]. Disponible en: http://www.eavigo.com.ar/escritos/continuidad_ de_lo_discontinuo.htm.

\section{Art i societat}

ALLOWAY, Lawrence. "Las artes y los medios de comunicación de masas". En El Independence Group: La postguerra británica y la estética de la abundancia. València: IVAM. Centre Julio Gonzalez. Generalitat valenciana. Conselleria d'Educació i Ciència, ca. 1990: p. 166-167. [Fragment. Arquitectural Design, febrer 1958]

- "Notas Urbanas". En El Independence Group: La postguerra británica y la estética de la abundancia. València: IVAM. Centre Julio Gonzalez. Generalitat valenciana. Conselleria d'Educació i Ciència, ca. 1990: p. 167. [Fragment. Arquitectural Design, gener 1959]

Baudrillard, J. Cultura y simulacro. Bar.: Kairós, 1987. ISBN 8472451429.

BREA, José Luis. "La fuerza del nihilismo: el desierto crece". En Nuevas estrategias alegóricas. Ma.: Tecnos, 1991: p. 119-124.

BRIHUEGA, Jaime. "Arte y sociedad. Genealogía de un parámetro fundamental". En BoZAL, Valeriano (ed.). Historia de las ideas estéticas y de las teorías artísticas contemporáneas. Ma.: Visor, 1996: vol. II, p. 109-126.

Eco, Umberto. Apocalípticos e Integrados ante la cultura de masas. Traducció: BOGLAR, Andres. Bar.: Lumen, 1968. ISBN 8426410391.

- La estructura ausente: Introdución a la semiótica. Bar.: Lumen, 1972. Palabra en el tiempo, 76. ISBN 8426410766

FREUND, Gisèle. "La fotografía bajo el segundo imperio". En La fotografia como documento social. Bar.: Gustavo Gili, 1983: 55 - 65. [parla sobre Baudelaire]

- "La fotografía como medio de reproducción de la obra de arte". En La fotografía como documento social. Bar.: Gustavo Gili, 1983: p. 87 - 93.

HEINZ, Hans. De la obra de arte a la mercancía. Bar.: Gustavo Gili, 1979. Punto y Línea. ISBN 842520920-X.

LASAOSA, Ma José. "La ciudad: un espacio para los afectos y la memoria". Zehar. (Guipúscoa) estiu 2000, núm. 43: p. 8-11.

PAZ, Alfredo de. La crítica social del arte. Bar.: Gustavo Gili, 1979. Punto y Línea. ISBN 8425209099.

RIBALTA, Jorge, "Un art útil". En Domini públic. Bar.: Centre d'Art Santa Mònica, Generalitat de Catalunya, 1994. p. 6-11.

WoLF, Janet. "Estructura social y creatividad artística". En La producción social del arte. Trad. BALSINDE, Isabel. Ma.: Istmo, 1997 [1981: 1a ed.; 1993: 2a ed. rev. per l'autora]: p. 23 - 40.

- "La producción social del arte". En La producción social del arte. Trad. BALSINDE, Isabel. Ma.: Istmo, 1997: p. 41 - 63. ["Tecnología": p. 49(tracta sobre el llibre i la impremta); "Instituciones sociales": p.55 (analitza la influència de diferents institucions sobre la producció artística i sobre la formació d'artistes)]

- "La muerte del autor". En La producción social del arte. Trad. BALSINDE, Isabel. Ma.: Istmo, 1997: p. 141 - 160. ["La naturaleza de la autoría": p. 145; "Las diversas voces del texto": p. 147] 


\section{Art, actitud, enunciats}

BANHAM, Reyner. "Matrimonio de dos mentalidades". En El Independence Group: La postguerra británica y la estética de la abundancia. València: IVAM. Centre Julio Gonzalez. Generalitat valenciana. Conselleria d'Educació i Ciència, ca. 1990: p. 10. [Poema]

BAUDELAIRE, Charles. Salones y otros escritos sobre arte. Traducció: SANTOS, Carmen. Introducció, notes i biografia: SolANA, Guillermo. Ma.: Visor, 1996. La balsa de la Medusa, 83. [dir. de la colı. BOZAL, Valeriano]. ISBN 8477745838.

BREA, José Luis. "Are you kidding, man?". En Nuevas estrategias alegóricas. Ma.: Tecnos, 1991: p. 8193.

- $\quad$ "Neobarroco: un viento sin norte (reprise)". En Nuevas estrategias alegóricas. Ma.: Tecnos, 1991, p. 145-150.

CLAIR, Jean. La responsabilidad del artista: Las vanguardias, entre el terror y la razón. Traducció: ARÁNTEGUI, José Luís. Ma.: Visor, 1998. La balsa de la Medusa, 92. [dir. de la coll. BozAL, Valeriano] ISBN 8477745927.

DuCHAMP, Marcel. Notas. Introducció: MoURE, Glòria. Trad. DíAz, Ma Dolores. Ma.: Tecnos, 1989. Col $\%$ Metrópolis. ISBN 84-309-1701-2.

FERRANDO, Bartolomé. La mirada móvil. A favor de un arte intermedia. Santiago de Compostela: Universidad de Santiago de Compostela, 2000. Colección monografías Master de Creatividad, núm.17. ISBN: 84-8121-831-6.

FOCAULT, Michel. Esto no es una pipa. Bar.: Anagrama, 1981. ISBN 8433913212.

GUASH, Anna Maria. "La acción y el compromiso: el happening en Europa". En El arte del siglo XX en sus exposiciones. 1945-1995. Bar.: Ediciones del Serbal, 1997: p. 70-76.

- "El arte en tanto que arte: lo conceptual". En El arte del siglo XX en sus exposiciones. 1945-1995. Bar.: Ediciones del Serbal, 1997: p. 203-214.

LEBEL, Jean Jacques. "El Happening". En MARCHÁN, Simón. Del arte obejtual al arte de concepto. Ma.: Akal, 1997: p. 392-394. [ca.1966]

"Manifiesto sobre el Happening". En MARCHÁN, Simón. Del arte obejtual al arte de concepto. Ma.: Akal, 1997: p. 391-392. [ca.1966]

MARCHÁN, Simón. "Del schocker-pop al realismo crítico social". En Del arte objetual al arte de concepto. Ma.: Akal, 1997: p. 65-77.[Primera edició 1972]

MitXelenA, P.; IMAZ, I. "Construir la intermediación. Ser artistas". Zehar, primavera 2000, núm. 42: p. $22-27$.

PÉREZ GUILLEN, Angel Luís. "Arte y deconstrucción. Los pliegues del sentido". Lápiz, juny 1995, núm. 113: p. 18-27. [Parla de: Manzoni, Duchamp, Picabia, Schwiters i d'artistes conteporanis: B. Kruger, A. Mc Collum, S. Levine, J. Koons, T. Rollins \& KOS, J. Holzer, J. Kosuth, etc.]

SCHWITTERS, Kurt. "La pintura Merz" (1919). En Cirlot, Lourdes (ed.). Primeras vanguardias artísticas. Textos y documentos. Bar.: Labor, 1995: p. 113.

- $\quad$ "Concepto de Merz" (1921). En Calvo SeRraler, Francisco i Gonzalez Angel. Escritos de Arte de Vanguardia. 1900 / 1945. Ma.: Itsmo, 1999.

Vostell, Wolf. "Arte y Política. La actividad pública". En MARCHÁN, Simón. Del arte obejtual al arte de concepto. Ma.: Akal, 1997: p. 396 - 399. [Entrevistat per HACKER, D., 22 / 08 / 1973]

WoDICZKo, Krysztof. "La vanguardia como arte público: el futuro de la tradición". En Krysztof Wodiczko. Bar.: Fundació Antoni Tàpies, 1992: p. 371-373.

\section{Surrealisme}

AdELANTADO, Eulalia. La revolución surrealista. València: Servei de publicacions, Universitat Politècnica de València, 1990. ISBN 8477211078.

BENJAMIN, Walter. "El surrealismo. La última instantánea de la inteligencia europea". En Imaginación y sociedad: lluminaciones I. Pròleg, traducció i notes: AgUIRRE, Jesús. Ma.: Taurus, 1971.

BRETON, André. El surrealismo. Puntos de vista y manifestaciones. Bar.: Seix Barral, 1972. ISBN 
Calvo SerRaler, Francisco. "La teoría artística del surrealismo". En BONET, Antonio (coord.). El surrealismo. Ma.: Cátedra, 1983: p. 27-56.

NADEAU, Maurice. Historia del Surrealismo. Traducció: CAPELLA, Juan-Ramón. Bar.: Ariel, 1972. ISBN 8434407000.

NIETO, Víctor. "Surrealismo y máquina: entre la metáfora y el objeto". En BONET, Antonio (coord.). El surrealismo. Ma.: Cátedra, 1983: p. 57-69.

OFICINA DE INVESTIGACIONES SURREALISTAS. "Declaración del 27 de enero de 1925". En Calvo/ González/ Marchán. Escritos de arte de vanguardia. Ma.: Turner, 1979; p. 362.

WESTERDAHL, Eduardo. "Panorama vital del surrealismo". En BONET, Antonio (coord.). El surrealismo. Ma.: Cátedra, 1983: p. 17-25.

\section{Pràctiques objectuals, pop art i nouveau réalisme}

BREA, José Luis. "Objetos inespecíficos". En Nuevas estrategias alegóricas. Ma.: Tecnos, 1991 p.47-64.

CIRLOT, Lourdes (ed.). Primeras vanguardias artísticas. Textos y documentos. Bar.: Labor, 1995. ISBN 84-335-3530-7.

DINE, Jim. "¿Qué es el Pop Art?". En MARCHÁN, Simón. Del arte obejtual al arte de concepto. Ma.: Akal, 1997: p. 351-352. [Entrevistat per SWENSON, Gene. "What is Pop Art?". Art News, nov., 1963]

GUASH, Anna Maria. "El arte de los objetos encontrados: el neodadá y el assemblage". En El arte del siglo XX en sus exposiciones. 1945-1995. Bar.: Ediciones del Serbal, 1997: p. 55-61.

- "La génesis de la cultura pop: el arte pop inglés". En El arte del siglo XX en sus exposiciones. 1945-1995. Bar.: Ediciones del Serbal, 1997: p. 48-54.

- "El dominio sobre lo real: el Nuevo Realismo francés". En El arte del siglo XX en sus exposiciones. 1945-1995. Bar.: Ediciones del Serbal, 1997: p. 77-84.

LUCIE-SMITH, Eduard. "Assemblage y neodadaismo". En El arte hoy. Del expresionismo abstracto al nuevo realismo. Ma.: Cátedra, 1983: p. 147-191.

- $\quad$ "El pop como estilo internacional". En El arte hoy. Del expresionismo abstracto al nuevo realismo. Ma.: Cátedra, 1983: p. 247-289.

LYNTON, Norbert. "La pintura y la escultura recientes". En MOSQUERA, Gerardo (comp.). Del Pop al Post. Una antología sobre la plástica y la arquitectura occidentales de los últimos 25 años. L'Havana: Arte y Literatura, 1993: p. 70-85.

MARCHÁN, Simón. "El pop, arte de la imagen popular". En Del arte objetual al arte de concepto. Ma.: Akal, 1997: p. 31 - 49.

- "Mitologías y nuevo reduccionismo". En Del arte objetual al arte de concepto. Ma.: Akal, 1997: p. $223-231$.

NAVARRO, Desiserio. "Pop-Art Inc. (Elegía crítica con más de una moraleja)". En MOSQUERA, Gerardo (comp.). Del Pop al Post. Una antología sobre la plástica y la arquitectura occidentales de los últimos 25 años. L'Havana: Editorial Arte y Literatura, 1993: p. 109-127.

PelegrinI, Aldo. "Nuevas tendencias de la pintura". En Mosquera, Gerardo (comp.). Del Pop al Post. Una antología sobre la plástica y la arquitectura occidentales de los últimos 25 años. L'Havana: Arte y Literatura, 1993: p. 19-69.

ReSTANY, Pierre. "Manifiesto de los nuevos realistas". En MARCHÁn, Simón. Del arte obejtual al arte de concepto. Ma.: Akal, 1997: p. 347-348. [1er manifest. Milà: 16 d'abril, 1960]

- "El Nuevo Realismo: ¿Qué es preciso pensar?". En MARCHÁN, Simón. Del arte obejtual al arte de concepto. Ma.: Akal, 1997: p. 348-350.

\section{Muntatge, apropiació i cinema}

BeNJAMIN, Walter "La obra de arte en la época de su reproductibilidad técnica". En Discursos Interrumpidos. Pròleg, trad. i notes: AGUIRRE, Jesús. Ma.: Taurus, 1973: p. 15-57.

BUCHLOH, Benjamin H.D. "Procedimientos alegóricos: apropiación y montaje en el arte contemporàneo". En Indiferencia y singularidad: La fotografía en el pensamiento artístico contemporáneo. Trad. VILLALONGA, Elena. Bar.: MACBA, 1997: p. 99-132. Llibres de recerca, 4. 
HANDHARDT, John G. "Modelos de interacción: cine y vídeo en una nueva era de los medios de comunicación". En JIMÉNEZ, José (ed.). El nuevo espectador. Ma.: UAM, 1998: p. 79-95.

LOTMAN, Yuri M.. "El concepto cinematográfico del plano y el texto literario". En Estructura del texto artístico. Ma.: Istmo, 1988: p. 316 - 320.

- "La yuxtaposición de elementos heterogéneos como principio de composición". En Estructura del texto artístico. Ma.: Istmo, 1988: p. 335 - 342.

\section{Espai, museu i arquitectura}

CAMERON, Dan. "El jardín salvaje. El paisaje como metáfora en instalaciones americanas recientes". En El jardín salvaje. Ma.: Fundación Caja de Pensiones, 1990: p. 15-47.

CRIMP, Douglas. "Sobre las ruinas del museo". En FOSTER, Hal (selec.). La Postmodernidad. Bar.: Kairós, 1985: p. 75-92.

FocaUlT, Michel. "Espacios diferentes" (1967). En Toponimias. Ocho ideas del espacio. Ma.: Fundación "La Caixa", 1994, p. 31-38.

GodoY, Guadalupe. "Documenta 5". En Documenta de Kassel (1955-1997) Medio siglo de arte contemporáneo. Dir. DE LA CALLE, Román. Tesi Doctoral inèdita. Facultat de Belles Arts, Universitat Politècnica de València. València: 1999: p. 346-418.

HeIDEGGeR, Martin. "El arte y el espacio". En Toponimias. Ocho ideas del espacio. Ma.: Fundación "La Caixa", 1994: p. 39-42.

KRAUSS, Rosalind. "La escultura en el campo expandido". En Foster, Hal (comp.) La Postmodernidad. Ma.: Kairós, 1985; p. $59-74$.

MARCHÁN, Simón. "Ambientes y espacios lúdicos". En Del arte objetual al arte de concepto. Ma.: Akal, 1997: p. 173-192.

PerelLó, Antònia. "Art, arquitectura, museu". En Mirades (sobre el Museu). Bar.: MACBA, 1996: p.13-19.

VeLÁZQUEZ, Isabel. "El tiempo de las cerezas". Zehar, estui 2000, n. 43: p. 20-25. [sobre la ciutat, l'urbanisme i l'espai polític].

\section{Estètica i teoria de l'art}

BENJAMIN, Walter. "El autor como productor". EnTentativas sobre Bretch: Iluminaciones III. Pròleg, trad. i notes: AGUIRRE, Jesús. Ma.: Taurus, 1975: p. 117-134.

BozAL, Valeriano. "Arte contemporáneo y lenguaje". En BozAL, Valeriano (ed.). Historia de las ideas estéticas y de las teorías artísticas contemporáneas. Ma.: Visor, 1996: vol. II, p. 15-25.

BREA, José Luís. "Releyendo El acto creativo. Por un escribismo iluminador". En Nuevas estrategias alegóricas. Ma.: Tecnos, 1991: p. 17-32.

BRIHUEGA, Jaime. "Las vanguardias artísticas: teorías y estrategias". En BOZAL, Valeriano (ed.). Historia de las ideas estéticas y de las teorías artísticas contemporáneas. Ma.: Visor, 1996: vol. II, p. 127146.

BÜRGER, Peter. "La historicidad de las categorías estéticas". Trad. GARCíA, Jorge. Pròleg: PIÑón, Helio. En Teoría de la Vanguardia. Bar.: Península, 1987: p. 51-70. [1a ed. 1974]

JAUSS, Hans Robert. Las trasformaciones de lo moderno. Estudio sobre las etapas de la modernidad histórica. Ma.: Visor, 1995. La balsa de la Medusa, 76. ISBN 8477745765.

- "La moral problemática de lo estético". Trad. LóPEZ, María Rosa. En JIMÉNEZ, José (ed.); El nuevo espectador. Ma.: Visor, 1998, p. 31-50. Debates sobre Arte.

- "Poiesis: el aspecto productivo de la experiencia estética. Construire et connaître". En Experiencia estética y hermenéutica literaria. Ensayos en el campo de la experiencia estética. Trad. SILES, Jaime i FERNANDEZ-PALACIOS, Ela María. Ma.: Taurus, 1986: p. 93-115.

- "Catarsis: la función comunicativa de la experiencia estética. Movere et conciliare". En Experiencia estética y hermenéutica literaria. Ensayos en el campo de la experiencia estética. Trad. SILES, Jaime i FERNANDEZ-PALACIOS, Ela María. Ma.: Taurus, 1986: p. 159-184.

LOTMAN, Yuri M.. "Tipología de los textos y tipología de las relaciones extratextuales". En Estructura del texto artístico. Ma.: Istmo, 1988: p. 345 - 357. 
- "Sobre la pluralidad de los códigos artísticos". En Estructura del texto artístico. Ma.: Istmo, 1988: p. $37-39$.

MARX, K.; Engels F. "Historia crítica de la teoría de la plusvalía". En Textos sobre la producción artística. Selecció, pròleg i notes: BOZAL, Valeriano. Ma.: CORAZÓN, Alberto, 1972: p. 84. Comunicación serie $B$ núm. 20.

TATARKIEWICZ, W. "Historia de la relación del arte con la poesía". En Historia de seis ideas. Ma.: Tecnos, 1987: p. 103-151.

\section{Metodologia, escriptura i edició}

AENOR. UNE 50 - 104 - 94 - Referencias bibliográficas. Contenido, forma y estructura. 1994. [Equivalent a: ISO 690: 1987].

Agullera CeRnI, Vicente (dir.). Diccionari de l'Art Modern: Conceptes - Idees - Tendències. València: Universitat Politècnica de València, 2002. [Trad. SeRVEI DE NoRMALITZACIÓ LINGÜÍstICA] 1a ed. TORRES, Fernando, 1980] ISBN 84970510009.

Agustí, Carme (et. al.) Reciclatge. (Nivell Superior). València: 3 i 4, 1999. ISBN 8475025625.

ALCINA, Franch. Aprender a investigar. Métodos de trabajo para la redacción de tesis doctorales (humanidades y ciencias sociales). Ma.: Compañía literaria, 1994. ISBN 8482130048.

Angulo, Tanya. Estrategias discursivas y significación del espectador en la obra de Marcel Broodthaers. Dir. MONLEÓN, Elena E. Treball d'Iniciació a la Investigació inèdit. Facultat de Belles Arts. Universitat Politècnica de València. València: 1999.

ATKINS, Robert. Artspeak. A guide to contemporary ideas, movements, and buzzwords. New York, Abbeville Press Publishers, 1990. ISBN 1-55859-127-3.

CASANY, Daniel. La cocina de la escritura. Bar.: Anagrama, 1995. Argumentos, 162. ISBN

CASTELLANOS, Carles i CASTELLANOS, Rafael. Diccionari francés - català. Bar.: Enciclopèdia catalana, 1984 (2a edició) / 1999, 7ena reimpressió. ISBN 8485194489.

CORRIPIO, Fernando. Diccionario de ideas afines. Bar.: Herder, 1996. ISBN 8425415152.

DE LA CALLE, Román. "Crítica y creatividad: las funciones del texto crítico". En 1ER CONGRESO DE LA ASOCIACIÓN VALENCIANA DE CRítICOS DE ARTE. (1er. 1990. València). Reflexiones sobre la crítica de arte. València: IVAM. Generalitat Valenciana, 1990: p. 59-85.

- "John Dewey: experiencia estética y crítica de arte". Kalías, 1993, any V, núm. 10: p. 22 - 35.

- "John Dewey: del arte a la estètica generalitzada". Quaderns de Filosofia i Ciència 23 / 24. València: Societat de Filosofia del País Valencià, 1994: p. 251 - 261.

- En torno al hecho artístico. Ensayos de teoría del arte. València: TORRES, Fernando (ed.), 1981. ISBN 8473661362.

DEWEY, John. "Crítica y percepción". En El arte como experiencia. Trad. Ramos, Samuel. Mèxic DF/ Buenos Aires: Fondo de Cultura Económica, 1949: p. 264-287.

DICCIONARI DE LA LLENGUA CATALANA. [En disc compacte (CD-ROM) amb traduccions al cast. i a l'anglés] Bar.: Enciclopèdia Catalana, 1994 (versió 1.0). Diccionaris de l'Enciclopèdia. ISBN 8477398410.

DicCIONARI ESSENCIAL: SinÒnImS I ANTÒNIMS de la Llengua CATALANA. Bar.: Vox, 1997. ISBN 847153956X.

DICCIONARI VALENCIÀ. València: Edicions Bromera. Generalitat valenciana. Conselleria de Cultura, Educació i Ciència, 1995. [Dir. LA CREU, Joseph. Pròleg: Institut Interuniversitari de Filologia Valenciana] ISBN 847660243X.

Eco, Umberto. Cómo se hace una tesis. Técnicas y procedimientos de estudio, investigación y

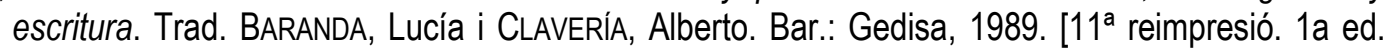
1977] ISBN 968-852-007-1.

GARCiA, Olegario. Metodología de la investigación científica. Cómo hacer una tesis en la era de la información. Ma.: CEES, 1994. ISBN 88881010.

GENESCÀ, Gabriel i RIGO, Antònia. Tesis i treballs. Aspectes formals. Presentació a càrrec de ALSIUS, Salvador. Vic: Eumo, c.a. 2000. ISBN 8476023359. 
GIORDANo, Carlos i YURKIEVICH, Saul. Collins Pocket Diccionario: Francés - Español. Espagnol Français. Bar.: Collins Grijalbo, 1989. ISBN 8425314666.

Gran Diccionari de la llengua catalana. Bar.: Enciclopèdia catalana, 1998. ISBN 844122790X.

HALVORSON, Michael i Young, Michael. "Parte 2. Microsoft Word". En Guía completa de Microsoft Office 97. Ma.: McGraw - Hill, 1997; p. 95 - 705.

INTERNATIONAL STANDARIZATION ORGANIZATION. ISO 690 - 2 - Information and documentation bibliographics references - Part 2: Electronic documentsor parts thereof. 1997.

MARTíNEZ DE SOUSA, José. Manual de edición y autoedición. Ma.: Pirámide, 1994. ISBN 8436808401

- Diccionario de tipografia y del libro. Ma.: Paraninfo, 1992. ISBN 8428311323.

MONLEON, Elena E. Híbridos. Escultura y fotografía en el arte contemporaneo. Dir. DE LA CALLE, Román. Tesi Doctoral inèdita. Facultat de Belles Arts. Universitat Politècnica de València. València: 1995.

RIGO, Antònia i GENESCÀ, Gabriel. Tesis i treballs. Aspectes formals. Presentació: ALSIUS, Salvador. Vic: Eumo, 2000. ISBN 8476023359.

SIERRA, Restituto. Tesis doctorales y trabajos de investigación científica. Metodología general de su elaboración y documentación. Ma.: Paraninfo, 1986. ISBN 8428314667.

SERAFINI, Ma Teresa. Cómo se escribe. Bar.: Paidós, 1996. Instrumentos Paidós, 12. [Col·l. dirigida per ECO, Umberto]. ISBN 847509998X.

- Cómo redactar un tema. Didàctica de la escritura. Bar.: Paidós, 1995. Instrumentos Paidós, 4. [Col·. dirigida per ECO, Umberto]. ISBN 8475095127.

VALOR, Enric. La flexió verbal. València: Papers bàsics 3 i 4, 1989. [1era ed. 1983] ISBN 8475020836. 
ÍNDEX ANALÍTIC 
actituds artístiques iròniques $\mathrm{i}$ desestabilitzadores ........60

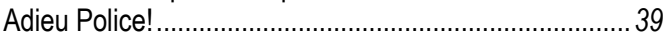
àguila representació ...........................104, 109, 114, 127, 159 representacions .............................................113, 121 significació .....................................................114, 118 simbologia.....................104, 113, 114, 117, 121, 126

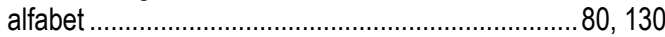

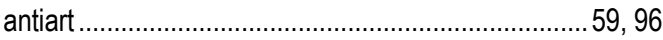

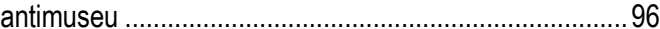

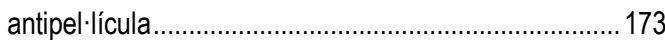
antologia .........................................126, 127, 129, 130 Anvers

Espai A 3790 89....................................................103

Wide White Space, galeria..................................... 160

apropiació ..49, 57, 59, 64, 74, 79, 83, 110, 113, 137, 168, $169,172,177,181$

arquitectura ...........................59, 100, 129, 137, 139, 167

Decor.................................................. 129

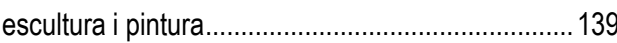

indústria cultural .................................................... 137

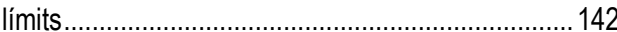

Merz ……..................................................... 143

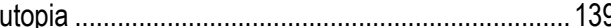

art

compromís .................................... 122, 138, 173

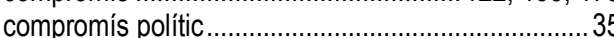

espai d'alliberació.................................................... 80

reflexió crítica........59, 60, 71, 114, 121, 137, 143, 178

art com a conseqüència.

art conceptual $\quad 110,113,114$

art i societat.......................................................... $35,36,178$

art i treball ..................................................... 138

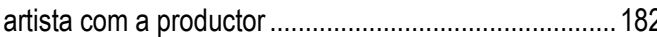

artista modern ............................................................ 138

assemblage....................................49, 57, 63, 64, 162

assemblage i escultura ......................................60, 63, 64

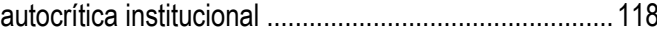

autonomia de l'art ............................................... 138, 178

crítica...................84, 91, 95, 122, 129, 138, 178, 182

autoria ............................................91, 127, 178, 182

dimensió utòpica .......................80, 138, 142, 143, 169

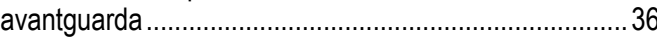

avantguardes i institucions .......................................... 36

avantguardes i societat .................................................... 36

B

ballon ce n'est pes fait pour se tuer, Le ...........................40 Baudelaire, Charles

$36,64,104,138,163,164,169$
Belga Vox - Mode - 20th Century Fox......................... 153

Bête Noire, La ...................................................40, 67, 84

Between ....................................103, 110, 117, 118, 151

Beuys, Joseph .....................................11, 122

Breton, André....................................................37, 38, 66

Briques.......................................................127, 167

Broodhtaers i Duchamp ............................................... 109

Broodthaers

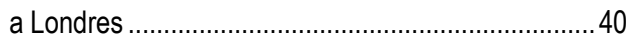

a París ............................................................. 40, 43

actitud artística contestatària ....................................57

actituds avantguardistes ........................................... 35

ambient intel'lectual a Brussel-les ............................ 35

articles d'opinió .................................................39, 50

assemblages....44, 49, 50, 58, 60, 63, 64, 67, 71, 127,

129,167

censura el museu........................................................ 71

creació artística com a forma d'alliberament ..........126

deserció de la poesia ............................................... 44

director/ conservador .............53, 95, 96, 113, 117, 126

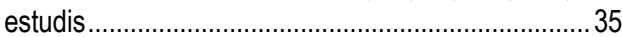

Exposició Universal de Brussel les ............................ 40

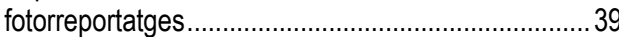

idea de monument .....................................................5

idea d'espai .................................................167

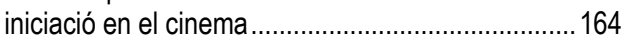

iniciament en el cinema ..............................................39

iniciament en la fotografia ....................................... 39

instrumentació del cinema .........................................173

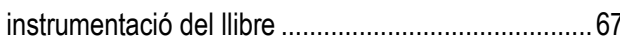

llibres de poesia ....................................................... 40

militància política.................................................... 35

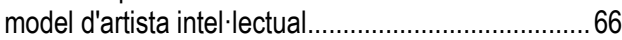

mort, lloc i data..................................................... 53

moviment surrealista belga ....................................... 35

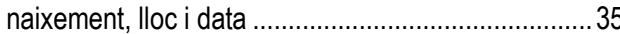

partit comunista belga .................................................

poètica cinematogràfica ............................................. 169

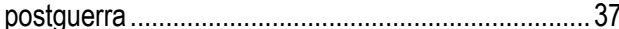

primera exposició personal .......................................... 49

primera iniciativa artística ................. Véase Premi Jove d'Escultura belga

procés creatiu...................................78, 83, 84, 89, 91

pseudònim............................................................. 35

secessió del moviment surrealista ...............................38

significació de l'acte creatiu .................................67,89

significació de l'acte expositiu .................................129

Surrealisme Revolucionari ............................................37

vincle social de l'art.................................................. 174

visites guiades de la Societat d'Exposicions del Palau

de Belles Arts de Brussel'les .............................39 


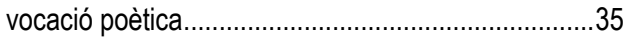

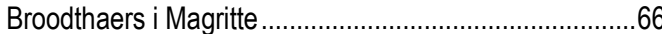

Broodthaers i Mallarmé ...................................................... 80

Broodthaers i Manzoni .......................................................43

Broodthaers i Schwitters .........................................71, 143

Bruegel et Goya, Journalistes ......................................168

Brüssel Teil II ...............................................................153

Brussel.les

30 Rue de la Pépinière..............................99, 130, 139

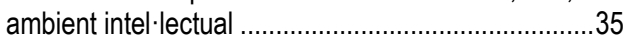

Aujourd'hui, galeria.....................................................43

Despatx del Surrealisme Revolucionari ........................37

Exposició Universal del 1958 ............................39 40

Palau de Belles Arts 39, 43, 57, 68, 95, 127, 142, 144 , $147,148,164$

Premi Jove d'Escultura belga ...................................57

Saint-Laurent, galeria ..................................................

Themis, galeria ...........................................................39

C

Caricatures et peintures du XIXe siècle ........................110 Catalogue - Catalogus .........................126, 127, 129, 147,

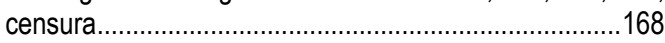

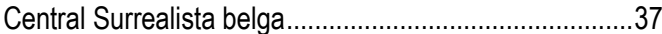

chant de ma génération, Le ............................................39

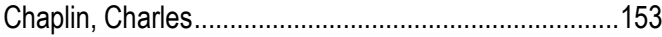

Charlie als Filmstar .......................................................153

Chavée, Achille …………………………………….........

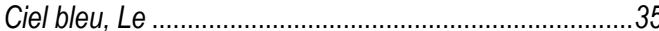

cinema..... 36, 39, 40, 44, 74, 78, 103, 129, 153, 164, 167 ,

$168,169,172,174$

caràcter instrumental...............................................162

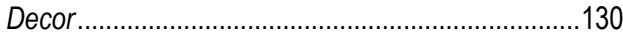

exposició com a representació................................162

immobilitat ............................................168, 173, 187

indústria cultural .......................................................137

model textual ..................................................167, 174

moviment.......................................153, 159, 173, 182

Musée d'Art Moderne .......................................151, 152

nova esfera de consum ...............................................74

reciclatge d'imatges.................................................168

representació de l'exposició .....................................164

representació del Museu ..........................................159

representació del Museu .........................................162

cinema com a art.....................................152, 162, 164

cinema com a representació .................................151, 152

cinema d'animació........................................................ 182

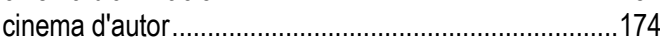

cinema experimental .................................................74, 173

cinema i espai expositiu .................................................. 151

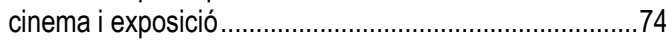

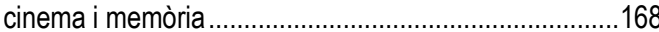

Cinéma Modèle ....................................103, 151, 159, 167

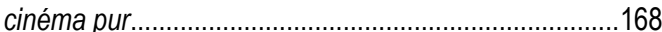

Cladders, Johannes .........................................95, 96, 122

Clef de l'Horloge, La (Poème cinématographique en I'honneur de Kurt Schwitters) ...............39, 71, 164, 168

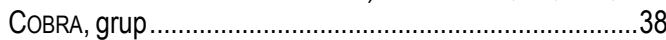

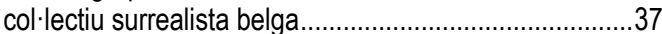

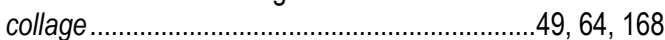

Colònia

Michael Werner, galeria

$. .99,103$ compromís

. .173

condició objectual de l'obra ....................67, 71, 78, 142

Conferència Internacional del Surrealisme Revolucionari

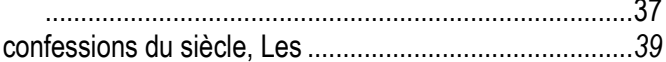

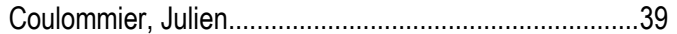

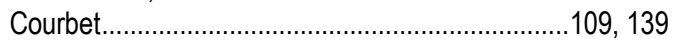

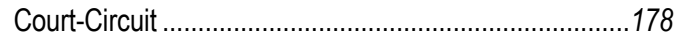

creació artística com a forma d'alliberament.................169

crítica de la crítica ........................................................5

crítica de l'acte creatiu...................................................127

crítica institucional..... $71,95,96,110,118,122,123,126$, $127,129,139,147,164$

cultura urbana

\section{D}

Daled, German . 100

de objecte

significació ..........................................................66

Decor..... 53, 95, 129, 130, 133, 137, 139, 143, 144, 147

$148,162,167,168,178$

arquitectura

129

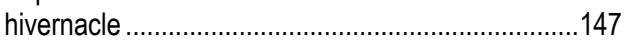

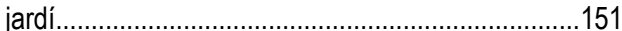

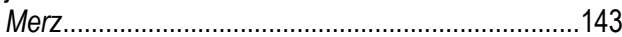

Museu...............................................................133

decorat ................................ 74, 130, 147, 148, 159, 163

decorat-jardí ................................................................148

decorat-Museu ............................................110, 144

decorats................................ 67, 95, 129, 144, 147, 148

Dejmo, Kurt .................................................39

Der Adler vom Oligozän bis heute ................................113

descontextualització ............................ 110, 133, 142, 148

Despatx del Surrealisme Revolucionari ..........................37

Deux peintres: Paul Delvaux et Ėmile Salkin et un de leurs élèves: Charles Deroux .....................................43

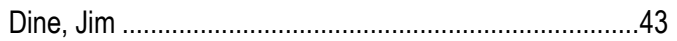

Documenta V.................53, 109, 118, 121, 122, 123, 126 Mythologies Individuelles .....................................122

Dokumentation Information ..................................110, 152

Dotremond, Cristian ............................................37, 38

Duchamp, Marcel58, 59, 63, 64, 75, 84, 91, 110, 113, 181

Düsseldorf

Burgplatz 12 ............................................103, 151

Städtische Kunsthalle.... 103, 104, 110, 113, 117, 118, 144, 151

E

escriptura automàtica

escriptura i moviment.

.36

escultura

182,187

$50,57,63,68,129,139,142$

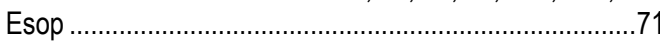

espacialització de la idea ..............................................159

espacialització de la poesia ...............................79, 83, 172

espacialització de l'objecte............................................162

espacialització del cinema ............................................167

espai de representació

$50,67,83,84,89,91,164$

espectador. $50,53,68,71,74,78,79,80,84,89,91,100$, $109,113,114,118,129,137,159,164,167,172$,

$173,174,177$ 
estètica de l'objecte ...................................................5 59 exercici de lectura .....83, 91, 159, 169, 172, 173, 174, 177 exposició

Decor

53,130

Exposition littéraire autour de Mallarmé .............. $78,83,84$

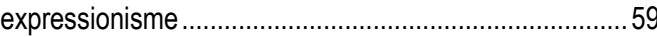

Exprmntl 4

74,164

$\mathbf{F}$

Fedre.

fet artístic com a succés social .....................................138

Film als Objekt - Objekt als Film .................129, 162, 167

fotografia ....36, 39, 40, 50, 64, 66, 89, 103, 109, 110, 144 , $148,153,159,168$

Fotos - Diapositives - Objectes. Àguiles des de l'any 3500 abans de J.C." 121

\section{G}

galeria Aujourd'hui

Brussel.les 43

Galerie du xxe siècle 109

Gare au defi! Le Pop Art, Jim Dine et l'influence de René

Magritte.

43

Germinal, setmanari ...................................................... 40

Gilissen, Maria ...............................................40, 50, 103

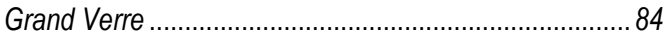

Grande caserole de moules.......................................... 167 gravat

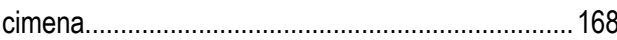

premsa contemporània .............................................168

H

Hahn, Otto ...50 Harten, Jürgen $103,110,113,117,118,126$

Hausmann, Raoul .

Havrenne, Marcel............................................................ 39

herència filosòfica alemanya .......................................... 36

hivernacle......................................................... 144, 147

Horta, Víctor

I

ideal il. lustrat 36 imaginació al poder, la

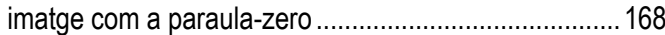
indústria cultural...

44,137

Ingres .........................................104, 109, 137, 139 intercanvi...........36, 43, 159, 162, 164, 169, 177, 181, 187 Invitation pour une expositon bourgeoise .129

\section{J}

jardí $103,130,144,147,148$

$$
\text { Decor. }
$$

.151 jeroglíicic $78,169,172,174,177$ Journal des Beaux-Arts ...................................40, 43, 49 Jules Barbey d'Aurevilly ou le perte-drapeau ................. 35 juxtaposició

$. .74,153,168,169,177$

\section{K}

Kathedrale des Erotischen Elends.

Knokke-Le-Zoute .143

Koenig, Kaspar ......................................................103

Koening ,Théodore ………………………………....... 35

L

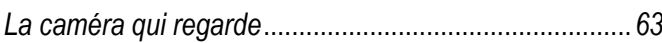

La Causa est entendre, libel ............................................... 37

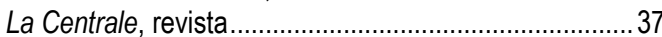

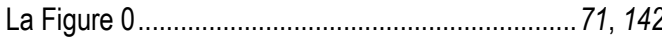

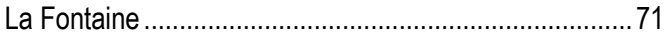

L'Angélus de Daumier..................................129, 130, 147

Le chant de ma génération .............................................168

Le Corbeau et le Renard ................................................... 74

Le Corbeau et le Renard, assemblage ...........................167

Le Corbeau et le Renard, edició................................74, 78

Le Corbeau et le Renard, exposició ................................. 78

Le Corbeau et le Renard, fragment del text....................84

Le Corbeau et le Renard, pel.lícula .......71, 163, 164, 167, 169, 172

Le Corbeau et le Renard, projecte.................................... 78

Le Musée et la Discussion .............................................152

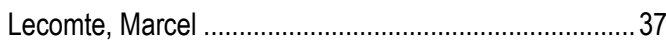

L'Entrée de l'Exposition..................................144, 147, 148

Lerin, Fernand............................................................ 43

Lichtenstein, Roy ......................................................... 58

L'Ille Sonnante, setmanari ........................................ 35

lingüística ...........................................63, 64, 66, 79, 160

L'invention du cinéma ....................................................159

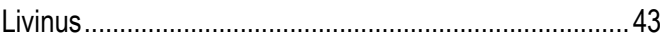

M

Magritte, René37, 43, 58, 64, 66, 104, 114, 137, 162, 169 , 177

Mallarmé, Stéphane........66, 78, 79, 80, 83, 152, 159, 169

Manzoni, Piero .......................................................... 43

mercaderia ...........................................172, 177, 178, 181

Merz ….............................................. $71,142,143,168$

Merzbau ........................................................142, 143

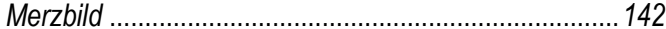

Middelburg (Països Baixos)

Museu Zeeuws

Minuit ................................................................. 40, 67

missatge.................................37, 43, 169, 172, 174, 177

Moholy-Nagy, Laszlo ..................................................... 39

Moi aussi, je me suis demandé si je ne pouvais pas vendre quelque chose............................................49

Mon livre d'ogre ...................................................... 40, 67

Monument Public N4 ................................................. 57

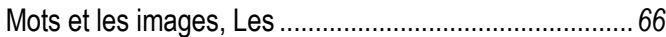

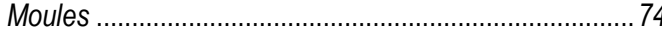

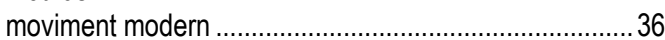

moviment surrealista..................................................36, 39

moviment surrealista belga ...................................... 35,37

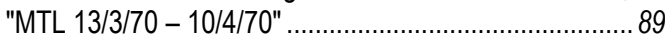

compromís de l'artista .................................................. 36

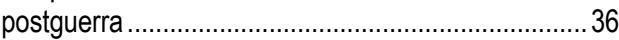

potencial revolucionari i contestatari........................... 37

MTL (DTH) ................................................ 89, 164 
MTL 13/3/70 - 10/4/70 $.83,129$

múltiples $67,74,75,78,127$ condició objectual de l'obra ..................................... signatura................................................................. utopia avantguardista ............................................75 muntatge . 50, 89, 103, 109, 110,121, 127, 129, 152, 163 , 168,169

Musée - Museum ........................................................139

Musée d'Art Ancien, Département des Aigles, Galerie du Xxe siècle............................................109, 121, 123

Musée d'Art Moderne Département des Aigles .53, 95, 96, $99,103,104,109,110,113,117,118,122,123,126$, $129,137,152,162$

arquitectura ... .139

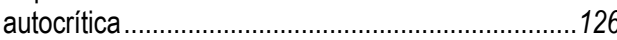

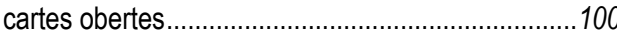
cinema .......................................151, 152, 153, 162

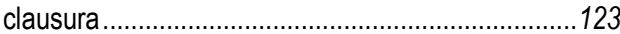

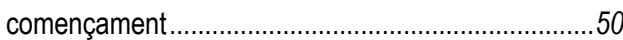

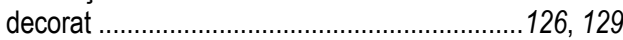
Documenta .............................................................118 jardí .................................................................144, 151 manifestacions i emplaçaments .................................99

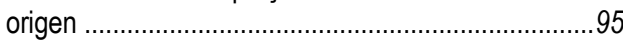
pel lícules .......................................................151, 152

Poèmes Industriels.................................................174

Salle Blanche ..............................................................130

Mythologies Individuelles ..........................................122

N

Nogué, Paul ...37 Nouveau Réalisme $49,57,59,174$

\section{0}

objecte com a obra d'art 58,59 objecte com a paraula zero .. .58 objectualització $58,60,63$

objet trouvé Objets de Broodthaers / Voorwerpen van Broodthaers ..57 obra com a objecte........................................................ 75

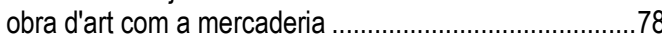
obra d'art i mercaderia ......................................................4 Offenbach, Jacques ...............................................40, 117 Oldenburg, Claes …....................................... 43, 58 originalitat..... $.59,75,79,181$

$\mathbf{P}$

paper de l'artista .36 paper social de l'artista..................................................138 partit comunista belga ...........................................................

Le Drapeau Rouge, revista ........................................37

Pas de quartiers dans la revolution, manifest .................37

Patriote Illustré, Le, revista..............................................39

pel-lícula com a suport experimental ..............................172

Pense-Bête, assemblage ....................................................68

Pense-Bête, llibre de poemes .......................44, 67, 68, 84

Phantomes, revista .........................................35, 39, 50 pintura ......36, 43, 49, 59, 64, 66, 67, 75, 84, 89, 129, 172

Piqueray, Gabriel ...

Planche à charbon poema-objecte

63,80

Poèmes Industriels $100,127,174,177$ poesia.. $35,49,68,80,139,142,143,167,168,169,173$, 177

poesia, incomunicació i abandonament .68

Poésie-Cinema 39,164 pop art

Pop Art, Nouveau Réalisme, etc. $49,57,59,74,174$ postguerra Problème allemand, Le ....................................................35

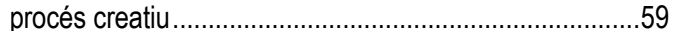
producció artística ........................................................138 producció de sentit ........................................78, 172, 177

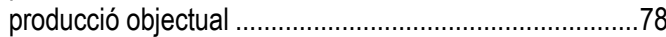

Project pour un film ........................................................38 Project pour un musée sur une îlle déserte, îlle du Musée .139

\section{$\mathbf{R}$}

Ray, Man 39 ready-made $49,58,59,63,181,182$ procediment. $58,59,75,78,83,89,164$ recepció artística registre de la realitat sociològica. . .59 reificació .....................................................137, 178 representació....... 50, 64, 66, 83, 113, 139, 147, 148, 151, $159,162,164,167,174,178,182$

representació museística resignificació

de l'objecte $57,78,109$

obra artística com a tex ..........................................172

pel-lícula com a text ................................................. 172

Restany, Pierre ...........................................................59

retrospectiva................................... 83, 126, 127, 129, 130

Rêve d'un jeune homme malheureux ou l'anarchiste

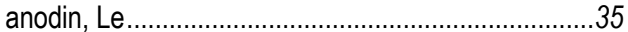

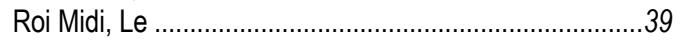

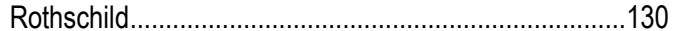

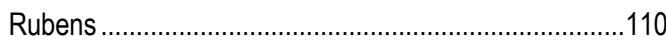

$\mathrm{s}$

Sadoul, Georges ....................................................159

Salle Blanche ...............................................................130

Salle Bleue ...........................................................130

Salle des Nuances .......................................................130

Salle Noir..................................................................130

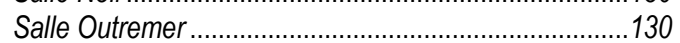

Salle Rose ................................................................130

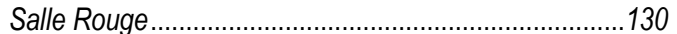

Salle Verte .........................................................130, 147

Salut Public, Le (Heddomadaire de précision politique et

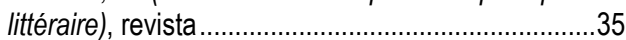

Sanders, Jan ....................................................40, 67

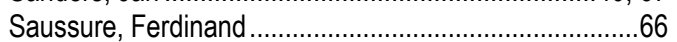

Savoir vivre, Le ..........................................................66

Schwitters, Kurt ............. 39, 63, 68, 71, 104, 142, 143, 168

Sculpture ..............................................................63

Section Cinéma ... 103, 104, 127, 151, 152, 153, 159, 162, 163

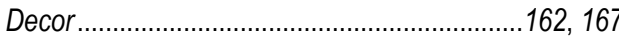

espai Museu ........................................................159 
exposició d'objectes

153,160

l'espai del cinema

$152,153,160$

l'espai Museu $152,153,159,160,162$

Section d'Art Moderne $99,109,121,122,123$

Section des Figures.....104, 109, 113, 114, 117, 118, 121 , 126, 127

Section Documentaire 100

Section Financière. 103,104

Section Folklorique Cabinet de Curiosités .....103

Section Littéraire. 100,110

Section Publicité $109,118,121,122$

Section XIxe siècle $99,100,103,109,110,117,139$ pel-lícules

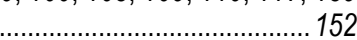

Section XIXE siècle (bis) ..........99, 103, 110, 113, 151, 152

Section XVIII siècle

100,110

Segal, George.

$43,50,58$

signatura $64,104,163,174,178,181,182,187$

Socle

.. 63,64

Statues de Bruxelles................................................. 39

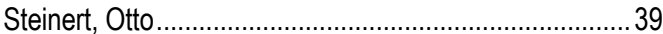

Surrealisme Revolucionari ...............................................38

Surrealisme Révolutionnaire, revista .............................. 37

Szeemann, Harald

122,143

T

Tapis de Sable 147,148

Théorie des Figures .127

trobada de funcions diferents

$63,64,162$ trobada d'objectes. 63

U

Umberto, Beni $.74,75,167$

Un autre monde..... .... 39

Un coup de dés 66,79

Un coup de dés jamais n'abolira le hasard ...79, 80, 83, 84

Un Jardin d'Hiver $144,151,164$

Un Jardin d'Hiver (ABC). 147,148

Un Jardin d'Hiver II 147

Un poète en voyage... à Londres..................................... 40

Un Voyage à Waterloo (Napoléon 1769-1969)............. 152

Une Discussion Inaugurale ...................103, 110, 151, 152

Une seconde d'eternité 182

V

valor de canvi

$43,177,181$

valor d'ús

$43,78,83,177,181$

Van Daalen, Piet

...103

Vandercam, Serge ..........................................39, 40, 67

vídeo

144,147

videoart 173

\section{W}

Wagner, Richard 117,139

White, Minor 